\author{
SZEGEDI TUDOMÁNYEGYETEM \\ NEVELÉSTUDOMÁNYI DOKTORI ISKOLA \\ INFORMÁCIÓS ÉS KOMMUNIKÁCIÓS TECHNOLÓGIÁK AZ \\ OKTATÁSBAN DOKTORI PROGRAM
}

NAGY GYULA

\title{
A Magyar Pedagógia folyóirat \\ TUDOMÁNYMETRIAI ÉS TARTALMI ELEMZÉSE
}

PhD értekezés

Témavezető:

Dr. Molnár Gyöngyvér

egyetemi tanár

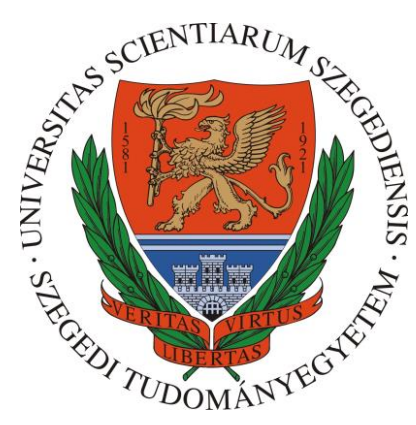

Szeged, 2019 


\section{TARTALOMJEGYZÉK}

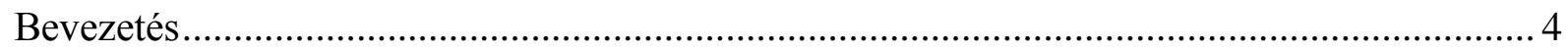

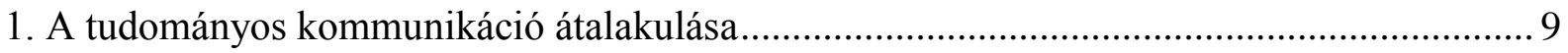

1.1. Általános trendek és a digitalizálódási folyamattal járó jelenségek ............................. 9

1.1.1. Retrospektív digitalizálás, adatbázisok és intézményi repozitóriumok .................. 10

1.1.2. Az Open Access jelenség és platformjai.............................................................. 11

1.1.3. A digitálisobjektum-azonosító (DOI), a szerzői azonosítók és a tudományos

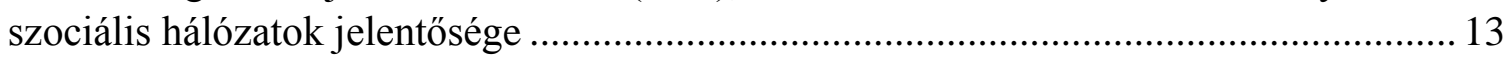

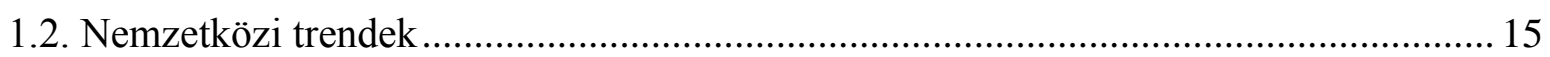

1.2.1. A neveléstudomány fő szervezetei és a folyóiratok kialakulása............................ 15

1.2.2. Tudománymetriai szempontból jelentős nemzetközi folyóiratok.......................... 16

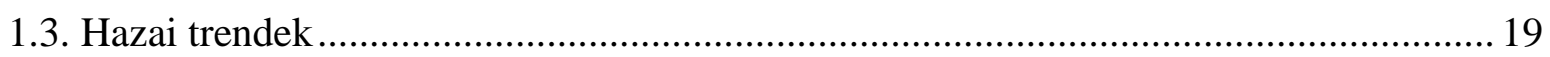

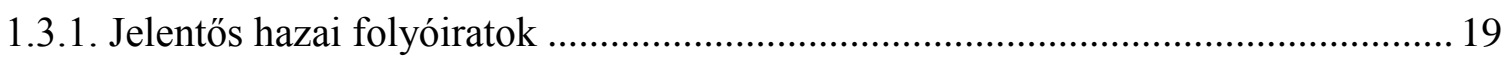

1.3.2. Pedagógiai folyóiratok a digitális térben ......................................................... 20

1.4. A hazai és nemzetközi folyóiratok szerepe a tudományos kommunikációban ............. 21

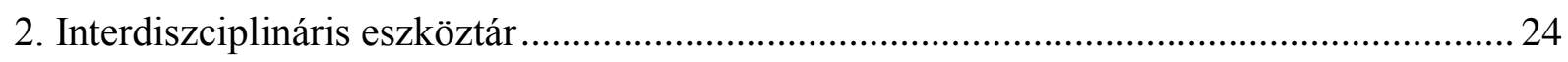

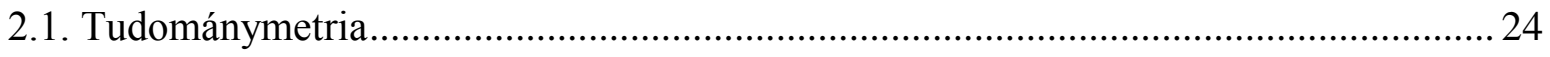

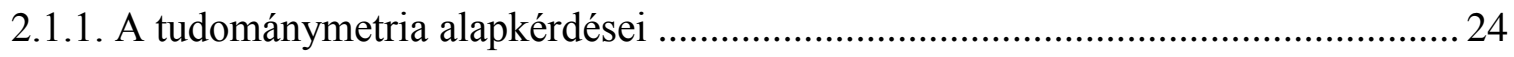

2.1.2. A Magyar Tudományos Müvek Tára................................................................ 28

2.1.3. A tudománymetria és a neveléstudomány kapcsolódási pontjai............................ 30

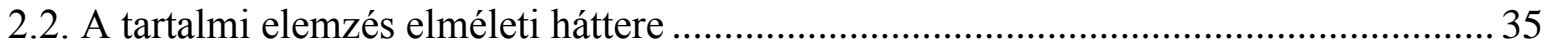

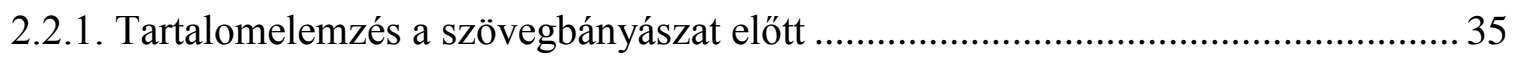

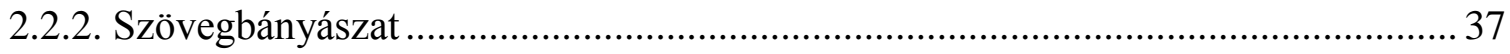

2.2.3. A szövegbányászat és a neveléstudomány találkozási pontja: Educational Data

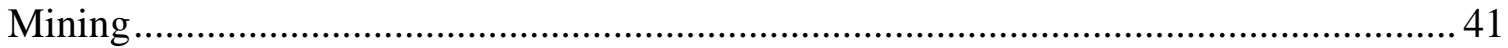

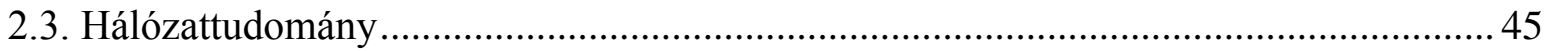

3. A Magyar Pedagógia folyóirat története és jelentősége ..................................................... 47

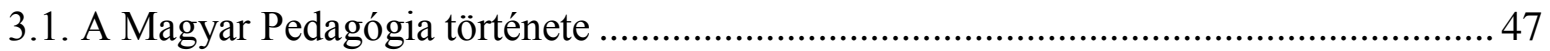

3.2. A Magyar Pedagógia szerepe a hazai neveléstudományban ........................................ 53

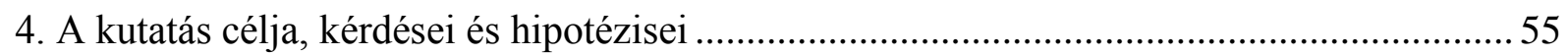

4.1. A metaadatok vizsgálatára vonatkozó kutatási kérdések és hipotézisek ......................55

4.2. A hivatkozások vizsgálatára vonatkozó kutatási kérdések és hipotézisek ...................56

4.3. A tartalmi elemzésre vonatkozó kutatási kérdések és hipotézisek .............................58

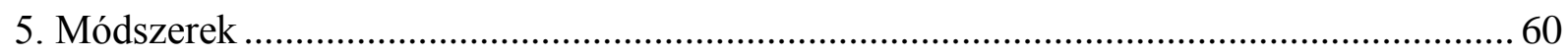

5.1. Előkészítő lépések és a metaadatok elemzésének módszerei ..................................... 60 


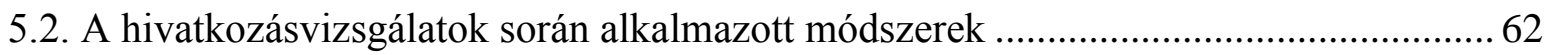

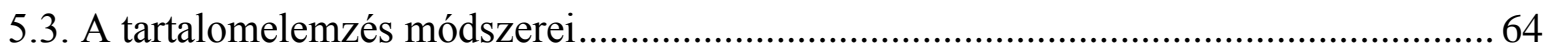

6. A cikkek metaadatainak tudománymetriai elemzése …................................................... 71

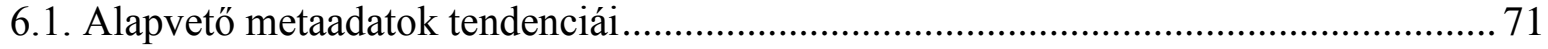

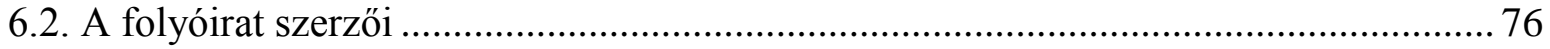

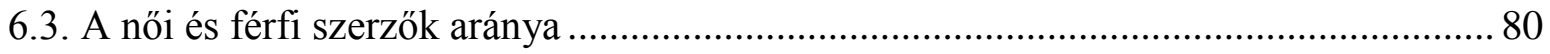

6.4. A társszerzőség jelenségei és a társszerzőségi gráf ..................................................... 82

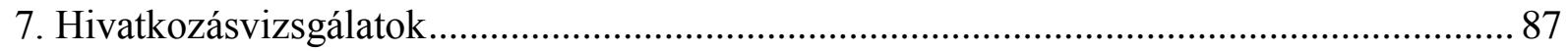

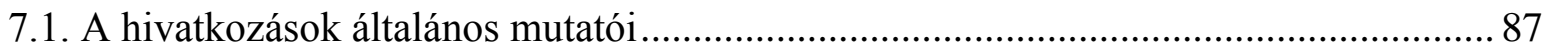

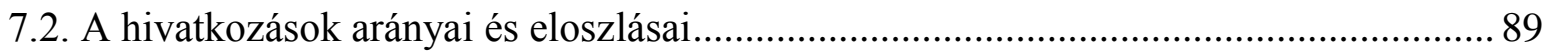

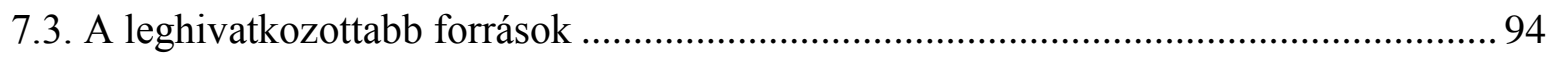

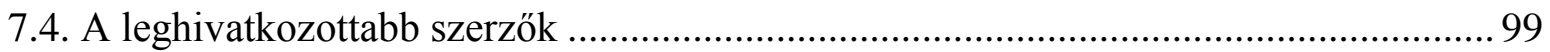

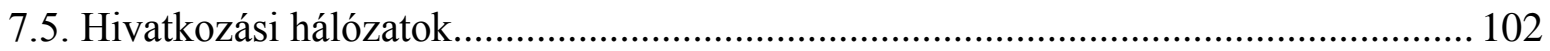

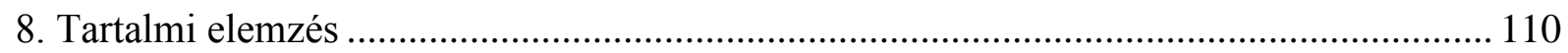

8.1. A tartalmi elemzés kiindulási alapjai és kezdeti fázisa ............................................ 110

8.1.1. Potenciálisan felhasználható segédforrások...................................................... 111

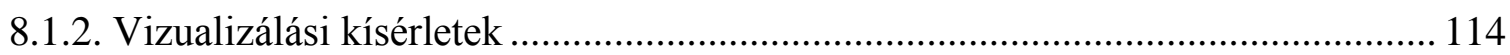

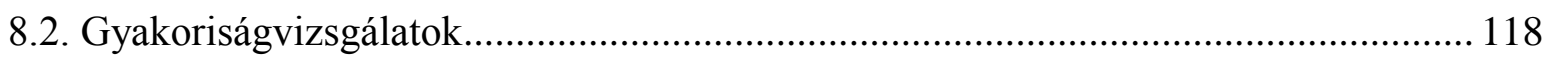

8.2.1. A gyakoriságvizsgálatok általános eredményei ................................................ 118

8.2.2. Abszolút és relatív gyakorisági toplisták: 1892-2014; 1991-2014 ...................... 120

8.2.3. A gyakorisági táblázatok alapján kibontakozó trendek hőtérképes vizsgálata..... 126

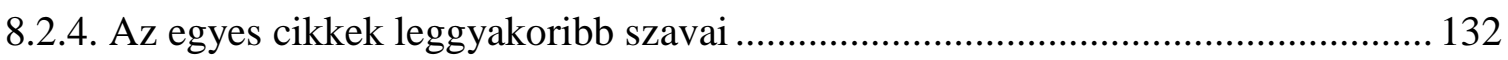

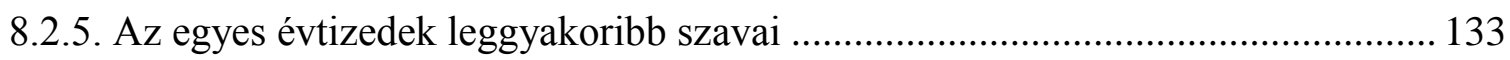

8.3. A kulcsszavakkal kapcsolatos vizsgálatok eredményei............................................. 143

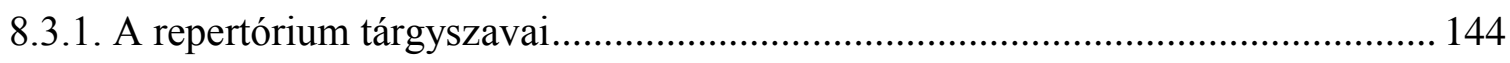

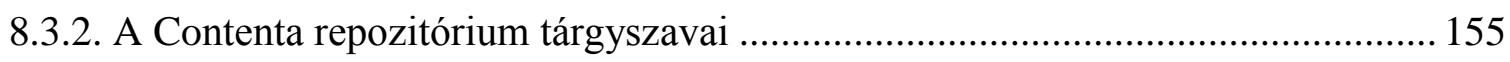

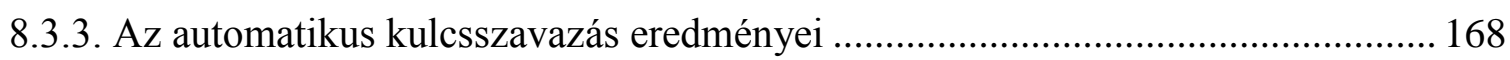

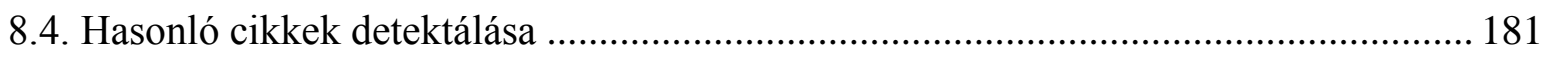

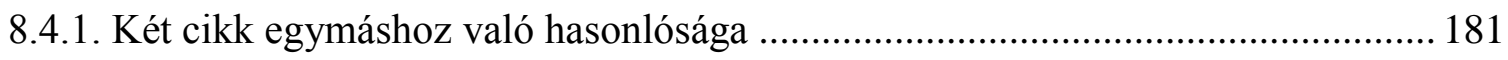

8.4.2. Klaszteranalízis, avagy több cikk egymáshoz való hasonlósága .......................... 182

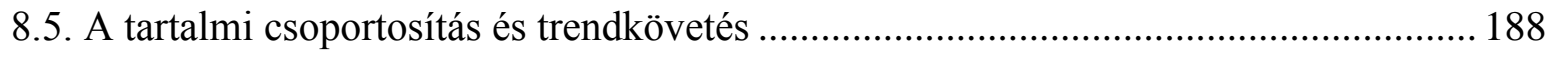

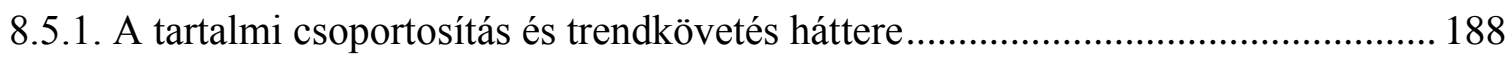

8.5.2. A tartalmi csoportosítás és trendkövetés eredményei ........................................ 192

8.6. Egyes szakkifejezések használatának változása és első előfordulásuk detektálása .... 207

8.7. További lehetőségek a tartalmi elemzések vizualizálására ........................................ 215 
9. Az eredmények összegzése, limitációk és további kutatási irányok ……......................... 218

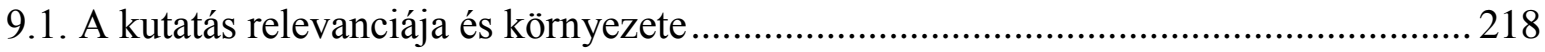

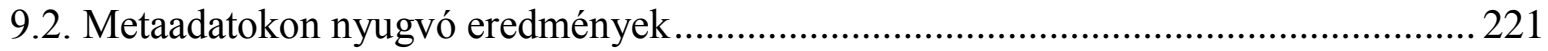

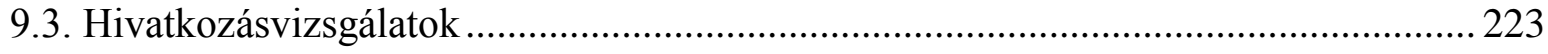

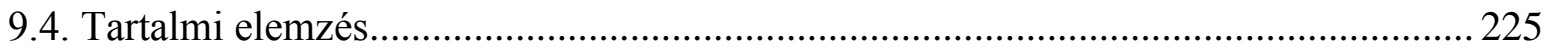

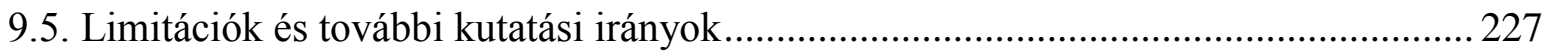

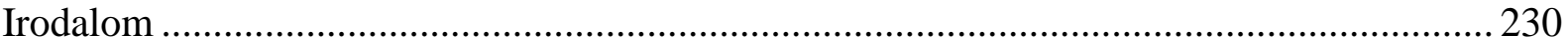

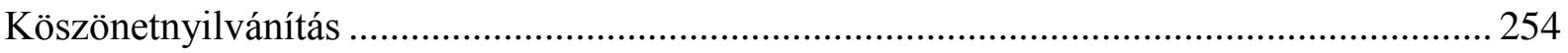

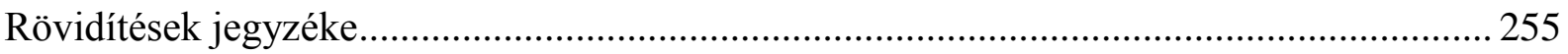

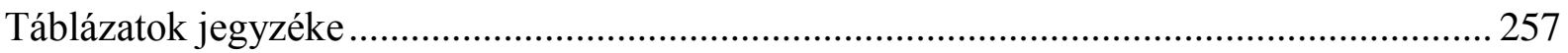

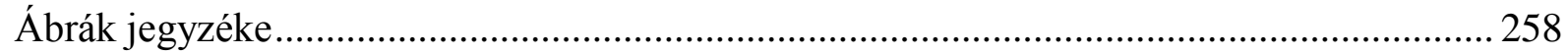

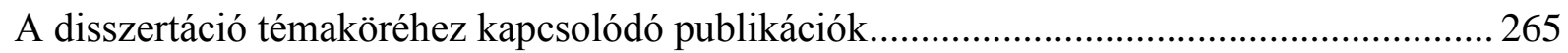

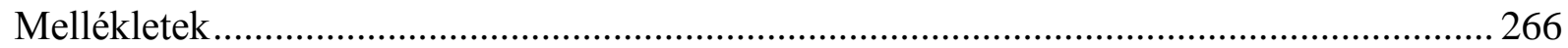

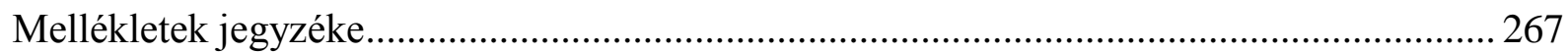




\section{BEVEZETÉS}

A tudományos publikálás, illetve a tudományos eredmények disszeminációja kapcsán számos változásnak lehettünk tanúi az elmúlt néhány évtizedben. Ezeket a változásokat elsősorban az információs és kommunikációs technológiák (IKT) infrastrukturális fejlődése (legfőképpen a világháló széleskörű térnyerése), illetve az IKT terület szolgáltatási portfóliójának jelentős bővülése indukálta. Az átalakulási folyamat napjainkban sem zárult le, hiszen a tudományos élet megannyi területén tapasztalhatjuk ma is a folyamatos útkeresést.

A digitalizálódás-elektronizálódás kifejezésekkel jellemezhető folyamat mellett ugyanakkor egy másik paradigmaváltás is lezajlott a tudományos publikálási szokások körében. A tudományos párbeszéd a szakkönyvek (monográfiák, szerkesztett és szintetizáló kötetek) világából nagyrészt áthelyeződött a folyóiratok területére (Larsen \& Von Ins, 2010). A folyamat először a természettudományok szférájában jelent meg, azonban a jelenség tovább gyürüzött, mára elérte a társadalomtudományokat, sőt bizonyos hatásai a bölcsészettudományok esetében is megfigyelhetőek (Csapó, 2011). Ezzel párhuzamosan szinte minden tudományterületen erősödött a tudósok közötti kollaboráció (Glänzel, Schubert, \& Czerwon, 1999). Egyre több a többszerzős, míg egyre kevesebb az egyszerzős publikáció, ezzel egyidejűleg a kutatók közötti verseny egyre inkább kiéleződik (Van Raan, 2001; Wong \& Hodson, 2010). Megerősítve ezt a jelenséget, kimutatható egy olyan irányú tendencia, mely szerint a többszerzős publikációkra több hivatkozás érkezik (Wuchty, Jones, \& Uzzi, 2007). A kiélezett versenyhelyzet és a folyamatosan zajló változások olyan új meta-tudományágak és jelenségek megszületését, majd intenzív jelenlétét eredményezték (a felsorolás teljességének igénye nélkül), mint például a tudománymetria (Hood \& Wilson, 2001) vagy az Open Access jelenség (Hajjem, Harnad, \& Gingras, 2006).

Az átalakulási folyamat természetesen nem áll meg a neveléstudomány határainál, az aktuális trendek elérték ezt a tudományágat is (Csíkos, 2013). Az elmúlt évtized hazai tudományos életének meghatározó fejleménye volt a Magyar Tudományos Művek Tárának (MTMT) elindulása és annak nemrégiben történt teljes megújulása (MTMT2). Hasonló horderejü fejleményt jelentett a folyamatosan épülő, a pedagógia szakterületét is érintő intézményi teljes szövegü repozitóriumok létrejötte. Ezen jelenségek és szolgáltatások egymáshoz való viszonyát, a kutatókra és magára a neveléstudomány egészére gyakorolt hatását mindenképpen vizsgálni szükséges, hiszen a változó közeg jelentősen befolyásolhatja a születő publikációk jellegét, sőt az egyes kutatók személyes tudományos életpályáját is. 
$\mathrm{Az}$ interdiszciplinaritás fontossága napjaink tudományos életében vitathatatlan (Van Noorden, 2015), ahogyan a neveléstudomány területén is régóta jelen van ez a szempont (Biró \& Nagy, 2018). A tudományágak közötti tudományágak általában hagyományos diszciplínák határterületeiből, jól sikerült tudományos együttmüködésekből és világméretü kutatási projektekből születnek. Létrejöttük szükségszerü, hiszen azt több változás párhuzamosan indukálja (Bhaskar, Danermark, \& Price, 2018). Az egyre összetettebb és bonyolultabb tudományos problémák megértésének szándéka együttmüködésre, saját tudományterületükön túlmutató módszerek alkalmazására és tanulásra sarkallja a tudósokat. Ennek a folyamatnak köszönhetjük például a biokémia vagy a kognitív tudomány létrejöttét. Kutatási projektünk teljes mértékben épített erre az interdiszciplináris szemléletmódra, kihasználva annak minden előnyét.

Legalább ennyire fontos, hogy a tudománynak elemi igénye van a rohamos technológiai fejlődés által nyújtott eszközök kurrens alkalmazására. Ehhez azonban az egyes diszciplínáknak folyamatosan integrálniuk kell a legújabb müszaki megoldásokat, ezen belül az informatika szerepe pedig különösen megkerülhetetlen. Számos új kutatási terület születik ezen a módon, amelyek sok esetben végigmennek az önálló tudományággá válás folyamatán (Csapó, 2005); így született a bioinformatika, a számítógépes nyelvészet, a digitális bölcsészet vagy a hálózattudomány. A technológiai fejlődés és az új elemzési eljárások új lehetőségeket teremtettek a neveléstudományi kutatásokban is. A disszertációban bemutatásra kerülő kutatás ezen innovatív informatikai megközelítés nélkül nem lett volna kivitelezhető.

Új típusú, korábban nem vizsgált és nem is vizsgálható kutatási kérdésekre kaphatunk választ az új interdiszciplináris és IKT módszerek alkalmazásával. Ebbe a kategóriába sorolhatóak a hazánkban talán még kevésbé ismert, azonban nemzetközi kutatásokban egyre gyakrabban alkalmazott Educational Data Mining (EDM) által biztosított lehetőségek (Winne \& Baker, 2013; Gobert, Kim, Sao Pedro, Kennedy, \& Betts, 2015) is. Magyarországon az ilyen típusú kutatásoknak eddig még kevésbé volt hagyománya. Saját kutatásunk célkitüzései között szerepelt ennek a hiánynak a pótlása, mintegy a rendelkezésre álló IKT lehetőségek ilyen irányú áttekintéseként.

Globalizálódott, multikulturális világunkban a hálózatok szerepe minden eddiginél fontosabbá vált, illetve a tudomány hálózatként való értelmezése is egyre természetesebb gondolat (Barabási, 2014). A tudománymetria mint a tudományok tudománya nagymértékben támaszkodik erre a megállapításra (Schubert, 2015a). Az egyes tudományágak szereplői a tudománymetriai elemzések által kaphatnak információt saját tudományterületükön belül elfoglalt helyzetükről. Publikációk tízezrei foglalkoznak a tudományos együttműködés 
(Barabási, Jeong, Néda, Ravasz, Schubert, \& Vicsek, 2002; Chen, Börner, \& Fang, 2013) és a tudományos hivatkozások (Liu, Zhang, \& Guo, 2013; Tight, 2014) által felvetett kérdésekkel: az előbbi a tudományos közleményeket együtt készítő társszerzők mintázatait, míg az utóbbi a szakirodalmi hivatkozásokat tárja fel a hálózattudomány eredményeire alapozva.

A citációk máig a tudománymetria egyik központi mozgatórugóját és kutatandó erőforrását jelentik, aminek következtében a tudománymetria leginkább a hivatkozásokon keresztül próbálja feltárni egy-egy tudományág kutatóinak hatástényezőit (Glänzel, 2008). Ugyanakkor, ahogyan azt Glänzel is kiemeli, nem hallgatható el az a tény sem, hogy a hivatkozásalapú tudománymetriát számos kritika éri, és folyamatosan felmerülnek a megközelítés korlátai által felvetett kihívások, kialakulóban vannak új, alternatív metódusok is (Piwowar, 2013). A minél teljesebb és objektívebb kép megalkotásának érdekében a tudomány mérésével foglalkozó szakemberek számos más tudományág eszközeit és eredményeit felhasználják (vö. interdiszciplinaritás) munkájuk során. Ennek két legillusztrisabb és legelemibb példáját a szövegbányászat és a hálózattudomány jelentik, melyek megoldásai jelen kutatási projekt sikeréhez is elengedhetetlenek voltak, akár a társszerzőségi, akár a hivatkozási hálózatok tekintetében (Fortunato et al., 2018).

A tudománymetriai adatbázisok (melyek hivatkozási adatbázisok néven is ismertek) jó néhány évvel ezelőtt léptek be az életünkbe (Garfield, 2006). Kezdetben csak a „kemény” tudományok tudták kiaknázni ezek előnyeit, azonban napjainkban a társadalomtudományok és a bölcsészettudományok is egyre fokozódó mértékben építenek ezekre a lehetőségekre (Hammarfelt, 2016). A potenciál ellenére azonban még így is számos tudományos publikáció létezik, amelyek hatása és szerzőik tudományos hatástényezője nem mérhető, mivel rengeteg olyan tudományos folyóirat létezik, amelyek nincsenek reprezentálva a nemzetközi hivatkozási adatbázisokban. Ezek az akadémiai lapok általában a bölcsészet- és társadalomtudományok területéről eredeztethetőek (Mongeon \& Paul-Hus, 2016), így a neveléstudományi kutatás különösen érintett. Ezek a folyóiratok lehetnek angol nyelvüek, vagy bármilyen egyéb nyelven kiadottak, de közös jellemvonásuk, hogy általában olyan feltörekvő periodikák, melyeknek fontos szerepük van egy-egy nemzet vagy egy-egy helyi közösség tudományos életében.

Két kérdés különösen rávilágít a probléma súlyosságára: mennyi tudományos publikáció születik globálisan, és ezek közül mennyit tartalmaz a Web of Science vagy a Scopus adatbázis? Természetesen az első kérdésre nem tudunk egzakt választ adni, de annyi bizonyos, hogy az első esetben jóval nagyobb nagyságrendű tudományos munka érintett, mint amit a második kérdésre adott válaszban kapott számok mutatnak. A probléma felderítéséhez a nemzetközi tudományos folyóiratok indexelő, nyilvántartó adatbázisai (Ulrich’s, DOAJ, ERIH Plus, stb.) 
jó összehasonlítási alapul szolgálhatnak. A nemzeti kutatás-nyilvántartási rendszerek (CRIS) szintén megfelelö összehasonlítási alapot jelenthetnek a kérdés vizsgálata során. Ahogyan Sivertsen (2014) a norvég nemzeti kutatás-nyilvántartási rendszer (Cristin) adatai alapján megállapítja, a tudományos élet jó néhány területén a nagy nemzetközi tudománymetriai szolgáltatók valójában csak igen gyenge lefedettséggel rendelkeznek. Sajnos a lefedettségi mutatók nagyon sok országban hasonlóak, vagy még rosszabbak, mint ahogyan az a norvég példából kiderül.

Mindez alátámasztja a tudományértékelésben tátongó ürt, egyúttal felmerülő igényt, melyet csak alternatív megoldások keresésével van esély áthidalni. Habár az itt bemutatott eredmények csak egy jól kiválasztott laphoz köthetőek, valójában mind a felmerülő probléma, mind a kifejlesztett metódus igazán univerzális, ahogyan az a példákból is kiderül. Meglátásunk szerint kutatásunk legnagyobb eredményét nem a disszertációban prezentált konkrét eredmények jelentik, hanem a kidolgozott és alkalmazott módszer, amely bárki által szabadon alkalmazható hasonló feltételek mellett. Hogyan is mérhetőek azok a folyóiratok, amelyek kívül esnek a nagy nemzetközi tudománymetriai szolgáltatók látókörén? Kisebb léptékben gondolkodva reprodukálnunk kell a nemzetközi szinten jelentős tudománymetriai szolgáltatók által alkalmazott technikákat. Az értekezés erre tesz kísérletet, miközben a kidolgozott módszertannal integrálja a neveléstudomány, a tudománymetria és a szövegbányászat megoldásait.

Az eddigiek alapján nyilvánvaló, hogy a tudományos kutatói munka egyik alapvető kimenetét, eredményét a különböző típusú publikációk jelentik. A társadalomtudományok esetében ez a jelenség fokozottan jelen van. A folyóiratcikkek fontossága, szerepe, jelentősége a többi tudománykommunikációs műfaj mezőnyét tekintve jelentős változásokon esett át. Ez a változás minden eddiginél indokoltabbá teszi, hogy alaposabban ismerjük folyóiratainkat: erősségeiket, gyengeségeiket és a folyamatosan zajló változásokat. A disszertációban bemutatásra kerülő kutatásban ezt a célt tüztük ki és a neveléstudomány egyik illusztris lapját állítottuk górcső alá. Minden eddiginél alaposabb és sokoldalúbb elemzéseknek vetettük alá a Magyar Pedagógia című folyóiratban 1892 és 2014 évek között megjelent tanulmányokat.

A kutatás három fő pillérből áll: az első a kijelölt időszakban megjelent folyóiratcikkekre vonatkozó metaadatok elemzése segítségével feltérképezi a folyóiratot ért legfontosabb hatásokat, tendenciákat, valamint a szerzőkre és a társszerzőségre vonatkozó mintázatokat. A második pillér a folyóiratcikkek végén közölt irodalomjegyzékek tételein alapul, melyek automatikus felismerésével és kinyerésével részletes hivatkozáselemzést végeztünk, megállapítva többek között a hivatkozások típusait, eloszlását és frissességét. Ezen elemzési 
körhöz sorolható továbbá az egyes hivatkozásokból felépített, összetett hivatkozási hálózatok megalkotása, majd vizsgálata, illetve annak gráfszerü felderítése, hogy a folyóirat szerzői jellemzően a hazai és nemzetközi színtér mely forrásait és szerzőit idézik. A hálózatok elemzésével felderíthető, hogy mely szerzők a létrejött hivatkozási hálózatok legtöbbet hivatkozott és legcentrálisabb szereplői. A kutatás harmadik pillére a folyóiratban - az adott időintervallumban - közölt tanulmányok tartalomelemzését tủzte ki célul, tetten érve a folyóirat több, mint százéves története során lezajlott témaváltásokat, meghatározó diskurzusokat és fő témacsoportokat.

A Magyar Pedagógia a magyar neveléstudomány egyik centrális folyóirata: meghatározó szerepe van a tudományágon belüli tudományos kommunikációban, a trendek és kutatási irányok diktálásában, hiszen a több mint egy évszázados múlt olyan vizsgálódásokra ad lehetőséget, amelyekre egy rövidebb életű orgánum esetében nem nyílna lehetőség (Tóth, Toman, \& Cserpes, 2008; Pap, 2009; Csapó, 2005). Jelen értekezés az elméleti háttér részletes tárgyalása után az elvégzett három pilléren alapuló empirikus kutatás kiindulási alapjait, majd annak eredményeit ismerteti. A disszertáció ezen második részegysége a kutatás céljainak, kérdéseinek, hipotéziseinek és alkalmazott módszereinek ismertetése után a három felvázolt pillér szerinti fejezetekre tagolható. Az eredmények a neveléstudomány jelen viszonyait tükrözik, a diszciplínán belüli hálózatiság hangsúlyozásával. Kik a legmeghatározóbb személyek? Milyen intézményi háttérrel rendelkeznek? Hogyan változtak az idők folyamán a publikálási szokások? Mi a nemzetközi és hazai tendenciák egymáshoz való viszonya? Ezekre a kutatási kérdésekre csak a folyóirat részletes tudománymetriai elemzése adhat választ. Az értekezésben ezt a feladatot végeztük el, összefoglaló képet alkotva magáról a folyóiratról, egyúttal megvilágítva a neveléstudomány térképének egy bizonyos szempontú nézetét. 


\section{A TUDOMÁNYOS KOMMUNIKÁCIÓ ÁTALAKULÁSA}

\section{1. Általános trendek és a digitalizálódási folyamattal járó jelenségek}

Az elmúlt időszakban számos külföldi és magyar szerző tárgyalta a tudományos kommunikáció átalakulásának folyamatát (Castelli, Manghi, \& Thanos, 2013; Pearce, Weller, Scanlon, \& Kinsley, 2012; Holl, 2016). Sok más tendencia mellett, a trend egyik megnyilvánulásaként a tudományos közlés a társadalom- és bölcsészettudományok esetében is egyre inkább áthelyeződik a szakkönyvek (monográfiák, szerkesztett és szintetizáló kötetek) világából a folyóiratok és a különböző konferencia-kiadványok területére (Nagy, 2016a; Bornmann \& Mutz, 2015; Larsen \& Von Ins, 2010). A társadalomtudományok egyik zászlóshajóját jelentő közgazdaságtudomány területén tevékenykedő Kóczy Á. László tudománymetriai témájú írásában jól megragadja a könyvek által jelentett egyik legfőbb problémát: „Mivel a szerző mellé nem teszi oda a nevét két tucat vezető tudós a világ minden tájáról, igazából senki sem tudja, hogy a könyv miféle szakmai megmérettetésen esett át, senki sem vállal garanciát a könyv minőségére. Hiába a kiváló szerző, szakkönyvekben sokkal több elírást, pontatlanságot, sőt hibát találni. A közgazdászok közül az ír könyvet, aki nem tud cikket írni, vagy aki ily módon szeretné a jövedelmét kiegészíteni. Az eredeti kutatási eredményeket tartalmazó könyv nem jellemző, a szerzők a mennyiség helyett a minőségre törekednek.” (Kóczy, 2015, p. 11)

A kitapintható átrendeződés különösen indokolttá teszi az egyes folyóiratok beható és alapos elemzését. A folyóiratok elemzésére ugyan többféle megközelítés kínálkozik, azonban a tudományos igényü vizsgálódás szempontjából ezek közül a tudománymetriai elemzés tünik legrelevánsabbnak (Mooghali, Alijani, Karami, \& Khasseh, 2012). A folyóiratoknak ezt az új aranykorát több párhuzamosan ható, sőt, egymást erősítő impulzus váltotta ki. Az egyik ilyen alapvető ok a folyóiratok elektronizálódásának 1990-es évek közepén történő elindulása: a korábban kizárólag papíralapon megjelenő periodikák folyamatosan kezdték megjelentetni internetes változatukat. Mostanra az analóg változatok teljes elhagyásának folyamata is nagy erőkkel zajlik, sőt számos újonnan induló lap már eleve csak internetes kiadásban jelenik meg (Holl, 2016).

Magának az Open Access (újabban még általánosabban az Open Science, azaz nyílt tudomány) mozgalomnak szintén meghatározó szerepe volt a folyóiratcikkek expanziójában, ahogyan azt Nagy (2016a) egy korábbi tanulmányban részletesen tárgyalta. Emellett további erős szerepe volt a felvázolt paradigmaváltásban a volumenében is jelentősen megnövekedett 
tudományos kibocsátásnak (Brint \& Carr, 2017), hiszen a palettán újonnan megjelenő publikációs többletnek megjelenési felület kellett, amelyhez az általában már online térben létező folyóiratok jóval gyorsabban tudtak alkalmazkodni, mint a hagyományos kiadói struktúrák (Dodds, 2017). Végül nem mehetünk el a tudományos könyvtárak folyamatra kifejtett katalizátorszerepe mellett sem (Sennyey \& Kokas, 2011; Nagy, Molnár, \& Kokas, 2017).

\subsubsection{Retrospektív digitalizálás, adatbázisok és intézményi repozitóriumok}

A technológia fejlődésének hatására az ezredforduló tájékán induló digitalizációs folyamat mára odáig jutott, hogy ma már nem tünik elképzelhetetlennek azon állapot elérése, amikor minden valaha létező és folyamatosan keletkező (analóg és már digitális formában született) információs anyag (szöveg, kép, hang, mozgókép) elérhető lesz a hálózaton (Nagy, 2014). Világszerte óriási ütemben zajlanak a különböző digitalizálási projektek, amelyekben kiemelt szerep jut a tudományos folyóiratoknak, amiből természetesen a neveléstudomány sem maradhat ki. Hazánkban elsősorban a könyvtári szféra (Bánkeszi, 2010; Kokas, 2014), illetve az Arcanum Adatbázis Kft. mutat fel jelentős eredményeket (Veroszta, 2013) a digitalizálás területén; azaz itthon egy hibrid modell keretében zajlik a papíralapú állományok digitális térbe kerülése, melynek során a közszféra és a magánszféra is képviselteti magát.

A tudományos kommunikáció digitalizálódásában - a folyóiratok elektronizálódása mellett - kiemelt szerep jutott az intézményi adattáraknak, az úgynevezett repozitóriumoknak (Lynch, 2003; Chan, 2004; Lynch \& Lippincott, 2005). Ezek az adatbázisok egy-egy felsőoktatási intézmény, kutatóintézet, de akár egy-egy diszciplína berkeiben tevékenykedő tudósok és kutatók tudományos teljesítményét hivatottak archiválni, egyben minél szélesebb közönség számára láthatóvá és elérhetővé tenni (Jones, Andrew, \& MacColl, 2006). A repozitóriumok szerves részét képezik magának az Open Access jelenségnek is, tulajdonképpen annak ,zöld útját” testesítik meg.

Végül, nem elhanyagolható kapcsolódási pontként az MTMT-ben egyre hangsúlyosabban megjelenő idézők adminisztrációja kapcsán is ki kell térni a teljes szövegü adatbázisok jelentőségére. Ezek hasznosságával minden saját idézőit nyilvántartó kutató találkozott már a „hivatkozás-vadászat” során. Jóval könnyebb lenne az MTMT felhasználóinak dolga az idézők keresése során, ha létezne egy közösen lekérdezhető, diszciplináris neveléstudományi, teljes szövegű adatbázis, amelyben a szerzők saját nevükre rákeresve eredményül kapnák a rájuk hivatkozó publikációk listáját. 


\subsubsection{Az Open Access jelenség és platformjai}

Csapó Benő (2007, p. 88) egy írásában kifejti az Open Access legfontosabb ismérveit: „A kiadók jelentős haszonra tesznek szert azáltal, hogy a tudományos közösség kénytelen drágán visszavásárolni azt a tudást, amit maga hozott létre. Ennek a helyzetnek a feloldására, a szabad hozzáférés lehetővé tételére egyre több új modell lát napvilágot. A hagyományos folyóiratkiadási modellből például ki lehetne kapcsolni a haszonszerzés mozzanatát úgy, hogy a publikálás költségét is - ami az elektronikus alapra helyezéssel jelentősen csökken - a kutatás finanszírozásával megegyező módon (az állami költségvetésből, kutatási támogatásból, illetve a kutatást támogató alapok, alapítványok révén) fedezzék. Emellett a nyílt hozzáférésnek meg lehet teremteni az alternatív útjait is, például cikk archívumok, új elveken müködő folyóiratok létrehozásával, ezek azonban már a hagyományos kiadói modell radikális átalakítását igényelnék." A Magyar Pedagógia főszerkesztője tanulmányában természetesen kitér saját folyóirata és az Open Access viszonyára is: a lapban 1991 óta megjelenő tanulmányok nyílt hozzáférés keretében érhetőek el (Csapó, 2007). Az általa használt „,cikk archívumok” kifejezés tulajdonképpen az intézményi repozitóriumokat és az általában diszciplináris módon szerveződő nemzetközi dokumentumszervereket (pl. arXiv.org) takarja, míg az „új elveken müködő folyóiratok" elnevezés az Open Access mozgalom különböző típusú folyóiratait és azokat az Open Access jelenséget támogató kiadói rendszereket fedi le, mint amilyet például az Open Journal System jelent (Laakso, Welling, Bukvova, Nyman, Björk, \& Hedlund, 2011).

A világszerte elterjedt Open Journal System (OJS) egy nyílt forráskódú szerkesztőségi rendszer, amely az online tudományos folyóiratok számára egy ingyenes, szabványos és nyílt hozzáférésü (Open Access) megjelenési felületet biztosít. Az egyes folyóiratok szerkesztésének és publikálásának összes lépését lefedő, egy-egy cikk teljes életútját végigkövető rendszerről van szó, amely minden szerkesztőség igényeihez, munkamenetéhez tetszés szerint hozzáigazítható. Kiemelendő, hogy az OJS számos olyan funkcióval rendelkezik, amely a más adatbázisokkal való adatcserét segíti elő, ezzel nagyban növelve a rendszerben megjelenő folyóiratcikkek láthatóságát a tudományos életben (Bower, Fisher, \& Gerodetti, 2017). A rendszer használatára már a neveléstudományban is akad példa, a közelmúlt egyik pozitív fejleménye az Iskolakultúra folyóirat beköltözése az Szegedi Tudományegyetem OJS folyóiratplatformjára. Emellett elmondható, hogy a Magyar Pedagógia folyóirat szerkesztősége is áttekintette az OJS alkalmazásának előnyeit és elindította a folyóirat-platformhoz való csatlakozás folyamatát.

A nyílt hozzáférés keretében két fő modellt különböztetünk meg, az ún. „arany utat” és a 
„zöld utat” (Harnad, Brody, Vallieres, Carr, Hitchcock, Gingras, \& Hilf, 2008). Az „arany út” a tudományos cikkek konkrét Open Access folyóiratokban való publikálását jelenti. Ezekben a folyóiratokban természetesen a publikációk ugyanúgy szigorú szakmai bírálaton esnek át, ugyanakkor legfontosabb ismérvük, hogy a cikkek bárki által ingyenesen hozzáférhetőek (Willinsky, 2009). A Lundi Egyetem Directory of Open Access Journals (DOAJ) folyóiratadatbázisa több, mint 10000 nyílt hozzáférésű folyóiratot tart nyilván. A regiszterben felsorolt kiadványok egy része nonprofit tudományos társasági, kutatóintézeti vagy egyetemi kiadvány (Ramesh \& Ramesha, 2013). A másik részük üzleti kiadókhoz köthető, amelyek a kiadás bemeneti oldali finanszírozását valósították meg azáltal, hogy a szerzőknek cikk-eljárási díjat kell fizetniük. Napjainkra a legtöbb hagyományos, nagy piaci súllyal rendelkező szereplö (Springer, Elsevier, stb.) kínál olyan megoldást, ahol a szerzői oldalon kerülnek finanszírozásra a folyóirat-kiadás körüli költségek (Holl, 2013a). Az „arany út” esetében tehát ugyanúgy szükség van komoly anyagi forrásokra, mint a hagyományos publikálási útvonal esetében, a költségek azonban máshol jelentkeznek (Bernius, Hanauske, König, \& Dugall, 2009). Az Open Access jelenség tárgyalása kapcsán mindenképpen meg kell említeni az úgynevezett predátor vagy parazita folyóiratokat, amelyek terjedése a legnagyobb veszélyt rejti az Open Access jegyében zajló publikálásra (Xia, Harmon, Connolly, Donnelly, Anderson, \& Howard, 2015). Ezek a lapok sok esetben semmilyen szakmai bírálatot nem alkalmaznak a beküldött cikkek esetében, kizárólagos céljuk az anyagi haszonszerzés.

A ,zöld út” a másik oldalról közelíti meg a kérdéskört: tulajdonképpen szövegarchiválást jelent egy-egy intézményi vagy egy-egy diszciplináris repozitóriumban; ebből is érzékelhető tehát, hogy a problémakör erősen összefügg a korábban tárgyalt intézményi repozitóriumokkal. Ezen adatbázisok nagy előnye, hogy a cikkekhez megbízható metaadatokat szolgáltatnak, illetve az archívumok OAI-PMH kompatibilisek, amely szabvány lehetővé teszi az adattárak egységes és egyidejű lekérdezését, valamint központi lekérdező felületre való aggregálását (Devarakonda, Palanisamy, Green, \& Wilson, 2011). Ilyen összesített regiszter például a brit OpenDOAR (University of Nottingham), az amerikai OAIster (University of Michigan) vagy a német BASE (Bielefeld Academic Search Engine - Universitätsbibliothek Bielefeld). Ezen gyüjtőoldalak mellett a European Science Foundation által müködtetett European Reference Index for the Humanities (ERIH Plus) adatbázist érdemes még kiemelnünk, mint a társadalomés bölcsészettudományok megfelelő minőségű időszaki kiadványait listázó portált. Ezen utóbbi adatbázis esetében a folyóiratoknak a bekerüléshez egy viszonylag szigorú kritériumrendszernek kell megfelelni: független bírálati rendszer, a szerkesztőbizottság tagjainak feltüntetése a folyóirat honlapján, affiliációk és elérhetőségek feltüntetése a cikkeken, 
angol nyelvü absztraktok, ISSN szám, egy intézményhez köthető szerzők megfelelő aránya. Összesen 7232 folyóirat alapvető adata szerepel az adatbázisban, míg a neveléstudomány szűkebb területéről 1048 folyóirat olyan adatai találhatóak meg, mint az alapítás dátuma, ISSN, nyelv, ország, kiadó, tudományterületi besorolás, státusz, bírálati rendszer.

Az MTA KIK kezdeményezése nyomán létrejött a magyar minősített repozitóriumokat és az OJS platform alatt üzemelő elektronikus folyóiratokat közösen kereső szolgáltatás is (Holl, 2017) OAI kereső néven. A repozitóriumok mellett a szerzői archiválás jóval kevésbé hatékony módját jelenti, amikor a szerző a saját vagy intézete honlapján, esetleg valamely tudományos szociális hálózaton (ResearchGate, Academia.edu) keresztül teszi elérhetővé tudományos munkásságát. Az így közzétett dokumentumok kevésbé láthatóak és hitelesek, mintha az elterjedt intézményi és diszciplináris repozitóriumokban történik az archiválás. A legszerencsésebb megoldást valójában e rendszerek párhuzamos használata jelenti.

\subsubsection{A digitálisobjektum-azonosító (DOI), a szerzői azonosítók és a tudományos szociális} hálózatok jelentősége

A DOI (Digital Object Identifier) az elektronikus dokumentumok körében használt egyedi azonosító rendszer, amelyet a folyóiratok világszerte alkalmaznak a cikkek interneten elérhető elektronikus változatainak megjelölésére (Paskin, 2010). A hazai gyakorlatban ilyen azonosítókat a Crossref és a DataCite nemzetközi ügynökségen keresztül lehet igényelni, általában valamely DOI irodát müködtető könyvtáron keresztül (pl. az MTA KIK és az SZTE Klebelsberg Könyvtár is kínál ilyen szolgáltatást). A DOI egy állandó azonosító, tulajdonképpen az egyes publikációkra lehet linkelni rajta keresztül, és ezek a link-kapcsolatok korrigálás után akkor is a dokumentumra mutatnak, ha az eredeti dokumentumot esetleg más helyre költöztették. Az azonosító igazából átirányítja a látogatót az adatbázisban az azonosítóhoz kapcsolt URL-re, ezzel olyan állandóságot és megbízhatóságot nyújtva, amelyre valóban szükség van a tudományos publikálás során (Holl, 2013b). A DOI használatának pozitív gyakorlata elérte a hazai neveléstudományt is, hiszen a tudományág meghatározó lapjai (Magyar Pedagógia, Iskolakultúra) a 2015-ös évtől kezdődően elkezdték annak használatát.

Az egyes publikációk azonosítása mellett legalább ilyen fontos azok szerzőinek azonosítása. A hatalmas online adatbázisok és az ott alkalmazott automatikus adatkinyerés megjelenésével újra előtérbe került az egyes szerzők megbízható azonosításának kérdése. A hibás alakok, elírások és a karakterek rossz felismerése mellett legalább ugyanakkora problémát okoznak a tulajdonképpen nem hibából eredeztethető névazonosságok, névváltozatok és 
esetleges időközbeni névváltoztatások. Az itt felsoroltak a problématér leggyakrabban előforduló és leghangsúlyosabb kérdéseit jelentik.

A későbbiekben részletesen tárgyalt tudományos értékelés esetében kiemelt szerep jut a szerzők megbízható azonosításának, hiszen a nem összetartozó eredmények hibás összevonódása, vagy ennek fordítottja, az egyként értelmezendő entitások szétesése nem teszi lehetővé a szerzők megbízható tudományos értékelését. Többek között ennek a problémának a kiküszöbölésére jött létre a szerzők önálló azonosítását lehetővé tévő rendszer, az ORCID (Open Researcher and Contributor Identifier), amely a kutatók egyértelmü azonosítását biztosító, nemzetközileg elfogadott szerzői azonosító kód (Thomas, Chen, \& Clement, 2015). Az ORCID használatával elkerülhető az azonos, gyakori nevü szerzők munkásságának keveredése, kezelhetővé válnak a különböző névalakok használatából vagy névváltozásból eredő problémák, egyúttal megkönnyíti az automatikus adatfeldolgozást az indexelő adatbázisokban (például a disszertáció szerzőjének saját ORCID azonosítója: 0000-0002-83912851). Egyre több kiadó teszi kötelezővé az ORCID használatát, sok esetben ennek megadása nélkül már nem is fogadnak be kéziratot (MTA KIK, 2017). A probléma bonyolultságát mutatja, hogy sajnos nem az ORCID a tudományos élet egyetlen szerzői azonosítója, hiszen emellett léteznek további azonosítók is, például: Scopus Author ID, Clarivate ResearcherID, ResearchGate ID, Google Scholar ID, MTMT ID, stb.

Az általában az akadémiai szféra által létrehozott és működtetett repozitóriumi hálózat mellett létrejött néhány, az üzleti szféra által üzemeltetett, a tudományos eredmények megosztását és a tudósok egymás közötti kapcsolatépítését lehetővé tévő portál is, mint például a ResearchGate vagy az Academia.edu (Ovadia, 2014). Ezek a tudományos közösségi hálózatok (angolul az Academic Social Networks elnevezéssel és az ASN rövidítéssel hivatkoznak rájuk) egyszerre több, kutatók által igényelt szolgáltatást is megpróbálnak kielégíteni a dokumentumokhoz való szabadabb hozzáférés biztosításán keresztül, illetve azáltal, hogy kommunikációs és kollaborációs lehetőséget biztosítanak a normál közösségi hálózatok esetében megszokott vagy ahhoz hasonló funkciókon keresztül. Nem szabad elfelejtenünk, hogy alapvetően üzleti vállalkozásokról van szó, ahol az elsődleges szempont a profittermelés, így a funkciók egy része csak az előfizetéses verziókon keresztül érhető el. A hivatalos tudományos kommunikációban betöltött szerepük még nem teljesen tisztázott, mindenesetre annyi bizonyos, hogy kutatók milliói használják őket nap mint nap. A legfrissebb kutatások alapján (Laakso, Lindman, Shen, Nyman, \& Björk, 2017) aktív használatuk számos előnyt biztosít a kutatói közösség felé; mindenesetre a valóban hosszú távú, biztos megőrzés érdekében használatuk mellett mindenképpen érdemes igénybe venni a hivatalos utat is, azaz az intézményi és diszciplináris repozitórumi hálózatot. 


\subsection{Nemzetközi trendek}

\subsubsection{A neveléstudomány fö szervezetei és a folyóiratok kialakulása}

A tudománnyá válás feltétele a tudományos közösség kialakulása, majd a kutatási eredmények különböző tudományos fórumokon történő rendszeres megvitatása (Price, 1979). A neveléstudomány esetében az American Educational Research Association (AERA) a világon elsőként teremtette meg a tudományág színtereit és tömörítette egységbe a pedagógia kutatóit (Mershon \& Schlossman, 2008). Az 1916-ban alapított AERA fó célja a neveléstudomány és a társtudományok kutatóinak összefogása, a szakma kommunikációjának javítása, a tudományterület érdekeinek képviselete, a kutatási eredmények terjesztése és a gyakorlatba történő átültetésének elősegítése.

Ennek megfelelően az AERA összesen hét magasan elismert, lektorált folyóiratot jelentet meg, ezek a következők: AERA Open, American Educational Research Journal, Educational Researcher, Review of Educational Research, Educational Evaluation and Policy Analysis, Journal of Educational and Behavioral Statistics és Review of Research in Education. A folyóiratok mindegyike anonim bírálati ('peer review') rendszerben müködik. Ezek közül kettőt külön is érdemes kiemelnünk, a társaság legrégebbi múltra visszatekintő folyóirataként a Review of Educational Research címüt, amely 1931-ben indult el, és az AERA Open címüt, amely, megfelelve az új idők szavának, már Open Access alapokon müködik. Az AERA folyóiratok többsége egyébként az 1970-es években indult el (Hódi \& Tóth, 2012).

Az európai társszervezet esetében időben jóval eltolódtak az események. Ennek oka egyrészt a kontinens megosztottsága, másrészt, hogy az európai kutatók egy része korábban már bekapcsolódott az AERA munkásságába. Az European Association for Research on Learning and Instruction (EARLI) megalapítását mégis az európaiság határozottabb kifejezésének igénye, illetve az európai kutatók közötti közvetlenebb kommunikáció megteremtésének igénye tette lehetővé (Csapó, 1997). A szervezetet 1985-ben alapították, székhelye Hollandiában található, az alapító tagok a legelső, meghívásos konferenciát ugyanebben az évben, Leuvenben tartották, mintegy százötven kutató részvételével (Csíkos, Józsa, Korom, \& Tarkó, 1997). Az alapítás óta eltelt idő alatt mind a tagok létszáma, mind pedig nemzetiségi összetétele jelentősen megváltozott. Míg kezdetben a tagok elsősorban a nyugat-európai vezető kutatók közül kerültek ki, az ezredfordulóra az EARLI egy olyan európai szervezetté vált, amelynek mind az öt kontinensről vannak tagjai (Korom, 1997).

Az EARLI legjelentősebb folyóirata az 1991-ben elindult Learning and Instruction, 
amely rövid idő alatt felvette a versenyt az amerikai versenytársakkal (vö. a folyóiratok 1. táblázatban ismertetett impakt faktorára vonatkozó adatait). További jelentős EARLI folyóiratok az Educational Research Review és a Frontline Learning Research, amely utóbbi szintén az Open Access modell szerint müködik. Az EARLI felvállaltan könyvsorozatokat is megjelentet, és az Elsevier kiadóval közreműködésben rendelkezik két, úgynevezett 'affiliated journal'-lel is: Learning, Culture and Social Interaction és Studies in Educational Evaluation (European Association for Research in Learning and Instruction, 2014).

\subsubsection{Tudománymetriai szempontból jelentős nemzetközi folyóiratok}

Csíkos Csaba (2013) a Thomson Reuters (2016-ban a Clarivate Analytics akvirálta a cég tudománymetriai üzletágát) Journal Citation Reports (JCR) adatbázisa alapján elemezte, hogy hány darab impakt faktoros folyóirat létezik a neveléstudomány területén. Egy szükebb kategóriát különböztet meg: oktatás és neveléstudományi kutatások ('Education \& Educational Research') és két tágabbat: oktatás, tudományos diszciplínák; oktatás, speciális ('Education, Scientific Disciplines'; 'Education, Special'). A cikk megjelenése óta az egyes kategóriákban található folyóiratok száma nem igazán változott. Az 'Education \& Educational Research' kategóriában jelenleg (2017 JCR Year) 238 darab folyóirat található, míg a föként természettudományos és orvosképzéssel foglalkozó 'Education, Scientific Disciplines' kategóriába 41 darab folyóirat került besorolásra, az 'Education, Special' kategóriában pedig ennél eggyel kevesebb, 40 darab folyóirat található.

Szolid mennyiségi bővülésről beszélhetünk tehát az eddig eltelt időszakban. Mindezek mellett, kapcsolódó tematikus kategóriaként említést kell még tennünk a ’Psychology, Educational' kategóriáról is, ebben további 59, az oktatáshoz valamilyen módon kapcsolódó folyóirat található jelenleg. Az 1. táblázat a legfőbb minőségi változók mentén tekinti át az 'Education \& Educational Research' kategória élmezönyét (Clarivate Analytics, 2017). Ez alapján megállapítható, hogy a toplistában több folyóirat is a két jelentős nemzetközi neveléstudományi szervezethez köthető. Az első helyezett például az AERA legrégebbi kiadványa, a Review of Educational Research. A negyedévente megjelenő folyóirat kritikai és interdiszciplináris szakirodalmi áttekintéseket ismertet a neveléstudomány és a társtudományok köréből. A hatodik helyezett Educational Researcher, amelyet 1971-ben alapítottak, évente kilenc alkalommal jelenik meg. A folyóirat a közérdeklődésre leginkább számot tartó témákban közöl tudományos eredményeket, illetve rendszeresen beszámol az AERA legnagyobb jelentőségü projektjeiről. 
1. táblázat. A JCR 'Education and Educational Research' kategória impakt faktoros folyóiratai 2017 [Forrás: http://jcr.incites.thomsonreuters.com]

\begin{tabular}{|c|c|c|c|c|c|c|}
\hline$\#$ & Folyóirat & $\begin{array}{l}\text { Háttérszer- } \\
\text { vezet }\end{array}$ & Kiadó & $\begin{array}{c}\text { Összes } \\
\text { hivatkozás }\end{array}$ & $\begin{array}{l}\text { Impakt } \\
\text { faktor }\end{array}$ & $\begin{array}{c}\text { Eigenfac- } \\
\text { tor }^{*}\end{array}$ \\
\hline 1. & $\begin{array}{l}\text { Review of } \\
\text { Educational } \\
\text { Research }\end{array}$ & AERA & SAGE & 8640 & 8,241 & 0,005220 \\
\hline 2. & $\begin{array}{l}\text { Internet and Higher } \\
\text { Education }\end{array}$ & & Elsevier & 2431 & 5,847 & 0,002810 \\
\hline 3. & $\begin{array}{c}\text { Educational } \\
\text { Research Review }\end{array}$ & EARLI & Elsevier & 1218 & 4,973 & 0,002600 \\
\hline 4. & $\begin{array}{c}\text { Computers \& } \\
\text { Education }\end{array}$ & & Elsevier & 13146 & 4,538 & 0,016050 \\
\hline 5. & $\begin{array}{l}\text { Educational } \\
\text { Psychologist }\end{array}$ & APA & $\begin{array}{c}\text { Taylor \& } \\
\text { Francis }\end{array}$ & 5128 & 4,488 & 0,003840 \\
\hline 6. & $\begin{array}{l}\text { Educational } \\
\text { Researcher }\end{array}$ & AERA & SAGE & 6755 & 4,000 & 0,006400 \\
\hline 7. & $\begin{array}{l}\text { Learning and } \\
\text { Instruction }\end{array}$ & EARLI & Elsevier & 4879 & 3,967 & 0,007290 \\
\hline 8. & $\begin{array}{l}\text { Metacognition and } \\
\text { Learning }\end{array}$ & & Springer & 801 & 3,706 & 0,001430 \\
\hline 9. & $\begin{array}{c}\text { Studies in Science } \\
\text { Education }\end{array}$ & & $\begin{array}{l}\text { Taylor \& } \\
\text { Francis }\end{array}$ & 627 & 3,455 & 0,000510 \\
\hline 10. & $\begin{array}{c}\text { International Journal } \\
\text { of Computer- } \\
\text { Supported } \\
\text { Collaborative } \\
\text { Learning }\end{array}$ & $\begin{array}{l}\text { International } \\
\text { Society of the } \\
\text { Learning } \\
\text { Sciences }\end{array}$ & Springer & 721 & 3,273 & 0,000680 \\
\hline
\end{tabular}

A friss eredményeket összevetve Hódi és Tóth (2012), Csíkos (2013), illetve Nagy (2016) adataival, az idősorból megállapítható, hogy az eltelt időben a Journal Citation Reports listáján jelentősebb átrendeződések is lezajlottak az elemzett kategóriában. Megjegyzendő, hogy az 'Education \& Educational Research' kategória listájának végén sokszor nem angol nyelvü, nemzetközi viszonylatban kevésbé tekintélyes, ugyanakkor egy-egy ország jelentősebb neveléstudományi folyóiratai helyezkednek el, ilyenek például a Revista Española de Pedagogía, az Eğitim ve Bilim vagy a Hrvatski časopis za odgoj i obrazovanje címü lapok (Clarivate Analytics, 2017). Ezen feltörekvő folyóiratok listákon való megjelenése figyelemre méltó, ugyanakkor még ezzel együtt is mindig nagyon távol vagyunk egy magasabb szintü lefedettség elérésétől.

\footnotetext{
* A metrika hátteréről bővebben: http://www.eigenfactor.org
} 
Az eddig megjelent neveléstudományi vonatkozású, hazai elemző tanulmányok eddig kevésbé vették számításba a versenytárs Elsevier tartalomszolgáltató óriás Scopus adatbázisán alapuló SCImago Journal Rank (SJR) listát, pedig ez a jegyzék napjainkban felnőtt a JCR mellé, sőt, bizonyos vonatkozásaiban túl is szárnyalja azt. Jelentősen több folyóirat szerepel benne, jelenleg körülbelül 34200, míg a JCR listáján majdnem csak harmadannyi cím, jelenleg körülbelül 12300. A tudományterületek között is komoly lefedettségi különbségek adódnak, a társadalom- és humántudományok esetében az SJR erősebbnek bizonyul. Ezért számos mértékadó tudománymetriai elemzésben már inkább ezt a folyóiratrangsort használják (Leydesdorff, de Moya-Anegón, \& de Nooy, 2016). A 2. táblázatban a SCImago lista (2017 SJR Year) 'Education' kategóriájának első 10 tételét közöljük, mely jól összehasonlítható az 1. táblázat megfelelő soraival. Az SJR 'Education' kategóriájában jelenleg összesen 1025 folyóirat szerepel, amely egyébként hasonló arányokat tükröz, mint a két adatbázisban található összes folyóirat számaránya.

2. táblázat. A SCImago Journal Rank Education kategória folyóiratai 2017 [Forrás: https://www.scimagojr.com]

\begin{tabular}{|c|c|c|c|c|c|c|}
\hline$\#$ & Folyóirat & Háttérszervezet & Kiadó & $\begin{array}{c}\text { Összes } \\
\text { hivatkozás } \\
\text { (3 év) }\end{array}$ & $S J R$ & $\begin{array}{c}H- \\
\text { index }\end{array}$ \\
\hline 1. & $\begin{array}{l}\text { Research Synthesis } \\
\text { Methods }\end{array}$ & $\begin{array}{l}\text { Society for } \\
\text { Research } \\
\text { Synthesis } \\
\text { Methodology }\end{array}$ & Wiley & 408 & 3,774 & 16 \\
\hline 2. & $\begin{array}{c}\text { Review of Educational } \\
\text { Research }\end{array}$ & AERA & SAGE & 596 & 3,719 & 126 \\
\hline 3. & Educational Researcher & AERA & SAGE & 687 & 3,473 & 94 \\
\hline 4. & Learning and Instruction & EARLI & Elsevier & 958 & 3,432 & 90 \\
\hline 5. & $\begin{array}{l}\text { Internet and Higher } \\
\text { Education }\end{array}$ & & Elsevier & 666 & 3,347 & 66 \\
\hline 6. & Sociology of Education & $\begin{array}{l}\text { American } \\
\text { Sociological } \\
\text { Association }\end{array}$ & SAGE & 205 & 3,203 & 75 \\
\hline 7. & $\begin{array}{c}\text { Studies in Science } \\
\text { Education }\end{array}$ & & $\begin{array}{l}\text { Taylor } \\
\& \\
\text { Francis }\end{array}$ & 69 & 3,111 & 35 \\
\hline 8. & $\begin{array}{l}\text { Journal of Second } \\
\text { Language Writing }\end{array}$ & & Elsevier & 242 & 3,066 & 60 \\
\hline 9. & $\begin{array}{c}\text { Educational Evaluation and } \\
\text { Policy Analysis }\end{array}$ & & SAGE & 307 & 3,055 & 63 \\
\hline 10. & Scientific Data & & Nature & 1514 & 3,026 & 26 \\
\hline
\end{tabular}




\subsection{Hazai trendek}

\subsubsection{Jelentős hazai folyóiratok}

Az oktatásüggyel és neveléssel kapcsolatos tudományos tevékenységnek hazánkban legalább száznegyven éves múltja van (Nagy, 2011). A magyarországi neveléstudomány intézményesült formájának művelése az 1891-ben megalakult Magyar Paedagogiai Társasághoz köthető (Klamarik \& Suppán, 1892). A következő évben már a társaság saját folyóiratát, a Magyar Paedagogiát is elindították.

Már a Magyar Paedagogia előtt is léteztek más, elsősorban nem tudományos igényeket kielégítő folyóiratok. A neveléstörténeti kutatások keretében részletes áttekintésre került a legjelentősebb hazai pedagógiai folyóiratok története, tehát egy jól feltárt és kutatott területről beszélhetünk (Szabolcs, 1999; Németh \& Biró, 2009; Géczi, 2010). A folyóiratok számossága a kiegyezéstől kezdődően folyamatosan magas volt, Géczi (2010) tanulmánya szerint a 19-20. század fordulóján kb. 700 (a tanulmányban tévesen 7000 szerepel) pedagógusra esett egy folyóirat. A pedagógusok számának növekedésével lépést tartott a folyóiratok számának növekedése is: 1890-ben kb. 36000 tanügyi munkatársra 49 darab, míg tíz évvel később, 1900ban 43000 pedagógusra 59 darab folyóirat jutott. Géczi (2007) megerősíti a konszenzust, hogy az első számú, a tudományos közlésmód igényeit leginkább kielégítő folyóirat a Magyar Paedagógia. A folyóirat ezen kiemelt szerepe a későbbiekben is fennmarad, színvonalát tulajdonképpen több, mint százéves története alatt mindvégig tartani tudja.

A rendszerváltást követően, a kilencvenes évektől kezdődően szűkebb értelmezés szerint a neveléstudományt négy tudományos igényü folyóirat uralta, amely hatás többé-kevésbé a mai napig érvényesül, mivel ezek a lapok még mindig mértékadóan befolyásolják a szakmai diskurzus fő vonalait. Ez a megállapítás egybeesik az MTA Pedagógiai Bizottságának korábbi állásfoglalásával, mely szerint ezek a folyóiratok a következők: a Magyar Pedagógia, az Educatio, az Iskolakultúra és az Új Pedagógiai Szemle (Biró, 2009a). Az utóbbi három kiadvány története a szocializmus nevelésirányításáig nyúlik vissza, általában egy-egy jelentősebb szakmai mühelyt reprezentálva (Németh \& Biró, 2009). A vezető folyóiratok rangsorát az empirikus hivatkozásvizsgálatok is megerősítették (Tóth, Toman, \& Cserpes, 2008; Pap, 2009). Ugyanakkor, mint Hérakleitosztól tudjuk „semmi sem állandó, csak a változás maga", ezért nem mehetünk el az elmúlt tíz évben lezajlott, folyóiratokat érintő átalakulások melett sem. Ilyen változás volt például az Új Pedagógiai Szemle néhány évvel ezelőtti jelentős profilváltása. 
Legalább ennyire fontos kiemelni, hogy a neveléstudomány területén a felsoroltak mellett létezik még jó néhány feltörekvő folyóirat, amelyek későbbi indulásuk miatt egyelőre még nem rendelkeznek olyan múlttal, mint a négy kiemelt nagy folyóirat (így például a hivatkozásfókuszú empirikus kutatásokban még kevésbé tudnak megjelenni); ettől függetlenül mindenképpen pozitív tendenciaként kell megemlítenünk létrejöttüket és folyamatos megjelenésüket. Álljon itt tehát néhány közülük, a teljesség igénye nélkül: Neveléstudomány: oktatás - kutatás - innováció (2013-); HERJ Hungarian educational research journal (2011-); Opus et Educatio (2014-); Oktatás-Informatika (2009-2015); Könyv és nevelés (1998-tól új folyammal). A felsorolt címek kivétel nélkül szerepelnek az MTA II. Filozófiai és Történettudományok Osztályának doktori eljárásra vonatkozó követelményei között szereplő folyóiratlistájában (MTA Pedagógiai Tudományos Bizottság, 2013). Ezek a folyóiratok egy szerves fejlődés keretében egyre inkább bekapcsolódnak a szakmai kommunikációba, ezt figyelembe véve pedig idővel fokozatosan átrendeződhet a domináns orgánumok száma és sorrendje.

\subsubsection{Pedagógiai folyóiratok a digitális térben}

Napjainkra a társadalomtudományok esetében is eljutottunk oda, hogy a formális és informális szakmai kommunikáció nagyobb része kizárólag a hálózaton zajlik (Szécsi, 2016), emiatt komoly pragmatikus és presztízsértéke van annak, ha egy neveléstudományi folyóirat méltó módon és hatékonyan láttatni tudja magát a virtuális térben. A szakirodalom szerint kimutathatóan magasabb azon cikkek hivatkozási aránya, amelyek olvashatóak az interneten (Moed \& Halevi, 2016). A tudománymetria müködésének szempontjából pedig egyenesen elengedhetetlen a teljes szövegü adatbázisok megléte (Meho \& Yang, 2007).

Ezeket a trendeket követve az elmúlt évtizedekben több hazai neveléstudományi folyóirat vált hozzáférhetővé az interneten ilyen formában: sok esetben nem csupán az újonnan megjelent lapszámok elektronikus közléséről beszélhetünk, hanem retrospektív, illetve történeti jelentőségű archívumokról is (Veroszta, 2013). A bevett gyakorlat egyelöre még inkább a folyóirat saját oldalán történő nyilvánosságra hozatal (pl. az Educatio és az Új Pedagógiai Szemle esetében), de a repozitálásnak is vannak már eredményei (pl. az Iskolakultúra és Magyar Pedagógia archívumai az MTA KIK REAL és az SZTE Klebelsberg Könyvtár Contenta rendszerében). Az Iskolakultúra folyóirat esetében legalább ekkora horderejü, pozitív végkicsengésű fejleménynek tekinthető a folyóirat közelmúltbeli OJS platformra való költözése. A Magyar Pedagógia esetében - jelen kutatási projekt keretében - tervezetten 
elkészült a folyóirat mindenre kiterjedő digitalizálása, teljes szövegü adatbázisba szervezése, továbbá a részletes tartalmi feltárást is magában foglaló analitikus feldolgozása. A Magyar Pedagógia olvasói a hazai folyóiratok között egyedülálló módon a folyóirat tartalmát több, párhuzamos csatornán is olvashatják az interneten:

- A folyóirat hivatalos oldalán (www.magyarpedagogia.hu) 1991-től kezdve, a tudományos igényü tanulmányokat illetően (a Szemle és a Könyvismertetések rovat tartalma nem szerepel az oldalon). Az archívumban visszakeresésre nincsen lehetőség.

- A legteljesebb (1892-2017) és legrészletesebb (teljes szövegü kereshetőség és tárgyszavazás) feldolgozottság mellett az SZTE Contenta Miscellanea gyüjteményében.

- Az Arcanum Digitális Tudománytárban, az 1892 és 2010 közötti évfolyamokat tekintve. A teljes szövegü visszakereshetőség biztosított, analitikus feltárás viszont nincs.

- A REAL-J repozitóriumban 1892 és 2017 között, teljes évfolyamonként feldolgozva, teljes szövegü keresés funkcióval.

Összességében elmondható, hogy a neveléstudomány digitális térben való reprezentálódását illetően komoly eredményeket sikerült elérni az utóbbi időszakban. Mindez előremutató fejleményként értelmezhető, és a tudományág megfelelő adaptációs képességét mutatja a megváltozott körülményekhez, hiszen nem minden tudományág vezető folyóiratai érhetőek el ilyen módon, azonban még szerencsésebb lenne a jelentősebb folyóiratok közös adatbázisba szervezése, mert így „együttkereshetővé” válnának ezek a kiadványok (Kokas, 2014), ennek minden járulékos hasznával együtt.

\subsection{A hazai és nemzetközi folyóiratok szerepe a tudományos kommunikációban}

Figyelembe véve az eddig tárgyalt folyamatokat, felmerülhet a kérdés, hogy tulajdonképpen miért van szükség nemzeti nyelvü tudományos folyóiratokra. Milyen szerepet töltenek be ezek a tudományos médiumok egy ország tudományos életében? A teljes problémakört rendkívül alaposan körüljárja Csapó Benő (2005) tanulmánya, amely éppen a saját kutatási témánk tárgyául szolgáló Magyar Pedagógia folyóirat helyét és szerepét keresi a hazai tudományos palettán, választ adva ezzel jó néhány, a neveléstudomány határain túlmutató kérdésre is. A tanulmány következtetései általános tanulságokkal szolgálnak a nemzeti nyelvü folyóiratok tudományos kommunikációban betöltött szerepét illetően. 
A Magyar Pedagógia főszerkesztője írásának bevezetőjében a következő kérdések szerepelnek: „Milyen funkciót látnak el e folyóiratok a neveléstudományban? Az eredményeit közzétenni kész kutatóréteg közösségi megnyilvánulási terei vagy a tudományos ismeretterjesztés helyei? Esetleg nem a kutatások, hanem a fejlesztések és alkalmazások eredményeinek nyilvánosságot adó mühelyek? Milyen kritériumok szerint szerkesztik ezeket a lapokat? Osztályozhatunk-e úgy, hogy egyesek a tudományt szolgálják, némelyek a gyakorlati tevékenységet támogatják, míg mások az oktatáspolitika közvetítői? Melyek azok a szempontok, amelyek a szaklapokat, azok egyes évfolyamait, tematikus számait alakítják?" (Csapó, 2015, p. 3)

Ahogyan azt Csapó lényeglátóan megfogalmazza, valójában két ellentétes érdeket kell összeegyeztetni. Egyrészt a hazai kutatóknak szüksége volna a minél több nemzetközi publikációra, hiszen a valódi rangot és elismerést csak ez hozhatja meg a számukra. Munkájukkal úgy tudják elérni a legnagyobb közönséget, ha azt nemzetközi folyóiratokban publikálják; egyúttal a nemzetközi publikálás jelentős megmérettetést jelent, ami nagyban hozzájárulhat a kutatók egyéni fejlődéséhez is. Ugyanakkor legalább ennyire fontos szempont, hogy a magyar tudománynak több okból is szüksége van a magyar nyelven megjelenő szaklapokra.

Talán a legfontosabb ilyen ok a magyar nyelvű szaknyelvi szókincs megteremtése (Csapó 2007). Egyes nem angol anyanyelvü országokban (pl. a skandináv államok) a tudomány, és bizonyos esetekben a felsőoktatás egyre inkább az angol nyelv használata felé tolódik (Kuteeva \& Airey, 2014). Ez számos kérdést és problémát felvet, ezek közül Csapó (2015) a következőt emeli ki: „Az egyes országokban egy-egy diszciplína változó távolságra van a nemzetközivé válástól, a nemzetközi tudományos kommunikációba való teljes értékű bekapcsolódástól. [...] Ma már reális probléma, hogy a fiatal kutató-generáció mind kevésbé akarja eredményeit anyanyelvén publikálni. Ez egy szűkebb körü specialistákat érintő tudományágnál nem okozhat gondot. Azonban egy olyan diszciplína esetében, mint a neveléstudomány, melynek szóhasználatát, beszédmódját a kutatókon, fejlesztőkön túl legalább a tanárok egy részének is ismernie kell, feltétlenül szükséges, hogy az anyanyelven megjelenjenek a legigényesebb tudományos munkák is. A kis nyelveken megjelenő folyóiratok funkciói valószínüleg a nemzeti identitás, a nyelvi és kulturális sokféleség megőrzésének irányába fognak eltolódni.” (Csapó, 2015, p. 6-7)

Az ellentétes érdekek összehangolását biztosíthatja az a megközelítés, hogy a nemzeti nyelvü folyóiratokra mintegy gyakorlóterepként, a nemzetközi publikációs térbe való belépés előszobájaként tekintünk. A pályájuk kezdetén lévő PhD-hallgatók és kezdő tudósok számára 
rendkívül fontos, hogy legyenek olyan publikációs terek, ahol a szerves fejlődésük kezdetibb szakaszában lévő anyagaikat meg tudják jelentetni a hazai közönség felé. Ezeket a munkákat a nemzetközi folyóiratok csak ritkán fogadnák be, azonban a hazai folyóiratok teret adva számukra elősegíthetik a későbbiekben a nemzetközi mezőnyben megjelenni szándékozó közösség kialakulását, épülését azáltal, hogy hasonló sztenderdek alapján müködnek, mint a nemzetközi lapok, felkészítve ezáltal a szerzőket a globális megmérettetésre. A nemzetközi publikációs termés még akár egy szükebb diszciplína esetében is jóval nagyobb nagyságrendet jelent, amely szinte lehetetlenné teszi a magyar szerzők munkájának nyomon követését. Ezzel szemben a hazai tudományos folyóiratok világa jóval szerényebb, így itt reálisabb esély kínálkozik az egy-egy diszciplínán belüli publikációs termés teljesebb nyomon követésére. A nemzeti nyelvű lapok publikációs fórumot biztosítanak a közlésre, amelynek a befogadói (olvasói) oldalról is nagy jelentősége van. 


\section{INTERDISZCIPLINÁRIS ESZKÖZTÁR}

\subsection{Tudománymetria}

\subsubsection{A tudománymetria alapkérdései}

„Mérd meg, ami mérhető, és tedd mérhetővé, ami nem az!” (Galilei) A kvantitatív nézőpont megjelenése a neveléstudományokban korszakalkotó jelentőségü volt. Egy teljesen új kutatási irányzat jelent meg a palettán, megteremtve a mérés-értékelési megközelítést, amely kutatási szemlélet azóta is vezető szerepet tölt be mind a nemzetközi (Winters, Wise, \& Towne, 2005), mind a hazai neveléstudományban (Molnár \& Pásztor, 2012). Ez a fajta mérés-értékelési típusú megközelítés nem a neveléstudomány sajátja. A tudományos eredmények értékelését tekintve ez a szemlélet időben tulajdonképpen megelőzte a módszer neveléstudományon belüli széleskörü elterjedését és kiteljesedését. A tudománymetria (scientometrics) terminus eredete ugyanis az 1960-as évekre nyúlik vissza és Vassily V. Nalimov nevéhez köthetö; a tudományos teljesítmény sokszor igen összetett és sokrétü mérését értjük alatta.

A tudományág fejlődésében meghatározó szerepet töltött be Derek J. de Solla Price (Price, 1979), Robert K. Merton (Merton \& Garfield, 1986) és Eugene Garfield (Garfield \& Merton, 1979; Garfield, 2009). Az önálló diszciplínává válásban döntő jelentősége volt a Scientometrics folyóirat 1978-as alapításának, illetve néhány jelentős publikáció megjelenésének (lásd Elkana, 1978), továbbá a folyóirat-alapító szerkesztő, Braun Tibor szerteágazó munkásságának (Moravscik, 1987). Az 1970-es évek vége produktív időszak volt az alapok lefektetését illetően. A következő felívelő szakasz a 2000-es évekre tehető, amely főként az informatika által nyújtott lehetőségek kiszélesedésén alapult (lásd Leydesdorff, 2008; Lane, 2010; González-Pereira, Guerrero-Bote, \& Moya-Anegón, 2010; Guerrero-Bote \& Moya-Anegón, 2012).

A Scientometrics folyóirat szerkesztőbizottságában több magyar kolléga is képviseltette és képviselteti magát, ami hozzájárulhatott ahhoz, hogy a magyar tudományszervezés komolyan beemelte eszköztárába a tudománymetriát. A tudománymetria egy önálló metadiszciplínának tekinthető, a tudomány egészét próbálja vizsgálni, mérni és értékelni (Glänzel, 2009). Hazánkban ez a folyamat az utóbbi időben elsősorban a Magyar Tudományos Müvek Tára körül csúcsosodott ki (Csaba, Szentes, \& Zalai, 2014), míg nemzetközi vonalon a nagy tartalomszolgáltató konglomerátumok tudománymetriai elemző ökoszisztémája (Clarivate Analytics - WoS, JCR, Incites; Elsevier - Scopus, SJR, SciVal) jelenti napjainkban az alkalmazott megoldások egyik fő sodrát. 
A kvantitatív paradigma 20. századi megjelenése a neveléstudományon kívül több társadalomtudományt is érintett. Ez a folyamat az ún. „kemény tudományok” felől haladt a „puha tudományok” felé, azaz a természettudományok területéről indult, amit az alkalmazott tudományok, a társadalomtudományok, majd a bölcsészettudományok területe követett. Hasonló terjedési irány figyelhető meg a tudománymetria alkalmazása esetében is. Napjainkra a bölcsészettudomány képviselői felé is elvárásként fogalmazódik meg a tudománymetriai szempont figyelembevétele a tudományos pálya objektív értékelésében (Nagy, 2016b).

Mindemellett a bölcsészet-, társadalom- és természettudományok esetében komoly eltérések és különbözőségek is adódnak: ilyenek a müfaji sokszínüség, illetve a nemzetközi tudomány kontextusában való érvényesíthetőség lehetőségei (Tóth, 2016). Ezen szempontokat természetesen mind szükséges figyelembe venni a tudományos eredmények tárgyilagos értékelése kapcsán (Tüskés, 2013). A rövid történeti kitekintő után áttekintjük a tudománymetria mai helyzetét és az általa felvetett aktuális kérdéseket. Napjainkra a tudománymetria a kutatók folyamatos értékelésének eszközévé vált, és egyre inkább financiális hatása van a támogatási összegekkel kapcsolatos döntések során. A tudománymetria központi, meghatározó gondolata az idézettség ('citation'), ennek privilégiumát jól jelzi, hogy az idézettséget a tudomány valutájaként szokták emlegetni (Glänzel, 2009).

A bibliometriából kialakuló tudománymetria napjainkban is folyamatosan fejlődik, ennek egyik bizonyítéka, hogy megjelent az 'altmetrics' fogalma, amely már nem csupán a tudományos közlés hivatalos formáit hivatott vizsgálni, hanem bármilyen, a tudós munkája által kiváltott hatástényezőt (Priem, Piwowar, \& Hemminger, 2012). Ez a hatás lehet a hagyományos közösségi média felségterületén elért megosztás, illetve bármilyen egyéb interakció. A mérés ezen új szintje logikus lépésként következik a tudománymetria kiterjesztéseként, az üzleti életből vett analógiák alapján, hiszen az általános cél döntően a tudományos világban is az elérés növelésében, a minél szélesebb közönséghez való eljuttatásban és valamilyen hatástényező kiváltásában rejlik. Jól illeszkednek ebbe a környezetbe az előző részben tárgyalt, kifejezetten a tudományos élet számára dedikált közösségi portálok, például a ResearchGate vagy az Academia.edu, amelyek legfőbb célja a kutatók és a kutatások láthatóságának növelése és az eredmények megosztása (Neal, 2012).

Scientometriai tanulmányok sora foglalkozik ezzel a tudományos láthatósággal ('scientific visibility'), ilyen például Monika Rehrl és munkatársainak írása (Rehrl, Palonen, Lehtinen, \& Gruber, 2014), amelyben beszámolnak arról, hogy az egyes kutatók tudományos hálózatban elfoglalt helye hogyan befolyásolja láthatóságukat, egyúttal kutatási projektjük helyét és presztízsét a tudományos életben. A legfontosabb trendeket és szabályszerüségeket az 
általuk végzett kutatás hivatott bizonyítani, amelyről részletes elemzést közölnek. Szintén népszerü kutatási témát jelent az utóbbi időben a fentiekben tárgyalt Open Access hatásának vizsgálata az idézettségre (Koler-Povh, Južnič, \& Turk, 2014; Asemi, 2010).

Nem mehetünk el a hivatkozási adatbázisok a tudományos kommunikáció átalakulási folyamatára kifejtett hatása mellett sem, hiszen ezek az adatbázisok a kezdetektől fogva főként a folyóiratok tudományos hatását próbálják mérni (Moed, 2009). Az utóbbi évtizedekben megjelent publikációs kényszer az összehasonlíthatóság igénye miatt, illetve a tudomány irányítóinak elvárásait tükrözve, a tudósokat minél magasabb mérőszámok elérésére sarkallja ezekben az adatbázisokban (Tóth, 2014). Öngerjesztő folyamatként az itt felvázolt jelenség szintén abba az irányba hat, hogy a rendelkezésükre álló erőforrásokat ebbe az irányba koncentrálják, azáltal, hogy olyan médiumokban publikáljanak, amelyek relevánsak a citációs adatbázisok számára. A három legjelentősebb szereplő ezen a területen a Web of Science, a Scopus és a Google Scholar adatbázisok (Bornmann, Thor, Marx, \& Schier, 2016). Természetesen ennek a típusú tudománymetriai megközelítésnek is megvan a maga árnyoldala, amelyet sok esetben éppen a területet müvelő, tudományméréssel és értékeléssel foglalkozó szakemberek fogalmaznak meg. A diskurzus szerteágazó és komplex mivolta miatt ezeket a kritikai aspektusokat a disszertáció keretei között nem kívánjuk tárgyalni. A témáról részletesen lásd a DORA néven elinduló kezdeményezést (San Francisco Declaration, 2013), Hicks, Wouters, Waltman, De Rijcke és Rafols (2015) Leiden Manifesto címü publikációját, illetve a tudományos teljesítmény értékelése körüli problémákról David és Frangopol (2015), illetve Schubert $(2018 ; 2015 b)$ írásait.

A Web of Science Eugene Garfield személyéhez köthető, aki 1955-ben alapította az Institute for Scientific Information (ISI) szervezetet, mely 1992-től a Thomson Reuters egyik divíziója volt, majd 2016-tól kezdve a Clarivate Analytics céghez kötődik. Garfield több más bibliometriai kezdeményezés mellett (Current Contents, Journal Citation Reports, Index Chemicus) a Science Citation Index (SCI) megalkotója volt (Garfield, 1955). Fél évszázad távlatából Garfield (2006) újra beszámolt az általa kitalált és létrehozott rendszer jelentőségéről. A versenytárs Scopus adatbázis az 1880-ban alapított holland gyökerű Elsevier kiadóhoz kötődik, ugyanakkor magának az adatbázisnak a múltja jóval rövidebb időtávra nyúlik vissza, mivel csak 2004-ben indították útjára, hasonlóan az itt most részletesebben nem tárgyalt Google Scholarhoz. A szakmai konszenzus alapján a Scopus gyors fejlődésének köszönhetően az Elseviernek sikerült utolérnie, sőt egyes mértékadó elemzések alapján, bizonyos részterületeken megelőznie a Web of Science (WoS) mintául szolgáló rendszerét (Harzing \& Alakangas, 2016). 
A tudományos értékelő adatbázisok és a hozzájuk kapcsolódó fél-automatizált értékelő rendszerek (InCites, SciVal) szakértő használatára felhívó általános figyelmeztetések mellett (Hicks, Wouters, Waltman, De Rijcke, \& Rafols, 2015), a két adatbázis minőségét, lefedettségét és a rendelkezésre álló eszközöket folyamatosan összehasonlítják, rávilágítva előnyeikre és hátrányaikra (Moed, 2017; Archambault, Campbell, Gingras, \& Larivière, 2009). A nemzetközi hivatkozási adatbázisokkal kapcsolatos szakirodalomból mindenképpen ki kell emelnünk az általános lefedettségi problémák közül (Krell, 2009) azt a motívumot, amely az egyik legfőbb kritika szokott lenni velük szemben, és amely egyúttal alátámasztja az általunk elvégzett kutatás létjogosultságát és relevanciáját, mégpedig az angol nyelvű lapok túlzott felülreprezentáltságát (Mongeon \& Paul-Hus, 2016; Alperin, 2014) és a nemzeti nyelvű tudományos lapok jóval szerényebb jelenlétét ezekben az adatbázisokban.

Sivertsen (2014) tanulmánya szerint a két vezető tudománymetriai adatbázis lefedettségi mutatói bizonyos tudományterületen nagyon alacsonyra tehetőek, ha a bennük elérhető adatok reprezentáltságát összehasonlítjuk a norvég kutatási információs rendszerben (Cristin) tárolt adatokkal. Eredményei alapján a Scopus a norvég felsőoktatási intézmények munkatársai által kibocsátott, lektorált folyóiratcikkek vagy valamilyen sorozatban megjelent tanulmányok 32\%át, míg a WoS csak 23\%-át tartalmazza a humán tárgyak esetében. A vonatkozó számok a társadalomtudományok esetében 54\%-ra és 42\%-ra, a szüken vett oktatás és neveléstudományi kategóriák esetében pedig 35\%-ra és 22\%-ra tehetőek a Scopus és a WoS esetében. A legtöbb ország esetében a norvég példához hasonló, vagy még rosszabb arányokat kapnánk egy kiterjedt vizsgálat során.

Szembenézve mindezekkel a trendekkel, az egyes országok, illetve tudományágak szakmai közösségeinek természetesen érdemes arra törekedniük, hogy az ezekben az adatbázisokban még nem reprezentált, de számukra nyelvi vagy intézményi szempontból fontos publikációs terepet biztosító hazai folyóiratok minőségét olyan szintre emeljék (például a publikációk bírálati és megjelentetési rendszerének fejlesztésével), hogy azoknak legyen esélye megmérettetni és esetlegesen bekerülni a mértékadó tudománymetriai adatbázisokba. Párhuzamosan ezzel a törekvéssel, legalább ennyire fontosnak látszik a „kimaradó” folyóiratok és kutatók számára - egyfajta alternatív lehetőségként - a nemzetközi ,jó gyakorlatból” kiinduló, hazai gyökerű megoldás adaptálása a hivatkozási adatbázisok technikai megoldásait, elemzési repertoárját és megközelítését illetően.

Ami a magyarországi intézményesített formában működő tudománymetriai szakmai műhelyeket illeti, ezek száma viszonylag alacsonyra tehető. A legnagyobb ilyen szervezetet a Magyar Tudományos Akadémia Könyvtár és Információs Központ kereteiben müködő nyolc 
fős Tudománypolitikai és Tudományelemzési Osztály jelenti. Mellettük bizonyos felsőoktatási intézményekben találhatóak még kisebb munkacsoportok, amelyek fö tevékenysége általában saját intézményük helyzetének tudománymetriai vizsgálata, hiszen az egyetemek ilyen szempontból több ponton is érintettek (nemzetközi rangsorok, tudományos teljesítmény és láthatóság).

A tudománymetria itthoni szakmai mühelyei mellett legalább ennyire fontos megemlékeznünk a konkrét hazai kutatásokról is, hiszen ezek szép számmal léteznek, bizonyítva azt az állítást, hogy alapvetően egy interdiszciplináris, gyakorlatorientált és alkalmazott tudományágról van szó. Ami az egyes hazai hátterü, tudománymetriai tárgyú kutatásokat illeti, ezek nagyon változatos környezetből indulhatnak: az eddigi példák sorát áttekintve talán az a jellemzőbb, hogy az adott tudományterület valamely érdeklődő kutatója áll egy-egy ilyen kutatás mögött, de azért elöfordulnak kifejezetten a tudománymetria, a tudományszervezés és tudományfilozófia oldaláról induló kezdeményezések is. Ilyen volt például az utóbbi évek egyik átfogó kutatása, mely a magyar tudomány intézményi szerkezetét és kompetenciáit próbálta meg feltárni a 2001 és 2010 közötti időszakban (Kampis, Soós, \& Gulyás, 2011). A kutatáshoz a Textrend elnevezésű szövegbányász-szoftvert használták.

Az általánosabb, nagyléptékü, interdiszciplináris-szintetizáló vizsgálatok mellett számos diszciplináris kutatás zajlik folyamatosan az egyes tudományágak képviselői által, abból a célból, hogy feltérképezzék saját tudományos közegük teljesítményét és viszonyait. Ezek közül csak néhányat emelnénk ki: Soós, Schubert és Pléh (2009) a pszichológia, Cselényi (2009) és Antal (2011) a politikatudomány, míg Popp, Balogh, Kovács és Jámbor (2015) publikációját az agrárgazdaságtan területéről, illetve Nagy Andrea Magdolna (2016) doktori disszertációját a közgazdaságtudomány berkeiböl.

\subsubsection{A Magyar Tudományos Müvek Tára}

A hazai tudományos élet szinte minden területét foglalkoztatják a Magyar Tudományos Művek Tára (MTMT) körüli problémák, többek között jól mutatja az MTMT fontosságát, hogy kormányhatározat is született a vele kapcsolatos feladatokról (Magyar Kormány, 2014). Az MTMT egy 2009 óta müködő egyedi nemzeti bibliográfiai és tudománymetriai adatbázis. A Magyar Tudományos Akadémia, a Magyar Felsőoktatási Akkreditációs Bizottság (MAB), a Magyar Rektori Konferencia, az OTKA és az Országos Doktori Tanács 2008 második felében kezdték meg az első egyeztető tárgyalásokat. Az öt alapító intézmény, továbbá a koncepciót támogató OKM és NKTH egyetértettek abban, hogy meg kell valósítani a hazai tudományos 
kutatás hiteles nyilvántartását és reprezentációját az MTMT, illetve a rendszerhez csatlakozó szervezetek segítségével. Az MTMT megalakulásáról a 35/2009. (VI. 23.) számú elnökségi állásfoglalás rendelkezik (Akadémiai Kutatóintézetek Tanácsa, 2009).

Az MTMT célja az ország tudományos műveinek összegyüjtése, egy helyen történő megjelenítése, nem magyar találmány, hiszen hasonló funkciójú rendszerek az Európai Unió szinte valamennyi országában léteznek. A különböző megoldások teljes mértékben nem feleltethetőek meg egymásnak, de tágabban értelmezve a problémakört valamelyest mégis lefedhetőek a 'current research information system' (CRIS) azaz kutatási információs rendszer terminussal. Kutatási információs rendszere lehet egy kisebb vagy nagyobb intézménynek (egyetem, kutatóintézet, stb.), de egy magasabb szinten egy teljes régiónak, tartománynak vagy egy egész országnak is. A nemzetközi példák alapján sokféle konstelláció létezhet, sőt ezek a rendszerek általában többet nyújtanak, mint az MTMT alapfunkciójának tekinthető bibliográfiai számbavétel, de általában ez a tevékenység mindig egy elengedhetetlen alapfunkciót jelent ezekben a rendszerekben. Az európai kutatási információs rendszerek közös szakmai szervezete, az euroCRIS, amely nagymértékben elősegíti a szakmai kommunikációt és az információáramlást az egyes szereplők között, többek között a rendszeresen megrendezésre kerülő konferenciáin keresztül (Tichy-Rács, 2012).

Taga (2014) tanulmányában az MTMT 2012-es és 2014-es statisztikái alapján számol be a számadatok változása nyomán tapasztalható egyértelmü és nagymértékü fejlődésről: a vizsgált időszakban mind a regisztrált szerzők, mind az adminisztrátorok száma közel a duplájára nőtt, illetve számos új intézmény csatlakozott a rendszerhez. A közlemény és idéző adatok esetében többnyire 50\%-os növekedésröl beszélhetünk. Az azóta eltelt időszak legújabb fejleményét a rendszer teljes megújulása jelenti, azaz az MTMT2-es szoftververzióra való átállás (Makara \& Seres, 2013; Micsik et al., 2016). A továbbfejlesztett rendszert jó néhány évig csiszolták, bevezetését a felmerülő gondok miatt többször elhalasztották. Az MTMT korábbi verziójához képest ez a rendszer merőben új adatbázis-struktúrára épül, amely bizonyos nehézségeket okoz a bevezetés során.

A tudósok attitüdje egyébként rendkívül eltérő a szolgáltatást illetően, az egészen végletes ostorozó hangnemtől (Scheuring, 2012) az éles kritikára adott korrekt, a nemzetközi gyakorlatot feltáró válaszokig (Tichy-Rács, 2012; Kollár, 2012). Elsősorban a Magyar Tudomány címü folyóirat adott teret ezeknek a vitáknak. Véleményünk szerint Csaba, Szentes és Zalai (2014) ugyanitt megjelent írása találta meg leginkább az arany középutat, hiszen a jogos kritikák mellett építő javaslatokkal is szolgált. A szerzők mintegy húsz oldalon keresztül, részletekbe menően tárgyalják az MTMT-t érintő legfontosabb és legaktuálisabb kérdéseket, problémákat. 
Többek között felvetik a könyvek szerepének háttérbe szorulását a tudományos kommunikációban, illetve MTMT-ben való privilegizálásuk hiányát. A folyamat nyilvánvalóan összefüggésben áll a hivatkozások felderíthetöségével, láthatóságával és a nemzetközi hivatkozási adatbázisok által biztosított technikai lehetőségekkel. Problémának látják az MTMT-ben rögzített közlemények besorolása körüli anomáliakat, a társzerzőségek által felvetett kérdéseket és a tudományterületek közötti különbségek kezelésének módját. Mivel valójában ezek sok esetben teoretikus polémiák, ezért jó részüket a továbbfejlesztett MTMT2 rendszerben sem sikerült meghaladni. A szerzők által szintén kifogásolt impakt faktor használatának MTMT-beli gyakorlata azonban sokat változott a cikk megjelenése óta eltelt időben.

\subsubsection{A tudománymetria és a neveléstudomány kapcsolódási pontjai}

Az utóbbi időben a hazai neveléstudomány is felfedezte magának a tudománymetria, illetve a tudományos láthatóság fontosságát. A magyar neveléstudománynak természetesen a mára mindennapi gyakorlattá váló MTMT adatfelvitelt meghaladóan is vannak kapcsolódási pontjai a tudománymetriához, hiszen egyre inkább elvárás egy-egy tudományterület teljesítményének vizsgálata, ugyanis egyre inkább finanszírozási döntések múlhatnak ezen (Csaba, Szentes, \& Zalai, 2014). A neveléstudomány a társadalomtudományok közötti relatív pozícióját tekintve nem áll kedvezőtlen helyen a tudománymetriai láthatóság terén. A neveléstudomány nemzetközi tendenciáit illetően a kvantitatív paradigma térnyerését még inkább megkövetelte a 2001-es No Child Left Behind törvény bizonyíték-alapú fejlesztési stratégiák iránti igénye (Kinney, 2006). Feuer, Towne és Shavelson (2002) a következő hat pontban foglalják össze a neveléstudományi tudományos kutatás alapelveit:

1. jelentős, empirikusan is kutatható kérdések kerüljenek vizsgálatra;

2. a kutatásnak legyen kapcsolata a vonatkozó elméletekkel;

3. olyan módszerek alkalmazására kerüljön sor, amelyek lehetővé teszik a kutatási kérdések közvetlen megválaszolását;

4. biztosítva legyen a következetes és egyértelmü érvelési láncolat;

5. a kutatási eredmények megismételhetőek és általánosíthatóak legyenek;

6. olyan adatok és módszerek is kerüljenek publikálásra, amelyek lehetővé teszik és elősegítik a szakmai ellenőrzést és kritikát.

Elmondható, hogy a generális, objektív és szintetizáló megközelítésű tudománymetriai diszciplína elemzései mellett szinte minden tudományágon belül folyamatosan születnek az 
adott szakterület belső viszonyait feltáró tudománymetriai elemzések. Jó néhány ilyen nemzetközi és magyar hivatkozásvizsgálati fókuszú elemzést tudnánk említeni, csak a neveléstudomány szükebb területéröl. Áttekintve az elmúlt egy-két év nemzetközi szakirodalmát a neveléstudomány és a hivatkozásvizsgálatok relációjában, jó néhány elemzést találunk, amelyek nagyobb része a korábban tárgyalt hivatkozási adatbázisokhoz köthető valamilyen módon, de ez a megközelítés korántsem jelent kizárólagosságot.

Ivanović és Ho (2017) a társadalomtudományi területen egyik legalapvetőbb forrásnak tekinthető Social Science Citation Index 'Educational Research' kategóriájának legidézettebb cikkeit veszik górcső alá: évek, folyóiratok, intézetek és országok közötti eloszlásokat vizsgálnak a kutatásba bevont mintegy 2091 publikáció tekintetében. Míg Youtie, Solomon, Carley, Kwon és Porter (2017) már távolabb tekintenek a neveléstudomány horizontjánál, azáltal, hogy a kognitív tudomány és a neveléstudomány kapcsolatát próbálják meg feltárni hivatkozási hálózatokon keresztül. Kiemelendő, hogy a vizsgálati időtartam (1994-2014) hasonló időszakot ölel fel, mint az általunk választott (1991-2014). Weller, Jordan, DeVries és Rolfe (2018) a nyílt oktatás térképét feltáró tanulmánya már túlmutat a hivatkozási adatbázisokon, mivel szociális hálózatelemzésen alapul (Borgatti, Mehra, Brass, \& Labianca, 2009). Kiemelkedő eredményt jelent az elkészült hivatkozási hálózat tematikus annotálása, a kirajzolódó témacsoportok valóban térképszerüvé teszik a kapott eredményeket.

A magyarországi viszonyokat tekintve két, nagyjából egy időben zajlott empirikus kutatásból részletes látleletet kaphatunk a hazai neveléstudomány tudományos aktivitásáról: azonosításra kerülnek a legmeghatározóbb tudományos orgánumok, a tudományos közeget meghatározó iskolák és képzőhelyek, a tudományág vezető kutatói. Még az MTMT elindulása előtti időszakra tehető a Tóth, Toman és Cserpes (2008) szerzői hármas által jegyzett, a Wargo Közgazdasági Elemző- és Piackutató Intézethez köthető részletes elemző tanulmány, amelyben a magyar neveléstudomány tudományos aktivitását kísérelték meg felmérni empirikus eszközökkel. A kutatásban egyrészt vizsgálták a terület meghatározó szakmai mühelyeit, a vezető kutatókat, illetve a legmeghatározóbb hazai szakfolyóiratokat. A tanulmány szakfolyóiratokat érintő végkövetkeztetése, hogy a Magyar Pedagógia tekinthető a hazai neveléstudomány legmeghatározóbb, vezető folyóiratának (Tóth, Toman, \& Cserpes, 2008). A tudománymetria központi gondolatát a hivatkozások vizsgálata jelenti (King, 1987; Kostoff, 1998), így a Wargo-tanulmány esetében is rendkívül hangsúlyosak a hivatkozásvizsgálatok, a szerzők részletes kimutatásokat közölnek ebben a témában. Ezek közül az 1. ábrán a folyóiratcikkekre történő hivatkozások általános emelkedő trendje látható, a legteljesebb adatsor éppen a Magyar Pedagógia vonatkozásában áll rendelkezésre. 


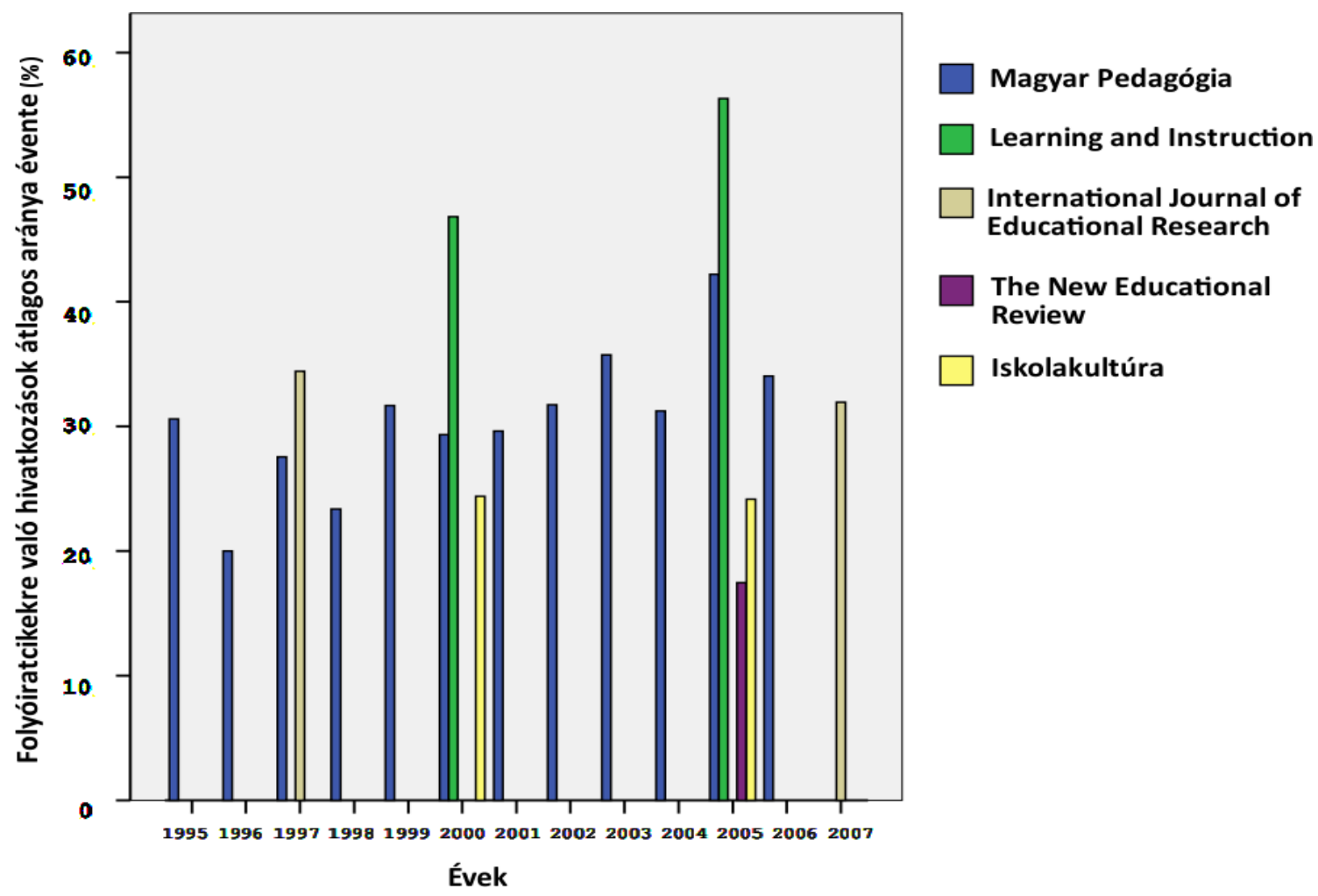

1. ábra

A folyóiratcikkekre való hivatkozások átlagos arányának alakulása 1995-2007 között (N=449) (Forrás: Tóth, Toman, \& Cserpes, 2008, p. 42)

További, hasonló nagyságrendü és mélységü empirikus kutatásként az Eötvös Loránd Tudományegyetem Neveléstudományi Doktori Iskolájának Pedagógiatörténeti Doktori Műhelyében 2007-2008, illetve 2012-2015 között, Németh András vezetésével zajló OTKAkutatássorozatokat emelnénk ki, amelynek egyik részeként egy korábban zajló francia-német kutatás adaptálását is megkísérelték. A vizsgálatok komoly eredményekkel szolgáltak a tudományterület főbb tendenciát és állapotát illetően. A kutatás eredményeit több összefoglaló kötetben (például Németh \& Biró, 2009; Németh, Biró, \& Garai, 2015) és számos publikációban közölték a szerzők (például Németh, Biró, \& Varga, 2009; Biró, 2009a; Biró, 2009b; Pap, 2009).

A vizsgálat egyik központi momentumában többek között a magyar neveléstudomány centrális folyóiratainak publikációs gyakorlatát vizsgálták az 1997-2006 közötti időszakban (Németh, Biró, \& Varga, 2009). Az eredeti kutatás a francia és német neveléstudományi kommunikáció 1955 és 1985 közötti összehasonlító elemzését tűzte ki célul, eredményeiről Schriewer és Keiner (1993) számolt be az 1990-es évek elején. A hazai kutatás egyik fő erénye, hogy lehetővé teszi a nemzetközi összehasonlíthatóságot, hiszen a magyar kutatási eredményeket beilleszti a francia és a német eredmények közé, ezáltal képet kaphatunk a területet érintő országspecifikus hasonlóságokról és különbségekröl. 
A lezajlott kutatás egyik következtetése az volt, hogy a vizsgált időszakban a szaklapok tükrében a Szegedi Tudományegyetem Neveléstudományi Intézetében uralkodó, a kognitív pszichológiai paradigmát megtestesítő iskola a domináns kutatói mühely (Biró, 2009b). Érdemes viszont azt is megjegyeznünk, hogy az adaptált német-francia kutatás készítői tanulmányukban reflektálnak a Wargo-tanulmány Magyar Pedagógia dominanciáját kiemelő megállapítására, és részben vitatják az eredményt, az Educatio című folyóirat vizsgálatból való kihagyásával indokolva kifogásukat (Biró, 2009a). Mindezt Pap K. Tünde hivatkozásvizsgálataival támasztják alá, amely vizsgálat ugyanebben a kutatási projektben került elvégzésre: a kutatás során a négy meghatározó neveléstudományi szakfolyóirat teljes hivatkozásszerkezetét próbálták meg felderíteni. A kutatás egyik szempontjaként a neveléstudomány zártságát/nyitottságát vizsgálták a hivatkozások tükrében, tehát nemcsak a folyóiratok belső hivatkozásait, esetleges egymásra utalásukat vizsgálták, hanem a kutatás kiemelt célja volt a kifelé mutató hivatkozások felderítése és annak kimutatása, hogy mennyire hatnak a neveléstudomány meghatározó orgánumaira az egyéb tudományterületek periodikái (Pap, 2009), mintegy az interdiszciplináris kapcsolódási pontokat keresve. Az elemzések főbb eredményeit a 2. ábra mutatja.

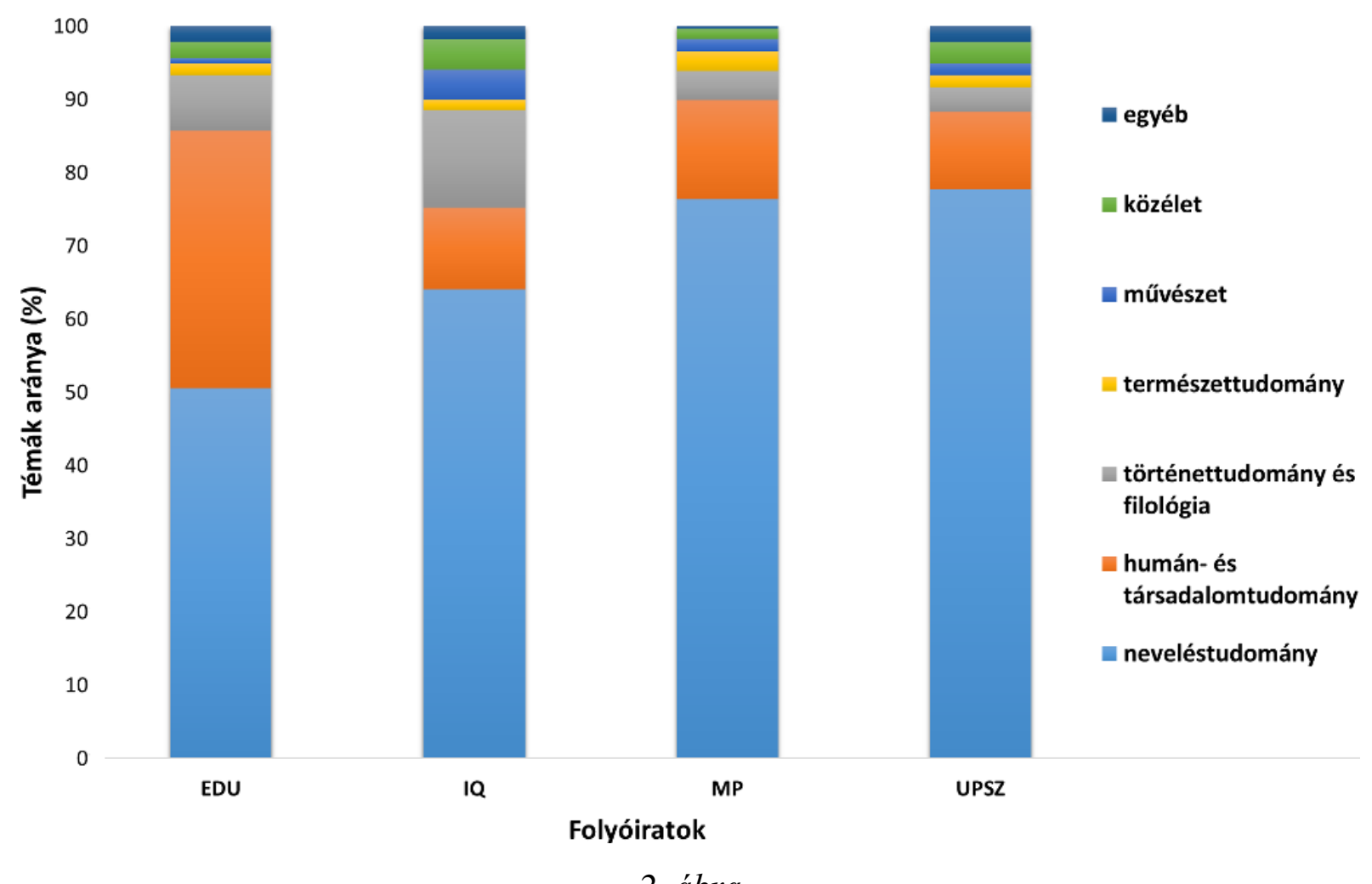

A folyóirat-hivatkozások tudományterületenkénti megoszlása a négy magyar pedagógiai folyóiratban (magyar folyóirat-hivatkozások száma összesen: EDU - 905; IQ - 2038; MP 1020; UPSZ - 688) (Forrás: Pap, 2009, p. 216) 
Az utóbbi évekből a neveléstudomány és a tudománymetria kapcsolatának egyik legátfogóbb összefoglalóját Csíkos Csaba (2013) tanulmánya jelenti, amelyben elsősorban a pedagógia területére vonatkozó impakt faktorral (mint a tudománymetria központi fogalmával) kapcsolatos kérdéseket tárgyalja. Az impakt faktor több szempontú vizsgálata mellett a szerző bemutatja az eljárást érintő legfontosabb kritikai észrevételeket is. Csíkos megállapítja, hogy a neveléstudományi kutatás és az impakt faktor jelenségvilága szoros összefüggésrendszert alkot. Tanulmányában elemzi ennek az összefüggésrendszernek a következményeit. Részletesen tárgyalja a tudományterület meghatározó, impakt faktorral rendelkező lapjait és a pszeudofolyóiratok jelenségét is. A tanulmány egy rövid kitekintővel zárul, amely a jövőt érintő gondolatokat és lehetőségeket vázolja fel (Csíkos, 2013). Nagy (2016) hasonló szemléletü, frissebb adatokat közlő tanulmánya már olyan szorosan kapcsolódó, ám általánosabb érvényü jelenségeket is tárgyal, mint a tudományos kommunikáció megváltozása, az Open Access jelenség, repozitóriumok és a digitálisobjektum-azonosító jelentősége. A szerző szisztematikusan áttekinti a területen tapasztalható legfontosabb változásokat és trendeket, amelyeket a korral, a nemzetközi tendenciákkal haladni kívánó kutatók nem hagyhatnak figyelmen kívül.

Csapó (2016) a tanárképzés és az oktatásfejlesztés tudományos hátterének elemzése során tartja kiemelten fontosnak, hogy az egyes kutatások és publikációk, ezáltal tulajdonképpen maguk a magyar kutatók a nemzetközi mezőnyben méressék meg magukat. A tudományos teljesítmények viszonyítási alapja ne provinciális, szigetszerü legyen, hanem minél objektívebben, a nemzetközi térben értelmeződjön. Ez a szemléletváltás alapvető fontosságú lenne a hazai neveléstudományban, miután várhatóan növelné a szakma színvonalát és elfogadottságát. Néhány más tudományág esetében ez az evolúciós folyamat természetes módon lezajlott. Ahhoz, hogy a magyar neveléstudományi kutatás minőségi mutatói javuljanak, mindenképpen szükség volna a nemzetközi irányba való fokozottabb nyitásra. Ehhez a változáshoz a tudománymetria modern módszereinek alkalmazása és tudatosítása elengedhetetlen volna.

A képzőhelyek tudományos teljesítményének vonatkozásában ki kell még emelnünk Fehér és Aknai (2016) kutatását, akik a hazai neveléstudományi doktori iskolák tudományos teljesítményét és kimeneti követelményeit hasonlították össze. Eredményeik alátámasztják a minőségi mutatók és elvárások nagyfokú szórását az ország öt neveléstudományi doktori iskoláját illetően. Egyúttal felvetik a minőségi követelmények egységesítésének, de legalábbis közelítésének szükségességét, élve a magyarországi doktori képzés 2016. szeptemberében történő átalakításának lehetőségével. Molnár Pál, Pintér Henriett és Tóth Edit kutatásai szintén 
a neveléstudomány belső viszonyait igyekeznek feltárni különböző értékelési szempontokon keresztül. Az utóbbi három kutató fő fókuszpontja elsősorban a neveléstudomány társszerzőségi hálózatainak felderítését célozza, eredményeikről számos konferenciaelőadásban és folyóiratcikkben számoltak be (Molnár, 2018; Molnár, Pintér, \& Tóth, 2018a, 2018b; Molnár, Tóth, \& Pintér, 2018a, 2018b, 2018c). A kutatási projektnek előzményei is vannak, hiszen Molnár néhány évvel korábban számolt be az első eredményekről (Molnár, 2012, 2013).

\subsection{A tartalmi elemzés elméleti háttere}

\subsubsection{Tartalomelemzés a szövegbányászat elốtt}

A tartalomelemzés kialakulása a XX. század fordulójára tehető, Krippendorff (1995) az első ilyen jellegü vizsgálatot 1893-ra teszi. A módszert a XX. század első felében nagyrészt a sajtókutatás területén használták, 1912-ben még olyan ötlet is felmerült, hogy a meteorológiai elörejelzések mintájára ún. „társadalmi időjárás-jelentéseket” lehetne készíteni a segítségével. A második világháború idején még inkább kiteljesedett a módszer széleskörü gyakorlati felhasználása (Móré, 2010). Az ilyen irányú kutatásokat az Amerikai Szövetségi Kommunikációs Bizottság (FCC) fogta össze. Többek között sikerült előre jelezniük több nagy katonai és politikai offenzívát, felbecsülniük a náci vezetés saját helyzetértékelését, az éppen uralmon lévő csoporton belüli politikai változásokat, illetve a tengelyhatalmak közti viszony aktuális módosulásait. Az egyik leghíresebb előrejelzés, amellyel a brit elemzők büszkélkedhetnek, az volt, amikor megjósolták a német csodafegyverek Anglia elleni bevetésének várható időpontját. Goebbels beszédeit figyelemmel kísérve az elemzők a fegyverek gyártására célzó áthallásokat tudtak kimutatni, így alig pár hetes időhatárok között meg tudták adni a támadások várható megindításának dátumát is.

Az 1950-es évek végén ismét jelentősen megnőtt az érdeklődés a módszer iránt, ezúttal már a számítógépes technológiában elért elörehaladásra építve. Speciális, a szöveges adatfeldolgozást segítő programnyelveket fejlesztettek ki, illetve több folyóirat is ekkor indult, melyek a számítógép humán- és társadalomtudományi felhasználásának lehetőségeit tárgyalták. Miután a számítógép a hardveres és szoftveres fejlődés következtében egyre inkább alkalmassá vált a szöveges adatfeldolgozásra, megjelentek a számítógépes szószámláló programok is. Többek között ezek teremtették meg a számítógépes-stilisztikának elnevezett új tudományág alapjait és forradalmasították a szövegfeldolgozást. Az egyik első számítógépes tartalomelemzést 1958-ban adták közre, információ-visszakeresési rutinműveletek segítségével 
kb. 4000 cseremisz népmesét elemeztek. Míg egy 1960-ban született Rand Corporation számára készült tanulmány 'Automatic Content Analysis' címmel azt vizsgálta, hogy miképpen lehetne létrehozni egy politikai dokumentumokat elemző számítógépes rendszert (Krippendorff, 1995).

A tartalomelemzés történeti előzményeiből kiderül, hogy alkalmazása számos tudományágban bevett módszernek tekinthető, így nem meglepő, hogy a neveléstudomány területén is komoly előzményei vannak, ezt számos elvégzett kutatás bizonyítja. A neveléstudományi terület meghatározó magyar nyelvű kutatásmódszertani alapművének tekinthető 'Bevezetés a pedagógiai kutatás módszereibe' címü könyv a következőképpen definiálja a tartalomelemzés módszerét: „A tartalomelemzés olyan kutatási technika, amely adatokból az adatok összefüggésrendszerére levonható érvényes, megismételhető következtetéseket fogalmaz meg." (Szabolcs, 2004, p. 332). Ennél jóval bővebb összefoglalót nyújt a tartalomelemzésről Lengyelné Molnár Tünde (2011) jegyzete, ahol mind az elmélettel (legfontosabb fogalmak, típusok, történeti kialakulása, folyamatok, módszerek), mind a gyakorlati alkalmazási lehetőségekkel (szoftverek és lehetséges felhasználási ötletek) megismerkedhetünk.

Varga Katalin (2005) tanulmánya inkább nyelvészeti és könyvtártudományi oldalról közelíti meg a kérdést, azonban ez annyiban érthető, hogy a kötet túlmutat a tartalomelemzés tárgyalásán, inkább a szövegközpontú megközelítés jelenti a fő irányvonalat. Ezzel szemben inkább az informatikai szempontú, pragmatikus megközelítés jellemző a Multiplikatív adatok kvalitatív elemzése című kötetre, amelyben igazából konkrét, a tartalomelemzésben használható számítógépes szoftverekről kapunk egy áttekintő képet, néhány kiválasztott szoftver esetében pedig ennél mélyebb elemzést, már-már egészen a használati útmutatók szintjéig (Sántha, 2013).

A módszertani jellegü írások mellett természetesen léteznek konkrét kutatási beszámolók is, ahol a tartalomelemzés módszerét használták a neveléstudomány képviselői. Az egyik jelentős tartalomelemzéses kutatás a neveléstudomány területéről Szabolcs Éva 1868-1890 között megjelent folyóiratokban reprezentálódó gyermekkép vizsgálata volt. A Néptanítók Lapját, a Kisdednevelést, illetve a Család és Iskola című folyóiratokat vizsgálta; a kutatás során bebizonyosodott, hogy a korabeli gyermekkép számos alkotóeleme felszínre hozható és megragadható a tartalomelemzés módszerével (Szabolcs, 1999).

Nóbik Attila (2010) Klasszikusok és kánonképzés a magyar neveléstörténeti tankönyvekben (1867-1956) című doktori disszertációjában szintén tartalomelemzési munkát végzett, bár szorosan véve nem az ebben a fejezetben bemutatott klasszikus tartalomelemzés módszerét használta. Ebből is láthatjuk tehát, hogy a tartalomelemzés terminus kettős: jelentheti 
egyrészt a fejezetben tárgyalt tudományos módszert, illetve jelentheti a különböző dokumentumok (jelen esetben a neveléstörténeti tankönyvek) mindenféle szempontú tartalmi vizsgálatát, elemzését. Erről a kettőségről soha nem szabad megfeledkeznünk, ha a tartalomelemzés szót használjuk. Mindehhez kiegészítésképpen még annyit érdemes hozzátennünk, hogy a tartalomelemzés tágabb értelmezésébe akár a nem szöveges alapú anyagok (álló- és mozgóképek, hanganyagok) tartalomra fókuszáló elemzései is beletartozhatnak, például, mint az a hat oktatási folyóirat körében elvégzett, több, mint 5000 képen alapuló kutatás, amelyről Somogyvári (2014) közölt tanulmányt.

\subsubsection{Szövegbányászat}

A szövegbányászatra szöveges adatbányászatként (text data mining) is szoktak hivatkozni, illetve a kezdetekben elterjedt volt még a szöveg analízis (text analytics) terminus is. Kialakulása az üzleti intelligenciához (business intelligence) köthető és 1950-es évek végére tehető: az adatfeldolgozó gépek használhatóak dokumentumok auto-referálására és autokódolására (Luhn, 1958). A számítógépes infrastruktúra, a mesterséges intelligenciakutatás és a gépi tanulóalgoritmusok fejlődésének hatására az 1990-es években kezdtek el újra komolyabban foglalkozni a szövegbányászattal, az adatbányászat egy speciális aleseteként, például Hearst számítógépes nyelvészeti megközelítésü cikkét érdemes említenünk (Hearst, 1999), illetve ebben az időszakban szintén elkezdődött egy „Szeged Treebank” elnevezésű korpusz kialakítása, ami bizonyítja, hogy nemzetközi viszonylatban a hazai kutatók egyáltalán nem voltak lemaradva.

A módszer számtalan alkalmazási területét lehetetlen bemutatni, azonban néhány példát mégis kiragadnánk. Számos elemzés származik az orvosbiológia (Cohen \& Hersh, 2005; Vincze, Szarvas, Farkas, Móra, \& Csirik, 2008), az üzleti informatika (Ghosh, Haider, \& Sen, 2015), a számítógépes nyelvészet (Schneider, 2014), vagy a könyvtártudomány (Nagarkar, 2015) területéről. Összességében elmondható, hogy szinte minden olyan diszciplína esetén lehetne példát találni a használatára, ahol nagyobb mennyiségű szövegek fordulnak elő, emiatt magától értetődő, hogy az oktatási terület és az azt kutató neveléstudomány sem jelent ez alól kivételt.

A szövegbányászat és az előző fejezetben bemutatott klasszikus tartalomelemzés közös tulajdonsága, hogy mindkettő vizsgálati tárgyát a szöveges dokumentumok képezik. Ugyanakkor, míg a tartalomelemzés általában különböző manuális módszerekre épít (melyek során természetesen felhasználják az informatika által nyújtott lehetőséget is), addig a 
szövegbányászat előszeretettel használ különböző automatizált, algoritmizált megoldásokat. Ez nem véletlen, hiszen az informatika oldaláról fejlödött ki, valójában annak szöveges dokumentumok elemzésével foglalkozó részterületét jelenti, a mostanában megannyi területen alkalmazott adatbányászatból alakult ki. A legfőbb különbség a két terület között, hogy amíg az adatbányászat (data mining) legalább valamilyen szinten organizált adatokkal dolgozik, (amelyek sok esetben numerikusak), addig a szövegbányászat (text mining) inputjaként bármilyen szöveges dokumentum szóba jöhet.

A szövegbányászatot mint modern informatikai módszert legalaposabban tárgyaló, összefoglaló jellegü magyar nyelvü forrás Tikk Domonkos nevéhez köthető. A szerző informatikus, így egyértelműen a gyakorlati alkalmazás kerül előtérbe, egészen a módszer keretében felhasználható konkrét algoritmusok szintjéig (Tikk, 2007). A szövegbányászat a klasszikus tartalomelemzést lehetőségeiben meghaladó módszer, így elsősorban erre alapozott megoldásokat használtunk kutatási projektünkben. Meg kell azonban jegyezni, hogy minden különbözőség ellenére valamelyest mégis rokon eljárásoknak tekinthetőek, emiatt vált szükségessé a klasszikus tartalomelemzési előzmények bemutatása. Annál is inkább, mert a klasszikus kvantitatív tartalomelemzésnek komoly pedagógiai hagyományai vannak, ahogyan az kiderült az előző fejezetből.

A szövegbányászatot általánosan tárgyaló angol nyelvü szakirodalomból elsősorban a témával foglalkozó kézikönyveket érdemes kiemelnünk, hiszen a módszer túl összetett ahhoz, hogy egy-egy konkrét kutatást, kísérletet, implementációt részletesebben, egy-egy említésen túl bemutassunk egy disszertáció szabta terjedelmi keretek között. Több másik kötet mellett ilyen alapmünek tekinthetőek a Text Mining: Predictive Methods for Analyzing Unstructured Information (Weiss, Indurkhya, Zhang, \& Damerau, 2005), illetve a Mining Text Data címü kézikönyvek (Aggarwal \& Zhai, 2012).

Az eljárás lényege abban áll, hogy nagy mennyiségü, természetes nyelvű szöveg automatikus gépi elemzésével próbálunk olyan következtetéseket levonni a szöveget illetően, amelyek esetében akár az is elképzelhető, hogy azok explicit módon nincsenek benne a szövegben, vagy csak rejtetten, esetleg az óriási mennyiségű szövegkorpuszokban elvesznek ezek az egyébként lényeginek tekinthető információk. A szövegbányászat különböző lépések, eljárások, algoritmusok felvonultatásával rejtett mintázatokat próbál találni a szövegekben, amelyekből azután a módszert alkalmazó hozzáértő kutató különféle tudományos következtetéseket tud levonni (Tikk, 2007). Természetesen ezt az innovatív informatikai megoldást nem csak tudományos célra használják, sokkal inkább a tudomány emelte át saját 
eszköztárába a gazdasági életből, azonban kutatásunk kapcsán relevancia hiányában nem tartjuk szükségesnek az üzleti alkalmazás gyakorlatának tárgyalását.

Mivel a szövegbányászat az adatbányászatból alakult ki, ezért mindenképpen szükséges a két terület viszonyának a tisztázása, annál is inkább, mert mindkét kutatási eljárást használják a pedagógiai kutatásokban a későbbiekben ismertetésre kerülő Educational Data Mining szubdiszciplína keretei között (Hung, 2012; Romero, Ventura, Pechenizkiy, \& Baker, 2010; Ueno, 2004). A legfőbb különbség a két terület között, hogy míg az adatbányászat strukturált adatokkal dolgozik, addig a szövegbányászat strukturálatlan szövegeket használ input alapanyagként, ezért tehát elmondhatjuk, hogy a szövegbányászat az informatika szöveges dokumentumok elemzésével foglalkozó ága. Esetünkben a folyóirat-hivatkozások ugyan hordoznak egyfajta struktúrát, szabályosságot, lásd az American Psychological Association (2010) vagy a Magyar Pedagógia korábbi publikációs stílusát, azonban a hivatkozások feldolgozása a textuális dominancia miatt már egyértelműen a szövegbányászat területe.

Tikk (2007) definíciója egészen pontosan így határozza meg a szövegbányászatot: strukturálatlan, vagy kis mértékben strukturált szöveges adatokon végzett feldolgozási és elemzési tevékenység, melynek célja a dokumentumokban rejtetten meglévő információk feltárása, azonosítása és elemzése. A szövegbányászat interdiszciplináris, alkalmazásorientált szakterület, amelynek általános modellje a 3. ábrán látható.

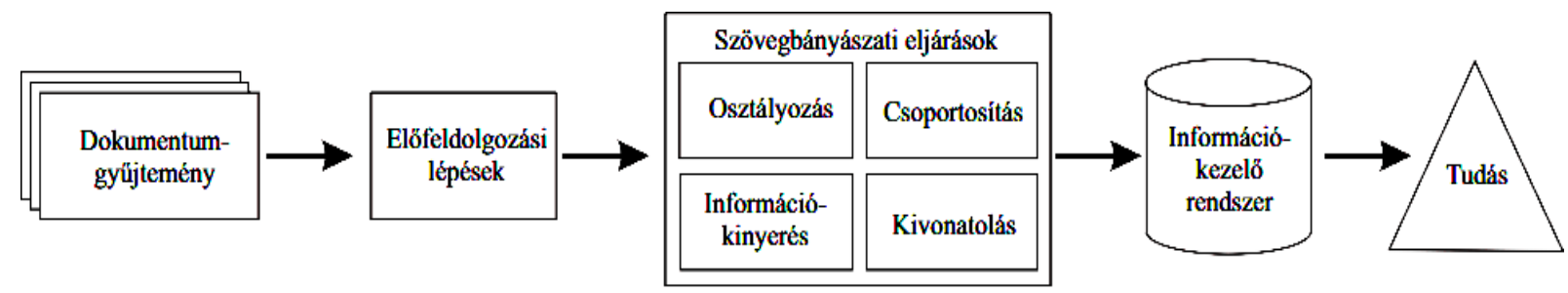

3. ábra

A szövegbányászat általános modellje (Forrás: Tikk, 2007, p. 22)

Bevett alkalmazási technikákat képvisel a kategorizálás, a klaszterezés, a kivonatolás (összefoglalás), az információ kinyerés, a trendkövetés, a szemantikus elemzés és a vizualizáció (Feldman \& Sanger, 2007). Mivel ezek közül több eljárást is felhasználtunk munkánk során, így részletesebb bemutatásuk is szükséges Tikk (2007) munkája nyomán:

- Osztályozás, kategorizálás: Az osztályozás célja szöveges dokumentumok elöre definiált halmazból vett tematikus kategóriacímkékkel való ellátása.

- Csoportosítás, klaszterezés: Az osztályozás és a csoportosítás között a leglényegesebb különbség, hogy az utóbbi esetben nem áll rendelkezésre tematikus kategóriarendszer, 
amelybe a dokumentumokat be lehetne sorolni, ezt a szöveg feldolgozása során a gépi tanulás útján kell megteremtenünk a kiinduló szövegből.

- Trendkövetés: Egy kutatás során kibontakozó témacsoportok tárgyalásának végigkövetése és a felbukkanó új fogalmak vizsgálata. Ez tulajdonképpen a szövegbányászat hagyományos vizsgálati módszereivel kapott eredmények időtengelyre való kivetítése. Az eredmények túlzott elaprózódásának elkerülése végett fontos lépés az időskála helyes megválasztása.

- Vizualizáció: A nagyméretủ szöveges kutatási anyagok miatt az eredmények megfelelö prezentálása nem mindig egyszerü feladat, és általában szükség van valamilyen, a mindennapos, konzervatív vizualizációs megoldásokat (hisztogram, vonalgrafikon, stb.) meghaladó, innovatívabb vizualizációs eszköztár felvonultatására, például tematikus hőtérkép, címkefelhő, dendrogram, vagy egy-egy egyedi infografika, de akár saját fejlesztésủ megjelenítési környezet adaptálására is (Börner \& Polley, 2014).

A szegedi kutatók (Számítógépes Algoritmusok és Mesterséges Intelligencia Tanszék és MTA-SZTE Mesterséges Intelligencia Kutatócsoport és ezek elődei) már az 1990-es évek vége óta jelen vannak a területen: „Szeged Treebank” néven építettek korpuszgyüjteményt, melyet számtalan szövegbányászati és számítógépes nyelvészeti kutatás felhasznált (Csendes, Csirik, Gyimóthy, \& Kocsor, 2005). Mellettük az utóbbi időszakban Szegeden Farkas Richárd és kollégái foglalkoztak még behatóbban a témával és váltak a terület elismert, sokat publikáló szerzőivé (Farkas, Szarvas, \& Ormándi, 2007; Farkas, Vincze, \& Schmid, 2012; Berend, 2016).

A szöveg- és adatbányászat tudománymetriai vonatkozású felhasználása külön értekezést érdemelne, ennek részletes bemutatására jelen keretek között nem törekedhetünk, a kapcsolat (és főleg annak mélységének) megállapítása azonban elengedhetetlen az általunk alkalmazott módszer elméleti alátámasztottsága érdekében. A modern, informatikai alapokon nyugvó tudománymetria elképzelhetetlen lenne a hatalmas adatmennyiség észszerü feldolgozását lehetővé tévő automatizált megoldások nélkül. Egyszerüen nem létezhetnének a hivatkozásokat szinte valós időben nyomon követő tudománymetriai adatbázisok és professzionális elemzőeszközök, legalábbis a jelenlegi nagyságrendben és minőségben semmiképpen. Professzionális módon tárgyalja napjaink lehetőségeit és összetett ökoszisztémáját a két terület vonatkozásában Katy Börner (2010, 2015) rendkívül tartalomgazdag és igényesen illusztrált könyveiben. A bloomingtoni Indiana Egyetem professzorának teljes munkássága a tudománymetria és az információtudomány találkozási pontjának nagyszerű eredményeiről ad tanúbizonyságot. 


\subsubsection{A szövegbányászat és a neveléstudomány találkozási pontja: Educational Data}

\section{Mining}

Mivel kutatásunk céljait a publikációk szövegének automatikus feldolgozásán keresztül kívánjuk elérni a szövegbányászat innovatív eszközeinek alkalmazásával, így szükséges bemutatni a módszer neveléstudományi kutatásban használt gyakorlatát és előzményeit. Mind a szövegbányászatot, mind az elözményének tekinthető adatbányászatot használják a pedagógiai kutatásokban (Hung, 2012; Romero, Ventura, Pechenizkiy, \& Baker, 2010; Ueno, 2004). A szakirodalomban az 'Educational Data Mining' (EDM) terminussal hivatkoznak erre a szubdiszciplínára, míg magyarul az oktatási adatbányászat kifejezés (Szücs \& Kiss, 2015) terjedt el leginkább.

Az EDM speciális területe az ezredfordulót követő évtized második felében kezdett el kialakulni. A terület saját folyóirata a 'Journal of Educational Data Mining' címmel jelenik meg. Az önálló folyóirat mellett évenkénti konferenciát is rendeznek a szakértők. A folyóirat első számának első tanulmánya (Baker \& Yacef, 2009) kiválóan összefoglalja a célkitüzéseket és az akkori állapotokat. A tanulmány szerzői a következőképen határozták meg az EDM fogalmát: az 'Educational Data Mining' egy feltörekvő diszciplína, melynek célja, hogy releváns módszereket fejlesszen ki az oktatási intézményekből származó egyedi adattípusok felfedezésére és ezeket a módszereket a diákok és a kapcsolódó körülmények megértésére használja. A terület egyik legtöbbet publikáló szerzője, Cristobal Romero így kategorizálta az EDM-et: statisztika és vizualizáció; web bányászat; klaszterizálás, osztályozás és eltérés detektálás; szabály asszociáció bányászat és szekvenciális mintázat bányászás; szövegbányászat (Romero \& Ventura, 2007).

Kutatásunk elméleti hátterének megalapozottsága miatt legalább ennyire fontos területet jelent a hivatkozási adatbázisok technikai müködési alapjainak feltárása, és azoknak az informatikai eljárásoknak az alapvető tisztázása, amelyek segítségével általában a tudományos publikációkban található hivatkozások felismerése és extrakciója zajlik (Peng \& McCallum, 2006). A projekt egyik kiindulási alapját jelenti ugyanis az alkalmazott megoldások kisebb léptékben történő, a rendelkezésre álló erőforrásokhoz való adaptálása és reprodukálása. A nemzetközileg elismert hivatkozási adatbázisok által alkalmazott módszerek alapvetően a hivatkozások publikációkon belüli automatikus detektálásán, részegységekre bontásán, majd strukturálásán alapulnak (Sarawagi, 2007). A strukturálatlan szövegekből kinyert strukturált adatok azután természetesen már adatbázisba szervezhetőek, számos új lehetőséget nyitva ezzel a további felhasználás számára (Thuraisingham, 2014). Bár volt néhány próbálkozás a 
szemantikus alapú, strukturált metaadatokat natívan kezelő publikációs megoldásokra (lásd például Murray-Rust \& Rzepa, 2002), amelyeknél a hivatkozások felismerésére, extrakciójára nem lett volna szükség az adatbázisba szervezéshez, mivel a már eleve strukturált módon létező adatok automatikusan kinyerhetővé és összekapcsolhatóvá váltak volna, de ezek a módszerek a magas erőforrásigény miatt soha nem terjedtek el igazán széles körben. Valamelyest hasonló logikára épül egyébként a digitálisobjektum-azonosítók rendszere is, bár itt a strukturált metaadatok nem az egyes publikációkban tárolódnak, hanem egy külső rendszerben, amelyhez a DOI számok biztosítják az élő összeköttetést.

Az informatikai módszereket és szövegbányászati eljárásokat tekintve természetesen több metódus is szóba jöhet, a szakirodalom alapján az egyik legrelevánsabb megoldás a rejtett Markov-modell alkalmazása (Ojokoh, Zhang, \& Tang, 2011; Hetzner, 2008). E módszer mellett a szakemberek más mesterséges intelligencia-alapú megközelítéseket is alkalmaznak, amelyeket általában különféle gépi tanulási algoritmusok segítségével érnek el (Tkaczyk, Bolikowski, Czeczko, \& Rusek, 2012; Tkaczyk, Szostek, Fedoryszak, Dendek, \& Bolikowski, 2015). Sarawagi (2007) nagyívü összefoglaló munkájában rendszerbe foglalja az automatizált alapú információ-kivonatoló módszereket, több helyen külön is kiemelve a hivatkozásokkal, mint speciális információtípussal kapcsolatos tudnivalókat. A bemutatott eljárások egyik csoportját a szabály-alapú megközelítés adja: ebben az esetben valamilyen előre definiált szabálykészlet alapján (mint amilyet egy jól dokumentált hivatkozási stílus is jelent) történik a felismerés, melyet általában valamilyen szabálytanuló algoritmus közbeiktatásával oldanak meg.

A szabály-alapú megközelítés következtében az automatikus hivatkozásfelismerésifolyamatban az egyik legkritikusabb szerep valójában a sztenderdizált hivatkozási stílusoknak (Lipson, 2018) jut. A kezdőlépést minden esetben az egyes dokumentumokon belül az irodalomlisták helyének detektálása jelenti, ennek megtalálása után következhet az egyes hivatkozási tételek részekre bontása és strukturálása. A szövegbányászat által biztosított számos további eljárás bemutatására jelen írás keretei között nincsen mód, ahogyan az interneten rendelkezésre álló számtalan erre a célra szolgáló szoftvermegoldás, vagy a digitálisobjektumazonosítók (DOI) hivatkozások azonosításában és nyomon követésében betöltött szerepére sem térünk ki részletesebben.

A következőkben szelektív válogatást közlünk a szövegbányászat neveléstudományi vonatkozású alkalmazásáról, néhány olyan kutatáson keresztül, melyek céljaink szerint alátámasztják a módszer széleskörű felhasználhatóságát. Hung (2012) tanulmányában az elearning domain alá tartozó 2000-2008 közötti trendeket vizsgálta bibliometriai és 
szövegbányászati módszerekkel. Munkájuk során az SAS Enterprise Miner 5.3 szoftvert használták fel. Elsődleges céljuk a legfontosabb témákról való fastruktúra kialakítása volt (lásd 4. ábra), amelyhez klaszterezést használtak. Fontos mérőszámnak tekintik a cikkek számát és időbeli eloszlását az egyes részterületeken, hiszen ezek megmutatják a változások legfőbb irányát. A tanulmány az 'Instructional Approaches', 'Learning Environment' és 'Metacognition' kulcsszavakat találta az adott időszak legnépszerübb témáinak.

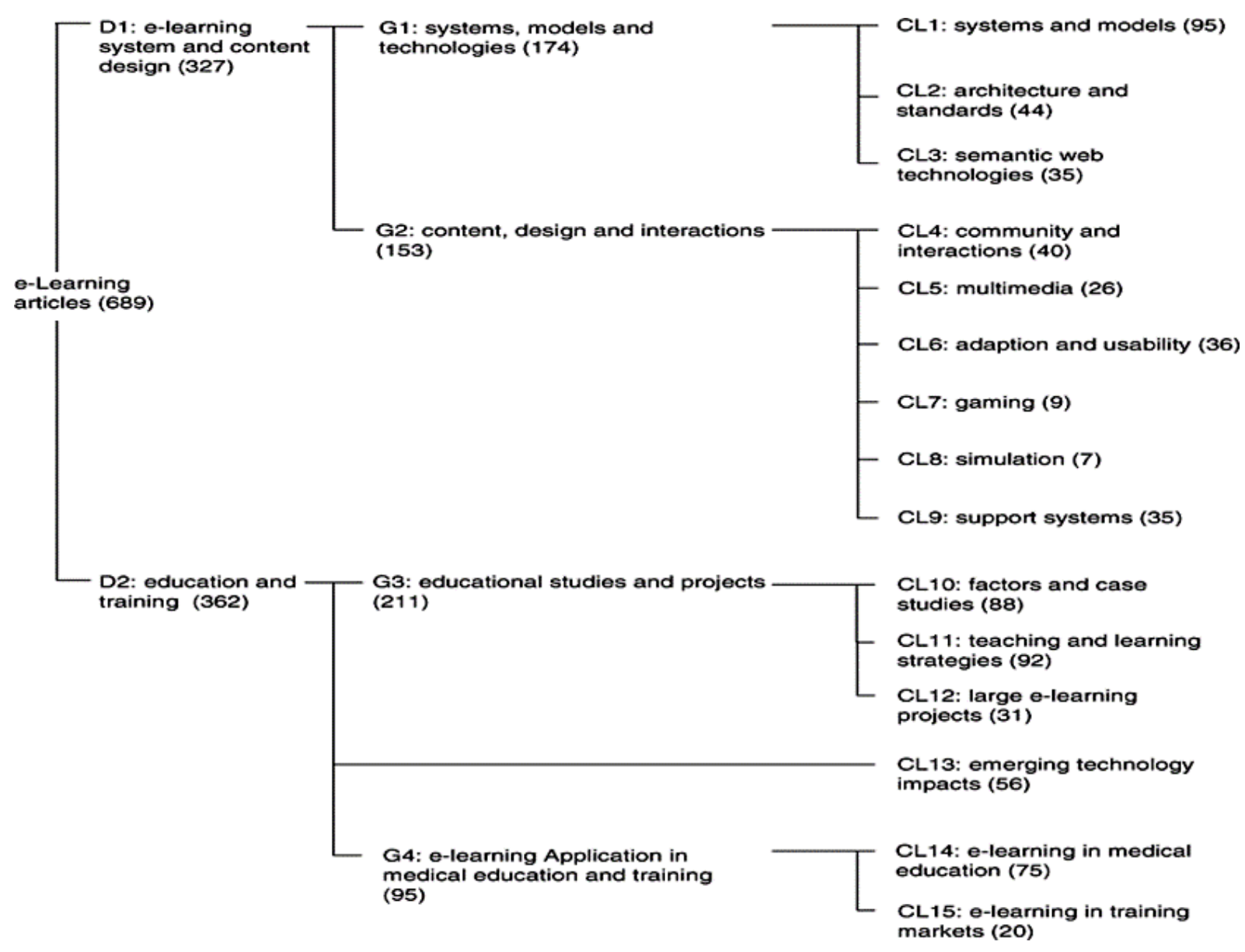

4. ábra

Az e-learning terület kutatásának taxonómiája (Forrás: Hung, 2012, p. 9)

Wang, Bowers és Fikis (2017) kutatásának megközelítése rendkívül hasonló az általunk kitüzöttekhez. Az Educational Administration Quarterly címủ oktatásirányítási témájú folyóirat 50 évének elemzését végezték el az 1965-2014 közötti periódusra nézve. Ez mindösszesen 1539 darab cikk vizsgálatát jelentette. A vizsgálat keretében 19 fó témacsoportot sikerült azonosítaniuk, mint például a 'social justice' (társadalmi igazságosság), a 'female leadership' (női vezetés) és a 'school leadership preparation' (felkészülés az iskolai vezetésre). A szerzők a kutatás fő célját a következőképpen fogalmazták meg: az elkészült tematikus tájkép látványos 
panorámája egyedülálló háttérként szolgál ahhoz, ahogyan a tudósok az oktatásirányítási kutatás jövőjét szemlélik.

Conde, Larrañaga, Arruarte, Elorriaga és Roth (2015) felsőoktatási tankönyvek (asztronómia és molekuláris biológia témakörökben) tartalmát vizsgálták meg szövegbányászati eszközökkel, míg referenciakorpusznak a Wikipédiát használták fel (ez a nagy kiterjedésủ és szabadon felhasználható természetes nyelvi szövegkorpusz miatt bevett gyakorlatnak számít a tudósok között). A kutatás összetett és sokrétü volta miatt többfajta szoftvereszközt is felhasználtak.

Patricia Anne Levine-Brown (2014) a Texasi Egyetemen matematikai fejlesztés témában készített doktori disszertációjához az elvégzett megfigyelésekkel, interjúkkal és dokumentumelemzésekkel párhuzamosan a szövegbányászatot is felhasználta a szövegekben rejlő mélyebb struktúrák és mintázatok feltárására az IBM SPSS Text Analytics for Surveys programot használva.

Wu He (2013) tanulmányában egy újszerü oktatási megoldást, a live video streaming (LVS) tanulási környezetet vizsgálta szövegbányászati eszközökkel. Az LVS egy viszonylag új technológia az online tanulásban, amely annyiban különbözik a már bevált e-learning módszerektől, hogy a hagyományos osztálytermi környezetet próbálja szimulálni a videóstream megoldásokkal, ugyanakkor lehetővé téve a kölcsönös interakciót az oktató és a diákok között. A tanulmány felhasználja az LVS környezet által automatikusan rögzített adatokat, melyek egy része természetesen strukturálatlan szöveg (például chatbeszélgetések, kérdések, feladatmegoldások, stb.). A kutatók az SPSS Clementine és NVivo 9 szoftvereket használták fel. Ehhez hasonlóan, a tanulásmenedzsment rendszerek (LMS) használata során keletkezett naplófájlokat (logokat), már korábbi kutatásokban is elemeztek, amely felhasználási mód egyébként kiválóan megvilágítja a szövegbányászatban rejlő lehetőségeket. Olyan, korábban értéktelennek tekintett strukturálatlan adatokat tudtak így bevonni a kutatásba, amelyek használatára korábban semmi esély nem volt, mivel nem álltak rendelkezésre a megfelelően kidolgozott eszközök és eljárások, ezért a különböző logfájlok tipikusan azt az adattípust képviselik, amelyet hatékonyan csak valamilyen adat- és szövegbányászatra alapozó megoldással lehet elemezni (Black, Dawson, \& Priem, 2008).

Szintén a logfájl-elemzések területéről valósított meg egy innovatív és hiánypótló analízist szövegbányászati eszközök felhasználásával Paolo Blikstein (2011), aki a programozás tanításának és tanulásának folyamatát taglalta a következőképpen: a programozási környezet által eltárolt naplófájlokat vizsgálta meg, amelyekből kiderültek a tanulás során tapasztalható buktatók, fejlődésbeli ugrások és nehézségek. A logokban található információk 
elemzésével nyilvánvalóan hatékonyabbá tehető a programozás tanítása és a tananyagok továbbfejlesztése.

A következő bemutatott példa még az EDM korai időszakából származik, és az online tanulási megoldásokhoz, illetve az ezeken a platformokon zajló aszinkron diszkusszióhoz köthető. Érthető az e-learning környezetek ilyen szempontú vizsgálata, hiszen esetükben az írásbeli kommunikációnak sokszor kiemelt szerepe van, így mindenképpen indokolt ennek mélyrehatóbb hatékonysági vizsgálata, amelyhez ideális eszközt jelent a szövegbányászat (Dringus \& Ellis, 2005). Egy néhány évvel későbbi kutatásban szintén az online kurzusokhoz kapcsolódó vitafórumokban zajló interakciókat vizsgálták, ahol a szerzők kiemelik, hogy az informatikában lezajlott fejlődés jelentősen megkönnyítette a nagyméretü szöveges állományokkal való munkát. Az elemzésekhez más neveléstudományi kutatásokban is előszeretettel igénybe vett Weka elnevezésű nyílt forrású szoftverkörnyezetet használták fel (Lin, Hsieh, \& Chuang, 2009).

Végül, de nem utolsósorban akad példa a szövegbányászat oktatási mérés-értékelési célú adaptálására is, például a tanítási folyamatról beszámoló rövid szöveges üzenetek (SMS) vizsgálatánál. A visszajelzéseket a módszer segítségével sikerült automatikusan kategóriákba sorolni, ezáltal lehetővé vált a tanítási folyamat akár több szempontú értékelése (Leong, Lee, \& Mak, 2012). A bemutatott példák alapján összességében elmondható, hogy az Educational Data Mining, azaz az adat- és szövegbányászat neveléstudományi célú felhasználása egyre inkább terjed a nemzetközi (és valamelyest a hazai) kutatásokban, ugyanakkor a módszer igazán széleskörü magyarországi elterjedéséről egyelőre még nem tudunk beszámolni néhány ilyen irányú kutatáson kívül (pl. Molnár, 2016; Szabó \& Korom, 2017).

\subsection{Hálózattudomány}

A hálózattudomány alkalmazási köre az elmúlt másfél évtized folyamán talán még a szövegbányászaténál is jelentősebbé vált. A terület magyar származású szakértője, Barabási (2016, p. 39-40) így fogalmaz monográfiájában: „A hálózatok tudománya új tudományág. Megjelenésének időpontja vitatott, de egy biztos: csak a 21. században vált önálló tudományággá. Minden komplex rendszer mögött egy bonyolult hálózat áll, s az határozza meg az adott rendszer elemei közötti kölcsönhatásokat.” A hálózatkutatás több alapfogalma a matematika egyik részterületéről, a gráfelméletből származik. A hálózatkutatást az különbözteti meg a gráfelmélettől, hogy inkább tapasztalati alapú, és az adatokat, illetve az eredmények felhasználhatóságát állítja saját érdeklődésének középpontjába. A hivatkozásvizsgálatok a 
citációk hálózatba szerveződése miatt nagyban támaszkodnak a hálózattudomány megoldásaira (például lásd Omodei, De Domenico, \& Arenas, 2017), így szükségesnek tartjuk a legfontosabb hálózattudományi terminológiai fogalmak tisztázását.

A tudományos irodalomban a hálózat és gráf kifejezéseket gyakran egymás szinonimájaként használják, de a való életben is csak ritkán teszünk közöttük különbséget. A hálózat és gráf kifejezéseket (és minden hozzájuk kapcsolódót) jelen írás kereteit tekintve ezért egymás szinonimájaként kezeljük, tesszük mindezt Barabási (2016, p. 61) nyomán: „A tudományos irodalomban a hálózat és gráf kifejezést szinonimaként használják: hálózatkutatásgráfelmélet; hálózat-gráf; csomópont-csúcs; kapcsolat-él. De van valamelyes különbség a kétféle szóhasználat között. A hálózat, a csomópont és a kapcsolat szó gyakran valóságos rendszerekre utal, olyanokra, mint például a WWW (a weben levő dokumentumok URL-ekkel egymáshoz kapcsolt hálózata), a társadalom (egyének hálózata; ezeket az egyéneket a család, a barátság vagy a munkahely kapcsolja össze) és az anyagcsere-hálózatok (a sejteken belüli kémiai reakciók összessége). A gráf, a csúcs és az él kifejezést viszont a hálózatok matematikai ábrázolásakor használjuk. Például van webgráf, kapcsolati gráf (a Facebook által bevezetett „social graph”) és van anyagcseregráf. A valóságban ritkán teszünk közöttük különbséget, a két szóhasználat legtöbbször tehát felcserélhető.”

A tudomány hálózatként való értelmezése egyre inkább elterjedt és elfogadott gondolat, amely szintén nagymértékben épít a hálózattudomány alapelveire és eredményeire. A tudományos publikálás mai rendszerét szemlélve teljesen kézenfekvő gondolat a tudomány ilyetén való értelmezése. A néhány oldallal korábban tárgyalt tudománymetria, mint a tudományok metatudománya teljesen alapvető módon támaszkodik erre a megállapításra, ahogyan azt Schubert (2015a) részletesen bemutatja, számos tudománymetriai relevanciájú hálózattudományi alapfogalmat tisztázva írásában. A társszerzőség és a hivatkozások vizsgálatának esetében tulajdonképpen magától értetődő a gráfok használata, így nem meglepő módon, a disszertációban bemutatott eredmények nagymértékben támaszkodnak a hálózattudomány nyújtotta eszközökre. Jó néhány hasonló, nemzetközi kutatás zajlott számos tudományágon belül, amelyek hasonló eszközökre építenek a társszerzőség (Bordons, Aparicio, González-Albo, \& Díaz-Faes, 2015) és hivatkozások vizsgálatának tekintetében (Tang \& Tsai, 2016; Griggs \& Christopher, 2016). 


\section{A Magyar Pedagógia folyóirat töRténete ÉS JelentősÉge}

\subsection{A Magyar Pedagógia története}

A neveléstudományi kutatói szakma nagyrészt konszenzusos módon az 1892-ben indult Magyar Pedagógia címü folyóiratot tartja az egyik legjelentősebb hazai orgánumnak (Biró, 2009a; Nagy, 2016a). A majdnem 120 évfolyamos múlt nemzetközi összevetésben is jelentősnek mondható a neveléstudományok lapok mezőnyében. Több hazai repozitórium gyüjti a folyóirat cikkeit, illetve szerepel a European Reference Index for the Humanities and the Social Sciences (ERIH Plus) adatbázisban is (amely Magyarországról összesen 38 folyóiratot listáz). A folyóirat százéves történetéről részletes tanulmányt közölt Mészáros István (1992), mely megkerülhetetlen forrásnak bizonyul a folyóirat szinte teljes történetének tárgyalása során. A Németh András vezetésével zajló, „A magyar neveléstudomány fejlődésének új irányzatai a XX. század második felében”, illetve „A magyar neveléstudomány története a szakmai folyóiratok tükrében (1945-1989) - tudományos kommunikáció, szakmai diskurzusok" címü OTKA-kutatási projektek eredményeként a Gondolat Kiadónál megjelent „Neveléstudomány-történeti tanulmányok" könyvsorozat egyes kötetei szintén fontos forrást jelentenek a neveléstudományi kommunikáció feltárásának vonatkozásában. A Magyar Pedagógia több szempontú elemzése is elképzelhetetlen lett volna az itt közölt eredmények figyelembe vétele nélkül.

Már az 1891-ben alapított Magyar Paedagogiai Társaság alapszabályában is célként szerepelt „a paedagogiának és segédtudományainak magyar nyelven müvelése, a hazai közoktatásügy egész körében felmerülő elvi kérdéseknek tudományos jellegü tárgyalása, a paedagogia múltjának kutatása, a paedagogiai elvek népszerüsítése és terjesztése”, nem véletlen tehát, hogy ugyanennek a célkitüzésnek kíván megfelelni a társaság folyóirata is (Klamarik \& Suppán, 1892). A lapszámokat havonta (kivéve a júliust és augusztust) kapták kézhez a társaság tagjai tagilletményként. A tiszteleti és alapító tagok, valamint a száz rendes tag nem fizetett érte (nekik tagdíjfizetési kötelezettségük sem volt), a külső tagoknak évi 2 forint tagsági díjuk fejében térítésmentesen járt. Egyéb esetekben 5 forint volt az éves előfizetési díj (mai értéken számolva körülbelül 17000 forint). A folyóirat egy évfolyamnyi terjedelme általában 600-700 nyomtatott oldal között mozgott az 1917-es évig, ezután azonban csökkenésnek indult. Nem volt külön szerkesztőségi hivatal, a kéziratok az aktuális szerkesztő lakására vagy iskolájába érkeztek (a postacímet mindig jelezték az újságban) (Mészáros, 1992). 
A folyóirat első, felelős szerkesztője Csengeri János budapesti latin-görög szakos középiskolai tanár, aki bár a „Csengery” névalakot is használta - sőt Tar (2007) szerint ez a gyakoribb - a Magyar Pedagógia címlapjain még következetesen Csengeri Jánosként szerepel, ezért a disszertációban is ehhez a változathoz ragaszkodtunk. Az újonnan induló folyóirattal kapcsolatos elképzeléseit így fogalmazta meg: „A Magyar Paedagogia mindenekelőtt a paedagogiai tudományágak művelését tűzte ki feladatául s az általános érvényü paedagogiai eszméknek organuma kíván lenni. [...] mindeddig nem volt oly lap, mely a nevelésügy munkásait egyesítse, öket egymással megismertesse, élénkké tegye köztük az összetartozás érzetét, a közös cél tudatát $\mathrm{s}$ lehetővé tegye egymásnak megértését, méltánylását. [...] A Magyar Paedagogia közös tere akar lenni a paedagogia gyakorlati és elméleti munkásainak; nyílt mezeje a vélemények szabad nyilvánításának és higgadt megvitatásának." (Csengeri, 1892, p. 1-2). Csengeri, a Magyar Pedagógia szerkesztői feladatainak ellátását meghaladó munkásságával részletesen foglalkozik a Magyar Pedagógia 2007. évi első tematikus száma (Tar, 2007; Géczi, 2007; Kinyó, 2007; Csapó, 2007), ezek alapján elmondható, hogy a lap első szerkesztője egy nagy müveltségü, széles látókörü, távlatokban gondolkodó tudósember volt, aki 1924-1925 között a szegedi Ferenc József Tudományegyetem rektori tisztségét is betöltötte. Szegedi müködése során már sokkal inkább a Csengery névalakot használja (például a Szegedi Újság főszerkesztőjeként).

A lap aktuális szerkesztői természetesen Csengeri után is mindig nagy hatással voltak az éppen uralkodó tematikus kurzusra és a folyóirat tudományszervező tevékenységére. Időrendben a következő személyek vitték a lapot szerkesztőként: Csengeri János (1892-1895), Négyesy László (1896-1899), Kovács János (1900-1907), Weszely Ödön és Fináczy Ernő (1908-1912), Imre Sándor és Fináczy Ernő (1913-1919), Fináczy Ernő és Nagy József Béla (1919-1932), Nagy József Béla és Kornis Gyula (1932-1938), Kornis Gyula, Pintér Jenő és Nagy József Béla (1938-1939), Kornis Gyula, Prohászka Lajos és Gyulai Ágost (1940-1943), Prohászka Lajos és Faragó László (1944-1947), Mérei Ferenc (1949-1950) Nagy Sándor (1961-1985), Köte Sándor (1986-1990), valamint Csapó Benő (1991-). A felsorolásból kivehető, hogy egyes nyugalmasabb időszakokban bizonyos személyek akár egész hosszan is közremüködtek a folyóirat életében.

Az egyik felívelő szakasz egyértelmüen a folyóirat életciklusának elejére tehető. Mészáros (1992, p. 8-9) így számol be a leghaladóbbnak tartott évekről: „1904 januárjában Fináczy Ernőt választották a Társaság elnökévé. Ettől kezdve a hagyományos neveléselméleti, didaktikai és neveléstörténeti témákon belül és kívül sajátos új témák jelentek meg a Magyar Paedagogiában. Több tanulmány az ekkor felerősödő „gyermektanulmány” témaköreiből 
merített; azután a nemi nevelés, a koedukáció, az intelligencia-vizsgálatok problematikájából, továbbá a cserkészet pedagógiájából vette tárgyát; nagyhatású tanulmány szerepelt „értékelmélet és pedagógia” címmel, írások szóltak a kriminál-pedagógiáról, a tehetséges gyermekről és más, ekkor friss témákról. Mindezek jelzik az egyre bővülő, az újabb neveléstudományi áramlatokkal lépést tartó szerkesztési koncepciót: az időtálló hagyományos pedagógia mellett a már eredményekkel bizonyító reformszándékú pedagógiai áramlatok elismerését, a Magyar Paedagogia által való közvetítésének szándékát. Ugyancsak új tény, hogy a Magyar Paedagogia sorozatosan közölte a három hazai tudományegyetem (Budapest, Debrecen, Kolozsvár) neveléstudományi tanszékein tartott neveléstudományi előadások témáit és előadóit. Újdonság, hogy a folyóirat minden évben közreadta az előző év hazai pedagógiai szakirodalmának teljes repertóriumát. S egy ugyancsak folyamatosan visszatérő új összefoglalás: a „Nemzetközi nevelésügyi mozgalmak” címü, igen részletes kitekintés a különféle nyugati reformpedagógiai áramlatokra. Új témát hozott az első világháború négy esztendeje, ilyen címadásokkal: „Köznevelésünk és a háború”, „A háború pedagógiai tanulságai”, „A békére nevelés” s hasonlók. Alaphangjuk ez: a háború kényszerüségét tudomásul veszik, de hangsúlyozzák embertelenségét, embert deformáló hatásait. A háborúra lelkesítésnek semmi nyoma sem található a Magyar Paedagogia lapjain.”

Közvetlenül az első világháború utáni periódusban Trianon, majd a két világháború közötti időszakban a folyamatosan erősödő és hatalomra jutó náci propaganda állította újabb megpróbáltatások elé a lapot. Mindezek ellenére próbáltak megmaradni a tárgyilagosság talaján a nemzeti szocialista tanügy fejleményeinek ismertetése során. A második világháború lezárulta után, a kommunista hatalomátvétel olyannyira megnehezítette a lap kiadását, hogy az 1940-es évek végén néhány összevont, terjedelmében jóval szűkebb, témájában már az uralkodó ideológiai kurzushoz igazodó lapszám kiadása után, 1951 és 1960 között teljesen ellehetetlenült a folyóirat kiadása, és ebben az időszakban egyetlen lapszám sem jelent meg. Mészáros (1992) tanulmányában teljesen elhatárolódik a hiátust megelőző hányattatott időszak lapszámaitól. Saját megítélésünk szerint ez az időszak is a lap életútjához tartozik, az évfolyamszámozás is folyamatos (58. és 59. évfolyamok), vizsgálatainkban ennek szellemében kezeltük ezt az időszakot.

Ehhez hasonlóan, az évfolyamszámozás alapján a Nagy Sándor vezetésével 1961-ben újrainduló folyóirat is jogfolytonos kiadványnak tekinti magát. Mészáros (1992, p. 15) így számol be erről az új korszakról: „Az új folyóirat évente négyszer jelent meg; egy-egy évfolyam össz-oldalszáma a három évtized alatt mindvégig 450-500 között mozgott. [...] A föszerkesztő „A Magyar Pedagógia új feladatok előtt” címmel vázolta fel szerkesztési koncepcióját. 
Hangsúlyozta: „Az új Magyar Pedagógia a szocializmus építésének történelmi feltételei között a marxista-leninista szellemű neveléstudomány hazai kutatási eredményeinek publikálásával kíván hozzájárulni nevelésügyünk kérdéseinek megoldásához.” A Magyar Tudományos Akadémia a folyóirat megjelentetésével „,a szocialista neveléstudomány hazai fejlődésének általános előmozdításán túl lehetőséget kíván nyújtani a Pedagógiai Bizottságnak, hogy hatékonyabban tudja a pedagógiai kutatás országos irányítását és koordinálását elvégezni.” Az általános közállapotokhoz hasonlóan az egyoldalú és szigorú ideológiai felhang az idő múlásával valamelyest tompult a folyóiratnál. Az 1970-es évek elejétől olyan új témák is megjelentek a lapban, mint például a később oly meghatározóvá váló iskolai teljesítmények mérése és értékelése, iskolai teljesítménytesztek, csoportmunka, a neveléstudományi kutatástervezés és a pedagógiai kutatásmódszertan aktuális kérdései. A közölt recenziók vonatkozásában szintén megfigyelhető egyfajta nyitás a nyugati világ szakirodalma felé.

Az általunk elvégzett tartalmi elemzésekhez való kapcsolódás okán mindenképpen érdemes itt szerepeltetnünk (Mészáros nyomán, aki tanulmányában igen részletesen elemzi az 1961-1990 közötti időszakot) a Nagy Sándor (1981) főszerkesztő által közölt meghatározó témacsoportokat:

1. Oktatáspolitika, a köznevelés, a közmüvelődés aktuális kérdései.

2. A neveléstudomány fejlődésével, helyzetével, a pedagógiai kutatásokkal kapcsolatos kérdések.

3. Nevelés- és oktatáselméleti kérdések.

4. A felsőoktatás és felnőttoktatás elméleti és gyakorlati kérdései.

5. Neveléstörténeti és összehasonlító-pedagógiai kérdések.

6. Tantervi, tantervelméleti kérdések.

7. Tankönyv, szakirodalom, nevelöképzés.

8. Ismertetések (könyvek, folyóiratok, konferenciák stb.)

Az 1980-es évek viszonylag haladóbb szemléletü megközelítése után a teljes korszakváltás nem meglepő módon csak a rendszerváltás lezárulta után következhetett be. A folyóirat teljesen megújult szerkesztőgárdával, új főszerkesztővel, és ami mindennél fontosabb, meröben új megközelítéssel jelentkezett. Csapó Benő, aki 1991 óta az újjáalakult folyóirat főszerkesztője, jó néhány tanulmányában körüljárja a több mint százéves folyóirat történetét, illetve a neveléstudományban betöltött szerepét és feladatát (Csapó, 1991, 1992, 2000, 2005, 2007), jó néhány esetben teszi mindezt a tetten érhető útkeresés szándékával. Mindezek mellett a téma esetleges behatóbb kutatói számára további, részletesen kifejtett adalékok találhatóak a hivatkozott Mészáros cikk irodalomjegyzékében szereplő tanulmányokban. Szintén hiánypótló 
forrásnak tekinthető a Csapó és Pukánszky (1993) által összeállított százéves repertórium. A tartalmi elemzés részben természetesen még tételesen vissza fogunk csatolni ezekre a Magyar Pedagógia múltját feltáró neveléstörténeti munkákra.

Csak az itt közölt rövid történeti összefoglalóból is látható, hogy a folyóiratnak története során számos alkalommal meg kellett újulnia, azonban a visszanézés távlatából kijelenthető, hogy mindezek a megújulások tették azt lehetővé, hogy a lap mai napig fennmaradjon, és hamarosan egy 120. évfolyamába lépő folyóiratról beszélhessünk. A történelmi korszakváltások miatt kikényszerített profilváltások mellett magabiztosan kijelenthető, hogy a lehetőségekhez képest a periodika folyamatosan lépést tartott a neveléstudomány éppen aktuális nemzetközi trendjeivel.

A tartalmi jegyek nyomon követése mellett érdemes néhány szót ejteni a folyóirat hosszú története során lezajlott formai átalakulásokról is. Ilyen elemek például a folyóirat logójának és tipográfiájának időnkénti változásai, melyek lecserélése általában az esetek nagy részében összekapcsolódik egy-egy szakaszhatárral a folyóirat életében. A tipográfia a folyóirat életének kezdeti szakaszában viszonylag állandónak mondható, a nyomda egészen sokáig a Franklin Társulat Könyvnyomdája maradt, amely információt folyamatosan szerepeltették is a címlapon. A folyóirat emblémája a kezdetektől Pallasz Athéné portréja, aki köztudomásúlag a bölcsesség, a művészetek és a képzés istennője a görög mitológiában, így érthető a választás. A logó tipográfiailag mindig a címlapon, annak alsó harmadában foglalt helyet. Az első változás 32 év múltával, 1923-ban történt, amikor Pallasz Athéné portréja 15 éven keresztül lecserélődött az 5. ábra jobb oldalán látható stilizált bagolyábrázolás könyvespolc előtti képére. Ugyanekkor történt az első komolyabb változás a címlapképben is, egyéb változtatások mellett az addig a címben és a társaság nevében is használt „Æ” ligatúra helyett, áttérnek a különálló „AE” karakterek használatára a „paedagógia” szóban és annak alakváltozataiban, ez a változás azután egészen 1947-ig érvényben marad, ezután már végig a modern „pedagógia” írásmód van használatban. 

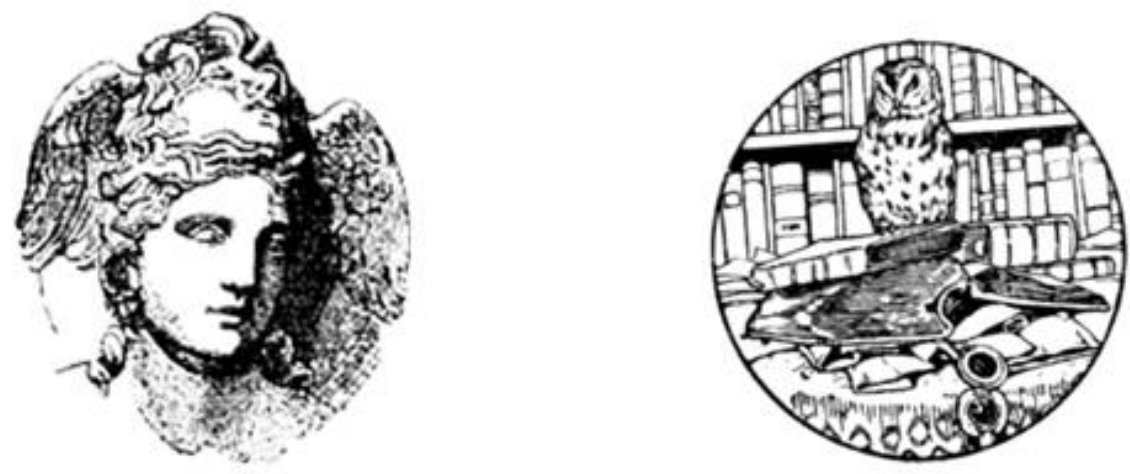

\section{5. ábra}

A Magyar Pedagógia emblémái: Pallasz Athéné portréja (1892-1922, 1939-1947, 1991-) és a stilizált bagoly egy könyvespolc elött (1923-1938)

A logót illetően 1939-ben a folyóirat szerkesztői visszatértek a gyökerekhez, újra a tudományok védnöke került a címlapra, egészen az 1947-es évfolyamig bezárólag. Az ezt követő zavaros években, amikor néhány éven keresztül csak összevont számok jelentek meg, nem került semmilyen embléma a lap elejére. A folyóirat 1960-as újraindulásakor teljesen új tipográfiával jelentkezett, a szerkesztőség érthető módon ezen a vonalon sem akarta erősíteni a számára terhes kapcsolatot a háború előtti időszakkal, így a kezdeti néhány évben csak a Magyar Tudományos Akadémia jelképe található a címlapon. Ugyanekkor áttérnek az év közbeni lapszámok következetes jelölésének rendszerére, ekkortól kezdve egy évfolyamon belül négy önálló vagy esetlegesen időnként egy-egy összevont számmal jelentkezett a folyóirat. 1963-tól kisebb változás történt a belívek nyomdaképében és a címlap stílusát illetően is, ezeken az új címlapokon már semmilyen grafikus embléma nincs. Az ekkor bevezetett stílus egészen a lap rendszerváltás utáni megújulásáig tartja magát: változó, általában valamilyen élénk színü címlap előtt ugyanazzal a betütípussal és tipográfiával írt Magyar Pedagógia felirat a címlap felső harmadában, míg a jobb oldali dobozban felirat: „A Magyar Tudományos Akadémia Pedagógiai Bizottságának folyóirata”, a bal oldali alsó harmadban pedig az év és lapszám jelölés, az évfolyam külön jelzése nélkül.

A rendszerváltás utáni új főszerkesztő, Csapó (1991, p. 4) így fogalmaz a folyóirat első, megújult külsővel megjelenő számában: „A szerkesztő bizottság törekedni fog arra, hogy a Magyar Pedagógia akadémiai folyóirathoz illő rangja esztétikus külső megjelenésében is kifejeződjön. A borítót és a tipográfiát a hagyomány és a modern technika által kínált lehetőségek összekapcsolásával alakítottuk ki. A borítót tekintve visszatértünk az alapítók által kialakított formához, egyéb formai elemek esetében a nemzetközi folyóiratokat tekintettük mérvadónak.” A folyóirat egy papírpéldányát kézbe véve (a Magyar Pedagógia a mai napig 
papíron is megjelenik) a saját szemünkkel is láthatóvá válik, hogy a folyóirat 1991-es megújulása után nemcsak a szavak szintjén tartja magát az 1892-es folyóirat szellemi jogutódjának, hanem olyan gesztusokon keresztül is, mint az eredeti Pallasz Athéné-féle emblémához való visszatérés, amely napjainkig megtalálható a folyóiratszámok elején. A tipográfia és a nyomdakép sokat egyszerüsödött ugyanezen megújulás keretében, mindazonáltal az egyszerüsítés ellenére az új design sokkal elegánsabb, modernebb benyomást kelt, amely az eltelt 27 év távlatából is egy igényes tudományos lap benyomását kelti az olvasóban.

\subsection{A Magyar Pedagógia szerepe a hazai neveléstudományban}

Bár a folyóirat 1991-es megújulása óta már több mint negyed évszázad eltelt, ezt az életszakaszt ennek ellenére elsősorban mégsem történeti jelleggel szeretnénk tárgyalni, hiszen a lap kiadásának szellemiségét jelenleg is a rendszerváltáskor megfogalmazott alapelvek határozzák meg. Az akkor lefektetett elképzelések és koncepció fó vonalaiban a mai napig érvényesek. Ez nagyrészt a főszerkesztő személyének és az általa biztosított állandó és stabil szerkesztőségi háttérnek tudható be. Csapó Benő - az általunk itt alkalmazott szemlélethez hasonlóan - a történeti megközelítésen túl, több írásában foglalkozott a Magyar Pedagógia hazai neveléstudományban betöltött szerepével. Ezekben az írásokban a jelen és a jövő feladatai általában mindig hangsúlyosan megjelennek. Az egyik legrészletesebb ilyen cikk, amelyben többek között ismertetésre kerülnek az 1991-es megújulás körüli dilemmák is, 2005-ben jelent meg az Iskolakultúrában, ebből egy szemelvényrészletet szó szerint közlünk, mivel nagyon tömören és hatékonyan rávilágít a folyóirat fö küldetésére, egyfajta küldetésnyilatkozatként is felfogható ez a néhány bekezdésnyi szövegrészlet (Csapó ugyanezen cikkének korábban közölt megállapításaival együtt):

„Az 1990-es évek elején, a rendszerváltozást követően az ideológiai-politikai korlátok megszünésével új lehetőségek nyíltak a neveléstudományi kutatások előtt, és egyben szükségessé vált a folyóirat szerepének újraértelmezése is. A Magyar Pedagógia abban az időben már a Magyar Tudományos Akadémia Pedagógiai Bizottságának folyóirata volt, és a bizottság körében zajlottak le azok a viták, amelyek az új missziót körvonalazták. A különböző álláspontok között felmerült a megszüntetés gondolata (,érdemes-e egy a múlt rendszerben kompromittálódott orgánumot életben tartani?”), az angol nyelven való megjelentetés (,a világ számára hozzáférhetővé kell tenni az itteni eredményeket!"), továbbá egy ismeretterjesztőtanártovábbképző funkció (,el kell juttatni a tanárokhoz a kutatási eredményeket!”) is. A sok 
lehetőség közül az akadémiai funkció, a tudományos folyóirat jelleg és a magyar nyelvü megjelentetés kerekedett felül. Ezeket az általános alapelveket azonban még összhangba kellett hozni a konkrét müködési feltételekkel. Végül az az álláspont alakult ki, mely szerint a Magyar Pedagógia a tudományos folyóiratok nemzetközi normáit, formai és stilisztikai alapelveit követve jelenik meg, magyar nyelven, angol nyelvű összefoglalóval. (Csapó, 1991) Ennek megfelelően határoztuk meg a közlési feltételeket, ehhez igazodott a külső megjelenés, a tördelés. A publikációs stílus és a hivatkozási rendszer a legkidolgozottabb és legelterjedtebb rendszert, az Amerikai Pszichológiai Társaság publikációs stílusát (APA Publication Manual) vette alapul, és ennek a magyar nyelvre adaptált változatát mi készítettük el. A folyóirat hagyományaira mint a „tudományos patina”, megjelenésére és mint megbecsülendő, megőrzendő értékre, a szakmai identitás mással nem pótolható forrására tekintettünk. [...] A hagyományok és az elődök iránti tiszteletből visszatértünk az eredeti logóhoz, és a címlapot is az alapításkori megjelenéshez közelítettük.” (Csapó, 2005, p. 5).

Értekezésünk 1.4-es pontjában már részletesen tárgyaltuk a hazai és nemzetközi folyóiratok szerepét a tudományos kommunikációban. Kiemelten hangsúlyozandó, hogy az ott ismertetett megállapítások kivétel nélkül érvényesek a Magyar Pedagógia rendszerváltás utáni életpályájára és neveléstudományban betöltött hiánypótló szerepére, így az ott bemutatott funkciókat nem ismételjük meg jelen keretek között. Szintén nem ismételnénk meg a lap színvonaláról és más lapokkal való összehasonlításáról szóló számtalan kutatás megállapításait, hiszen ezekre korábban már több helyen is hivatkoztunk. 


\section{A KUTATÁS CÉLJA, KÉRDÉSEI ÉS HIPOTÉZISEI}

A disszertáció alapjául szolgáló kutatási projekt szükséges kiindulási céljai közé tartozott a Magyar Pedagógia folyóirat teljes körü digitalizálása, analitikus feltárása és a teljes szövegü elérés biztosítása a szakmai közönség számára, egyúttal a folyóirat hatékonyabb internetes láthatóságának biztosítása. Ezen kiinduló lépések megtörténte után lehetett hozzálátni a kutatás fő céljának teljesítéséhez, mely a folyóirat nemzetközi és hazai trendek alapján történő teljes körü tudománymetriai elemzése volt. A célok között szerepelt a lap társszerzőségi gráfjának elkészítése a folyóirat alapításának kezdeteitől, illetve a folyóirat belső és teljes hivatkozástérképeinek megalkotása a szabványos hivatkozási stílus bevezetésének kezdeteitől, azaz 1991-től, a kutatás kezdőidőpontjáig, azaz 2014-ig. A projekt tartalomelemzési pillérét tekintve a fó célok a következőkben kristályosodtak ki: a Magyar Pedagógia tematikus feltárása, elsősorban kvantitatív megközelítésű tartalom- és szövegelemzés, illetve szövegbányászat segítségével; trendkövetés, a folyóirat egyes évtizedeire leginkább jellemző diskurzusok és azok változásainak detektálása. Mivel a disszertációban szereplő összes viszgálatra érvényes, hogy két eltérő időszakot (1892-2014 és 1991-2014) érinthetnek, ezért a könnyebb áttekinthetőség miatt az időablakokról részletes összefoglalást készítettünk az egyes elemzések vonatkozásában (lásd 11. melléklet).

\subsection{A metaadatok vizsgálatára vonatkozó kutatási kérdések és hipotézisek}

1. Hogyan változott időben a publikációk száma és a tanulmányok átlagos hossza?

2. Kik a folyóirat legtöbbet publikáló szerzői? Közülük kik gyakorolták a legnagyobb hatást más szerzőkre?

3. Milyen intézményi háttérrel rendelkeznek az egyes szerzők?

4. Hogyan változott a társszerzős cikkek aránya? Jellemzően kik az együtt publikáló szerzők?

5. Hogyan alakult a folyóirat életében a férfi és női szerzők aránya?

$\mathrm{H}_{1}$ : Feltételezésünk szerint mind a publikációk száma, mind terjedelmük növekvő tendenciát mutat a rendszerváltást követően a felsőoktatás tömegesedése (Oktatási Hivatal, 2017, Polónyi, 2008) és a társadalomtudományi doktori képzés kiteljesedése okán (Inzelt \& Csonka, 2018), hiszen emiatt valószínüleg egyre többen foglalkoznak oktatással és neveléstudományi kutatással.

$\mathrm{H}_{2}$ : Biró (2009b) eredményei miatt feltételezzük, hogy a Magyar Pedagógia szerzői között is megfigyelhető lesz a Szegedi Tudományegyetem Neveléstudományi Intézetében 
uralkodó, kognitív pszichológiai paradigmát képviselő, domináns kutatói csoport jelenléte, így várakozásaink szerint a folyóiratban legtöbbet publikáló és legnagyobb hatású szerzők közülük fognak kikerülni.

$\mathrm{H}_{3}$ : A szerzők intézményi háttérét vizsgálva azt feltételezzük, hogy kimutathatóak lesznek elkülönülő csoportok a társszerzőségi gráfban (Molnár, Tóth, \& Pintér, 2018a; 2018b).

$\mathrm{H}_{4}$ : A társszerzőséget illetően a nemzetközi trendeknek megfelelően hipotézisünk alapján kimutathatóan növekedett a társszerzős cikkek aránya az egyszerzős publikációkhoz képest (Fanelli \& Larivière, 2016; Tóth, 2014; Inzelt, Schubert, \& Schubert, 2008).

$\mathrm{H}_{5}$ : A tudományos publikálást érintő nemzetközi trendek (West, Jacquet, King, Correll, \& Bergstrom, 2013; Mauleón, Hillán, Moreno, Gómez, \& Bordons, 2013) és a hazai felsőoktatási statisztikák (Oktatási Hivatal, 2017; Eurostat, 2017; Polónyi, 2008) alapján feltételezzük, hogy az elemzett folyóiratban növekedett a női szerzők aránya.

\subsection{A hivatkozások vizsgálatára vonatkozó kutatási kérdések és hipotézisek}

A hivatkozásvizsgálatok esetében a referenciák elfogadható megbízhatóságú és automatizált felismerésén és kivonásán túl kutatási céljaink két csomópont mentén fogalmazhatóak meg. Elsődleges cél volt a kinyert hivatkozások általános és minél több szempontú elemzése az alábbiakban megfogalmazott kutatási kérdések mentén. További célt jelentett két, eltérő típusú hivatkozási hálózat létrehozása: egy belső (a Magyar Pedagógia zárt terén belül maradó), illetve egy teljes (minden citációt tartalmazó) hivatkozási hálózat létrehozása, vizualizálása, majd elemzése. A hivatkozásvizsgálatokra vonatkozó kutatási kérdéseinket elsősorban Németh és Biró (2009), illetve Tóth, Toman és Cserpes (2008) megállapításai nyomán, valamint a tudománymetriai témájú publikációkban (például Nederhof, 2006; Fox, Paine, \& Sauterey, 2016) bevett mutatók alapján határoztuk meg.

6. Melyek a leggyakrabban előforduló, legidézettebb szakirodalmi források? A hivatkozások megoszlása alátámasztja-e a közmegegyezés szerint legelismertebb négy neveléstudományi folyóirat szakmán belüli szerepét, illetve mi ezek sorrendje?

7. A Magyar Pedagógia hivatkozásai alapján mely könyvek tekinthetőek a neveléstudomány referenciamüveinek, továbbá hogyan reprezentálódnak a hivatkozások tükrében a konferencia-előadások és a disszertációk?

8. Kik a legnagyobb hatású, legidézettebb szerzők? Milyen az ő nemzetközi reputációjuk? Milyen intézményi háttérrel rendelkeznek a leginkább idézett szerzők? 
9. A hivatkozások felhasználásának tükrében idővel hogyan változik olyan minőségi mutatók eloszlása, mint a szakirodalmi források mennyisége, frissessége, nemzetközisége és interdiszciplinaritása? Növekvő vagy csökkenő tendenciát mutatnak az impakt faktorral rendelkező folyóiratokra érkező hivatkozások?

A kutatási kérdéseket kiegészítendő, a hivatkozáselemzések eredményeit illető hipotéziseink a következők voltak:

H6: A publikációkban történő idézések nagyobb aránya folyóiratcikkekre történik (Bornmann \& Mutz, 2015; Larsen \& Von Ins, 2010), és ez a megoszlás az időben elörehaladva egyre inkább növekvő tendenciát mutat a többi tudományos müfaj rovására. A szakirodalom (Tóth, Toman, \& Cserpes, 2008; Pap, 2009) álláspontja és saját várakozásunk alapján is arra számítunk, hogy a négy leghivatkozottabb forrás a Magyar Pedagógia, az Iskolakultúra, az Educatio és az Új Pedagógiai Szemle folyóiratok lesznek.

$\mathrm{H}_{7}$ : Összhangban $\left(\mathrm{K}_{7}\right)$ kérdésünkkel - annak ellenére, hogy a könyv dokumentumtípus tudománymetriai vizsgálata nem egyszerű müfaj, lásd erről Giménez-Toledo, MañanaRodríguez, Engels, Ingwersen, Pölönen, Sivertsen és Zuccala (2016) megfontolásait elképzeléseink szerint létezik néhány kiemelkedő hatású szerkesztett tanulmánykötet, illetve monografikus mü, amelyek jelentős hatással voltak a neveléstudományi diskurzusra és a rájuk érkező hivatkozások száma alapján a leghivatkozottabb források listáján előkelő helyen szerepelnek. Emellett valószínüleg a tanulmányok hivatkozási listáiban kimutathatóan megjelennek a konferencia-előadások és disszertációk (Mahood, Van Eerd, \& Irvin, 2014), bár szerepük kevésbé jelentős.

$\mathrm{H}_{8}$ : Mivel a tudománymetriai elemzésekben a magas idézettséggel rendelkező szerzők, illetve intézményi hátterük vizsgálata sok esetben az érdeklődés homlokterében áll (Tijssen, Visser, \& Van Leeuwen, 2002), ezért ezt a szempontot szerettük volna érvényesíteni a kutatásban. A szorosan vett neveléstudomány területéről Bárd (2009), illetve Tóth, Toman és Cserpes (2008) közöl adatokat a referenciaszemélyekről. A Magyar Pedagógia esetében a legidézettebb szerzők listája valószínüleg összefüggést mutat a folyóiratban legtöbbet publikáló szerzőkkel, illetve a magyar neveléstudomány elismert alakjaival (MTA doktorok, vezető kutatók, egyetemi tanárok stb.). Kiegészítésképpen, Csapó (2016) tanulmánya nyomán érdemes vizsgálnunk a vezető magyar kutatók nemzetközi reputációját. A Magyar Pedagógia leghivatkozottabb kutatói esetében a nemzetközi idézettség nagyságrendjének tekintetében a vizsgált folyóiratban tapasztalhatókkal összevethető eredményekre számítunk. Hasonlóan a társszerzőségi hálózatoknál tapasztalhatókhoz (Nagy \& Molnár, 2017; Molnár, Tóth, \& Pintér, 
2018b), feltevésünk szerint a hivatkozási gráf mintázatai esetében az intézményi háttér tekintetében jellemzőek az elkülönülö csoportok.

H9: Ware és Mabe (2015), illetve Bornmann és Mutz (2015) alapján úgy gondoljuk, hogy az egyes tanulmányokban felhasznált szakirodalmi hivatkozások száma növekvő tendenciát mutat az idő előrehaladtával, és a szerzők egyre frissebb szakirodalmat használnak munkájukhoz. Csíkos (2013) nyomán pedig érdemes megvizsgálnunk, hogy az impakt faktorral rendelkező, illetve azzal nem rendelkező nemzetközi forrásokra történő hivatkozások aránya valóban növekszik-e a cikkekben, ahogyan a Bárd (2009) tanulmánya óta eltelt időben az interdiszciplináris forrásokra való hivatkozások aránya esetében szintén emelkedő trendet várhatunk.

\subsection{A tartalmi elemzésre vonatkozó kutatási kérdések és hipotézisek}

A tematikus elemzés során felhasznált széleskörü szövegbányászati módszerek legfontosabb eredménye a különbözö felbontású tematikus kategórialisták megalkotása, amely az egyes évtizedek általános tartalmi keresztmetszetét hivatott reprezentálni a könnyebb összehasonlíthatóság végett. Cél annak kimutatása, hogy a folyóirat története során hogyan változtak az egyes tárgyalt témák, az egyes évtizedekben mi foglalkoztatta leginkább a folyóirat szerzőit. Mindehhez az elméleti hátteret és kiindulási alapot föként Németh András recepciótörténeti megközelítésü munkái (Németh, 2015, 2014, 2013) és az irányításával zajló „A magyar neveléstudomány fejlődésének új irányzatai a XX. század második felében”, illetve „A magyar neveléstudomány története a szakmai folyóiratok tükrében (1945-1989) tudományos kommunikáció, szakmai diskurzusok" című OTKA-kutatási projektek adták. Mindezek alapján kibomló kutatási kérdéseink a tartalmi elemzés részre a következőek:

10. Korszakonként melyek voltak a leghangsúlyosabb tématerületek a folyóirat életében és hogyan változtak a tartalmi tendenciák évtizedről évtizedre a folyóirat története során? Mennyire követték a szerzők az éppen aktuális nemzetközi kutatási irányokat?

11. Milyen korszakhatárok rajzolódnak ki a folyóirat publikációi alapján és mikor történtek éles tematikus váltások? A folyamatos egymásra épülés, rétegződés, szerves fejlődés vagy inkább éles tematikus váltások jellemzőek az éppen uralkodó politikai ideológia hatására?

12. Egybeesnek-e folyóiratban tapasztalható korszakhatárok a magyar neveléstudományban elfogadott korszakhatárokkal? 
$\mathrm{H}_{10}$ : Évtizedes időszakaszokat vizsgálva a tématerületek kimutathatóan folyamatos változásban vannak. A Magyar Pedagógiában megjelenő témák rövid időbeliséggel követik a nemzetközi neveléstudományban felbukkanó trendeket. Mészáros (1992) a folyóirat történetét feltáró tanulmánya erre enged következtetni.

$\mathrm{H}_{11}$ : A cikkek tartalmában mind az éppen aktuális, meghatározó, a neveléstudomány egészét foglalkoztató korszakos kérdések, mind az éppen uralkodó politikai ideológiák hatásai megfigyelhetőek lesznek, illetve trendszerüen kimutathatóvá válnak majd. Szintén Mészáros (1992) alapján gondoljuk ezt.

$\mathrm{H}_{12}$ : A tartalmi elemzések folyamán kimutatható korszakhatárok a főbb vonalakat tekintve egybeesnek a hazai neveléstudomány fö sodrával (Németh, 2015, 2014, 2013; Németh, Biró, \& Garai, 2015; Németh \& Biró, 2009). 


\section{MóDSZEREK}

\subsection{Előkészítő lépések és a metaadatok elemzésének módszerei}

A kutatás mintáját a Magyar Pedagógia címü folyóirat 1892-2014 közötti lapszámainak digitális szövegkorpusza és az ebben az időszakban megjelent cikkekre vonatkozó metaadatok alkották. Az elemzések előfeltétele volt a folyóirat teljes digitalizálása és automatikus karakterfelismertetése (OCR), melynek karakterszintủ megbízhatósága a tesztek alapján a 9799\%-os tartományban mozog. Mintegy a kutatás előkészítő lépéseként, ez a tevékenység a 2014-es esztendőben zajlott a folyóirat szerkesztőségének beleegyezésével és támogatásával (lásd 1. melléklet). Az 1991-2014 közötti idöszak lapszámai elektronikus formában is rendelkezésre álltak, amelyet megkaptunk a szerkesztőségtől. A folyóirat megjelenése az 18922014 közötti időszakban folyamatos, kivéve az 1951-1960 közötti tíz éves hiátust, ebből következik, hogy a kutatás alapjául szolgáló minta összesen 113 évfolyamot tesz ki. A teljes szövegkorpusz mintegy 50 ezer oldalra tehető, tömörítetlen XML szövegfájlként mérete 260 megabájt.

A kutatás megkezdéséhez elengedhetetlen volt a cikkek manuális analitikus feldolgozása, amelyet a Szegedi Tudományegyetem Klebelsberg Könyvtárának munkatársai végeztek el a MARC (MAchine Readable Cataloging; magyarul: géppel olvasható katalogizálás) szabvány szerint. A tárgyalt időszakban megjelent és feltárt cikkek száma 7618-ra tehető, azonban ezek között vannak olyan rövid közlemények vagy hírek, amelyeket későbbi kutatásainkban nem vettünk figyelembe, elsősorban azok rövid terjedelme miatt. Az elemzésbe bevont tanulmányok száma összesen 6574, bár a tanulmányok között szerepelnek olyan írások is, amelyek az elfogadott normák alapján szigorú értelemben nem tekinthetőek tudományos, saját eredményeken nyugvó publikációnak (például könyvismertetések, recenziók). Az analitikus feldolgozás során előálló metaadatok önmagukban is számos elemzést tesznek lehetővé a megjelent tanulmányok általános jellemzőit illetően, illetve maradéktalanul alkalmasak a társszerzőségi gráf előállítására.

A metaadatokkal, hivatkozásokkal és a tartalmi elemzéssel kapcsolatban végzett feladatok során természetesen folyamatosan kezelni kellett a felmerülő kihívásokat, nem várt problémákat, ezekre megpróbáltunk minden esetben adekvát válaszokat adni. Ilyen volt például a folyóirat életpályájának első felében, a szerzők által előszeretettel használt monogramok feloldásának kérdése. A szerzői jelek és álnevek (jellemzően monogramok) feloldásában a Magyar Királyi Ferenc József Tudományegyetem Pedagógiai Intézete által 1933-ban Szegeden 
kiadott, „A Magyar Paedagogia negyven évfolyamának tartalom- és névmutatója: 1892-1931” címet viselö kötet volt nagy segítségünkre. A feloldott monogramok listáját a 3. mellékletben között közöljük.

Szintén szükséges volt kezelni az ismert névegyezéseket, például amikor kiderült, hogy a folyóirat tudományos színvonalát kettő Nagy József nevü, igen produktív szerző is emelte az évek során. Miután mindezt eltérő időszakban tették, így lehetséges volt az egyértelmü elkülönítés, azonban még így is külön figyelmet kellett rá fordítani, hogy a két szerző önálló entitásként kezelödjön, és ne torzítsák egymás statisztikáit. Az 1960 után, ez alatt a név alatt megjelenő cikkeket Nagy József I., míg az ez előtt megjelent publikációkat Nagy József II. alakokkal jelöltük (tovább bonyolította az elemzéseket, hogy 1916-tól Nagy József Béla főszerkesztő is müködött, akit szintén külön entitásként kezeltünk). Az eredmények megfelelő értelmezhetősége miatt bizonyos esetekben szintén szükség volt az előforduló nevek normalizálására, ez általában a valamelyest eltérő, ám ugyanarra a személyre vonatkozó névhasználatból eredt. A különböző alakú, de egy személyre vonatkozó névalakokat egy név alatt kellett aggregálnunk, hogy a kapott eredmények ilyen módon ne ugorjanak szét az eltérö, bizonyos esetekben akár hibás (legalábbis a Magyar Pedagógia szabályaihoz nem alkalmazkodó) névhasználat miatt. Ez a megközelítés ugyanígy érvényes volt a hivatkozott folyóiratok címére: optimalizálnunk kellett az esetleges kis- és nagybetűs, illetve írásjelbeli eltéréseket. E folyamat során el kellett távolítani a címböl minden írásjelet, szóközt és számjegyet, majd az egész alakot kisbetűs formára hoztuk, vagyis például a hivatkozott „Magyar Pedagógia” mindenféle variánsait "magyarpedagógia" normalizált alakra aggregáltuk.

$\mathrm{Az}$ eredmények jobb összehasonlíthatósága érdekében néhol a kitekintés eszközével éltünk és más neveléstudományi folyóiratokat is bevontunk elemzéseinkbe. Bár a tárgyalt periodikumok kivétel nélkül tudományos folyóiratok, ettől függetlenül az előző bekezdésben vázolt probléma itt is jelentkezett, hiszen a folyóiratokban megjelent írások széles múfaji szórást mutatnak: tanulmányok, könyvismertetők, közlemények és rövidebb-hosszabb írások jelentik tartalmukat. Ezek besorolása nem mindig egyszerü, ezért döntöttünk úgy, hogy a Magyar Pedagógiára nézve azzal a megkötéssel élünk, hogy a kutatásba csak a tanulmányokat, könyvismertetőket és egy időszakban rendszeresen megjelenő Szemle rovatot vonjuk be. Nem szerepeltetjük a jelentéseket, beszámolókat, ülések jegyzőkönyveit vagy más, közlemény típusú írásokat. A többi, kutatásba bevont folyóirat esetében ugyanilyen széles a műfaji paletta, ezeknél a Matarka adatbázist (Magyar folyóiratok tartalomjegyzékeinek kereshető adatbázisa; www.matarka.hu) használtuk adatforrásként. 


\subsection{A hivatkozásvizsgálatok során alkalmazott módszerek}

Miután az egységesen szabályozott hivatkozási stílus csak a Magyar Pedagógia 1991-es megújulása után került bevezetésre, ezért a hivatkozásvizsgálatok csak ebben az időszakban értelmezhetőek. Ezt megelőzően a szerzők hivatkozáshasználata teljesen esetleges volt: egyaránt előfordulnak szövegközi hivatkozások, hivatkozások a lábjegyzetekben, néha a tanulmányok végén. Emellett megjelentek a publikációk eltérő müfaji sajátosságaiból adódó problémák is. A társszerzőségi és a hivatkozási gráfok hasonló elemzésnek vethetőek alá, azonban fontos felhívni a figyelmet arra a körülményre, hogy a gráfok előállítása csak eltérő metodika alapján valósítható meg, valamint a fentiek alapján a vizsgált időtávok is eltérők lesznek a két gráftípus kapcsán. Míg a társszerzőségi gráf megkonstruálásához szükséges metaadatok a strukturáltabb és ezáltal könnyebben feldolgozható MARC adatszerkezetben állnak rendelkezésre, addig a hivatkozási gráf létrehozásához szükséges információk csak félig automatikusan szerezhetőek be (a publikációk és az azon belüli hivatkozások szegmentálásának nehézségei miatt).

A hivatkozásvizsgálatok elvégzéséhez szükség volt a hivatkozások cikkekből való kinyerésére és strukturálására, amely művelet elvégzése - tekintettel a nagy elemszámra ( $\mathrm{N=14039)}$ automatikus eszközökkel történt, építve a szövegbányászat nyújtotta lehetőségekre. Ehhez a lépéshez szükséges volt a szövegkorpusz PDF-ből XML formátumra való átalakítására, amelyet az SZTE Klebelsberg Könyvtár erre a célra fejlesztett megoldása tett lehetővé. A hivatkozások konkrét kinyerését, illetve a tartalomelemzés kapcsán szükséges szövegbányászati feladatok elvégzését a Szegedi Tudományegyetem Számítógépes Algoritmusok és Mesterséges Intelligencia Tanszékével való együttmüködés tette lehetővé. Az előállított metaadatokat strukturált CSV fájlokban tároltuk, amelyek kezelésére a LibreOffice irodai programcsomagot használtuk, míg a társszerzőségi gráf ábrázolására, illetve elemzésére a nyílt forráskódú Gephi programcsomag (Bastian, Heymann, \& Jacomy, 2009) szolgált.

A kinyert hivatkozásokat szintén CSV fájlokban tároltuk, melyek kezelésére általában a metaadatoknál már jól bevált LibreOffice irodai programcsomag szolgált, ugyanakkor az adatok manipulálására és vizualizálására a Microsoft Office bizonyult alkalmasabbnak. Egyes kiegészítő feladatok esetében a Notepad++ is praktikusan használható volt. A hivatkozási hálózatok ábrázolására, illetve elemzésére ugyanúgy a gráfokra specializálódott, nyílt forráskódú Gephi programcsomagot használtuk, ahogyan a társszerzőségi hálózat esetében is történt. Emellett, a gráfok elemzése kapcsán a CitNetExplorer, az iGraph és a Cytoscape programok esetleges alkalmazását teszteltük még. 
Az igénybe vett automatikus eszközök alkalmazását a Magyar Pedagógia 1991-es megújulása óta következetesen használt hivatalos hivatkozási stílus tette lehetővé, amely a vizsgálati időszakban (1991-2014) ugyan teljes egészében nem egyezett meg a neveléstudományban nemzetközileg széleskörüen elfogadott és elterjedt APA hivatkozási stílussal (American Psychological Association, 2010), azonban nagyban épített arra (a folyóirat 2016-tól teljesen áttért az APA publikációs stílus alkalmazására). Mivel a folyóirat ezt az egységesen szabályozott hivatkozási stílust az 1991-es évtől kezdve használta, ezért a hivatkozásvizsgálatok csak ebben az időszakban értelmezhetőek, leszükítve így a problémateret a rendszerváltás utáni időszakra. A hivatkozások esetében hangsúlyosan jelentkeztek a különböző publikációk eltérő műfaji sajátosságai (a Tanulmányok, a Szemle, a Könyvekről és az Információk rovatok vonatkozásában) által felvetett kérdések. Ezért a hivatkozásvizsgálatokba csak azok a tanulmányok kerültek bevonásra, amelyek a tudományos normáknak megfelelő irodalomjegyzékkel rendelkeztek. Így a huszonnégy évnyi kinyert, a 14 ezres számot is meghaladó hivatkozás ezen kiegészítő információk figyelembevételével értelmezendő.

A hivatkozások felismerésére, kivonatolására és elemzésére léteznek kész szoftveres megoldások, ezeket a projekt kezdetén felderítettük és kipróbáltuk. Az automatikus kivonatoló eszközök közül a nyílt forráskódú ParsCit és a Crossref céghez köthető Pdf-extract programokat teszteltük potenciálisan alkalmazható alternatívaként, azonban bizonyos nehézségek miatt végül elvetettük kutatásban való felhasználásukat. Szintén megvizsgáltuk a 2010-ben pályázati források felhasználásával indult MATRICA (Magyar Társadalomtudományi Citációs Adatbázis) projekt eredményeit és az ott alkalmazott módszereket az esetleges előremutató tapasztalatok miatt. Végül az automatikus kinyerés reguláris kifejezéseken (Fitzgerald, 2012) alapult, olyan kiegészítő többletinformációk felhasználásával, mint az egyes adatelemeket reprezentáló karakterek félkövér vagy kurzív mivolta. Ezt a mintafelismerési eljárást a szerkesztőségtől megkapott kiadói PDF-ek tették lehetővé, hiszen ezekben a fájlokban az ilyen stílustulajdonságok is tárolódtak, mivel szerves részei voltak az adott időszakban alkalmazott kötelező hivatkozási stílusnak (Magyar Pedagógia, 1993). Az XML konverzió során ezeket a többletinformációkat is figyelembe vettük, ahogyan minden további lépésnél, így a hivatkozások konkrét felismerésénél és kinyerésénél is segítséget jelentettek.

A munka során adódott néhány nehézség is, amelyekkel lépésről lépésre meg kellett küzdenünk. Ezek általában a hivatalos hivatkozási stílus nem eléggé következetes alkalmazásából adódtak: elírások, hibák, hiányzó adatelemek. A felismerés hatékonyságának fokozása miatt, a fentiek figyelembevételével és a tipikus hibák folyamatos monitorozása 
mellett a kinyerést végző szövegbányászati algoritmus az előzetes konfigurálás után további finomításokra szorult. Az algoritmus ilyen jellegü csiszolása mellett természetesen utólagos adattisztításra is szükség volt, nem beszélve a kinyert hivatkozások szúrópróbaszerü, ám szisztematikus ellenőrzéséről és megerősítéséről.

A szerzők azonosítása körül a következő típusú hibák fordultak leginkább elő: speciális karakterek a mezőben; számok a mezőben; kis kezdőbetű a mező elején; kiadó a szerző mezőben; URL a mezőben; túl hosszú (>20) karaktersorozat a mezőben; túl rövid (<3) karaktersorozat a mezőben; mts, mtsai, munkatársai, stb. karaktersorozatok a mezőben. Emellett előfordult a keresztnevek nem következetes módon való használata a hivatkozásokban, azaz például a Csapó B. és a Csapó Benő alakok párhuzamos előfordulása, holott ezeket egy névegységesítés keretében azonos entitásként volt szükséges kezelni a továbbiakban. Összességében az elvégzett szúrópróbaszerü, ám tendenciózus tesztek alapján (öt véletlenszerű módon kiválasztott, eltérő időszakból származó teljes lapszám esetében az összes megjelent cikk hivatkozásainak száma összevetésre került az azokból automatikusan kinyert hivatkozások darabszámával), becsléseink szerint az adott időszak publikációinak irodalomjegyzékeiből a hivatkozások legalább 95\%-át sikerült kinyerni. Ez az érték a szakirodalomban (például Tkaczyk, Szostek, Fedoryszak, Dendek, \& Bolikowski, 2015; Kovačević, Ivanović, Milosavljević, Konjović, \& Surla, 2011) található hasonló számokkal összevetve megfelelőnek tekinthető.

Munkánk során, már a hivatkozások nyers kivonásán túli analizáló szinten, az egyes konkrét vizsgálatok elvégzéséhez olyan indexelő, illetve tudománymetriai adatbázisokat is felhasználtunk egy-egy elemzéshez, mint a Matarka, a Web of Science vagy a Scopus. Arról, hogy pontosan milyen célokra, és milyen módon kerültek alkalmazásra a felsorolt adatbázisokból nyert adatok, mindig az adott résznél közlünk részletes, magyarázó információkat.

\subsection{A tartalomelemzés módszerei}

A metaadatok analízise és a hivatkozások vizsgálata mellett kutatásunk harmadik nagy részterületét a tartalomelemzés jelenti. Ennek sikeres elvégzéséhez mintegy elözetes lépésként a kutatás megtervezése során mindenképpen szükséges volt a megfelelő módszerek, eljárások és kutatási eszközök felmérése, azonosítása. Kézenfekvő módon, a lehetőségek számbavétele során természetesen felmerült a neveléstudomány területén már több esetben is használt, az elméleti részben részletesebben bemutatott klasszikus tartalomelemzés módszere. Azonban 
figyelembe véve a vizsgálandó korpusz nagyságát és azt a megfontolást, hogy nem véletlenszerü, szükített mintavételes vizsgálatot szeretnénk végezni, hanem a folyóirat teljes élettartamára vetített, minden cikkre kiterjedő kutatást, így elkerülhetetlen volt annak felismerése, hogy a tartalomelemzés módszere által biztosított eszköztárat meghaladó kutatási eszközre van szükség, mivel az korlátai miatt nem alkalmas ekkora méretű szövegkorpusz vizsgálatára, legalábbis az észszerü hatékonysági mutatók figyelembevételével semmiképpen sem.

A minta mérete által támasztott követelményeknek a szövegbányászat eszközeinek bevetésével próbáltunk megfelelni. A konkrét módszerek, a technika és a szükséges lépések egymásra épülésének pontos kidolgozásához, finomhangolásához első lépésben pilotvizsgálatokat végeztünk. Természetesen itt is előfeltételként jelentkezett a korábban leírt digitalizálási munka, valójában csak ennek elkészülte után vált lehetségessé a használni kívánt módszer kidolgozása. A kutatás lefolytatásához komoly informatikai szaktudás, erős hardverés adekvát szoftverkörnyezetre volt szükség, emellett törekedni kellett a minél nagyobb fokú automatizáltságra a hatékonyság és a pontosság növelése érdekében. A végül alkalmazott módszer kiválasztását alapos kutatómunka előzte meg, melynek során feltártuk a potenciálisan szóba jöhető szoftveres megoldások körét.

A szakirodalmi feltárás során több szövegbányászati célú szoftverrel is találkoztunk, ezek egy része dobozos, a piacon megvásárolható program volt, sőt általában egy-egy komplex szoftvercsomag speciális célfeladatért felelős modulja, ebbe a kategóriába tartoztak például az IBM SPSS Text Analytics és a STATISTICA Text Miner szoftverek. Egy második kategóriát jelentett a nyílt forráskódú szoftverek csoportja. Ezek teljesen ingyenesen használhatóak, az internetről szabadon letölthető komponensekkel; a kategória jeles képviselője például az újzélandi University of Waikato Machine Learning Group által gondozott Weka szoftvercsomag. A felmerült lehetőségek közül szintén a szabadon letölthető kategóriába tartozott a magyar kötődésű Textrend szoftver bemutató verziója, amely több, szabad szoftveres komponens felhasználásával készült és többek között tartalmazza az előző bekezdésben említett Weka csomag egyes elemeit, a szövegfeldolgozásban széleskörüen használt R programnyelvet vagy a hálózatok vizualizációjára szolgáló Cytoscape komponenst. Az itt felsorolt szoftverekkel elvégzett kísérletek után elvetettük azok használatát, így az elöre megírt, kulcsrakész szoftverek alkalmazása helyett az egyedi szövegbányászati tapasztalat bevonása mellett döntöttünk a tartalomelemzés során is.

Az alkalmazott módszernek alkalmasnak kellett lennie a tartalomelemzés kutatási részegységben megfogalmazott célok teljesítésére, azaz a folyóirat egyes korszakaiban 
leginkább jellemző diskurzusok és azok változásainak kimutatására, illetve egy-egy neveléstudományi szakkifejezés első előfordulásának detektálására. Az előkészítő lépések elvégzése után különböző speciális szövegbányászati eljárások és algoritmusok segítségével történt a kutatási eredmények előállítása, melyeket a következőkben röviden ismertetek.

A nulladik lépésnek is tekinthető elökészítő fázisban olyan munkálatokat kellett elvégezni, amelyek végén előállt a megtisztított szövegkorpusz. Többek között a cikkek szegmentálását, a fejlécek eltávolítását és a sortörések kezelését kellett elvégezni ebben az XML feldolgozásnak nevezett lépésben. Ekkor történt az érdemi publikációk XML-ből történő kinyerése, a publikációk közti határok automatikus meghatározása, alapvető szógyakorisági statisztikák elkészítése, illetve szükség esetén az OCR hibák automatikus javítása. Az itt felsorolt eljárások bemeneteként a publikációkat digitalizált formában tartalmazó XML állomány szolgált, míg a tulajdonképpeni részeredményként megszülető kimenetet az adatbázisban szereplő tudományos igényü, külön állományokra bontott cikkek előfeldolgozott verziói jelentették. Az ebben a lépésben elvégzett egyes részfeladatok a következők voltak: a tudományos cikkek kigyüjtése, a sor- és oldaltörések kezelése, valamint a dokumentumhatárok detektálása. Bár rendelkezésre álltak az egyes publikációk fizikai és logikai oldalszámai, azonban a publikációk kezdő, valamint végoldalain be kellett tudni azonosítani az egy oldalara eső publikációk kezdeteit, valamint befejeződéseit. Ehhez nagy segítséget jelentettek az egyes publikációkhoz rendelkezésre álló MARC adatszerkezetben elérhető metaadatok. Potenciális nehézséget a nem megfelelő minőségü metaadatok, illetve a publikációk szkenneléséből adódó OCR hibák okozhattak, melyek a publikációs határok megtalálását esetlegesen megnehezíthették. Emiatt szükség volt a sztringegyezést relaxáltan vizsgáló algoritmusra, mellyel a hiba mértéke csökkenthető volt; a megfelelő minőség szavatolása érdekében a szegmentálás helyességét emberi erő bevonásával kellett ellenőrizni.

A következő lépésben olyan, a szövegbányászatban széleskörüen alkalmazott eljárások zajlottak, mint a tokenizálás (számítógépes nyelvészeti fogalom, melynek során egy karakterfüzért tokenekre, azaz alapvető nyelvi objektumokra osztanak), a stopszószürés (a leggyakoribb, általános használatú szavak, például névelők, kötőszavak eltávolítása), a lemmatizálás (számítógépes nyelvészeti fogalom, melynek során a szavak szótári alakja áll elő) és a vektortérmodell dimenziójának csökkentése (a vektortérmodell tartalmazza a dokumentum összes releváns szavát). Ezen lépések kimeneteként összeállt a későbbi eljárások során felhasználandó szó-dokumentum mátrix. Tikk (2007, p. 32) a következők szerint definiálja ezt a szövegbányászatban alapvetőnek tekinthető fogalmat: „A vektortérmodellben a D = $\left\{\mathrm{d}_{1}, \ldots, \mathrm{d}_{N}\right\}$ dokumentumgyüjteményt a szó-dokumentum mátrixszal (term-document matrix) 
reprezentáljuk ( $\mathbf{D} \in \mathbb{R}^{\mathrm{M} \times \mathrm{N}}$ ), ahol a mátrix $\mathrm{d}_{k i}$, eleme a $k$-adik szó $\left(\mathrm{t}_{k}\right)$ relevanciáját reprezentálja az $i$-edik dokumentumban, $\mathrm{d}_{i}$-ben. A $\mathrm{d}_{i}$ dokumentumot reprezentáló dokumentumvektort $\mathbf{d}_{i}=$

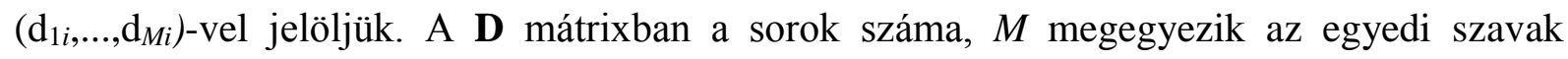
számával, másképpen a vektortér dimenziójával, N pedig a dokumentumok száma.”

A dokumentumokban, illetve a belölük kinyert szótárban előforduló összes szót érthető módon nem tekinthetjük egyenrangúnak, mivel a tartalmi értéküket tekintve a szavak jelentősége eltérő. Az olyan témaspecifikus szavak, mint például a reziliencia vagy a motiváció, sokkal jobban jellemeznek egy dokumentumot az általánosabb kontextusban használt szavaknál (például: módszer, eredmény, stb.). A nyelvben emellett nagy számban előfordulnak olyan szavak is, amelyek témától függetlenül megjelennek minden dokumentumban, mint a névelők, a határozószók és a névutók. Ezeket a szavakat az angol terminológia alapján stopszavaknak (stop words) nevezik. Az ilyen, tartalmi információt egyáltalán nem tartalmazó, megkülönböztető képesség nélküli stopszavakat már a tokenizálás fázisa után kizárják a további elemzésekből. Mivel a stopszavak szinte minden dokumentumban előfordulnak, ezért a szótárból való elhagyásukkal lényegesen csökkenthető a szó-dokumentum mátrix bejegyzéseinek száma, ezáltal annak mérete. A potenciális stopszavakat általában egy-egy dokumentumgyüjtemény szógyakorisági adatai alapján állítják elő, amit azután manuálisan ellenőriznek, emiatt a stopszólista mérete függ az alkalmazás jellegétől (Tikk, 2007). Saját kutatásunk során a magyar nyelven talán a legszélesebb körben használt „magyarlánc” nyelvi feldolgozó eszköztár (Zsibrita, Vincze, \& Farkas, 2013) által is használt stopszólistát használtuk. A dokumentumokon a „magyarlánc” 2.3-as verziószámú modell elemzőjét használtuk. A program a szótövesítés mellett a szavak morfoszintaktikai elemzését is elvégzi, ennek keretében az egyes szavak szófajai is meghatározásra kerültek. Azokban az esetekben, amikor több szófaji besorolás is lehetséges, az algoritmus a szövegkörnyezetben található szavakat figyelembe véve próbálja kiválasztani a megfelelő szófajt.

A különösebb információtartalmat nem képviselő stopszavak által jelentett mintaszükítés mellett a minél teljesebb körü eredmények elérése miatt egy ellentétes megközelítésre is szükség volt, amelynek során a magas információtartalmú szókapcsolatok vonatkozásában bővíteni kellett a mintát. Ezért a tudományos nyelvben sürün előforduló többszavas szakkifejezések figyelembevétele miatt szükség volt egy kollokációs lista megalkotására, majd annak finomítására. A lista kinyerése ugyan az automatikus elemzés eredményein nyugodott, azonban ezt manuálisan kellett validálni, majd további szókapcsolatokkal kiegészíteni. A kollokációs lista ( $\mathrm{N}=1036)$ alkalmazásával így olyan szópárok bizonyos típusú vizsgálatoknál való figyelembevételére nyílt lehetőség, mint például: „idegen nyelv”, „mastery learning”, 
„,proszociális tanulás”, „korrelációs együttható”, „induktív gondolkodás”, „kommunista párt”, „,családi élet”, „kombinatív képesség”, „olvasási stratégia”.

A legegyszerübb vizsgálati módszert a stopszólistás gyakoriságvizsgálatok jelentették, ez a triviálisnak mondható vizsgálat elvégzésre került minden egyes cikk esetében, mind a különálló évek, mind az évtizedek vonatkozásában. A következő lépésben az elemzések nagyobb csoportját a különféle tárgyszavakkal kapcsolatos müveletek képviselték. Különféle bevett algoritmusok (pl. kölcsönös információtartalom, khí-négyzet próba,) alapján (Schütze, Manning, \& Raghavan, 2008) megtörtént az egyes cikkek automatikus kulcsszavazása. Mindkét eljárás a szavak adott időszakon belüli és éppen ellenkezőleg, azon kívüli előfordulásának, illetve elő nem fordulásainak mennyiségi összehasonlításából számít statisztikákat. A fö különbség ott érhető tetten, hogy míg a kölcsönös információtartalom inkább valószínüségeken alapul, addig a khí-négyzet nyers előfordulási értékekkel, illetve azok várható értékével dolgozik (ezáltal a valószínűségek áttételesen itt is megjelennek). Emiatt a két eljárás kimeneteként kapott értékek sorrendje jelentős mértékben nem tér el egymástól.

A tárgyszavak vonatkozásában egyedülálló lehetőséget jelentett a gépi intelligencia kimenete alapján megszülető tárgyszavak összehasonlító elemzése a rendelkezésre álló két, szisztematikus, humán intelligencia által alkotott tárgyszólistával: egyrészt az 1993-as kiadású repertórium tárgyszavaival, másrészt az 1892-2014 között minden cikk esetében rendelkezésre álló könyvtári tárgyszó-rendszer megfelelő elemeivel. A rendelkezésre álló, három párhuzamos tárgyszó-rendszer szerint meghatározott kulcsszavak időbeli kiterítése is szerepelt a tervekben, azonban a hatalmas adatamennyiség miatt ennek vizuális megjelenítése már egyáltalán nem tartozik a triviális feladatok közé. Az olyan hagyományos, statikus ábrázolási módok mellett, mint a hisztogram vagy a vonaldiagram, hasonló vizsgálatok esetében alternatívát jelenthet egy dinamikusabb rendszerben való láttatás, esetleg valamilyen animált hőtérkép vagy akár egy animált címkefelhő jellegű megoldás alkalmazása.

Ahogyan azt az elméleti részben ismertettük, a szövegbányászat két különböző megközelítésű tematikus szelekciót ismer, melyeket az osztályozás vagy kategorizálás és a csoportosítás vagy klaszterezés terminusokkal illet. Előzetes terveink szerint mindkét típusú vizsgálat elkészült volna az összes cikk vonatkozásában, azonban menet közben, a klaszterezés teljes körü lefuttatása után ezt az elképzelést átértékeltük, egyrészt a klaszterezés során szerzett pozitív (minőségi) tapasztalatok alapján, másrészt a rendelkezésre álló erőforrások szűkös mivolta miatt. A klaszterezés magukból a szövegekből képez csoportokat, alkalmazása esetén nincsenek előre definiált kategóriák, azok tulajdonképpen csak a folyamat során állnak elő gépi tanuló algoritmusok segítségével a kiinduló szövegekböl. A projekt keretében megtörtént a 
különböző felbontású topikmodell kategóriák kialakítása, majd a cikkek azokba való besorolása. A végül elvetett másik szelekciós módszer, a kategorizálás során előre definiált kategóriacímkéket terveztünk előállítani a repertórium tárgyszavaiból, majd az egyes cikkek ezekbe a kategóriákba kerültek volna. Mivel 1992-től ezek nem álltak rendelkezésre, így ezt követően a korábban az algoritmus által megtanultak szerint, vagy a MARC rekordok 650-es mezője alapján definiált kategóriacímkék szerint sorolódtak volna be a cikkek a különböző kategóriákba. Az eredeti tervek szerint a két módszer (klaszterizálás és kategorizálás) szerinti kimutatások eredményeit összehasonlító elemzésbe vontuk volna be. Feltételezésünk szerint a két eltérő megközelítés lényegében hasonló eredményekkel szolgált volna, részben ez is indokolatlanná tette párhuzamos elvégzésüket.

A topikmodellezésnek nevezett folyamat során zajlott a dokumentumok klaszterezése, majd a klasztereken belüli szavak fontosságának meghatározása. A bemenetet az adatbázisban szereplő tudományos igényü cikkek szeparált állományai, míg a kimenetet a detektált témakörök jellemző szavai jelentették. A feladat megoldásához az LDA (latent Dirichlet allocation; magyarul: rejtett Dirichlet allokáció) eljárást alkalmaztuk, melynek során a releváns, meglévő tudás beépítéséért felelős hiperparaméterek (a paraméter paraméterei) megtalálása volt az egyik fö cél. A rejtett Dirichlet allokáció egy valószínüségi szövegmodell, amely a szövegeket témák keverékének tekinti, amelyben mindegyik téma saját szóeloszlással rendelkezik. Ez a modell a rejtett szemantikai indexelés (latent semantic indexing) modell kibővítésének és racionalizálásának tekinthető, valamint a többszörös okkeverék (cause mixture) modellhez is kötődik (Russell \& Norvig, 2005). Tulajdonképpen egy generatív valószínűségi modellről van szó, amely egy korpusz dokumentumait reprezentálja rögzített számú téma keverékeként. A témákat a korpusz szókészlete felett multinomiális valószínüségeloszlásokkal reprezentálja, egy dokumentum pedig ezen eloszlások keveréke (Bíró, 2009). A topikmodellezés során a nyers szövegekben az OCR hibák kapcsán jelentkező pontatlanságok okozhattak problémát, melyek kritikus jelenléte helyesírás-ellenőrző és -javító algoritmusok alkalmazását tették szükségessé.

A klaszterizálás eredményeinek vizuális megjelenítésénél már a tervezési fázisban is törekedtünk a sokrétüségre, ezért több módszer is szóba jött az eredmények láttatása terén, ilyenek például a címkefelhő, a halmozott területdiagram, a 100\%-ig halmozott területdiagram (full stacked area chart), a dendrogram, tematikus hőtérkép, különféle kategóriadobozos megoldások (lásd 114-116. ábra) vagy a gráf típusú megjelenítések. A tapasztalatok azt mutatták, hogy a nagy adatmennyiségü, hosszú időtávot átfogó, trendvizsgálat-jellegü elemzések esetében a halmozott és a 100\%-ig halmozott területdiagramok váltak be leginkább, 
így az eredmények ismertetése során leggyakrabban ilyen típusú ábrákat közlünk, azonban módszertani okokból minden általunk alkalmazott, akár kísérleti jellegủ vizualizálási megoldás ismertetetését fontosnak tartjuk.

A trendkövetés jellegü vizsgálatok esetében tulajdonképpen az időbeliség nézőpontja jelenti azt a rendező elvet, amely az ilyen jellegü megközelítés alapját adja. Terveinkben ezek alapján szerepelt az évtizedekre bontás, majd az eredmények időskálára való kiterítése, és az így kirajzolódó trendek detektálása. A megközelítés kiterjesztése emellett lehetővé teszi az egyes évtizedek névjegyének előállítását is, olyan információcsoportok alapján, mint a cikkek száma, a szerzői toplisták és a hangsúlyos témák. Arra az alapvetőnek számító kérdésre is megpróbáltunk választ találni, hogy az egyes években melyek voltak a leggyakoribb témák.

A következő vizsgálatcsoportot a hasonló cikkek megtalálása jelentette. Ennek a típusú vizsgálatnak komoly hagyományai vannak a tudománymetriában, lásd Boyack, Newman, Duhon, Klavans, Patek, Biberstine és Börner (2011) vagy Sternitzke és Bergmann (2009) tanulmányait. A projekt során kereszttáblázat készült az egymásra tartalmilag leginkább hasonlító publikációpárosok között, azt vizsgálva, hogy egy szerző egy-egy publikációja mennyire hasonlít valamely másik publikációra. A publikációkon túl a vizsgálati módszer kiterjesztéseképpen akár az egyes szerzők közötti hasonlóság is elemezhetővé válna az eredmények aggregálása által. Sőt, a tartalmi hasonlóságok dimenziójának elemzése mellett az idézési szokások is figyelembe vehetőek lennének, mintegy kiegészítve a vizsgálatot annak kimutatásával, hogy a tartalmi elemzések során közelinek mondható szerzők mennyire idézik egymás munkáit, és általában milyen irányúak ezek a hivatkozások.

Az utolsó elemzéstípust a tartalmi analízisek körében egy-egy témakör elöfutárainak azonosítása, azaz a kulcstémák első előfordulásának detektálása, illetve egy-egy szakkifejezés (pl. mastery learning, proszocialitás, önszabályozó tanulás) felfutásának és lecsengésének vizsgálata jelentette. Az alfejezetben bemutatott módszereken túl a tartalmi elemzések megtervezése során további vizsgálódási lehetőségek is felmerültek. Például a metaadatok tengeréből kiválasztva a cím mezőt, azt önálló dokumentumegységként kezelve, a fentiekben ismertetett vizsgálatok közül számos elvégezhető lenne az így nyert mintán. Az így kapott eredmények összehasonlítóak lennének a cikkek teljes szövegéből származó eredményekkel. 


\section{A CIKKEK METAADATAINAK TUDOMÁNYMETRIAI ELEMZÉSE}

\subsection{Alapvető metaadatok tendenciái}

A felsőoktatás tömegesedése miatt elözetes hipotézisünk $\left(\mathrm{H}_{1}\right)$ alapján a Magyar Pedagógia címủ folyóiratban megjelent publikációk számának folyamatos növekedését vártuk. Az eredmények összehasonlíthatósága miatt további folyóiratokat is bevontunk az elemzésbe, hogy a négy legjelentősebb hazai neveléstudományi folyóirat (Magyar Pedagógia, Iskolakultúra, Educatio, Új Pedagógiai Szemle) esetében összkép jelleggel lássuk a vonatkozó általános tendenciákat. Az 3. táblázatban ezek alapján a négy vezető folyóiratban megjelent cikkek darabszámát tekintve láthatóak a legfontosabb értékek a tárgyalt időszakban.

\section{3. táblázat. A vezető neveléstudományi folyóiratok számszaki adatai}

\begin{tabular}{cccccc}
\hline \hline & $\begin{array}{c}\text { MP 1892- } \\
2014\end{array}$ & $\begin{array}{c}\text { MP 1991- } \\
2014\end{array}$ & $\begin{array}{c}\text { Iskolakultúra } \\
1991-2014\end{array}$ & $\begin{array}{c}\text { Educatio } \\
1992-2014\end{array}$ & $\begin{array}{c}\text { Uedagógiai } \\
\text { Szemle } \\
1993-2014\end{array}$ \\
\hline $\begin{array}{c}\text { Publikációk } \\
\text { száma: }\end{array}$ & $6574^{*}$ & $569^{*}$ & $5188^{* *}$ & $1805^{* *}$ & $3710^{* *}$ \\
\hline Szerzők száma: & $2520^{*}$ & $389^{*}$ & N/A & N/A & N/A \\
\hline $\begin{array}{c}\text { Hivatkozások } \\
\text { száma: }\end{array}$ & - & $14039^{*}$ & N/A & N/A & N/A \\
\hline \hline
\end{tabular}

Megj.: * az SZTE Contenta; ** a Matarka adatbázis adatai alapján

A 6. ábrán, ugyanezen értékek az időbeliség felbontásában mutatják meg az Iskolakultúra, az Educatio és az Új Pedagógiai Szemle című folyóiratok évenkénti publikációszámának változását. A három esetből két esetben - előzetes hipotézisünkkel ellentétben - egyértelmü csökkenést figyelhetünk meg, míg az Educatio folyóiratnál a publikációk számának stagnálása a jellemző. Szintén a csökkenő tendenciát támasztja alá a Magyar Pedagógia című folyóirat azonos adataival való összevetés (7. ábra). A kiemelten vizsgált 1991-2014-es időszak mellett a publikációk darabszámát tekintve az elemzést elvégeztük a folyóirat teljes élettartamára is, hogy az utóbbi időszak alacsonyabb cikkszámait ebben a kontextusban is össze lehessen hasonlítani, ennek eredményei a 8. ábrán láthatóak. Összességében elmondhatjuk tehát, hogy mind a Magyar Pedagógia, mind a másik három, jelentős neveléstudományi folyóirat esetében a publikációk száma alapvetően csökkenő tendenciát mutatott a rendszerváltást követően, illetve a Magyar Pedagógia esetén a folyóirat korábbi évfolyamaihoz viszonyítva is jelentős csökkenés figyelhető meg. 


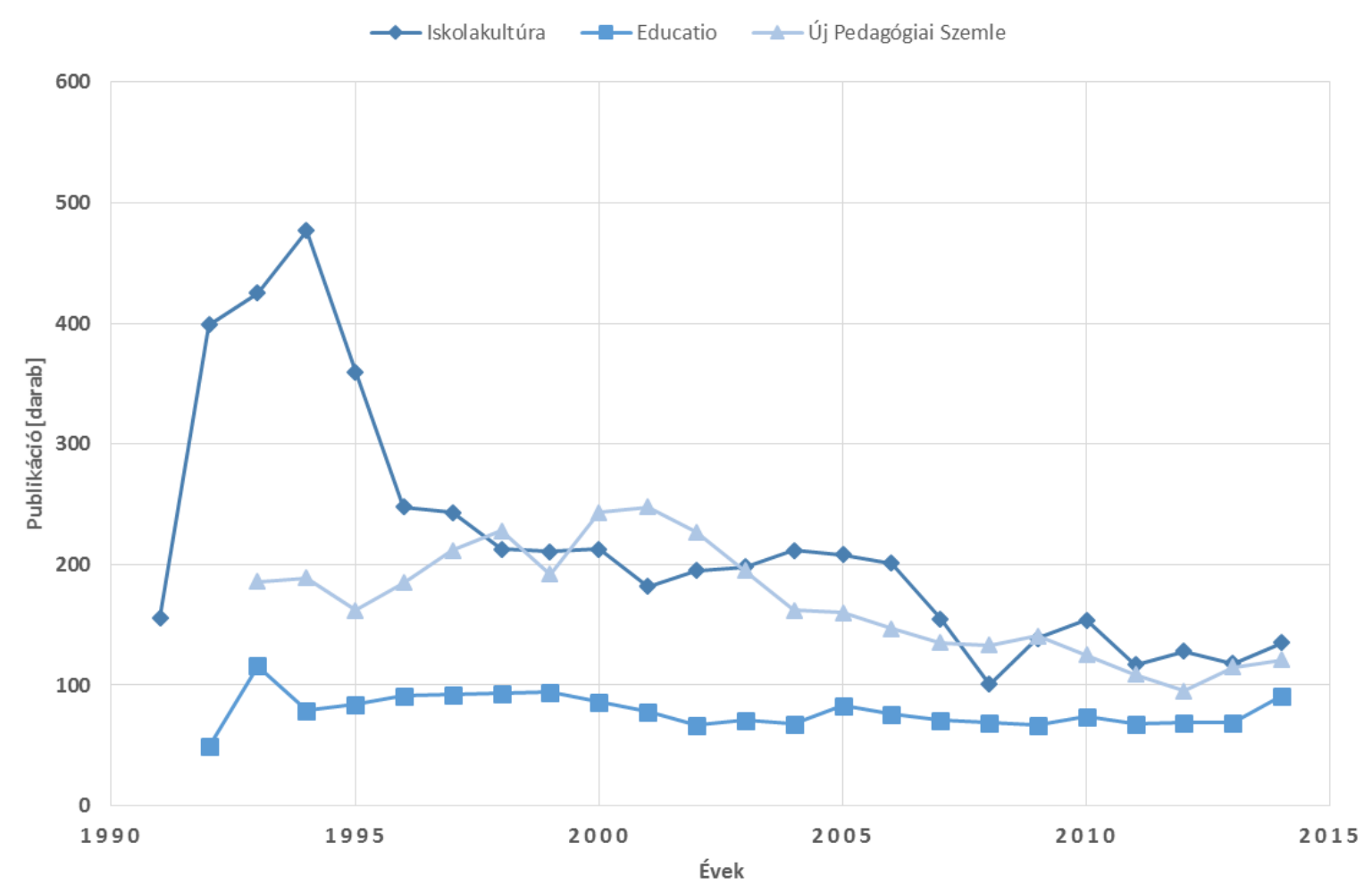

6. ábra

Az Iskolakultúra, Educatio és az Új Pedagógiai Szemle folyóiratokban megjelent publikációk számának időbeli változása 1991-2014 [Forrás: Matarka]

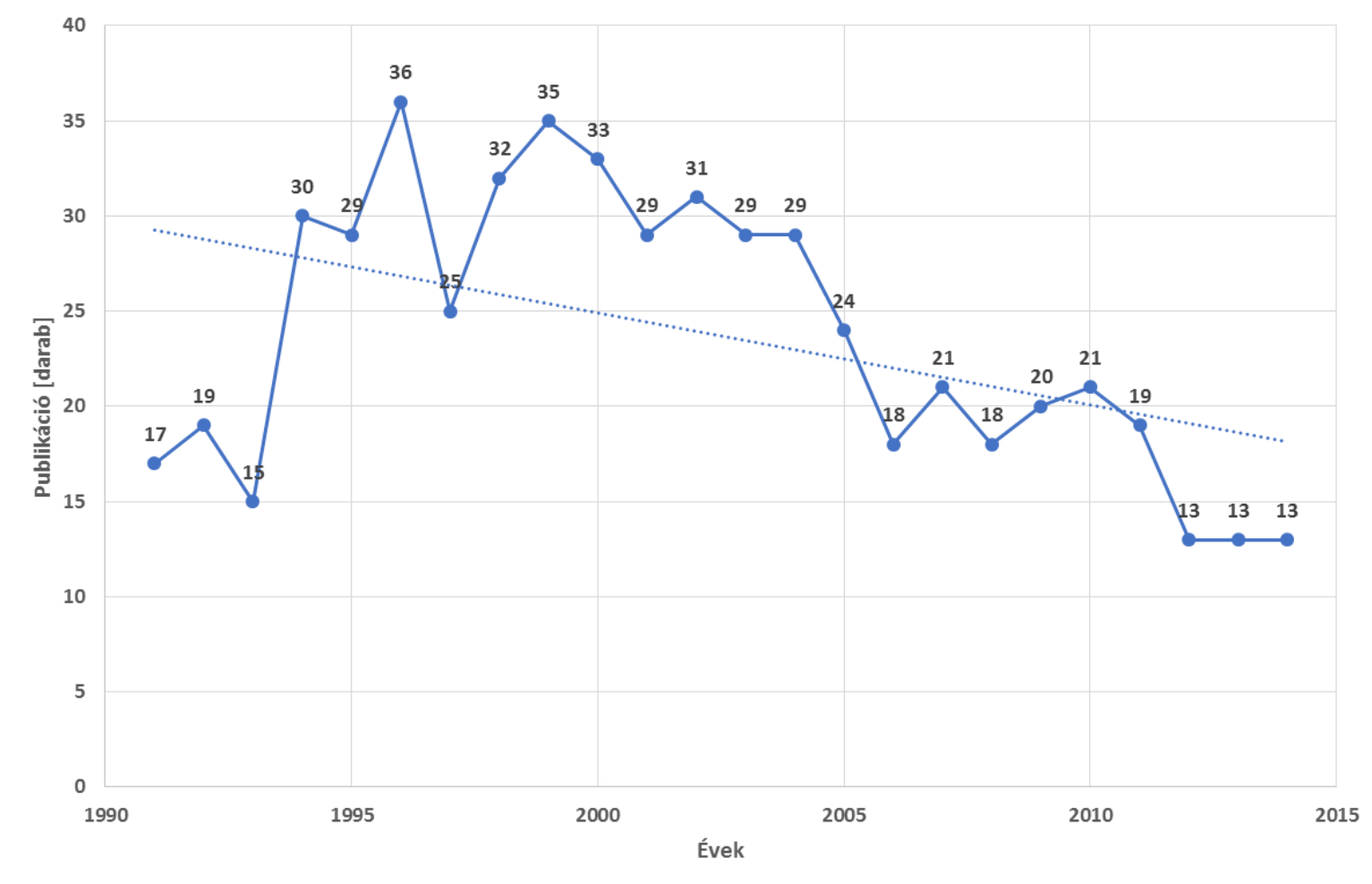

7. ábra

A Magyar Pedagógiában megjelent publikációk számának időbeli változása 1991-2014 


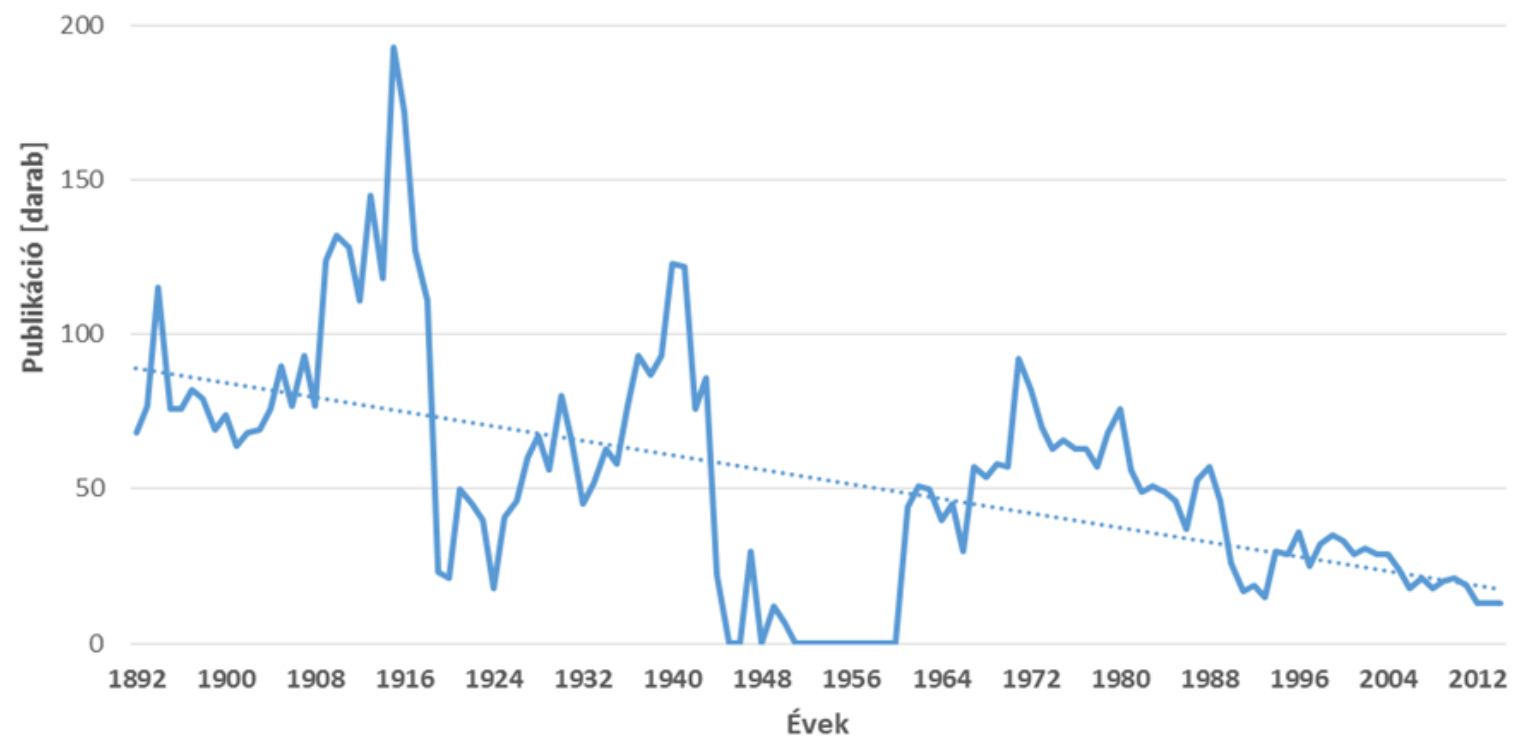

\section{8. ábra}

A Magyar Pedagógiában megjelent publikációk számának időbeli változása 1892-2014

További következtetések levonására ad lehetőséget, ha a kapott eredményeket összevetjük egyrészt Csapó (2016) elemzésével, aki nemzetközi színtéren mutatta ki a magyar neveléstudományi kutatók többi tudományághoz viszonyított alacsony tudományos aktivitását, másrészt pedig rápillantva a nemzetközi teljesítményt láthatóvá tévő és leképező tudománymetriai adatbázisokra, a csökkenő tendencia nem sok jót sejtet a neveléstudomány egészére nézve. Az Elsevier cég SciVal elnevezésű, a Scopus adatain alapuló tudománymetriai elemzőeszközének friss kimutatásai alapján a 2013 és 2017 közötti időszakban az 'Education' (Oktatás) kategóriában az adatbázis szerint Magyarország tudományos kibocsátása 489 szerzőtől 348 publikációt jelentett a kiválasztott területen, amelyek összesen 827 idézést gyüjtöttek be az adott időszakban. Az adatbázis taxonómiájából fakadóan az Oktatás kategória jóval túlmutat a szorosan vett neveléstudományi témákon (egy tágabb értelemben tartalmazza az oktatási vonatkozású publikációkat), így az eredmények ennek tükrében értelmezendőek. Az évenkénti publikációszámok eloszlása grafikus formában a 9. ábrán kísérhető figyelemmel. 


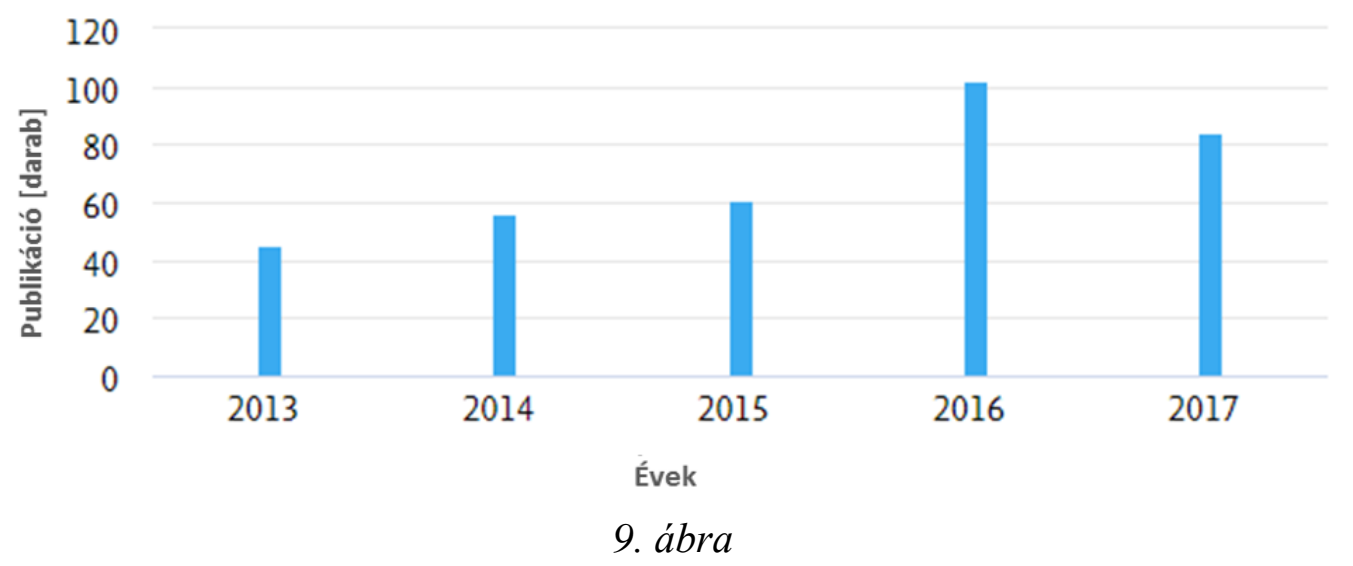

A magyar szerzők nemzetközi publikációs aktivitása a SciVal adatbázis 'Education' kategóriája alapján 2013-2017 között

Ezek fényében elmondható - összhangban Csapó (2016) és Polónyi (2016) megállapításaival -, hogy az eredmények magyar és nemzetközi vonalon egybevágnak, tehát a hazai kutatók alacsony nemzetközi publikációs rátája nem a hazai lapokban közölt nagyszámú cikk miatt alacsony, és természetesen ez az állitás fordítva is igaz. A tanulmányok számának növekedésére vonatkozó hipotézisünk tehát nem igazolódott be: a felsőoktatás tömegesedése nem okozta automatikusan a neveléstudományi tudományos aktivitás növekedését, legalábbis ez tapasztalható az eredmények elsődleges közlését biztosító folyóiratcikkek esetében. További kutatási lehetőséget jelentene a mögöttes okok vizsgálata. Talán éppen a megnövekedett oktatási tevékenység vonja el a kutatók figyelmét a folyóiratcikkek írásától? Emellett magyarázatul szolgálhat más típusú műfajok népszerüsége; érdemes volna megvizsgálni hogyan alakult a tudományos aktivitás a monográfiák, a szerkesztett kötetek és a különböző konferencia-műfajok esetében. Szintén egy nagyszabású kutatást jelentene annak vizsgálata, hogyan változott a neveléstudománnyal foglalkozó kutatók száma a rendszerváltást követően az egyes képzö- és kutatóhelyeken, hiszen ez alapvetően befolyásolja a teljes tudományág aktivitását.

Bár a cikkek darabszámának növekedésére vonatkozó hipotézisünk nem igazolódott be, első kutatási kérdésünkben azt is feltételeztük, hogy a Magyar Pedagógia publikációinak oldalszámban mért hossza növekvő tendenciát mutat az évek előrehaladtával. Ez a feltételezés beigazolódik, hiszen egyértelmü növekedés tapasztalható a tanulmányok oldalszámának vonatkozásában (lásd 10. ábra), ugyanakkor emögött valószínüleg olyan látens okok is meghúzódhatnak, mint az irodalomjegyzékek tételszámának bővülése, valamint a megértést segítő ábrák, képek és táblázatok elterjedésével együtt járó terjedelmi gyarapodás. Az egyes évfolyamokra vonatkozó összterjedelem általában a 250-500 oldal közötti tartományba esik, amely értékek jól mutatják az egyes évfolyamok közötti nagy terjedelembeli ingadozást. 


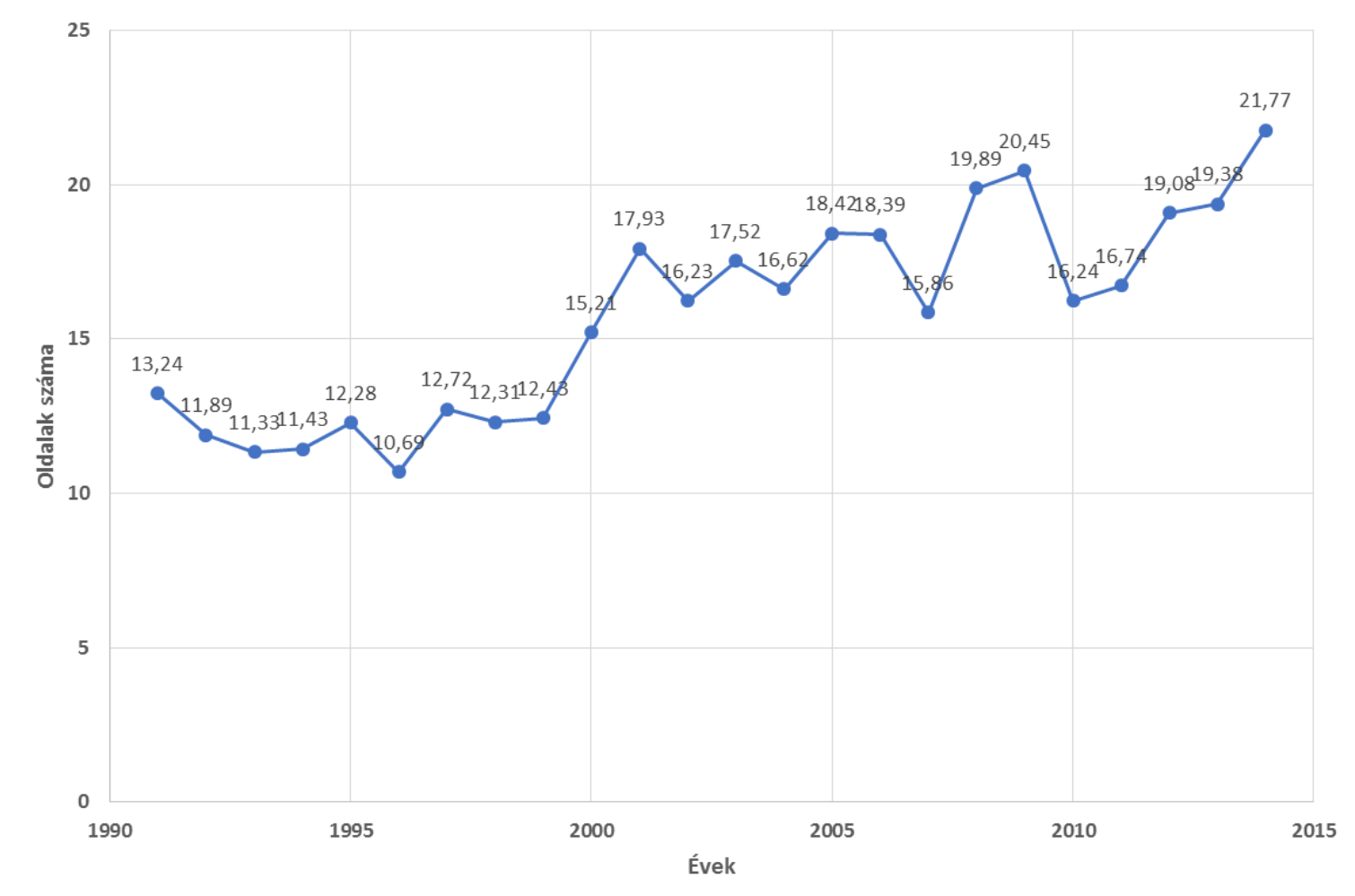

10. ábra

A Magyar Pedagógia publikációk átlagos hosszának évenkénti változása 1991-2014

Összességében megfigyelhető egyfajta sajátos szelekció, amely egyrészt a publikációk számának csökkenésében, másrészt a hosszabb, részletesebb és kidolgozottabb tanulmányok megjelenésében tapasztalható, amelyet a következő fejezetben bemutatandó hivatkozásvizsgálatok eredményei is megerősítenek. Emiatt ezeket az eredményeket érdemes együtt értelmeznünk: ilyen például a hivatkozások számának, tematikus és müfaji összetételének, frissességének, nemzetköziségének megváltozása. A célul kitüzött minél teljesebb körü tudománymetriai elemzés érdekében ezeknek a mutatóknak a vizsgálata mindenképpen indokolt volt egy reális összefoglaló kép eléréséhez. 


\subsection{A folyóirat szerzői}

A 2-3. kutatási kérdéscsoport (Kik a folyóirat legtöbbet publikáló szerzői? Közülük kik gyakorolták a legnagyobb hatást más szerzőkre? Milyen intézményi háttérrel rendelkeznek az egyes szerzők?) megválaszolásához szükséges legfontosabb információkat a 4. táblázatban foglaltuk össze.

4. táblázat. A Magyar Pedagógia 16 legtermékenyebb szerzője 1991-2014

\begin{tabular}{ccccc}
\hline \hline$\#$ & Szerzö & Cikkekszáma & $\begin{array}{c}\text { MP-ben detektált } \\
\text { hivatkozások száma }\end{array}$ & Intézményi háttér \\
\hline 1. & Molnár Gyöngyvér & 16 & 136 & SZTE \\
\hline 2. & Csapó Benő & 14 & 361 & SZTE \\
\hline 3. & Nagy Péter Tibor & 13 & 35 & OKI/OFI \\
\hline 4. & Szabolcs Éva & 12 & 24 & ELTE \\
\hline 5. & Csíkos Csaba & 11 & 63 & SZTE \\
\hline 6. & Józsa Krisztián & 10 & 208 & SZTE \\
\hline 7. & Németh András & 10 & 88 & ELTE \\
\hline 8. & Csizér Kata & 8 & 41 & ELTE \\
\hline 9. & Géczi János & 8 & 22 & PE \\
\hline 10. & Kasik László & 8 & 40 & SZTE \\
\hline 11. & Faludi Szilárd & 7 & 4 & BCE \\
\hline 12. & Kárpáti Andrea & 7 & 72 & ELTE \\
\hline 13. & Kelemen Elemér & 7 & 15 & ELTE \\
\hline 14. & Nikolov Marianne & 7 & 99 & PTE \\
\hline 15. & Pukánszky Béla & 7 & 56 & SZTE \\
\hline 16. & Réthy Endréné & 7 & 46 & ELTE \\
\hline \hline & & & & \\
\hline
\end{tabular}

A 4. táblázat azokat a szerzőket tartalmazza, akiknek legalább 7 publikációjuk jelent meg az érintett periódusban a Magyar Pedagógia folyóiratban. Ezek müfaját nem vizsgáltuk, ezért a publikációk között lehetnek tanulmányok, könyvismertetések, recenziók, illetve a Szemle rovatban megjelent cikk is. A táblázat negyedik oszlopában szereplő hivatkozások számát az adott szerzőre beérkező hivatkozások (függő és független) darabszámaként definiáltuk, azaz hogy az adott kutató valamely (nem kizárólag a Magyar Pedagógiában megjelent) munkáját hányszor említette meg valamelyik szerző egy-egy Magyar Pedagógiában közölt publikáció irodalomjegyzékében. Elemzéstechnikailag azt vizsgáltuk, hogy hány olyan hivatkozási tételt 
detektáltunk a teljes szövegü irodalomjegyzékekből, ahol az adott szerző neve szerepel. Ez az oka, hogy az önhivatkozásokat is tartalmazza ez az elemzés.

Ha azokat a személyeket keressük, akik leginkább meghatározták a többiek munkáját, akkor nem tekinthetünk el azon kutatók nevének közlésétől sem, akik ugyan nem írtak legalább 7 cikket a folyóiratba, így nem szerepelnek a fenti táblázatban, ugyanakkor nagyszámú hivatkozás érkezett munkásságukra. Ilyen szerző Nagy József (198), Zsolnai Anikó (78), Dörnyei Zoltán (77), Vidákovich Tibor (56), Kozma Tamás (54), Halász Gábor (48), Báthory Zoltán (46), B. Németh Mária (46), Falus Iván (45) és Fülöp Márta (44).

A 4. táblázat utolsó oszlopa azt az intézményt tartalmazza, amelyet az adott szerző anyaintézményének tekintünk. Ennek eldöntése sok esetben nagyon nehéz, hiszen számos esetben előfordul, hogy idővel egy kutató intézményt vált, vagy egyszerre több intézményhez is köthetö. Az intézményi affiliáció meghatározásához egyrészt a cikkekben közölt adatokra, másrészt pedig a Magyar Tudományos Müvek Tára és az Országos Doktori Tanács adatbázisokra támaszkodtunk. Azon kollégák esetén, akik az érintett periódusban munkahelyet váltottak, azt az intézményt választottuk, ami véleményünk szerint a legmeghatározóbb lehetett az érintett személy pályáján. A topszerzők intézményi hovatartozása esetében hat-hat szerzővel a Szegedi Tudományegyetem és az Eötvös Loránd Tudományegyetem a két legmeghatározóbb intézmény (ez egyébként a teljes szerzői lista figyelembevételével ugyanígy érvényes), míg további négy szerző négy különböző intézményt képvisel.

A topszerzőkön túl a teljes szerzői gárda (389 szerző) intézményi, nemzetiségi és szektorbeli hátterét is vizsgáltuk. Ez sok esetben szintén egyéni döntéseket igényelt, az egyedi esetek miatt: külföldi származású, de magyar intézménynél tevékenykedő szerzők; magyar származású, de külföldi intézménynél dolgozó szerzők; határon túli magyar szerzők. A grafikonokon közölt számszaki adatok anomáliáját ilyen esetek magyarázzák. [Például a 12. ábrán a FOR (külföldi hátterü szerzők) oszlopa egy hosszú évek óta a Szegedi Tudományegyetemen tevékenykedő finn származású szerző miatt nem egyezik meg a 11. ábra 2-19. oszlopának összegével, ahogyan azt előzetesen várnánk.]

A 13. ábrán a szerzők intézményének jellegét közöljük (akadémiai szféra, külföldi intézmények, oktatásirányítási szervezetek, közoktatási intézmények, nincs adat és egyéb intézmények). Itt a tisztán külföldi szerzők intézményi jellegének meghatározására nem vállalkoztunk, kivéve a határon túli magyar intézményeket, itt ebből adódik a külföldi szerzőket reprezentáló oszlop korábbiaktól eltérő adata. Ezen módszertani nehézségek ellenére is fontosnak gondoltuk a szerzők hátterének vizsgálatát, hiszen a 11-13. ábra alapján egy lényeges és átfogó képet szerezhetünk arról, hogy általánosságban milyen háttérrel rendelkeznek a 
Magyar Pedagógia folyóiratban publikáló szerzők. A folyóiratban relatívan magas a külföldi szerzők aránya (lásd 11. ábra). Ez a tendencia elsősorban az ezredforduló környéki időszakban volt jellemző. További kutatást igényelne annak magyarázata, hogy az utóbbi időben miért csökkent ez a szám.

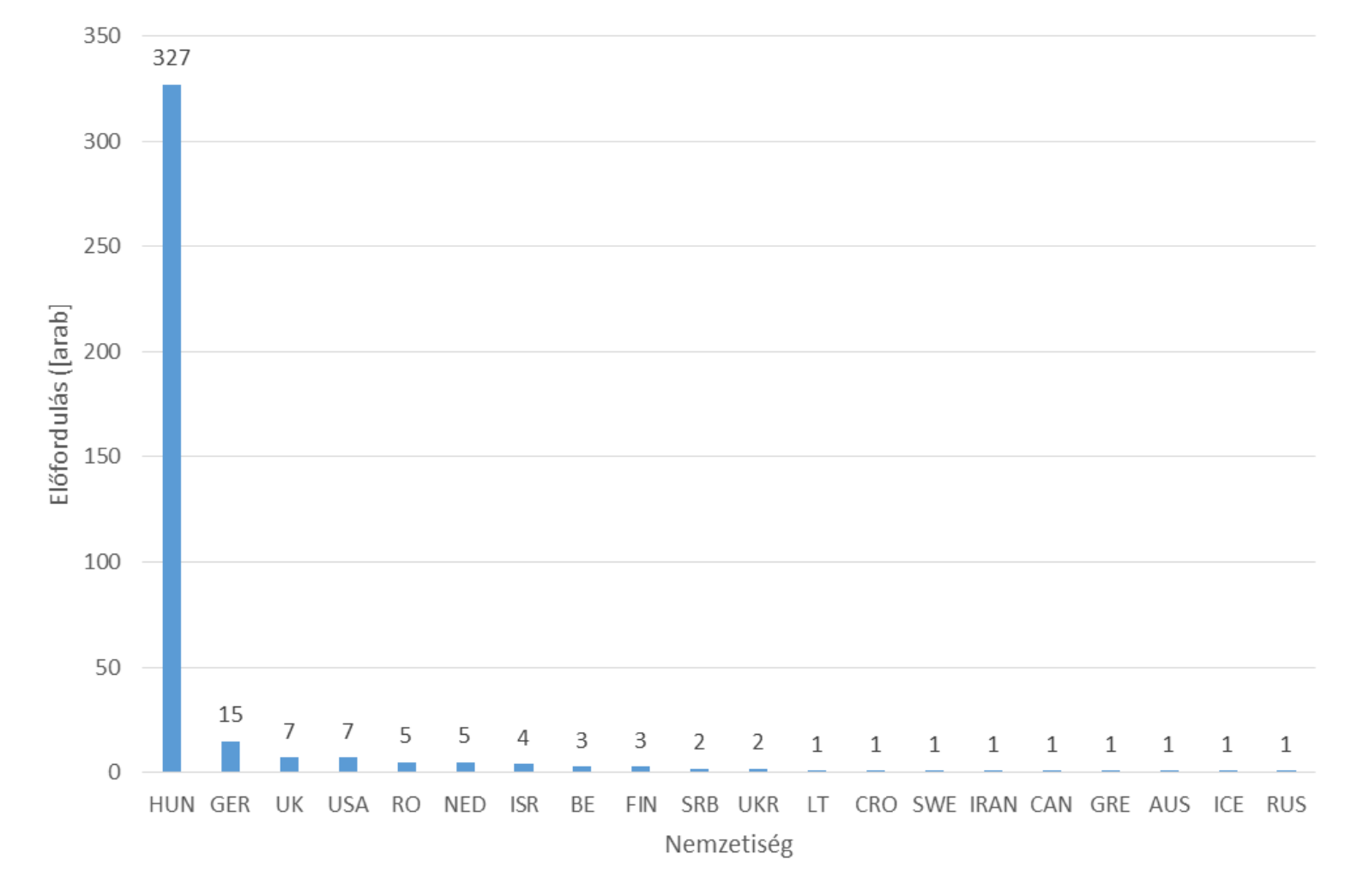

$$
\text { 11. ábra }
$$

A Magyar Pedagógia szerzőinek nemzetiségi megoszlása 1991-2014

[USA: Amerikai Egyesült Államok, AUS: Ausztrália, BE: Belgium, UK: Egyesült Királyság, FIN: Finnország, GRE: Görögország, NED: Hollandia, CRO: Horvátország, IRAN: Irán,

ICE: Izland, ISR: Izrael, CAN: Kanada, LT: Litvánia, HUN: Magyarország, GER: Németország, RUS: Oroszország, RO: Románia, SWE: Svédország, SRB: Szerbia, UKR:

\section{Ukrajna]}

A hazai szerzők tekintetében a 12. ábra grafikonja alátámasztja a topszerzők esetében ismertetett eredményeket. Meghatározó a Szegedi Tudományegyetem és az Eötvös Loránd Tudományegyetem szerepe, a sorban őket a másik két nagy vidéki tudományegyetem követi. Feltételezésünk szerint ez egyértelmüen az ezen intézményekben megtalálható neveléstudományi doktori iskoláknak, illetve kutatócsoportjaik hangsúlyos szerepének köszönhető. Említésre méltó még a Semmelweis Egyetem, továbbá az Oktatáskutató és Fejlesztő Intézet, illetve a közoktatásban tevékenykedő szerzők szerepe. Az utóbbi két szféra jelenlétét a 13. ábra aggregált adatai szintén megerősítik. 


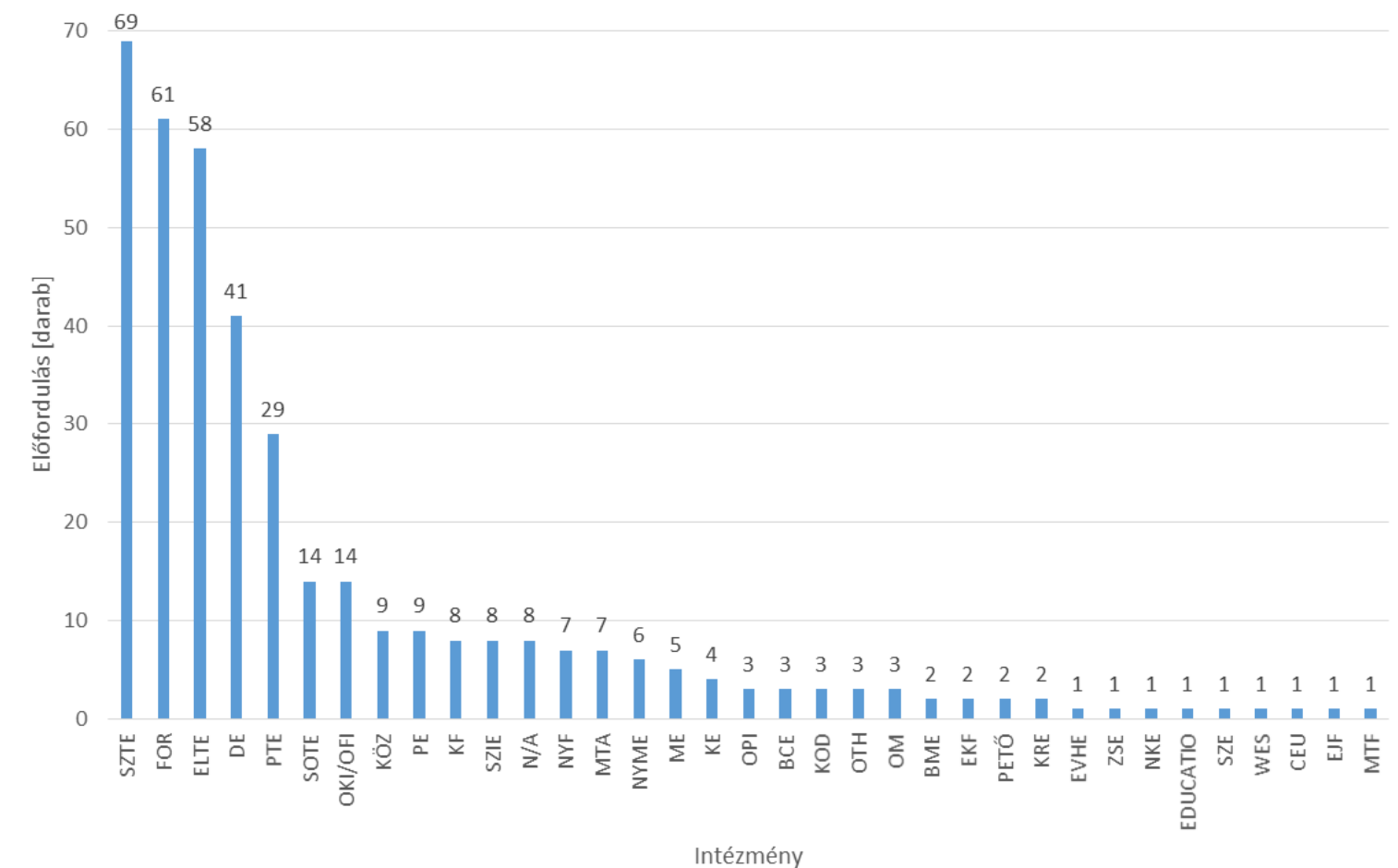

12. ábra

A Magyar Pedagógia szerzöinek intézményi háttere 1991-2014

[Jelmagyarázat az 4. mellékletben]

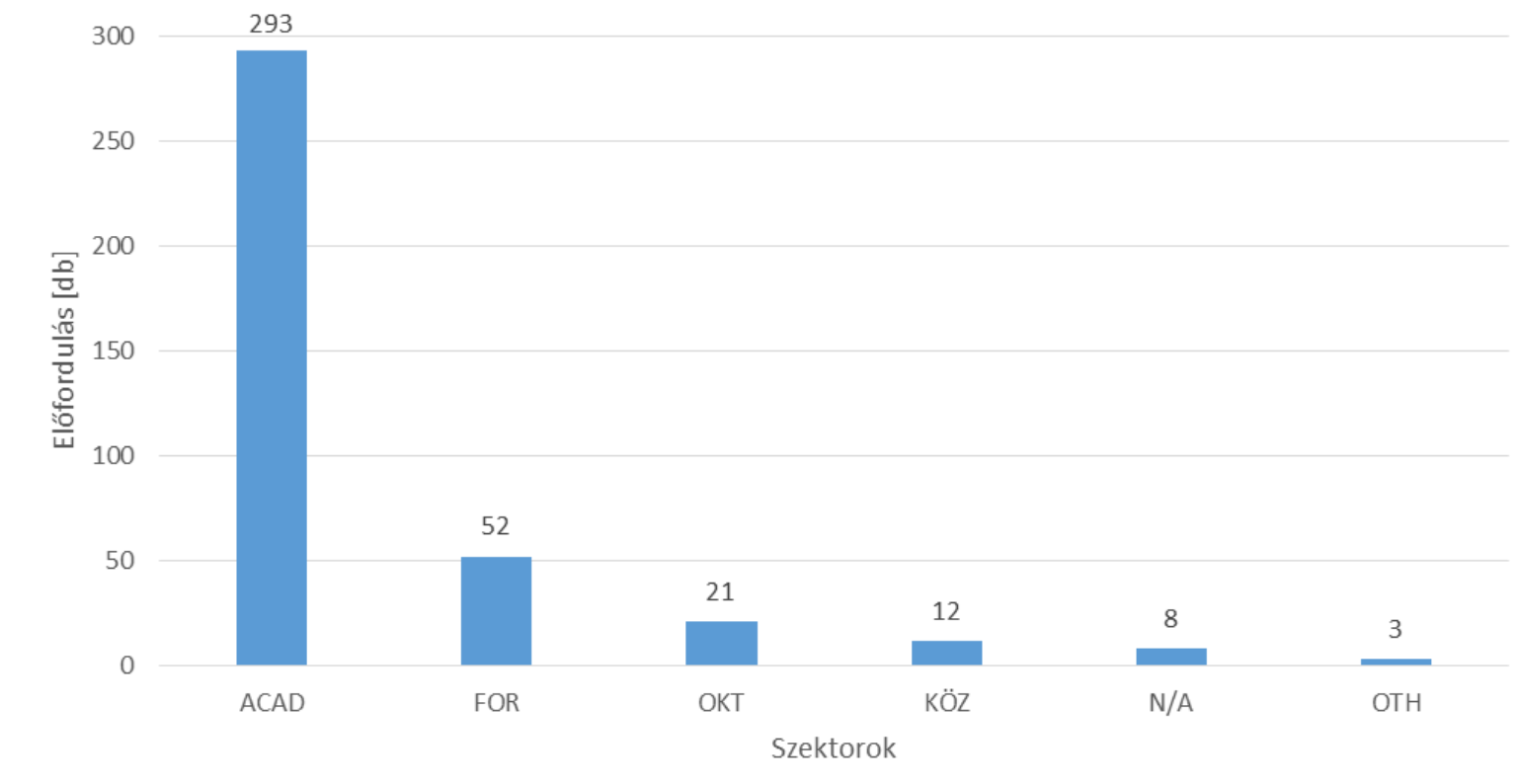

13. ábra

A Magyar Pedagógia szerzőinek szektorok szerinti megoszlása 1991-2014

[ACAD: akadémiai szféra; FOR: külföldi intézmény; KÖZ: közoktatási intézmények; N/A:

nincs adat; OKT: oktatásirányitási szervezetek; OTH: egyéb intézmények] 


\subsection{A női és férfi szerzők aránya}

Következő kutatási kérdésünk $\left(\mathrm{K}_{5}\right)$ kapcsán a férfi és női szerzők arányát vizsgáltuk. Feltételezésünk szerint a női szerzők arányának folyamatos növekedést kell mutatnia a XX. században a tudományban és az élet más területein is lezajlott változásoknak köszönhetően. Az elemzést a folyóirat teljes élettartamára vetítve és külön, a kiemelten vizsgált 1991-2014 közötti időszakra is elvégeztük az eredmények kifinomultabb nyomonkövethetősége miatt. A vizsgálatok alapvetően automatizálva zajlottak, melyhez a női és férfi keresztnevek listáját használtuk fel, míg a kérdéses eseteket pedig kézzel validáltuk. A nem magyar keresztnévvel rendelkező szerzők esetében az azonosítás kizárólag egyesével volt lehetséges, mely alapos internetes kutatómunkát igényelt. A 14. ábra világosan felfedi előttünk azt a hatalmas változást, amely a XIX. század végétől a XXI. század elejéig lezajlott a nők tudományos szerepvállalását illetően. Természetesen ez a változás nem csupán a neveléstudomány sajátja, hasonló átrendeződés lenne megfigyelhető más tudományágak esetében is.

Nagyon sokáig egy teljes évfolyamot tekintve, csupán egy-két szerző képviseli a női nemet; egészen az 1960-as évekig kell várnunk arra, hogy számuk stabilan az évenkénti tízes szám fölé emelkedjen. A rendelkezésre álló adatok birtokában megállapítható, hogy a női szerzők arányának növekedése valójában ennek az évtizednek a második felében kezdődött el. Mint ahogyan az sejthető, a második világháborút megelőzően csupán elvétve akadtak nők a folyóirat szerzői között. Vannak olyan évek, amikor egyetlen női szerző sem publikált, de általánosságban is elmondható, hogy arányuk a folyóirat életének első felében maximum 10\%ra volt tehető. A grafikonon természetesen az is megjelenik, hogy mely években szünetelt a folyóirat kiadása, az ábra közepén látható hiátusoknak ez a magyarázata.

A következő, 15. ábrán grafikusan megjelenített, az utolsó kiemelten vizsgált időszakra (1991-2014) szükített eredmények tovább árnyalják hipotézisünket. Az ekkor lezajlott, még nagyobb léptékünek tekinthető fordulat valószínűleg a felsőoktatásban és a tudományos életben a rendszerváltás után kiteljesedő emancipációnak köszönhető. Az utóbbi évtizedben már egyértelmüen kijelenthető a női szerzők túlsúlya a Magyar Pedagógia szerzői esetében. További kutatást igényelne ugyanennek az aránynak a meghatározása a többi neveléstudományi folyóirat esetében, illetve a női oktatók-kutatók arányának meghatározása a magyarországi kutató- és képzőhelyeken. Erre jelen kutatás keretei között nem vállalkozhattunk, azonban erősen feltételezhető, hogy ezekben az esetekben is hasonló tendenciák lennének megfigyelhetőek. 


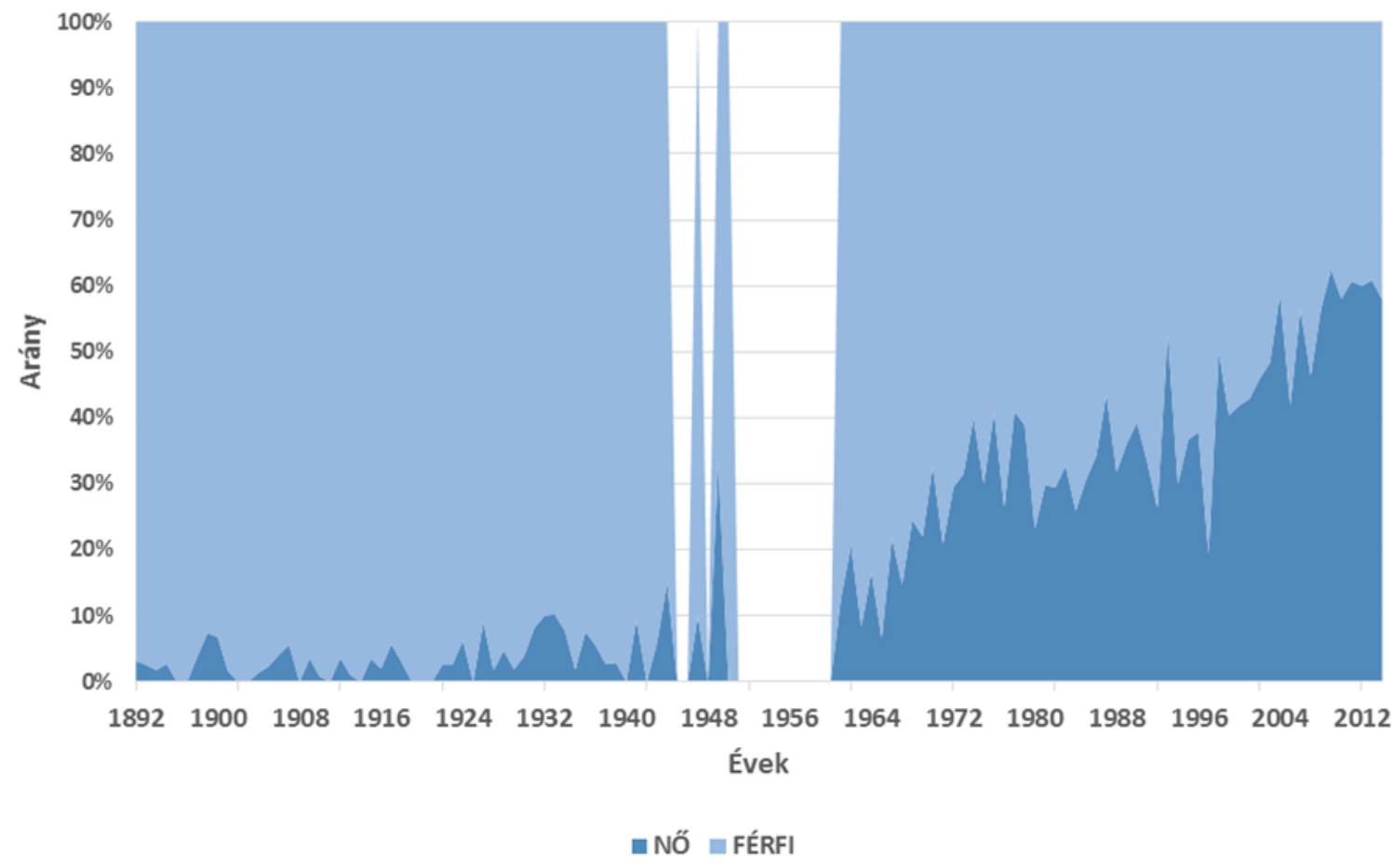

14. ábra

A női és férfi szerzők aránya a Magyar Pedagógia szerzői között (1892-2014)

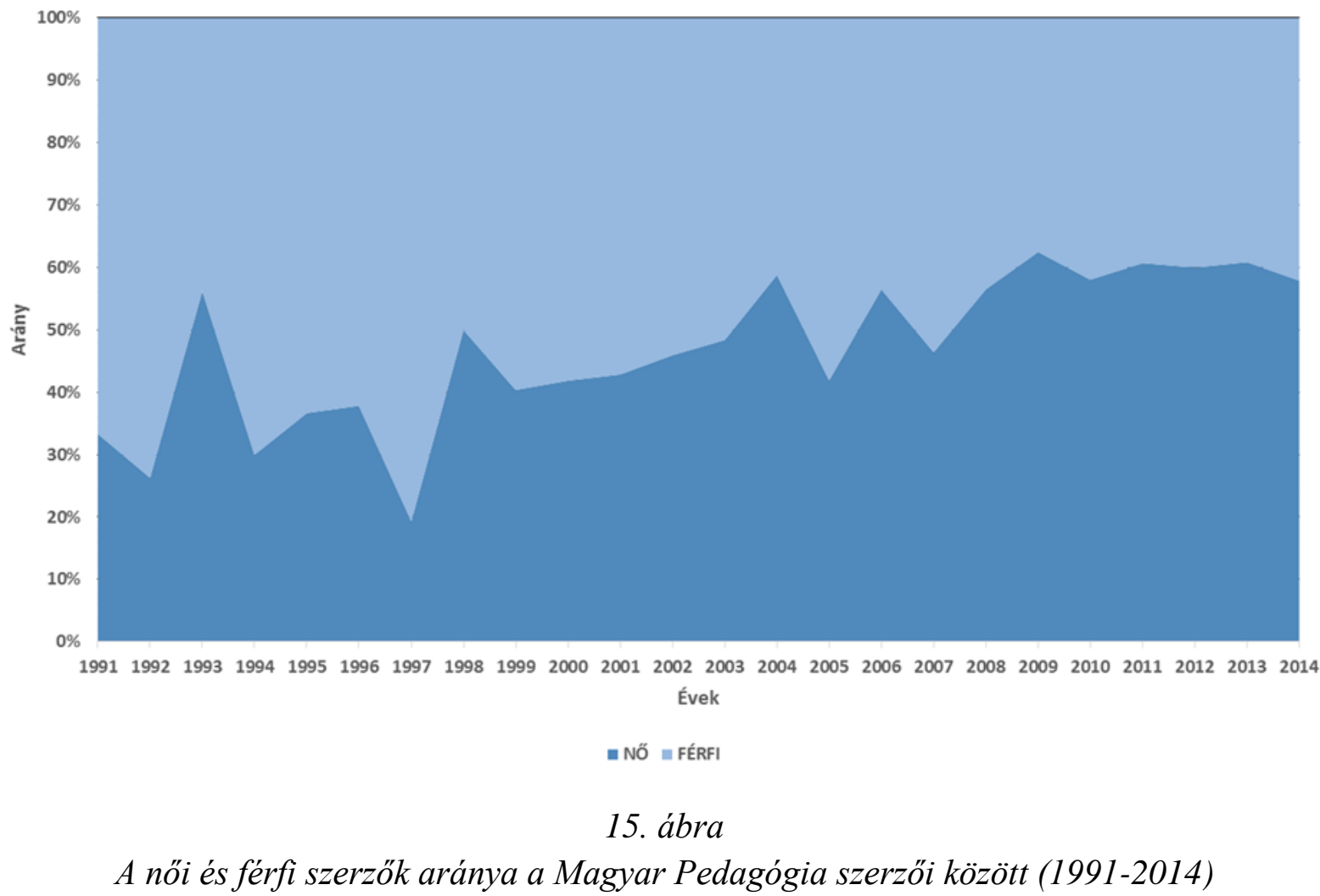




\subsection{A társszerzőség jelenségei és a társszerzőségi gráf}

Ahogyan azt a longitudinális kutatások megerösítik, a többszerzős tanulmányok aránya tudományterülettől függetlenül világszerte növekvő tendenciát mutat (Adams, 2012; Henriksen, 2016). A kutatás keretein belül kitértünk a magyar neveléstudomány vezető folyóiratai szerzői összetételének elemzésére. A nemzetközi szakirodalom alapján, előzetes hipotézisünk szerint a Magyar Pedagógia címü folyóiratban a többszerzős tanulmányok aránybeli növekedését várjuk. A korábbi évek lineárisan alacsony bázisa miatt az elemzés alapját az 1991-es föszerkesztőváltás utáni időszak adta. Az eredmények (16. ábra) egyértelműen igazolták előzetes hipotézisünket, miszerint a társszerzős cikkek aránya növekedő tendenciát mutat.

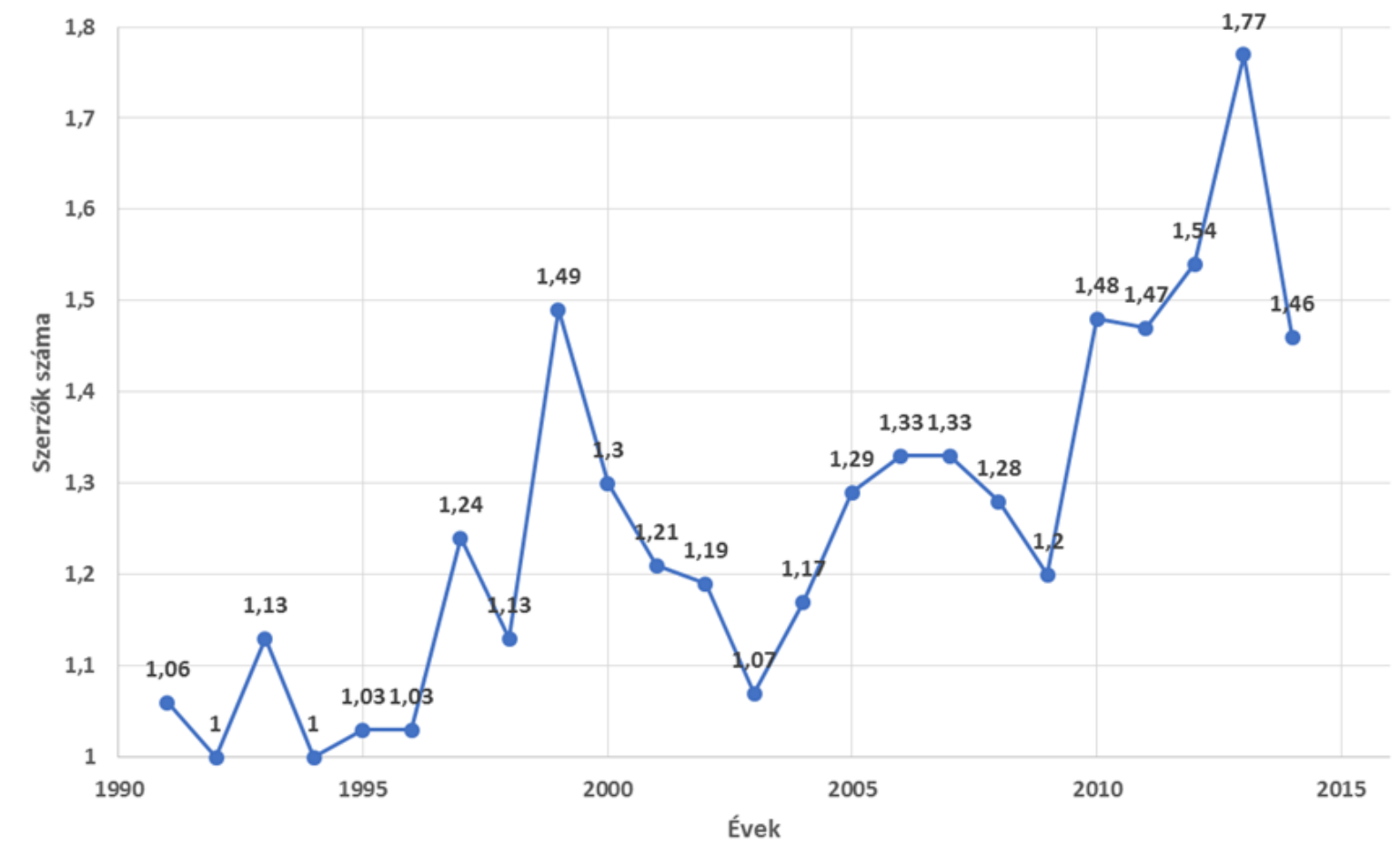

16. ábra

A Magyar Pedagógia címü folyóirat tanulmányaira eső szerzők számának évenkénti változása 1991-2014

A változás irányának meghatározása mellett a társszerzőségi mintázatok feltérképezését is elvégeztük. Ennek grafikus megjelenítésére világszerte széleskörüen a hálózattudomány eszközeit használják (pl. Liu \& Xia, 2015; Leifeld, Wankmüller, Berger, Ingold, \& Steiner, 2017; Fagan, Eddens, Dolly, Vanderford, Weiss, \& Levens, 2018), úgynevezett társszerzőségi gráf segítségével ábrázolva a szerzők között lévő kapcsolatokat. A társszerzőség feltételez egyfajta együttmüködést, kapcsolatot a tudományos életben a szerzőtársak között, amely jóval 
túlmutat a véletlenszerüségen. Ilyen indukáló tényező lehet a mester-tanítvány viszony, egyegy kutatócsoportbeli közremüködés, a közös kutatási téma, illetve az azonos intézményi háttér. További kutatást igényelne az eredmények alapján kirajzolódó együttmüködések alapjainak feltárása, amire a jelen kutatásban - annak túlságosan mélyreható volta miatt - nem kerülhetett sor.

A teljességre törekvés miatt a Magyar Pedagógia társzerzőségi gráfját a folyóirat alapításától, azaz 1892-től kezdődően készítettük el. A gráf az összes olyan szerzőt tartalmazza, aki az idők folyamán bármikor közös tanulmányt írt bármely másik szerzővel. Az irányítatlan gráf összesen 348 csomópontból és a csomópontok között húzódó 337 élből áll. Ez azt jelenti, hogy 348 olyan szerzőt azonosítottunk, aki valamikor legalább egy szerzőtárssal közösen publikált a folyóiratba. Természetesen többszörösen előforduló társszerzőségek is előfordulnak, hiszen létezik olyan publikáció is, amelyet 7 szerző jegyez. A gráf 108 különálló komponensből áll, amely egy ekkora elemszámú gráfnál erős tagoltságot jelent. A széttagoltságot valamelyest magyarázza a nagy időtáv, melyet a gráf lefed, hiszen egyes szerzőknek fizikai lehetőségük sem nyílhatott az együttpublikálásra, mivel teljesen más korban fejtették ki munkásságukat.

A fontosabb hálózati statisztikai adatokat (Barabási, 2016) összefoglalva a gráf átlagos fokszáma 1,937, míg átlagos súlyozott fokszáma 2,121, sürüsége 0,006, az átlagos úthossz 2,47. A gráf legnagyobb átmérője 6 , amely a 17. ábrán látható legjelentősebb összefüggő komponensnek köszönhető. A teljes gráf nagy mérete miatt az egész társszerzőségi hálózatot nem tudjuk itt közölni, ezért a legdominánsabb összefüggő komponensekre koncentrálunk. A 17-19. ábra színskálája reprezentálja a különböző intézményeket, míg a pontok mérete és az élek vastagsága a számosságokat hivatottak jelezni, azaz, hogy az adott szerző hány másik szerzővel, hányszor publikált együtt. Minél nagyobb egy pont, az adott szerzőre annál inkább jellemző a közös cikkírás és annál inkább központi szerepet tölt be a többi szerző között a társszerzőséget tekintve. A centrális személyek detektálására jól használható a PageRank mutató (Yan \& Ding, 2011), amelyet az 5. táblázatban közlünk >0,005 értékig. 
5. táblázat. A Magyar Pedagógia szerzői a társszerzőségi gráf PageRank értékei alapján.

\begin{tabular}{cccc}
\hline \hline Név & Intézmény & Fokszám & PageRank érték \\
\hline Kozma Tamás & DE & 15 & 0,01172737 \\
\hline Józsa Krisztián & SZTE & 10 & 0,01077452 \\
\hline Kárpáti Andrea & ELTE & 9 & 0,00887490 \\
\hline Mihály Ottó & ME & 11 & 0,00795626 \\
\hline Nikolov Marianne & PTE & 8 & 0,00738085 \\
\hline Kemény Ferenc & OLD & 5 & 0,00703076 \\
\hline Csizér Kata & ELTE & 6 & 0,00660650 \\
\hline Varga Lajos & OLD & 5 & 0,00647426 \\
\hline Kasik László & SZTE & 5 & 0,00600282 \\
\hline Falus Iván & ELTE & 4 & 0,00518953 \\
\hline Csapó Benő & SZTE & 7 & 0,00512609 \\
\hline Hunyady Györgyné & ELTE & 7 & 0,00512609 \\
\hline Báthory Zoltán & OKI/OFI & 7 & 0,00504064 \\
\hline \hline
\end{tabular}

Előzetes hipotézisünk alapján azt feltételeztük, hogy az intézményi háttér erősen befolyásolja majd a társszerzőségi hálózatot, azaz kimutathatóak lesznek az intézmények szerinti elkülönülő csoportok a gráfban. Azonban az eltérő intézményi háttér a vártnál kevésbé magyarázza a komponensek magas számát. A társszerzőségi gráf közel összes meghatározóbb komponensére jellemző a széles színbeli szórás, amely azt jelenti, hogy az egyes magyarországi neveléstudományi mühelyek között komoly együttmüködés tapasztalható, amely erősen megjelenik a közös cikkírásban. Akadnak olyan kisebb komponensek is, ahol egy-egy intézmény szerzői dominálnak. Erre jelent példát a 19. ábrán bemutatott három különálló komponens debreceni, szegedi és ELTE-s szerzőkkel. Ugyan ezek még kevésbé kiterjedt társszerzőségi hálózatokat reprezentálnak, azonban itt egyértelműen tetten érhető az intézmények szerinti elkülönülés a publikálási szokásokban. Az idő előrehaladtával ezek a kisebb gráfkomponensek valószínüleg be fognak tagozódni valamely nagyobb, összefüggő komponensbe, miután ehhez már az is elegendő lenne, ha egyik szerzőjük együtt publikálna valamely másik komponens szerzőjével.

Ez a jelenség felhívja figyelmünket a hálózattudomány egyik nagy felismerésére, a skálafüggetlen hálózatokra (Barabási, 2016), azon belül is a magas fokszámú csomópontok kiemelt összekötő szerepére. A 17-18. ábrán jól látható ez a jelenség, sokszor egy-egy magas PageRank értékkel rendelkező szerző egy-egy más szerzővel közös tanulmányán múlik a gráf összekötöttsége. Ábráinkon egyértelműen ilyen szerepet tölt be Kozma Tamás, Józsa Krisztián 
vagy Nikolov Marianne. Kisebb léptékben ugyanígy megfigyelhető a jelenség a 19. ábrán Máth János, Kasik László és Csizér Kata híd szerepében.

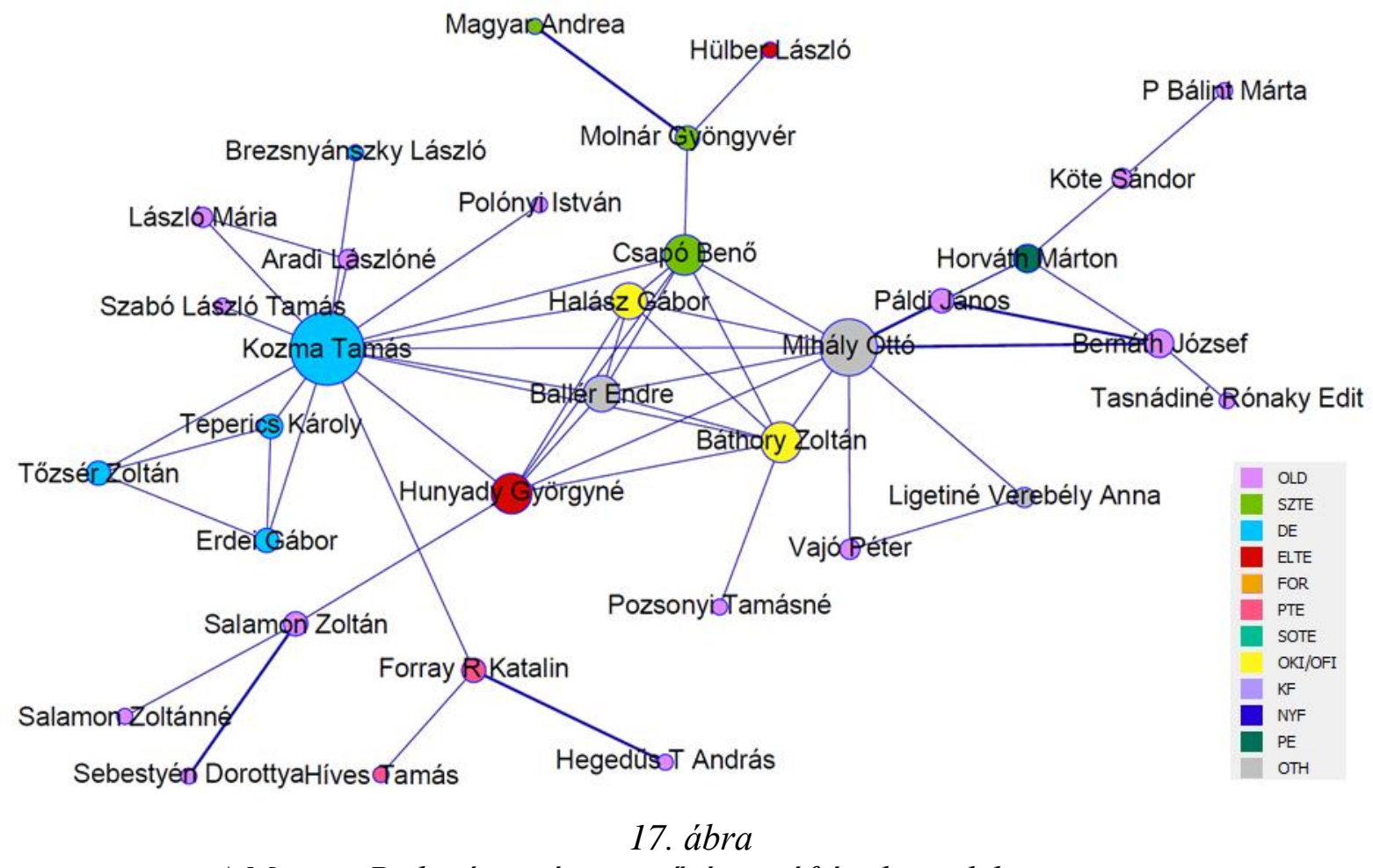

A Magyar Pedagógia társszerzőségi gráfjának egyik komponense

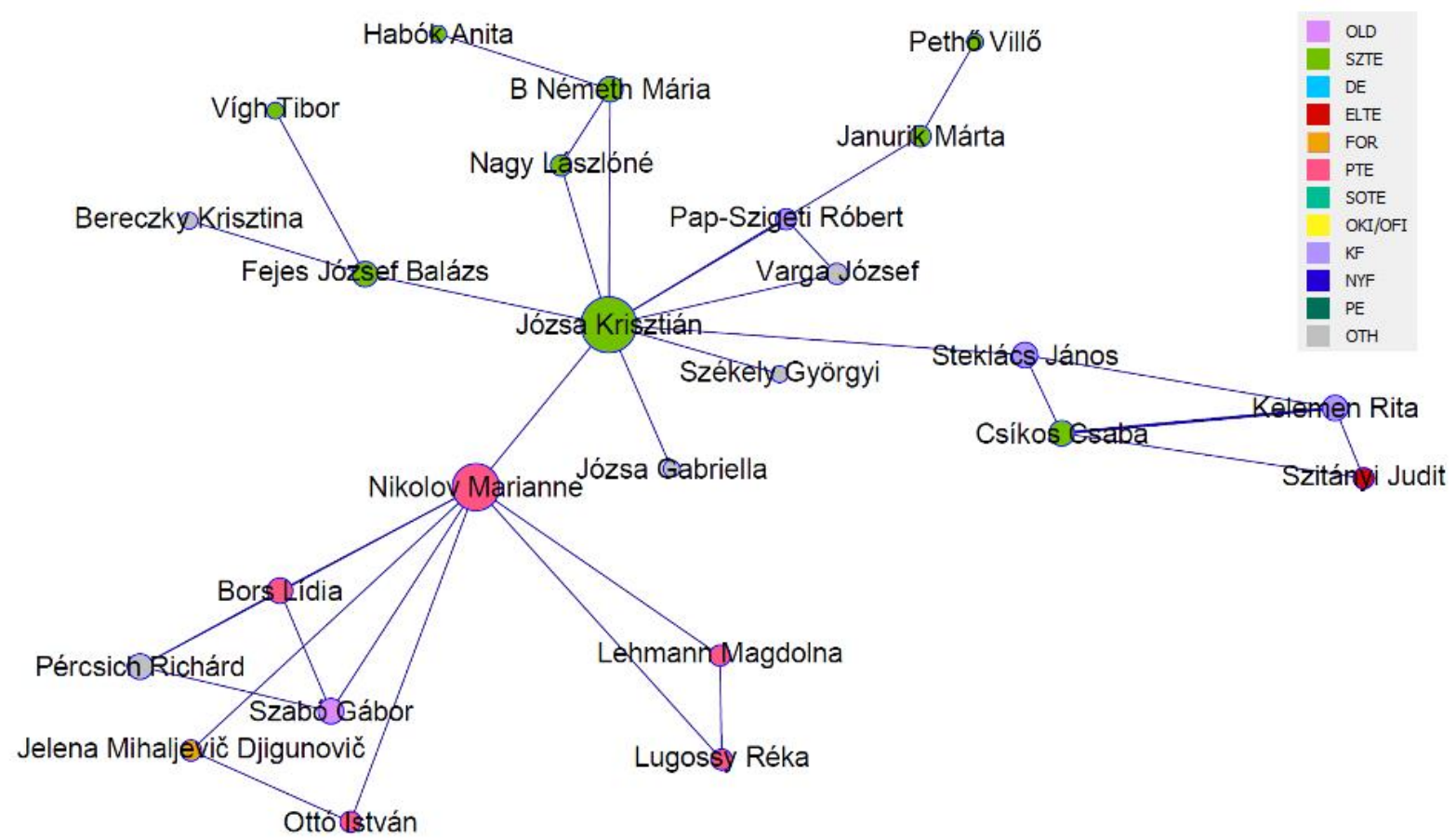

18. ábra

A Magyar Pedagógia társszerzöségi gráfjának egyik komponense 

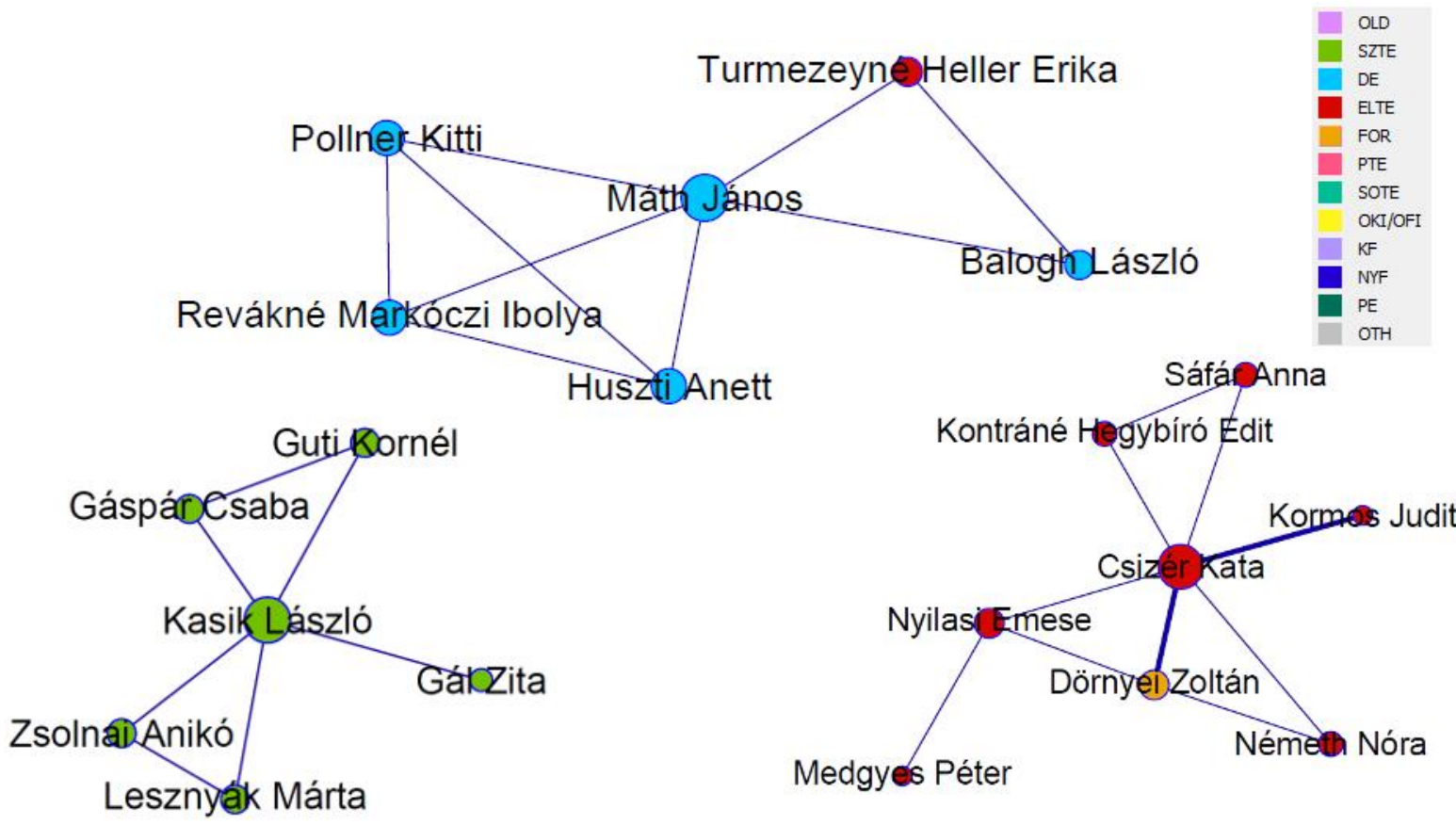

19. ábra

A Magyar Pedagógia társszerzöségi gráfjának három kisebb komponense 


\section{HivATKOZÁSVIZSGÁLATOK}

\subsection{A hivatkozások általános mutatói}

Az eredmények közül elsőként az egyik triviális mutatót, a hivatkozások átlagos számának változását (Bornmann \& Mutz, 2015) érdemes megvizsgálni. Előzetes feltételezésünk $\left(\mathrm{H}_{9}\right)$ szerint a publikációkban felhasznált források száma évről évre növekvő tendenciát mutat a Magyar Pedagógia cikkeiben, melyet a kapott eredmények egyértelműen meg is erősítettek. A növekvő tendencia már az 1990-es évek végétől tetten érhető, de az ezredforduló után még inkább kiteljesedett ez a jelenség. Minden idők legkiemelkedőbb, 2009es adata után ugyan két évig valamelyest visszaesett a cikkenként idézett források száma, azonban 2012 óta ismét masszívan növekvő tendenciát láthatunk. Az eredményeket a medián értékek is megerősítik, hiszen esetükben hasonló tendencia bontakozik ki, mint a számtani átlagoknál. A kiugró értékeket megvizsgálva elmondható, hogy kilenc olyan év is szerepel a vizsgált időszakban, amelyekben van legalább egy, az irodalomjegyzékében több, mint 100 tételt tartalmazó cikk. Az abszolút rekorder ebben a müfajban egy, a szociális kompetencia és a zeneterápia viszonyát feltáró, az átlagos cikkhosszúság mintegy dupláját kitevő, negyven oldalas tanulmány (Szabadi, 2014) 159 tételes irodalomjegyzékkel.

Összességében elmondható, hogy a kilencvenes években sokkal inkább a tízes és húszas nagyságrendủ tartományban mozgó szakirodalmi hivatkozásszám az utolsó tíz évben egyértelműen megugrott és áthelyeződött a harminctól ötvenes számtartományba (20. ábra). Ez egyrészt a folyóirat életében lezajlott müfaji változásoknak is betudható, de legalább ekkora szerepet játszhatott - a korábbi eredményekkel összhangban - a cikkek átlagos hosszúságának növekedése. Ezt támasztja alá, hogy a két, összefüggő jelenség nagyjából egy időben zajlott: az ezredfordulótól tapasztalható trendek alapján ennek a mutatónak az átlagos értéke is áthelyeződött a korábbi 10-13 oldal közötti tartományból a 15-22 oldal évenkénti terjedelmi határok közé (lásd 10. ábra). 


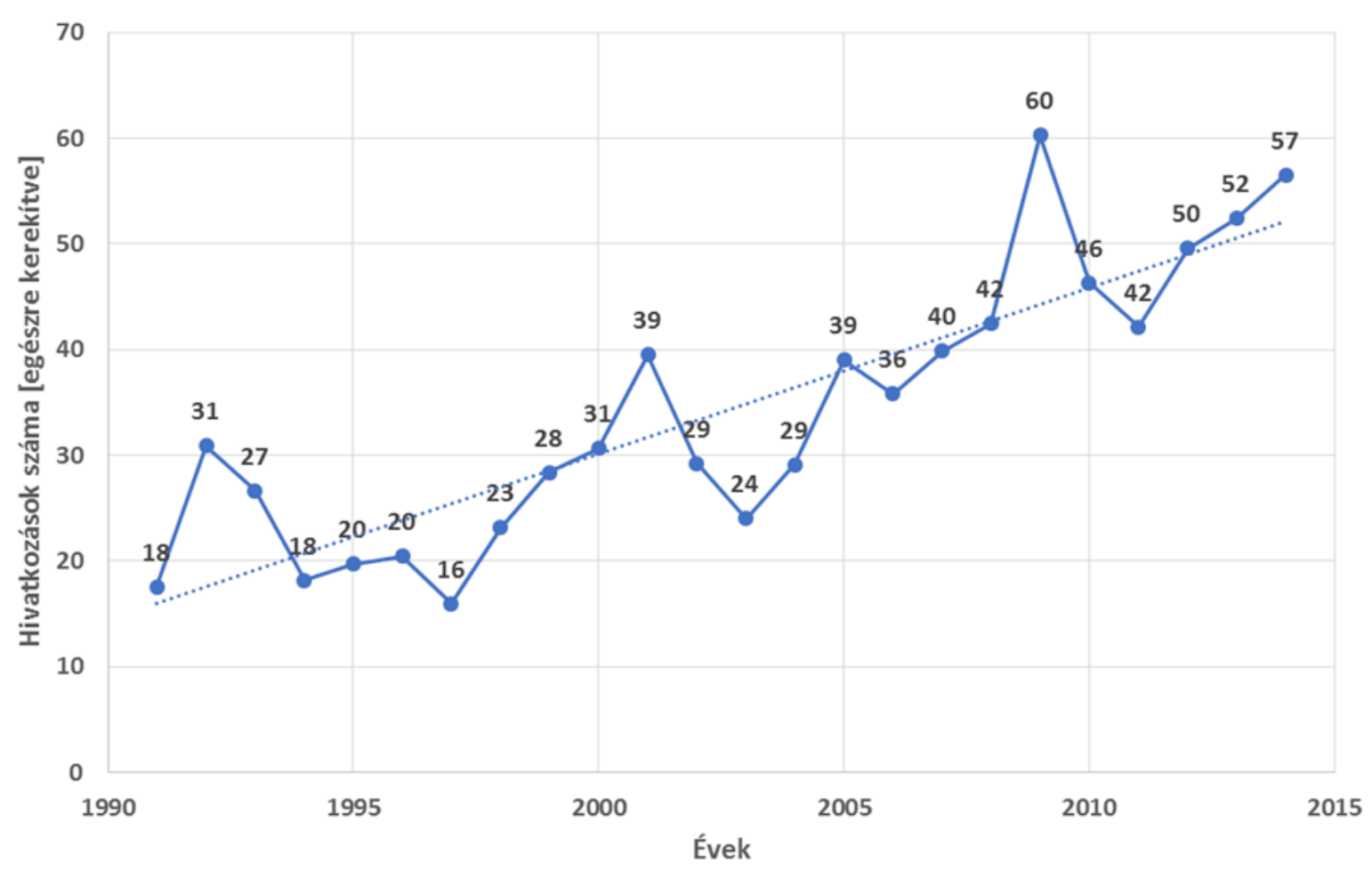

20. ábra

A Magyar Pedagógia tanulmányok átlagos hivatkozási számának évenkénti változása (1991-2014)

Az egyszerủ mennyiségi mutatók mellett második fontos indikátorként a szakirodalmi források frissességét jelöltük ki. Előzetes feltevésünk $\left(\mathrm{H}_{9}\right)$ és a vonatkozó szakirodalom (Bornmann \& Mutz, 2015) szerint pozitív trendeket vártunk, amelyet a kapott eredmények a mennyiségi emelkedéshez hasonlóan visszaigazoltak. 2002 óta ugyanis a szerzők által felhasznált források megjelenési éveinek átlaga kivétel nélkül a 11 és 18 év közötti tartományba esik a megelőző évtizedben tapasztalható jóval magasabb számokhoz képest (jellemzően 20 és 30 év fölötti értékek, amelyek részletesen nyomon követhetőek a 21. ábrán). Az évenkénti medián értékek esetében hasonló eloszlás figyelhető meg, míg a módusz értékek nagyobb szórást mutatnak ezekhez a tendenciákhoz képest, mivel esetükben a legtöbb évre tekintve öt éven belüli érték a jellemző.

A kiugró értékek esetében arra a következtetésre jutunk, hogy tendenciózusan minden évben előfordultak olyan hivatkozások, amelyek legalább egy-egy, régmúltban született cikket idéztek, mely források jellemzően legalább 100 évesek. Még alaposabban megvizsgálva a jelenséget, ezek a régebbi idézések két kategóriába sorolhatók: egyrészt alátámasztják azt a vélekedést, hogy a Magyar Pedagógia írásai között előfordulnak neveléstörténeti jellegü írások (pl. Kéri, 2004), másrészt igazolják azt az elképzelést, hogy egyes szerzők, egyes esetekben egészen komoly történeti visszatekintéssel élnek egy-egy nem feltétlenül neveléstörténeti téma 
esetében is (példa lehet erre is Szabadi 2014-es tanulmánya). A neveléstörténeti témájú írások folyóiratban való részarányáról a tartalmi elemzések fognak pontosabb adatokkal szolgálni.

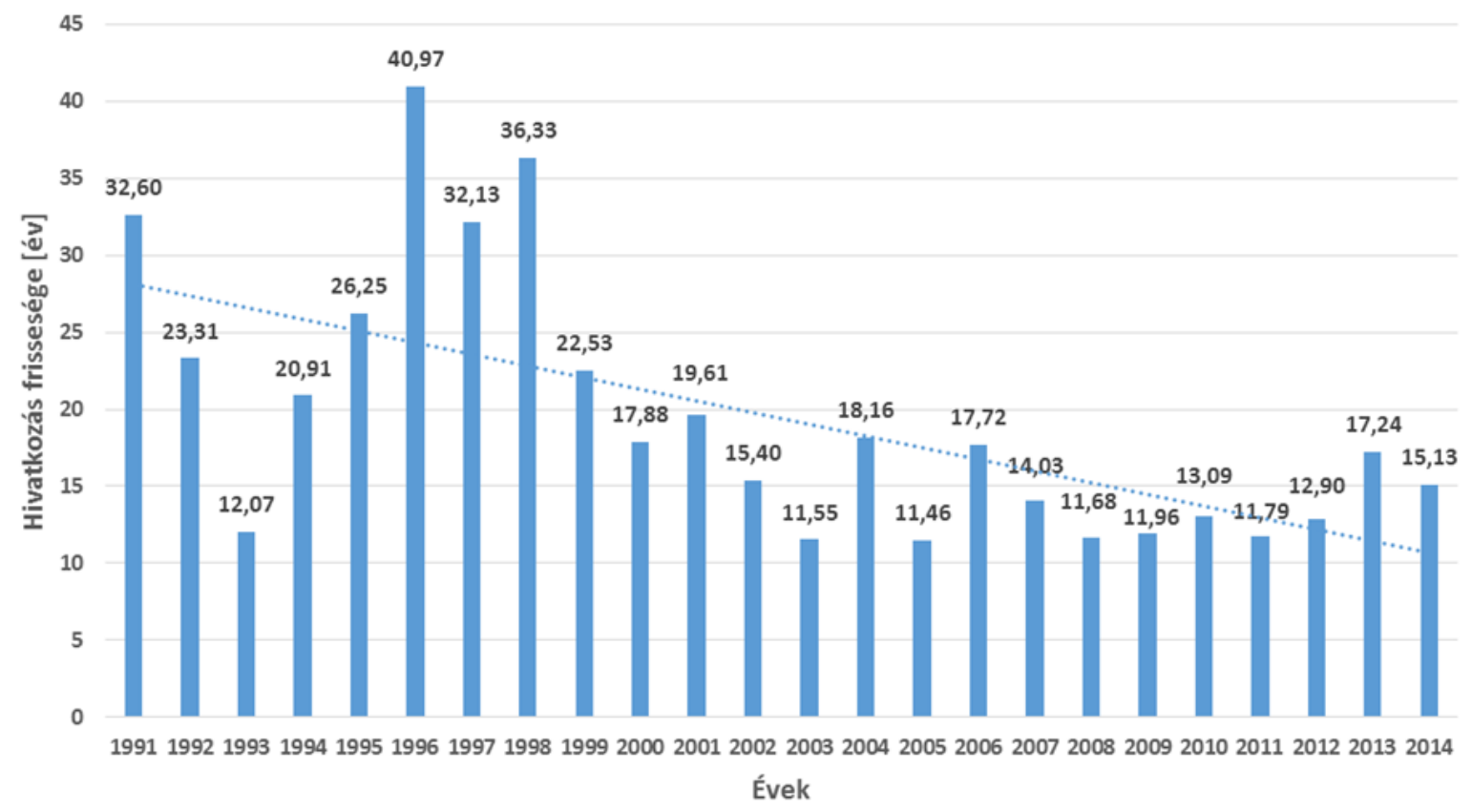

21. ábra

A Magyar Pedagógia tanulmányok hivatkozásainak átlagolt frissessége (1991-2014)

\subsection{A hivatkozások arányai és eloszlásai}

Több kutatási kérdés $\left(\mathrm{K}_{6}, \mathrm{~K}_{7}, \mathrm{~K}_{9}\right)$ megválaszolásához és hipotézis $\left(\mathrm{H}_{6}, \mathrm{H}_{7}, \mathrm{H}_{9}\right)$ bizonyításához szükséges volt az egyes hivatkozott források müfajának, illetve nemzetközi vagy magyar mivoltának meghatározása. Ez a feladat a nagy elemszám és a rengeteg különböző felhasznált forrás miatt egyáltalán nem triviális művelet, emiatt az általunk alkalmazott módszer több megközelítést is figyelembe vett. A folyóiratok azonosítására a magyar címek esetében a Matarka adatbázis címlistáját használtuk, míg a nemzetközi címek azonosítására a Journal Citation Reports indexlistáját. Egy további lépésben mindez kiegészült a tipikus, csak a folyóiratok címére jellemző kifejezések szürésével (pl. quarterly, bulletin).

A módszer leírásából tetten érhető, hogy a kategorizálás elsősorban a folyóirat-nem folyóirat és a magyar-nemzetközi tengelyeken mozgott, így a különböző létrejövő halmazok metszetei és különbségei nyomán olyan csoportokat tudtunk alkotni, mint például a magyar és nemzetközi folyóiratok. A kialakult csoportokat ezután olyan alcsoportokra tudtuk osztani, mint az impakt faktorral rendelkező folyóiratok vagy az interdiszciplinaritás vizsgálata jegyében szigorúan véve nem oktatási tematikájú folyóiratok alcsoportja. Történt mindez azzal a céllal, hogy az egyes kategóriák egymáshoz való aránya vizsgálható legyen, ezáltal lehetővé 
téve különböző következtetések levonását és az uralkodó tendenciák megállapítását a hivatkozott források eloszlását és időbeli változását illetően.

Az ebben a szakaszban vizsgált ismérveket a korábbi pontokban ismertetettekhez képest olyan indikátoroknak tekintjük, amelyek a Magyar Pedagógia egyfajta evolúcióját hivatottak alátámasztani hipotéziseink nyomán. A fejlődés főleg a nemzetközi publikációs térhez való közeledés (Kampis, Soós, \& Gulyás, 2011) tettenérésében és a nemzetközi tudományos életben tapasztalható trendek követésében nyilvánul meg. Pozitív tendencia, hogy a magyar kutatók egyre inkább bekapcsolódnak a tudomány nemzetközi vérkeringésébe, mind a nemzetközi folyóiratokba való publikáláson keresztül, mind azáltal, hogy egyre nagyobb mértékben használják ugyanennek a nemzetközi térnek a minőségi forrásait. Az egyes szerzőkön túl, a kutatási projektünkben elemzett folyóiratra vonatkozó eredmények is azt a képet erősítik, hogy ezek a hatások nemcsak a szerzőkre, hanem az egyes hazai orgánumokra is hatással lehetnek, alakítva és fejlesztve ezzel a hazai tudományos kommunikációt.

$\mathrm{Az}$ elméleti háttérben részletesen ismertetett tudománykommunikációs változások hatásait kiterjesztve a referenciák világára, hipotézisünk $\left(\mathrm{H}_{6}\right)$ szerint az egyes publikációkban történő idézések nagyobb aránya folyóiratcikkekre érkezik, és ez a megoszlás egyre inkább növekvő tendenciát mutat az idő előrehaladtával. Ha az arányokat vizsgáljuk, akkor nagyjából egyharmad (36\%; 5029) - kétharmad (64\%; 9010) megoszlást kapunk a folyóirat - nem folyóirat dimenziót illetően. Ez az eredmény magában állva láthatóan nem esik egybe egyes számú hipotézisünk első felének állításával, hiszen a Magyar Pedagógia szerzői a vizsgált időszakban majdnem kétszer olyan gyakran hivatkoztak valamely nem folyóiratban megjelent tudományos munkára, mint valamely folyóiratban közölt tanulmányra. Ezzel szemben, ha a hipotézis második felére koncentrálunk és az időbeliséget is tekintetbe vesszük, már kedvezőbb a kép, ahogyan a fellendülés a 22. ábrán is nyomon követhető. A kezdeti időszakban a folyóirathivatkozások százalékos aránya főként a 10-20\%-os tartományban mozog, míg a periódus közepén a 30\%-os tartományban, a ciklus végére már az évenkénti 40\%-os és afölötti értékek a jellemzőek. 


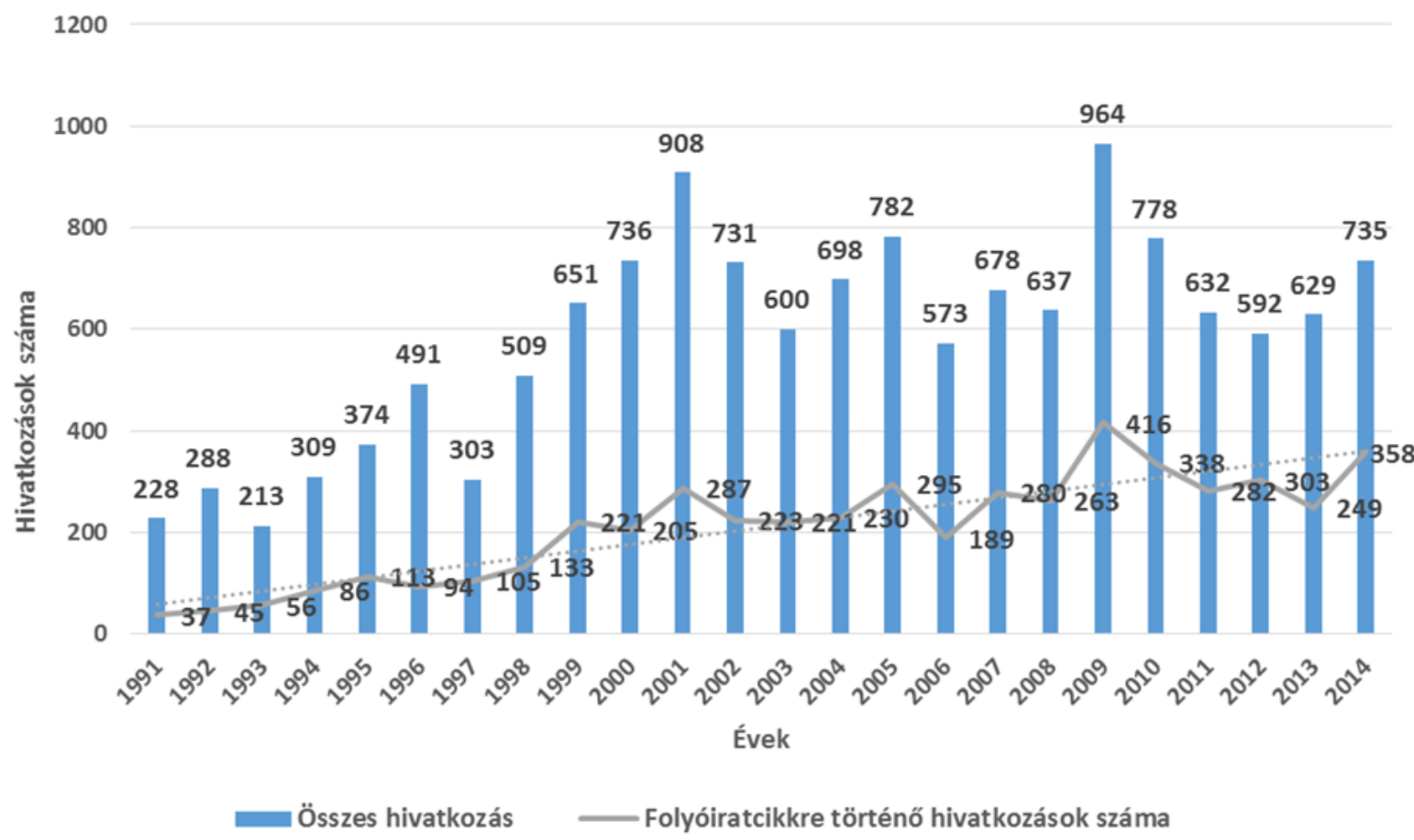

22. ábra

A folyóiratcikkekre történö hivatkozások arányának változása az összes hivatkozás tükrében

Az összes hivatkozás mintegy egyharmadát kitevő, folyóiratokra történő 5029 hivatkozást részletesebben feltárva különböző dimenziójú megoszlásokat térképezhetünk fel, például a nemzetközi és magyar folyóiratcikkekre történő hivatkozások arányának vagy az interdiszciplináris, illetve neveléstudományi lapokból történő idézési szokások változását, támaszkodva a Tóth, Toman és Cserpes (2008) által alkalmazott módszerekre. Feltételezésünk $\left(\mathrm{H}_{9}\right)$ szerint a folyóiratcikkekre való hivatkozási kedv növekedésén belül a nemzetközi folyóiratokra való hivatkozásoknak kiemelt szerepe van, azaz ezek arányának is folyamatosan növekvő tendenciát kell mutatnia. Az összes hivatkozáson belül, a folyóirat-hivatkozások almintáját vizsgálva összességében a 43-57\%-os megoszlást tapasztaljuk a magyar-nemzetközi vonalon, tehát már ezen adat birtokában bátran kijelenthető a nemzetközi hivatkozások túlsúlya. Az adatok időbeli eloszlását is figyelembe véve (23. ábra) megállapítható, hogy a nemzetközi folyóirat-hivatkozásoknak valóban egyre nagyobb szerep jut a felhasznált források körében, hiszen 2007-től már folyamatosan évenkénti 60 és 70 százalék körüli megoszlási értékek jellemzőek a nemzetközi folyóiratok javára. 


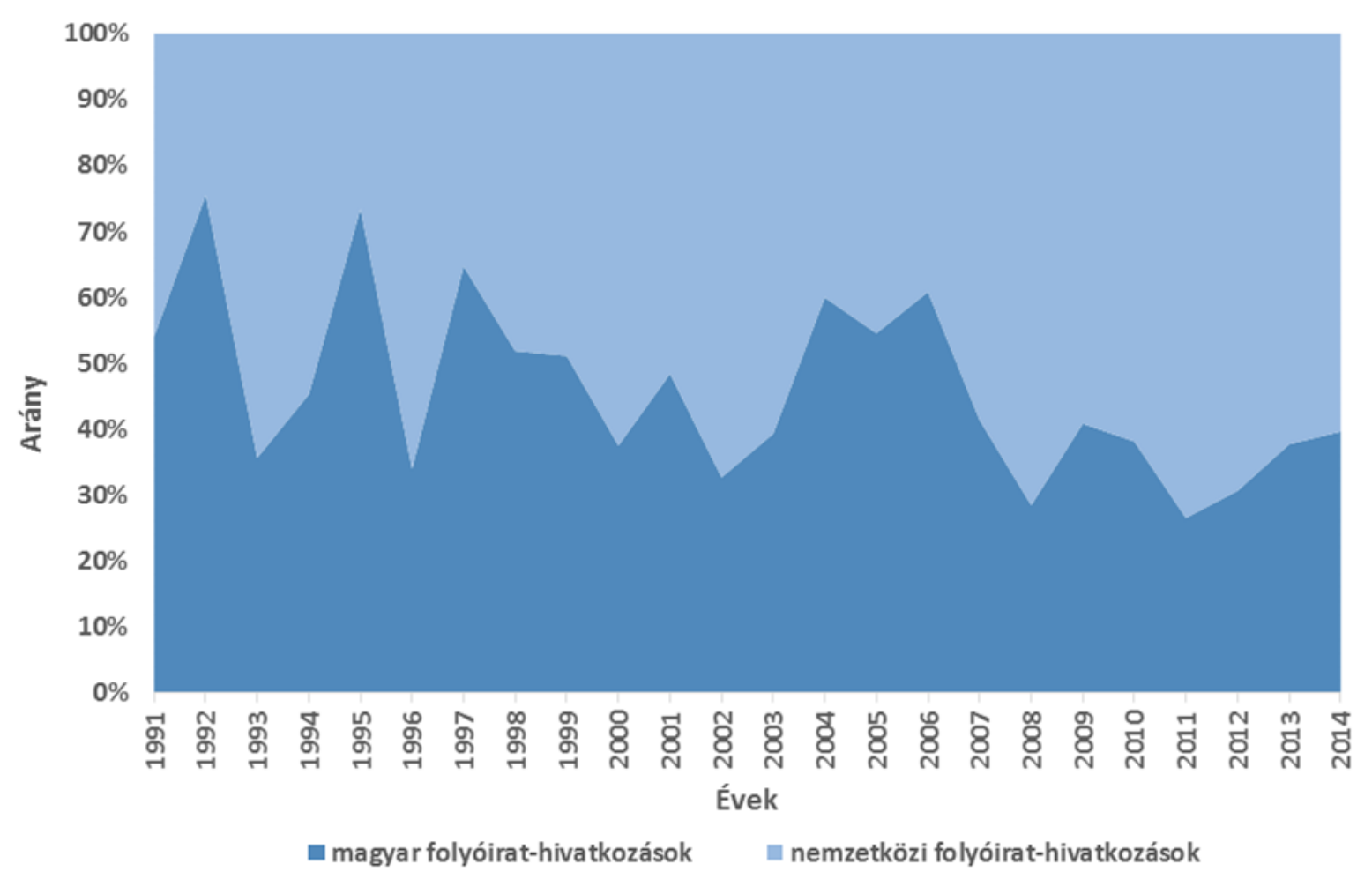

23. ábra

A magyar és nemzetközi folyóiratcikkekre történö hivatkozások időbeli változása

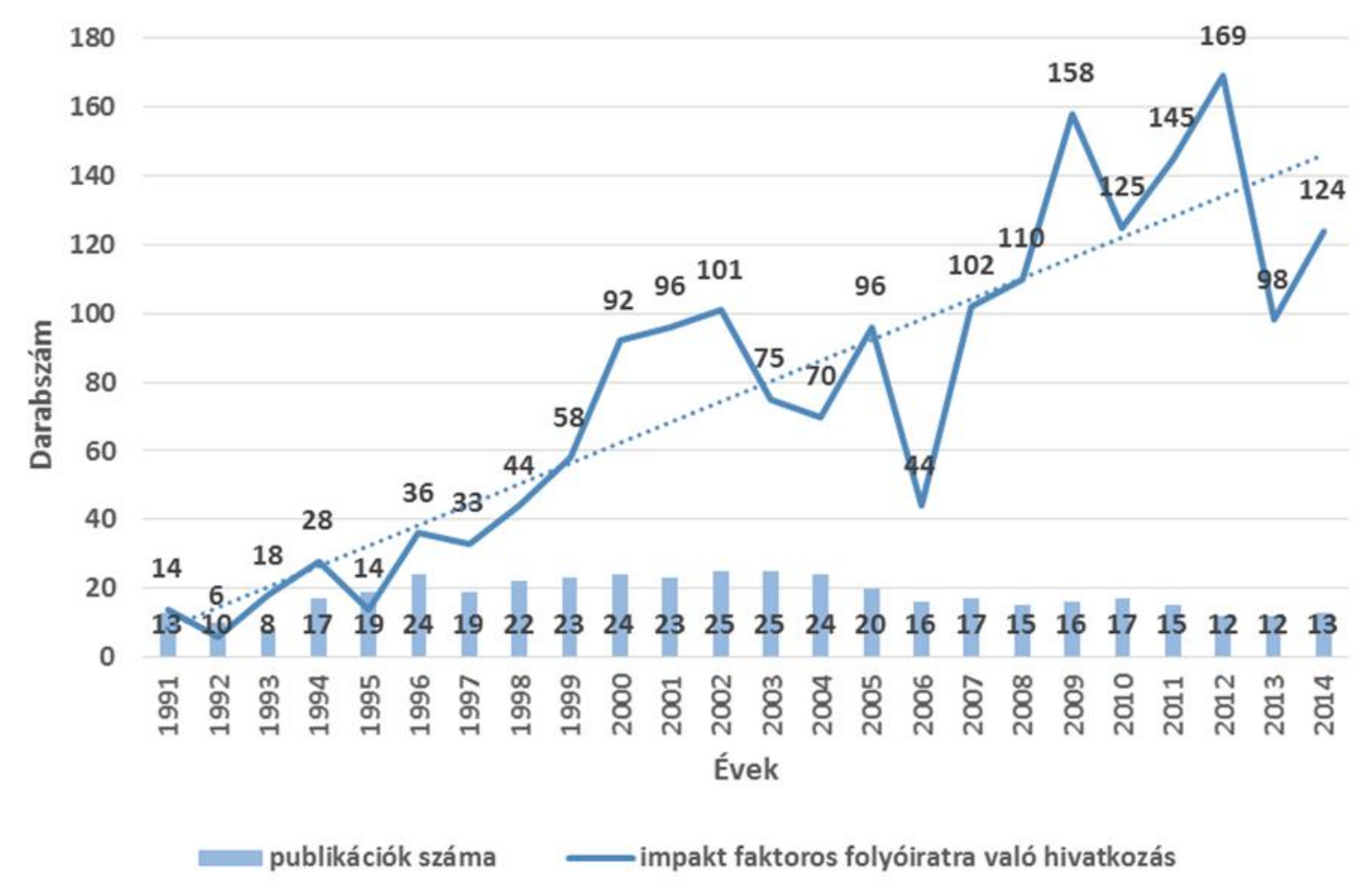

24. ábra

Impakt faktoros folyóiratokra való hivatkozások az évente megjelenö publikációszám tükrében 
A nemzetközi folyóirat-hivatkozások szerepének növekedését mutató eredmények elörevetítik feltételezésünk (H9) második részének helyességét, miszerint egyre több, impakt faktorral rendelkező folyóiratot idéznek a szerzők. A 2014-es év impakt faktor adatain (Clarivate Analytics, 2014) alapuló, 24. ábrán kirajzolódó emelkedő trend egyértelmüen megerősíti ezt az előfeltevést.

A korábbi folyóirat- és hivatkozáselemzések során kiemelt szerep jutott az interdiszciplinaritás vizsgálatának [a Németh és Biró (2009) tanulmánykötetben 21-szer fordul elő kifejezés]. A fö szempont általában annak vizsgálata volt, hogy mennyire nyitott tudományág ilyen szempontból a neveléstudomány, vagyis az egyes citációk mennyire szórnak különböző tématerületekre. Az általunk felhasznált nemzetközi és magyar folyóiratlisták tematikusan is besorolják az egyes folyóiratokat, így ezek felhasználásával kísérletet tettünk a neveléstudományi témájú folyóiratcímek azonosítására.

Két kategória jött így létre, az oktatási témájú és a nem oktatási témájú lapok csoportja, mely felosztásba mind a magyar, mind a nemzetközi kategória címei besorolódtak. Ezen megközelítés alapján a referenciák 58\%-a valamely oktatási folyóiratban megjelent közleményekre vonatkozik, míg 42\%-a valamely nem szigorúan véve oktatási tematikájú lapban megjelent tanulmányra történt (lásd 25. ábra). Ha megvizsgáljuk a konkrét folyóiratcímeket, kiderül, hogy az utóbbi kategória esetében a pszichológiai témájú lapokra történő hivatkozás a legjellemzőbb. Ugyanakkor ez nem azt jelenti, hogy csak ez a két tudományág képviselteti magát a hivatkozásokon keresztül, valójában elég széles tartalmi spektrumon szóródnak a citációk, de még így is a neveléstudomány és a pszichológia szolgáltatja a két legfontosabb referenciaterületet a Magyar Pedagógia publikációi számára. Az oktatási témájú hivatkozások magasabb aránya miatt az interdiszciplinaritás alapvetően nem kérdőjeleződik meg, ugyanakkor eredményeinket összevetve a korábbi kutatások számaival (Pap, 2009), arra a következtetésre juthatunk, hogy a Magyar Pedagógia a neveléstudományi szaksajtón belül egy zártabb szaklap, ahol az esetek nagyobb részében inkább a szoros tudományághoz közelebbinek tekinthető forrásokat használnak a szerzők a publikációk készítése során.

Ha a 25. ábra alapján alaposabban megvizsgáljuk az oktatási folyóiratokra történő hivatkozásokat és ezen a kategórián belül kivetítjük a belső hivatkozásokat, azaz azokat az idézéseket, amikor valamely Magyar Pedagógiában megjelent publikációt citáltak a szerzők, akkor látható, hogy az oktatási tematikájú lapokban közölt írások mintegy 15\%-át ( $\mathrm{N}=434)$ ezek, a folyóirat publikációs terén belül maradó, ún. „belső hivatkozások” teszik ki. Ha a

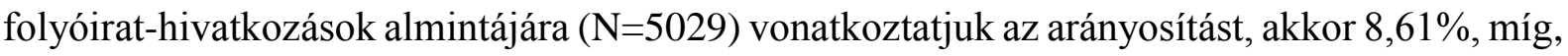


ha a hivatkozások teljes sokaságára ( $\mathrm{N}=14039)$, akkor 3,08\%-ot kapunk a Magyar Pedagógiában megjelent írásokra vonatkozóan.

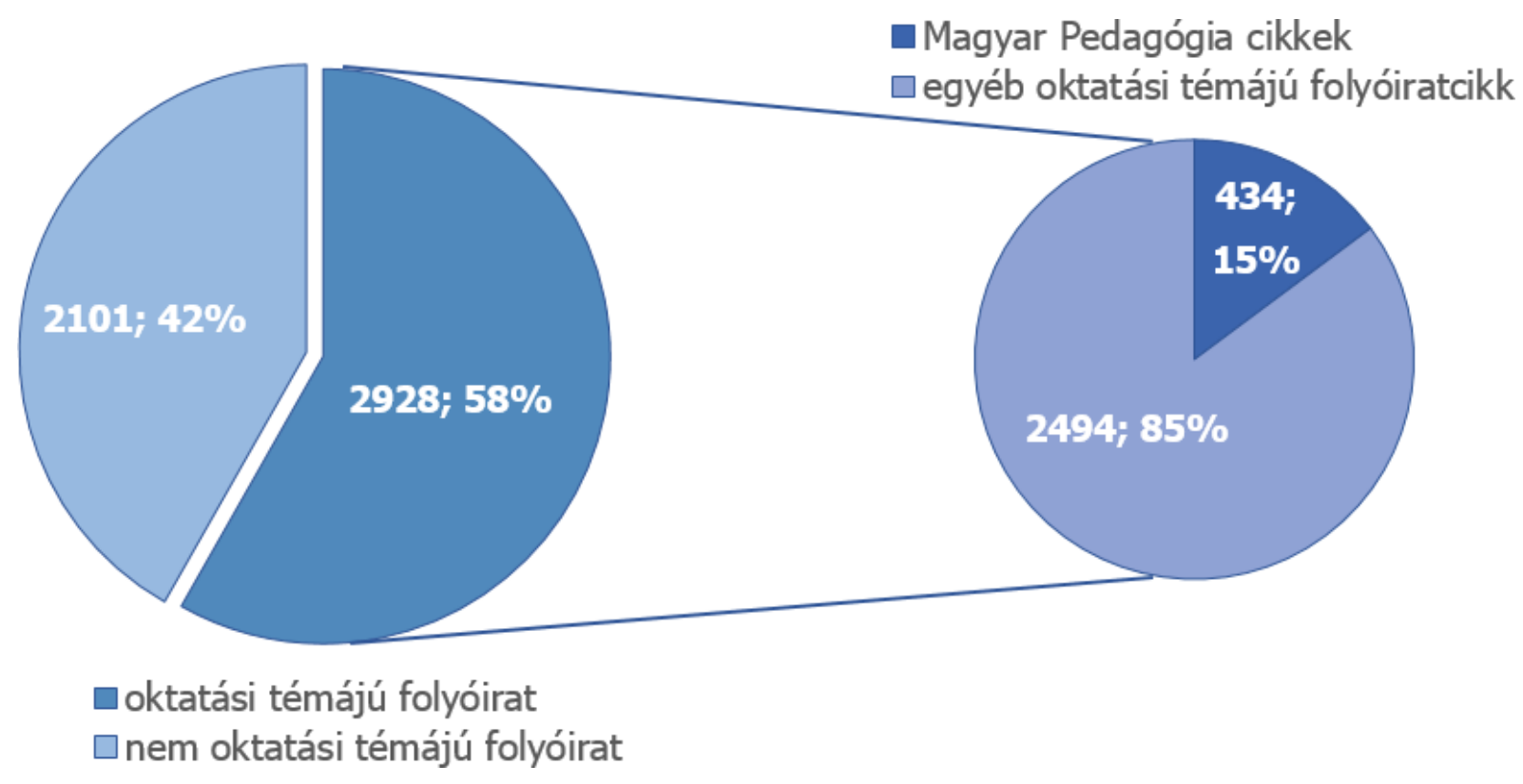

25. ábra

Az interdiszciplinaritás a hivatkozások tükrében és a Magyar Pedagógia cikkekre érkezö hivatkozások aránya

\subsection{A leghivatkozottabb források}

Az elvégzett hivatkozásvizsgálatok során kutatási kérdéseink megválaszolásához az egyik legfontosabb feladat a leghivatkozottabb szakirodalmi források azonosítása, majd a kapott eredmények összesítése volt. Az elkészült lista első harminc sorát a 6. táblázatban közöljük. A teljes lista összesen 6971 elemből áll, azaz ennyi különböző forrás között oszlik meg a 14039 darab hivatkozás. Teoretikusan, ha a két értéket arányosítjuk, mindez azt jelentené, mintha a szerzők minden forrásra nagyjából kétszer hivatkoztak volna munkájuk során. Azonban részletesebben elemezve az adatokat megállapítható, hogy a források legnagyobb csoportjára valójában csak egyszer történt hivatkozás a tanulmányokban, míg a leghivatkozottabb öt forrást pedig több mint százszor idézték.

Elözetesen azt vártuk $\left(\mathrm{H}_{6}\right)$, hogy a lista eleji helyezések a szakmán belüli konszenzus szerinti négy legelismertebb neveléstudományi folyóirat (Magyar Pedagógia, Iskolakultúra, Új Pedagógiai Szemle és Educatio) között oszlanak majd meg. Ez a feltételezés majdnem igazolódott is, annyi történt csupán, hogy az Educatio-t a negyedik helyen megelőzte egy nemzetközi orgánum, a Journal of Educational Psychology. Az eredmények alátámasztják a 
feltételezés elvi helyességét, mivel ettől az egy címtől eltekintve a lista elején valóban a felsorolásban szereplő folyóiratokra koncentrálódnak a hivatkozások.

Ha tovább vizsgáljuk a listát $\left(\mathrm{H}_{7}\right)$ fényében, akkor látható, hogy bár a folyóiratok dominánsabbak rajta, ugyanakkor sikerült azonosítani néhány nagy hatású könyvet is, amelyekröl az eredmények alapján valószínüleg kijelenthető, hogy a neveléstudomány meghatározó műveinek tekinthetőek. A lista alapján a következő kötetek tartoznak ebbe a körbe: Az iskolai tudás; Az iskolai müveltség; Az olvasási képesség fejlődése és fejlesztése; Jelentés a magyar közoktatásról; Tanulmányok a neveléstudomány köréből; XXI. század és nevelés; Neveléstudomány az ezredfordulón. A Magyar Pedagógia hivatkozásai alapján a felsorolt művek a neveléstudomány fontos referenciaműveinek tekinthetőek. Messzemenőbb következtetések levonásához és szélesebb körü általánosításhoz több neveléstudományi szakirodalmi forrás (folyóiratok és könyvek) vizsgálata volna szükséges.

A 6. táblázatban 17 magyar és 13 nemzetközi forrás szerepel, müfajukat tekintve az előbbi kategóriából 10 folyóirat és 7 könyv, míg az utóbbi kategóriából 12 a folyóiratok száma, és csak 1 cím (Handbook of Self-Regulation) képviseli a könyv müfajt. A leghivatkozottabb 30 forrás listáján szereplő címek összesen 2465 hivatkozást fednek le, ami az összes hivatkozás 17,55\%-a. A táblázatban szereplő nemzetközi folyóiratokról kivétel nélkül elmondható, hogy a Journal Citation Reports (Clarivate Analytics, 2014) tagjai, azaz impakt faktorral rendelkező folyóiratokról van szó, amely eredmény kiegészíti a 24. ábrán közölt adatokat, címeket rendelve a kategória legnépszerübb folyóiratai mellé. A harmincas toplistán összességében 515 hivatkozást fed le ez a kör.

A lista adatait az interdiszciplinaritás szemszögéböl vizsgálva elmondható, hogy a szigorúan véve oktatási témájú források jóval inkább megjelennek ezen a válogatott listán (még inkább megerősítve ezzel a korábban tapasztalt túlsúlyukat): a címek mintegy háromnegyede ebbe a tematikus kategóriába sorolható, míg a maradék egynegyed kizárólag pszichológiai témájú. A táblázatban található címek által lefedett hivatkozások darabszámának aránya még ennél is komolyabb eltolódást mutat az oktatási tematikájú szakirodalom felé, a hivatkozások 87,79\%-a ilyen témájú folyóiratra vagy könyvre irányul. 
6. táblázat. A Magyar Pedagógia 30 leghivatkozottabb szakirodalmi forrása 1991-2014 között

\begin{tabular}{|c|c|c|c|c|}
\hline$\#$ & Cim & $\begin{array}{l}\text { MP-ben detektált } \\
\text { hivatkozások száma }\end{array}$ & Nemzetköziség & Típus \\
\hline 1. & Magyar Pedagógia & 434 & magyar & folyóirat \\
\hline 2. & Iskolakultúra & 398 & magyar & folyóirat \\
\hline 3. & Új Pedagógiai Szemle & 271 & magyar & folyóirat \\
\hline 4. & Journal of Educational Psychology & 114 & nemzetközi & folyóirat \\
\hline 5. & Educatio & 106 & magyar & folyóirat \\
\hline 6. & Pedagógiai Szemle & 97 & magyar & folyóirat \\
\hline 7. & Az iskolai tudás & 94 & magyar & könyv \\
\hline 8. & Köznevelés & 72 & magyar & folyóirat \\
\hline 9. & Learning and Instruction & 56 & nemzetközi & folyóirat \\
\hline 10. & $\begin{array}{c}\text { Journal of Personality and Social } \\
\text { Psychology }\end{array}$ & 53 & nemzetközi & folyóirat \\
\hline 11. & Az iskolai műveltség & 52 & magyar & könyv \\
\hline 12. & Magyar Pszichológiai Szemle & 52 & magyar & folyóirat \\
\hline 13. & $\begin{array}{l}\text { Az olvasási képesség fejlődése és } \\
\text { fejlesztése }\end{array}$ & 49 & magyar & könyv \\
\hline 14. & Psychological Review & 46 & nemzetközi & folyóirat \\
\hline 15. & Pszichológia & 44 & magyar & folyóirat \\
\hline 16. & Child Development & 41 & nemzetközi & folyóirat \\
\hline 17. & Contemporary Educational Psychology & 41 & nemzetközi & folyóirat \\
\hline 18. & Handbook of Self-Regulation & 41 & nemzetközi & könyv \\
\hline 19. & Jelentés a magyar közoktatásról & 38 & magyar & könyv \\
\hline 20. & Review of Educational Research & 37 & nemzetközi & folyóirat \\
\hline 21. & A biológia tanítása & 36 & magyar & folyóirat \\
\hline 22. & American Psychologist & 35 & nemzetközi & folyóirat \\
\hline 23. & Educational Psychologist & 35 & nemzetközi & folyóirat \\
\hline 24. & Science Education & 33 & nemzetközi & folyóirat \\
\hline 25. & Modern Nyelvoktatás & 33 & magyar & folyóirat \\
\hline 26. & $\begin{array}{c}\text { Tanulmányok a neveléstudomány } \\
\text { köréből }\end{array}$ & 32 & magyar & könyv \\
\hline 27. & XXI. század és nevelés & 32 & magyar & könyv \\
\hline 28. & Neveléstudomány az ezredfordulón & 32 & magyar & könyv \\
\hline 29. & Modern Language Journal & 31 & nemzetközi & folyóirat \\
\hline 30. & Developmental Psychology & 30 & nemzetközi & folyóirat \\
\hline
\end{tabular}


A leghivatkozottabb források listájának eredményeit alátámasztandó, az egyes forrásokra érkező hivatkozások darabszámát pontdiagramon ábrázolva (26. ábra) a klasszikus hosszú farok eloszlást (Wu, Luesukprasert, \& Lee, 2009) kapjuk, tehát a lista elején és a grafikon bal oldalán szereplő, sürün hivatkozott források mellett kifejezetten sok olyan müvet is felhasználtak a szerzők, amelyek csak egyszer-egyszer fordulnak elő, jelentősen megnövelve ezzel az előforduló források számosságát. Az idézett címek 9\%-a a legidézettebb öt munka között oszlik meg, ezek mind 100 fölötti hivatkozásszámmal rendelkeznek. 10 és 99 közötti hivatkozást 108 cím kapott, lefedve így a hivatkozások 18\%-át, míg 9 és 2 közötti számú hivatkozást 1264 cím gyüjtött be, a hivatkozások 27\%-át reprezentálva ezzel. Végül a legnagyobb csoportot azok a címek képviselik, amelyekre csak egyetlen egyszer hivatkoztak, 6402 cím, az összes hivatkozás 46\%-a; ebben az utolsó kategóriában érhető tetten a 26. ábrán közölt grafikon hosszú farok része.

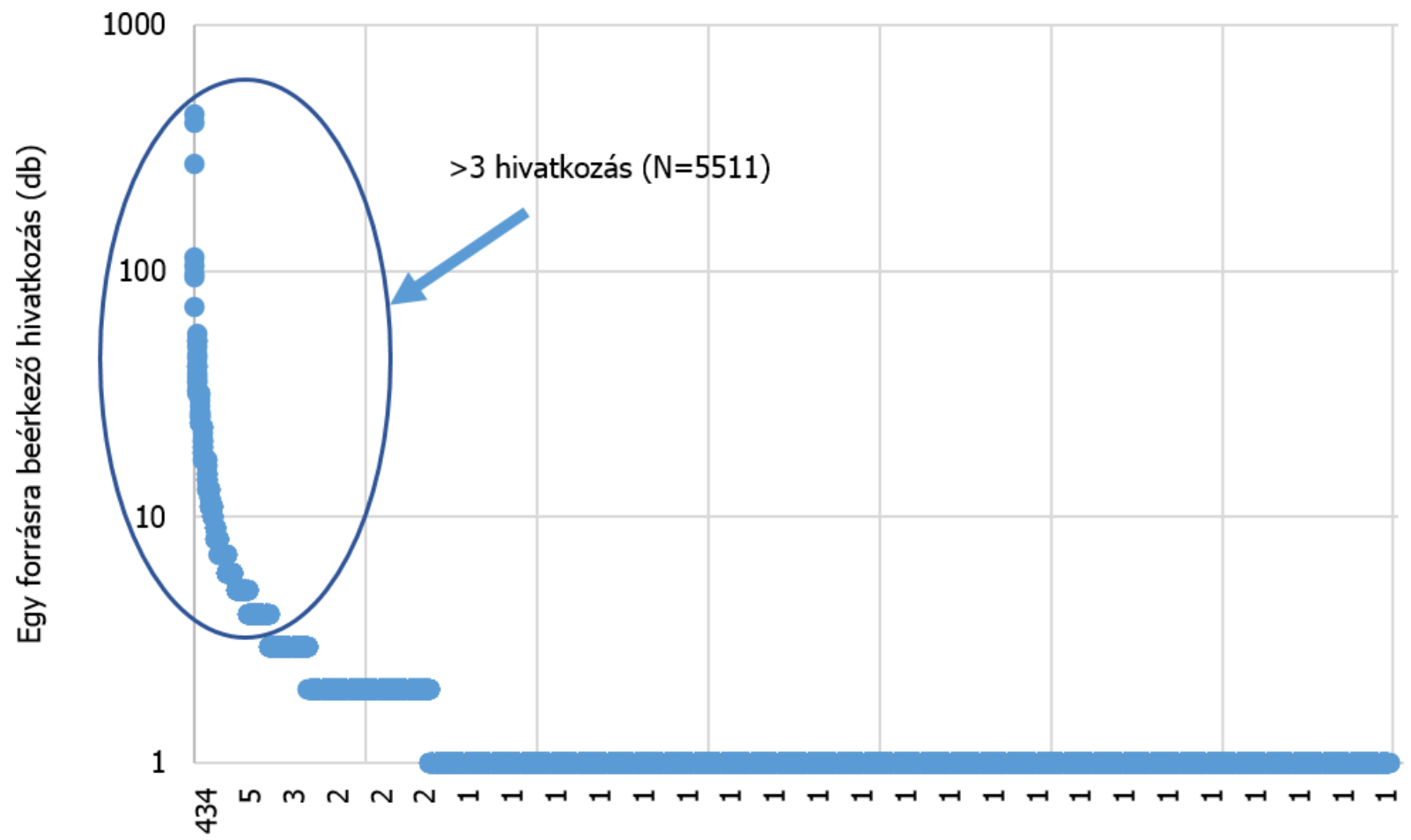

Hivatkozásszám szerint aggregált szakirodalmi források

26. ábra

A hivatkozások darabszámának $(N=14039)$ eloszlása a hivatkozott források szerint és a leghivatkozottabb források szükitett mintája

A leghivatkozottabb források listájára alapozva további elemzésekre nyílik tér, ennek keretében az összes, háromnál több hivatkozást kapott forrás müfaja manuálisan is ellenőrzésre és besorolásra került, fokozva ezzel a lépéssel az automatikus felismerés megbízhatóságát. Ezek alapján az eljárás során egy szükített mintát kaptunk (N=5511), amely a legtöbbször idézett 
forrásokra korlátozódik, így az összes hivatkozás 39,25\%-át tartalmazza, különállóan vizsgálhatóvá téve a kiemelt jelentőségű forrásokat (26. ábra ellipszissel kiemelt része).

A manuálisan is validált, szükített lista alapján látható, hogy a hivatkozások több mint kétharmada (69\%) valamilyen folyóiratcikkre történik, alátámasztva ezzel a teljes mintára érvénytelennek bizonyult $\left(\mathrm{H}_{6}\right)$ hipotézisünk állítását („A publikációkban történő idézések nagyobb aránya folyóiratcikkekre történik, és ez a megoszlás az időben előrehaladva egyre inkább növekvő tendenciát mutat a többi tudományos müfaj rovására.”). Ennek nyomán megállapítható, hogy a feltételezés csak abban a speciális esetben igaz, ha csak az idézettebb forrásokat vesszük figyelembe a vizsgálat során. Ami a többi műfajt illeti, ugyanezen a mintán a hivatkozások 30\%-a érkezett a könyv müfajra, míg 0,68\% a konferencia müfajt képviselő közleményekre és csupán a szükített minta hivatkozásainak 0,34\%-a disszertációkra (27. ábra).

Az eredményekből az derül ki, hogy ebben a szükített mintában a folyóiratok hivatkozási aránya felülreprezentálódik a teljes mintához képest. Ez logikus és érthető eredmény, hiszen a valóságban a folyóiratok száma összességében jóval kisebb, mint az összes többi müfaj dokumentumai együttvéve, emiatt tapasztalható egyfajta csomósodás a nagyobb presztízsü folyóiratokra történő hivatkozások tekintetében. Egy-egy folyóirat sok esetben akár évente több ezer tanulmányt szervezhet egyetlen gyüjtőcím alá évfolyamok hosszú során át. Ezzel szemben a könyvek számosságukat tekintve nyilvánvalóan túlszárnyalják a folyóiratokét, ugyanakkor még hosszabb, szerkesztett tanulmánykötetek esetében is maximum pár százas (az átlag természetesen ennél jóval kevesebb) lehet az általuk egy gyüjtőcím alatt lefedett tanulmányok száma.

A fenti eredményeken túl, tágabban is felmerülhet a kérdés, hogy mi a helyzet a folyóiratcikkeken és könyveken túli müfajokkal. Hol helyezkednek el egészen pontosan a hivatkozott források sorában a disszertációk és a konferenciák? Ahogyan az a 27. ábráról leolvasható, arányuk eléggé alacsony még ebben a kisebb elemszámú $(\mathrm{N}=5511)$, szükített almintában is. Az első forrás a konferencia müfajból a legidézettebb források listáján 24 darab hivatkozással az Országos Neveléstudományi Konferencia a 41. helyen, míg a Pedagógiai Értékelési Konferencia a 75. helyen szerepel 14 darab begyüjtött hivatkozással. A disszertáció müfaja az 55. ugyanezen a listán, 19 darab hivatkozással. A kapott eredmények így messzemenően igazolják feltételezésünket $\left(\mathrm{H}_{7}\right)$ ezeknek a kevésbé népszerü müfajoknak a szerepét illetően. 


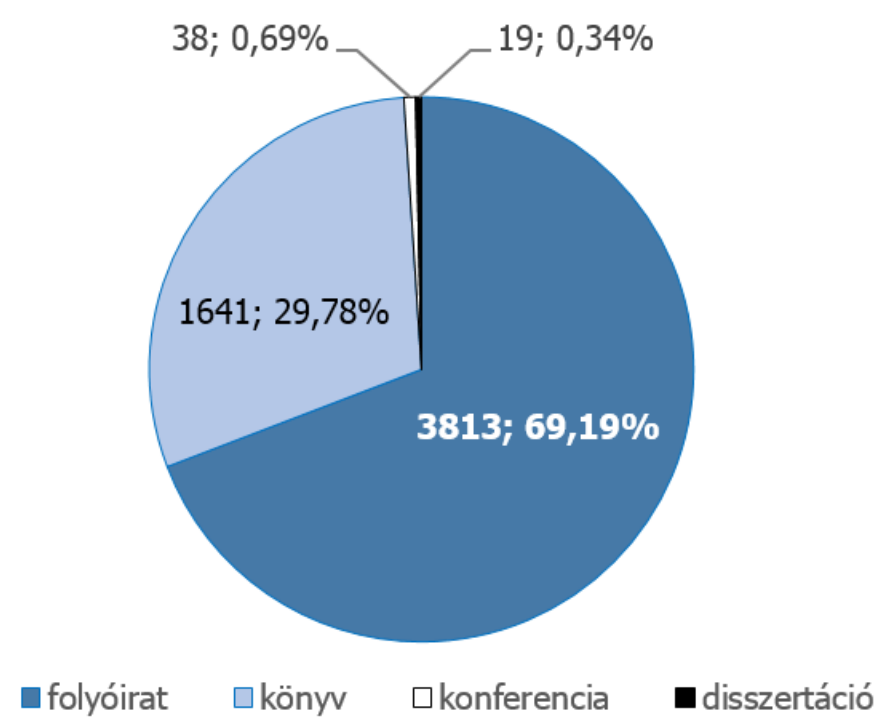

27. ábra

Hivatkozástípusok megoszlása a több mint három hivatkozással rendelkezö források esetében

\subsection{A leghivatkozottabb szerzők}

A szerzői összetétel hátterének felderítése, illetve a neveléstudomány referenciaszemélyeinek meghatározása hangsúlyosan megjelent Tóth, Toman és Cserpes (2008), Biró (2009b) és Bárd (2009) tanulmányaiban. Továbbá a disszertáció egy korábbi fejezetében részletesen tárgyalásra került a Magyar Pedagógia folyóirat legproduktívabb szerzőinek teljesítménye, ahol az egyes szerzők által begyüjtött hivatkozásszámokat is közöltük, akkor nem a hivatkozások száma volt az elemzések fókuszában. Az ott részletesen ismertetett módszertani megfontolások ugyanakkor érvényesek a most közölt eredményekre is.

A hivatkozási toplisták létrejötte mellett elkészült a hivatkozások kétdimenziós nézete is, több hivatkozási mátrix, vagy más néven hivatkozási kereszttábla formájában. A sorok itt mindig a hivatkozó szerzőket reprezentálják, míg az oszlopok a hivatkozott személyeket. A sorok és az oszlopok metszetében található mezőkben pedig az a numerikus érték szerepel, hogy X szerző hányszor hivatkozta Y személyt. A hivatkozási mátrixok tulajdonképpen a létrehozandó hivatkozási gráfok alapanyagául is szolgáltak a későbbiekben, ugyanakkor időbeli felbontásuk miatt információtartalmukban meg is haladják azt. A hivatkozási hálózatoknál alkalmazott megközelítéshez hasonlóan itt ugyanúgy elkészült egy összesített kereszttábla a vizsgált időszak egészére (1991-2014) nézve a teljes hivatkozási teret figyelembe véve, illetve egy szükített tábla, csak a belső hivatkozási tér vonatkozásában. A két, aggregált eredményeket tartalmazó fájl mellett 24-24 különálló hivatkozási mátrix is született az időszeletes bontás miatt, amelyek esetében szintén érvényesültek a teljes és belső hivatkozási tér dimenziói. 
A belső hivatkozási kereszttábla mérete 143x165, amely értékek azt jelentik, hogy 143 olyan szerző volt, akitől ki lehetett nyerni legalább egy folyóiraton belül történő hivatkozást, illetve 165 olyan szerzőt sikerült azonosítani, akinek Magyar Pedagógia-beli cikkére hivatkozott a 143 hivatkozó szerző valamelyike. Ez körülbelül 23600 ki-hivatkozik-kit párost jelent, azaz ekkora a teljes táblázat: az összes cellából 467-ben van nullától eltérő érték, vagyis nagyjából az esetek 2\%-ában. Mindez nagyjából 680 folyóiraton belüli hivatkozás esetében azt jelenti, hogy átlagosan 680/467-szor, vagyis körülbelül 1,4-szer hivatkozik egy-egy Magyar Pedagógia szerző a folyóirat egy korábbi szerzőjére; ez az átlag azonban megtévesztő, mert az önhivatkozásokat is tartalmazza. A valóságban a legtöbb párost legtöbbször csak egyszeres él köti össze.

A 7. táblázat a 44 legidézettebb kutatót tartalmazza, közülük 31 tekinthető egy személyben a Magyar Pedagógia folyóirat szerzőjének is, hiszen legalább már egy írást közölt a lapban, míg a táblázatban szürke háttérrel kiemelt 13 kutató 2014-ig nem publikált egyetlen közleményt sem a folyóiratban, így nem szerzője az elemzett lapnak a vizsgált időszakban. Kutatási kérdésünkre ( $\mathrm{K}_{8}$ - „Kik a legnagyobb hatású, leidézettebb szerzők?”), a Magyar Pedagógia hivatkozásai alapján a 7. táblázat adja meg a kimerítő választ.

Ha a táblázatban szereplő kutatókat nemzetközi kitekintésben is el szeretnénk helyezni, akkor az eredmények kontextusba helyezése miatt legalább a Magyar Pedagógia szerzőinek esetében (fehér hátterü sorok a 7. táblázatban és vízszintes tengely a kapcsolódó grafikonon) érdemes megvizsgálni a közölt adatok alapján a hazánkon belül nagy hatást elért szerzők nemzetközi reputációját. Ehhez a vizsgálathoz valamely nemzetközi citációs adatbázist hívhatjuk segítségül, a 28. ábrán elkészült összehasonlítás a Scopus adatbázis adatain alapul. Meglepő módon, a diagram alapján a Magyar Pedagógiában begyűjtött hivatkozások a legtöbb esetben nem mutatnak korrelációt a Scopus-beli hivatkozások számával, kivéve néhány, nemzetközileg is jól beágyazott szerzőt, akiknek írásait a globális publikációs térben is rendszeresen hivatkozzák. A diagramon láthatunk néhány egészen kiemelkedő eredményt is, amelyek esetében a Scopus hivatkozások száma jelentősen meghaladja a Magyar Pedagógiában begyüjtött hivatkozások számát. 
7. táblázat. A Magyar Pedagógia 44 leghivatkozottabb kutatója név szerint 1991-2014 között

\begin{tabular}{|c|c|c|c|c|c|}
\hline$\#$ & Név & $\begin{array}{c}\text { MP-ben detektált } \\
\text { hivatkozások } \\
\text { száma }\end{array}$ & $\#$ & Név & $\begin{array}{l}\text { MP-ben detektált } \\
\text { hivatkozások } \\
\text { száma }\end{array}$ \\
\hline 1. & Csapó Benő & 361 & 18. & Sternberg R. J. & 40 \\
\hline 2. & Józsa Krisztián & 208 & 19. & Imre Sándor & 38 \\
\hline 3. & Nagy József & 198 & 20. & Mészáros István & 37 \\
\hline 4. & Molnár Gyöngyvér & 136 & 20. & Pintrich P. R. & 37 \\
\hline 5. & Nikolov Marianne & 99 & 21. & Molnár Éva & 36 \\
\hline 6. & Németh András & 88 & 22. & $\begin{array}{c}\text { Fazekasné Fenyvesi } \\
\text { Margit }\end{array}$ & 35 \\
\hline 7. & Zsolnai Anikó & 78 & 22. & Nagy Péter Tibor & 35 \\
\hline 8. & Dörnyei Zoltán & 77 & 22. & Sáska Géza & 35 \\
\hline 9. & Kárpáti Andrea & 72 & 23. & Gardner R. C. & 34 \\
\hline 10. & Csíkos Csaba & 63 & 24. & Bárdos Jenő & 33 \\
\hline 11. & Pukánszky Béla & 56 & 24. & Fináczy Ernő & 33 \\
\hline 11. & Vidákovich Tibor & 56 & 24. & Kozéki Béla & 33 \\
\hline 12. & Kozma Tamás & 54 & 24. & Piaget J. & 33 \\
\hline 13. & Halász Gábor & 48 & 25. & $\begin{array}{l}\text { Csíkszentmihályi } \\
\text { Mihály }\end{array}$ & 32 \\
\hline 14. & B. Németh Mária & 46 & 25. & Feuerstein R. S. & 32 \\
\hline 14. & Báthory Zoltán & 46 & 25. & Klauer K. J. & 32 \\
\hline 14. & Réthy Endréné & 46 & 25. & Pléh Csaba & 32 \\
\hline 15. & Falus Iván & 45 & 26. & Oláh Attila & 31 \\
\hline 16. & Fülöp Márta & 44 & 27. & Elliot A. J. & 30 \\
\hline 17. & Csizér Kata & 41 & 27. & Fejes József Balázs & 30 \\
\hline 18. & Kasik László & 40 & 27. & Wigfield A. & 30 \\
\hline 18. & Korom Erzsébet & 40 & 28. & Alderson J. C. & 27 \\
\hline
\end{tabular}

Mielőtt messzemenő következtetéseket vonnánk le az értékekből, meg kell jegyeznünk, hogy a legtöbb esetben a Scopus hivatkozások hiánya így vagy úgy, de az időfaktorral magyarázható. Általában vagy olyan fiatal szerzőkről van szó, akiknek életkorukból fakadóan még alacsonyabb lehet ez a mérőszámuk, vagy olyan, régebbi időszakban publikáló szerzőkről beszélhetünk, akik akkor voltak pályájuk csúcsán, amikor a hazai tudományos életben még nem volt jellemző a nemzetközi publikálás, de ha esetleg történtek is volna ilyenek, az indexelö adatbázisok nyilvánvalóan nem foglalkoznak ilyen régi cikkekkel. Az előző bekezdésekben ismertetett, kiugróan magas és alacsony értékek mellett nagyjából a diagramon szereplő kutatók 
harmada felel meg az előzetes várakozásoknak $\left(\mathrm{H}_{8}\right)$ : ők azok, akik nagyságrendileg hasonló számú hivatkozást gyüjtöttek be a Magyar Pedagógiában közölt írásaikra, mint amennyi hivatkozással a Scopus adatbázisban rendelkeznek.

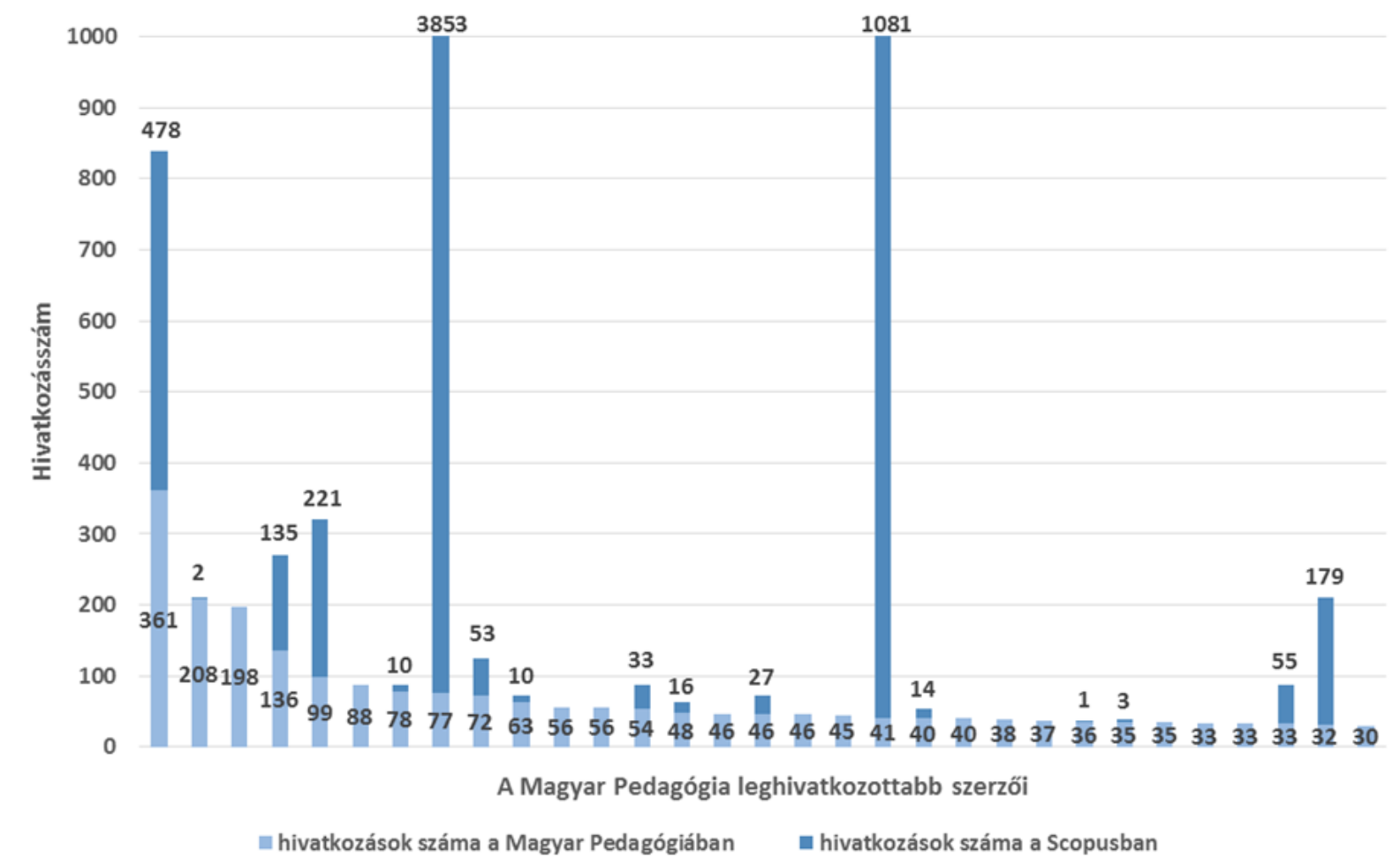

28. ábra

A leghivatkozottabb Magyar Pedagógia szerzők reprezentációja a Scopus adatbázisban

\subsection{Hivatkozási hálózatok}

Mint ahogyan a kutatási célok részben ismertettük, a hivatkozási hálózatok vizsgálata során két eltérő típusú gráf készült. Az első célkitüzésünk egy belső, a folyóirat zárt terén belül maradó hivatkozási gráf létrehozása volt. Ahogyan az sejthető, ez egy kisebb elemszámú, egyszerübb és ebből fakadóan jóval áttekinthetőbb hálózat, ezáltal bizonyos szempontból sokkal jobban vizsgálható, mint az összes hivatkozást tartalmazó, nagy kiterjedésű, teljes hivatkozási gráf. A hivatkozási hálózatok részletekbe menő tárgyalása előtt egy fontos módszertani különbségről kell még megemlékezni, amely a hálózat szerkezetét is alapvetően meghatározza. A hivatkozási hálózatokat megjelenítő ábrákon látható csomópontok az egyes önálló, hivatkozott személyeket reprezentálják, tehát ők jelentik a hálózat legkisebb vizsgált egységeit. Ezt a félreértések elkerülése végett fontos leszögezni, mert a rendelkezésünkre álló adatokból többfajta megközelítésű hivatkozási hálózatot is lehetett volna alkotni, néhányat be is mutatunk ezek közül, mintegy gondolatkísérlet jelleggel. 
Lehetnének például csomópontok az egyes önállóan hivatkozott publikációk: itt a különböző szerzői közléssel, címmel és évszámmal azonosítható tudományos munkák jelentenék a legkisebb elemzett egységet. Ez nyilvánvalóan egy jóval nagyobb és kiterjedtebb irányított hálózatot eredményezne, hiszen csak egy alapvető aggregáció történne, egy folyóirat vagy tanulmánykötet adott tanulmánya jelentené a gráf egy csúcsát, míg az irányított élek kezdő csomópontjai az egyes Magyar Pedagógia publikációk lennének, így valószínűleg egy eléggé széttagolt, sok komponensböl álló hálózat jönne létre. Ebben az esetben az egymásra hivatkozó Magyar Pedagógia tanulmányok tulajdonképpen egy belső, összefüggő hálózatot alkotnának, míg az összes többi hivatkozás ezekből a csomópontokból kimutató élekkel kapcsolódna a hálózathoz, olyan módon, hogy nekik mindig csak bejövő éleik lennének, egészen pontosan annyi, ahány Magyar Pedagógia cikkben hivatkozták őket.

Egy másik megközelítésben lehetnének a hálózat csomópontjai a korábbi fejezetben részletesen elemzett gyüjtőorgánumok (folyóiratok, könyvek, konferenciák), tehát azok az aggregáló mủvek, amelyekben az egyes önálló és hivatkozott publikációs produktumok megjelentek. Ebben az esetben olyan elnevezések szerepelnének a hálózat csomópontjai mellett, mint például az Iskolakultúra (398 bejövő éllel) vagy Az iskolai tudás ( 94 bejövő éllel). Ez a megközelítés valójában egy nagyon furcsa irányított gráfot eredményezne, hiszen minden él egy központi, Magyar Pedagógia óriáscsomópontból indulna, és az irányított élek egyes kisebb-nagyobb súlyú hivatkozott orgánumok felé mutatnának. Mivel a hivatkozások általunk csak a Magyar Pedagógiából kerültek kinyerésre, ezért az elképzelt ábra kisebb pontjaiból semmilyen visszafelé mutató kapcsolat nem lenne ezt az elképzelt univerzumot uraló, központi Magyar Pedagógia „égitest” felé. Ebben az esetben a Magyar Pedagógiából a Magyar Pedagógiára érkező hivatkozások egy, a központi csomópontból kiinduló hurokként jelennének meg az ábrán, hasonlóan a szerzőknél jelentkező önhivatkozásoknál tapasztalhatóhoz.

A bemutatott két gondolatkísérlet mellett több más megoldás is felmerülhetne a különböző hivatkozási gráfok létrehozása kapcsán, de ezek ismertetetésétől eltekintünk, helyette álljon itt a választott megoldás leírása. Az általunk ténylegesen létrehozott hivatkozási hálózatokban az egyes csomópontok az egyes szerzőket reprezentálják, míg az élek pedig a szerzők között történő hivatkozási aktusokat hivatottak szimbolizálni. A gráfok természetesen irányítottak, tehát figyelembe veszik azt, hogy ki hivatkozott kire, a csomópontok esetében így mérőszámként a ki-fok és be-fok értékek elkülönülnek (Barabási, 2016). A vizualizálás során a csomópontok méretének meghatározásánál a be-fok értéket vettük figyelembe. A gráfok tartalmazzák az önhivatkozásokat is, ez jól felismerhető az egyes csomópontokból kiinduló, 
majd ugyanarra a pontra ívelten visszamutató nyilakból (30. ábra). Az itt leírt ismérvek mind a belső, mind a teljes hivatkozási gráfra érvényesnek tekinthetőek.

A többszerzős publikációk esetében a hivatkozások természetesen minden szerzőnél elkönyvelődnek. Ha a példa kedvéért kiválasztunk egy többszerzős cikket (pl. Józsa \& Nikolov, 2005), akkor elmondható, hogy az erre a cikkre érkező hivatkozások a Józsa Krisztiánt és a Nikolov Mariannet jelölő csomópontoknál is meg fognak jelenni, mint befelé mutató élek, egyúttal hozzáadódnak ezeknek a csomópontoknak a be-fok értékeihez, ahogyan a 29. ábrán szemléltetve is van. A vizsgált időszakban ez konkrétan kettő darab valós hivatkozást jelent, de a teljes hivatkozási gráfon összesen mégis nyolc élet fog eredményezni ez a két hivatkozási aktus. Az első hivatkozás esetében a három szerző-csomópontból (akik közül az egyik az eredeti írás szerzője is) összesen hat él indul ki (az egyik önhivatkozásként), míg a második hivatkozási alkalom esetében két él fog kiindulni az eredeti írás egy-egy társszerzője felé, összesen nyolc kapcsolatot létrehozva ezzel a teljes hivatkozási hálózatban.

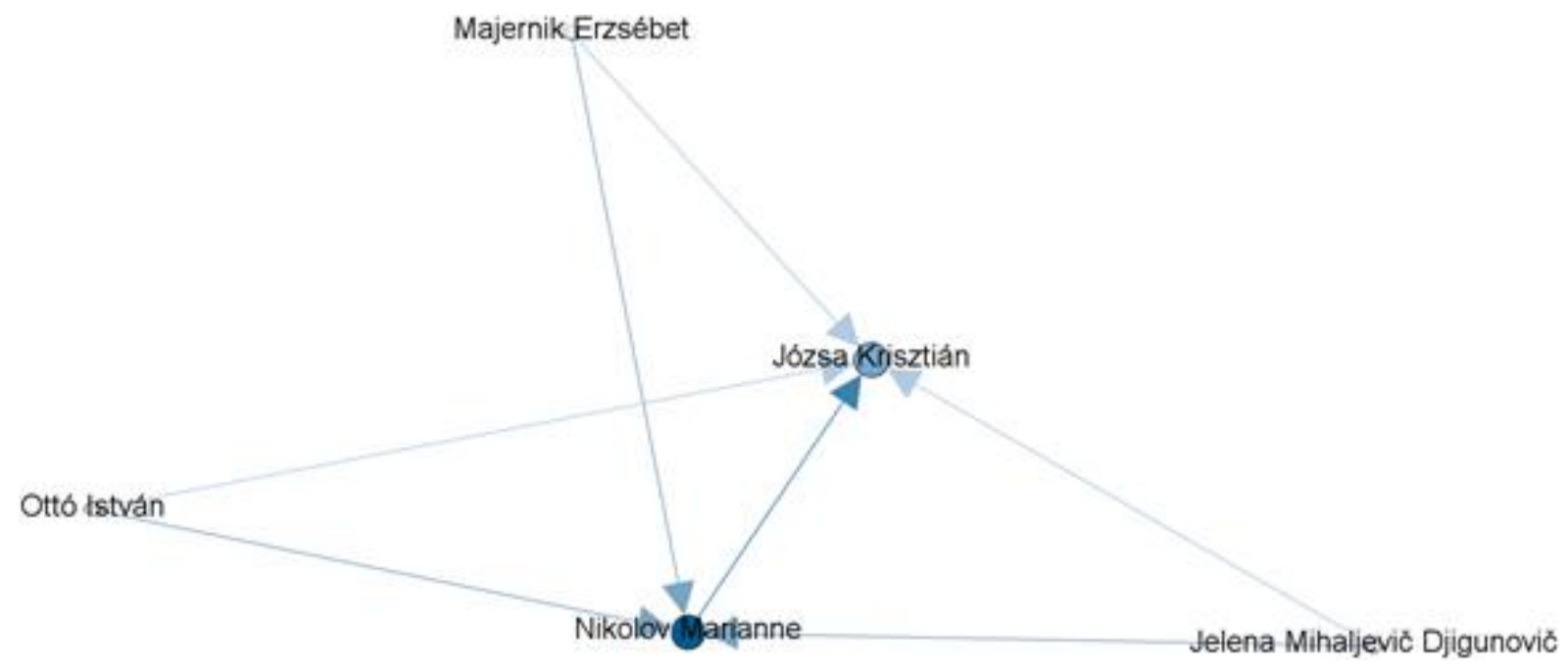

29. ábra

Egy többszerzős cikk idézéseinek elvi megjelenitése a hivatkozási gráfban

A módszertani megfontolások minél alaposabb ismertetése miatt szükséges kitérni a 7. táblázat és a hivatkozási gráfok alapjául szolgáló számszaki viszonyokra, mivel a kivonatolt 7 . táblázat (és annak teljes verziója is) csak a beérkező hivatkozások darabszámát tárolja, míg a hivatkozási gráfok alapjául szolgáló mátrixok az egyes szerzők közötti hivatkozásikapcsolatokat is tárolják. Mindez például a leghivatkozottabb szerző, Csapó Benő esetében azt jelenti, hogy összesen 96 különböző szerző hivatkozza valamely munkáját (azaz ennyi a be-fok értéke), ő maga pedig 263 szerzőt hivatkozik (azaz ennyi a ki-fok értéke), összeadva a két értéket, 359-es fokszámot kapunk a teljes hivatkozás gráf tekintetében. A véletlen müve, hogy 
ebben az esetben a kapott érték nem esik távol a 7. táblázatban szereplő 361-es hivatkozási darabszámtól, amely mutató azt takarja, hogy hány olyan hivatkozási tételt sikerült kinyerni az egyes publikációk irodalomlistájából, amelyekben Csapó Benő neve felbukkan. Ezek alapján levonható a következtetés a felvázolt értékek egymáshoz való viszonyát illetően, konkrét példánk esetében tehát 96 különböző szerző összesen 361 alkalommal hivatkozta a 7. táblázat leghivatkozottabb szerző valamely müvét.

A belső és a teljes hivatkozási gráf közötti különbségeket tárgyalva elmondható, hogy a belső hivatkozási hálózat esete speciálisabb, hiszen itt minden csomópontra igaznak kell lennie annak a szükítő feltételnek, hogy a csomópont által reprezentált személy egyúttal a Magyar Pedagógia szerzője, ettől válik tulajdonképpen ez a hivatkozási hálózat egyfajta belső hivatkozási hálózattá. A szűkítő feltétel miatt az élek mindig a folyóiratban közölt írásokban szereplő, más Magyar Pedagógia cikk szerzőjét citáló referenciákat jelenítenek meg. A folyóiraton belüli hivatkozási hálózat 222 csomópontból és a közöttük húzódó 467 kapcsolatból áll, átlagos fokszáma 4,207, átlagos súlyozott fokszáma 3,077, a hálózat átmérője 9, a gráf sürüsége 0,001, modularitása (a fogalmat Newman és Girvan 2004-es publikácója vezette be) 0,608, a komponensek száma 15, a csomópontok közötti átlagos úthossz 3,519-re tehető. A hivatkozási gráfok legalapvetőbb tulajdonságai az itt felsorolt hálózattudományi alapfogalmak segítségével ragadhatóak meg, ezek jelentésének pontos tisztázását lásd Barabási (2016) összefoglaló jellegü munkájában.

$\mathrm{Az}$ egész, kiterjedt hivatkozási gráf vizuális megjelenítésére egy oldalakra tördelt dokumentum nem igazán alkalmas, így a 30. ábrán csak egy kiragadott, jellemző részletet tudunk bemutatni, amely a gráf központi részét ábrázolja. A 7 . táblázatban közölt leghivatkozottabb szerzők listájának éléről jó néhány szerző megtalálható az ábrán. Ez az egybeesés nem véletlen, hiszen a leghivatkozottabb szerzők a hálózat leginkább beágyazott, legközpontibb szereplői, az egyes csúcsok egymáshoz való viszonya sem a véletlen műve, a gráf-vizualizáló program természetesen próbálja figyelembe venni az egyes szereplők közötti viszonyokat. Akik egyáltalán nem hivatkoznak egymásra, még áttételesen, további szerzőkön keresztül sem, távolabb kerülnek egymástól az ábrázolás során. 


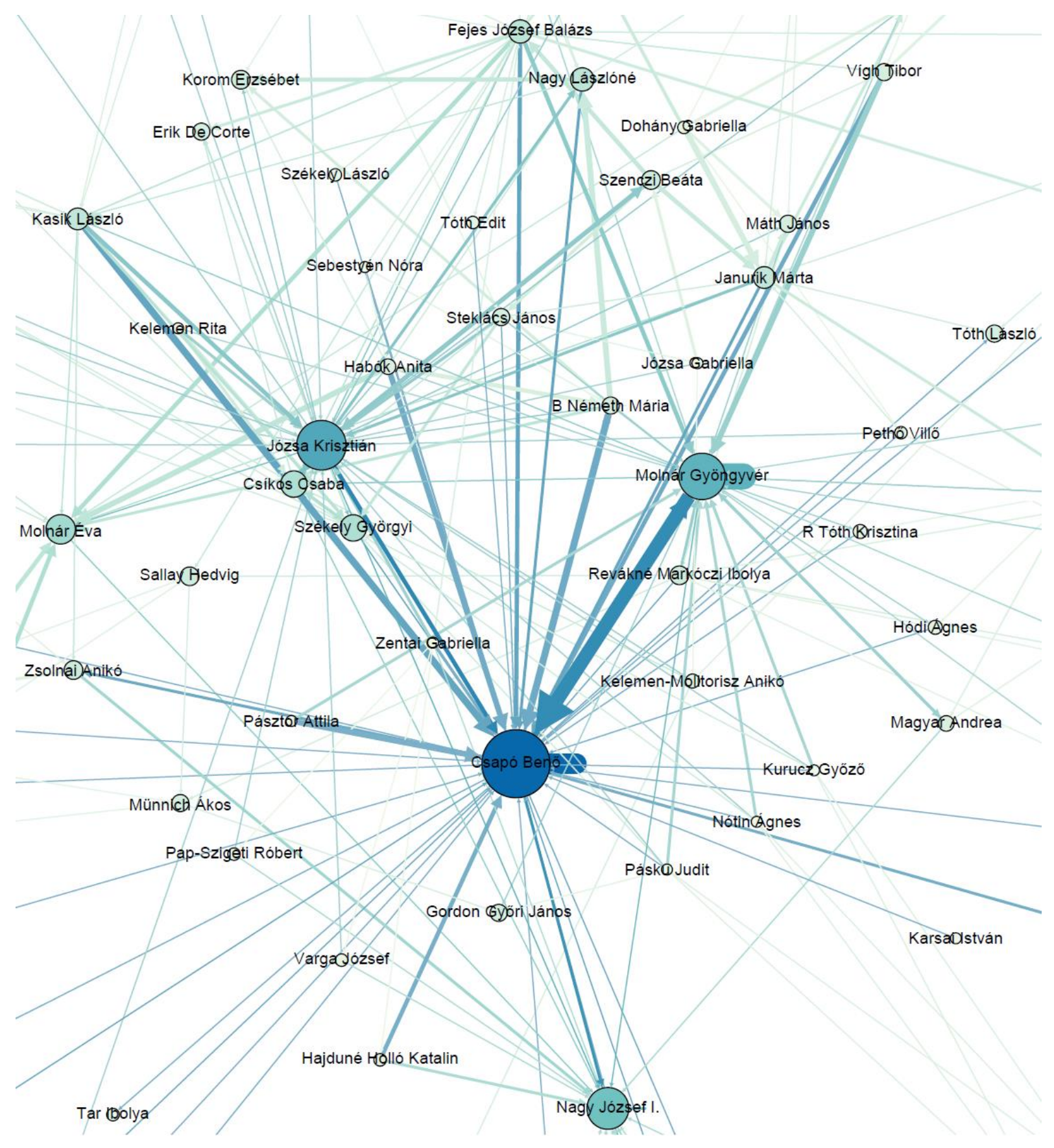

30. ábra

A belső hivatkozási hálózat egy kiragadott, centrális része

A 6.4. fejezetben a társszerzőségi hálózatok alaposabb vizsgálatának céljával azonosítottuk, majd a grafikus ábrázolás során felhasználtuk az egyes szerzők intézményi hátterét. Ennél a résznél minden ezzel kapcsolatos nehézséget és bizonytalanságot megfogalmaztunk, amelyek itt - külön ismétlés nélkül - ugyanúgy érvényesnek tekintendőek. Hasonlóan az ott közölt eredményekhez - egyben támaszkodva is azokra - a belső hivatkozási hálózatra alapozva is elvégeztük az egyes szerzők affiliációs hátterének meghatározását, ezáltal 
bizonyítva a következő hipotézist $\left(\mathrm{H}_{8}\right)$ : ,a hivatkozási gráf mintázatai esetében az intézményi háttér tekintetében jellemzőek az elkülönülő csoportok.”

A kapott eredmények a 31. ábrán láthatóak, amelyből kiderül, hogy a gráf legcentrálisabb szereplői a Szegedi Tudományegyetem szerzői. Ha megvizsgáljuk a szerzők által képviselt intézmények eloszlását, akkor a legalább $1 \%$ részaránnyal megjelenő intézmények esetében rendre a következő értékeket kapjuk: Szegedi Tudományegyetem: 22,07\%; Eötvös Loránd Tudományegyetem: 16,22\%; régebbi szerzők, nem azonosítható affiliációs háttérrel: 16,22\%; Debreceni Egyetem: 8,11\%; Pécsi Tudományegyetem: 6,31\%; külföldi szerzők: 4,95\%; korábbi Kecskeméti Főiskola: 3,6; Szent István Egyetem: 2,7\%; Oktatáskutató és Fejlesztő Intézet: 2,7\%; közoktatási intézmények: 2,7\%; Semmelweis Egyetem: 2,25\%; Magyar Tudományos Akadémia: 1,8\%; korábbi Nyíregyházi Főiskola: 1,35\%. A felsorolásból különös módon hiányzik az Eszterházy Károly Főiskola (jelenleg Eszterházy Károly Egyetem), ennek az lehet a magyarázata, hogy a vizsgált időszakban (1991-2014) az intézmény szerzői nem publikáltak a Magyar Pedagógiában, így nyilvánvaló módon a lap belső hivatkozási hálózatában sem tudnak megjelenni, mivel nincsen hozzájuk affiliált szerző a vizsgált mintában.

Az előzetes feltételezésünkben $\left(\mathrm{H}_{8}\right)$ szereplő állítás részben bizonyul igaznak, mivel a 31 . ábrán sok esetben tetten érhetőek az egymás melletti, azonos színű pontok, jelezve ezzel az adott intézmények szerzői között meghúzódó, hivatkozásokon keresztül is érvényesülő, szorosabb kapcsolatot. Ez a megállapítás a nagyobb részaránnyal képviselt intézmények esetében szinte minden esetben érvényes, a Szegedi Tudományegyetem, az Eötvös Loránd Tudományegyetem, a Debreceni Egyetem és a Pécsi Tudományegyetem szerzői a legtöbb esetben nagyobb mértékben hivatkoznak intézményi kollégáik munkásságára.

Logikus jelenségről van szó, hiszen az egy intézményben dolgozó kutatók nagyobb eséllyel ismerik egymás munkásságát, így arra is nagyobb esély nyílik, hogy felhasználják azokat saját munkavégzésük során. Ha a kibontakozó eredményeket összevetjük a társszerzőséggel kapcsolatos korábbi elemzésekkel, akkor még inkább megerősíthető ez az összkép. Mindez ugyanakkor nem jelenti azt, hogy a különböző magyarországi intézmények szerzői ne hivatkoznának más intézményben dolgozó kollégáik munkáira, hiszen akkor a hivatkozási gráf nem lenne ennyire összefüggő, és jóval több különálló komponensből állna. 


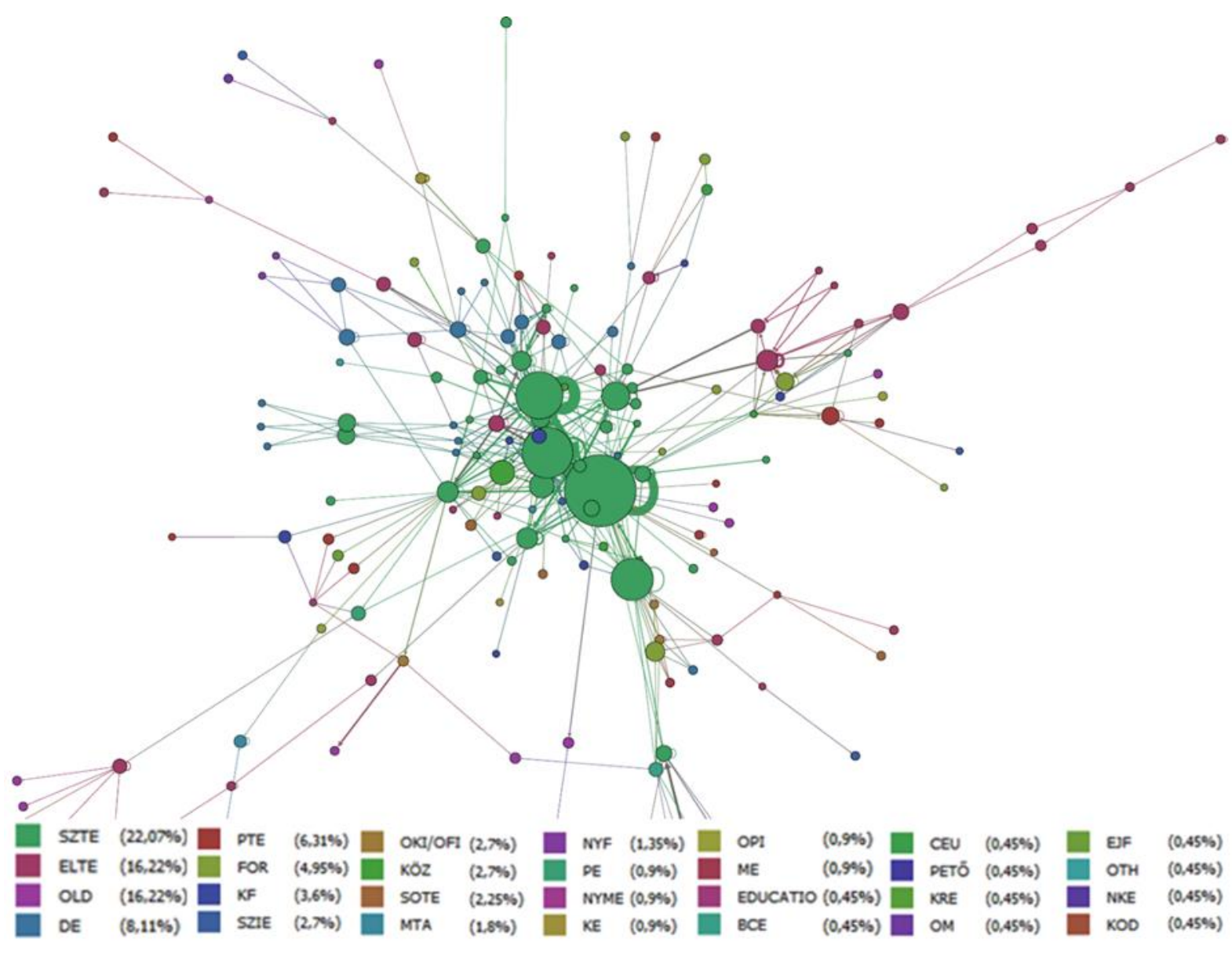

31. ábra

A belsö hivatkozási hálózat szerzőinek intézményi háttere

A teljes hivatkozási hálózat vizuális megjelenítése még nagyobb kihívást jelent a hatalmas elemszám és kiterjedt méret miatt, így ezt pusztán illusztrációs céllal szerepeltetjük a 32. ábrán. Az ábra tanulmányozása által biztosított grafikai benyomásszerzés mellett a gráf legfontosabb ismérvei sokkal inkább lehetővé teszik annak alaposabb megismerését és tanulmányozását (ezek fogalmi tisztázását lásd ismét Barabási, 2016 munkájában). Ahogyan egybevág minden előzetes feltételezéssel, a létrejött teljes hivatkozási hálózat egészen nagyméretü, mivel összesen 10382 csomópontból és a köztük húzódó 19182 kapcsolatból áll. A hálózat átmérője 9, átlagos fokszáma 3,695, míg átlagos súlyozott fokszáma 2,648. A csomópontok közötti átlagos úthossz 3,981-re tehető.

Gráfelméleti szempontból egy ritka gráfról beszélhetünk (Lee \& Streinu, 2008), mivel a gráf sürüsége (egy véges gráfban az élek lehetséges és tényleges számának aránya) három tizedesjegyig számolva 0,000-re tehető. Ha alaposabban megvizsgáljuk a számokat, akkor érthetővé válik ez az érték, hiszen kiszámolva a számtani átlagot, „csupán” 1,847 kapcsolat jut egy-egy csomópontra, ez az érték nagyságrendileg is jóval kisebb tartományban mozog, mint az élek maximálisan elérhető száma a tízezer feletti csomópontszámnál. A gráf modularitása 
0,764, a komponensek száma 6, amelyet illetően fontos kiemelni, hogy a legnagyobb, egybefüggő komponens 10245 csomóponttal rendelkezik, ebből már kikövetkeztethető, hogy a további 5 komponens már csak alacsony elemszámuk és összekapcsoltságuk hiánya miatt sem tölthet be jelentős szerepet a teljes hivatkozási gráfban.

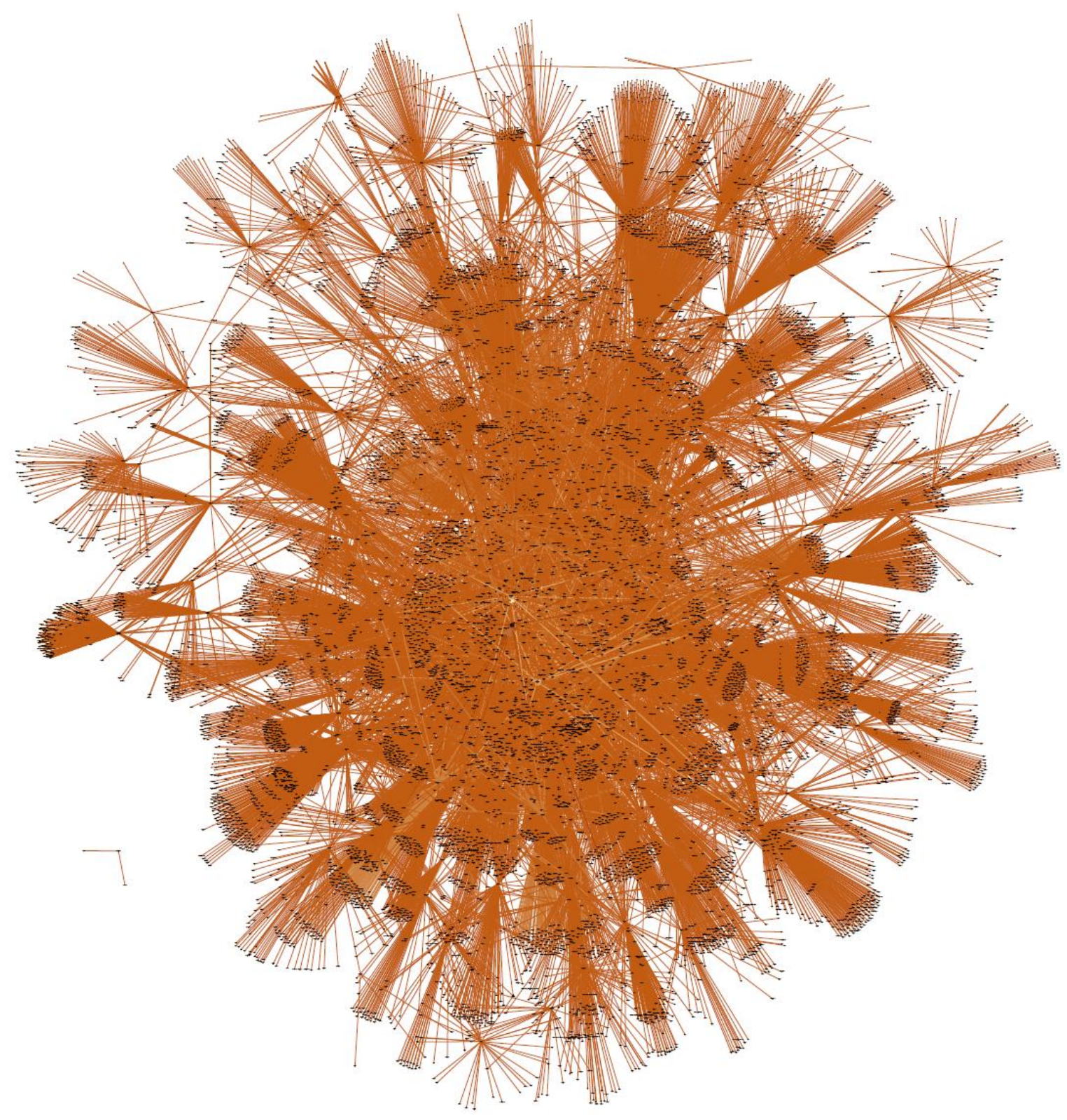

32. ábra

A teljes hivatkozási hálózat vizuális megjelenitése 


\section{TARTALMI ELEMZÉS}

\subsection{A tartalmi elemzés kiindulási alapjai és kezdeti fázisa}

A kutatási projekt harmadik, egyben legtöbb kihívást tartogató része a tartalomelemzés volt. A legföbb nehézségek egyrészt a hatalmas adatmennyiségből, másrészt a folyamatos módszertani útkeresésből fakadtak. A tartalomelemzés elméleti és módszertani hátterét a megfelelő fejezetekben kifejtettem, ugyanakkor az eredmények részletes ismertetése előtt még egyszer ki kell emelni az alkalmazott megoldás hazai keretek közötti újszerüségét. Ekkora időtartamot (1892-2014) és ekkora terjedelmet (50000 oldal) átölelő, tudományos folyóiratot érintő szövegbányászati vizsgálatról ugyanis nincs tudomásunk a hazai gyakorlatban. Ez a körülmény természetesen megnehezítette a dolgunkat, viszont fokozta a kutatás útkeresés jellegéből fakadó izgalmait, egyúttal alátámasztva azt az elképzelést, hogy ebben a speciális esetben a kutatási folyamat, illetve annak kidolgozása már önmagában is a kutatási projekt egyik kimenetének és eredményének tekinthető. Ez a típusú megközelítés így azt a megfontolást indukálja, hogy magát a kutatási procedúrát és az alkalmazott eljárásokat is egyfajta kutatási eredménynek fogjuk fel.

Mindenképpen szerettük volna a folyóirat teljes élettartamát bevonni a tartalmi vizsgálódásokba, hiszen a trendkövetés típusú elemzéseknél sok esetben éppen ebből származhatnak a kutatás legfőbb nóvumai. Az előző bekezdésben említett útkeresés több fronton is jelen volt a munka során: egyrészt meg kellett határoznunk, hogy pontosan mit és milyen módszerekkel akarunk vizsgálni; másrészt arra is megfelelő válaszokat kellett találnunk, hogy a sokszor nagymennyiségü szöveges adatként megjelenő eredményeket hogyan tudjuk majd prezentálni és befogadhatóvá tenni, akár egy-egy előadás, egy tudományos publikáció, vagy jelen esetben egy disszertáció formájában. A teljes tartalmi elemzés szakaszról elmondható, hogy általánosságban a nagyszámú ábra, illetve még inkább a sokszor ugyanannak az időszaknak, ugyanazt a vizsgálati egységét több eltérő módszer, megközelítési mód, nézőpont szerint bemutató tartalmi vizualizáció azt a közös célt hivatottak szolgálni, hogy ezeket a nézeteket közösen, egymás mellett értelmezve minél inkább visszaadják az adott időszak tartalmi keresztmetszetét. A tartalom sokszínűsége és különböző rétegei miatt ugyanis sok esetben egy-egy módszer erre önmagában nem lett volna alkalmas. 


\subsubsection{Potenciálisan felhasználható segédforrások}

A felvázolt nehézségek mellett azonban a folyóirat cikkeinek tartalmára vonatkozóan rendelkezésre állt jó néhány olyan forrás, melyekre építeni lehetett a tartalmi elemzések során. Ezek a források sok esetben kiindulásként, majd később vonatkoztatási pontként, bizonyos esetekben pedig ellenőrzési lehetőségként szolgáltak, emiatt mindenképpen érdemes számba vennünk őket, annál is inkább, mert egy részüket bizonyos pontokon szerves módon is felhasználtuk.

Az első forráscsoportot, amelyet érdemes tekintetbe venni, a különféle repertóriumok képviselik. A repertórium latin eredetü szó, a jegyzék, lajstrom, leltár, tárgymutató, tartalommutató, cím- és müjegyzék, cikkbibliográfia, forrásjegyzék, adattár szavakkal lehet leginkább körülírni. Több megközelítésben létezik, és valójában elég széles müfaji palettán mozoghatnak a repertórium névvel ellátott kiadványok, ez indokolja a sok elnevezést. A Magyar Pedagógia esetében az első repertórium jellegü kezdeményezés az 1905-ös évre vonatkozóan készült el, Hellebrant Árpád jóvoltából a magyar, míg Gyulai Ágost munkája nyomán a külföldi kiadványok vonatkozásában. Fontos kiemelni, hogy itt még nem egy metajellegü repertóriumról van szó, hiszen az nem a lap saját tartalmait hivatott jobban feltárni, hanem egy általános, a pedagógiai szakirodalom egészét felfedő indítványról. A kezdeményezésről így számoltak be a lap hasábjain: „Ide tartozik továbbá az a megállapodás, melyre a magyar paedagogiai irodalom évenkénti könyvészete ügyében egy munkatársunkkal jutottunk, ki ezentúl minden esztendőben az előbbi év teljes magyar paedagogiai repertóriumát közölni fogja folyóiratunkban. Ily módon ismét segít Társaságunk tagjainak buzgósága paedagogiai irodalmunk némely hiányain, bár az a terv, mely legelőször már 1892-ben Badics Ferenc rendes tagtársunk indítványában fölmerült, t. i. egy kimerítő teljes magyar paedagogiai repertórium, még mindig a pia desideria közé tartozik.” (Magyar Paedagógiai Társaság, 1906, p. 131)

Később a repertórium összeállítója, Hellebrant Árpád így számol be az általa elvégzett nagyívű munkáról: „A tudományos irodalom s vele együtt a hírlapirodalom hazánkban évrőlévre oly mértékben fejlödik, hogy az abban való tájékozódásra a könyvészet nem nélkülözhető. Ha valaki egy kérdéssel foglalkozni akar, első feladata: hogy tájékozást szerezzen arról, vajon van-e már tárgyának irodalma? Foglalkoztak-e már mások is az illető tárggyal? Mit írtak róla? Ezt pedig csak úgy érhetjük el, ha a müvek címeit, vagy a hírlapokban megjelent dolgozatokat rendszeresen egybegyüjtjük. Nem kevésbé szükséges ez a paedagogia széles mezején. A múlt évi statisztikai kimutatás szerint hazánkban 400-nál több hírlap és folyóirat jelent meg, melyek 
közül mintegy 50 a paedagogiának van szentelve. E gondolat lebegett a Paedagogiai Társaság elnöksége előtt, midőn a múlt évben a társaság elnökének indítványára elhatározta oly évi repertórium vagy könyvészet összeállítását, mely a paedagogiára vonatkozó irodalmat felölelje. E munka elkészítésével a társaság engem bízott meg. Készséggel teszek eleget e megbízásnak s alább nyújtom a paedagogiai irodalom 1905-iki könyvészetét.” (Hellebrant, 1906, p. 402)

Saját vizsgálódásunk szempontjából a legfontosabb információt azok a kategóriák hordozzák, amelyeket a repertórium kialakítása során megalkottak, mivel ezekből általános benyomást szerezhetünk az 1905-ös esztendő és azt követő évek főbb tématípusairól. Az anyag összeállítója közli ezeket: „Az egész anyagot a társaság elnökével való megbeszélés alapján következő 11 csoportba osztottam:

1. Elméleti paedagogia és általános didaktika.

2. Gyakorlati paedagogia.

3. Módszertan.

4. Iskolai törvényhozás, szervezet, felügyelet, tanító- és tanárképzés.

5. Nőnevelés.

6. Testi nevelés.

7. Szakoktatás.

8. Gyógypaedagogia.

9. Külföldi tanügy.

10. Neveléstörténet.

11. Vegyes" (Hellebrant, 1906, p. 403)

A folyóirat hasonló tematikus felosztás mentén ezután évenként rendre közreadta az előző év hazai pedagógiai szakirodalmának teljes termését egészen az 1920-as évek elejéig.

A következő nagyszabású kezdeményezés a szegedi kötődésű, 1933-ban megjelent „A Magyar Paedagogia negyven évfolyamának (1892-1931) tartalom- és névmutatója”, amely Tettamanti Béla egyetemi magántanár és a pedagógiai szeminárium tanársegéde, Márer Erzsébet nevéhez köthető. A jegyzéket a szemináriumban dolgozó ifjabb tagok segítségével szerkesztettek meg öt év alatt. A repertórium a Magyar Tudományos Akadémia és a Magyar Királyi Ferenc József Tudományegyetem Barátainak Egyesülete támogatásával jelenhetett meg. Gyulai Ágost (1934) recenziójában alapvetően méltatja a kötetet, ám megfogalmaz néhány hiányosságot is: a korábbiakhoz hasonlóan szintén felhívnánk a figyelmet a repertóriumban alkalmazott tartalmi besorolás kategóriáira: „A tartalommutató a Magyar Paedagogia 40 évfolyamában megjelent összesen 4725 külön, folyó sorszámmal ellátott közleménynek rendszeres, lajstromozó feldolgozását tartalmazza. A feldolgozás a 
közleményeket a neveléstörténet, neveléstan, a nevelés ágai, köznevelés, iskola, a nevelés nemzetközi vonatkozásai, különfélék és a Magyar Paedagogiai Társaság közleményei címek alatt összesen 8 fejezetbe sorolja. Minden fejezetnek alfejezetei vannak, egyik-másiknak 5-6, sőt 10 is. Mindegyik alfejezetnek 3-3 azonos osztálya van, melyekbe 1. az önálló cikkek, 2. az ismertetett müvek és értekezések és 3. a hírek és adatok vannak sorolva. Ez rendszerességet és egyöntetüséget biztosít ugyan a tartalommutatónak, minthogy azonban ekkora anyaggal szemben kevés a kategóriák száma, s minthogy csupán névmutató, vagyis a szerzők abc-rendü lajstroma csatlakozik a könyv végéhez, abc-rendü tárgymutató azonban nem.” (Gyulai, 1934, p. 177).

$\mathrm{Az}$ eddigi legteljesebb, papíralapú repertórium megjelenésére a folyóirat százéves évfordulójáig kellett várni, 1993-ban jelent meg ugyanis Csapó és Pukánszky szerkesztése mellett „A Magyar Pedagógia első száz évének repertóriuma”. A gyüjtemény összesen 6022 tételt tartalmaz az 1892-1991 közötti időszak cikkeit lefedve ezzel. A kötet legnagyobb erénye a korábbi kezdeményezésekkel szemben az átgondolt és teljes körü tárgyszavazás, mivel a szerzők a repertórium minden egyes tételéhez hozzárendeltek legalább egy, de sok esetben több különböző tárgyszót. Egy ilyen szintű feltárás kiváló tematikus reprezentációt nyújt, amelyet munkánk során valamilyen módon mindenképpen fel kívántunk használni.

A tárgyszavazás által biztosított lehetőségek nem érnek véget a százéves évfordulóra kiadott repertóriumban használt tárgyszavakkal, hiszen több intézmény által épített adatbázisban is megtalálható a Magyar Pedagógia cikkeire vonatkozó tematikus feltárás valamely szűkített vagy akár a teljes időszakra nézve. Ilyen forrást jelent például az Országos Pedagógiai Könyvtár és Múzeum (OPKM) PAD adatbázisa, amelyben az összes, körülbelül 60 ezer rekordból összesen 313 vonatkozik a Magyar Pedagógiára a 2000-2014 közötti időszakból. Az OPKM tartalmi feltárása igen széleskörü, a cikkek egy részét több mint tíz tárgyszóval látták el a PAD adatbázis adminisztrátorai. Saját kutatási programunk keretében az adatbázis-építés során a Csapó-Pukánszky-féle repertóriumban található tárgyszavak rögzítése mellett az SZTE Klebelsberg Könyvtár saját tárgyszó-rendszere szerinti mutatószavak is bekerültek az egyes cikkek analitikus rekordjaiba. Ennek fényében jelen pillanatban mind a tartalmi feltártság mélységét, mind az átívelt időtávot tekintve a Contenta Miscellanea adatbázisában található Magyar Pedagógia rekordok tekinthetőek a legteljesebb repertóriumnak, annál is inkább, mert ez a teljes szövegü adatbázis azóta is naprakészen frissül és azonos feldolgozási elvek alapján gyarapodik, a legfrissebb publikációk is folyamatosan elérhetőek ezáltal. Kutatásunk céljaira természetesen ezt a legteljesebb gyüjteményt használtuk fel. Minden metaadat, így a tárolt kulcsszavak is innen kerültek át a későbbiekben használt kiexportált fájlokba. A tartalmi 
elemzés során a fentiekben bemutatott kulcsszavak által biztosított lehetőségeket a fenti források, illetve saját új eredményeink vonatkozásában is külön szakaszban tárgyaljuk.

A repertóriumok és adatbázisok mellett a folyóirat tartalmi hátterét feltáró források között mindenképpen helye van Mészáros (1992) tanulmányának, aki egészen a kezdetektől a cikk születésének idejéig sorra veszi - ahogyan ő fogalmaz - a tartalmi alakulás kérdéseit. A felvázolt folyamatos tartalmi átalakulás mibenléte mint egyfajta viszonyítási pont rendkívül fontos volt az általunk elvégzett tartalomelemzések során, azonban terjedelmi okok miatt ebből nem közlünk további részleteket, mivel egyrészt megtettük ezt a 3.1. fejezetben, másrészt pedig a tartalomelemzés megfelelő részeinél utalunk a hivatkozott tanulmány ilyen jellegü megállapításaira.

\subsubsection{Vizualizálási kísérletek}

Már a projekt elején számoltunk azzal, hogy a hatalmas adattömeg grafikus prezentálása nem lesz egyszerű feladat, ezért a szóba jöhető vizualizálási megoldásokat minél szélesebb körüen megpróbáltuk felderíteni a szakirodalom alapján (Börner, 2010, 2015; McCandless, 2010; Yau, 2011; Börner \& Polley, 2014), választ keresve az előttünk álló kihívásokra. A számtalan konvencionális diagramtípus (oszlop-, sáv-, vonal-, kördiagram) mellett olyan további, ritkábban használt, ám a speciális információtartalom megjelenítésére alkalmasabb eszközöket vizsgáltunk, mint a hőtérkép, a címkefelhő, a dendrogram, a 100\%-ig halmozott területdiagram, a szórásdiagram (más néven pontfelhődiagram), kategóriadobozok és gráfok. Mindezek mellett további opcióként felmerült különböző dinamikus vagy mozgóképes megoldások használata is, mint a bemutatható adatmennyiséget egységnyi képernyőn növelni tudó időbeli kiterjesztés. Több kísérleti próbálkozás is elkészült ebből a müfajból, de nyilvánvalóan egy ilyen dimenzióbeli kiterjesztést nem lehet bemutatni a klasszikus disszertáció állította statikus formai keretek között.

A 2. mellékletben több példát is közlünk a nyers, XML fájlokban tárolt szövegekről, melyek tulajdonképpen a tartalmi elemzések kiindulópontját jelentették. Amíg ezekből a tisztán szöveges oldalakból a későbbiekben bemutatott színes ábrák elkészültek, számos lépésen kellett keresztülmenniük. A folyamat során alkalmazott eljárásokat a kutatási módszerek között mutattuk be. Az elvégzett tevékenységek közül az egyik legnehezebb, egyben utolsó lépés, a kapott eredmények minél áttekinthetőbb, értelmezhetőbb és esztétikus formában történő megjelenítése volt. A tartalmi elemzések vizualizálása összetett és nehéz feladatot állított elénk, ezért röviden ismertetjük a teljes eljárást és az alkalmazott módszereket, beleértve a 
kísérletezési fázist is, hiszen ennek a kezdeti szakasznak is voltak előremutató tanulságai, továbbá az esetleges hasonló megközelítésü, jövőbeli kutatások számára potenciálisan megfontolandó kimenetei. Az alább közölt ábrák (33-36. ábra) a kezdeti fázis kísérletezésének eredményei, amelyek ugyan már eredményeket tartalmaznak és közvetítenek, de itt elsősorban még nem ezért szerepelnek, hanem mint a leendő grafikus megjelenítés lehetséges megoldásai még az elökészítő, tervezési fázisból. A hosszú kísérletezés és útkeresés bizonyítékaiként állnak itt, így információtartalmukat bővebben nem magyarázzuk.

Biztos kiindulási alapként természetesen megvizsgáltuk a triviális grafikontípusok, mint a sáv- és vonaldiagram alkalmazhatóságát is. A 33. ábrán egy ilyen próbálkozás eredménye látható az „eugenika” szó vízszintes oszlopdiagramon ábrázolt példáján keresztül. Az előzetes pilot kísérletek során elég hamar felléptek az egyszerübb diagramtípusok korlátai, mivel ezek egy-egy szó vonatkozásában többé-kevésbé ugyan még elégségesnek bizonyultak, azonban amint a problématér növekedett (mivel egyszerre több szót és kifejezést szerettünk volna párhuzamosan vizsgálni azok összehasonlíthatósága miatt) nehézségekkel találtuk szembe magunkat. Nem könnyített a helyzeten a hosszú, összesen 123 évet felölelő vizsgálati időablak sem.

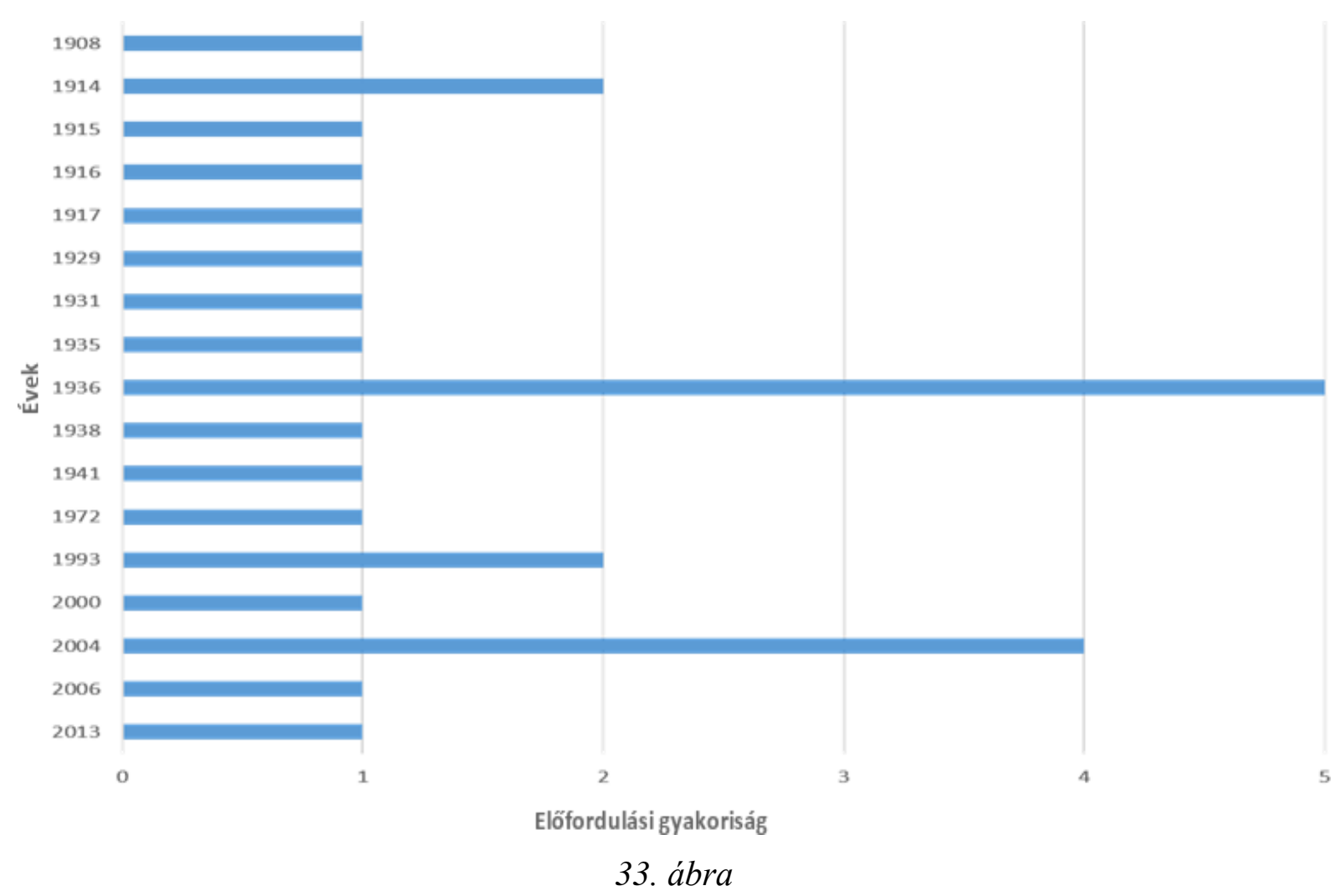

Az eugenika kifejezés évenkénti elöfordulása 1892-2014 között sávdiagramon 
A kezdeti kísérletező fázisban - az előző bekezdés fényében - áttekintve a klasszikus grafikonoknál általában használt dimenziókat és tipikusan előforduló tengelyeket, az adatsürüség fokozása érdekében a mátrix típusú elrendezés előremutató alternatívaként merült fel a vizuális megjelenítés optimalizálása érdekében. Ebből fakadóan a hőtérképes (heat map) ábrázolási mód már a kezdetektől fogva potenciális megjelenítési lehetőségként vetődött fel, hiszen ezt a típusú diagramot általában kifejezetten nagymennyiségü adat vizuális bemutatására használják, mivel az információtartalom sürüsége igen magas szintü ennél a grafikontípusnál. Ez főként abból adódik, mert a hőtérkép által lefedett terület teljes egésze kihasználásra kerül, szinte egyáltalán nem jelentkezik üres, fehér térrész, ahogyan például egy pontdiagram vagy egy vonaldiagram esetében gyakran tapasztalható, hiszen ezeknél a diagramtípusoknál sokszor a lefedett terület $90 \%$ fölötti részaránya üres, ezáltal semmilyen információt nem közvetít.

A hőtérképek és a belőlük származtatott színképes skálák kiindulási alapját a korábban előállított gyakorisági táblázatok jelentették. A hőtérkép jellegü ábrák létrehozásához a Microsoft Excel 2013-as szoftvercsomagjának „Feltételes formázás/Színskálák” funkcióját használtuk fel. A gyakorisági értékek egymáshoz való viszonyítása és a színértékek automatikus hozzárendelése mindig az adott soron belül történik az Excel megfelelő algoritmikus szabályai szerint. A 34. és 35. ábrán egy-egy ilyen típusú ábra látható a kísérletezés időszakából.

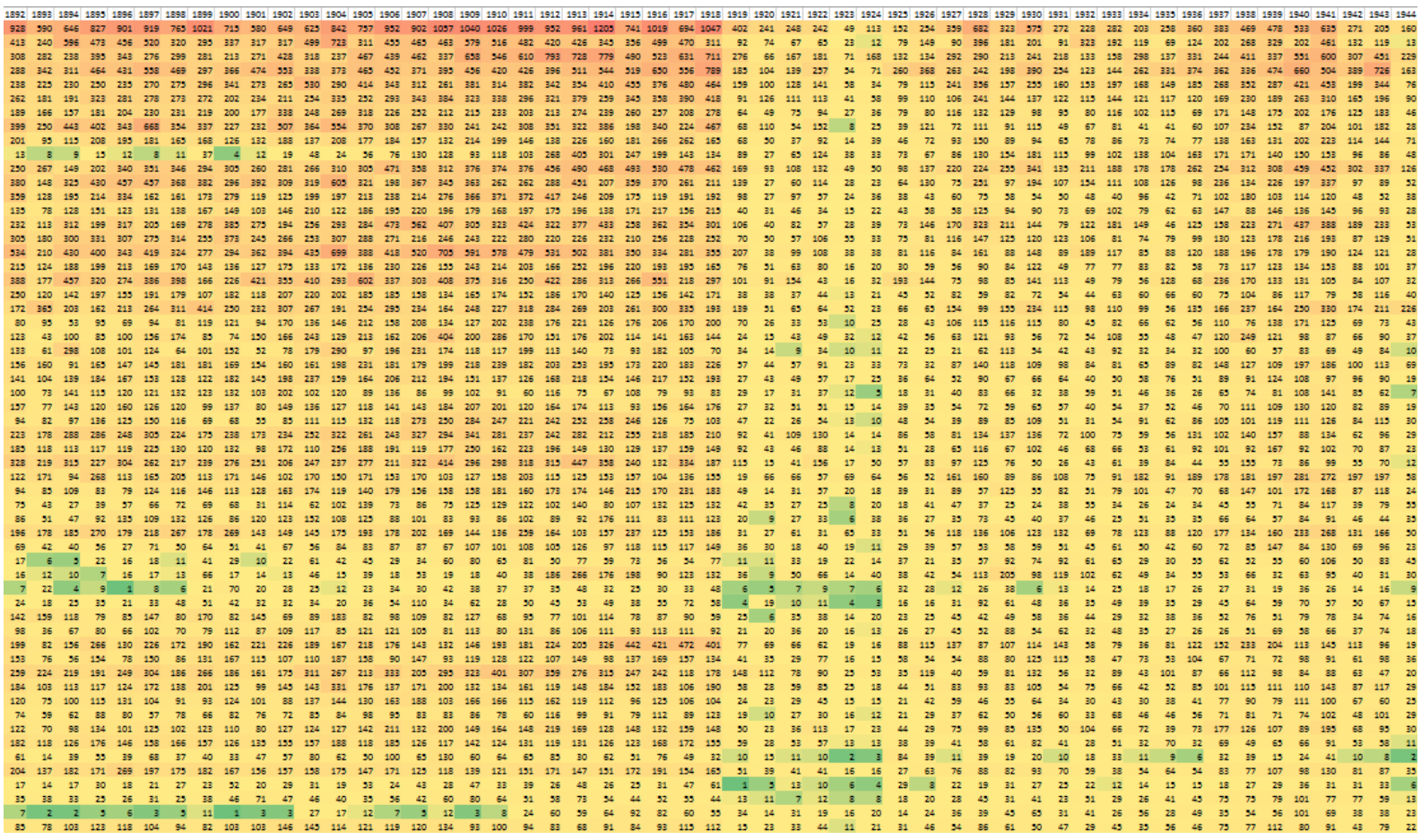

34. ábra

Az egyes szavak évenkénti elöfordulását mutató tematikus hötérképes megjelenités

\footnotetext{
* Jelmagyarázat: zöld-sárga-piros színek - alacsony-közepes-magas gyakoriság
} 


\begin{tabular}{|l|r|r|r|r|r|r|}
\hline & $196 x$ & $197 x$ & $198 x$ & $199 x$ & $200 x$ & $201 x$ \\
\hline mastery learning & 0 & 20 & 8 & 4 & 11 & 14 \\
\hline önszabályozó tanulás & 0 & 0 & 0 & 1 & 44 & 11 \\
\hline proszociális & 0 & 0 & 3 & 22 & 23 & 17 \\
\hline kognitív & 8 & 23 & 152 & 314 & 920 & 359 \\
\hline értékelés & 643 & 1092 & 871 & 631 & 910 & 441 \\
\hline
\end{tabular}

35. ábra

Egyes szakkifejezések évtizedenként aggregált elöfordulását mutató tematikus hötérkép ${ }^{*}$

Az eddig bemutatott vizualizálási kísérletek fő fókuszát a gyakoriság, a trendszerűség és az időbeli változás tettenérése, illetve láttatása jelentette. Az eredmények alternatív szempontú vizualizálása miatt szükséges volt megtalálni azt a megoldást, amely elsődlegesen a tartalmat állítja a középpontba, míg az időbeli változásra egyáltalán nem, vagy csak kevésbé koncentrál. Ennél a típusú ábrázolásnál az időbeliség csupán a statikus ábrák egymásutánisága miatt érhető tetten. A hosszabb szövegek tartalmi leképezésének egyik legelemibb vizuális módszerét a címkefelhő vagy szófelhő módszer jelenti napjainkban (Heimerl, Lohmann, Lange, \& Ertl, 2014; Cui, Wu, Liu, Wei, Zhou, \& Qu, 2010). Emiatt már a kezdeti terveink között megjelent az ezzel kapcsolatos kísérletezés, mint potenciális alternatíva. A 36. ábrán egy ilyen próbálkozás eredménye látható. Több hasonló program és online szolgáltatás megvizsgálása után a szófelhő típusú ábrák létrehozásához végül a WordArt.com szolgáltatását használtuk fel. Mivel az egyes szavakhoz kapcsolódó gyakorisági értékek CSV táblázatokban a rendelkezésünkre álltak, ezért kézenfekvő módon a program CSV import funkciójával volt érdemes dolgoznunk. A szavak ismétlését kikapcsoltuk, formának a klasszikus felhő alakot választottuk, betűtípusként az ékezetes karaktereket is helyesen kezelő Heuristica fontcsaládot, a színeket illetően ugyanabból a hat, jól elkülönülő színből áll palettát használtuk az ilyen típusú ábráknál.

\footnotetext{
* Jelmagyarázat: zöld-sárga-piros színek - alacsony-közepes-magas gyakoriság
} 


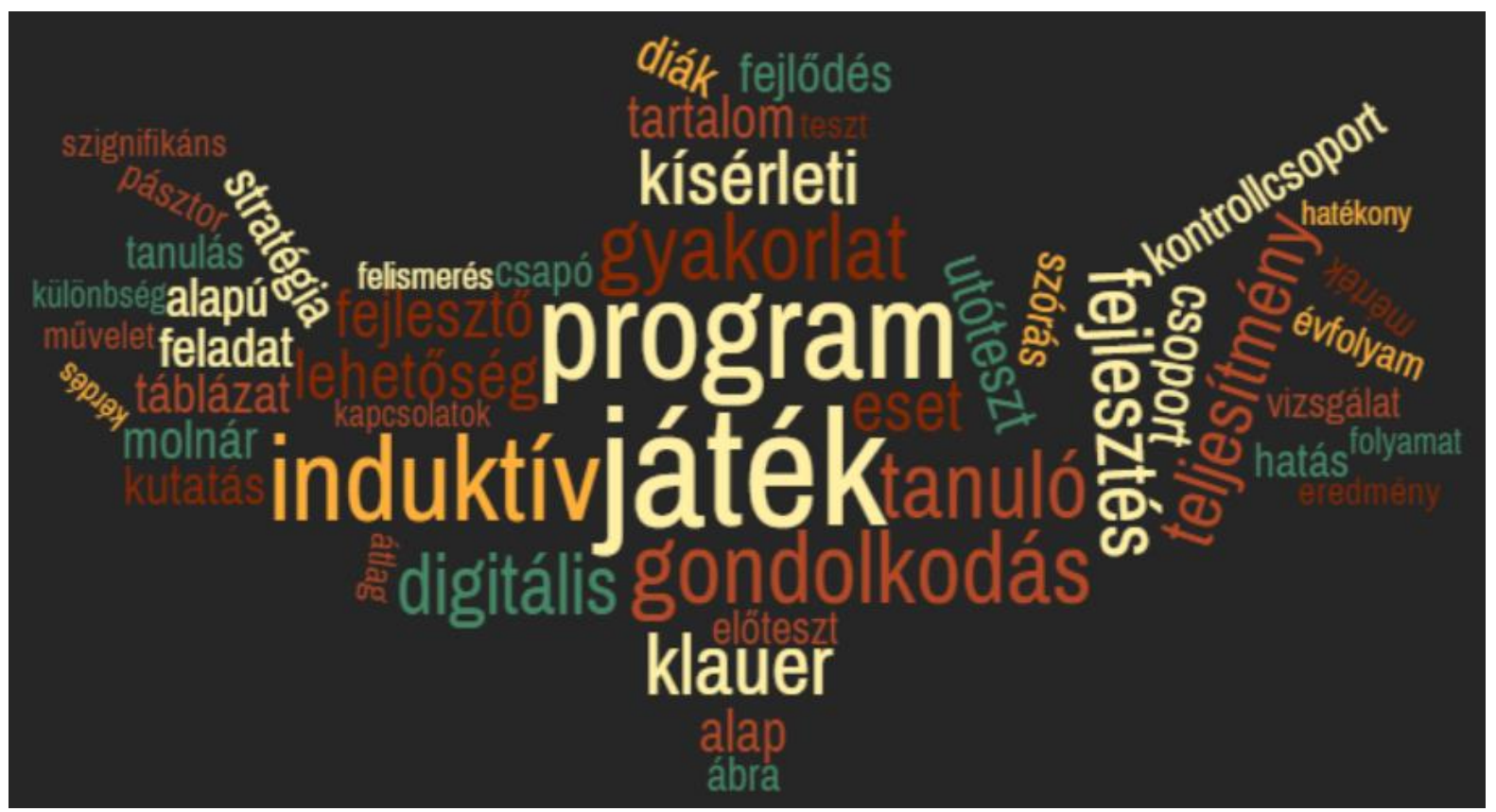

36. ábra

Egy véletlenszerüen kiválasztott cikk (Pásztor, 2014) korai szófelhős megjelenitése

A vizualizálási kísérletek során bizonyosságot nyertünk arról, hogy a szófelhős ábrázolási mód alkalmas lesz az egyes cikkek tartalmi reprezentációjára és az évtizedekre bontott tematikus válogatások könnyen értelmezhető, befogadható megjelenítésére. További vizualizálási megoldásokról a 8.7-es pontban, az egyéb próbálkozások között fog szó esni.

\subsection{Gyakoriságvizsgálatok}

\subsubsection{A gyakoriságvizsgálatok általános eredményei}

A tartalmi elemzések egyik alapvető, ugyanakkor egyik legegyszerübb vizsgálati módszerét a gyakoriságvizsgálatok jelentik. Ebben a vizsgálattípusban az egyes szavak előfordulási gyakoriságát tártuk fel, majd számszerüsítettük mindenféle egyéb súlyozás vagy normalizálás nélkül. A XX. század során elvégzett tartalmi elemzések sok esetben ezt a megközelítést alkalmazták, mivel egyszerűsége ellenére nagy biztonsággal alkalmazható alapvető jelenségek, trendek tettenérésére és megfigyelésére; sok esetben csak az igazán kifinomult kutatási igények esetén jelentkeznek korlátai. A gyakoriságvizsgálatok lehetnek abszolút megközelítésűek, amikor a korpuszban előforduló egyes szavak minden előfordulását regisztráljuk. Ilyenkor, ha valamelyik szó egy dokumentumban többször is előfordul, akkor minden egyes esetben önállóan elszámolódik annak gyakorisága. Ezzel szemben a relatív gyakorisági megközelítés szerint a szavak diszkrét előfordulásai dokumentumonkénti felbontásban, aggregálva regisztrálódnak. Ilyenkor hiába fordul elő egy adott szó egy adott 
dokumentumban akár huszonötször, csak egynek számít az összesítésben, kiszürve így az esetleges halmozott előfordulások okozta hatásokat. A statisztikai alapú gyakoriságvizsgálatok alapján rendkívül pontosan azonosítani lehet egy-egy szó vagy kifejezés előfordulásainak csomósodásait, illetve időbeli tengelyre vetítve az eredményeket, azok változásai is jól nyomon követhetővé válnak.

A kutatás keretében elvégzett tartalmi elemzések során különböző megközelítésű gyakoriságvizsgálatokat alkalmaztunk. A tartalmi elemzés előkészítő fázisában a „magyarlánc” nyelvi feldolgozó eszköztár segítségével azonosítottuk a korpusz szótövesített szavainak szófajait. A stopszavak mellett az olyan tartalmilag indifferens elemeket, mint az igék, névmások, névelők, központozási jelek, stb. eltávolítottuk a további vizsgálati mintából. Így a gyakoriságvizsgálatokba és a tágabban értelmezett tartalmi elemzésekbe csak a főnevek és a melléknevek kerültek bevonásra, mivel egy cikk témáját leginkább ezek alapján lehet meghatározni (Feldman et al., 1998). A mintában ezt a két szófaji kategóriát a későbbiekben még kiegészítettük a nem beazonosítható kategóriával, mely alapvetően a szövegben előforduló külföldi kifejezések jelzésére szolgált. A valóságban ilyenből viszonylag kevésnek kellene szerepelnie a modern szövegekben, de esetünkben a régies írásmód és bizonyos karakterfelismerési hibák miatt többször nem beazonosítható kategóriájúnak lettek besorolva potenciálisan érdekes szavak, így ezek is bekerültek a vizsgálati mintába. Mindezek után az így kapott mintát egy alapos manuális ellenőrzés után kiegészítettük további 1185 darab többszavas (szak)kifejezéssel.

Ha az itt leírt vizsgálati minta összeállítása előtt az ismertetett szűrőfeltételektől eltekintve, közvetlenül a „magyarlánc” eljárás kimenetén megvizsgáljuk az automatikus elemzés szerinti különböző szófajok eloszlását, akkor a következő eredményeket kapjuk: főnév 28,52\%, írásjelek 16,87\%, melléknév 12,84\%, névelő 9,86\%, ige 7,47\%, kötőszó 6,28\%, határozószó $6,23 \%$, névmás 4,47\%, nem beazonosítható 3,18\%, számnév 3,01\%, névutók $1,20 \%$, indulatszó $0,06 \%$. Az eredmények értelmezése miatt ezeket az eloszlásokat érdemes összevetni valamely manapság széles körben használatos magyar nyelvű referenciakorpusszal (pl. Szeged Dependencia Treebank), ahol a leggyakoribb szófajok eloszlása igen hasonló képet mutat: 30\% főnév (23+7\% köznévi és tulajdonnévi lebontásban), írásjelek 13,7\%, melléknevek 13,4\%, determinánsok (névelők és bizonyos névmások) 12,7\%, igék 8,7\%, határozószók 7,2\%. A számokból egyértelműen kiolvasható, hogy valójában nincs lényegi eltérés az eloszlásokban, annak ellenére sem, hogy saját mintánk és a referenciakorpusz eltérő müfajú szövegekből állt össze (Vincze, 2013). 
Az abszolút és a relatív gyakoriságokat tekintve elkészült a mintáról a teljes időintervallumra nézve egy-egy óriási méretű ( $\mathrm{N}=125 \times 383498)$, összesített gyakorisági táblázat évenkénti felbontással a néhány bekezdéssel ezelőtt bemutatott szükítő feltételekkel. Ebben az összes, 1892 óta legalább egyszer használt, szótövesített főnév és melléknév szerepel a hozzá tartozó gyakorisági értékekkel együtt. Az egyik táblázat az abszolút gyakorisági értékeket tartalmazza, míg a másik a cikkek szerinti relatív gyakorisági értékeket. Tehát ha egy szó tízszer szerepelt egy cikkben, az a korábbi táblázatban tízzel növeli az értékeket, míg a későbbi táblázatban csupán eggyel. A táblázatok első oszlopa a szótöveket, a második a summázott előfordulást, míg a táblázatok további oszlopai az egyes évekre vonatkozó gyakoriságokat közlik. Az utolsó huszonöt év változásainak kitüntetett nyomon követésének szándékával ugyanezen elvek alapján rendre elkészült két, időintervallumában szűkített (19912014; N=26x77513) gyakorisági táblázat is.

Bizonyos típusú gyakoriságok változásának láttatására a hőtérképes módszert használtuk. Mivel az idők folyamán a folyóirat terjedelme folyamatos változást mutatott, ezért ezt a körülményt mindenképpen szükséges figyelembe venni az eredmények értelmezése során. Emiatt minden ilyen típusú ábra első sorában, mintegy referenciacsíkként mindig közöljük a cikkek darabszámából következő eloszlás színképét, ennek alapján tulajdonképpen az egyes sávok korrelációjából vonhatóak le a változások irányát illető következtetések.

\subsubsection{Abszolút és relatív gyakorisági toplisták: 1892-2014; 1991-2014}

Az alábbiakban közölt 8-11. táblázat ezeknek a gyakorisági mátrixoknak a felhasználásával készült, tulajdonképpen azok első 25 elemre szűkített, kivonatolt változata, kiegészítve az abszolút és relatív gyakoriságok egymáshoz való viszonyának mutatójával az utolsó előtti oszlopban és az időbeli változás mutatójával az utolsó oszlopban. Az első viszonyszám egyfajta indikátornak tekinthető, mivel, ha az abszolút és relatív gyakorisági listán elért helyezések távolabb esnek egymástól, az két ellentétes jelenségre hívhatja fel a figyelmet. Az adott szót vagy egy-egy dokumentumban használták nagyon sokszor, tehát csomósodás tapasztalható egyes cikkeknél (magasabb abszolút, de alacsonyabb relatív gyakoriság), vagy éppen ellenkezőleg, egy univerzális szóról van szó, amely viszonylag a cikkek nagyobb részében előfordul, ugyanakkor nincsen kitüntetett szerepe azokban, mivel az egyes publikációkban ugyan sürün, de nem kitüntetetten magas számban jelenik meg (előkelő relatív gyakoriság, átlagos vagy alacsony abszolút gyakorisággal). 
8. táblázat. A 25 leggyakoribb szó abszolút gyakorisága a mintában 1892-2014

\begin{tabular}{|c|c|c|c|c|}
\hline \# & Szó & $\begin{array}{l}\text { Abszolút } \\
\text { gyakoriság }\end{array}$ & $\begin{array}{l}\text { Sorszám a relativ } \\
\text { gyakorisági listán }\end{array}$ & $\begin{array}{c}\text { Sorszám az 1991-2014 } \\
\text { abszolút gyakorisági } \\
\text { listán }\end{array}$ \\
\hline 1. & iskola & 61850 & 2. & 2. \\
\hline 2. & tanuló & 46199 & 15. & 1. \\
\hline 3. & nevelés & 35958 & 10. & 35. \\
\hline 4. & magyar & 34529 & 5. & 5. \\
\hline 5. & munka & 33175 & 1. & 22. \\
\hline 6. & kérdés & 27355 & 3. & 13. \\
\hline 7. & alap & 24149 & 6. & 5. \\
\hline 8. & osztály & 24102 & 42. & 47. \\
\hline 9. & feladat & 23959 & 11. & 4. \\
\hline 10. & pedagógiai & 23917 & 32. & 10. \\
\hline 11. & élet & 23470 & 7. & 90. \\
\hline 12. & tanár & 22881 & 27. & 15. \\
\hline 13. & oktatás & 21884 & 30. & 26. \\
\hline 14. & eredmény & 21828 & 8. & 3. \\
\hline 15. & gyermek & 21672 & 44. & 51. \\
\hline 16. & rész & 21005 & 4. & 20. \\
\hline 17. & tanitás & 20625 & 21. & 89. \\
\hline 18. & iskolai & 19372 & 19. & 9. \\
\hline 19. & nyelv & 19073 & 55. & 29. \\
\hline 20. & általános & 18987 & 13. & 27. \\
\hline 21. & ember & 18821 & 23. & 100. \\
\hline 22. & fejlődés & 16752 & 22. & 32. \\
\hline 23. & módszer & 16347 & 38. & 41. \\
\hline 24. & vizsgálat & 15882 & 64. & 8. \\
\hline 25. & szempont & 15609 & 9. & 48. \\
\hline
\end{tabular}

Ha a táblázatok első és utolsó elötti oszlopa közötti differencia meghaladja a 15-ös küszöbértéket, akkor az adott sor esetében e két ismérv valamelyike érvényesül, ezért ezeket a sorokat szürke háttérrel emeltük ki. Ha az első és utolsó oszlop között tapasztalható 15-nél nagyobb különbség, akkor a nem egyenletes időbeli használatra vonatkozóan vonhatóak le következtetések, ezeket a sorokat kék diagonális vonalak jelölik. Mivel bizonyos esetekben a 
két mutató kilengése egybe is eshet, ezért egy harmadik színkód is megfigyelhető a táblázatokban, a két korábbi jelölés kombinációjaként.

9. táblázat. A 25 leggyakoribb szó relatív gyakorisága a mintában 1892-2014

\begin{tabular}{|c|c|c|c|c|}
\hline$\#$ & Szó & $\begin{array}{l}\text { Relatív } \\
\text { gyakoriság }\end{array}$ & $\begin{array}{l}\text { Sorszám az abszolút } \\
\text { gyakorisági listán }\end{array}$ & $\begin{array}{l}\text { Sorszám az 1991-2014 } \\
\text { relativ gyakorisági listán }\end{array}$ \\
\hline 1. & munka & 4872 & 5. & 13. \\
\hline 2. & iskola & 4825 & 1. & 9. \\
\hline 3. & kérdés & 4594 & 6. & 5. \\
\hline 4. & rész & 4566 & 16. & 1. \\
\hline 5. & magyar & 4507 & 4. & 2. \\
\hline 6. & alap & 4424 & 7. & 4. \\
\hline 7. & élet & 4250 & 11. & 62. \\
\hline 8. & eredmény & 4006 & 14. & 6. \\
\hline 9. & szempont & 3975 & 25. & 14. \\
\hline 10. & nevelés & 3907 & 3. & 121. \\
\hline 11. & feladat & 3886 & 9. & 17. \\
\hline 12. & fontos & 3877 & 28. & 3. \\
\hline 13. & általános & 3795 & 20. & 19. \\
\hline 14. & figyelem & 3761 & 49. & 8. \\
\hline 15. & tanuló & 3746 & 2. & 30. \\
\hline 16. & szám & 3706 & 26. & 7. \\
\hline 17. & hely & 3678 & 54. & 56. \\
\hline 18. & irodalom & 3664 & 59. & 351. \\
\hline 19. & iskolai & 3573 & 18. & 24. \\
\hline 20. & hatás & 3546 & 34. & 21. \\
\hline 21. & tanitás & 3531 & 17. & 100. \\
\hline 22. & fejlödés & 3515 & 22. & 44. \\
\hline 23. & ember & 3492 & 21. & 118. \\
\hline 24. & szükséges & 3468 & 52. & 42. \\
\hline 25. & tanulmány & 3452 & 29. & 18. \\
\hline
\end{tabular}


10. táblázat. A 25 leggyakoribb szó abszolút gyakorisága a szükitett mintában 1991-2014

\begin{tabular}{|c|c|c|c|c|}
\hline$\#$ & Szó & $\begin{array}{l}\text { Abszolút } \\
\text { gyakoriság }\end{array}$ & $\begin{array}{l}\text { Sorszám a relatív } \\
\text { gyakorisági listán }\end{array}$ & $\begin{array}{c}\text { Sorszám az 1892-2014 } \\
\text { abszolút gyakorisági } \\
\text { listán }\end{array}$ \\
\hline 1. & tanuló & 9561 & 30. & 2. \\
\hline 2. & iskola & 8701 & 9. & 1. \\
\hline 3. & eredmény & 6912 & 6. & 14. \\
\hline 4. & feladat & 6498 & 17. & 9. \\
\hline 5. & alap & 5894 & 4. & 7. \\
\hline 6. & magyar & 5540 & 2. & 4. \\
\hline 7. & eset & 5344 & 15. & 27. \\
\hline 8. & vizsgálat & 5178 & 36. & 24. \\
\hline 9. & iskolai & 4946 & 24. & 18. \\
\hline 10. & pedagógiai & 4372 & 33. & 10. \\
\hline 11. & képesség & 4354 & 74. & 66. \\
\hline 12. & kutatás & 4249 & 27. & 55. \\
\hline 13. & kérdés & 4206 & 5. & 6. \\
\hline 14. & tanulás & 4140 & 78. & 53. \\
\hline 15. & tanár & 4125 & 52. & 12. \\
\hline 16. & szint & 4025 & 41. & 91. \\
\hline 17. & folyamat & 4000 & 28. & 41. \\
\hline 18. & csoport & 3941 & 61. & 62. \\
\hline 19. & táblázat & 3888 & 177. & 150. \\
\hline 20. & rész & 3864 & 1. & 16. \\
\hline 21. & fontos & 3704 & 3. & 28. \\
\hline 22. & munka & 3655 & 13. & 5. \\
\hline 23. & kapcsolat & 3654 & 23. & 38. \\
\hline 24. & diák & 3630 & 158. & 161. \\
\hline 25. & hatás & 3555 & 21. & 34. \\
\hline
\end{tabular}


11. táblázat. A 25 leggyakoribb szó relativ gyakorisága a szükített mintában 1991-2014

\begin{tabular}{|c|c|c|c|c|}
\hline$\#$ & Szó & $\begin{array}{l}\text { Relativ } \\
\text { gyakoriság }\end{array}$ & $\begin{array}{l}\text { Sorszám az abszolút } \\
\text { gyakorisági listán }\end{array}$ & $\begin{array}{l}\text { Sorszám az } 1892-2014 \\
\text { relatív gyakorisági listán }\end{array}$ \\
\hline 1. & rész & 541 & 20. & 4. \\
\hline 2. & magyar & 531 & 6. & 5. \\
\hline 3. & fontos & 529 & 21. & 12. \\
\hline 4. & alap & 526 & 5. & 6. \\
\hline 5. & kérdés & 522 & 13. & 3. \\
\hline 6. & eredmény & 510 & 3. & 8. \\
\hline 7. & szám & 498 & 37. & 16. \\
\hline 8. & figyelem & 495 & 68. & 14. \\
\hline 9. & iskola & 493 & 2. & 2. \\
\hline 10. & szerep & 491 & 28. & 52. \\
\hline 11. & pedagógia & 490 & 10. & 68. \\
\hline 12. & különbözö & 485 & 30. & 37. \\
\hline 13. & munka & 481 & 22. & 1. \\
\hline 14. & szempont & 480 & 48. & 9. \\
\hline 15. & eset & 477 & 7. & 47. \\
\hline 16. & lehetöség & 477 & 54. & 83. \\
\hline 17. & feladat & 475 & 4. & 11. \\
\hline 18. & tanulmány & 473 & 52. & 25. \\
\hline 19. & általános & 470 & 27. & 13. \\
\hline 20. & megfelelö & 470 & 55. & 36. \\
\hline 21. & hatás & 468 & 25. & 20. \\
\hline 22. & terület & 468 & 40. & 73. \\
\hline 23. & kapcsolat & 464 & 23. & 31. \\
\hline 24. & iskolai & 453 & 9. & 19. \\
\hline 25. & jelentős & 452 & 56. & 147. \\
\hline
\end{tabular}

Az általános gyakorisági számokat vizsgálva a leguniverzálisabb nyertesnek az „iskola” szó tekinthető, mivel mind a négy táblázatban igen előkelő helyen $(1 ; 2 ; 2 ; 9)$ szerepel. Az eredmény meglepőnek nem nevezhető, bár, ha előzetesen kellett volna megjósolni a Magyar Pedagógiában várhatóan sűrün előforduló, hangsúlyos szavakat, nem valószínü, hogy ez a szó szerepelt volna az első helyen - de feltételezhető, hogy az élmezőnyben lett volna ezen az elképzelt listán is. A 37. ábra alapján megállapítható, hogy a kezdeti időszakban a szó relatív 
gyakorisága az abszolút gyakorisághoz viszonyítva magasabb, míg az utóbbi évtizedekben az arány megfordulni látszik.

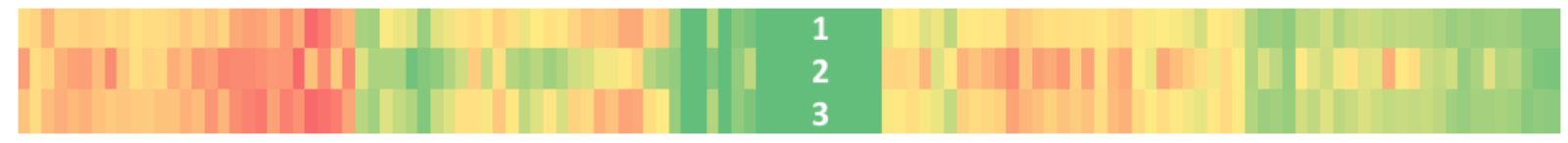

37. ábra

Az , iskola” szó abszolút és relativ gyakoriságának színképe a cikkek számának eloszlásához képest (1892-2014) [1 - cikkek száma; 2 - abszolút gyak.; 3 - relatív gyak.]

Kiemelendő a 8. táblázatban második helyezettként, a 10. táblázatban első helyen szereplö „tanuló” szó helyzete, mivel mindkét vizsgált időszakot tekintve megfigyelhető, hogy az abszolút és relatív gyakorisági listákon elért helyezések között nagy a szórás ennél a szónál. Tehát különösen érvényes rá a megállapítás, hogy az egyes szerzők bizonyos cikkekben nagyon sokszor használják, ugyanakkor létezik jó néhány olyan cikk, amelyek egyáltalán nem tartalmazzák ezt a szót. Színképét tekintve a 38. ábra jellemzi, hasonlóan az „iskola” szóhoz; ez is a kezdeti időszakban fordult elő több tanulmányban, míg a későbbi időszakban egyre kevesebb cikkben, de azokban viszonylag sokszor szerepelt. Ez magyarázza, hogy a teljes relatív gyakorisági listán a 15 . helyet érte el, míg az időben szükített relatív gyakorisági listán csak a 30. helyen foglal helyet, mutatva ezzel a használati tendencia irányát.

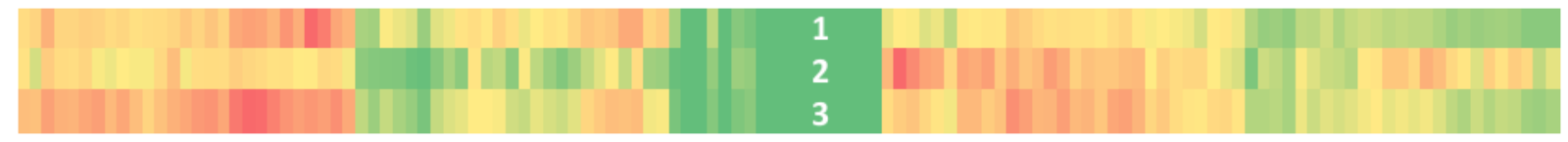

38. ábra

A „,tanuló” szó abszolút és relatív gyakoriságának szinképe a cikkek számának eloszlásához képest (1892-2014) [1 - cikkek száma; 2 - abszolút gyak.; 3 - relatív gyak.]

A 8. táblázat harmadik szavát (,nevelés”) ismét érdemes megvizsgálnunk annak fényében, hogy a teljes időszakra tekintve egészen előkelő helyeken szerepel, ugyanakkor a frissebb cikkeket tartalmazó, rendszerváltás utáni szükített korpuszból generált gyakorisági listákon használata jelentősen visszaesik (ahogyan az az 39. ábráról leolvasható), csak a 35. és 121. helyeken találjuk meg az abszolút és relatív gyakorisági listákon. Felmerül a kérdés, hogy melyek azok a további szavak, amelyek esetében hasonló trendeket tapasztalhatunk, és tetten érhetjük az egyes szavak használatának időbeli változásait. Ha megvizsgáljuk egy jelentésében tulajdonképpen azonosnak tekinthető szó két alakjának mintázatait a „gyermek” és a „gyerek” szavak segítségével, akkor újabb kiváló példát kapunk a szóhasználati változásokat illetően (40. ábra).

\footnotetext{
* Jelmagyarázat: zöld-sárga-piros színek - alacsony-közepes-magas gyakoriság
} 


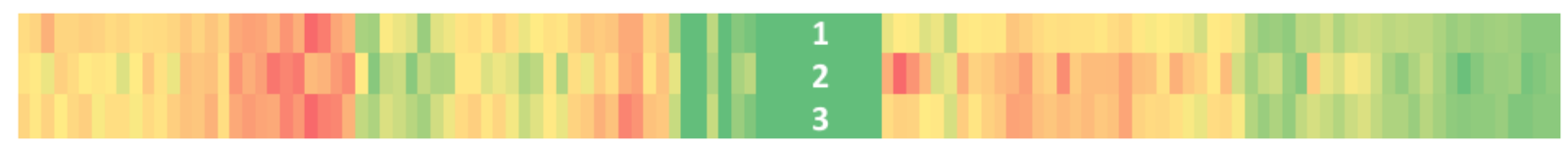

39. ábra

A „,nevelés” szó abszolút és relativ gyakoriságának színképe a cikkek számának eloszlásához képest (1892-2014) [1 - cikkek száma; 2 - abszolút gyak.; 3 - relatív gyak.]"

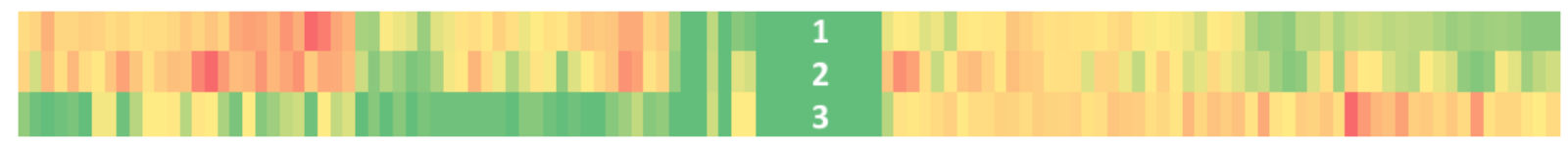

40. ábra

A „gyermek” és a „gyerek” szó abszolút és relativ gyakoriságának szinképe a cikkek számának eloszlásához képest (1892-2014) [1 - cikkek száma; 2 -abszolút gyak.; 3 - relatív gyak. $]^{*}$

\subsubsection{A gyakorisági táblázatok alapján kibontakozó trendek hötérképes vizsgálata}

A 39. és 40. ábrákról leolvasható jelenség egy szélesebb körű trendre hívja fel a figyelmünket: az egyes szavak időben változó népszerüségére és a tudományos publikálásban betöltött aktuális szerepére. Mivel a jelenség a maga összetettségében csak szélesebb körü összevetések készítésével vizsgálható, ezért bemutatására ismét a táblázatos formát választottuk. Az egyes szavak időbeli használatának megváltozását a korábban bemutatott abszolút és relatív gyakorisági mátrixokra támaszkodva a 12-16. táblázatok tartalmazzák. Az egyes szavak a változás irányát tekintve négy kategóriába sorolhatóak: felszálló trend, lecsengő trend, egyenletes használat és speciális esetek.

A táblázat első három sorának hátterét illetően ugyanaz a magyarázat: a „paedagógia” szóalak időközben megváltozó írásmódja. Ha ezt a szót ábrázolnánk hasonló hőtérkép-csíkon, akkor éppen ellentétes eredményeket kapnánk, mint a táblázat első három sora (kivéve az 1992ben tapasztalható kiugró értéket, melynek Mészáros (1992) történeti jellegü tanulmánya az oka). A következő nyolc szó (,probléma” - „,személyiség”) felívelését főként egy újfajta neveléstudományi megközelítésmód megjelenése, majd széleskörű elterjedése magyarázhatja, míg az ezt követő öt szó (,jelentős” - „oktatási”) esetében valószínüleg nyelvhasználati változásokról van szó. Az utolsó, „képzés” szó esetében láthatjuk, hogy ugyan valamelyest kilóg a többi szó közül, de a felívelő trend azért itt is megfigyelhető.

\footnotetext{
* Jelmagyarázat: zöld-sárga-piros színek - alacsony-közepes-magas gyakoriság
} 
12. táblázat. A vizsgált időszak (1892-2014) elején kevésbé használt, majd felfutó szavak elöfordulása az abszolút gyakoriságok alapján*

\begin{tabular}{l}
\hline Cikkszám \\
\hline pedagógia
\end{tabular}

Néhány kiválasztott szó esetében, a 13. táblázatban párhuzamosan közöljük a relatív gyakorisági adatokat is, mivel azok valamelyest eltérnek a 12. táblázat abszolút gyakoriságaitól. Általánosságban az tapasztalható, hogy a felívelő trendek az abszolút gyakoriságok esetében hangsúlyosabban megjelennek (vö. például a „probléma”, „folyamat”, „terület” csíkok jobb oldali szegmensét), mint a relatív gyakoriságoknál. Ez azt jelenti, hogy ezen szavak számottevő jelenléte valószínüleg kisebb számú szerzőhöz köthető, amennyiben ők aktívan és viszonylag nagyobb számban használják öket. Elöfordul néhány, egyébként viszonylag nagyobb gyakoriságú szó a táblázatban, amelyeknél megfigyelhető, hogy a kezdetekben évekig, sőt akár hosszú évtizedekig nem igazán voltak használatban, ilyen szavak például a „téma”, „szint”, „,teljesítmény”, „szakmai”, „értékelés”. Ezen túl, a táblázat utolsó négy sorát kell még kiemelni, hiszen a „kutatás” - „értékelés” szavak újabb kori hangsúlyosabb megjelenése szintén a modern neveléstudomány új megközelítési irányait jelzik, amely esetükben rendkívül jól tetten érhető az itt bemutatott eredményekből.

\footnotetext{
* Jelmagyarázat: zöld-sárga-piros színek - alacsony-közepes-magas gyakoriság
} 
13. táblázat. A vizsgált időszak (1892-2014) elején kevésbé használt, majd felfutó szavak elöfordulása a relatív gyakoriságok alapján*

\begin{tabular}{|c|c|}
\hline Cikkszám & मा म \\
\hline probléma & 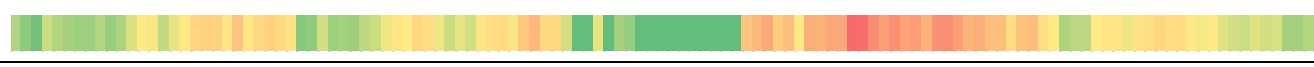 \\
\hline folyamat & 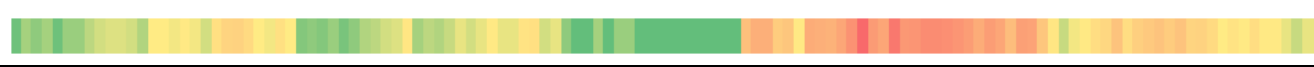 \\
\hline téma & +1 \\
\hline program & 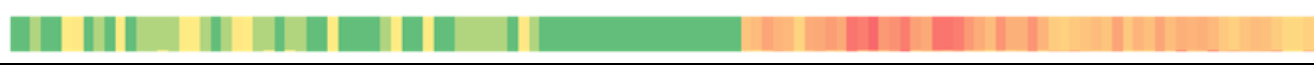 \\
\hline terület & 11 \\
\hline szint & 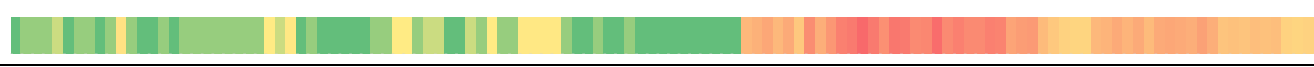 \\
\hline jelentős & 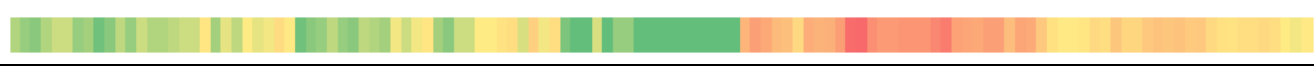 \\
\hline gyerek & 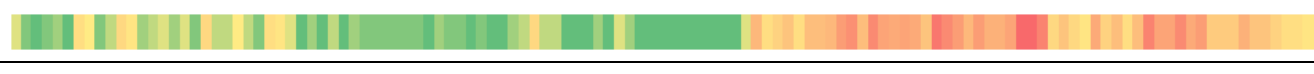 \\
\hline oktatási & 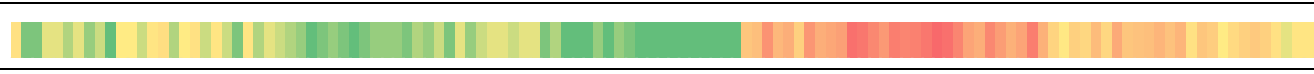 \\
\hline szakmai & L \\
\hline tevékenység & 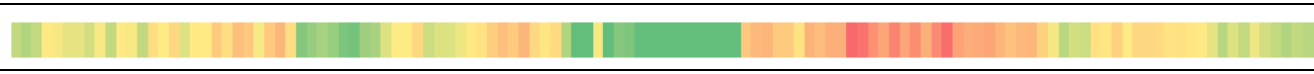 \\
\hline teljesítmény & 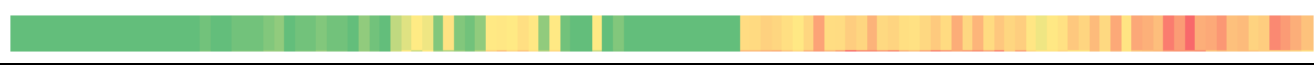 \\
\hline személyiség & 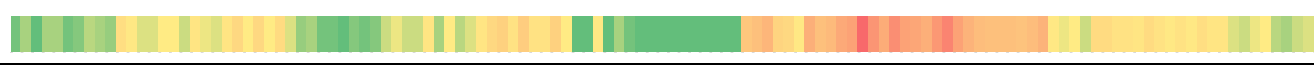 \\
\hline diák & 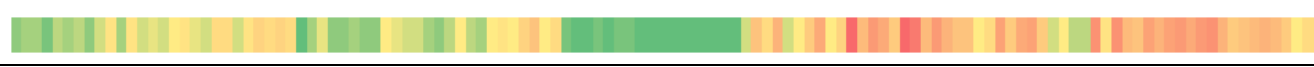 \\
\hline kutatás & 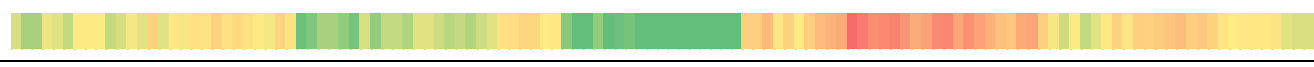 \\
\hline elemzés & 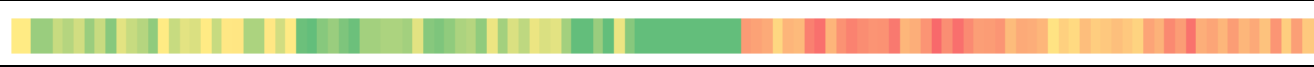 \\
\hline táblázat & 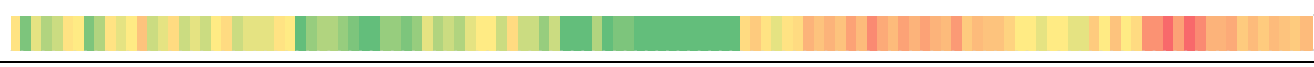 \\
\hline értékelés & 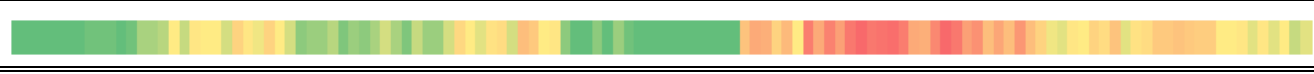 \\
\hline
\end{tabular}

A következő két táblázatban (14-15. táblázat) az eddig tárgyaltakhoz képest ellenkező irányú trendek bontakoznak ki, azaz a korábban divatosnak tekinthető, aktívan használt szavak veszítenek népszerüségükből, használatuk mintegy lecseng, de legalábbis kimutatható mértékben visszaesik. A korábbihoz hasonlóan az ilyen szempontból érdekes esetekben egyegy szó párhuzamosan is előfordulhat az abszolút és relatív gyakoriságokat taglaló táblázatokban. A legtöbb esetben ezt a változást a tematikus a diskurzus átalakulása indokolja. Ebbe a kategóriába a következő szavak tartozhatnak: „erkölcsi”, „szellemi”, „szellem”, „törvény”, „polgári”, „müveltség”, „tanterv”, „nemzet”, „nemzeti, „,népiskola”, „ifjúság”, „reform”, „nevelés”, „nevelő”, „ember”. Más esetekben köz- és szaknyelvi szóhasználati változásokról lehet inkább szó: „tanító”, „tanítás”, „tárgy”, „intézet”, „dolog”, „előadás”, „növendék”, „gyermek”, „lélek”. Az „,irodalom” és a „nyelv” szavak csökkenő előfordulásának hátterében is valószínűleg az első ok, azaz a tematikus érintettség sejlik fel. Régebben minden

\footnotetext{
* Jelmagyarázat: zöld-sárga-piros színek - alacsony-közepes-magas gyakoriság
} 
bizonnyal a szerzők többet foglalkoztak az újság hasábjain az irodalom és a nyelv kérdéseivel. Az eddig felsoroltak mellett előszeretettel használták még a „régi” és „helyes” szavakat is. Az első egyfajta múltba fordulást sejtet a második világháború előtti időszakban, míg az utóbbi a cikkekben való folyamatos értékítélet jelenlétét ugyanebben az időszakban.

14. táblázat. A vizsgált időszak (1892-2014) elején aktívabban használt, majd lecsengő szavak elöfordulása az abszolút gyakoriságok alapján

\begin{tabular}{|c|c|}
\hline Cikkszám & 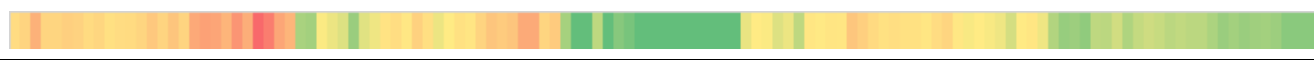 \\
\hline gyakorlati & 1 \\
\hline irány & $\mid$ \\
\hline irodalom & 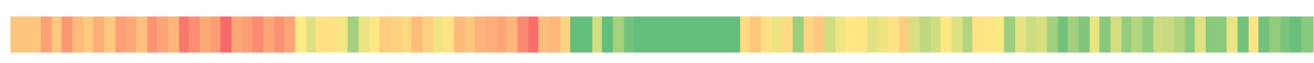 \\
\hline tanterv & || | | | \\
\hline tanár & 1 \\
\hline tudomány & 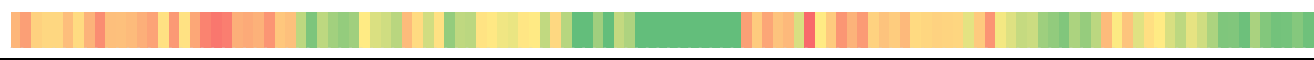 \\
\hline erkölcsi & \|\|$\|$ \\
\hline tanító & 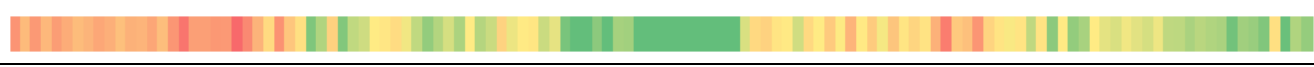 \\
\hline intézet & 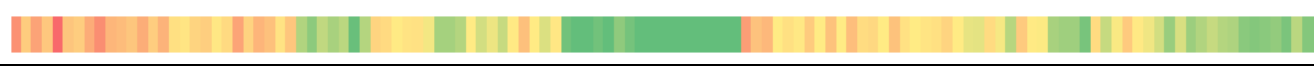 \\
\hline középiskola & 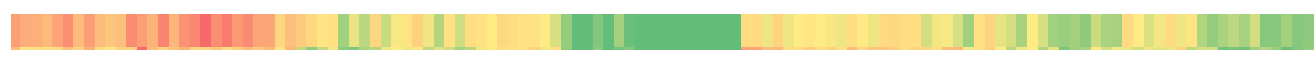 \\
\hline dolog & 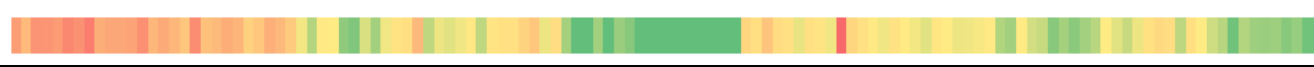 \\
\hline szellemi & 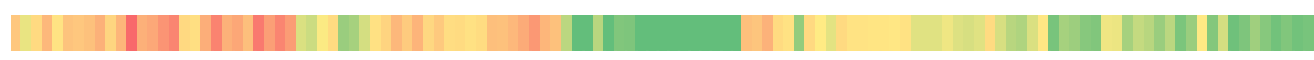 \\
\hline szellem & $1+1=1$ \\
\hline törvény & || || || || || ||||||| \\
\hline előadás & || || || || \\
\hline polgári & 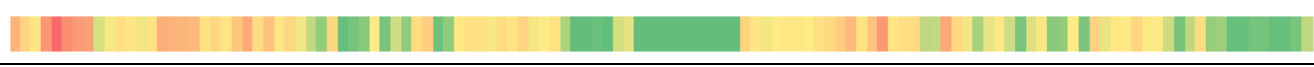 \\
\hline müveltség & 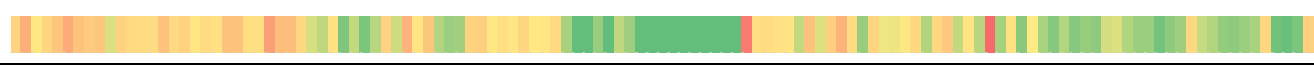 \\
\hline növendék & 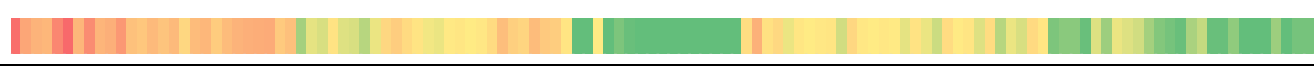 \\
\hline nemzet & 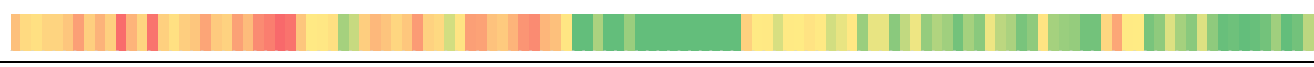 \\
\hline nemzeti & 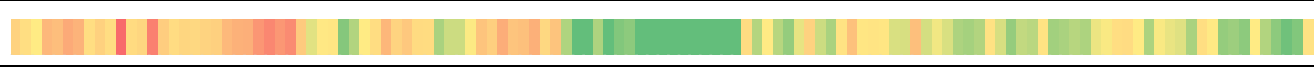 \\
\hline ifjúság & 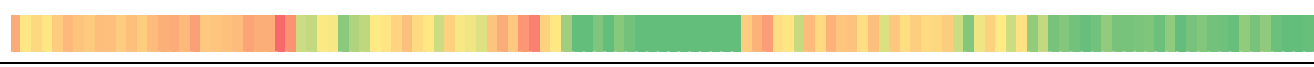 \\
\hline reform & 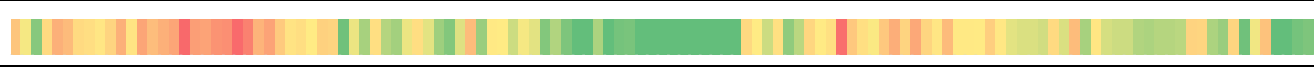 \\
\hline tárgy & 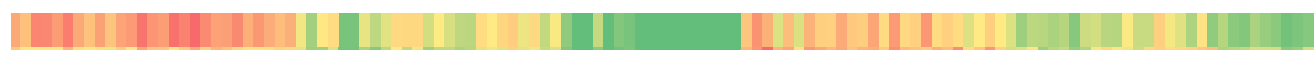 \\
\hline
\end{tabular}

\footnotetext{
* Jelmagyarázat: zöld-sárga-piros színek - alacsony-közepes-magas gyakoriság
} 
15. táblázat. A vizsgált időszak (1892-2014) elején aktívabban használt, majd lecsengö szavak elöfordulása a relatív gyakoriságok alapján*

\begin{tabular}{|c|c|}
\hline Cikkszám & 1 \\
\hline irodalom & - \\
\hline nyelv & I \\
\hline dolog & 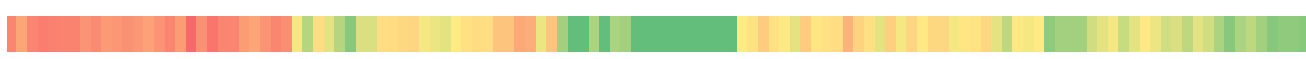 \\
\hline osztály & 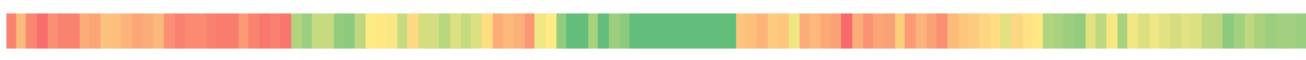 \\
\hline tanítás & || || || || || \\
\hline ember & 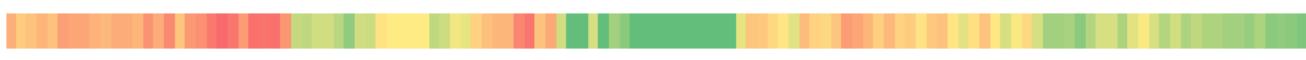 \\
\hline nevelés & 111 \\
\hline nevelö & 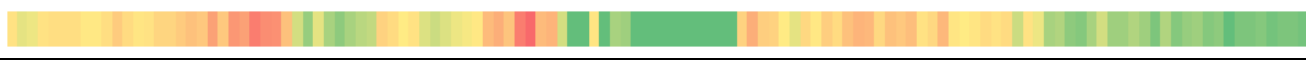 \\
\hline tárgy & 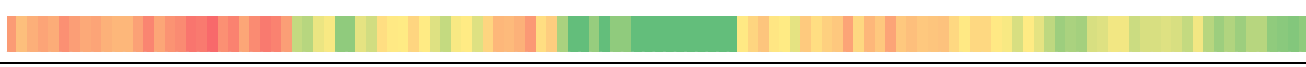 \\
\hline könyv & $1+11$ \\
\hline népiskola & 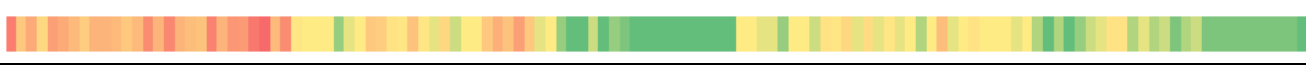 \\
\hline gyakorlati & 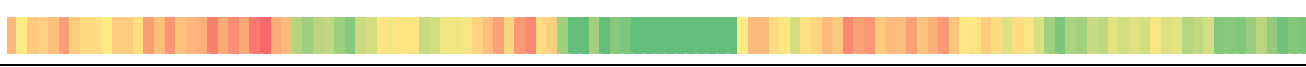 \\
\hline lélek & 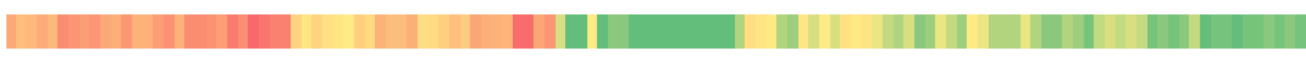 \\
\hline helyes & 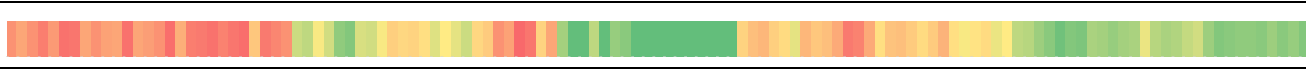 \\
\hline gyermek & 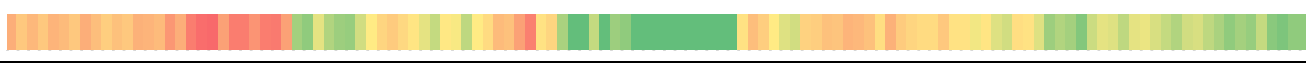 \\
\hline anyag & 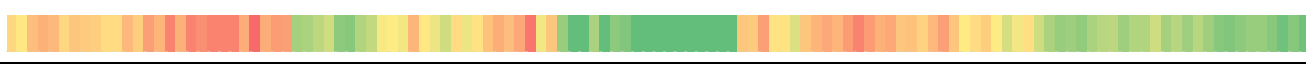 \\
\hline tudományos & 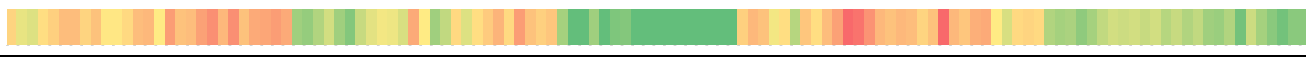 \\
\hline dolog & 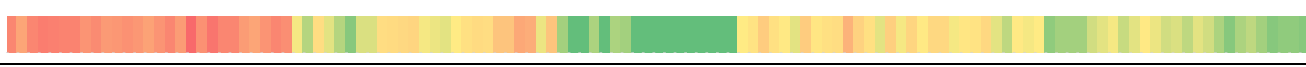 \\
\hline szellemi & 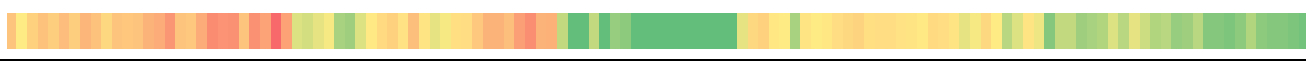 \\
\hline régi & 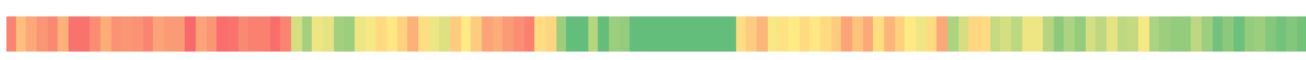 \\
\hline
\end{tabular}

A gyakorisági eloszlásokat tekintve harmadik, egyben legáltalánosabb kategóriának tekinthető, a szavak időbeli egyenletes használatát leképező színképeket nem közlünk, mivel azok a kutatás szempontjából nem hordoznak magukban további információt. Általános színképüket tekintve többé-kevésbé a cikkek számának eloszlását leképező színképre hasonlítanak dinamikájukban, illetve kevés esetben előfordul, hogy a szavak előfordulása az adott évben megjelent cikkek számától függetlenül, nagyjából konstans értékre állt be, ezekben az esetben a színkép uralkodó színét a sárga és annak árnyalatai jelentik (közepes előfordulási gyakoriság). Végül az utolsó színképeket bemutató 16. táblázatban a feltárt speciális esetek közül bocsátunk közre néhányat. Ezen szavak bizonyos időszakokban való alulreprezentáltságának vagy akár teljes negligálásának, más időszakokban pedig meredek

\footnotetext{
* Jelmagyarázat: zöld-sárga-piros színek - alacsony-közepes-magas gyakoriság
} 
felfutásának a legtöbb esetben egyedi és összetett magyarázata van. A 16. táblázat „szocialista” - „társadalmi” sorai mögött egyértelmüen a szocialista nevelésirányítás kiteljesedése és a számára kedves témák szaksajtóban való masszív jelenléte tapintható. A bemutatott esetek közül talán az egyik legérdekesebb mintázatot a „német” szó 123 évet átfogó előfordulása mutatja, mivel nem a vártnak megfelelően, a második világháború táján tetőzik, hanem korábban, még az első világháború ideje alatt. Az már sokkal jobban illeszkedik a várt trendhez, hogy a szocializmus alatt szinte eltünik a témák közül, azonban az 1990-es években újra visszatér, majd az utolsó évtizedben újra visszaesik az előfordulása. A „szülő” szó előfordulása szintén érdekes mintázatot mutat, mivel ennél a szónál semmilyen következetes trend nem rajzolódik ki, sok esetben évről évre változik, hogy éppen használják a szerzők vagy nem. Lokális csúcsok és lappangás váltogatják egymást. A „felső” szó közelebb áll a lecsengő szavak színképének mintázatához, azonban annyiban speciális eset, hogy igazából az első világháború végéig tartja magát, utána már jóval kevésbé jellemző. Az utolsó példa a speciális esetek közül a „szociális” szó, amely a kezdeti években szinte egyáltalán nincsen használatban, utána is módjával, hogy aztán a rendszerváltást követően erősen felfusson. Ezt a mintázatot az ekkor frissen beinduló kutatási domének indukálják: szociális fejlődés, szociális készségek, szociális kompetencia, szociális viselkedés, proszocialitás, stb.

16. táblázat. A vizsgált időszakban (1892-2014) tapasztalható speciális esetek elöfordulása az abszolút gyakoriságok alapján*

\begin{tabular}{l|l|l|l|l|}
\hline \hline Cikkszám & & & & \\
\hline szocialista & & & & \\
\hline szovjet & & & & \\
\hline
\end{tabular}

\footnotetext{
* Jelmagyarázat: zöld-sárga-piros színek - alacsony-közepes-magas gyakoriság
} 


\subsubsection{Az egyes cikkek leggyakoribb szavai}

Az egyes szavak előfordulását taglaló gyakoriságok természetesen nemcsak aggregált formában állnak rendelkezésre, hanem cikkenkénti bontásban is. Az elemzésböl két változat készült: az egyik fajta nézet az eddig tárgyalt minta megkötései szerint (kizárólag fö- és melléknevek, szelektált többszavas kifejezésekkel kiegészítve) tartalmazza minden 1892-2014 között megjelent különálló publikáció $(\mathrm{N}=6574)$ leggyakoribb huszonöt szavát előfordulási értékeikkel együtt. Emellett elkészült egy bővített nézet is, ebben már az igék is szerepelnek, továbbá a cikkenkénti leggyakoribb ötven szó van fellistázva a megfelelő gyakorisági értékekkel együtt. A fájlokban használt adatszerkezet minden további átalakítás nélkül tökéletesen alkalmas szófelhők generálására, így ezt illusztrálandó, a folyóiratban megjelent legelső cikkröl, illetve egy további, véletlenszerüen kiválasztott tanulmányról elkészítettünk egy-egy ilyen ábrát. Az első esetben az ötven szavas listát (41. ábra), míg a második példánál a huszonöt szavas listát (42. ábra) felhasználva. Természetesen hasonló ábrákat az összes cikk vonatkozásában le lehetne gyártani, ehhez minden szükséges adat rendelkezésre áll, azonban jelen keretek között csupán a kutatási projekt egyes kimenetei által biztosított lehetőségeket szeretnénk felvillantani. Az egyszerű gyakorisági elemzések mellett az egyes cikkek hangsúlyos szavainak detektálásához különböző megközelítésü algoritmikus módszereket is alkalmaztunk, melyek eredményeit hasonló formában mutatjuk majd be a megfelelő fejezetben.

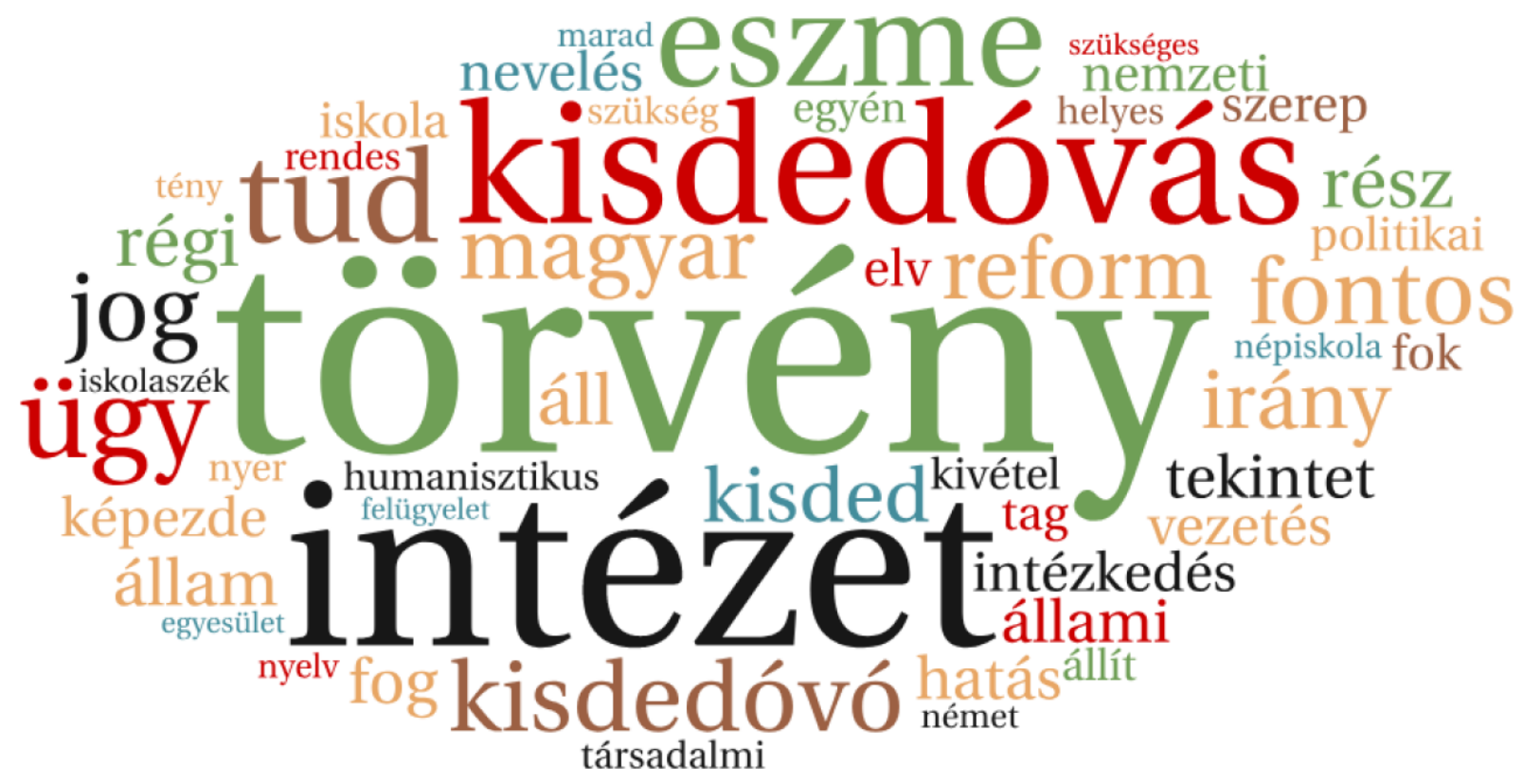

41. ábra

A minta legelsö cikkének (György, 1892) ötven leggyakoribb szava 


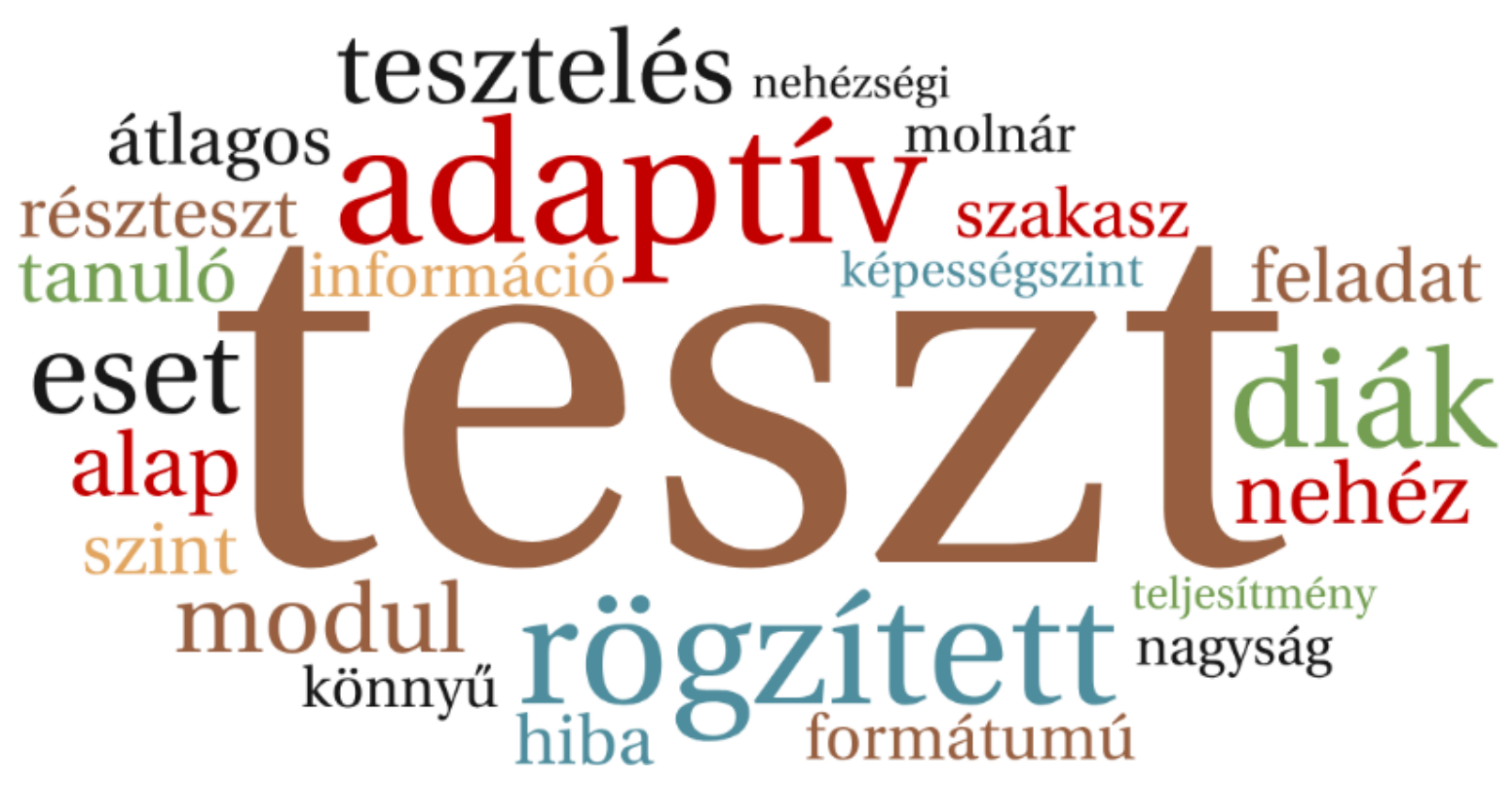

42. ábra

Egy véletlenszerüen kiválasztott cikk (Magyar \& Molnár, 2013) huszonöt leggyakoribb szava

\subsubsection{Az egyes évtizedek leggyakoribb szavai}

Az eddig ismertetett eredmények mutatják, hogy a minta tartalomelemzése különböző szinteken zajlott: először megtörtént az egyes cikkek szintjén, majd az egyes különálló évfolyamok vonatkozásában (egy-egy apró területegység a hőtérképes ábrázolásokon), illetve az évekre vonatkozó értékek láncba füzésével a teljes vizsgált időszakot tekintve is. Bizonyos vizsgálatok esetében külön, kiemelt jelentőségüként kezeltük a 1991-2014 közötti időszakot (10-11. táblázat), azonban az eddig felsorolt szintek mellett egy további, köztes szint vizsgálatba való bevonása is kívánatos volt a tartalomelemzésre vonatkozó hipotézisek $\left(\mathrm{H}_{10}\right.$ $\mathrm{H}_{12}$ ) teljes körű megválaszolásához. Ezt a köztes szintet az évtized jelentette, ahogyan azt az előzetes hipotézisek $\left(\mathrm{H}_{10}\right)$ között is megfogalmaztuk („Évtizedes időszakaszokat vizsgálva a tématerületek kimutatható módon folyamatos változásban vannak.”). Az évtizedes bontás vizsgálatára az egyes cikkek tartalmi vizualizálása kapcsán már bevált szófelhős módszert alkalmaztuk, ahol egy ábrán, szintetizálva látszik az egyes szóalakok és azok használatának gyakorisága. Az ilyen típusú ábrákon mindig a szavak töltik be a vezető, hangsúlyos szerepet, mivel előfordulásuk gyakorisága nincsen pontosan számszerüsítve, arra a méretek egymáshoz való grafikus arányosításából lehet következtetni. Éppen emiatt alkalmas ez a típusú ábrázolás a fő tendenciák láttatására, mert nem veszik el a részletekben, valóban csak a legfontosabb, lecsupaszított információtartalom vizualizálását kísérli meg.

A 8-11. gyakorisági táblázatokban és a 37-40. ábrákon közölt színképes gyakoriságok esetén népszerünek bizonyult szavak természetesen az évtizedek leghasználtabb szavait 
bemutató ábrákon is előkelő módon reprezentálódnak, azonban az évtizedek múlásával komoly átrendeződések is megfigyelhetőek erre vonatkozóan. Az 1892-1939 közötti időszakban a leginkább használt szónak folyamatosan az ,iskola” bizonyult, az első változás ebben az 19401950 közötti időszakban tapasztalható, amely teljes mértékben megfelel előzetes elképzelésünknek $\left(\mathrm{H}_{11}\right)$ a politikai változások folyóiratban való leképeződéséről a „magyar” és „nevelés” szavak élre kerülése nyomán (az „iskola” a harmadik helyre esett vissza). Az 1970es évekig kell arra várni, hogy az „iskola” újra a legtöbbet használt szó legyen, mivel az 1960as években megelőzik a „tanuló” és a „munka” szavak, melyek hipotézisünk mentén szintén jól tükrözik a szocializmus nevelési ideáit. Az „iskola” ezután három évtizedig újra az élen szerepel, majd a 2000-es évek után újból átadja helyét a „tanuló”-nak. A 2010-es évekre már jelentősen visszaesik a legtöbb évtized nyertese, mivel a „tanuló” mellett már olyan szavak is megelözik, mint az „,eredmény”, „alap”, „vizsgálat”, „,eset”, „feladat”, „kutatás”, „,képesség”. Az itt felsorolt szóalakok előkerülése már egyértelműen a mérés-értékelési, kvantitatív kutatási irányzat elöretörésének tudható be, amely trend ismét jól illeszkedik a korábban megfogalmazott hipotézisek $\left(\mathrm{H}_{12}\right)$ közé.

A 43-54. ábrák segítségével elemezzük az egyes évtizedek sajátos és különösen jellemző szavait, választ adva $\mathrm{K}_{10}$ kérdésünkre. Az első szakaszra különösen jellemző kulcsszavaknak tekintjük a „népiskola”, „polgári”, „polgári iskola”, „felső”, „latin”, „görög”, „franczia”, „,német”, „czél” szóalakokat. Néhány közülük már a következő évtizedben (1900-1909) veszít jelentőségéből, ilyen például a „polgári” és a „polgári iskola”. Nő a „latin”, egyelőre stagnál a „görög”, hangsúlyosabb szerepet kap az „irodalom”, visszaesik a „czél”. Szintén nő a „magyar”, „tanítás”, „nevelés” szavak használati gyakorisága, ezzel szemben jelentősen visszaesik az „osztály”. Az 1910-es években több minden változik, mint az előző két évtizedben: tovább nő a „,nevelés”, ,élet”, „munka” szerepe. A nyelveket illetően csökken a „latin”, növekszik a „német”, a korábbi „franczia” szó átalakul „francia’ alakra, eltűnik a száz leggyakoribb szó közül a „görög” (amely utána soha nem is tér vissza). Szintén ebben az évtizedben kezd átalakulni - szóváltozataival együtt - a „paedagógia” alak a „pedagógia” formára. Akadnak olyan általános szóalakok, amelyek mindhárom évtizedben nagyjából hasonló arányban fordulnak elő: „ember”, „magyar”, „oktatás”, „gyermek”, „nyelv”. Egyértelműen az első világháborúra utal a „háború”, „gazdasági” szóalakok megjelenése. Az 1920-as években még inkább előretör a „magyar” és a „,nevelés”, megmarad az „élet” és a „munka” jelentősége, még mindig jelen van a „háború”. Megjelennek olyan, lokalitást kifejező szavak is, mint a „Budapest” vagy „Magyarország”, ez korábban nem volt jellemző az évtizedekre bontott gyakorisági listák élén. Az egész szóhasználat észrevehetően sokkal 
modernebbé válik ebben az évtizedben a legnépszerübb száz szó vonatkozásában is. Olyan manapság is népszerü szavak esetében érhető ez tetten, mint a „probléma”, „fejlődés”, „,eredmény”, „,vizsgálat”, ,idegen [nyelv]”, „világ”, „kapcsolat”. Ezért az 1920-as éveket ilyen szempontból egyfajta korszakhatárnak tekinthetjük, választ adva az egyik kutatási kérdésben $\left(\mathrm{K}_{11}\right)$ megfogalmazottakra. A gyakoriságvizsgálatok arra utalnak, hogy ebben az esetben inkább egymásra épülő, organikus fejlődésről van szó.

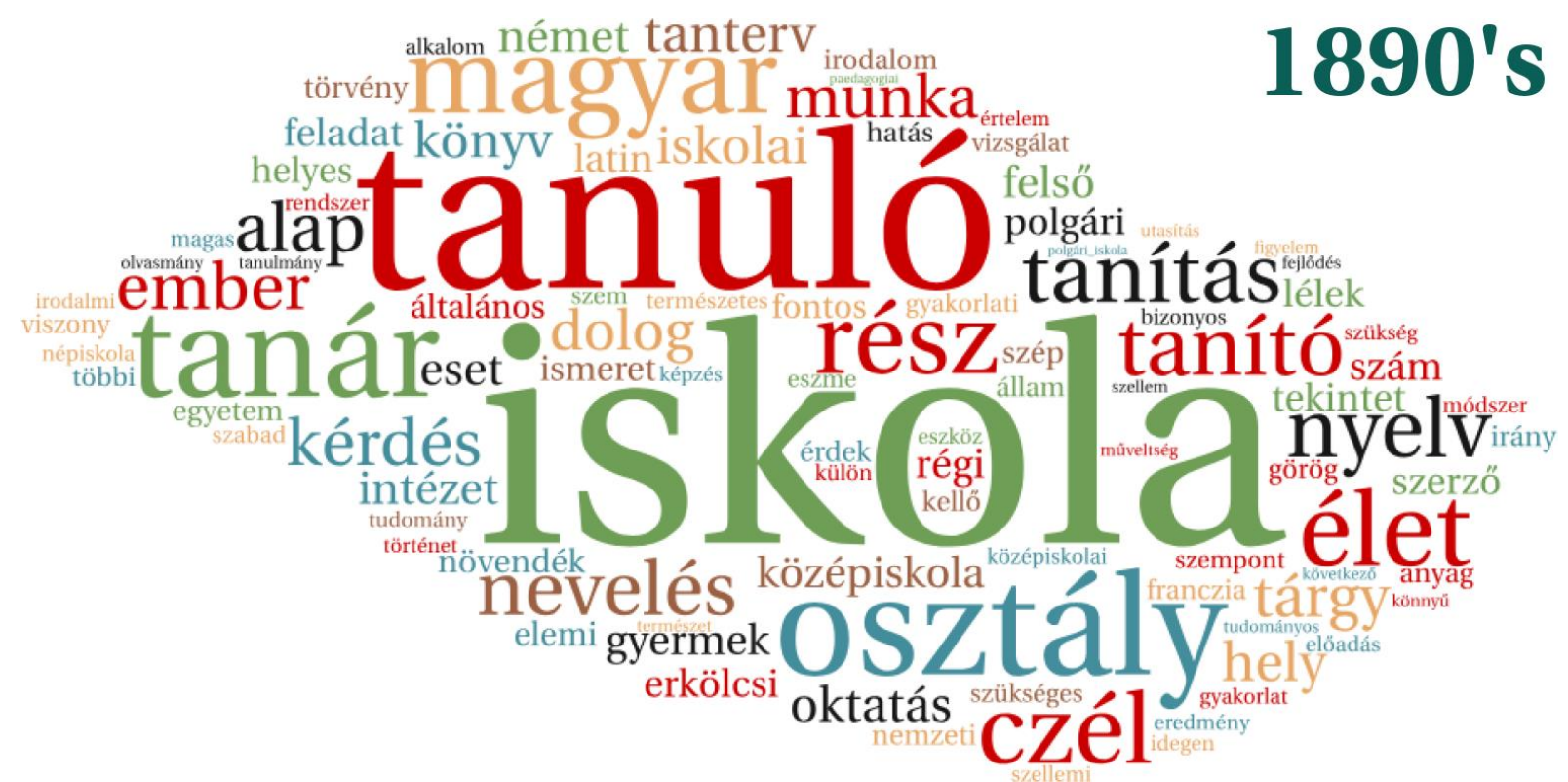

43. ábra

Az 1892-1899 közötti évek száz leggyakoribb szava a Magyar Pedagógia cikkeiböl képzett mintában

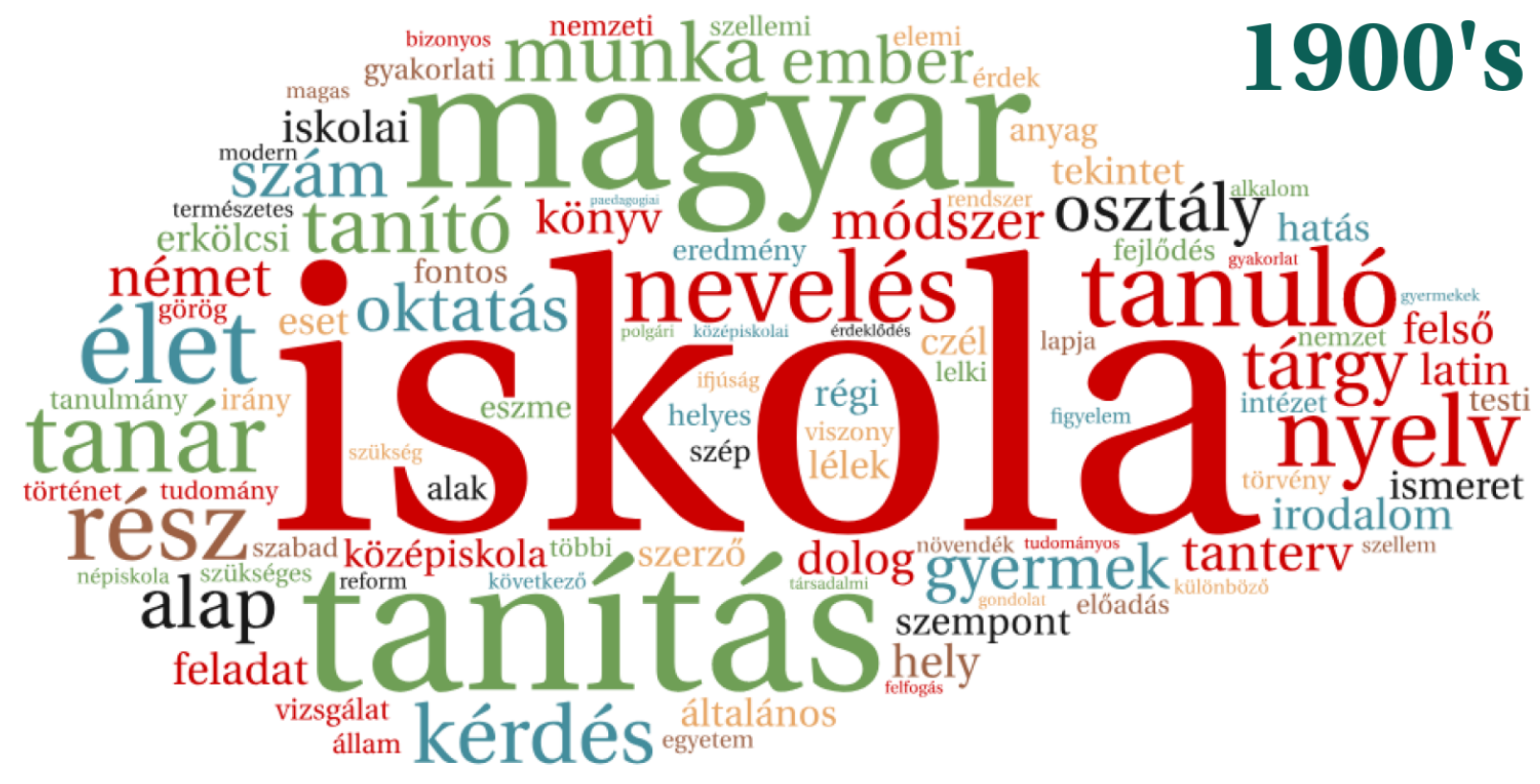

44. ábra

Az 1900-1909 közötti évek száz leggyakoribb szava a Magyar Pedagógia cikkeiböl képzett mintában 


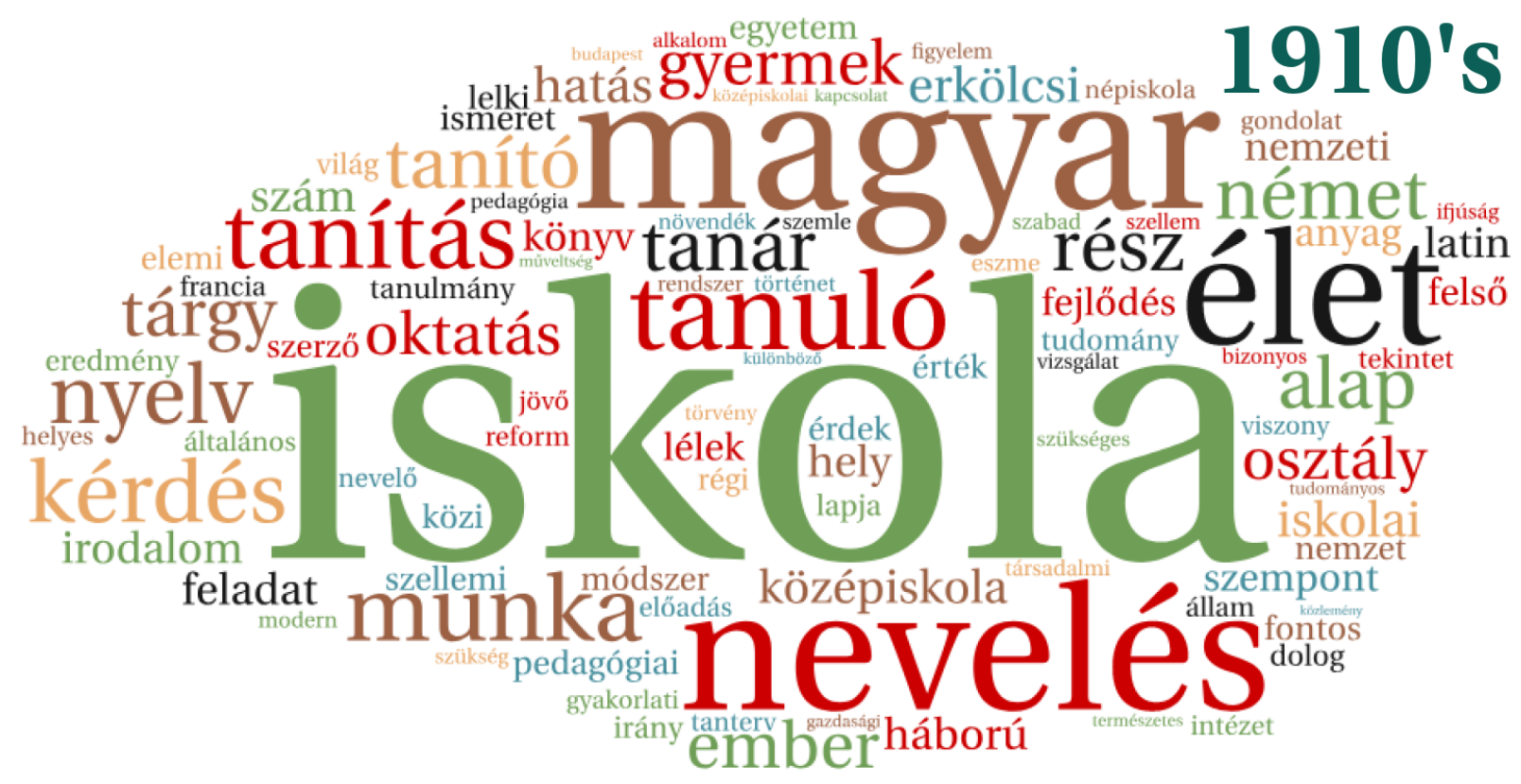

45. ábra

Az 1910-1919 közötti évek száz leggyakoribb szava a Magyar Pedagógia cikkeiböl képzett mintában

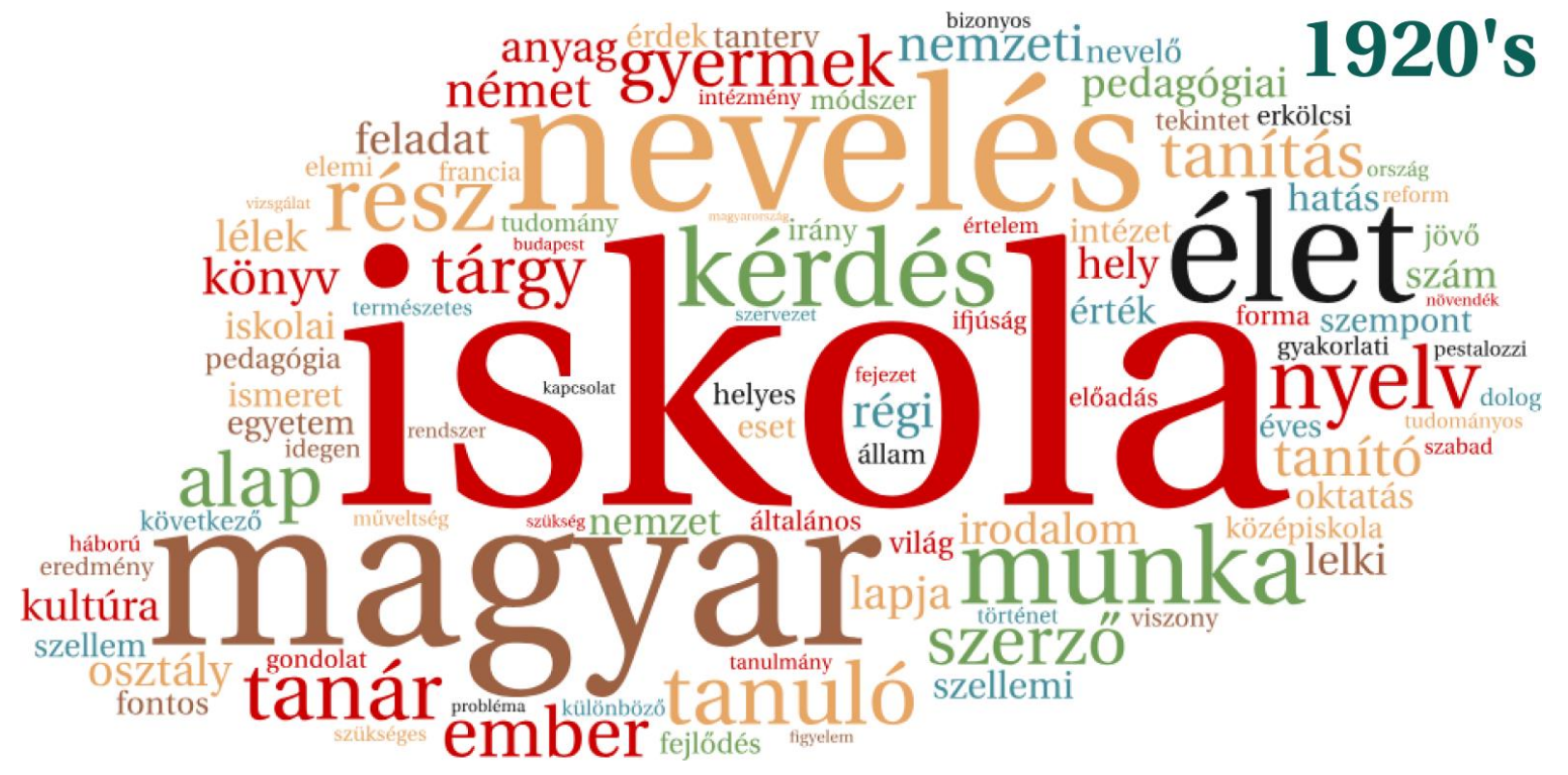

46. ábra

Az 1920-1929 közötti évek száz leggyakoribb szava a Magyar Pedagógia cikkeiböl képzett mintában

Az 1930-as évek száz leggyakoribb szavából készült 47. ábra alapvetően megerősíti Mészáros (1992) véleményét, miszerint ebben az évtizedben a folyóiratban tárgyalt témákat illetően még nem igazán érhető tetten a következő évtizedben beköszöntő háború előszele, illetve a szélsőjobb térnyerése. Az esetleges nacionalista vagy nemzetibb értékű nevelési elvek csupán néhány szó vonatkozásában tételezhetőek fel: „nemzet”, „nemzeti”, „politikai”, 
„törvény”, „felfogás” vagy a „német” kiemelkedése a többi nyelv közül. Szintén ezt a vonalat erősíti a „magyar” szó hangsúlyos jelenléte az évtized tematizálásában. Az 1940-es évek vizsgálati mintája a lap hányattatásai miatt jóval szükebb, hiszen előfordultak olyan évek, amelyekben egyáltalán nem jelent meg a folyóirat. Kivételesen az évtizedhez soroltuk az 1950ben megjelent egyetlen lapszámot, mivel az terjedelmében olyan rövid, hogy nem láttuk értelmét az önálló vizsgálatnak, még a megelőző években lezajlott ideológiai váltás ellenére sem. Történelmi ismereteink birtokában tudható, hogy az 1940-es években kettős arculat várható, mivel a nacionalista megközelítéstől az évtized végére eljutunk a kommunista nevelési elvek erőteljes jelenlétéig. Ez a kettős arculat a leggyakoribb száz szóból alkotott szófelhő esetében csak mérsékelten érhető tetten. Az évtized egyik legfontosabb sorrendi változása, hogy a „magyar” és a „nevelés” szavak megelőzik az eddig abszolút győztesnek tekinthető „iskola” szót. Továbbra is kimutathatóan jelen vannak az 1930-as éveknél felsorolt nemzeti tematikát uraló szavak, ugyanakkor megjelennek olyanok is, amelyek valószínüleg az 1940-es években lezajlott változások miatt jelentek meg a 48. ábrán: „társadalmi”, „szociális”, „közösség”, „eszmény”, „valóság”. A korábban fokozottan jelen lévő nyelvek, a „német” kivételével eltünnek, a „Budapest” viszont tovább erősödik.

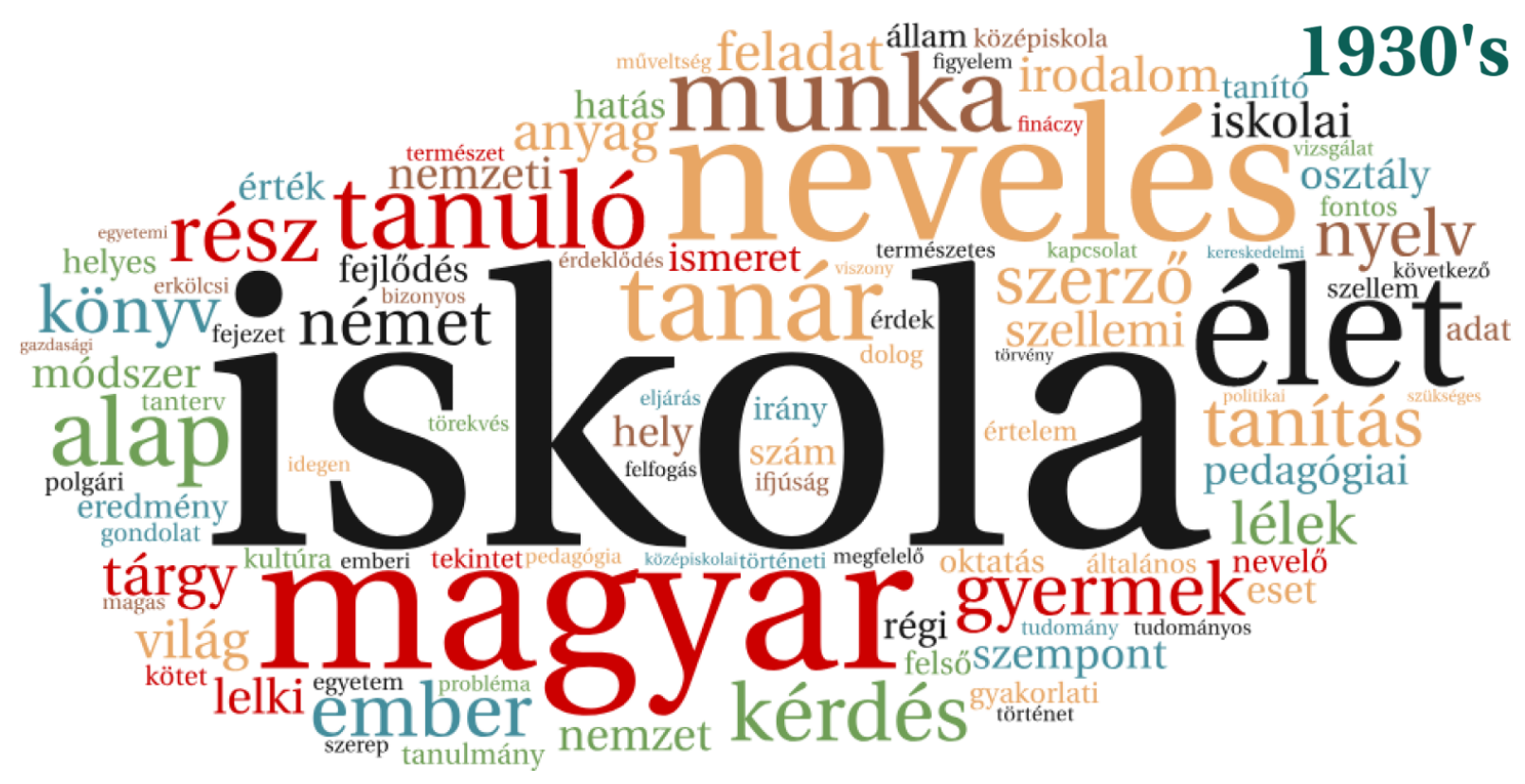

47. ábra

Az 1930-1939 közötti évek száz leggyakoribb szava a Magyar Pedagógia cikkeiböl képzett mintában 


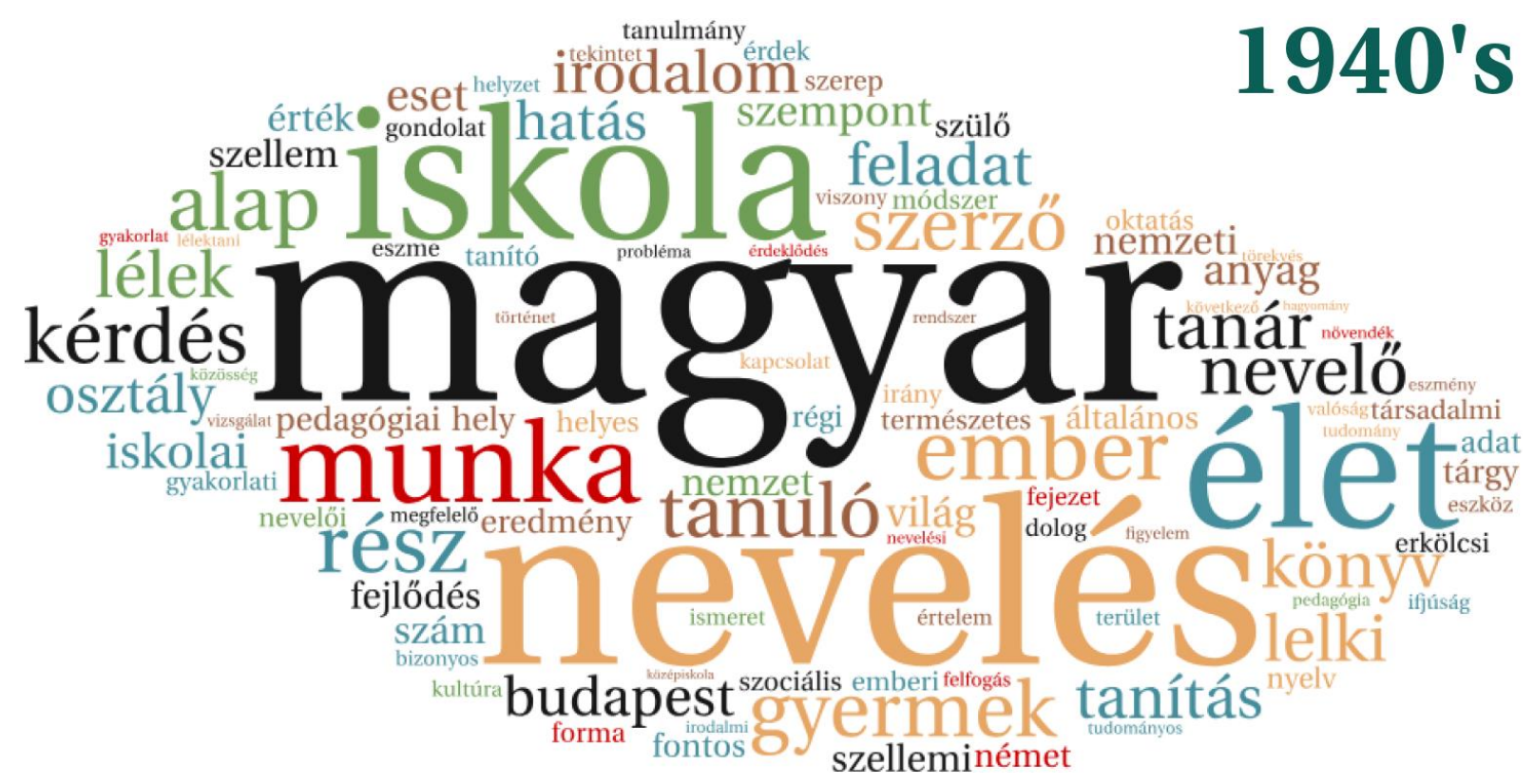

48. ábra

Az 1940-1950 közötti évek száz leggyakoribb szava a Magyar Pedagógia cikkeiböl képzett mintában

Az 1960-as években a „nevelés” szó használata jelentősen visszaesik, míg a „munka” jelentősége kifejezetten megnő. A leghangsúlyosabb az évtizedben a „tanuló”. A szocialista nevelési eszményt olyan szavak képviselik, mint a „társadalom”, „társadalmi” és a „szocialista”. A nyelvhasználat egyre modernebb, a mindennapi iskolai életet jellemző szavak mellett egyre inkább feltűnnek a neveléstudományi kutatást reprezentáló szavak: „,vizsgálat”, „kísérlet”, „elemzés”, „tudomány”, „tényező”, „folyamat”., „kutatás”, „hatás”, „adat”. Az 1970-es években folytatódik ez a tendencia: „kutatás”, „módszer”, „eredmény”, „,vizsgálat”, „tanulmány”. A „tanuló” és ,iskola” szavak helyet cserélnek, és a „magyar” szó tovább veszít népszerüségéből. A 49. ábrára egy idegen nyelv neve sem fér fel ebben az évtizedben, amiből az erre az időszakra jellemző szegényes nyelvtanulási lehetőségekre következtethetünk, amely hiányosság a mai napig érezteti hatását. Az előző évtizedhez képest meglepően sok szó lecserélődik a korábbiakhoz képest, és teljesen új szavak tűnnek fel az 1970-es évek szófelhőjén. Emellett néhány, korábban kisebb súllyal szereplő szó használata pedig előretör: „pedagógiai”, „oktatás”, „kérdés”. Az 1960-as és 1970-es évek vonatkozásában jóval több változás tapasztalható, mint a rákövetkező 1970-es és 1980-as évek között. Emiatt ezt a két évtizedet viszonylag egységes korszaknak tekinthetjük a gyakoriságok alapján. 


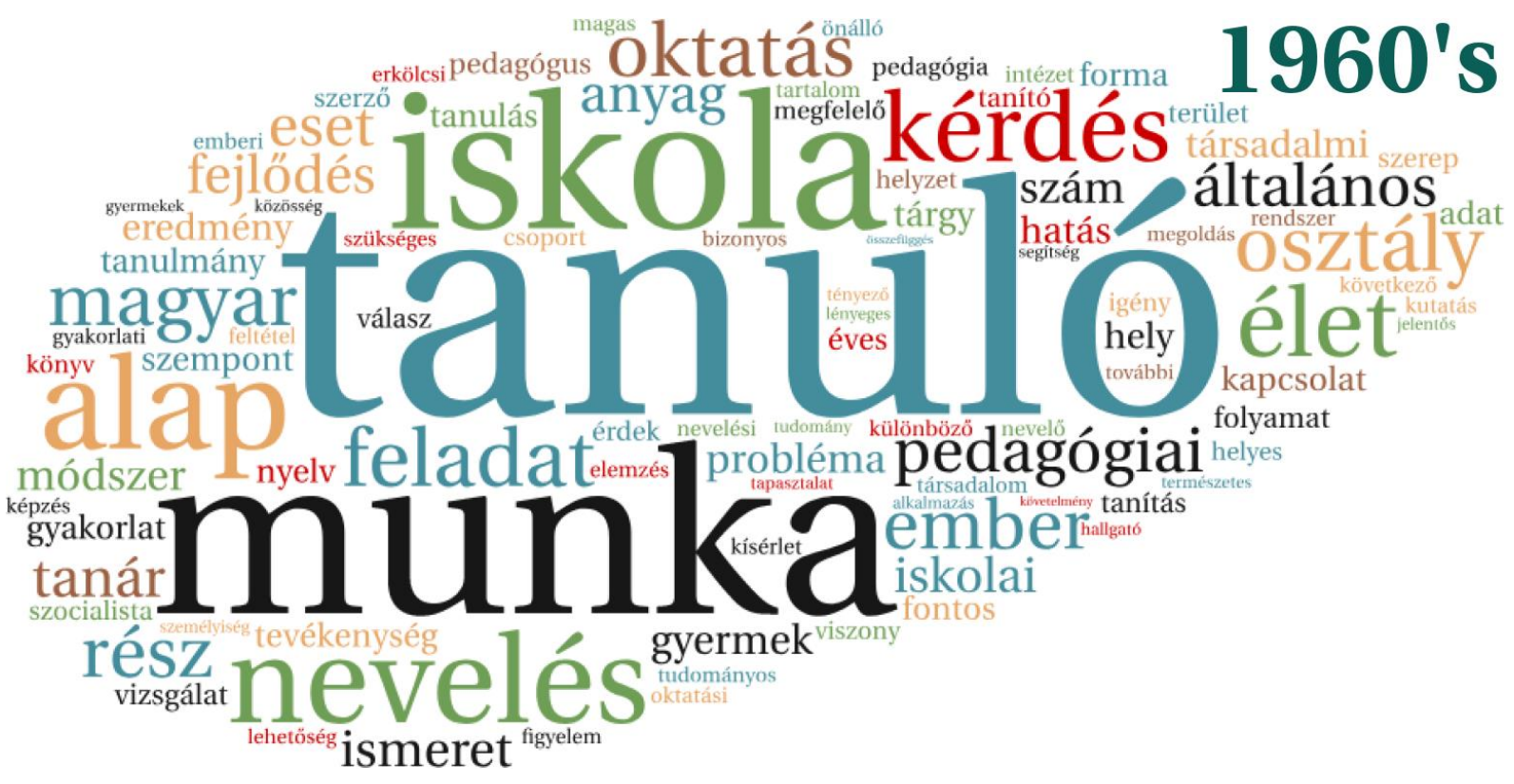

49. ábra

Az 1961-1969 közötti évek száz leggyakoribb szava a Magyar Pedagógia cikkeiböl képzett mintában

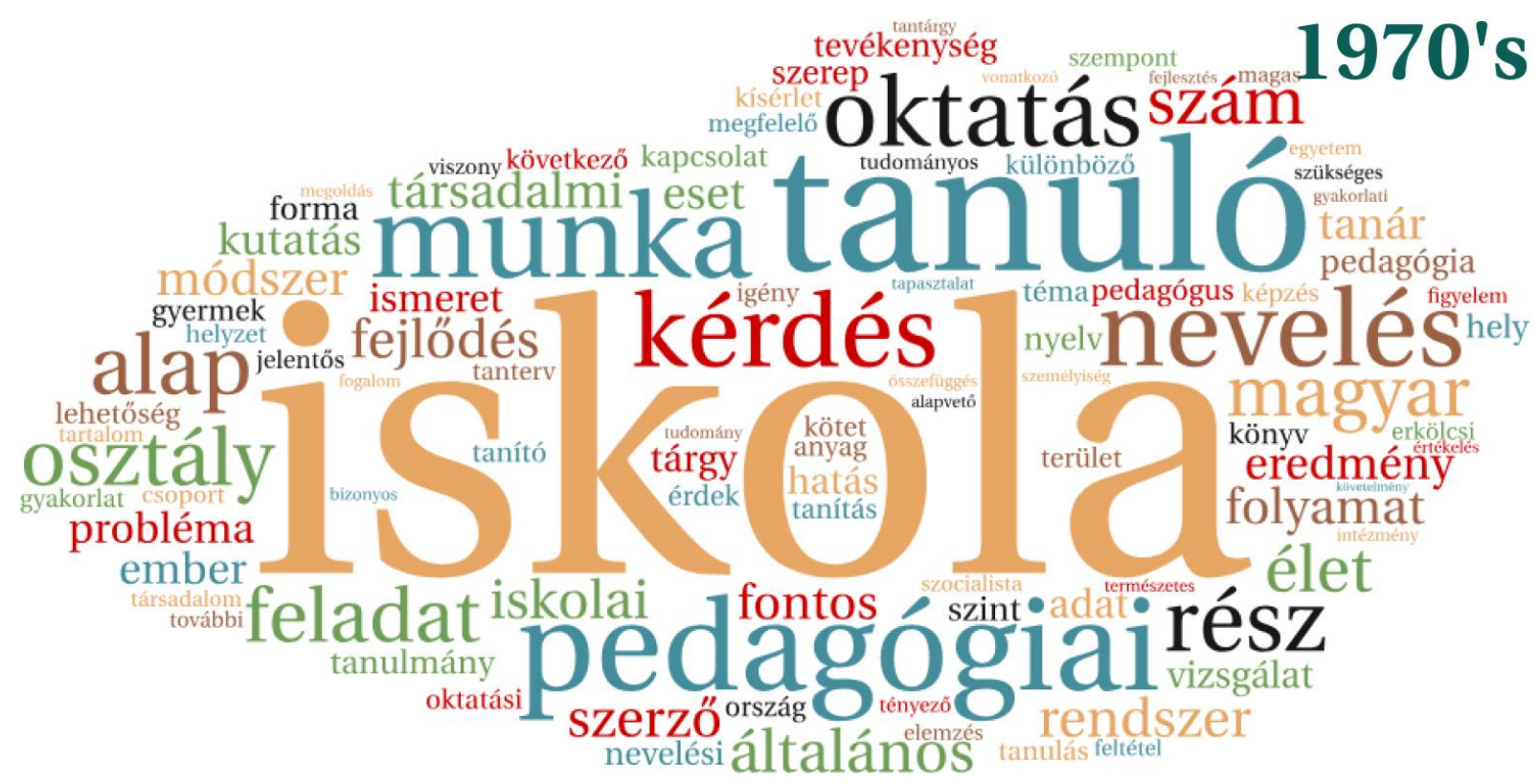

50. ábra

Az 1970-1979 közötti évek száz leggyakoribb szava a Magyar Pedagógia cikkeiböl képzett mintában 


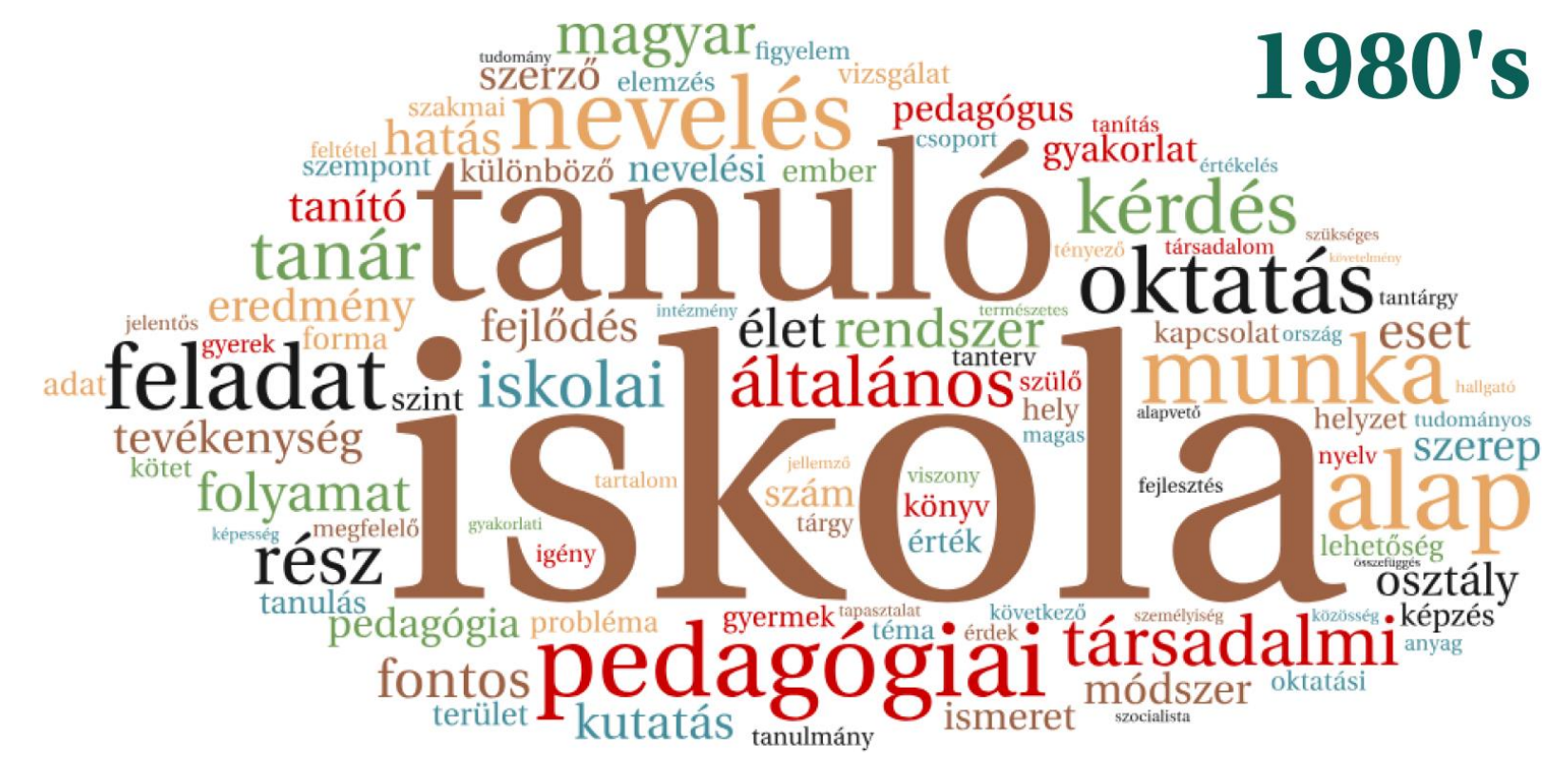

\section{1. ábra \\ Az 1980-1989 közötti évek száz leggyakoribb szava a Magyar Pedagógia cikkeiböl képzett mintában}

Az előzetes feltételezések szerint a rendszerváltás akkora változást jelentett a folyóirat témáit illetően, amelynek tetten érhetőnek kell lennie a gyakoriságok alapján is. Az ábrák alapján ez csak félig-meddig igazolható, mert bár felfedezhető néhány erre utaló trend, illetve újonnan megjelent mozzanat, azonban élesnek mondható váltásról valójában nem beszélhetünk az 1980-as évtized és az 1990-es évtized között. Feltűnik a népszerü szavak között a „diák”, amely aztán napjainkig folyamatosan erősödő tendenciát mutat. A korábban oly nagy jelentőségü „,nevelés” és szóváltozatainak aránya egyre inkább csökken, ahogyan a „,munka” is visszaesik. A megelőző, szocialista időszakban tapasztalhatóhoz képest ismét előretör a „magyar” és újra megjelenik a „,német”. Az „,angol” szó majd csak a 2000-es évtizedben fér fel először a listára, egyébként egyből meg is előzve a „német”-et. Maga a „nyelv” szó is gyakrabban előfordul, mint korábban. A 2000-es éveket tekintve ismét egy szerves átalakulásról beszélhetünk az 1990-es évekhez képest, mivel a fő vonalak megmaradnak, bár helycserék és masszív előretörések is megfigyelhetőek a használt szavakat illetően. Újból az élre kerül a „tanuló”, számottevően gyakoribb használat jellemzi ekkor, mint a korábbi évtizedben leggyakoribb ,iskola” szót. Az évszázad elejének ábráival összehasonlítva az elmúlt három évtized ábráit, észrevehető a korábban már tárgyalt „gyermek”-,gyerek” szópáros helycseréje is. A 2000-es évek jellemző szavai közül a következőket emelnénk ki: „képesség”, „,feladat”, „eset”, „szint”, „teszt”, „fejlődés”, „,csoport”, „teljesítmény”, „módszer”, „lány”, „kognitív”, „összefüggés”, „stratégia”. A felsorolás már egyértelműen a neveléstudományi irányzaton belüli kognitív megközelítés és a mérés-értékelési irányvonal megerősödését és 
térnyerését mutatja. A korábban kiemelt fontosságú „nevelés” szó olyannyira marginálissá válik a 2000-es években, hogy éppen csak belefér a száz leggyakoribb szó közé. Az utolsó szófelhő mintája a 2010-es évekből fél évtizedet ölel fel. Az 54. ábráról leolvashatjuk, hogy egyes, a 2000-es években feltünő hangsúlyos szóalakok további növekedést mutatnak, talán még inkább rávilágítva a kvantitatív paradigma uralkodására a lapban megjelenő cikkeknél. Felsorolni is nehéz a rengeteg ezt alátámasztó szót az ábráról: „minta”, „modell”, „kérdőív”, „mérés”, „szignifikáns”, „,faktor”, „,változó”, „átlag”, „skála”, stb. Kifejezetten hangsúlyossá válnak az előző évtizedhez képest az ,alap”, „,eset”, „eredmény” szavak. Új kutatási irányok megjelenéséről tanúskodnak a „,zenei”, „olvasás”, „olvasási”, „szociális” kifejezések.

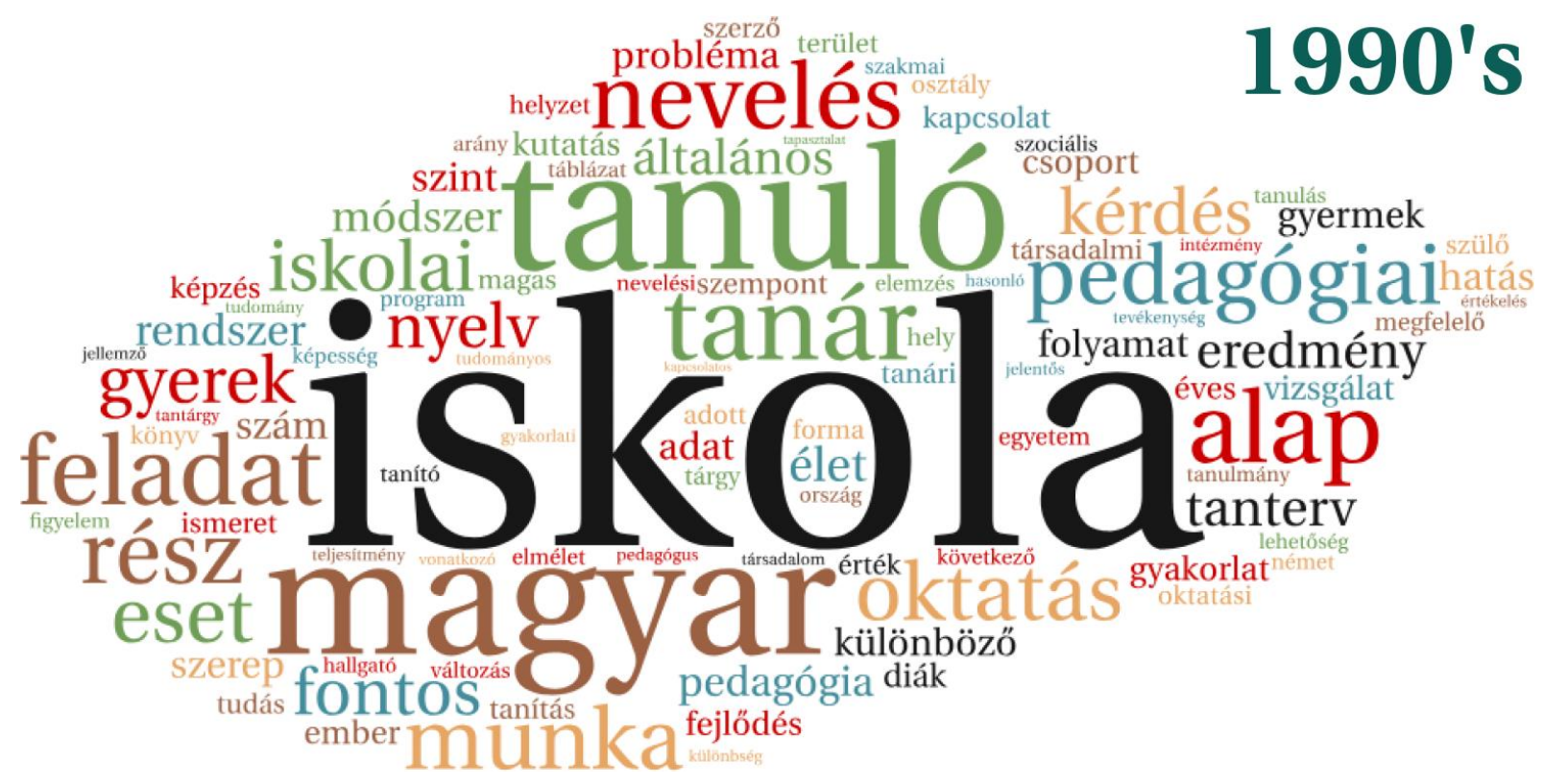

52. ábra

Az 1990-1999 közötti évek száz leggyakoribb szava a Magyar Pedagógia cikkeiböl képzett mintában 


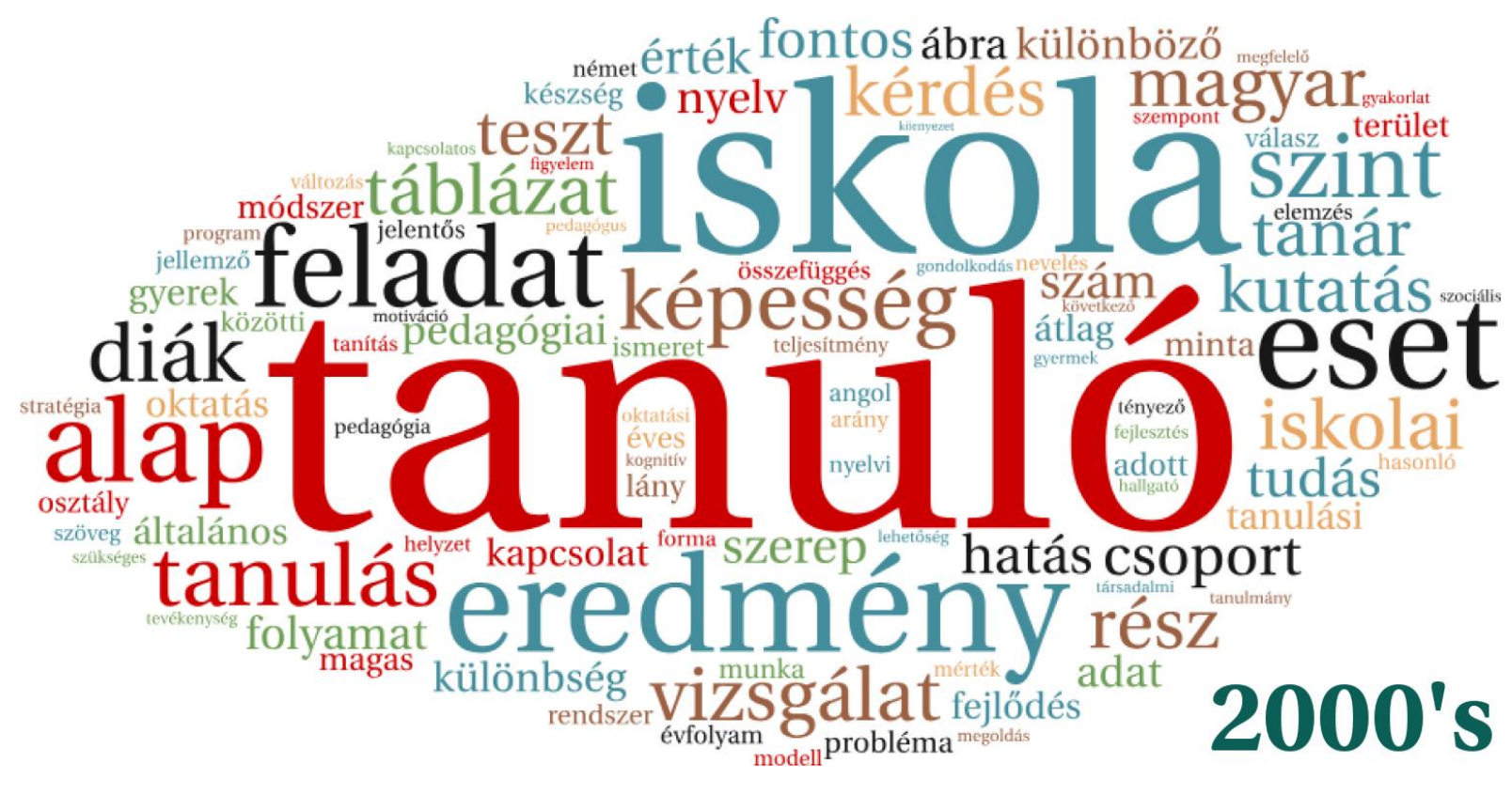

53. ábra

A 2000-2009 közötti évek száz leggyakoribb szava a Magyar Pedagógia cikkeiböl képzett mintában

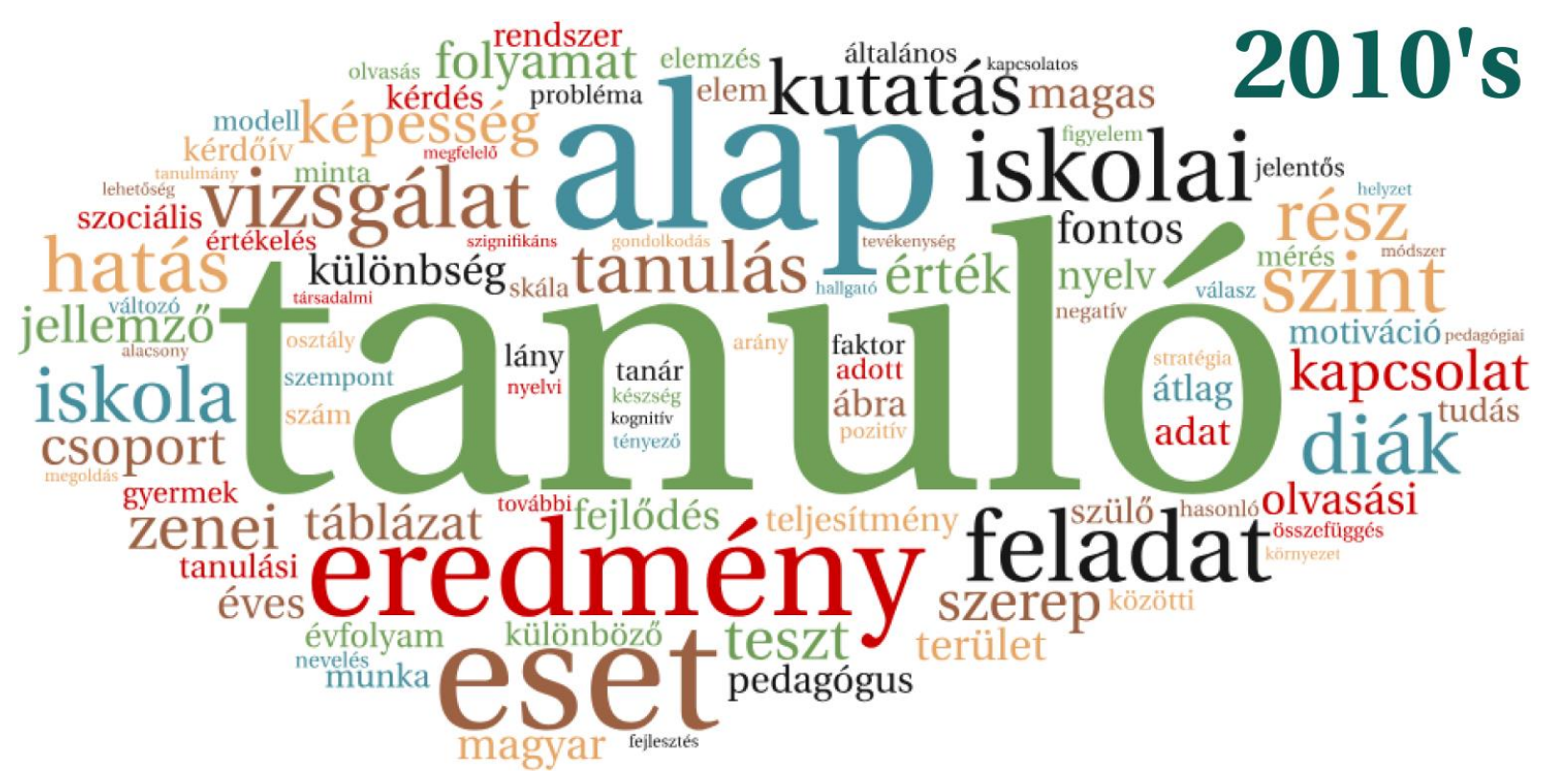

54. ábra

A 2010-2014 közötti évek száz leggyakoribb szava a Magyar Pedagógia cikkeiböl képzett mintában 


\subsection{A kulcsszavakkal kapcsolatos vizsgálatok eredményei}

A 8.1.1. pontban bemutatottak alapján több olyan forrás is rendelkezésre állt az analizált folyóirattal kapcsolatban, amely annak tartalmát különböző megközelítésben és mélységben tárta fel. Ezeket az előzményeket nem hagyhattuk figyelmen kívül saját elemzéseink során; sőt, a kulcsszavak (a kulcsszó és tárgyszó szavakat egymás szinonimájának tekintjük a következőkben) beható vizsgálatának vonatkozásában komoly lehetőséget jelentett az ezen forrásokra való támaszkodás. Mivel az ott ismertetett, különböző tárgyszavak mindig valamilyen humán vagy gépi tartalmi előfeldolgozás, illetve kivonatolás eredményei, ezért megbízhatóságuk és információtartalmuk jóval magasabb, mint ami az egyszerü gyakoriságvizsgálatokon alapuló eredmények esetében tapasztalható. A több, rendelkezésre álló, potenciálisan az elemzésbe bevonható forrás közül kettőt használtunk fel a gyakorlatban is: a Csapó-Pukánszky-féle repertóriumot és az SZTE Klebelsberg Könyvtár Contenta adatbázisának tárgyszavait.

A tárgyszavak vizsgálatának elsődleges célja elsősorban itt is az egyes évtizedekre jellemző tematikus sokszínűség, továbbá ennek évtizedes felbontású változásainak detektálása volt, ezért az eredmények jól összehasonlíthatóak a 8.2.5. pontban ismertetett, az egyes évtizedek leggyakoribb szavait tartalmazó konzekvenciákkal. A tárgyszavakkal kapcsolatos vizsgálódások esetében ugyanúgy az egyes cikkek automatikus kulcsszavazása (8.3.3-as pont) során alkalmazott algoritmusokat (pl. khí-négyzet próba, közös információtartalom) használtuk. A korábban már részletesen tárgyalt gyakorisági értékekhez hasonlóan, az egyes kulcsszavakhoz egy-egy numerikus mérőszámot rendelő eljárások eredményeképpen itt is azok egymáshoz viszonyított arányossága került megállapításra, amely táblázatokból azután ugyanúgy előállíthatóvá váltak a korábbi módszerek szerinti szófelhők.

A következő példa segítségével szemléltetjük, hogy az elemzések során miért alkalmaztunk különböző adatforrásokat és módszereket, előállítva ezzel a nagyszámú grafikus kimenetet. A folyóirat egyszerü lapozgatásából kitűnik, hogy a könyvismertetéseknek a lap életében végig nagy szerepük volt, arányuk folyamatosan magas, a teljes időszakban a folyóiratban megjelent cikkek majdnem harmada ebbe a müfaji kategóriába sorolható. A Contenta adatbázis tárgyszavaiból kiderül, hogy az elemzésbe bevont 6574 darab cikkből 1934

darab biztosan valamilyen könyv, könyvrészlet, folyóiratcikk vagy valamilyen tanulmány ismertetése. Az 1993-ban kiadott repertóriumban ezeknek a recenzióknak csak egy része azonosítható leíró ismertetőként, mert nem kaptak erre utaló egységes tárgyszót, ehelyett különböző tárgyszavak alá lettek besorolva. A legnagyobb ilyen kategóriát, az ötszázat 
valamelyest meghaladó elemszámmal a „Lapszemle” kulcsszó jelenti. Ha mindkét hivatkozott adatforrást megvizsgáljuk, továbbá mindezt kiegészítjük a saját kutatásunk keretében kapott eredményekkel, akkor sokkal teljesebb képet kaphatunk a folyóirat több mint százéves tartalmi reprezentációjáról, mintha csak egy-egy forrásra alapoztuk volna a kutatást.

\subsubsection{A repertórium tárgyszavai}

A rendelkezésre álló adatforrásokból fakadóan a repertórium tárgyszavait ábrázoló szófelhőket három különböző módszer szerint tudtuk előállítani: az egyes tárgyszavakra vonatkoztatott egyszerü gyakorisági értékek, a kölcsönös információtartalom eljárás alapján megállapított mérőszámok és a khí-négyzet próba alapján előállított, egyes kulcsszavakra vonatkozó értékek szerint. A repertórium tárgyszavainak esetében a cikkek tartalmát nem vizsgáltuk, mivel maguk a tárgyszavak nem feltétlenül szerepelnek magukban a dokumentumokban (pl. „Egyiptom oktatásügye”). Emiatt azok a releváns, de a dokumentumokban le nem írt (azaz abból ki nem nyerhető) kifejezések jogtalan hátrányba kerültek volna más, kinyerhető kulcsszavakhoz képest. A repertórium tárgyszavait és az egyes cikkek viszonyát tehát úgy kezeltük, mintha azokban kizárólag a tárgyszavak lettek volna leírva, a minőségi mutatókat ez alapján számoltuk ki.

A gyakoriságvizsgálatokhoz hasonlóan a következőkben tíz évtized (az 1950-es évek és a 1994 utáni időszak kimarad) népszerü és kevésbé népszerü tárgyszavaiból megalkotott szófelhőkön keresztül válik követhetővé az a nagyívü változás-fejlődés, amely a Magyar Pedagógia folyóiratot folyamatosan jellemezte. A tárgyszavak a magasabb szintü kategóriaalkotás megléte miatt pontosabb eredményekkel szolgálnak, mint a teljes szövegen alapuló egyszerü gyakoriságvizsgálatok. A kulcsszavakat vizsgálandóan is élhetnénk az abszolút jellegü, összeszámoló típusú gyakoriságvizsgálatokkal, ahol csupán az adott évtizedben előforduló kulcsszavak számossága kerülne összeadásra, a példa kedvéért az 55. ábra ez alapján a megfontolás alapján készült. Azonban a későbbiekben kerülnénk ezt a módszert, helyette a kölcsönös információtartalom és a khí-négyzet próba eljárások alapján előálló mérőszámok alapján készült ábrákat közöljük. A két technika lényegét a differenciálás szó írja le leginkább: esetünkben az egyes évtizedeket fogja megkülönböztetni egymástól, azoknak a hangsúlyos kulcsszavaknak a kiválasztásával, amelyek az adott évtizedre különösen jellemzőek voltak, a többi évtizedre pedig kevésbé. Más megfogalmazásban úgy is mondhatnánk: a szófelhőkön az adott korszak „forró témái” szerepelnek. Mivel a két eljárás lényegében hasonló elveken alapul, így a kimeneteik között nagy eltérés általában nem 
tapasztalható, ahogyan ez az 56. és 57. ábrán össze is hasonlítható. Mindezek figyelembevételével (csak a példa kedvéért szereplő első évtizedet kivéve), elsősorban helytakarékossági megfontolásból a repertórium tárgyszavait illetően csak a khí-négyzet eljárás kimenete alapján készült szófelhőket közöljük.

Az első vizsgált éveket az 1890-es évtized jelentette, itt a különböző eljárások kimenetét összehasonlítandó, három ábrát is közlünk ugyanabból az időszakból. Ezeken látható, hogy a nyelvtanítás és a tantervekkel kapcsolatos témák mindhárom ábrán hangsúlyos szerepet töltenek be. Az egyszerü, a kulcsszavak gyakoriságán alapuló ábra esetén ezek mellett még a különböző történeti jellegü (nevelés- és iskolatörténet) témák töltenek be fontos szerepet, amelyek azonban a többi évtizedtől való megkülönböztetést is figyelembe vevő ábrákon már egyáltalán nem hangsúlyosak. Ez a módszerek lényegét illusztrálandó abból fakad, hogy a neveléstörténeti jellegü témák ebben az évtizedben hiába fordulnak elő viszonylag magasabb abszolút számban, számuk egyáltalán nem bizonyul kiugrónak a minta többi évtizedét tekintve, bizonyítva ezáltal, hogy az 1890-es években a neveléstörténeti témáknak nem volt kiemelt jelentősége, tehát a XIX. század végére viszonylag kevéssé volt jellemző a múltba fordulás.

Ebben az időszakban előforduló különlegesebb témák közül az Egyiptom oktatásügyével foglalkozó cikkeket kell kiemelnünk, ez a téma annyira ennek az évtizednek a sajátossága, hogy a későbbiekben elő sem kerül igazán, ekkor azonban hat cikkben is foglalkoznak a témával a szerzők, emiatt nyilvánvalóan az ábrákon is hangsúlyosan megjelenik a téma. A különböző országok oktatásügyével foglalkozó cikkeknek egyébként is nagy divatja van a korban: Egyiptom mellett előfordul Németország, Franciaország, Amerika, Görögország, Málta és Svájc is. A trendet párhuzamba állítva a nyelvtanítással foglalkozó témák túlsúlyával, elmondhatjuk, hogy a folyóiratban publikáló szerzőknek nagyon fontos volt ebben az időszakban a világhoz való felzárkózás és az ott zajló trendek nyomon követése, és a diákok arra való pallérozása a nyelvtanításon keresztül, hogy az ország felzárkózzon a fejlettebb államokhoz. Mindezeket a megállapításokat történelmi kontextusba helyezve, nem meglepő a dolog, hiszen erre valóban ebben az időszakban volt a legnagyobb esélye az országnak.

A tanterv, tankönyv, tanügy, tanfelügyelet, oktatásügy, adminisztráció, középiskola müködése kulcsszavak esetében megfigyelhető a szabályozási és szervezési háttérrel kapcsolatos kérdések tárgyalásának fontossága is. Irodalmi témák szintén szép számmal előfordulnak: magyar irodalom, Homeros, Iliász, Robinson, verstan, müelemzés, ifjúsági olvasmányok, ifjúsági irodalom, drámairodalom, stb. A természettudományok már jóval szerényebben képviseltetik magukat: természettan, ásványtan, állattan, földrajztanítás. Talán meglepő, de számolással kapcsolatos témák egyáltalán nem kerülnek elő. A főbb kategóriák 
közül a vallási zenei és müvészeti oktatás, illetve a testi nevelés témái fordulnak még elő.

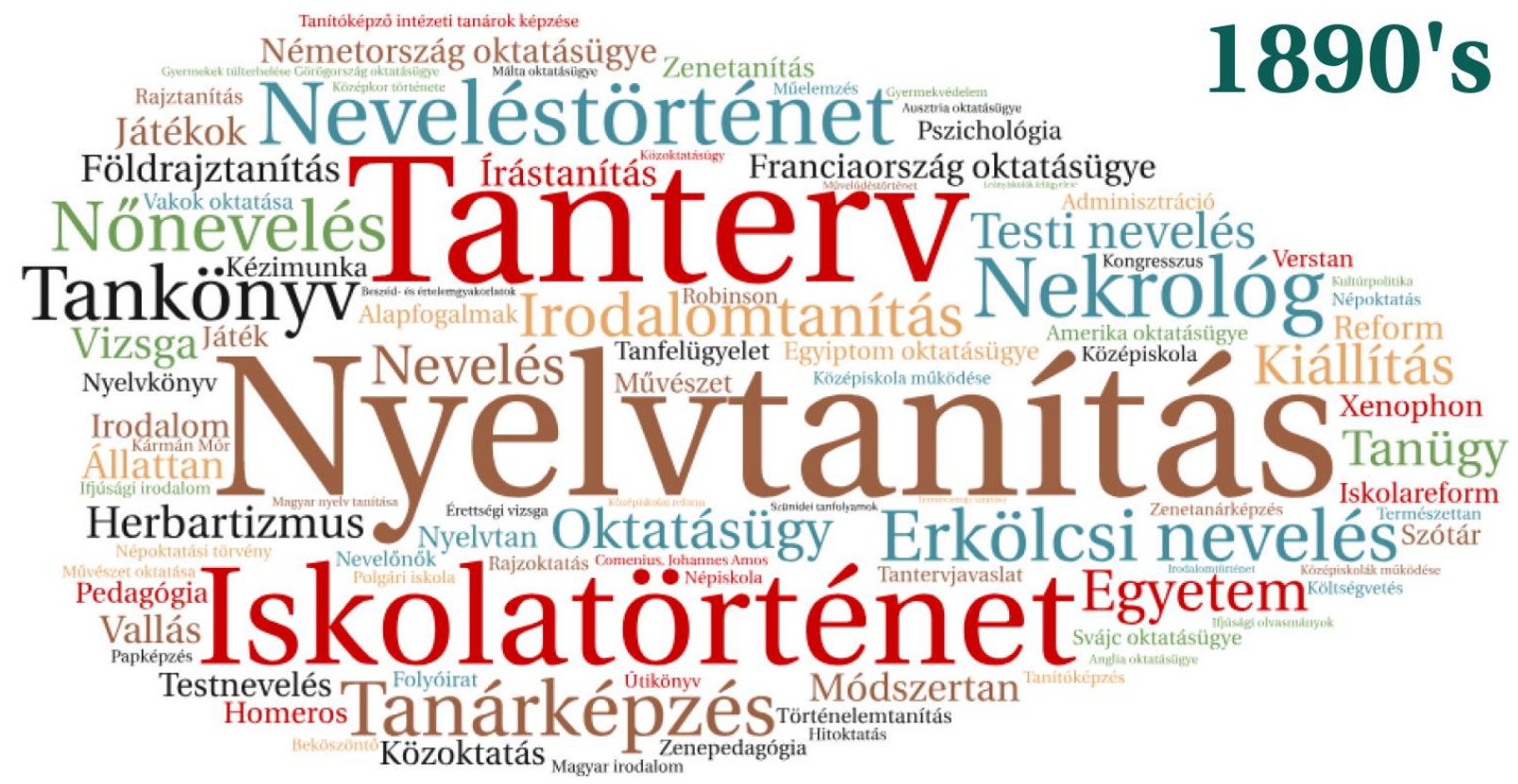

55. ábra

A Magyar Pedagógia repertórium száz leggyakoribb kulcsszava az 1892-1899 közötti évekböl

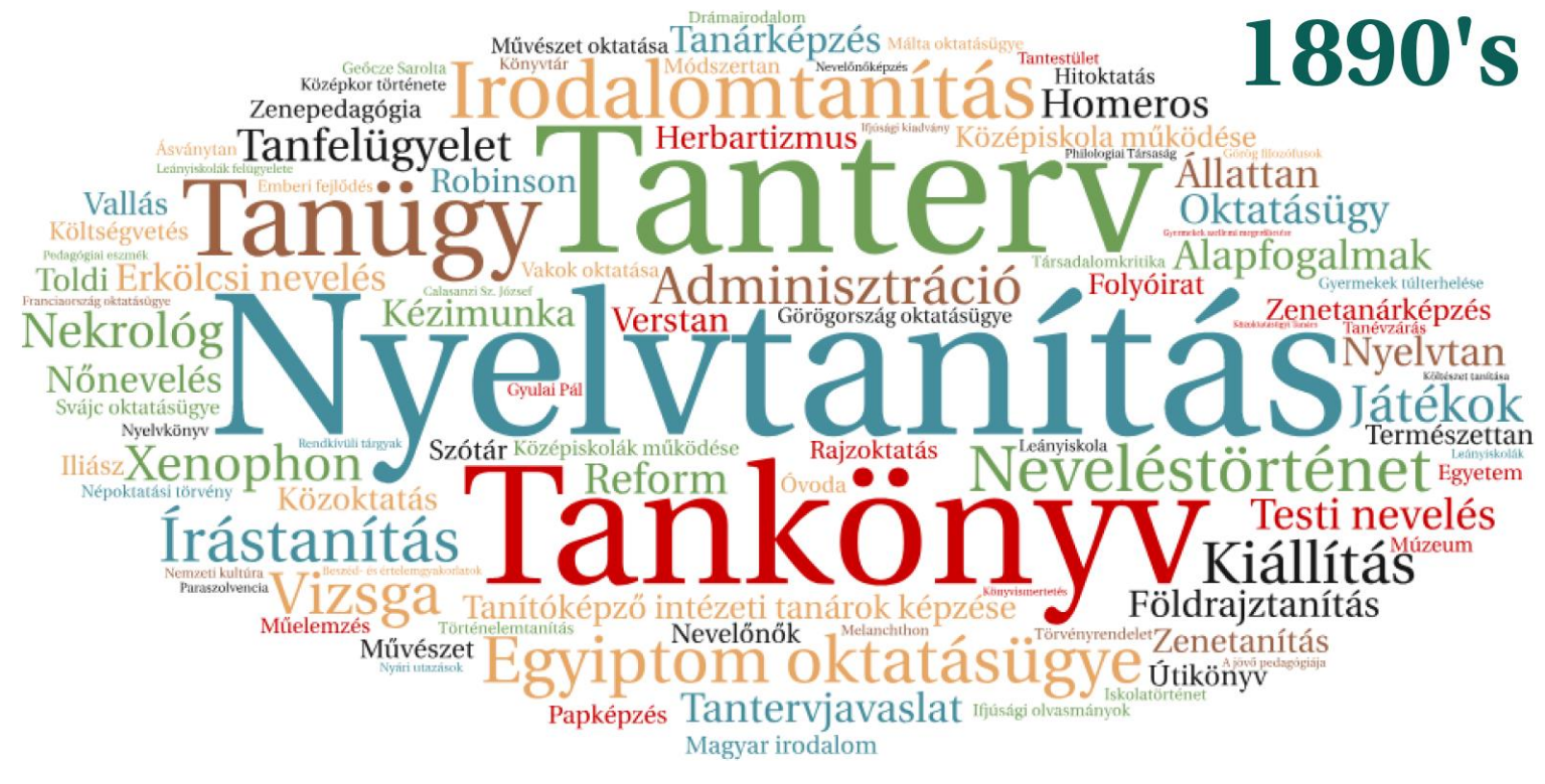

56. ábra

A Magyar Pedagógia repertórium száz leghangsúlyosabb kulcsszava az 1892-1899 közötti évekböl a kölcsönös információtartalom vizsgálati módszer alapján 


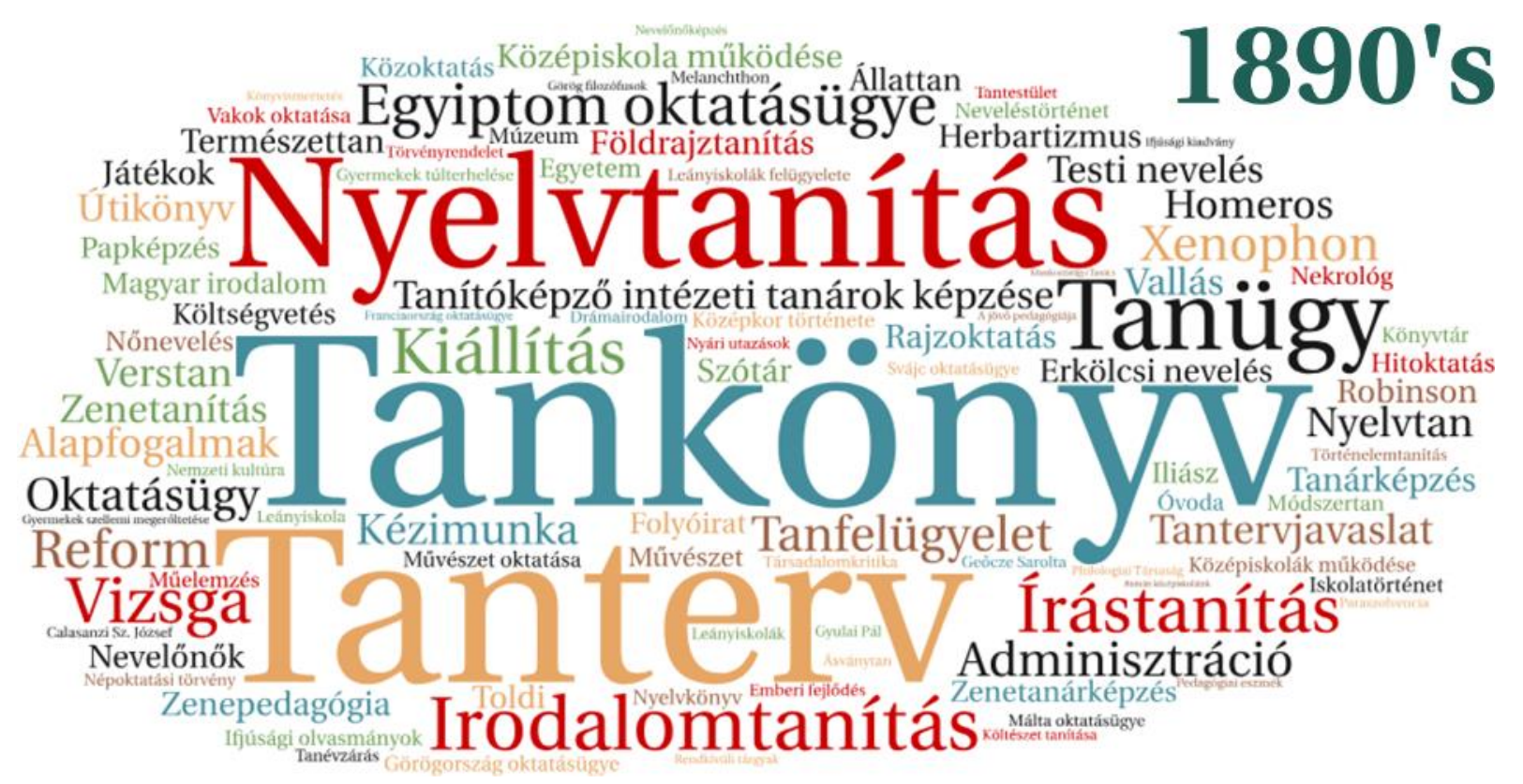

57. ábra

A Magyar Pedagógia repertórium száz leghangsúlyosabb kulcsszava az 1892-1899 közötti évekböl a khínégyzet vizsgálati módszer alapján

Az 1900-as évektől kezdődően, évtizedenként csak a repertórium kulcsszavain alkalmazott, a khí-négyzet vizsgálati eljárás eredményeképpen születetett ábrákat közöljük. Ahogyan az az 58. ábráról leolvasható, a XX. század első évtizedében különböző tudományos disszeminációs műfajok jelentek és erősödtek meg. A három legnépszerübb téma rendre: értekezések, lapszemle, könyvszemle. A különböző országok oktatásügyei még mindig jelen vannak, jelentőségük talán valamelyest háttérbe szorult más témák mellett, de Németország, Ausztria, Amerika oktatásügye még mindig kiemelt témák, ahogyan a kínai nevelés is. A matematika tanítása megjelent a második évtizedben, sőt, egyből elöre is tört, ahogyan a természettudomány oktatása kulcsszó is megelőzi például a neveléstörténetet az évtizedben. A múltba fordulást inkább az antik idők felé való figyelem jelenti olyan kulcsszavakon keresztül, mint például a fillozófiatörténet, filológia, ókor. A meglepő témák közül a szexuális felvilágosítás és szexuális nevelés témákat kell kiemelnünk. Olyan haladó témák is megjelentek, mint például a gyermektanulmányi mozgalom, vetítőgép, jobb- és balkezesség, tengerkutatás vagy az erdei iskola.

A következő évtizedet az 1910-es évek jelentik, az évtized releváns kulcsszavait az 59. ábrán találjuk. Az előzetes várakozásoknak megfelelően hangsúlyosan megjelennek a háborúval kapcsolatos témák: háború, békére nevelés, háború hatása, állampolgári nevelés, háború és iskola, politika és iskola, Bosznia-Hercegovina oktatásügye, Poroszország oktatásügye valamint háború és kultúra. A már korábban tapasztaltakhoz hasonlóan szintén megjelennek haladó témák is: kísérleti pedagógia, nemzetközi mozgalmak, kriminálpedagógia, 
koedukáció, pubertás, mentálhigiénia. Az irodalmi témák valamelyest talán ismét elötérbe kerülnek, különösen kiemelendőek a mesével kapcsolatos cikkek. A filozófia is több részterülettel képviselteti magát, a természettudomány azonban ismét visszaszorulóban van. $\mathrm{Az}$ eddigi évtizedeket tekintve ez tekinthető a neveléstörténet legerősebb évtizedének. Végül kiemelendőek még a nőneveléssel kapcsolatos témák, például a felső leányiskola, leányoktatás, nőnevelés kulcsszavak.

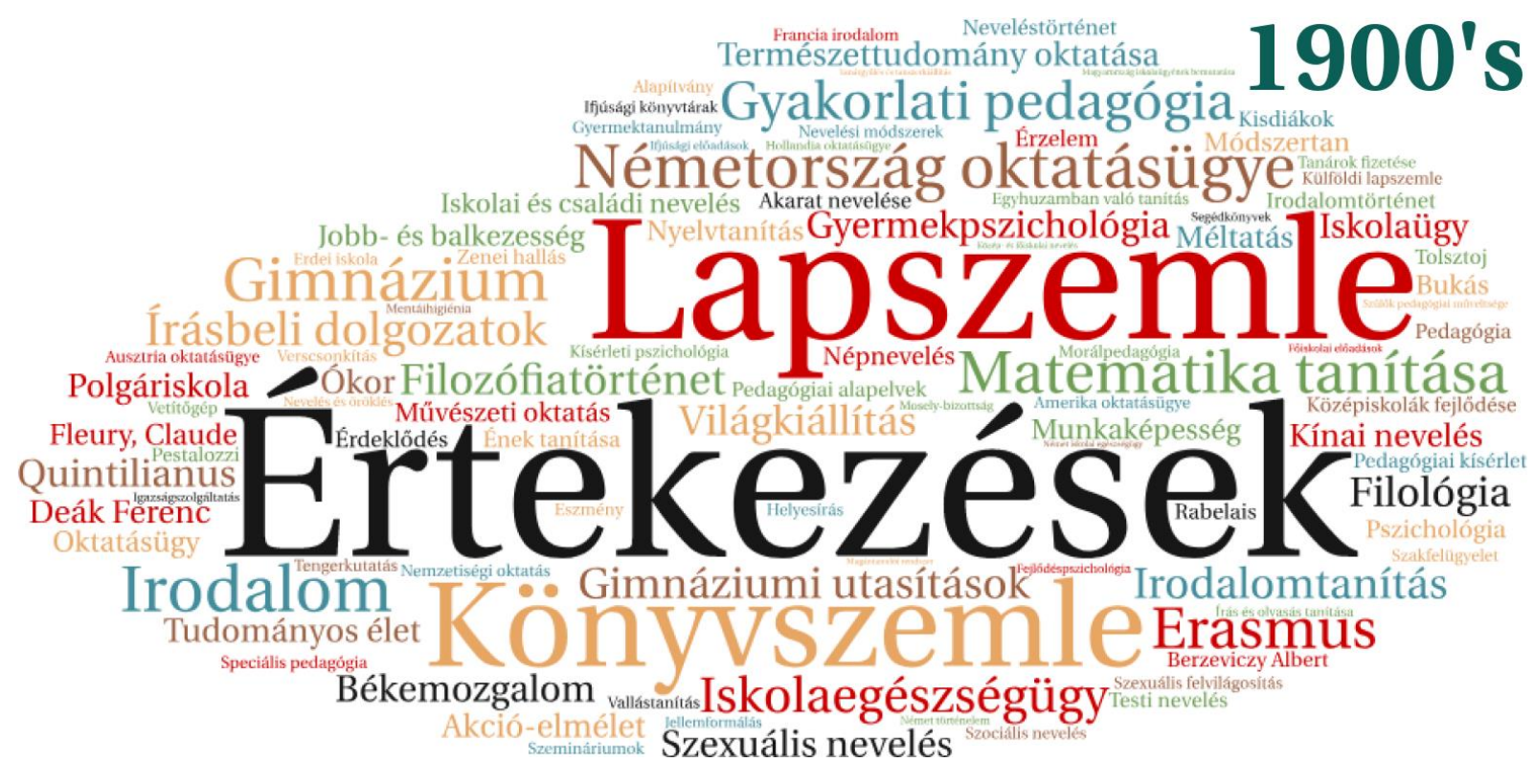

58. ábra

A Magyar Pedagógia repertórium száz leghangsúlyosabb kulcsszava az 1900-1909 közötti évekböl a khí-négyzet vizsgálati módszer alapján

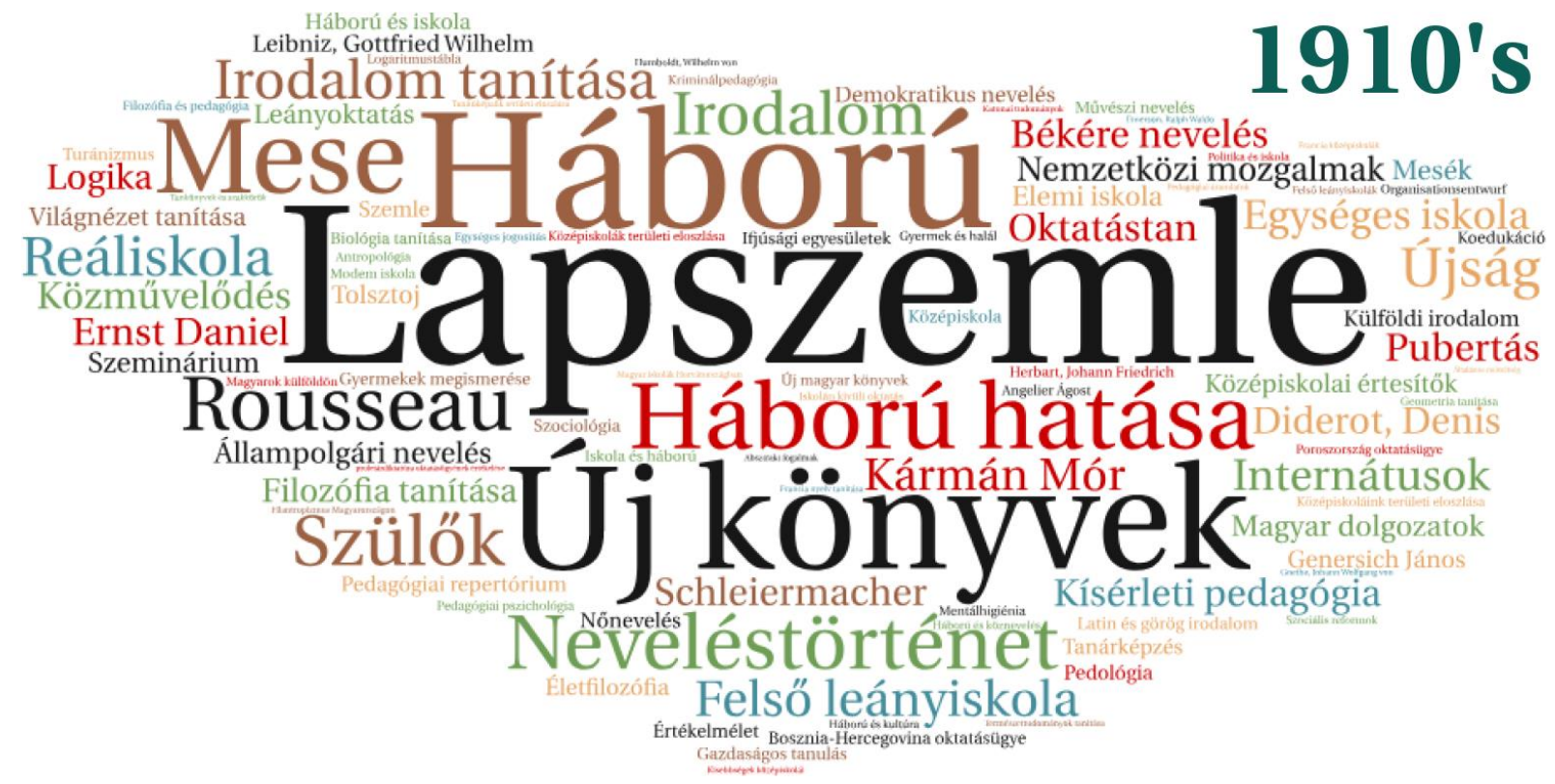

59. ábra

A Magyar Pedagógia repertórium száz leghangsúlyosabb kulcsszava az 1910-1919 közötti évekböl a khi-négyzet vizsgálati módszer alapján 
Az 1920-as éveket az eddigiekhez képest a témák viszonylagos egyenletes eloszlása jellemzi, ez a 60. ábrán ott érhető tetten, hogy viszonylag egyforma betümérettel jelennek meg a hangsúlyos témák is: nincs 2-3 kiemelkedő főtéma, ahogyan az az eddigi évtizedekre jellemző volt. Jelentős szerep jut a könyv- és folyóirat-ismertetéseknek, illetve jó néhány személynév is megjelenik a repertórium tárgyszavai között: Adolphe Ferriére, Kornis Gyula, Alfred Adler, Helen Parkhurst, Johann Heinrich Pestalozzi, Nemesné Müller Márta, Pósa Lajos, Leopold Ziegler, Heinrich von Kleist, Thurzó Imre, Molnár Oszkár, Teleki József, Sík Sándor, stb. Emellett elökerülnek olyan készségterületek, mint a gyermekrajzok, technika. A nyelvtanulás nagymértékben visszaesik, ahogyan a korábbi évtized felíveléséhez képest a neveléstörténet is. Hangsúlyos témaként jelentkeznek még a különböző lelki élettel kapcsolatos témák: női lélek, lelki fejlödés, önismeret. A különböző országok oktatásügyének tárgyalása szinte teljesen eltünik, helyette olyan patriotikusabb témák jelennek meg, mint a nemzeti zászló, nemzeti szellem, területi revízió, Védelmi Liga, nevelés és nemzeti értékek, valamint kultúra és politika. Tetten érhető néhány, korábban kevésbé jellemző, felsőoktatással kapcsolatos tárgyszó is: szabadegyetem, Mủegyetem, rektori beszéd.

A következő évtizedben (61. ábra) még mindig hangsúlyos szerep jut a recenzióknak, ahogyan az a lapszemle és az új magyar könyvek tárgyszavakból kiderül. Ezek mellett a beszámolók, értesítők és a Pedagógia lexikonnal kapcsolatos írások népszerüek. Az évtizedet leginkább meghatározó név Fináczy Ernő. Jean Piaget, Klebelsberg Kuno, H. G. Wells, John Dewey, Comenius és Pázmány Péter szintén fontos személyekként determinálják az évtizedet. Nem meglepő módon megjelenik a témák között a Harmadik Birodalom, a nemzeti szocializmus, a porosz tanárképzés, Ausztria és Svájc oktatásügye, német neveléstudomány és a Népszövetség, mint a kort történelmileg-politikailag tematizáló kulcsszavak. Ennek ellenpontjaként az emberközpontúság is hangsúlyosan jelen van, hiszen olyan kulcsszavak is előkerülnek, mint a család, szeretet, humanizmus, keresztyén nevelés, lélekrajz, emberismeret, életfelfogás. Az eddig tapasztaltakhoz képest sokat erősödnek a reál témák: kémia tanítása, számolás, földrajztanítás módszertana, földrajz tanítása, közgazdaságtan, felső kereskedelmi iskolák, természet. Az irodalom átadta a helyét a nyelvészeti témáknak, maga a nyelvtudomány kulcsszó is igen hangsúlyos, de emellé még olyanok kerülnek, mint például a beszédhiba. A közepesen reprezentáns neveléstörténet mellett megjelenik a sporttörténet témája. A pszichológiai témák szintén nem elhanyagolható módon vannak jelen: lélekrajz, zenepszichológia, jellemtípus, személyiség nevelése, stb. Először jelenik meg az ábrán a tesztek kulcsszó. 
Az 1940-es éveket tekintve (62. ábra) ismét háborús évtizedhez értünk, de az 1910-es évekhez képest talán mégis kevésbé jelennek meg ezek a témák; azért akad így is néhány, mint például a Harmadik Birodalom nevelésügye, fasiszta nevelés, Hitler-Jugend nevelése vagy Mussolini. Kevésbé direkten már sokkal inkább jelen vannak a korszellemet meghatározó témák: új német könyvek, nemzetnevelés, német nevelés, angol nevelés, Nietzsche, örökléstan, olasz didaktika, nemzetismeret, nemzet, német anyanyelvi oktatás, nevelőállam. Ezek mellett különösen hangsúlyos az évtizedben a lélektan (ill. gondolkodás-lélektan) és az egyetemtörténet témája, illetve Friedrich Fröbel pedagógiája. A neveléstörténet helyett megjelent a művelödéstörténet és a müvelödési eszmény kifejezés, illetve különösen népszerüek az évtizedben a vallási témák között a jezsuiták és a piaristák. Az antikvitás (ill. a reneszánsz) hatása is újból tetten érhető: Platón, platonizmus, görög filozófia, Ciceró, Erasmus és reneszánsz kulcsszavak. A természettudományok ismét nem mondhatóak kiemelkedően hangsúlyosnak, de azért jelen vannak: biológia oktatása, társadalomföldrajz, mennyiségtan tanítása, valamint számolás és mérés tanítása. Továbbá, a magyar mint tantárgy témái közül olyanok kerülnek elő, mint a szókincs, a helyesírás tanítása vagy az analfabéták oktatása. Új, jelentős témaként megemlítendő még a cserkészet és a háztartástan.

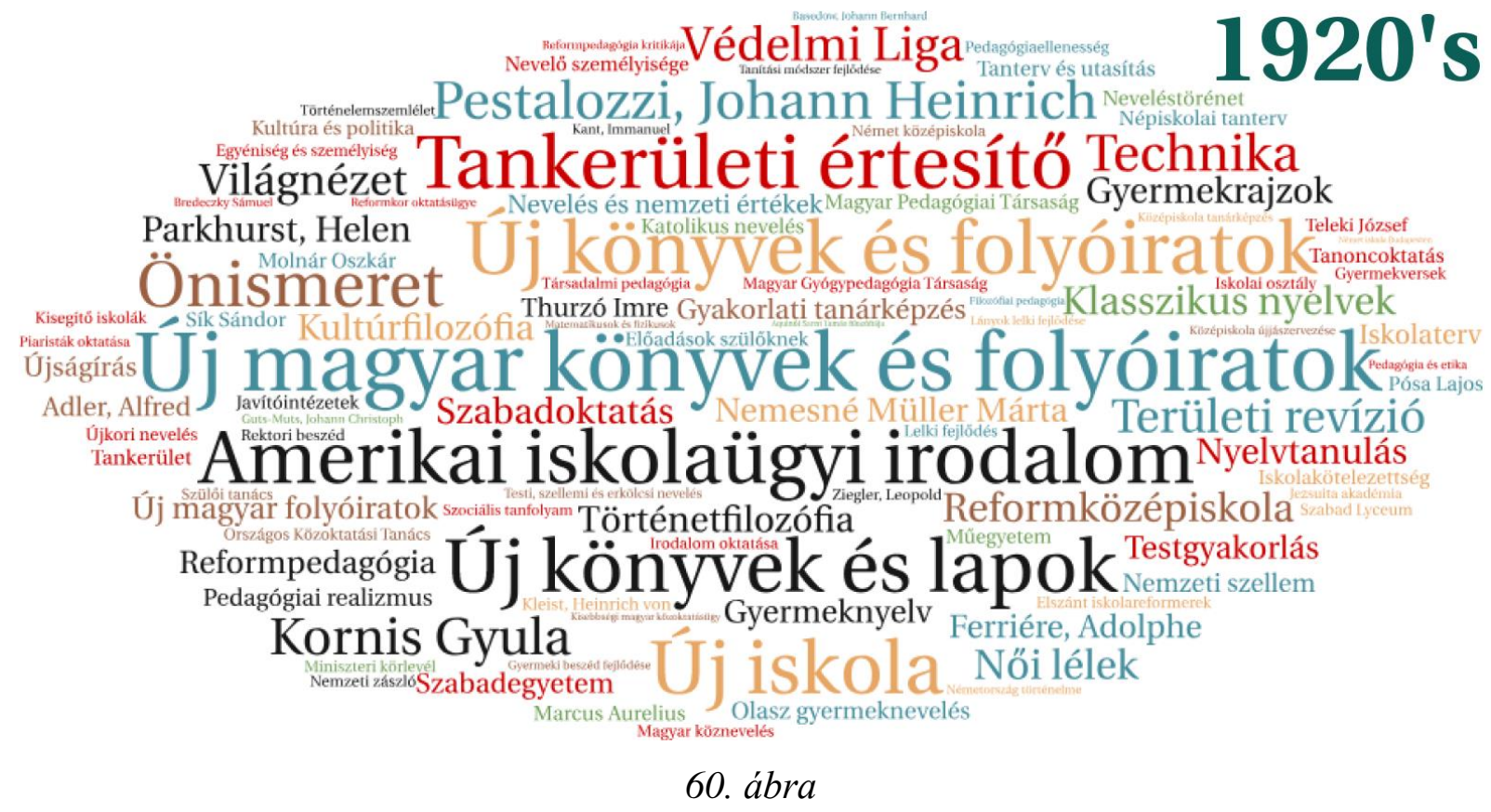

A Magyar Pedagógia repertórium száz leghangsúlyosabb kulcsszava az 1920-1929 közötti évekböl a khi-négyzet vizsgálati módszer alapján 


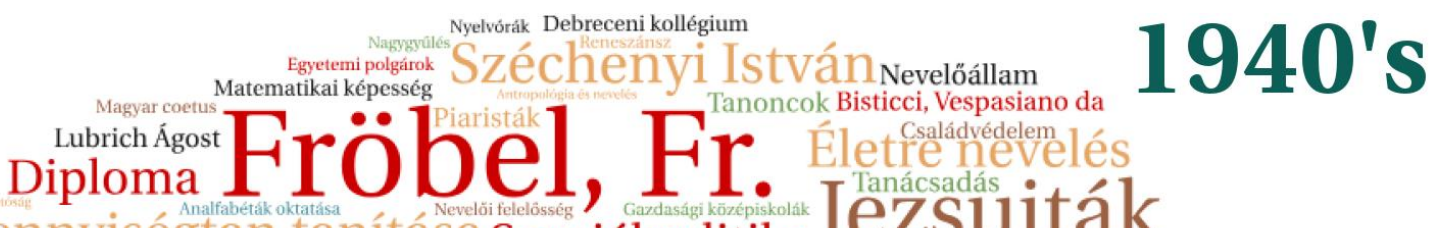

Mennyiségtan tanítása Szociálpolitika ezSuiták

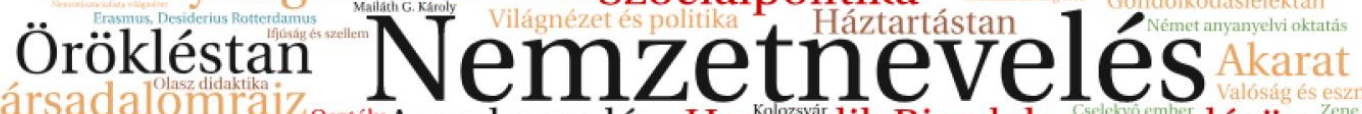

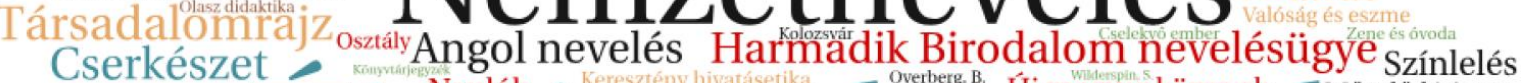

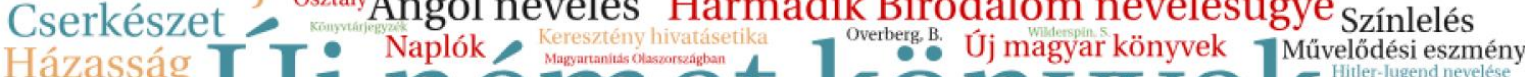
Platon Uázasság T Cicero Egyetemtörténe Egyém Platonizmus , szokincs Fasiszta nevelés

62. ábra

A Magyar Pedagógia repertórium száz leghangsúlyosabb kulcsszava az 1940-1949 közötti évekböl a khi-négyzet vizsgálati módszer alapján

A tízéves kényszerszünet után 1961-ban újrainduló lap teljesen új témákkal jelentkezett, amelyek a 63. ábráról is egyértelmüen visszaköszönnek. Az évtized legfontosabb témáját a programozott oktatás és a hozzá kapcsolódó oktató- és tanítógépek jelentik. A szocialista pedagógiai irányvonal egyértelmüen megjelent, a kulcsszavak nagyjából fele-harmada egyértelmüen ebből a szellemi irányzatból táplálkozik: szocialista pedagógia, Német 
Demokratikus Köztársaság oktatásügye, munkaerkölcs, világnézeti nevelés, szovjet pedagógia, Tanácsköztársaság, úttöröszervezet, építőtábor, marxi személyiségelmélet, felszabadulás, kommunista erkölcsi nevelés, Románia oktatásügye.

A különböző országok oktatásügyének tárgyalása ismét az érdeklődés homlokterébe került; jellemzően szocialista országokról van szó, mellettük Norvégia oktatásügye jelenik még meg, illetve a felnőttoktatás külföldön téma. Szarvas település erőteljes jelenléte magyarázatra szorul: az akkoriban ott kiteljesedő nevelőképzés magyarázza ezt a hangsúlyos jelenlétet. Ennek a történetszálnak ugyan vannak neveléstörténeti vonatkozásai is, de alapvetően ismét kevéssé jellemzi az évtizedet a neveléstörténet (a fontosabb kulcsszavak közül a népiskolai törvény, az óvodatörténet és Bessenyei György kerül még elő erről a területről). A természettudományok még mindig kevésbé reprezentálódnak, helyettük inkább olyan témák kerülnek előtérbe, mint a történelem tanítása, képzőművészeti nevelés, esztétikai nevelés. Egyelőre még csak lappangva, de újra megjelennek a nyelvek, ez példánkban az orosz és angol nyelvet jelenti. A neveléstudomány tudományos igényü müvelésének elöretörését mutatja az olyan kulcsszavak megjelenése, mint a pedagógiai tanulmányok, neveléstudományi kutatások, oktatási folyamat, elmélet és gyakorlat, tanulásmódszertan, stb. További érdekes és előremutató témákat képviselnek a túlterhelés, a kifáradásos neurózis, aktivizálás, affektivitás kulcsszavak.

Az 1970-es évek egyik legjelentősebb fejleménye a szocialista pedagógiai irányvonal témáinak viszonylagos mérséklődése, illetve a neveléstörténeti témák elöretörése. A neveléstörténet a harmadik legjelentősebb kulcsszóvá lépett elő a 64. ábrán. Ezt megerősítendő, további ilyen tematikájú, kiegészítő kulcsszavak is nagy számban feltünnek az ábrán: Ratio Educationis, Comenius, Orbis Pictus, II. Rákóczi Ferenc, Kolozsvári Jezsuita Iskola, Nagy László, stb. Természetesen a szocialista nevelési elveket tükröző témák sem tüntek el teljesen, hiszen olyan kulcsszavakkal találkozhatunk, mint a kommunista nevelés, marxista nevelésfilozófia, marxista pedagógia, Lenin, szovjet nevelésügy, szocialista ember. Számuk ugyanakkor szembetűnően csökkent az előző évtizedben tapasztalhatókhoz képest. Az általános nemzetközi helyzet tárgyalása is nyitottabbá vált a korábbiakhoz viszonyítva, hiszen a szocialista országok (Románia, Lengyelország) mellett szerepel Ausztria, Svédország oktatásügye is, sőt, olyan univerzális témák, mint az oktatás világhelyzete vagy az UNESCO világszervezet szerepe. További jelentős témacsoportokat képvisel a referáló irodalom, amely érinti a külföldi folyóiratokat, a külföldi, illetve magyar könyveket és egyéb tudományos közleményeket. A neveléstudomány metaszintjének témáiról a kutatásmetodika, a tudományos minősítés, a teljesítménymérés, a team-oktatás, a metodológia témái tanúskodnak. A nyelvtanítás és a természettudományok még mindig elég szerényen képviseltetik magukat a 
témák palettáján, helyettük inkább olyan általános témák vannak jelen nagyobb számban, mint a személyiségelmélet, tantárgypedagógia, köznevelés fejlesztése, általános iskola, nevelésszociológia, nevelésfilozófia, közösség.

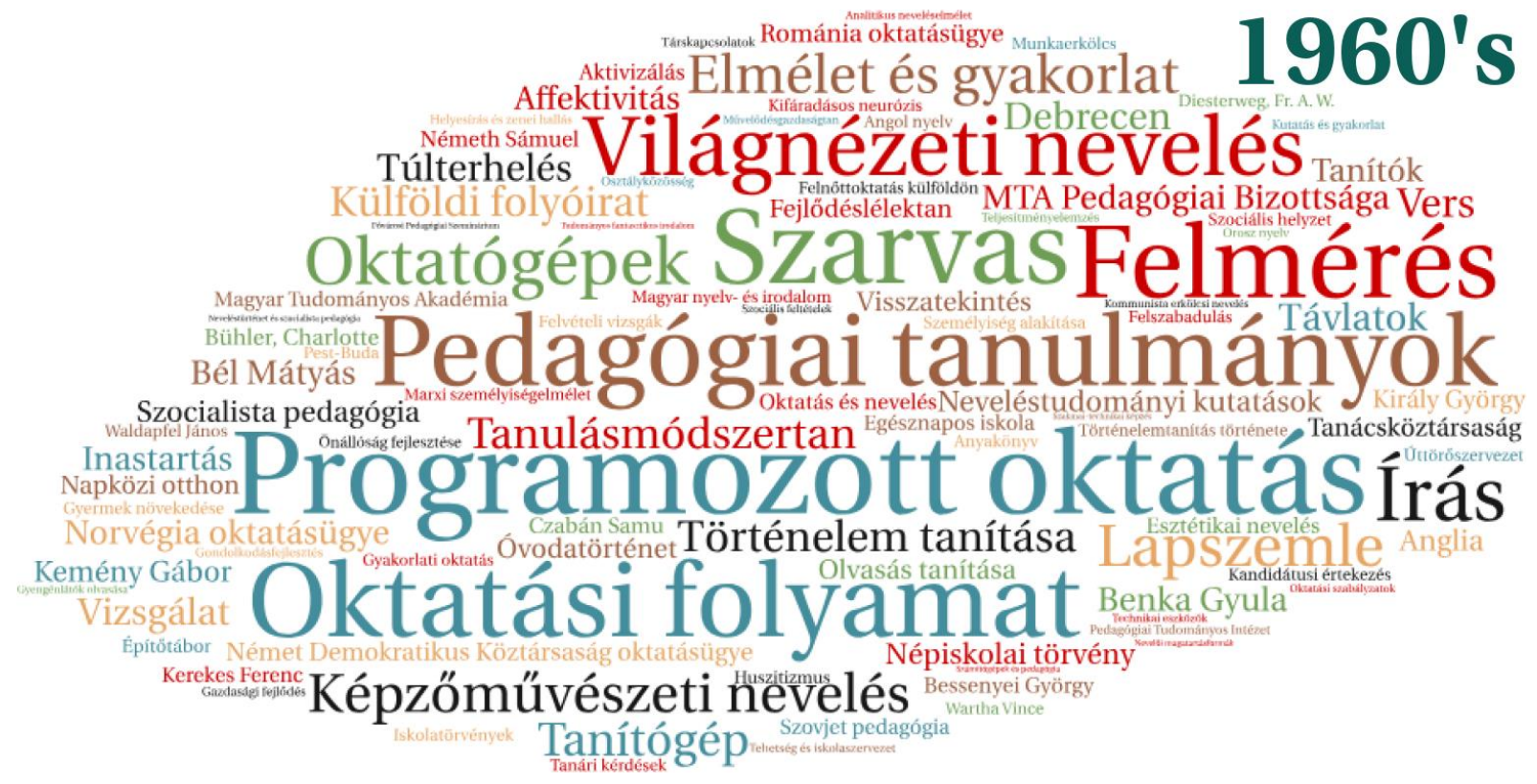

63. ábra

A Magyar Pedagógia repertórium száz leghangsúlyosabb kulcsszava az 1961-1969 közötti évekböl a khi-négyzet vizsgálati módszer alapján

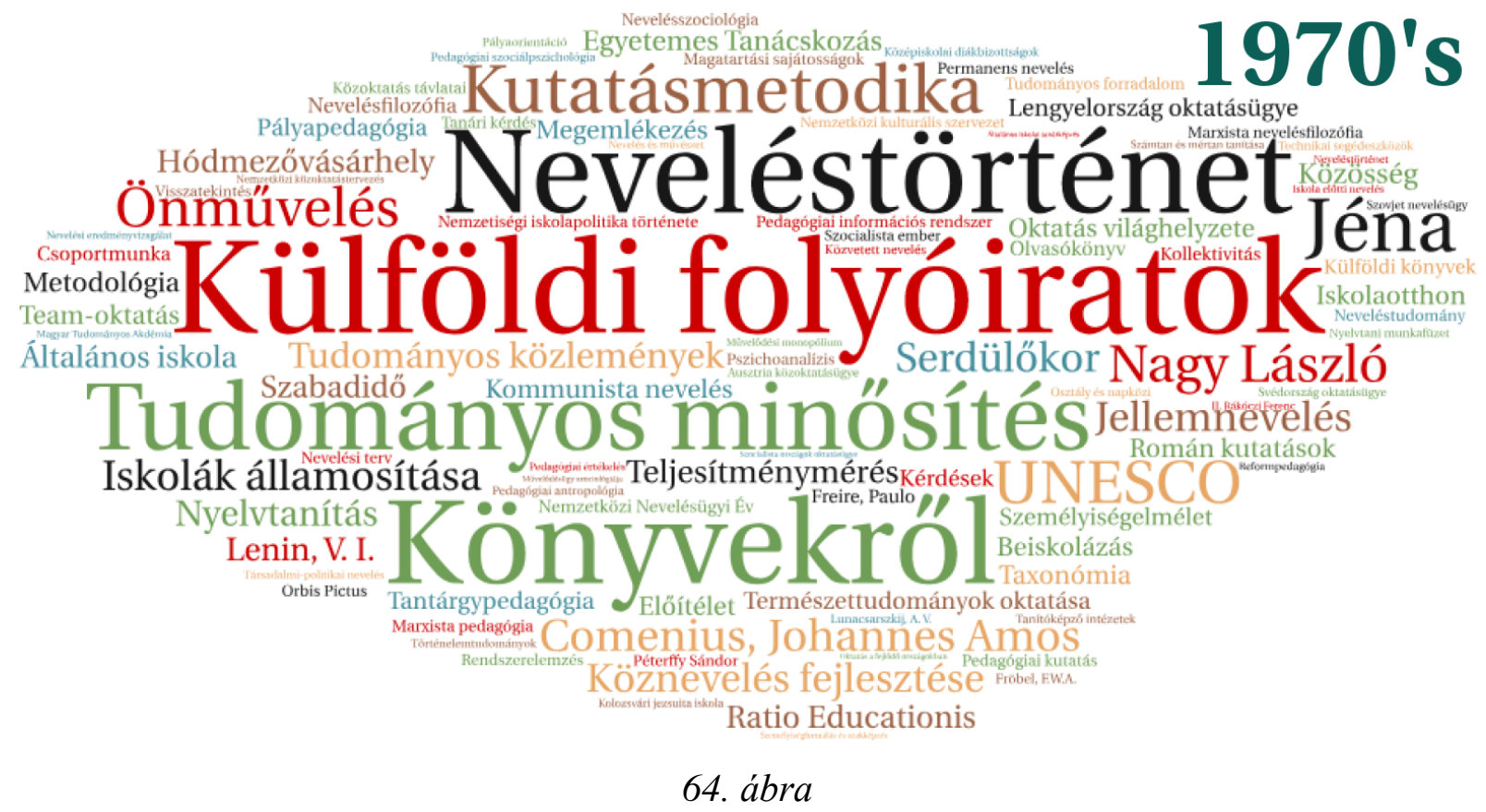

A Magyar Pedagógia repertórium száz leghangsúlyosabb kulcsszava az 1970-1979 közötti évekböl a khí-négyzet vizsgálati módszer alapján 
Eredményeink alapján (65. ábra) az 1980-as évek a neveléstörténet évtizede, hiszen egyetlen másik évtizedben sem voltak ennyire hangsúlyosak a neveléstörténeti témák, mint ekkor. A neveléstörténet, mint önálló kulcsszó mellett olyan további kulcsszavak is bizonyítják a téma központi szerepét, mint a reformkor, neveléstörténeti konferencia, Herbart, Tettamanti Béla, Entwurf, néptanítók, dualizmus, pedagógiatörténet. Szintén nagyon hangsúlyosan megjelennek, mintegy az IKT terület megalapozásaként az informatikával kapcsolatos kulcsszavak: informatika, számítástechnika, audiovizuális eszközök. Emellett a következő évtizedek hangsúlyos témáinak másik előfutáraként szintén kiemelendőek a motivációval kapcsolatos írások a motiváció, tanulási motiváció, önálló tanulás kulcsszavak mentén. A szocialista nevelési eszmény kulcsszavai szinte teljesen eltüntek az 1980-as évekre, egyedül Makarenko neve emlékeztet bennünket a témára. Áttörést ugyan még nem ért el, de valamelyest erősödött a nyelvtanulás (nyelvtanítás, kétnyelvűség kulcsszavak), bár az egyes önálló nyelvek nevei továbbra sem reprezentálódnak. Fontos szerep jut az évtizedben a szakképzés tárgyalásának, a korábbiakban (és a későbbiekben sem) ez a téma soha nem kapott ilyen kitüntetett szerepet. A közoktatás témái szokás szerint jelen vannak: köznevelés, közoktatás története, óraelemzés, értékelés, iskolai esélyegyenlőség, személyiségfejlesztés, stb. témákon keresztül. A felsőoktatás valamelyest szerényebben, az ELTE és a felsőoktatás kulcsszavak által képviselteti magát, jelentősen kisebb súllyal, mint a másik két képzési szint.

Mivel ezen fejezet vizsgálatának mintájául szolgáló repertórium csak az 1991-es évvel bezárólag tartalmaz kulcsszavakat, ezért az 1990-es évekre vonatkozó ábra az elemzésbe potenciálisan bevonható két év vonatkozásában torz eredményeket mutatna, így erről az évtizedről már nem közlünk a repertórium kulcsszavain alapuló ábrát. Ehelyett az 1990-es és ezt követő évtizedek vonatkozásában a Contenta repozitórium tárgyszavain és az automatikus kulcsszavazás eredményein alapuló ábrák szolgáltatnak megfelelő tanulságokat a folyóirat tartalmáról az utolsó huszonöt évből, melyeket a következő két fejezetben szerepeltetjük. 


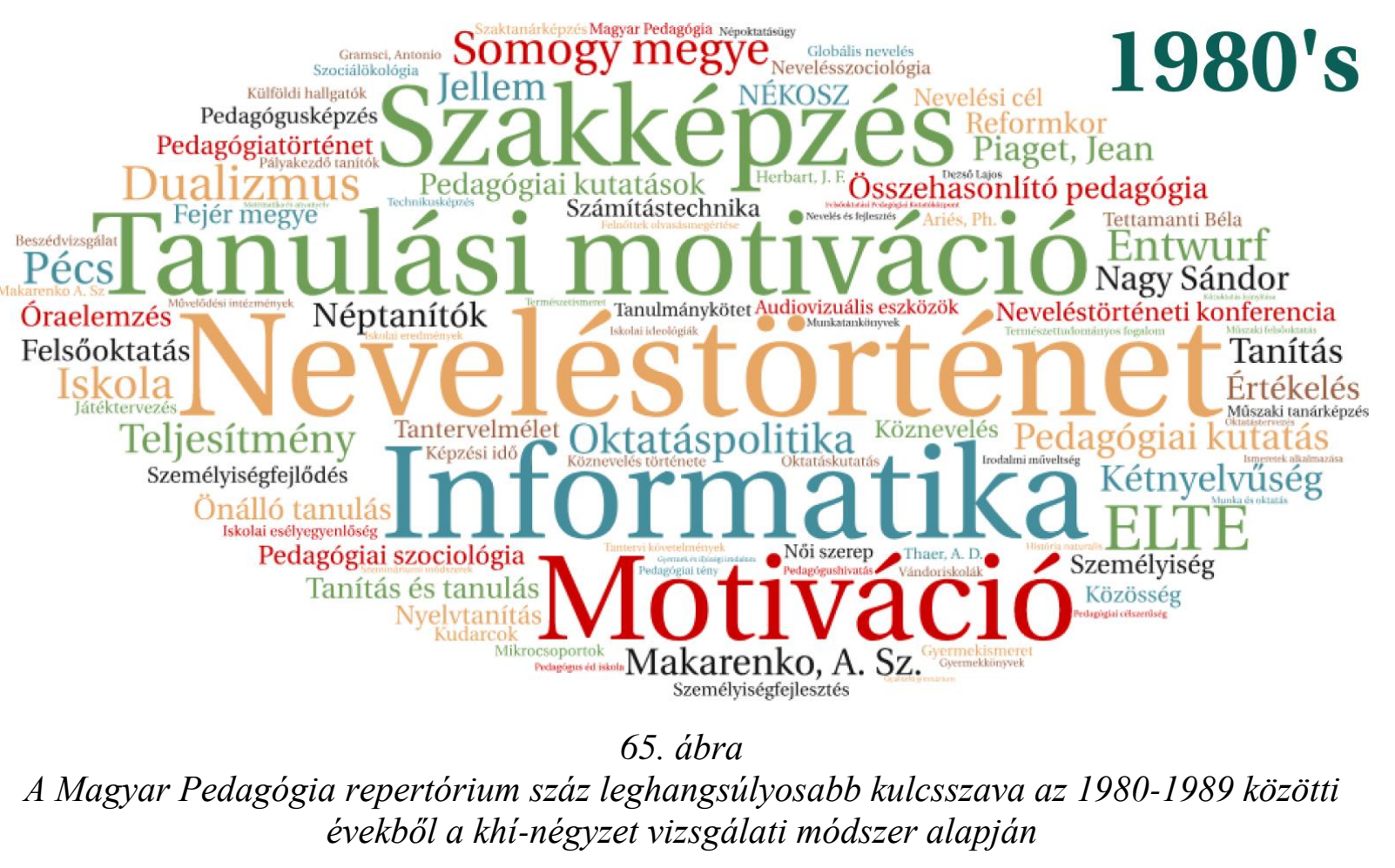

\subsubsection{A Contenta repozitórium tárgyszavai}

Hasonlóan az előző pontban ismertetettekhez, az SZTE Klebelsberg Könyvtár Contenta adatbázisának tárgyszavai esetében is háromféle adatforrás szerint voltak megalkothatóak az ábrák: az egyes tárgyszavakra vonatkoztatott egyszerü gyakorisági értékek, a kölcsönös információtartalom eljárás alapján megállapított mérőszámok, és a khí-négyzet próba során előállított, egyes kulcsszavakra vonatkozó értékek alapján. A Contenta tárgyszavainak esetében az ábrák a kölcsönös információtartalom módszer alapján születtek, kivéve az utolsó évtizedet, ahol a példa kedvéért ismét szerepel mindhárom módszer alapján készült ábra. A repertóriumnál már ismertetett módon, a Contenta kulcsszavainak esetében sem került be a mintába a cikkek tartalma, mivel maguk a tárgyszavak nem feltétlenül ugyanabban a formában szerepelnek a dokumentumokban (pl. „Nők helyzete”), ami miatt azok a releváns, de a dokumentumokban le nem írt (azaz abból ki nem nyerhető) kifejezések jogtalan hátrányba kerültek volna más, kinyerhető kulcsszavakhoz képest. Általánosságban elmondható ennek a szakasznak a kulcsszavairól, hogy mivel egy univerzális megközelítésü könyvtári tárgyszórendszer részét képezik, ezért összességében általánosabb kifejezéseket tartalmaznak, mint ami a repertórium esetében tapasztalható, ezáltal ez egyes tárgyszavak által definiált kategóriák mérete is nagyobb. Mindez azt eredményezi az ábrákon, hogy az egyes évtizedekben valóban hangsúlyos témák így még hangsúlyosabbá válnak.

Ahogyan az a 66. ábráról leolvasható, az 1890-es évtized legfontosabb témáit az 
oktatásügy, azon belül is a közoktatás jelentik. Ezt a képet árnyalják olyan további kapcsolódó témák, mint a tantervek, a középiskolák ellenőrzése (lásd még szakfelügyelet, tanfelügyelet) és a leányiskolák. Fontos szerep jut a nyelvoktatásnak: több európai modern nyelv (német, francia) és a klasszikus nyelvek (görög, latin) is szerepelnek az ábrán. Olyan speciálisabb jellegü témák is megjelennek, mint a vakok tanítása, a papképzés és hittudományi oktatás, valamint a zenetanárképzés. A tanárképzés természetesen önállóan is szerepel, ahogyan a zene- és művészeti nevelés is megjelenik önálló tárgyszavakkal. A készségtárgyak egyébként is fontosak, hiszen a zenetanítás mellett megjelenik a testnevelés és a rajz is. A klasszikusabb iskolai tárgyak, mint például az írás-olvasás tanítása, geometria és fizika sem maradnak le az ábráról. Az igazi kuriózumok közül a repertórium tárgyszavainak esetében is elökerülő egyiptomi oktatást a máltai oktatás tárgyszavak egészítik ki. Már ekkor is felmerülő kérdést jelent a zsidó vallású tanulók oktatása. A neveléstörténet egyelőre nem tünik jelentős tényezőnek.

A következő, 1900-as évtized legfontosabb témái a pedagógia, oktatásügy és magyar irodalom területekröl kerülnek ki (lásd 67. ábra). A bölcsészettudományoknak egyébként is hangsúlyos szerep jut az évtizedben, melyről a következő tárgyszavak tanúskodnak: filológia, bölcsészettudományok, görög irodalom, magyar nyelv tanítása, müvelődéstörténet, irodalomtanítás, etimológia, valamint filozófia története. Ha a fentiek alapján címkéznünk kellene az egyes évtizedeket, akkor az 1900-es évtized az ,irodalom évtizede” címkét kaphatná, ugyanis a magyar mellett jó néhány más ország irodalma is képviselteti magát az ábrán: francia, norvég, görög. Ugyanakkor kimutathatóan megjelennek a természettudományi témák is: matematika tanítása, elemi matematika, kémia, földrajz tanítása, tengerkutatás, természettudomány. A Contenta tárgyszavai megerősítik a repertórium kulcsszavainak elemzési részében közölt eredményeket a szexuális neveléssel kapcsolatos témák vonatkozásában, hiszen olyan tárgyszavak mutatják a téma népszerüségét, mint a szexuális felvilágosítás, nemi élet, nemi felvilágosítás, nemi erkölcs. Emellett további, haladónak mondható témák is megjelennek, például tanulmányi kirándulás, erdei iskola, táborozás, szellemi fogyatékosok nevelése, szuggesztív oktatás, neurózis, városi élet, bérezés, iskolaegészségügy. A készségtárgyakat tekintve a zene visszaesést mutat (szinte csak az ének tanítása kulcsszón keresztül jelenik meg), ugyanakkor a testnevelés viszonylag hangsúlyos marad. A mủvészeti nevelés létéről a művészetfilozófia és művészetelmélet kulcsszavak tanúskodnak. Az egyes idegen nyelvek vonatkozásában egyelőre a francia tűnik dominánsnak, legalábbis ami a Magyar Pedagógia hasábjait illeti. 


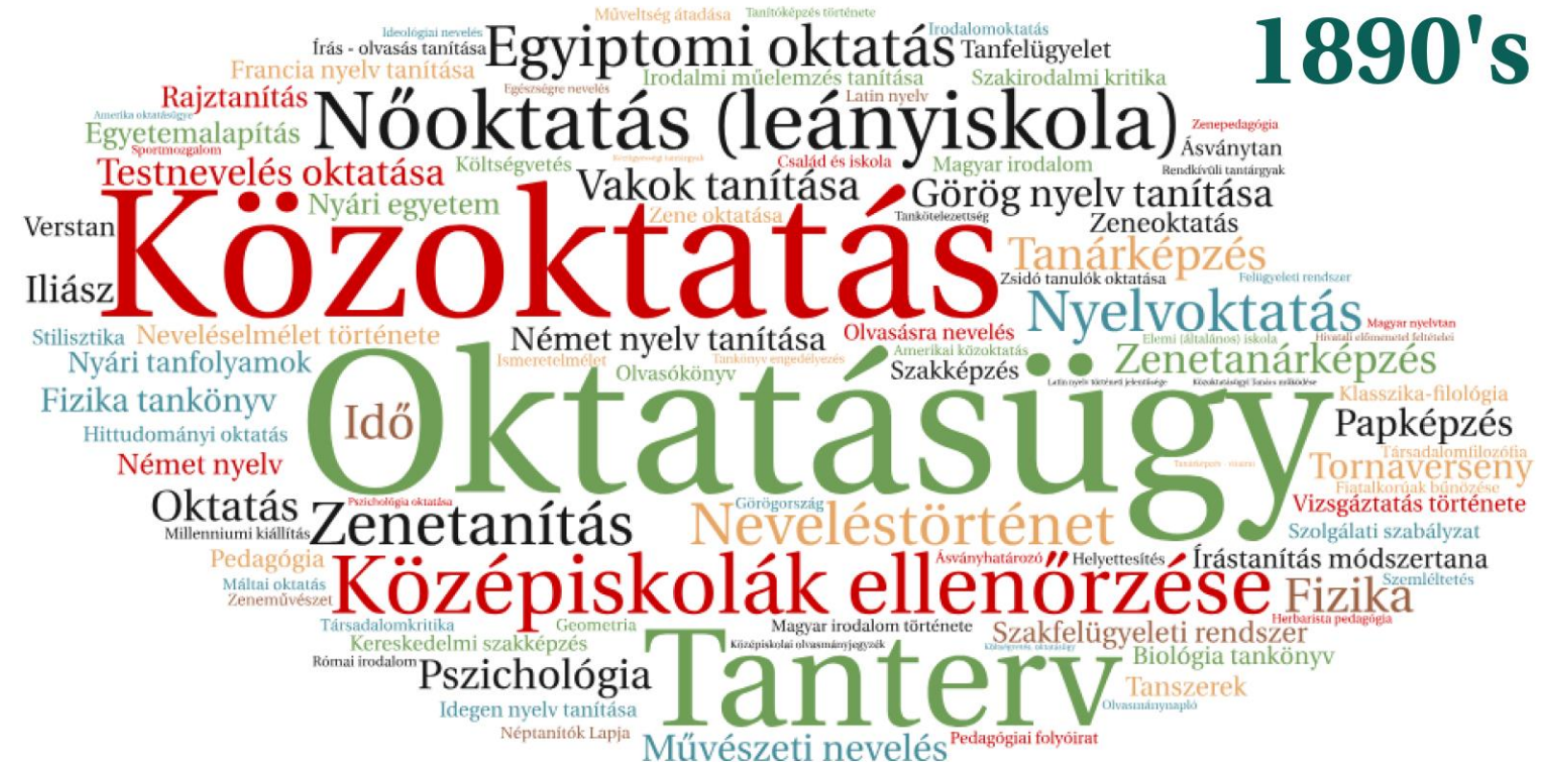

66. ábra

A Magyar Pedagógia cikkek száz leghangsúlyosabb tárgyszava a Contenta adatbázisban az 1892-1899 közötti évekböl a kölcsönös információtartalom vizsgálati módszer alapján

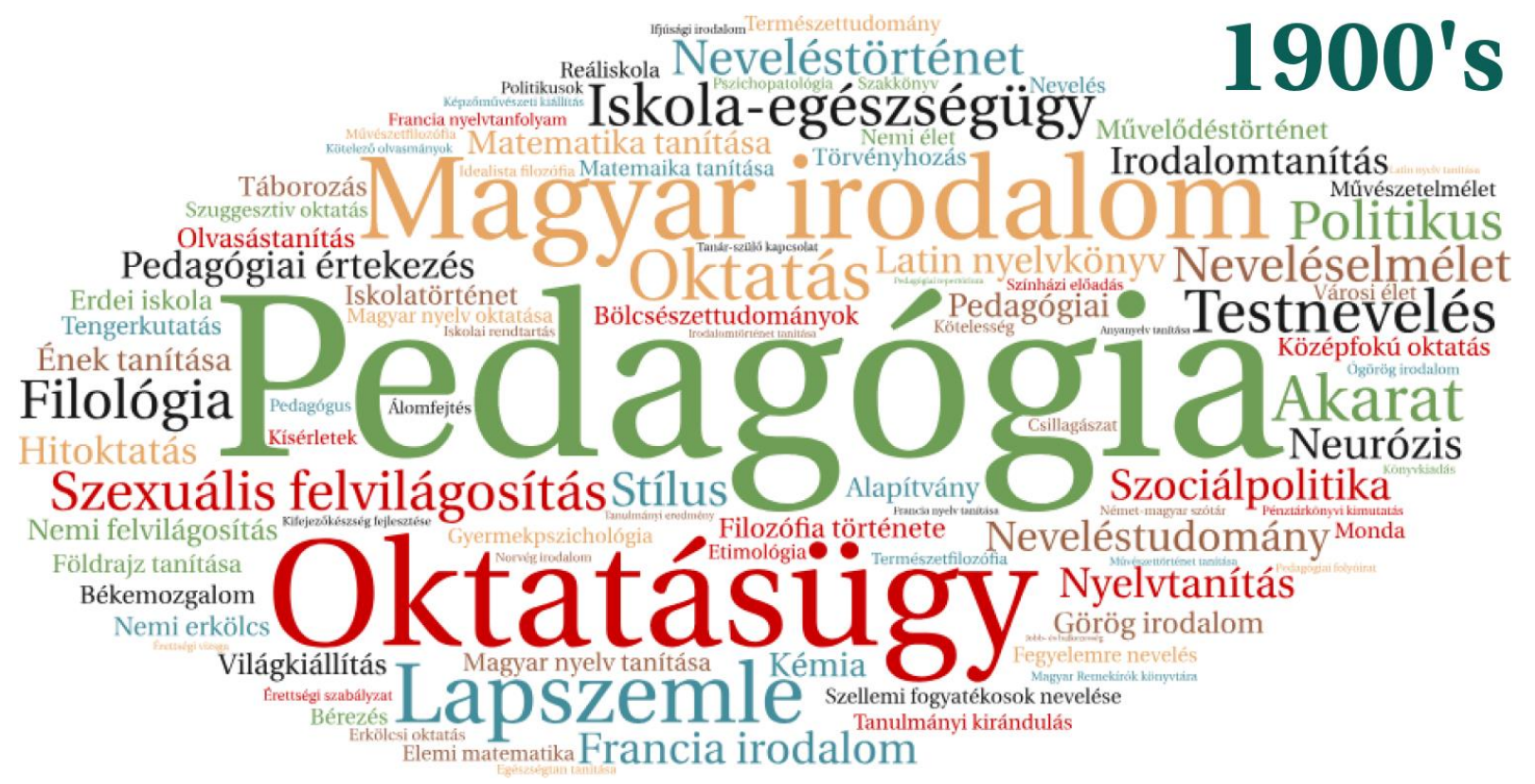

67. ábra

A Magyar Pedagógia cikkek száz leghangsúlyosabb tárgyszava a Contenta adatbázisban az 1900-1909 közötti évekböl a kölcsönös információtartalom vizsgálati módszer alapján 
Az első világháború évtizedében (68. ábra) jönnek a háborús témák: világháború, háború hatása, országismeret tanítása, állampolgári nevelés, turánizmus, sovinizmus, hazaszeretet, politika. Az évtizedre vonatkozó további tanulság, hogy nincsenek nagyon kiemelkedő témák, az egyes tárgyszavak által lefedett témák jelentőségüket tekintve viszonylag egyenletesen oszlanak el. A haladó szellemü témák közül megjelennek olyanok, mint a választójog, nőnevelés, feminizmus, kísérleti pedagógia, szemléltető oktatás, állatpszichológia, fejlődéslélektan, freudizmus, koedukáció, kriminálpedagógia, mesekutatás. Összességében elmondható, hogy a pszichológiai témák sokkal hangsúlyosabbak a korábban tapasztaltnál. Az oktatási szintek közül hangsúlyosnak tekinthető a középfokú oktatás, ugyanakkor egyetemmel kapcsolatos témák is előkerülnek, például az egyetem és az orvosképzés tárgyszavakon keresztül. A neveléstörténet marginális, ahogyan az irodalmi témák is háttérbe szorultak, ugyanakkor a filozófiai témák népszerübbé váltak. A természettudományi írások szintén visszaesést mutatnak, ahogyan a nyelvtanítás is vesztett jelenőségéből.

Az 1920-as évek (69. ábra) egyik legfontosabb témájának a reformpedagógia (és az iskolareform) bizonyult: ha címkéznünk kellene az évtizedet, akkor leginkább a „reformpedagógia évtizede” címke állná meg a helyét. A háború hatásai is érzékelhetőek még olyan kiemelt tárgyszavakon keresztül, mint a békére nevelés, nemzeti nevelés, zászló, trianoni békeszerződés, hadigondozás, kisebbségek. Megjelennek az egészségügyi témák: tuberkulózis, közegészségügy, gyermekpszichiátria, gyógypedagógia története. A filozófiai témák (filozófia, történetfilozófia, filozófia és pedagógia, idealizmus) továbbra is népszerüek, ahogyan vallási témák is előtérbe kerülnek, például kálvinizmus, evangélikus egyház. A nyelvoktatás tartja magát a népszerü témák között, míg a természettudományok főként a matematikusok és a fizikusok által vannak képviseltetve. Kimutathatóan jelen vannak a lélektani témák (hipnotizmus, fejlődéslélektan, gyermeklélektan), bár talán kevésbé hangsúlyosak, mint a megelőző évtizedben. A korszellemet tükrözik a német irodalom története és a technikai fejlődés hatása kulcsszavak is. A francia nyelv két évtizeddel ezelőtti hegemóniája láthatóan teljesen megszünt. A zene és a rajz háttérbe szorultak, ugyanakkor a testnevelés tartja magát a tárgyszavak között. 


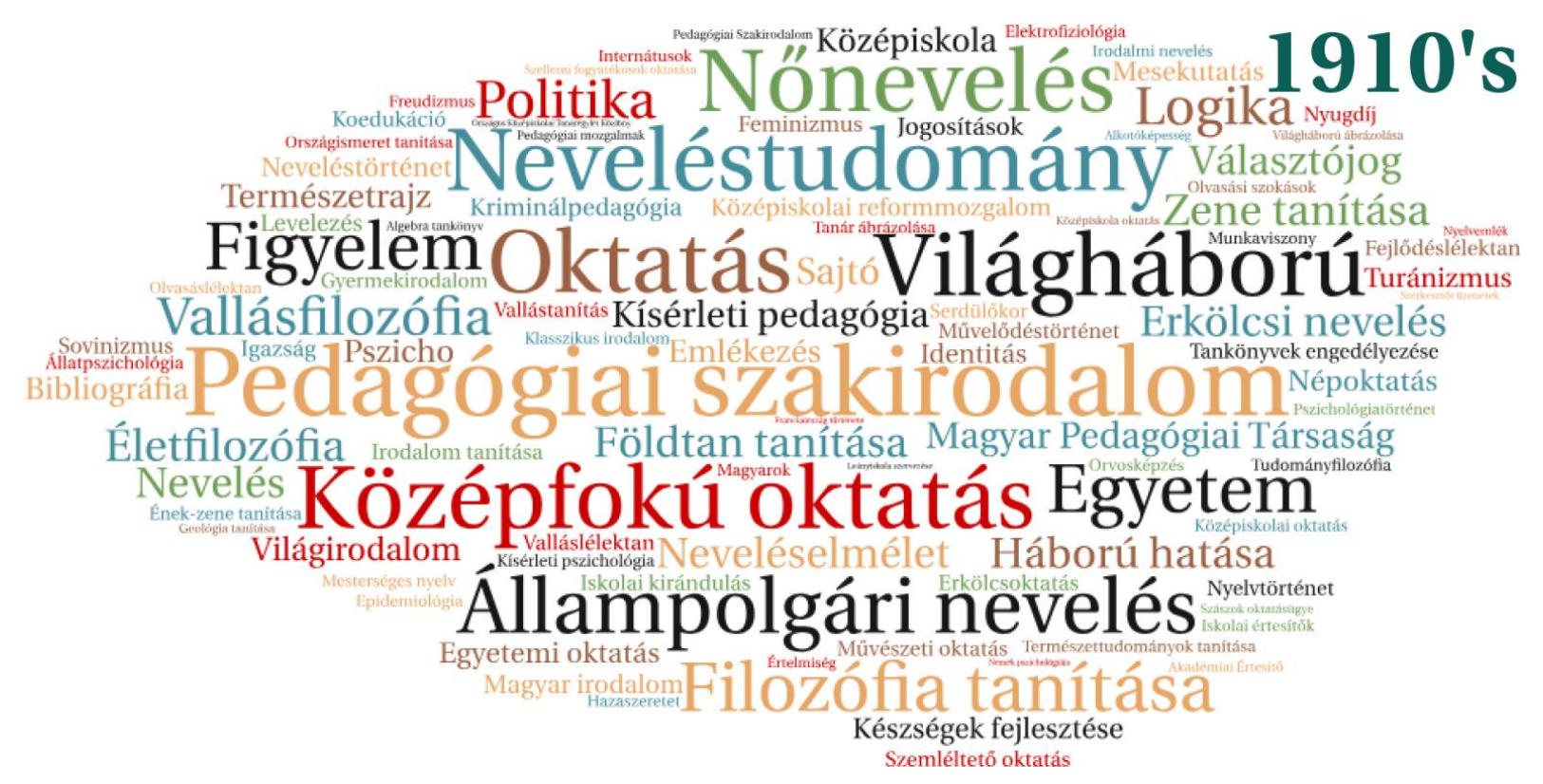

68. ábra

A Magyar Pedagógia cikkek száz leghangsúlyosabb tárgyszava a Contenta adatbázisban az 1910-1919 közötti évekböl a kölcsönös információtartalom vizsgálati módszer alapján

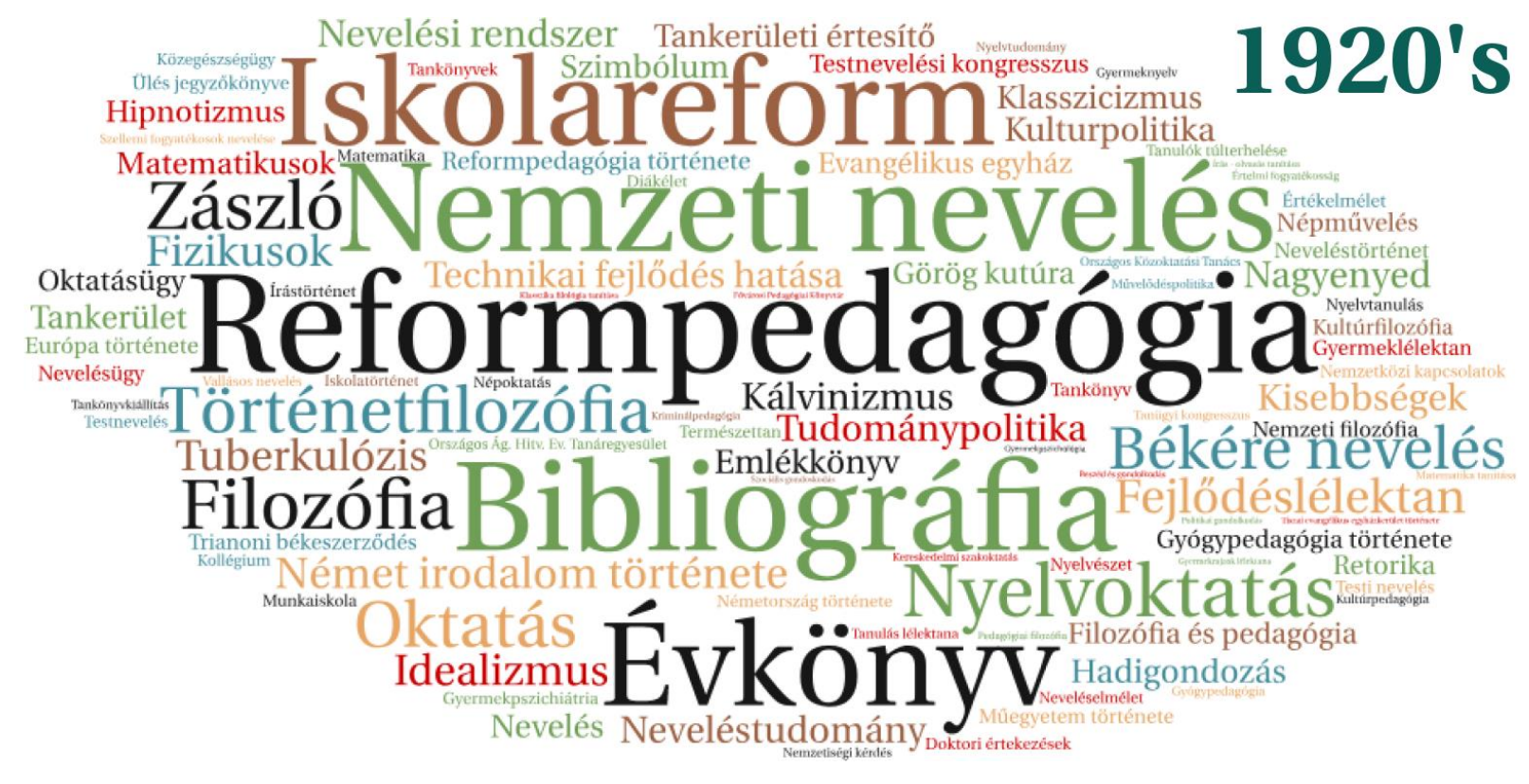

69. ábra

A Magyar Pedagógia cikkek száz leghangsúlyosabb tárgyszava a Contenta adatbázisban az 1920-1929 közötti évekből a kölcsönös információtartalom vizsgálati módszer alapján 
A korszellemet követve az 1930-as években (70. ábra) már megjelentek olyan kulcsszavak, mint a nemzeti szocializmus, fasizmus, katonai nevelés, honvédelem, repülés tanítása, Népszövetség, geopolitika, politikai semlegesség. Azt is mondhatnánk akár, hogy szinte a Magyar Pedagógiában megjelent cikkek is elörevetítették a készülő konfliktust. Szintén a korszellemet és nem utolsósorban az ekkortájt tomboló gazdasági válság visszatükröződését látjuk olyan kulcsszavak nyomán, mint a szorongás vagy pesszimizmus. A lélektani témák továbbra is jelen vannak, bár csökkenő részaránnyal, pl. zenepszichológia, pszichometria. A leghangsúlyosabb témákat a könyvkiadás, nyelvmüvelés és oktatásügy jelentik. A reformpedagógia ugyan még továbbra is jelen van, de sokat veszített az elmúlt évtizedbeli népszerüségéből. A vallások közül az évtized favoritja a katolikus egyház, az erkölcsi neveléssel kapcsolatos témáknak fontos szerep jut. A természettudományok közül kiemelkedik a földrajz tanítása. Haladó témákat jelentenek a műszaki fejlődés, logopédia, játékelmélet, időbeliség, tesztvizsgálat tárgyszavak. Olyan újnak mondható tudományágak is megjelennek, mint a közgazdaságtan (gazdaságtörténet, közgazdaságtan tanítása) vagy a néprajz. Meglepő módon a német nyelv nem reprezentálódik különösebben, bár igaz, hogy más idegen nyelv sem (a nyelvtanítás mint téma természetesen megjelenik, de kiugró népszerüséget nem mutat).

Az 1940-es években (71. ábra) az egyik általános témának tekinthető oktatásügy tárgyszó a legnépszerübb, amelyet ezután az egy tematika köré szerveződő hazafias nevelés, nemzetnevelés és világnézet kulcsszavak követnek. Fontos szerep jut még a közoktatás és az öröklődés kulcsszavaknak is. A zenei élet ismét hangsúlyosabban megjelenik, ahogyan olyan, a mindennapi iskolai életre jellemző dolgok is, mint a számonkérés és jutalmazás. A filozófia ismét elöfordul önálló diszciplínaként, illetve olyan tárgyszavakon keresztül is, mint a platonizmus, naturalizmus, utópia. Ebben az évtizedben talán meglepő módon már kevésbé van jelen a háborús tematika: csupán néhány olyan tárgyszón keresztül érhető tetten, mint a fajvédelem, katonai kiképzés, fasizmus és oktatás. A vallási témák továbbra is előkerülnek, úgymint teológia, piarista rend, pálos rend, egyházi irodalom, katolikus egyház. Új témaként jelennek meg az embertan, a cserkészet, a jóga, a rádióműsorok és a kézimunka tanítása. A természettudományi témák és a nyelvoktatás szinte teljesen eltünnek a témák közül. A neveléstörténet szintén nem túl jelentős az évtizedben, az egyetemtörténet tárgyszón keresztül érhető tetten. Jogi és szociológiai tárgyú írások is előkerülnek: büntetőjog, kriminalisztika, családvédelem, közigazgatás, társadalomrajz, diákszociológia, szociálpolitika. 


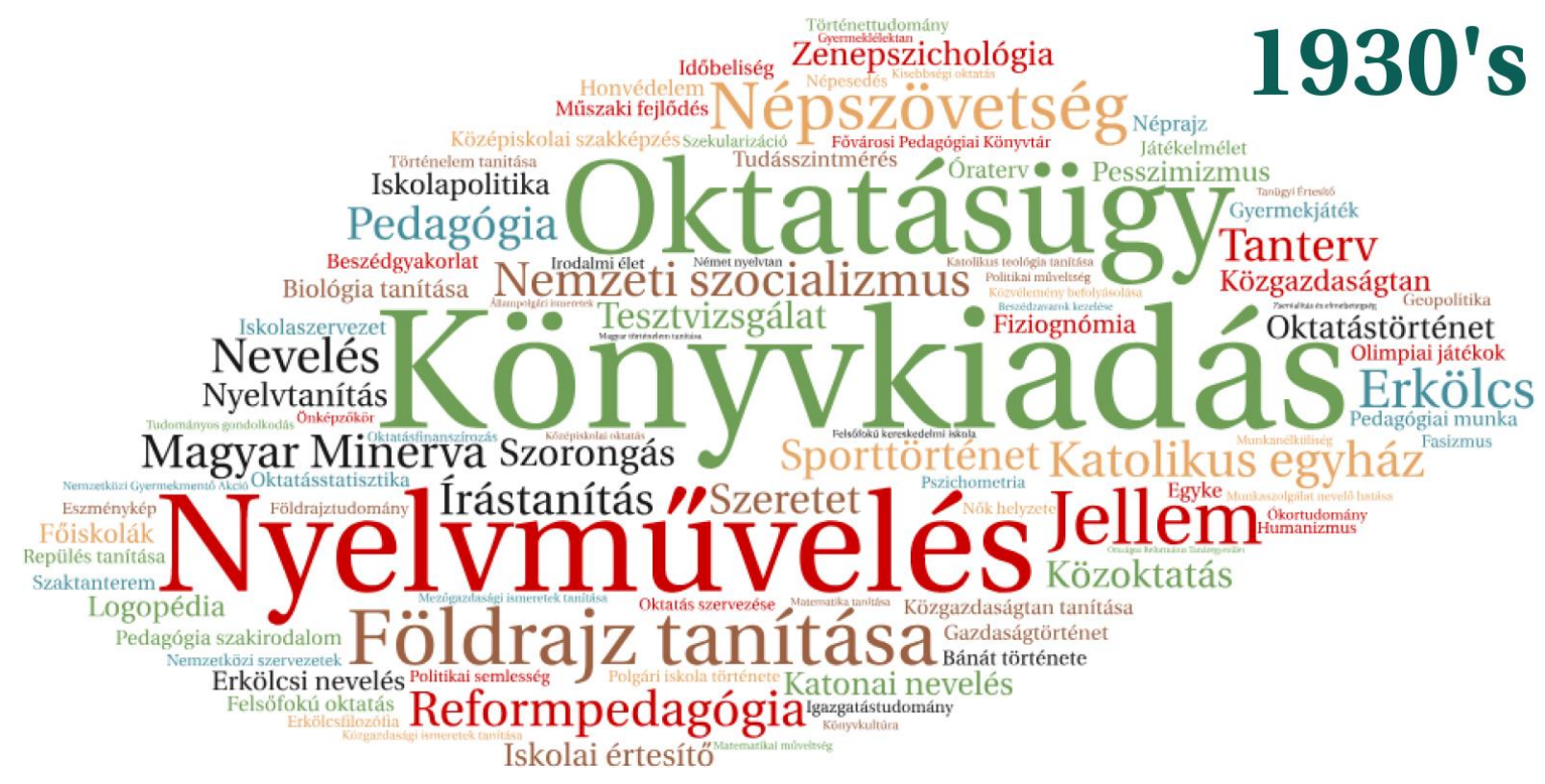

70. ábra

A Magyar Pedagógia cikkek száz leghangsúlyosabb tárgyszava a Contenta adatbázisban az 1930-1939 közötti évekböl a kölcsönös információtartalom vizsgálati módszer alapján

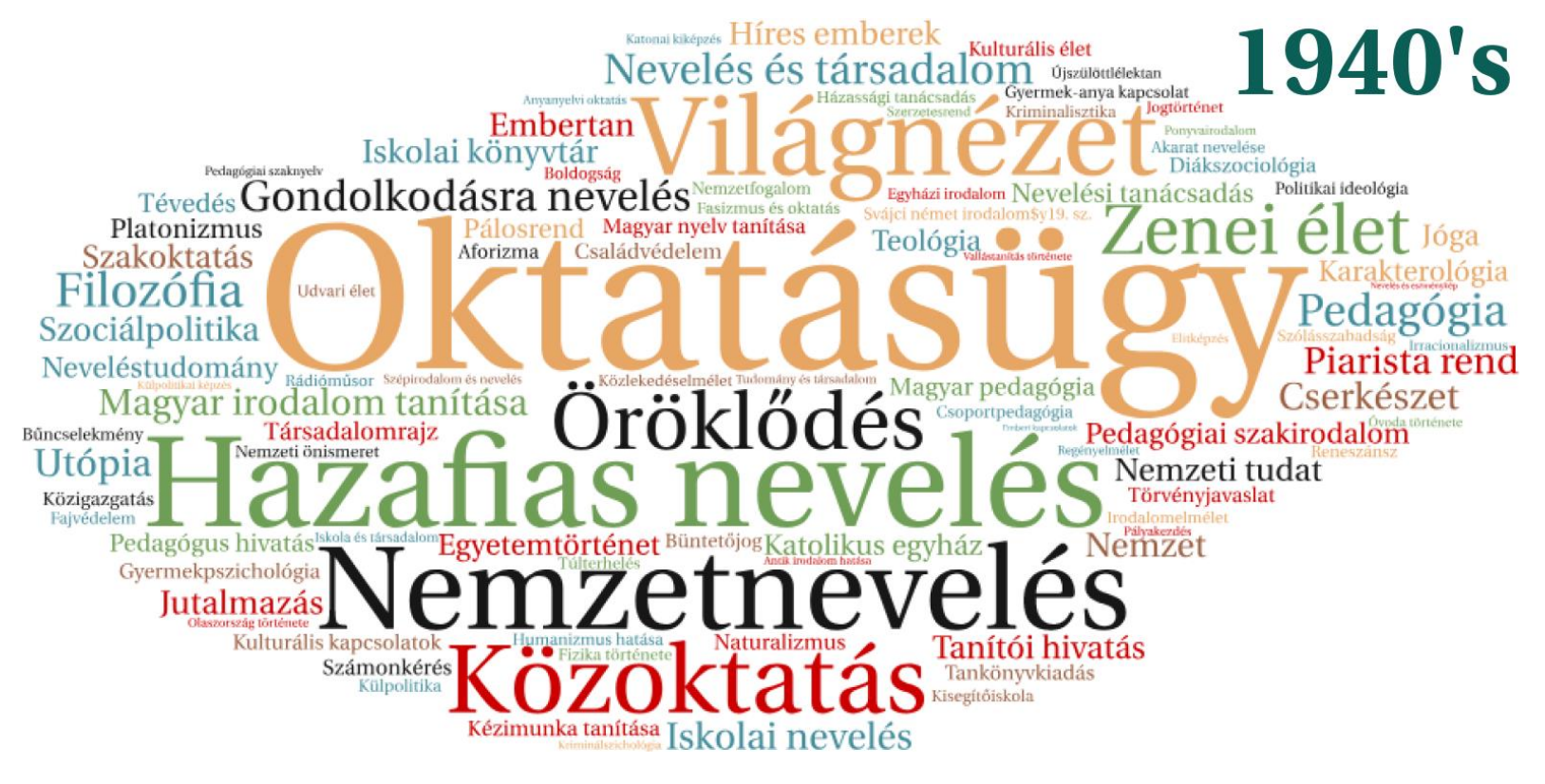

71. ábra

A Magyar Pedagógia cikkek száz leghangsúlyosabb tárgyszava a Contenta adatbázisban az 1940-1949 közötti évekböl a kölcsönös információtartalom vizsgálati módszer alapján 
A tíz éves kényszerszünet után a folyóirat merőben új témákkal jelentkezett a hatvanas években (72. ábra), ahogyan azt már a repertórium tárgyszavainak esetében is láthattuk. A legnépszerübb témát a neveléselmélet jelenti, ezt követi a pedagógia kulcsszó. Fontosak még a munkára nevelés, siker iskolai túlterhelés, pedagógiai szakirodalom kifejezések. A szocialista nevelési eszményt képviselik a világnézeti nevelés, az orosz nyelv tanítása, a munkaerkölcs, az építőtábor, a kommunista erkölcs, tudományos káderképzés tárgyszavak. A nyelvoktatás az orosz nyelv tanításán túl nem igazán van jelen témaként. A neveléstörténeti témák különösebben nem hangsúlyosak, föként az óvodapedagógia történetét érintik. A lezajló technikai fejlődés eredményeképpen önálló témaként jelenik meg az audiovizuális eszközök használata. A magyar irodalmi témák jelentősen visszaszorultak a folyóirat első néhány évtizedéhez képest, amikor igen nagy arányban fordultak elő; az 1960-as években olyan részterületekkel vannak jelen, mint az verselemzés vagy az olvasástanítás. Mind a filozófia, mind a pszichológia jelentősen visszaesik, ahogyan a természettudományok is. Helyettük főként az oktatásszervezés és a neveléstudomány különböző témái uralják a diskurzusokat. A zene és más müvészetek, illetve a testnevelés szintén nem annyira népszerü az évtizedben. Megjelenik viszont a motiváció kulcsszó is.

Az 1970-es évek legnépszerübb kulcsszavai között mind a folyóirat és a folyóiratszemle szerepelnek, elmondható tehát, hogy a különböző folyóiratokban megjelenő referáló szakirodalom különösen népszerü volt ebben az évtizedben. Szintén népszerüek olyan általános kifejezések, mint az iskola, az oktatási módszer, nevelés és az iskolaügy. A speciálisabb, új témaként felfoghatóak közül felfedezhetjük a team-oktatás, a mastery learning, programozott oktatás kifejezéseket. Szigorúan véve a szocialista berendezkedésre utaló tárgyszavak elvétve fordulnak már csak elő a 73. ábrán, például ilyen a szakszervezetek tárgyszó. Több, a technikai fejlődésre utaló kulcsszót is találunk: oktatástechnológia, audiovizuális oktatás, televízió, oktatófilm, technikai segédeszközök, oktatás korszerüsítése. Nagyobb számban megjelennek a neveléstudományi kutatásra utaló kifejezések: kutatásmetodika, kutatás, kutatómunka, didaktika, pedagógiai kutatás, publicisztika, Magyar Tudományos Akadémia, neveléstörténeti kutatás. Az egyes önálló tudományos diszciplínák hasonló arányban reprezentálódnak, mint az 1960-as években. Igazság szerint, jellemzően nem ezek tematizálják főként a lapot ebben a két évtizedben. A nyelvtanulás még az orosz vonatkozásában sem jelenik meg a legnépszerübb témák között. Viszonylag új témaként jelenik meg a művelődéstörténet. 


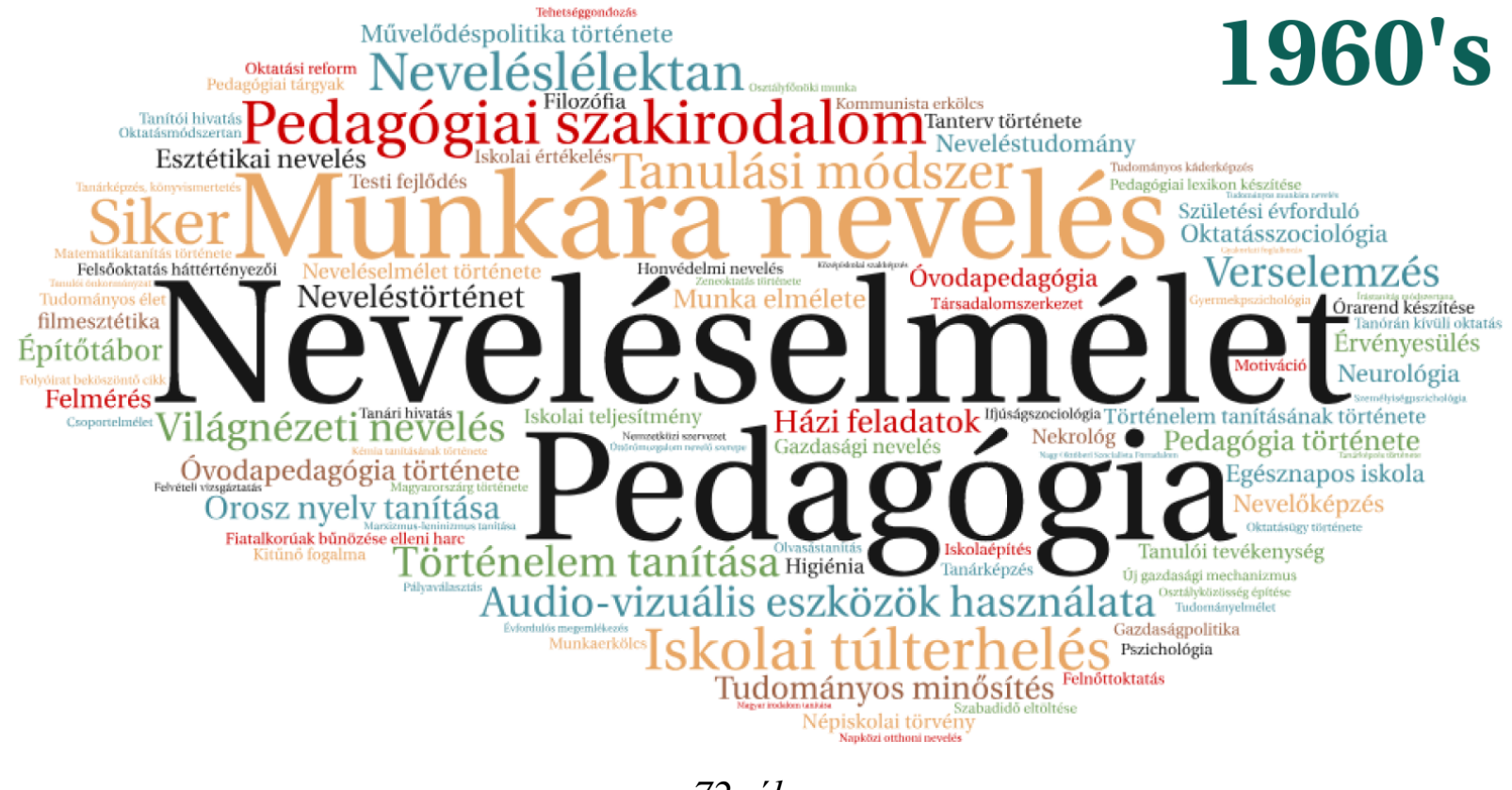

72. ábra

A Magyar Pedagógia cikkek száz leghangsúlyosabb tárgyszava a Contenta adatbázisban az 1961-1969 közötti évekböl a kölcsönös információtartalom vizsgálati módszer alapján

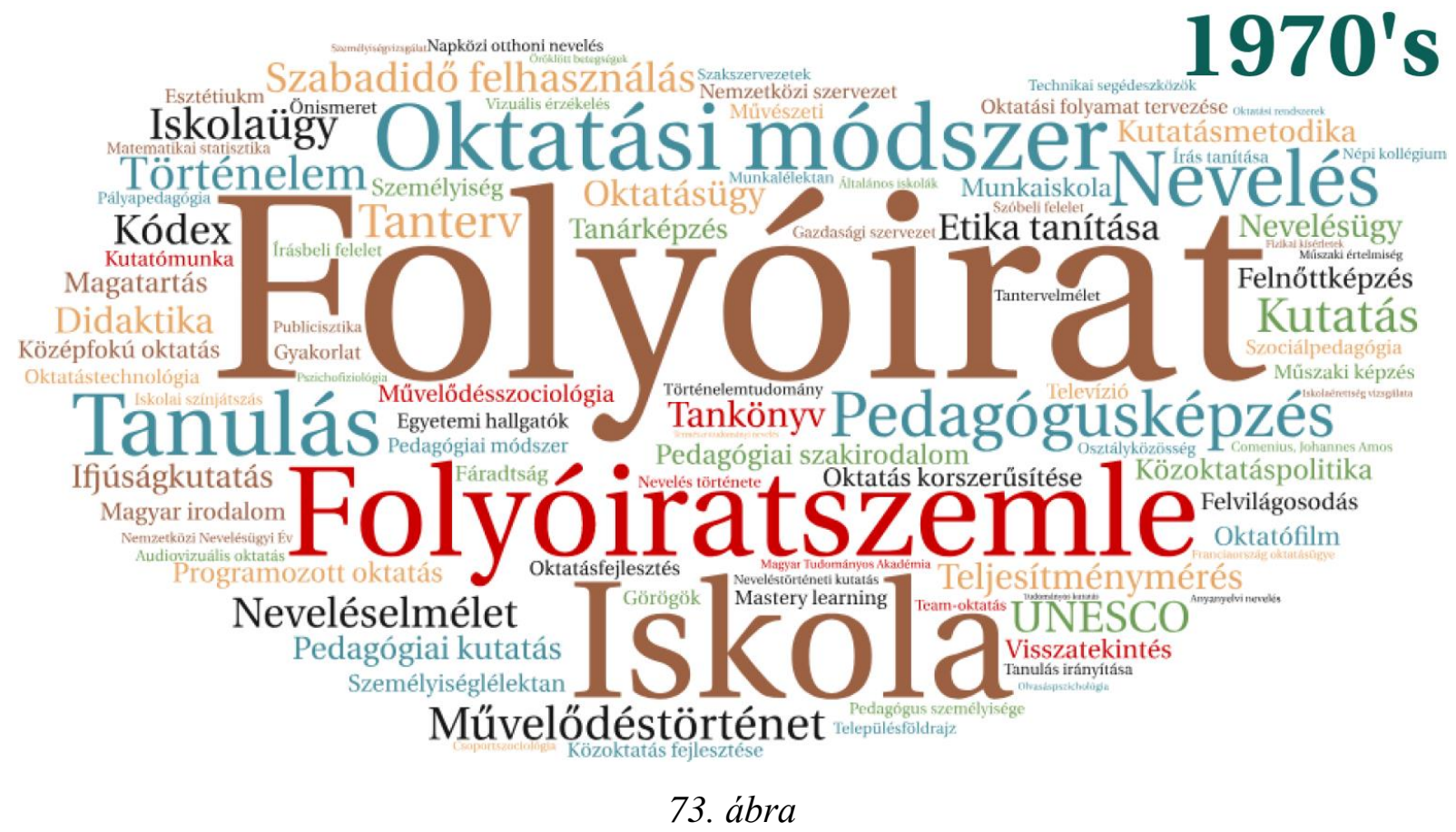

A Magyar Pedagógia cikkek száz leghangsúlyosabb tárgyszava a Contenta adatbázisban az 1970-1979 közötti évekböl a kölcsönös információtartalom vizsgálati módszer alapján 
Ahogyan az a repertórium tárgyszavaiból is egyértelmủen kiderült (74. ábra), az 1980-as évek a neveléstörténet évtizede a Magyar Pedagógiában. Hangsúlyosak még a különböző szociológiai megközelítésü témák, mint például a szociometria, esélyegyenlőség, nevelésszociológia, alkoholfogyasztás, értékszociológia, pedagógiai szociológia, deviáns magatartás. Újra fontossá váltak a személyiségfejlődéssel és -fejlesztéssel kapcsolatos témák. Tovább nőtt az oktatástechnológia jelentősége (informatika tanítása, számítástechnika, információs társadalom, oktatástechnika). Az oktatásirányítással kapcsolatos témák szintén jól reprezentálódnak: oktatáskutatás, oktatásügy, óraelemzés, óraszervezés, oktatástervezés, tananyagtervezés. Egyre hangsúlyosabban jelen vannak az értékeléssel kapcsolatos tárgyszavak: teljesítmény, osztályzás, értékelés. Újra megjelent a kulcsszavak között a cserkészet. Olyan speciális témák is előkerülnek, mint a humánbiológia és a gépészet oktatása. A müvészeti ágakat főként a vizuális kultúra, vizuális nevelés, drámapedagógia tárgyszavak képviselik. Ebben az évtizedben a különböző pedagógusok közül a tanítók reprezentálódnak leginkább a lapban. A szovjet irodalom még utoljára önálló témaként megjelenik.

Mivel az 1990-es évtizedről a repertóriumból már nem tudtunk szófelhőt előállítani, így itt nincs összehasonlítási alap. Az évtized legnépszerübb kulcsszavai (lásd 75. ábra) eléggé általánosak: oktatás, pedagógia, neveléselmélet. Sokkal inkább differenciálják azonban az évtized cikkeit az újra rendkívül hangsúlyosan megjelenő, nyelvoktatással kapcsolatos következő tárgyszavak: kétnyelvüség, nyelvtanulás, interkulturalizmus, angol nyelv tanítása. Az olvasással és irodalommal kapcsolatos témák szintén újra kiemeltté váltak. Kimutathatóan jelen van továbbra is a neveléstörténeti dimenzió, olyan kulcsszavak által, mint az iskolatörténet, gyermekkortörténet, egyetemtörténet, oktatástörténet, neveléstörténet, ciszterci rend története. Az önálló jogú, történeti témájú publikációk is jellemzőek, hiszen például a müvészettörténet és a történelem szintén megjelennek a témák között. Sok éves hiátus után végre újra felfutóban vannak a természettudományi jellegű témák is: természettudományos nevelés, biológia tanítása, orvostudomány, környezeti nevelés, természettudomány, matematikai gondolkodás, matematika tanítása. Új témaként jelent meg az analfabetizmus, a jobb- és balkezesség, problémamegoldás, motiváció, kompetencia, teljesítménymérés. Ezen utóbbiak a még hátralévő elemzett évtizedekben még fontosabbá válnak. További fontosságuk miatt kiemelendő témák: informatika, Delfi módszer, iskolai innováció, tanulók etnikai összetétele. 


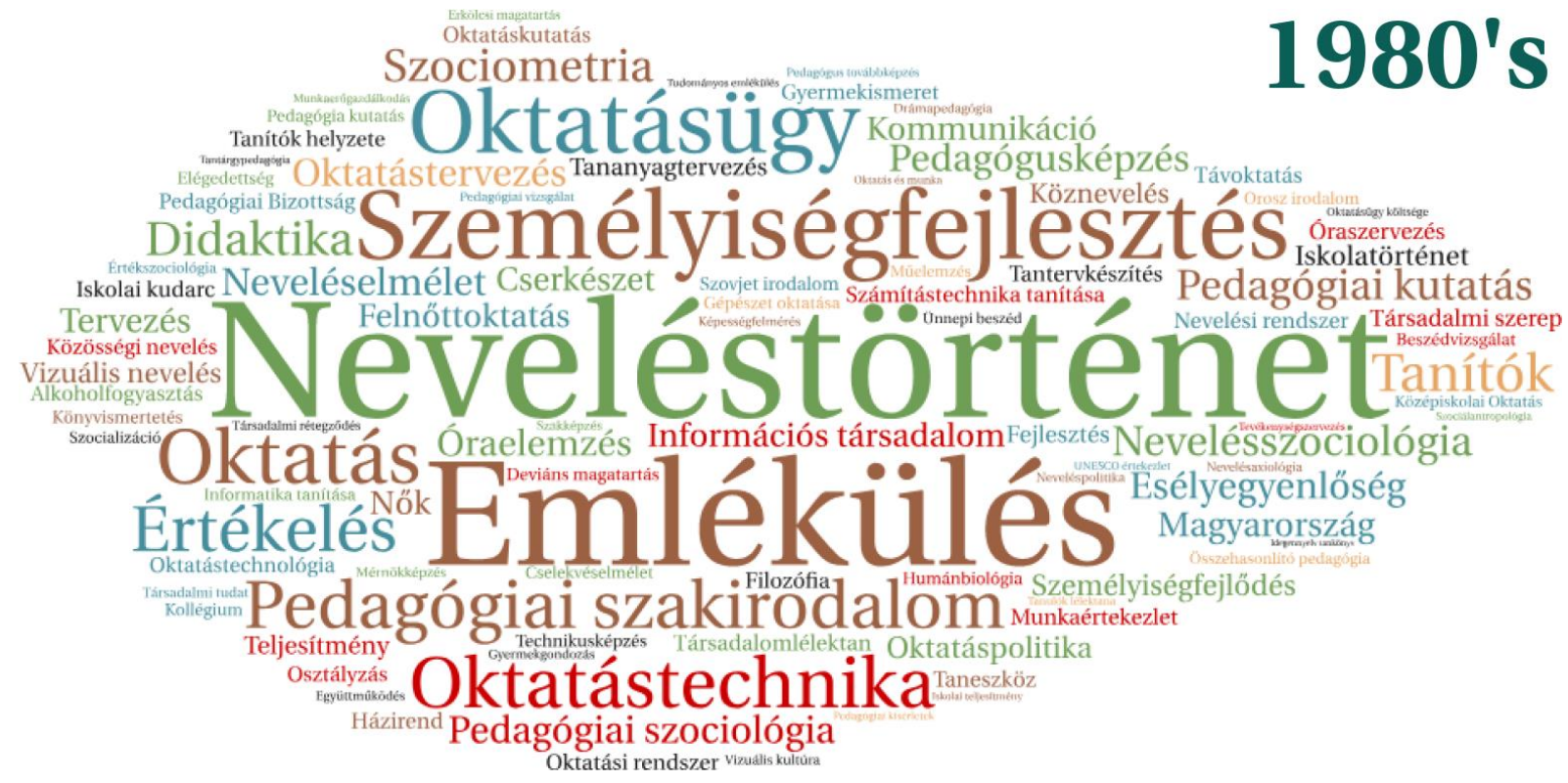

74. ábra

A Magyar Pedagógia cikkek száz leghangsúlyosabb tárgyszava a Contenta adatbázisban az 1980-1989 közötti évekböl a kölcsönös információtartalom vizsgálati módszer alapján

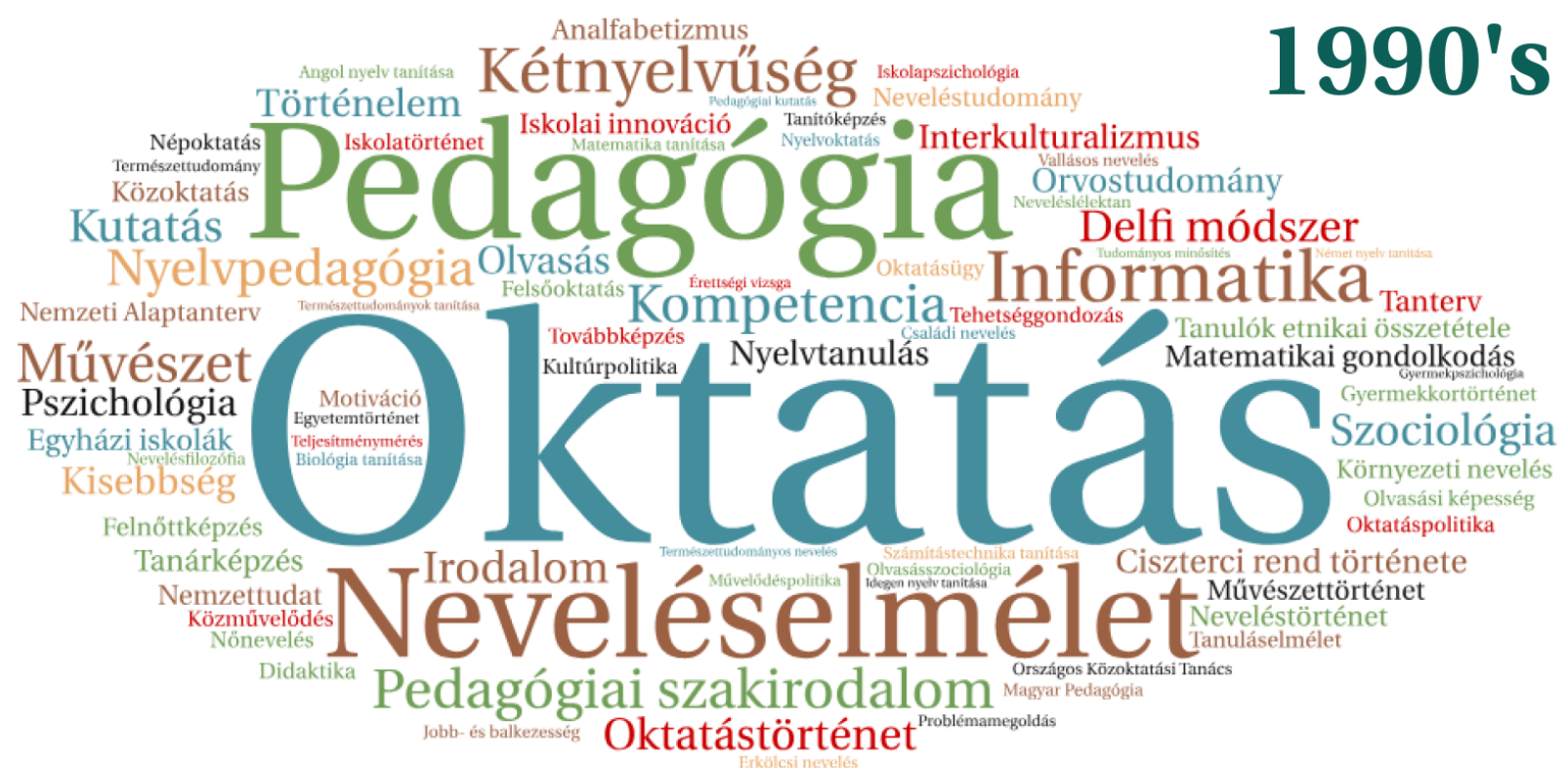

75. ábra

A Magyar Pedagógia cikkek leghangsúlyosabb tárgyszavai a Contenta adatbázisban az 19901999 közötti évekböl a kölcsönös információtartalom vizsgálati módszer alapján

Az ezredforduló utáni tíz év (76. ábra) egyértelmüen a „motiváció évtizede”, bár a problémamegoldás szintén versenyben van ezért címért. A harmadik említésre méltó tárgyszó az élről az általánosabb jelentésű oktatásügy kifejezés. A problémamegoldáshoz kapcsolódóan jelen van még a gondolkodásfejlesztés téma is. Összességében elmondható, hogy a 2000-es 
években sok új, korábban egyáltalán nem tipikus, vagy csak kevéssé jelenlévő téma bukkant fel, ilyenek: önszabályozó tanulás, önszabályozás, egészségnevelés, metakogníció, indukció, induktív logika mérése, mentorálás, szociális viselkedés, szociális kompetencia, integrált oktatás, teljesítménymérés, kompetencia. Az olvasással kapcsolatos témák továbbra is népszerübbek, mint a természettudományi topikok: olvasásstratégia, olvasás, szövegértés, olvasástörténet; míg az utóbbi témából: botanika, matematikai kompetencia. Kitapintható témacsoportként jelennek meg a csökkent képességü gyermekek, az integrált nevelés, az oktatáshoz való jog, a hátrányos helyzet, a cigány gyerekek helyzete és az emberi jogok. A nyelvoktatásnak ismét fontos szerep jut, ami az angol nyelv és idegen nyelv tanulása tárgyszavakon keresztül reprezentálódik. A müvészeti témák is kimutatható számban jelen vannak ebben az évtizedben: néptánc oktatás, Gödöllői Művésztelep, festészet, ének-zene oktatás. Neveléstörténeti témájú írások már csak elvétve fordulnak elő ebben az évtizedben.

Az utolsó elemzett időszakot a 2010 és 2014 közötti öt év jelenti (77. ábra), amely esetében a fele akkora időintervallum miatt a minta elemszáma jóval alacsonyabb, amit tovább torzít az utolsó időszakban kifejezetten alacsony szintre beálló publikációs aktivitás (lásd 6 . ábra). Mindezeket a körülményeket természetesen az eredmények értelmezése kapcsán is feltétlenül szükséges figyelembe venni, hiszen emiatt a tárgyszavak előfordulási súlyában sok esetben csak árnyalatnyi különbségek adódnak.

A legjelentősebb tárgyszó ebben az időszakban a neveléstudomány ernyőfogalom, ez alá nyilván sok minden besorolható. Mindenesetre a neveléstudomány kifejezés élre törése rávilágít arra a trendre, hogy a Magyar Pedagógia sokkal inkább tudományos folyóirattá vált, mint amilyen volt a rendszerváltást megelöző időszakokban, hiszen akkor sokkal több oktatásirányítással kapcsolatos publikáció jelent meg a későbbi időszak trendjeihez képest, amikor már inkább egy-egy konkrét kutatási projekt eredményeiröl számolnak be a szerzők írásaikban. Természetesen ez a tendencia a tárgyszavakon keresztül kiválóan tetten érhető. A második legnépszerübb téma, talán valamelyest meglepő módon (ismerve az elmúlt évtizedekben tapasztalható alulreprezentáltságát) a matematika oktatása. A motiváció és a problémamegoldás továbbra is igen népszerü témáknak számítanak, ahogyan az idegen nyelvek is: olasz nyelv, idegen nyelv tanulása, nyelvvizsgarendszer. A nyelvoktatás mellett a hagyományos olvasással kapcsolatos témák is tartják magukat. További előforduló témákat jelent a 2010-es évekből a szociálisprobléma-megoldó gondolkodás, a sportpszichológia, az oktatásinformatika, a katolikus nevelés, az induktív gondolkodás. Fontos szerepet tölt be az erőszakkal kapcsolatos témák tárgyalása. A már említett sportpszichológia mellett a sport területéről megjelenik még önálló témaként a labdarúgás története. A művészetek a zenei 
képességek, a zenei müveltség, a művészeti nevelés, müvészeti oktatás tárgyszavakkal képviseltetik magukat az évtizedet illetően. Az előző évtizedhez képest talán egy fokkal nagyobb szerepet tölt be a neveléstörténet.

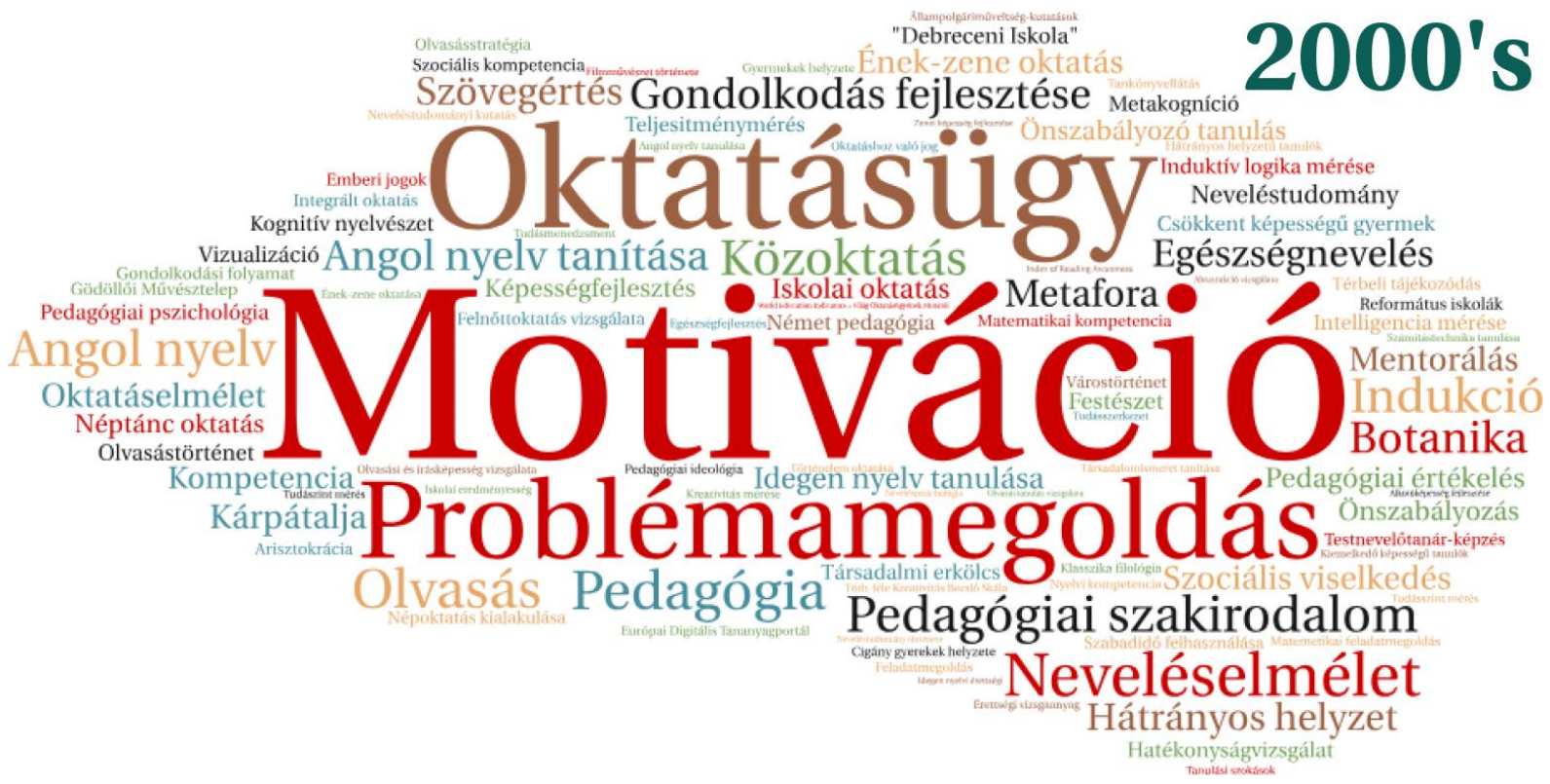

76. ábra

A Magyar Pedagógia cikkek leghangsúlyosabb tárgyszavai a Contenta adatbázisban a 20002009 közötti évekböl a kölcsönös információtartalom vizsgálati módszer alapján

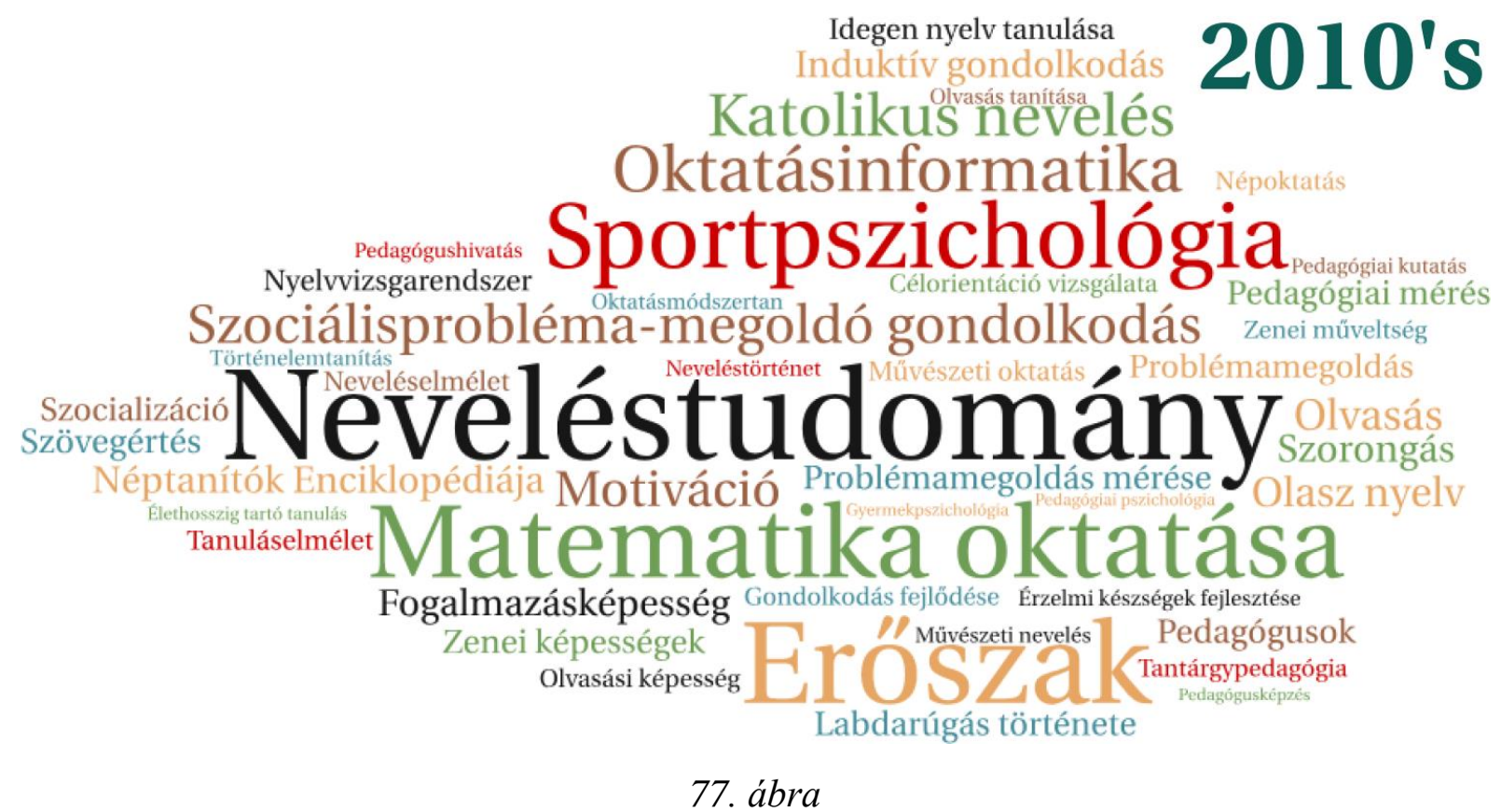

A Magyar Pedagógia cikkek leghangsúlyosabb tárgyszavai a Contenta adatbázisban a 20102014 közötti évekböl a kölcsönös információtartalom vizsgálati módszer alapján 


\subsubsection{Az automatikus kulcsszavazás eredményei}

A bemutatott forrásokból kinyert tárgyszavak felhasználása mellett megtörtént az egyes cikkek automatikus kulcsszavazása is a korábban ismertetett algoritmusok segítségével, illetve elkészültek a szokásos évtizedes felbontású listák az egyes cikkek automatikus tárgyszavainak aggregálásával. Leegyszerüsítve, a kölcsönös információtartalom és a khí-négyzet próbák azt próbálják meg kimutatni, hogy az egyes szavak mennyire jellemzőek az egyes dokumentumokra. Az eljárások kimeneteként kapott mutatók nagyjából azt számszerüsítik, hogy az adott kifejezés mennyire diszkriminatív, illetve mennyire képes szegregálni az adott cikket a többitől. Ilyen értelemben előfordulhat, hogy egy szó, amely ugyan csak elvétve szerepel egy adott évtized cikkeiben és emellett egyszer sem fordul elő bármely más évtized esetén, akár tökéletesen képes beazonosítani (természetesen saját súlyának megfelelően) a kérdéses évtizedet. Ennek fényében az eljárások elméleti háttere szerint az erre a szóra vonatkozó mutatószám magas értéket fog felvenni. Az így előálló értékek sorbarendezésével megkaphatjuk egy-egy cikk legrelevánsabb kulcsszavait, illetve ezek tetszőleges időtartamot felölelő aggregálásával az adott időszak legjellemzőbb kulcsszavait. Mivel az így kapott táblázatok szerkezete lényegében megegyezik a gyakoriságvizsgálatoknál használtakéval, így ugyanazon vizualizálási módszerek alkalmazhatóak itt is.

A 78. és 79. ábrán a kétfajta módszer szerint történt automatikus kulcsszavazás eredményei láthatóak az összehasonlíthatóság miatt ugyanazon cikkekre vonatkozóan, mint amiket a 41. és 42. ábra is bemutat. Az ábrákat összevetve megállapítható, hogy ezekhez képest a lenti ábrákon az általános szavak háttérbe szorultak és a speciális, az adott cikk esetében kifejezetten hangsúlyosnak mondható kulcsszavak szerepe megerősödött. Például az első ábrán ebből fakad a „honmentő” szóalak előkerülése és a „törvény” szó teljes eltűnése, de ugyanebből a jelenségből származik a különböző személynévalakok megjelenése is az ábrán. A második esetben, a 79. ábrán pedig az „adaptív” minőségi jelző felértékelődése vagy a „képességszint” kifejezés megjelenése tanúskodik a kétféle megközelítés közötti különbségekröl. 


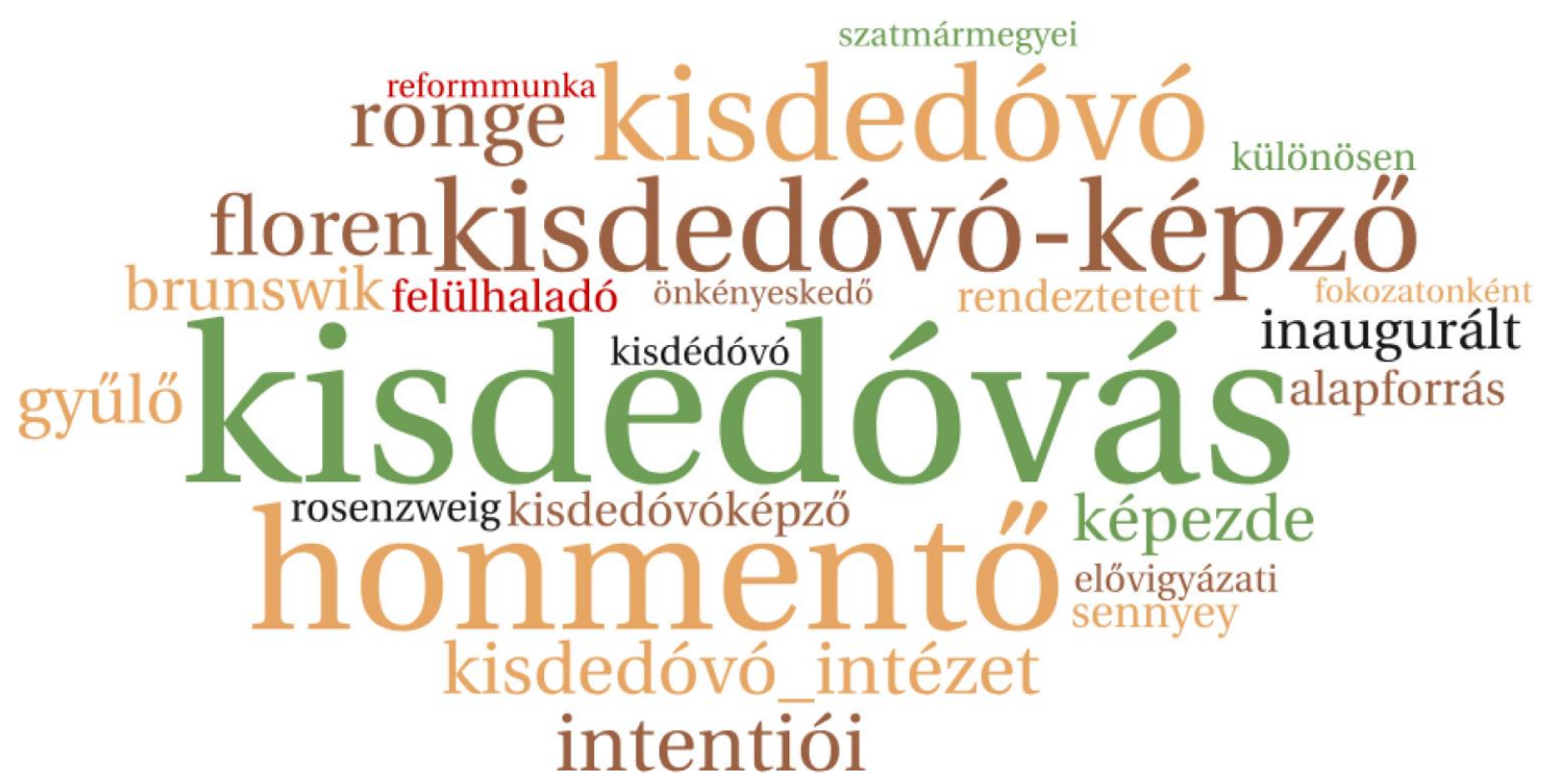

78. ábra

A minta legelső cikkének (György, 1892) khí-négyzet próba szerinti huszonöt legmagasabb értéket kapott automatikus kulcsszava

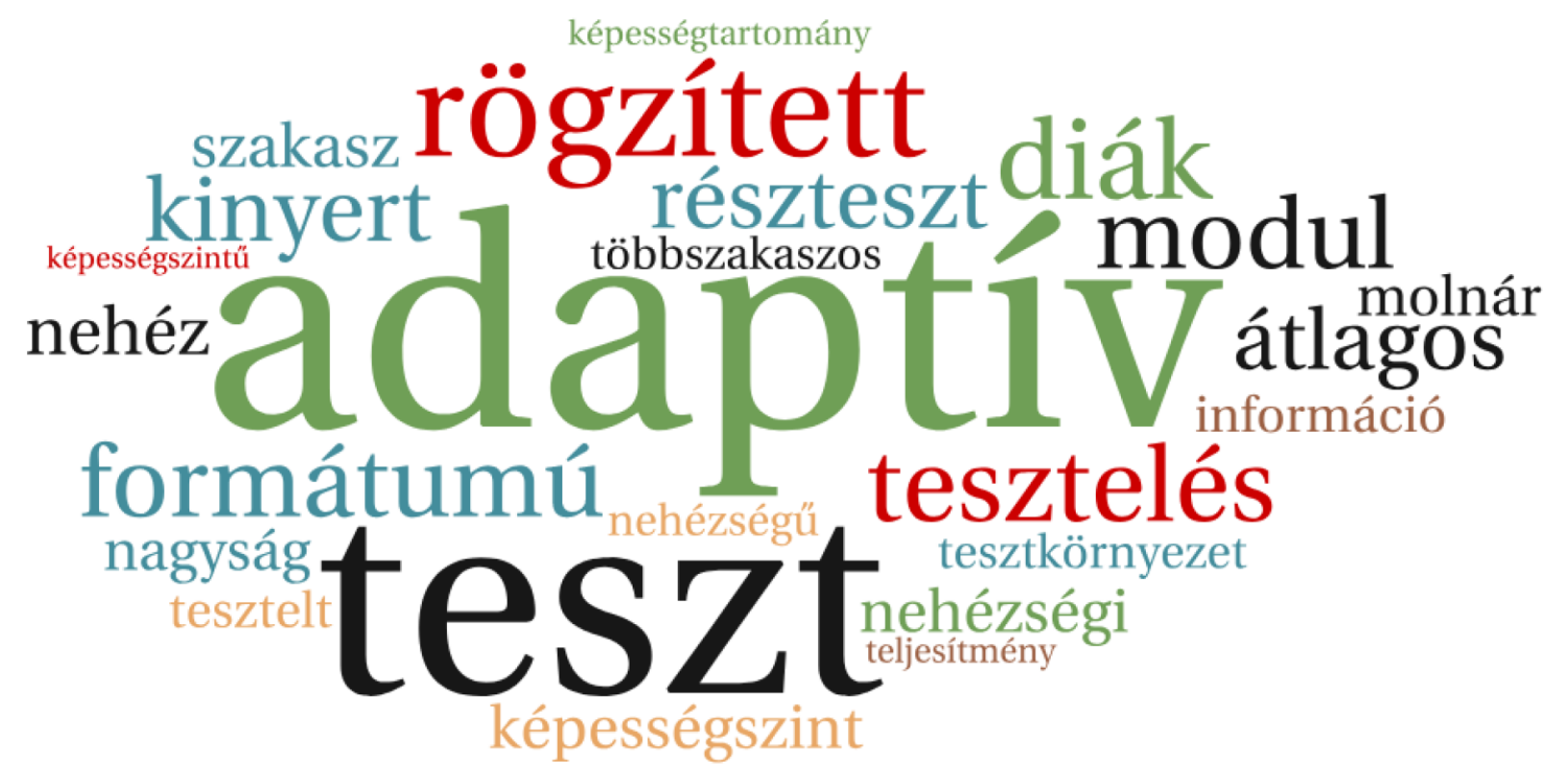

79. ábra

Egy véletlenszerüen kiválasztott cikk (Magyar \& Molnár, 2013) kölcsönös információtartalom szerinti huszonöt legmagasabb értéket kapott automatikus kulcsszava 
Az egyes cikkek automatikus kulcsszavainak összegzésével, a gyakoriságvizsgálatoknál már bevett módon megkaptuk az egyes évtizedekre jellemző szófelhők előállításához szükséges listákat, mind a kölcsönös információtartalom, mind a khí-négyzet alapú eljárások esetében. A két eljárás során kapott listák az évtizedek vonatkozásában általában nagy hasonlóságot mutatnak, amely egyezés egyébként erősíti a módszerek helyességébe vetett hitet, hiszen, ha a két eltérő módszeren alapuló eljárás közel azonos eredményt ad, az nagyban erősíti az eredmények validitását. Emiatt csak a khí-négyzet eljárás alapján készült, évtizedekre bontott ábrákat közöljük a felesleges duplikáció elkerülése miatt.

Az 1890-es éveket tekintve (80. ábra) a khí-négyzet eljárás alapú automatikus kulcsszavazás alapján készült szófelhő már a negyedik típusú ábrát jelenti a folyóirat első éveiről, azonban az eltérő szempontok miatt még itt is felszínre kerülnek ebben a korban fontosnak mondható, hangsúlyos témák, amelyek a korábbi ábrák esetében sok esetben rejtve maradtak a felettes kategóriákban vagy esetleg beolvadtak egy másként megfogalmazott kifejezés mögé. Ahogyan azt már a Contenta repozitórium tárgyszavain alapuló ábrák esetében is megállapítottuk, ebben a kezdeti időszakban az egyes nyelvek közül mindenképpen a francia tekinthető dominánsnak a folyóiratban. Az egyes iskolatípusok közül hangsúlyos a gimnázium (különböző írásmódokkal a 80. ábrán) és a polgári iskola. Az olyan klasszikus témák, mint a görög, Homeros, Sokrates, Xenophon, classicus, philosophia fontos szerepet töltöttek be az első évtizedben. Itt jegyeznénk meg, hogy az évtized egyik jelentős főszerkesztője, Csengeri János a klasszika-filológia professzora volt.

A következő évtized legnépszerübb automatikus kulcsszavait a tanítás és a népmívelés kifejezések jelentik. A megelőző évtized legnépszerübb szavaként a czél szó még mindig jelentős az ábrán, azonban ez nagyrészt az eltérő írásmódjából fakad; amennyiben cél alakban használták volna ebben a kezdeti időszakban is a szót, akkor az algoritmus bizonyosan kisebb jelentőséget tulajdonított volna neki. A polgári iskolák még mindig népszerüek, azonban a gimnázium kulcsszó már nem jelenik meg a szófelhőn, helyette a reáliskola és főreáliskola automatikus kulcsszavak láthatóak (bővebben lásd Pukánszky \& Németh, 1998). A klasszikus nyelvek, mint a görög és latin még mindig hangsúlyosak, ahogyan a francia is jelen van továbbra is. A 81. ábra szerint hangsúlyos szerep jut a lapszemléknek. Az egyes tantárgyak közül a nyelvek mellett talán a matematikának jut még nagyobb szerep. 


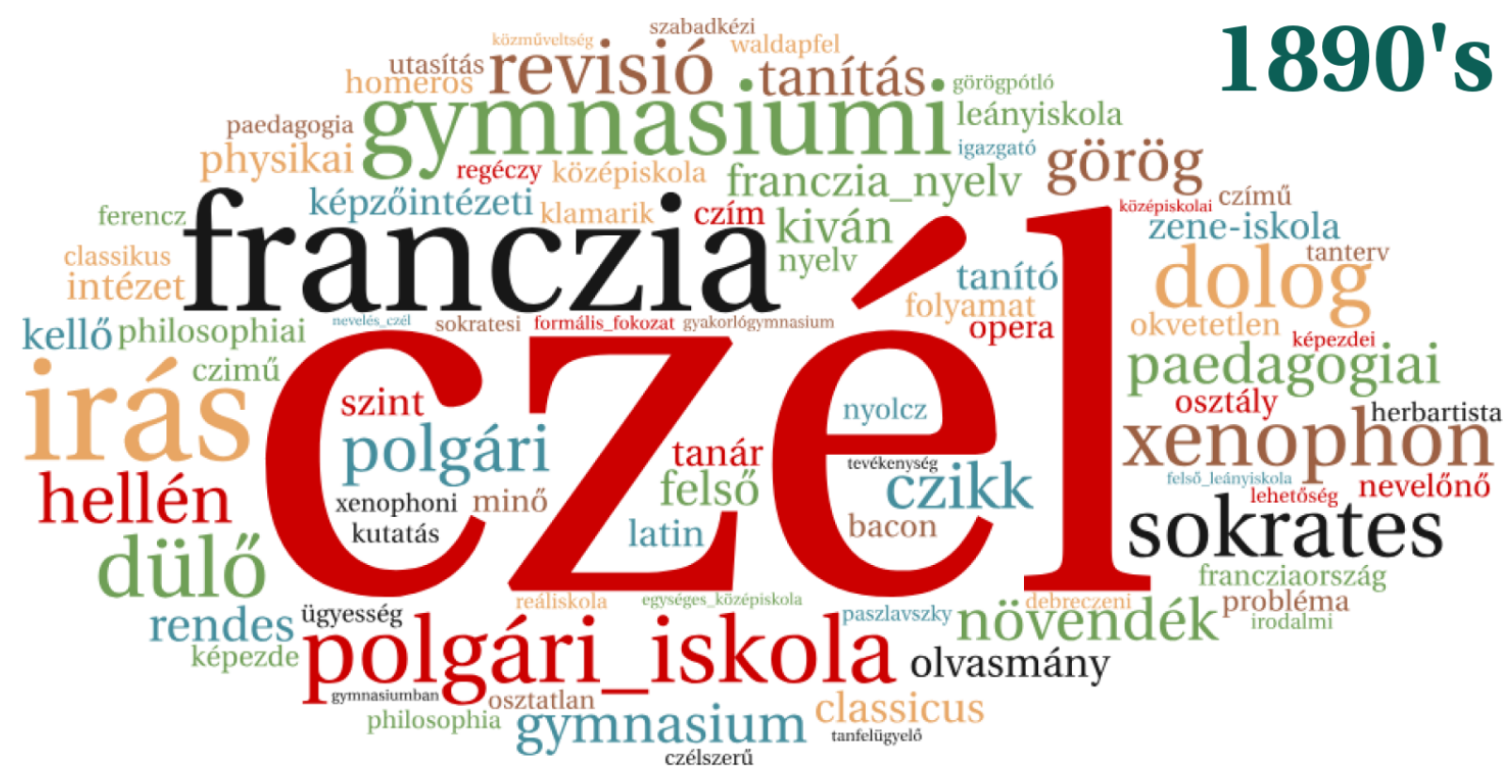

80. ábra

Az 1892-1899 közötti évek khí-négyzet vizsgálati módszer alapján generált automatikus kulcsszavai a Magyar Pedagógia cikkeiböl képzett mintából

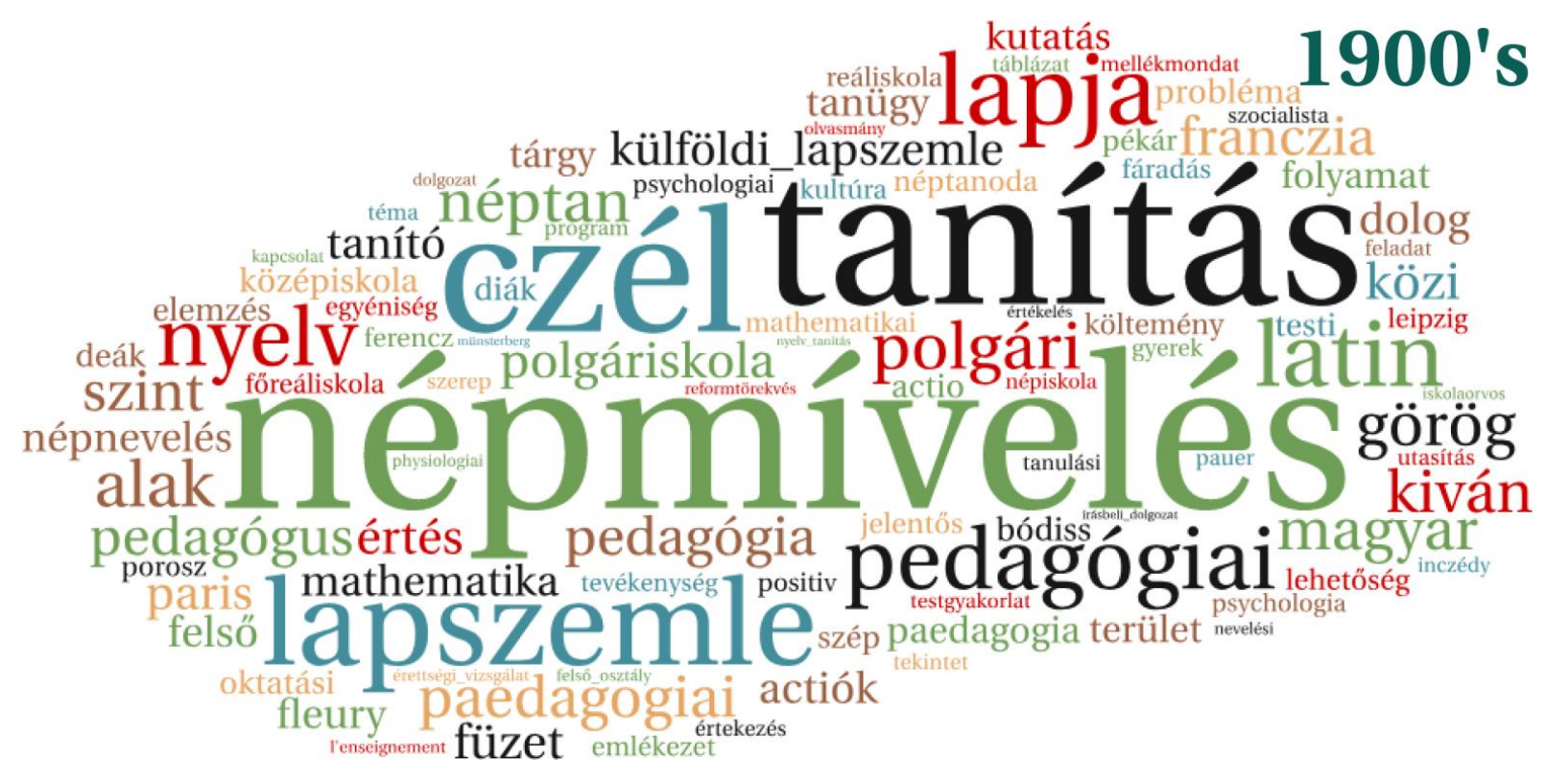

81. ábra

Az 1900-1909 közötti évek khí-négyzet vizsgálati módszer alapján generált automatikus kulcsszavai a Magyar Pedagógia cikkeiböl képzett mintából 
Minden eddigi eredményünkkel egybevágóan az 1910-es évek (82. ábra) egyik legfontosabb témáját a háború jelenti. Emellett központi szerep jut még a magyar és német kulcsszavaknak is, a francia azonban visszaesik. Az iskolatípusok ebben az évtizedben is hangsúlyosan jelen vannak: népiskola, polgári iskola, középiskola, fögimnázium. A következő évtizedet jelentő 1920-as évek az automatikus kulcsszavazás alapján született 83. ábra alapján egyértelmủen a néptanítók évtizede, hiszen minden más évtized mellett ekkor vált leghangsúlyosabbá ez a kifejezés a lapban. Nyilván ebben a Néptanítók Lapjának mint sokszor hivatkozott forrásnak is komoly szerepe van, ahogyan látható, hogy a „lapja” kulcsszó is előkelő helyet tölt be az évtizedben. Ismét találunk jó néhány, az első háború lecsengésére és a korban lezajló társadalmi átalakulásokra utaló automatikus kulcsszót: háború, pacifizmus, csonka-magyarország, weimari, trianoni, bolsevista, bolsevizmus, világszövetség. Szintén előkerül az évtizedre vonatkozó korábbi ábráknál szintén megjelenő tuberkulózis.

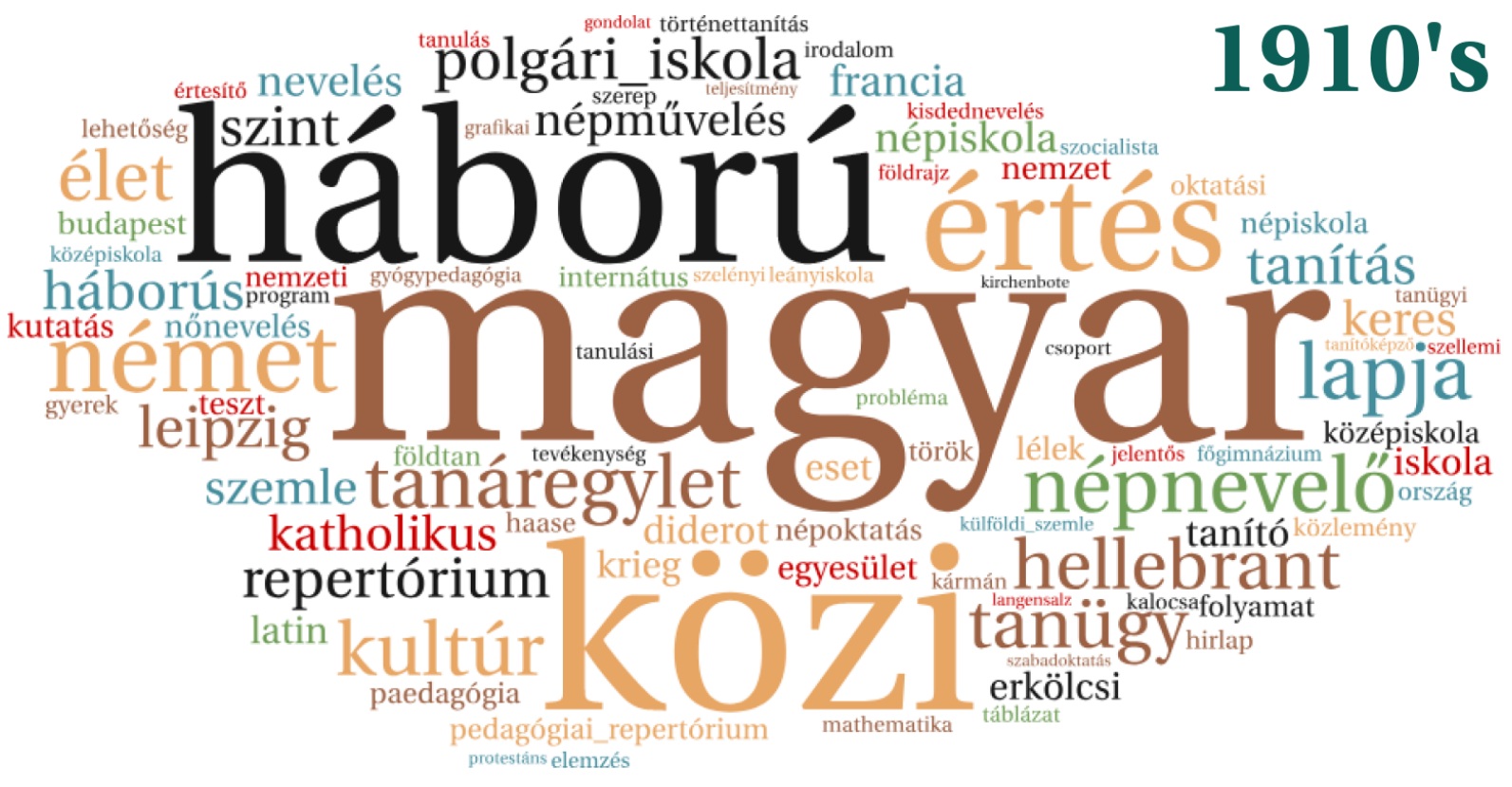

82. ábra

Az 1910-1919 közötti évek khí-négyzet vizsgálati módszer alapján generált automatikus kulcsszavai a Magyar Pedagógia cikkeiböl képzett mintából 


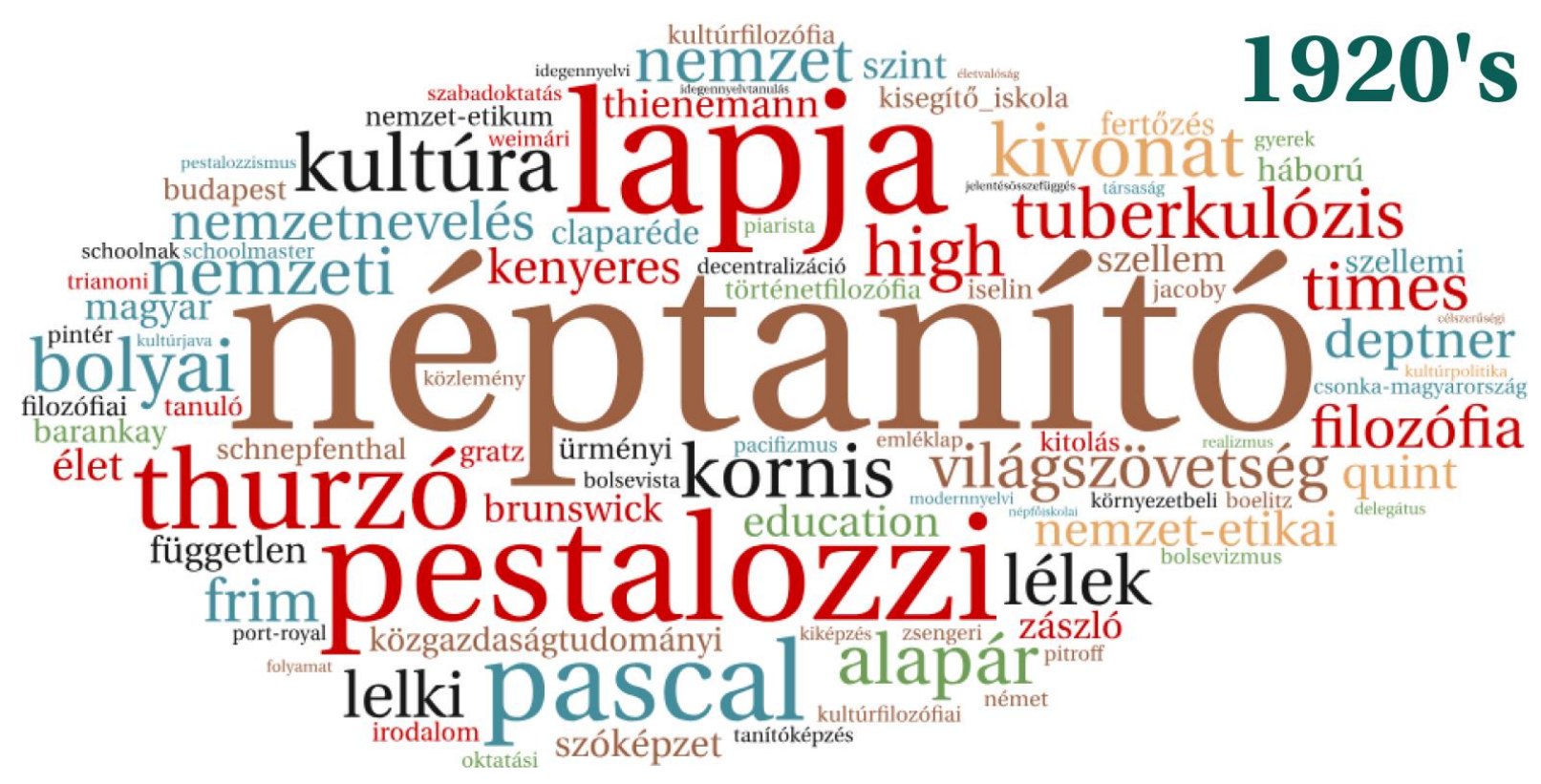

83. ábra

Az 1920-1929 közötti évek khi-négyzet vizsgálati módszer alapján generált automatikus kulcsszavai a Magyar Pedagógia cikkeiböl képzett mintából

Az 1930-as évek (84. ábra) esetében a Fináczy [Ernő] automatikus kulcsszó elsősége szintén nem meglepő, hiszen hasonló eredményeket láthattunk az 1930-as évekből a repertórium tárgyszavain alapuló szófelhő esetében is. Ebben az évtizedben is jelen vannak a korszellemet meghatározó személyek és kifejezések, mint például Hitler, Népszövetség. Egyedi, különleges témaként jelennek meg a zsinórírás, a karakterológia és a jellemiskola automatikus kulcsszavak. Az 1940-es évek legfontosabb automatikus kulcsszavai a következőképpen alakultak: Budapest, nevelői, Széchenyi, nevelő, lelki, lélek, lélektani, élet, magyar, irodalom, népi. Egyértelmüen megfigyelhető a modern írásmód térnyerése, a 85. ábrán nem találunk régiesen írt szóalakot, ami a korábbi évtizedekben pedig még rendszeresen előfordult. Az ábrán viszonylag sok személynév szerepel, melyeket külön nem sorolunk fel. Az ábra alapján hangsúlyeltolódás figyelhető meg a pszichológiai témák irányába. Elkezdenek megjelenni a népiséggel kapcsolatos témák a népi és népi hagyomány kulcsszavak vonatkozásában. Az emberközpontúság szintén kitapintható a humanizmus, humanitás, ember, emberi, lelkiség, lelki alkat és szellem automatikus kulcsszavak nyomán. 


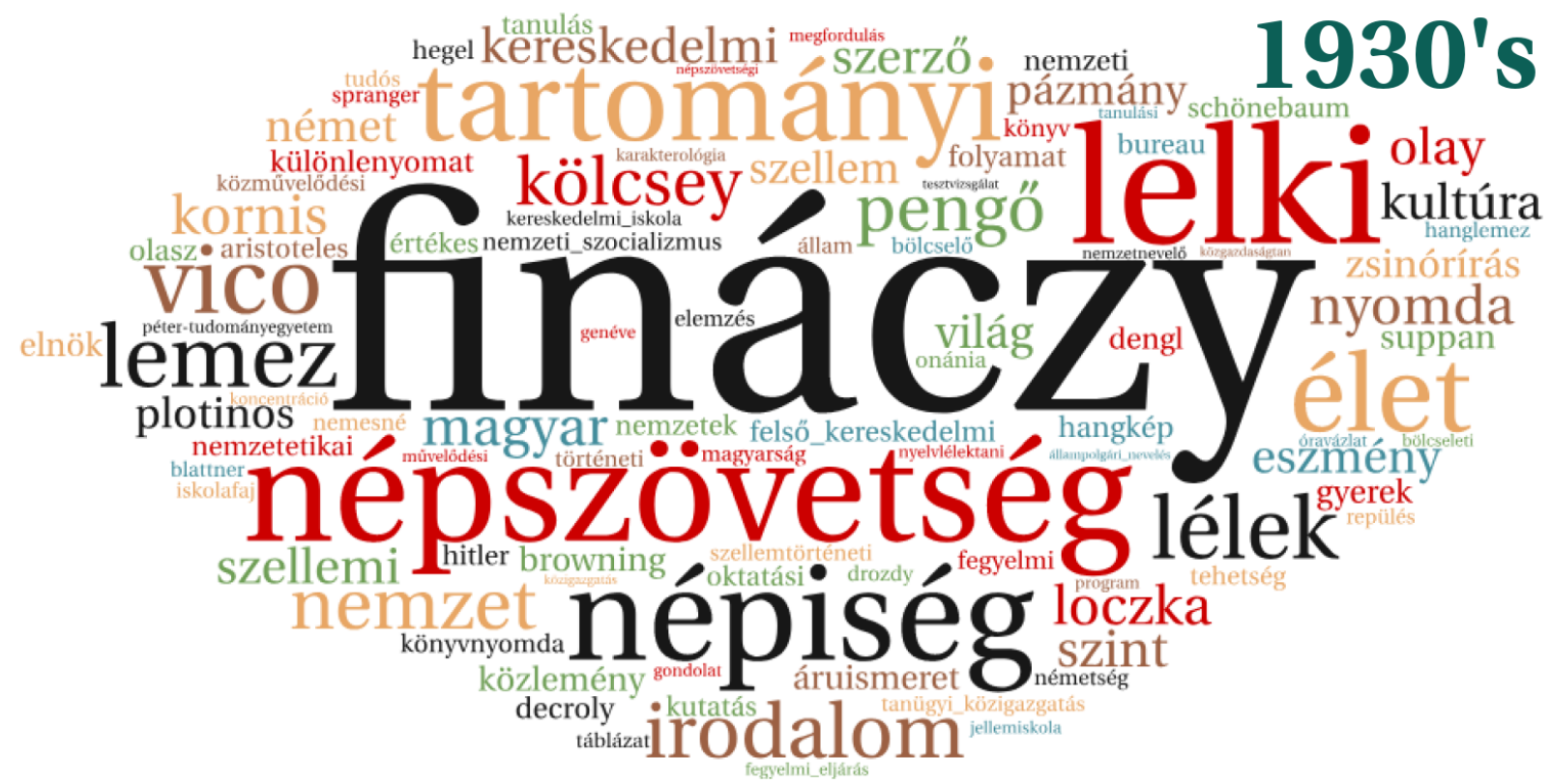

84. ábra

Az 1930-1939 közötti évek khí-négyzet vizsgálati módszer alapján generált automatikus kulcsszavai a Magyar Pedagógia cikkeiböl képzett mintából

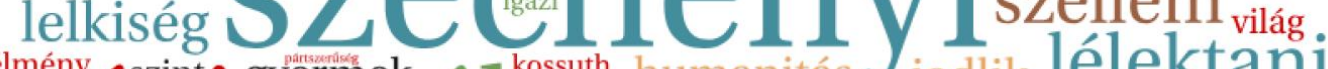

élmény szint• gyermek < kossuth humanitás jedlik lélektani

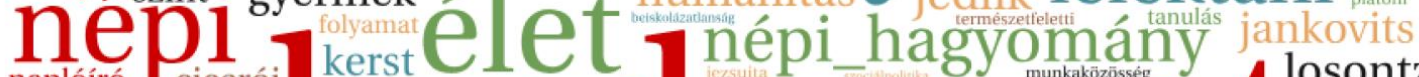

biczó Magyar humanizmus önzés

1940's naplóíró cicerói

magyarság

földes

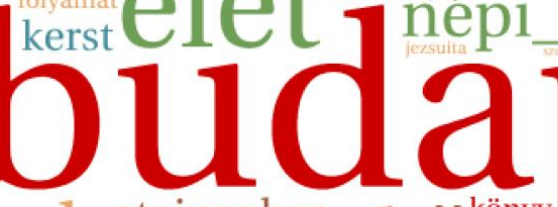

fröbel steinacker

"könyv hagyomán

bodahy

eidetikus

szegényparaszt

OzSdánov 1 ?

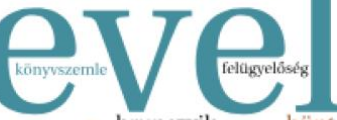

szerző hrunszvik

85. ábra

Az 1940-1949 közötti évek khi-négyzet vizsgálati módszer alapján generált automatikus kulcsszavai a Magyar Pedagógia cikkeiböl képzett mintából 
Bár a Magyar Pedagógia tekintetében az 1950-es évek korántsem tekinthető teljes évtizednek, hiszen csupán egyetlen rövidített évfolyam jelent meg 1950-ben, ennek ellenére most mégis közöljük ennek az egyetlen évnek a szövegkorpusza alapján készült automatikus kulcsszavazás eredményeinek szófelhőjét (86. ábra). Az ötvenes évekre vonatkozóan eddig ezt a korábbi eljárások szerint készült évtizedes bontások esetében nem tettük meg a kisméretű minta miatt, ezért most kivételt tennénk, hogy ez az egyébként fontos korszakváltást tükröző időszak ne maradjon ki az elemzésekből. Egyáltalán nem meglepő módon a tartalmi váltást tekintve a kommunista ideológia hatása közel száz százalékosnak mondható. Az automatikus kulcsszavak nagy része már első ránézésre kapcsolódik a kommunista irányvonal szóhasználatához, a legnépszerübbek pedig különösen: [Nagyezsda Konsztantyinovna] Krupszkaja, ötéves terv, Szovjetunió, tervgazdaság, burzsoá, munkásosztály, termelőeszköz, kozmopolitizmus, nép demokrácia, reakciós, stb.

Tovább árnyalja a képet, hogy azon kulcsszavak esetében, ahol elsőre talán nem ennyire szembeötlő a kötődés a kommunista rendszer szóhasználatához, - mélyebben megvizsgálva az előfordulásokat és a szövegkörnyezetet - szintúgy kiderül, hogy valójában ugyanúgy ideológiai megközelítésủ írásokról van szó. Ilyen módon kerültek be az automatikus kulcsszavak közé, mintegy a kommunista ideológusok antitéziseként a következök: klérus, klerikális, holdas, ravasz, felekezeti iskola, kapitalizmus, monopólium. Mindezek mellett a korszellemet még inkább tükrözendő, érdemes kiemelnünk azokat az automatikus kulcsszavakat, amelyek első ránézésre talán furcsán hatnak egy neveléstudományi folyóirat tartalmát leíró kulcsszavak között, azonban, ha alaposan belegondolunk a korszak hátterébe, akkor mindennél jobban mutatják ezeknek az éveknek a miliőjét. Nem tipikusan neveléstudományi szakkifejezések a 86. ábráról a mütrágya, a nehézipar, a gépállomás, a kisüzem, a nagyüzemi, a pionírszervezet, a mezőgazdaság és a mezőgazdasági termelés.

Az 1960-as évekre konszolidálódott a tudományos diskurzus és a szélsőséges elhajlások eltüntek a folyóiratból (87. ábra). Természetesen a kommunista ideológiára jellemző automatikus kulcsszavak még mindig jelen vannak, de egyrészt érzékelhetően kisebb számban, másrészt pedig annyira kirívó esetek nem fordulnak elö közöttük, mint a fentiekben bemutatottak. Néhány példa a szocialista nevelési diskurzus legnépszerübb szóhasználatát illetően: szocialista, kommunista, dolgozó, KISZ, szocialista erkölcs, elidegenülés, Marx, elvtárs, Tanácsköztársaság, világnézeti nevelés, úttörö, marxista, kommunizmus. Ezek mellett természetesen előkerülnek a repertórium és a Contenta tárgyszavak alapján az 1960-as évekre várható témák is: tanítógép, programozott tanítás, film, magnetofon, oktatási folyamat, programozott. Ezek mellett azonban új témák is előbukkannak az automatikus kulcsszavazás 
mentén: vers, szakkör, történelemtanítás, kísérleti osztály, politechnikai, gyógypedagógia, technikum.

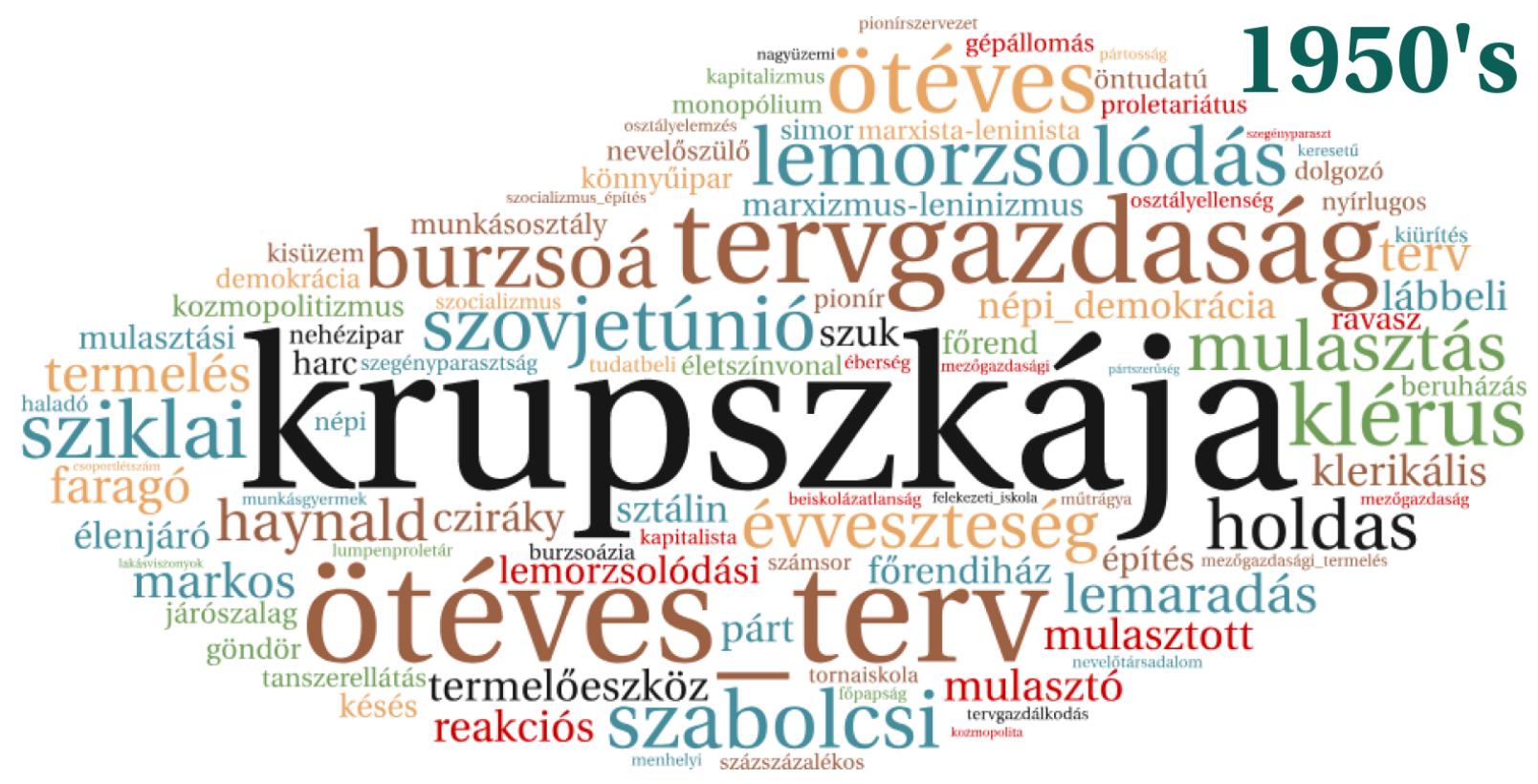

86. ábra

Az 1950-es év khí-négyzet vizsgálati módszer alapján generált automatikus kulcsszavai a Magyar Pedagógia cikkeiböl képzett mintából

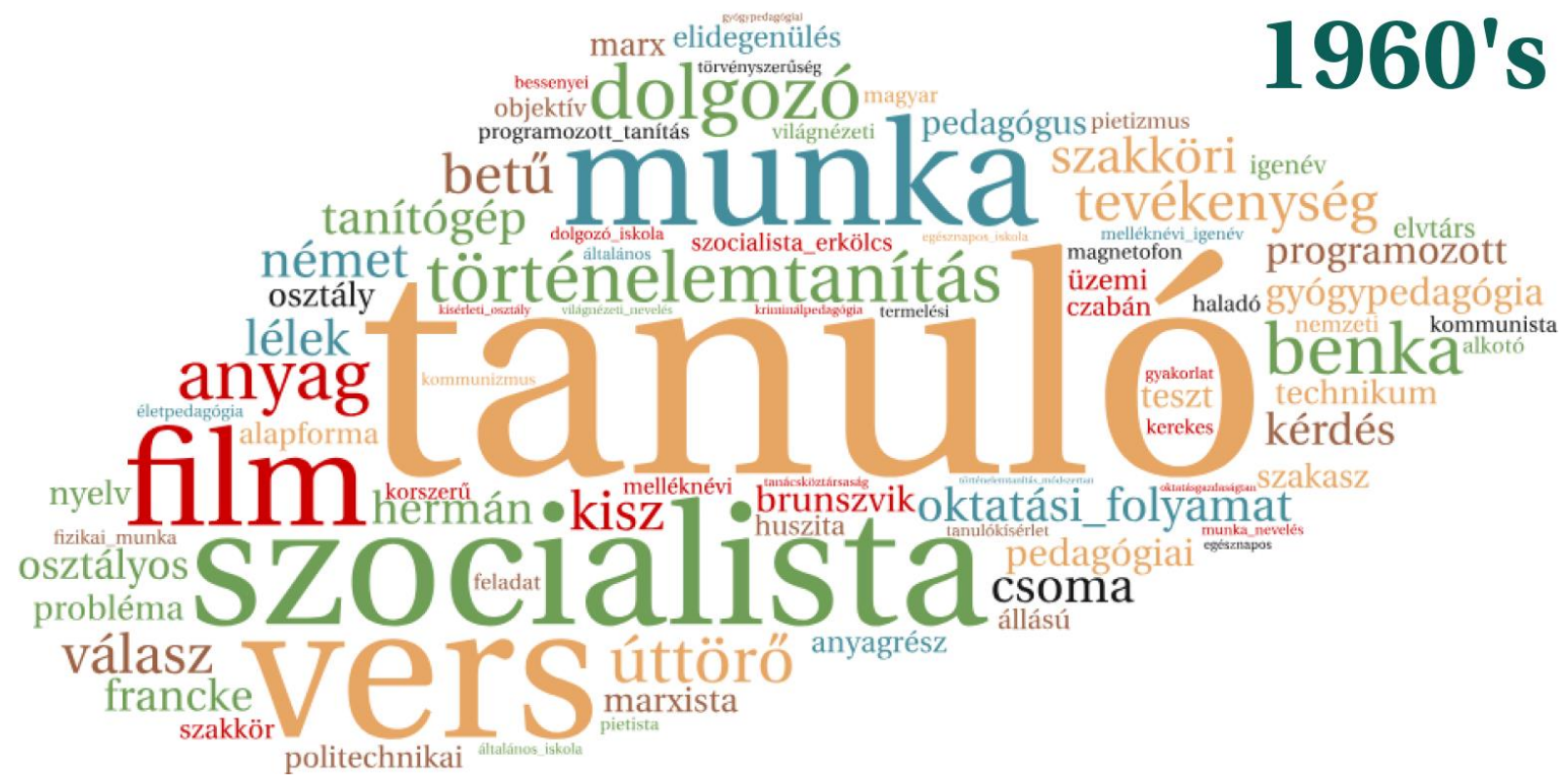

87. ábra

Az 1961-1969 közötti évek khí-négyzet vizsgálati módszer alapján generált automatikus kulcsszavai a Magyar Pedagógia cikkeiböl képzett mintából 
Az 1970-es évek automatikus kulcsszavas szófelhőjének (88. ábra) tematikája főbb vonalait tekintve megegyezik az 1960-as években tapasztalhatóakkal. Ugyanúgy megtalálhatóak a szocialista nevelési filozófiára jellemző kulcsszavak: szocialista, Lenin, marxista, kommunista, szovjet, Szovjetunió, szakszervezet, szocialista ország. A szocialista szó mellett a toplista elején állnak még a pedagógiai, a lengyel, az UNESCO szóalakok. A következő nagyobb csoportot ismét a konkrét neveléstudományi témák személynevei és szakkifejezései jelentik, mint például Comenius, lélek, permanens nevelés, nevelésfilozófia, kutatás, csoportmunka, struktúra, felnőttoktatás, programozott oktatás, nevelési folyamat, köznevelési rendszer. Néhány automatikus kulcsszó egyértelmüen neveléstörténeti megközelítésű cikkekből származik, így ezáltal is tetten érhető a neveléstörténet felívelő pályája az 1970-es és 1980-as években, melyet a korábbi elemzésekben már egybevágóan kimutattunk.

Az 1980-as évtized legerősebb automatikus kulcsszavát [Anton Szemjonovics] Makarenko (1888-1939) neve jelenti. A születési és halálozási évszámokból kiderül, hogy alapvetően (szocialista) neveléstörténeti megközelítésű cikkekről van szó. Természetesen ezen túl is jelentek meg neveléstörténeti témájú írások ebben az évtizedben. A nyolcvanas években már viszonylag kevés, a szocialista nevelési ideát megjelenítő kulcsszót láthatunk a 89. ábrán. A nyugatnémet témák láthatóan elökerülnek, több kulcsszó is bizonyítja ezt (NSZK, NyugatBerlin, német). Az 1980-as éveket illetően az eddig bemutatottakhoz képest az automatikus kulcsszavazás eredményeként újdonságként kerül elő a szentlőrinci [iskolakísérlet].

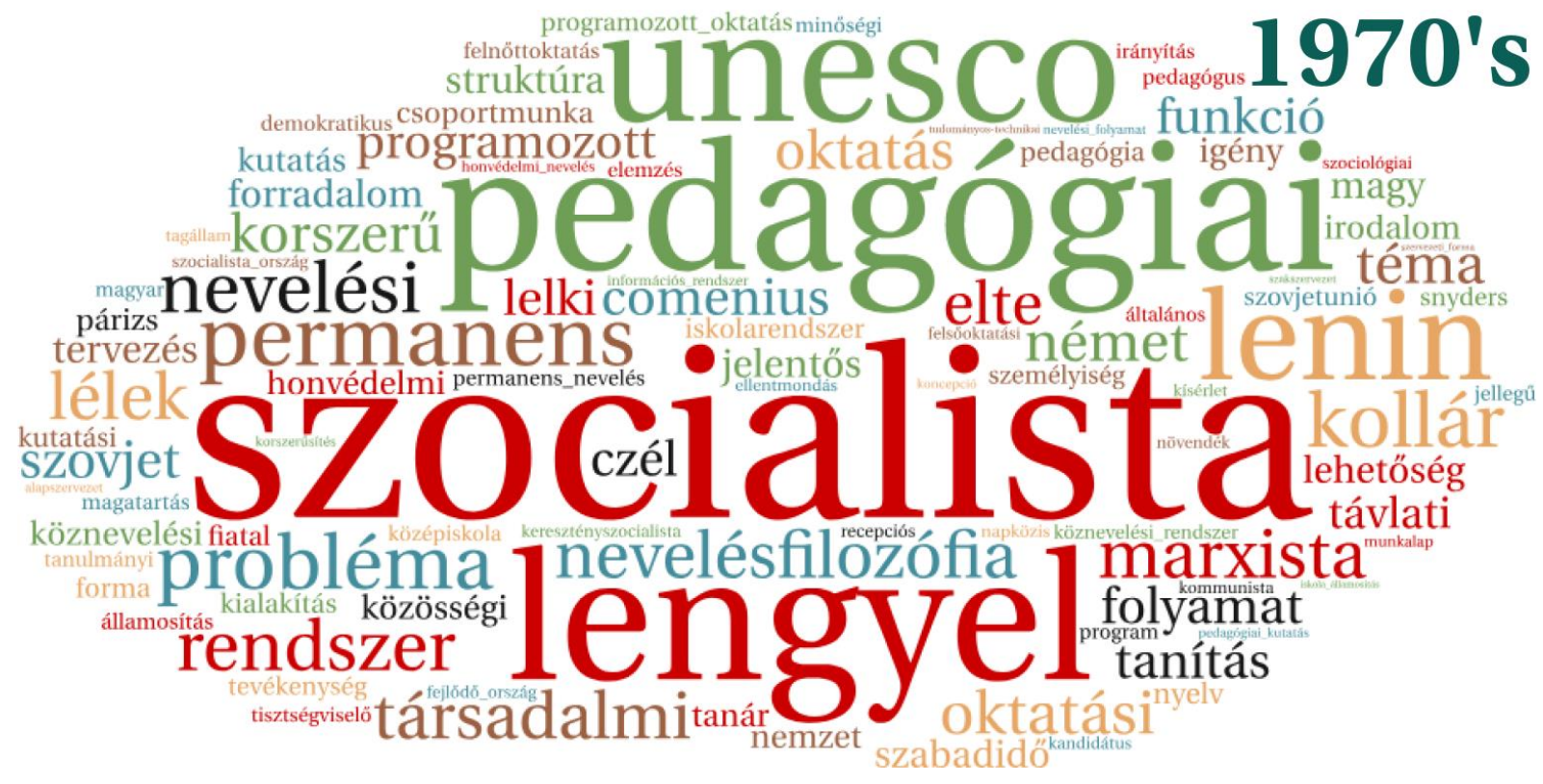

88. ábra

Az 1970-1979 közötti évek khi-négyzet vizsgálati módszer alapján generált automatikus kulcsszavai a Magyar Pedagógia cikkeiböl képzett mintából 


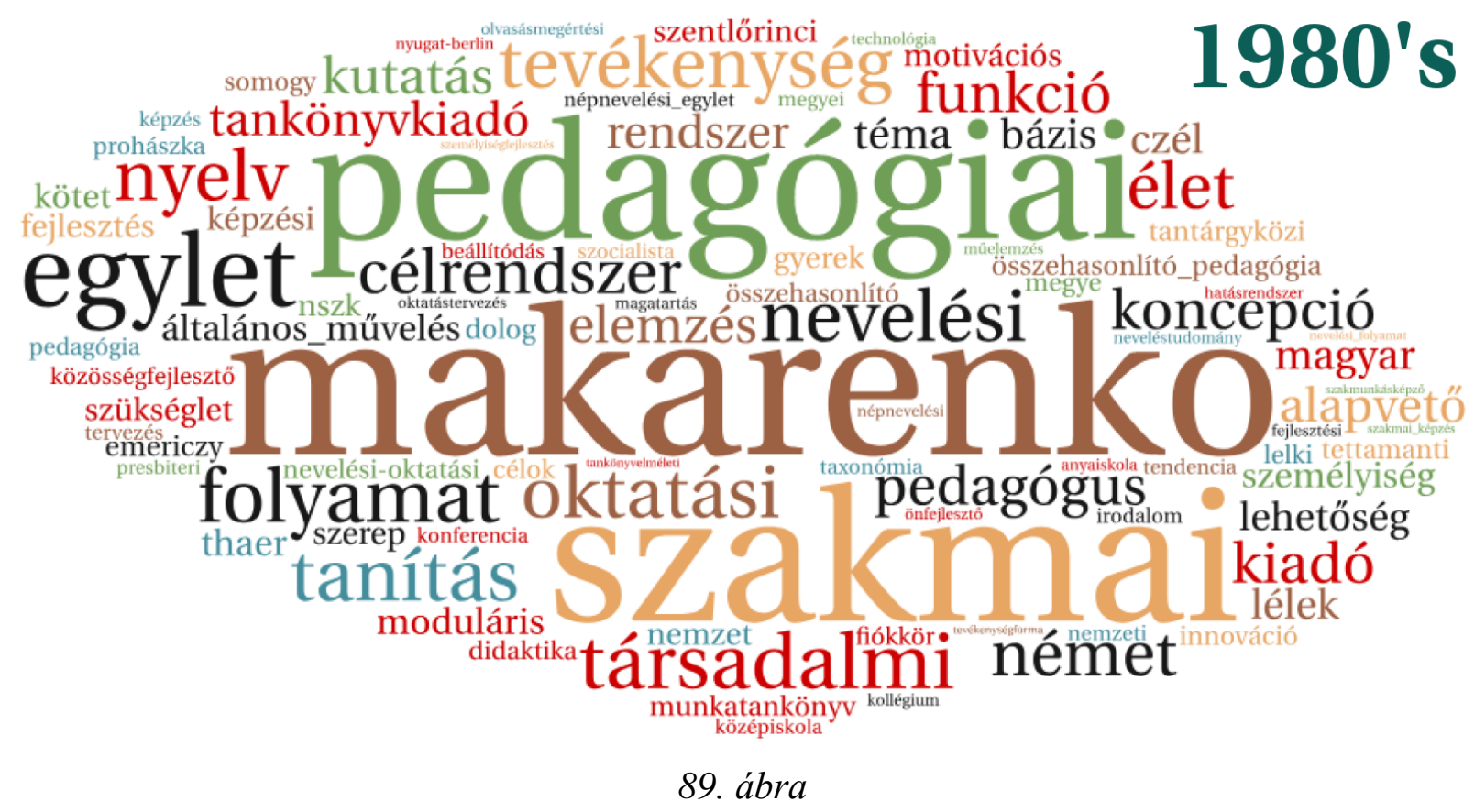

Az 1980-1989 közötti évek khi-négyzet vizsgálati módszer alapján generált automatikus kulcsszavai a Magyar Pedagógia cikkeiböl képzett mintából

Az automatikus kulcsszavazás alapján készült szófelhő alapján elmondható (90. ábra), hogy az 1990-es évek a gyerekek évtizede volt, hiszen jól látható módon a gyerek szóalak kimagaslik az összes többi kulcsszó közül. Néhány további kulcsszót közlünk még felsorolásszerüen, amelyek az eddigi, 1990-es évtizedre vonatkozó ábrák mellett tovább árnyalják az ekkor lezajlott kurzusváltást. Ezek a szavak nem igazán jellemezték a korábbi szóhasználatot, ezért tudtak dominánssá válni a rendszerváltást követő évtizedben, figyelembe véve a használt algoritmus alapelveit: információs technológia, autonómia, empátia, funkcionális analfabetizmus, multikulturális, kétnyelvüség, kéttannyelvü, zsüritag, paradigma, árnyékoktatás. Talán még inkább a felsorolt témák újszerüségét mutatják a vizsgált évtizedben a következők: finn, japán, iszlám, cigány. Az automatikus kulcsszavak alapján látható, hogy a neveléstörténeti témák nem csengtek le teljesen a rendszerváltást követően sem, erre a jelenségre utalnak a következők: [John Henry] Newman, Csepreg, ciszterci, Festetics, Apponyi.

A 2000-es éveket jellemző 91. ábra szófelhője alapján a legnagyobb változást (amellett, hogy a gyerek szó helyett a diák szóalak jön használatba) a konkrét, szigorúan véve tudományos megközelítésű, neveléstudományi kutatási projekteket ismertető publikációk számának növekedése és egyben a korábbi tudományos szóhasználat teljes átalakulása mutatja. Ezt az átalakulást felfoghatjuk a folyóirat egyfajta professzionalizálódásának is. A folyamat az automatikus kulcsszavak nyomán egyértelműen tetten érhető. Tovább árnyalja a képet, hogy a 91. ábrán látható kulcsszavak a kognitív megközelítés és a kvantitatív mérés-értékelési paradigma térnyeréséről tanúskodnak. 
A különböző statisztikai szakkifejezések mellett a leghangsúlyosabbak között szerepel a táblázat szóalak, ami arra utal, hogy a szerzők nagy számban kezdtek el táblázatos formájú kutatási adatokat közölni a cikkeikben, amelyekre azután természetesen a szövegeikben is hivatkoznak. Az alábbiakban felsorolt automatikus kulcsszavak a fent vázoltakat támasztják alá: teszt, szórás, kérdőív, kutatás, minta, item, ábra, átlag szórás, gyakoriság, szint, modell, lány, felmérés, mérés, szignifikáns, válasz, gamma, változó, átlag, skála, részminta, faktor, mutató, korreláció, longitudinális. Kutatási irányokat jellemző szakkifejezések szintén elöfordulnak: elsajátítási, stratégia, képesség, attitüd, motiváció, kompetencia, problémamegoldás, önszabályozás, énkép, kognitív, kooperatív, kombinatív, flow, valamint induktív és induktív gondolkodás. A kulcsszavak között megjelenik a politikailag korrektebbnek tartott roma szóalak, egyértelmüen felváltva a korábbi cigány szóalakot. Neveléstörténeti tárgyú írásokra utaló automatikus kulcsszavakat itt már egyáltalán nem találunk, az ebben az évtizedben megjelent és ismert ilyen tárgyú írás nem mutatkozik meg az automatikus kulcsszavak között, hiszen a neveléstörténet mint témakategória marginálissá vált a korábbiakhoz képest, helyette a fent bemutatott irányvonalak váltak uralkodóvá. Az egyes tantárgyakat illetően a matematikára, illetve a magyar nyelv és irodalomra utaló kulcsszavakat tudtunk azonosítani az 91. ábráról: szöveg, nyelvi, metafora, kombinatív képesség, matematika, matematikai. Egyéb tantárgyakat nem sikerült azonosítani az automatikus kulcsszavazás alapján készült szófelhő nyomán.

Az utolsóként elemzett 2010-es (fél) évtizedben lényegében az előző évtizedben elkezdődött trendek folytatódtak és teljesedtek ki még inkább, talán annyi különbséggel, hogy az egyes kulcsszavak eloszlása sokkal egyenletesebb (ez a 92. ábrán abban a momentumban figyelhető meg, hogy a szófelhő szavainak betűméretei sokkal közelebb állnak egymáshoz). Az automatikus kulcsszavak többsége ismét két dimenziót érint: statisztikai és/vagy mérésértékelési szakkifejezések, illetve az aktuális neveléstudományi diskurzus fő témacsoportjai és azok jellemző kulcsszavai jelennek meg az évtizedet feltáró 92. ábrán. Az első csoportba a teljesség igénye nélkül a következő automatikus kulcsszavak sorolhatóak: skála, szignifikáns, faktor, kérdőív, mérés, tesztelés, kutatás, átlag, teszt, dimenzió, táblázat, mérőeszköz, kutatás, átlag, papír alapú, papír, számítógép alapú. Míg a másodikba pedig ezek: olvasási motiváció, iskolai erőszak, adaptív, célorientáció, magatartásminta, zaklató, támadó, erőszak, szorongás, énkép, agresszió, stressz, szövegértés, iskolai kötődés, kognitív, tanulási motiváció, zenei, olvasási motívum, szociálisprobléma-megoldó, rendszerező képesség, élethosszig tartó tanulás. Már ezen a viszonylag rövid önkényes felsoroláson belül is azonosítható egy iskolai és családi erőszakkal foglalkozó témakategória, amely szintén újdonság a korábbi évtizedek témáihoz 
képest. A tantárgyak vonatkozásában a korábbi évtized matematika, illetve magyar nyelv és irodalom irányvonala helyett a 2010-es években inkább a zenei és sport témák kulcsszavai kerülnek előtérbe (zenei, zenei müveltség, edző, sportoló), azzal a megkötéssel, hogy az olvasáskutatás az egyik legerősebb témává lépett elő.

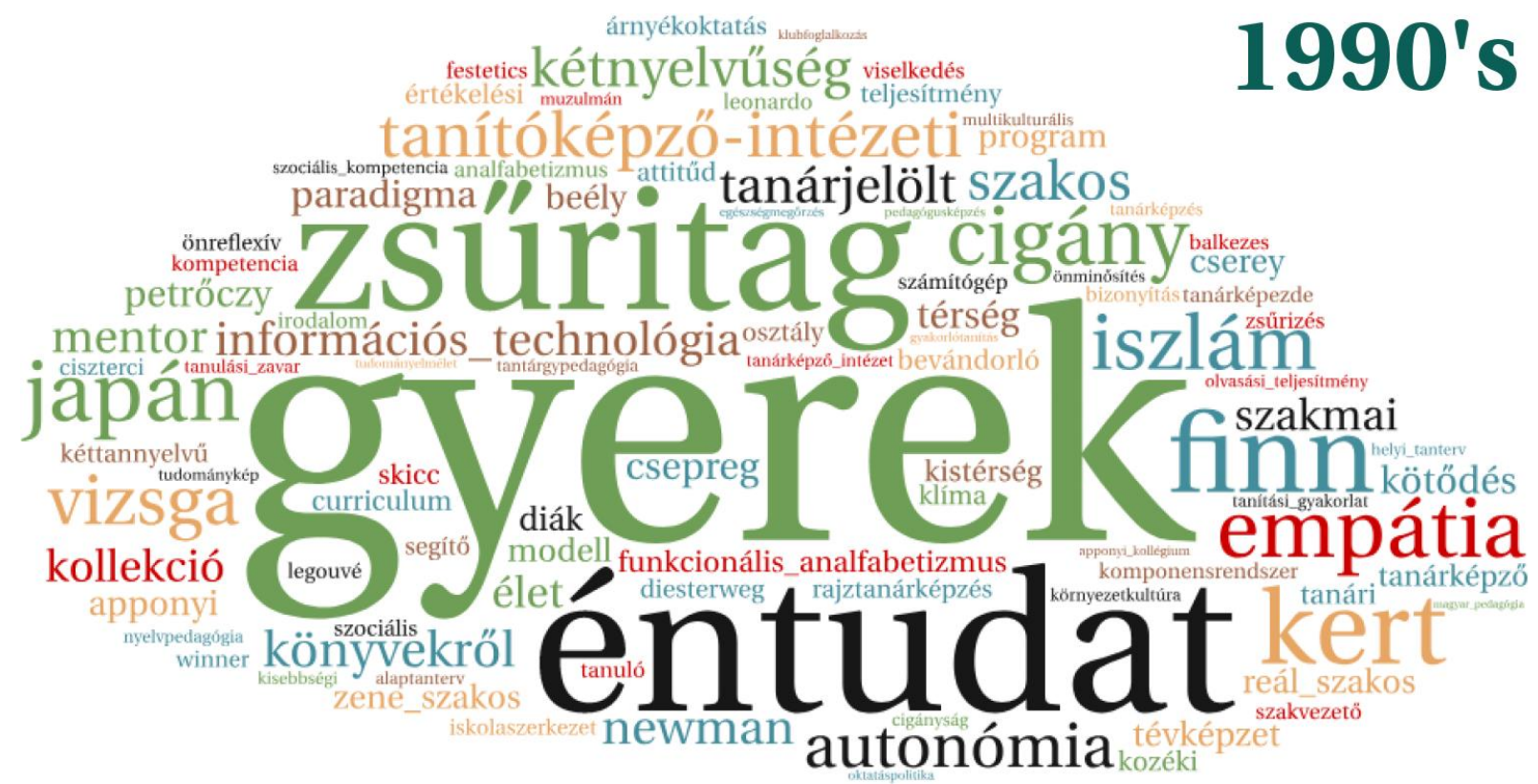

90. ábra

Az 1990-1999 közötti évek khí-négyzet vizsgálati módszer alapján generált automatikus kulcsszavai a Magyar Pedagógia cikkeiböl képzett mintából

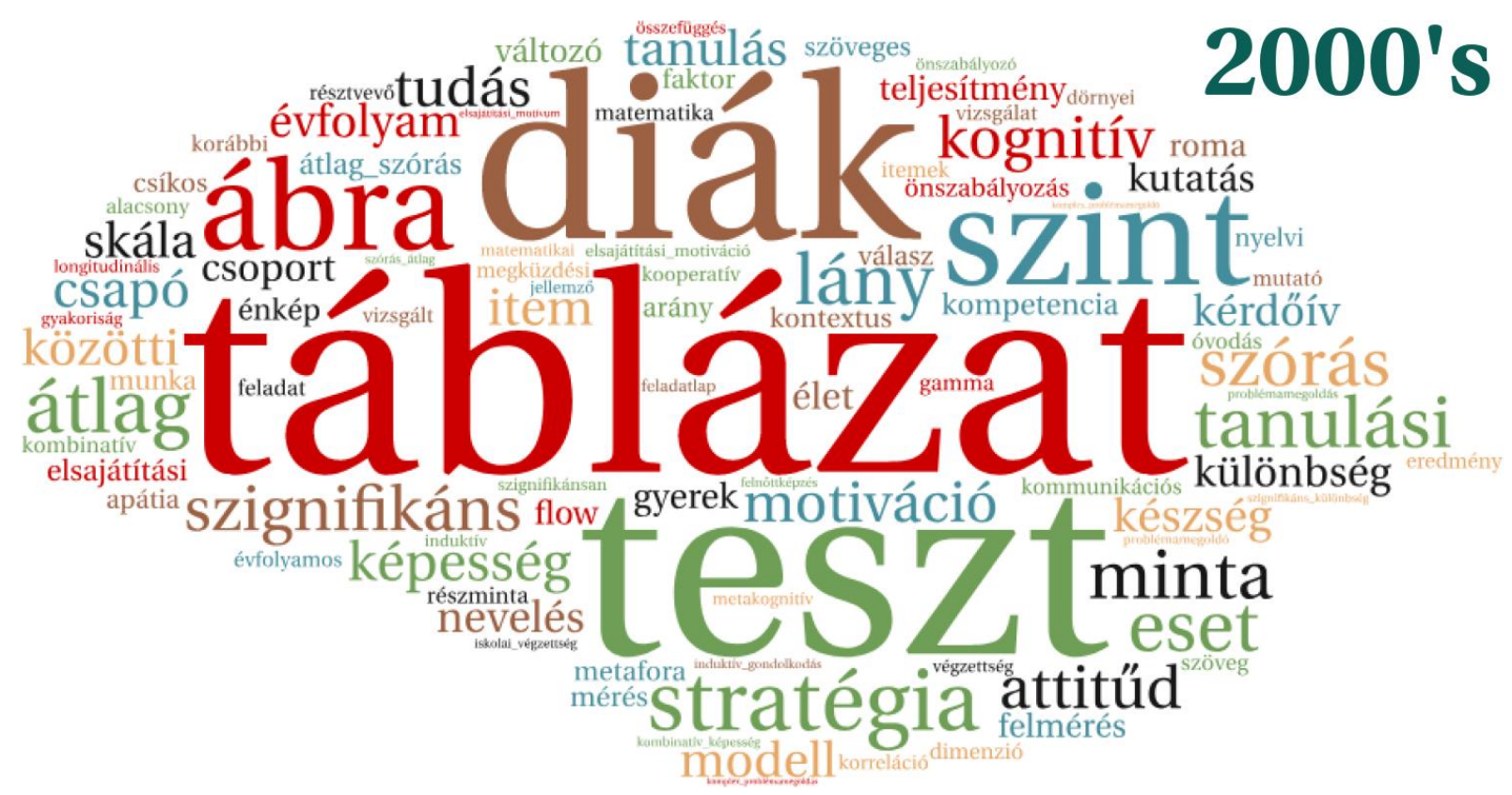

91. ábra

A 2000-2009 közötti évek khí-négyzet vizsgálati módszer alapján generált automatikus kulcsszavai a Magyar Pedagógia cikkeiböl képzett mintából 
iskolai_kötő̉dés kognitív

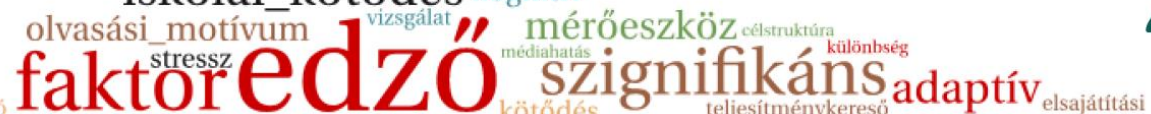

2010's

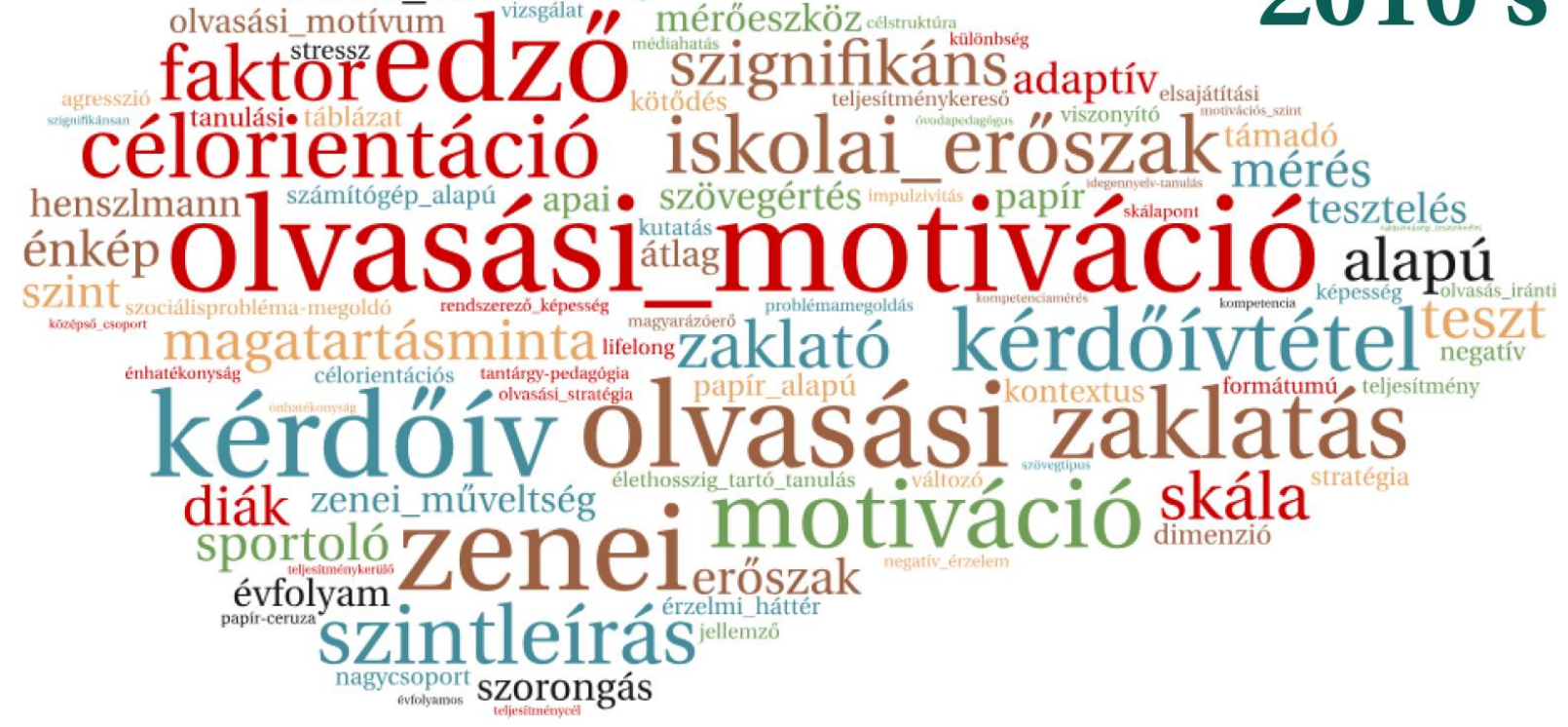

92. ábra

A 2010-2014 közötti évek khí-négyzet vizsgálati módszer alapján generált automatikus kulcsszavai a Magyar Pedagógia cikkeiböl képzett mintából

\subsection{Hasonló cikkek detektálása}

\subsubsection{Két cikk egymáshoz való hasonlósága}

A tematikus hasonlóságok detektálása régóta kurrens témát jelent a mesterséges intelligencia kutatásokban. A különféle, napjainkra igen széles körben használt ajánlórendszerek alapját ugyanis ez a technológia jelenti. Szigorúan a tudományos publikálás és disszemináció területén maradva, egy kifejezetten jól működő példára hivatkozva mutatnánk be a módszerben rejlő potenciált: hasonló elven működik az Academia.edu (és más hasonló portálok) ajánlórendszere is. Mivel a 8.5. pontban tárgyalt topikmodellek megalkotása segítségével kimutathatóvá vált egy számszerüsíthető távolság az egyes dokumentumok hasonlóságának mérésére, ezért a tartalmi kategóriák megalkotása mellett a leghasonlóbb cikkek detektálására is lehetőség nyílt. A topikmodellezés a rejtett Dirichlet allokáció módszer alapján történt, míg az egyes eloszlások hasonlóságát a Kullback-Leibler divergencia alapján határoztuk meg. A kapott eredményeket egy táblázatban foglaltuk össze, melynek szerkezete a következő: az A és B oszlopokban a leghasonlóbbnak bizonyuló cikkek egyedi azonosítója szerepel, míg a C és D oszlopokban azok címe. A két cikk közötti távolság az E oszlopban jelenik meg, amely minél kisebb értéket vesz fel, az adott sorban található két cikk annál hasonlóbbnak tekinthető egymáshoz képest a tartalmi elemzés szerint. 
Az elemzés elkészült a teljes időszakra és a szükített 1991-2014 közötti időszakra is. Az utóbbi esetében, talán a kisebb elemszám és a nagyobb nyelvi homogenitás következtében meggyőzőbbek az eredmények. Néhány kimondottan adekvát példa ebből az időszakból: Kéri Katalin két tanulmánya, az „Alapfokú oktatás a középkori iszlám világban” publikációjához tartalomra nézve a „Tanárok a középkori iszlám világban” cikke bizonyult a leghasonlóbbnak, vagy egy másik szerző, Felkai László két cikke („Gróf Zichy János, a kultuszminiszter” és „Berzeviczy Albert, a müvelődéspolitikus”) esetében szintén megtörtént a tartalmi összepárosítás.

A teljes időszak leghasonlóbb cikkei listájának élén leginkább különféle könyvismertetések állnak. Több esetben egymásra hasonlító cikként sikerült detektálni egy előzménycikket, majd a rá érkező válaszcikket, például: „A kereskedelmi szakiskolák reformja” és "Észrevételek Dr. Szántó Sámuelnek a „Kereskedelmi szakiskolák reformja” czímü értekezésére”. Az 1910-es és a rákövetkező évből „A magyar paedagógiai irodalom 1909-ben”, majd „Paedagogiai repertorium” cikkpár, vagy az 1970-es évek végéről és az 1980-as évek elejéről „A személyiség irányultságának formálása mint nevelési cél” és „A marxista személyiségelmélet neveléselméleti konzekvenciái” szintén a pozitív példákat gyarapítja. A kiragadott példák sorát természetesen tovább lehetne folytatni, hiszen egy több ezer soros táblázatról van szó. Összességében elmondható, hogy a téves találatok aránya, melyek esetében első ránézésre nem világos, hogy miért detektálta a program hasonlónak a két cikket, viszonylag alacsonynak tekinthető.

\subsubsection{Klaszteranalizis, avagy több cikk egymáshoz való hasonlósága}

A cikkek egymástól való távolságának mérése természetesen lehetővé teszi kettőnél több cikk hasonlóságának kimutatását is a klaszteranalízis segítségével. A klaszteranalízis vagy egyszerüen klaszterezés és annak klasszikus vizualizálási módszere, a dendrogram (egyfajta hierarchikus fastruktúra) bevett eljárásnak számít a tartalmi elemzések között, ahogyan arról a szakirodalmi részben beszámoltunk (lásd 4. ábra). Először a dokumentumokból egy gráf épül, ahol minden cikk a hozzá leghasonlóbb $\mathrm{N}$ darab másik cikkel kerül összeköttetésbe tartalmi hasonlóságuk alapján, ezután az előálló gráf úgy darabolódik fel, hogy az minél nagyobb modularitást (Newman \& Girvan 2004) eredményezzen. A modularitás lényege, hogy az azonos csoportba sorolt pontok közötti élek súlya minél inkább meghaladja a csoportok között húzódó élek súlyát. A modularitás alapú klaszterezést egy második szintű klaszterezés követte, amely már magát a dendrogramot hozta létre. Erre azért volt szükség, mivel a modularitáson alapuló 
klaszterezés önmagában csak a pontokat particionálná, de nem rendelne hozzájuk hierarchiát, e müvelethez egy külön hierarchikus-agglomeratív klaszterező eljárást kellett használnunk. Az elvégzett lépések alapján kutatásunk eredményeként elkészült a Magyar Pedagógia folyóirat cikkeinek klaszteranalízise, az előző pontban tárgyalt, két cikk egymáshoz való hasonlóságának detektálása nyomán a teljes, illetve a szükített (1991-2014) vizsgálati időszakra nézve.

Eredményeink három eltérő granularitási szinten mutatják be az egyes cikkek klaszterekbe való tartozását. Az egyes granularitási szintek mutatják meg azt, hogy hány föklaszter van az adott elemzési szinten, azaz hány felső szintü fastruktúra bomlik ki a továbbiakban. A felső szintű klaszterek száma a teljes vizsgálati időszakban rendre 918, 136, 48, míg a szükített időszakban pedig 93, 20, 15. A klaszteranalízis vizualizációját egy dinamikus, hiperlinkekkel operáló táblázat formájában valósítottuk meg. Az oszlopokban egyegy klaszterazonosítóra lehet szürni, amely alapján kiderül, hogy mely dokumentumok kerültek közös csoportba. Mindez a 93. ábrán bemutatott módon valósult meg, azután pedig az egyes klaszterazonosítókra kattintva a 94-96. ábrákon látható nézet jelenik meg.

A 94. ábrán látható, \#628-as számú klaszterbe különböző, a programozott oktatással kapcsolatos tanulmányok kerültek, míg a 95. ábrán látható klaszter részletén különböző típusú képességek fejlesztésével kapcsolatos publikációk sorolódtak egymás mellé. Az itt példaként szereplő klaszteranalízisek közül a 96. ábrán már a szükített, 1991-2014 közötti időszakból mutatunk be egy klaszterrészletet, ahol különböző problémamegoldással kapcsolatos cikkek szerveződnek egy csomópontba. 
89 mp_1995_001_002_6095_097- Kiss Árpád emlékezete

90 mp_1995_001_002_6096_101- Somos Lajos, 1952-ben, a III. B-röl

$\# 25 \quad \# 3 \quad \# 1$

91 mp_1995_001_002_6097_113- Kötöttség és/vagy szabadság?

$\# 28 \quad \# 4 \quad \# 2$

92 mp_1995_001_002_6098_119- Új tanári szakok és tantervi programjaik

$\# 23 \quad \# 9 \quad \# 6$

93 mp_1995_001_002_6099_139- Bábosik István és Mezei Gyula: Neveléstan. Telosz Kiadó, Budapest, 1994. 273 o.

94 mp_1995_001_002_6100_142- Galicza János - Schődl Lívia: Pedagógusok gubancai

$\# 29 \quad \# 4 \quad \# 2$

95 mp_1995_001_002_6101_144- Pukánszky Béla - Németh András: Neveléstörténet

$\# 12 \quad \# 4 \quad \# 2$

$96{ }_{200}^{\mathrm{mp}} 1995 \_003 \_004 \_6102 \_157-$ Segités és pedagógia

$\# 69 \# 3 \quad \# 1$

97 mp_1995_003_004_6103_201- Tanári szerepek percepciója: egy általános iskolai felmérés tanulságai

$\# 21 \quad \# 5 \quad \# 8$

98 mp_1995_003_004_6104_229- A természettudományos nevelés és a tudományelméletek

$\underline{19} \quad \# 7 \quad \underline{4}$

99 mp_1995_003_004_6105_251- Az informatikai-számítástechnikai tudás rétegzôdése

$\# 71 \# 19 \# 14$

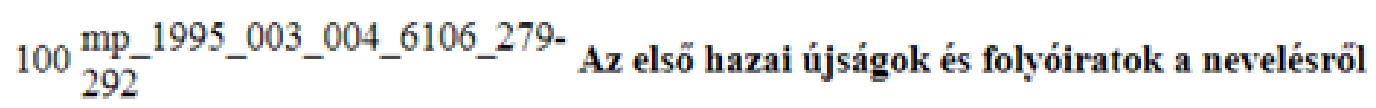

$\# 32 \quad \# 3 \quad \# 1$

$$
\text { 93. ábra }
$$

A klaszteranalízis kiinduló oldalának részlete 


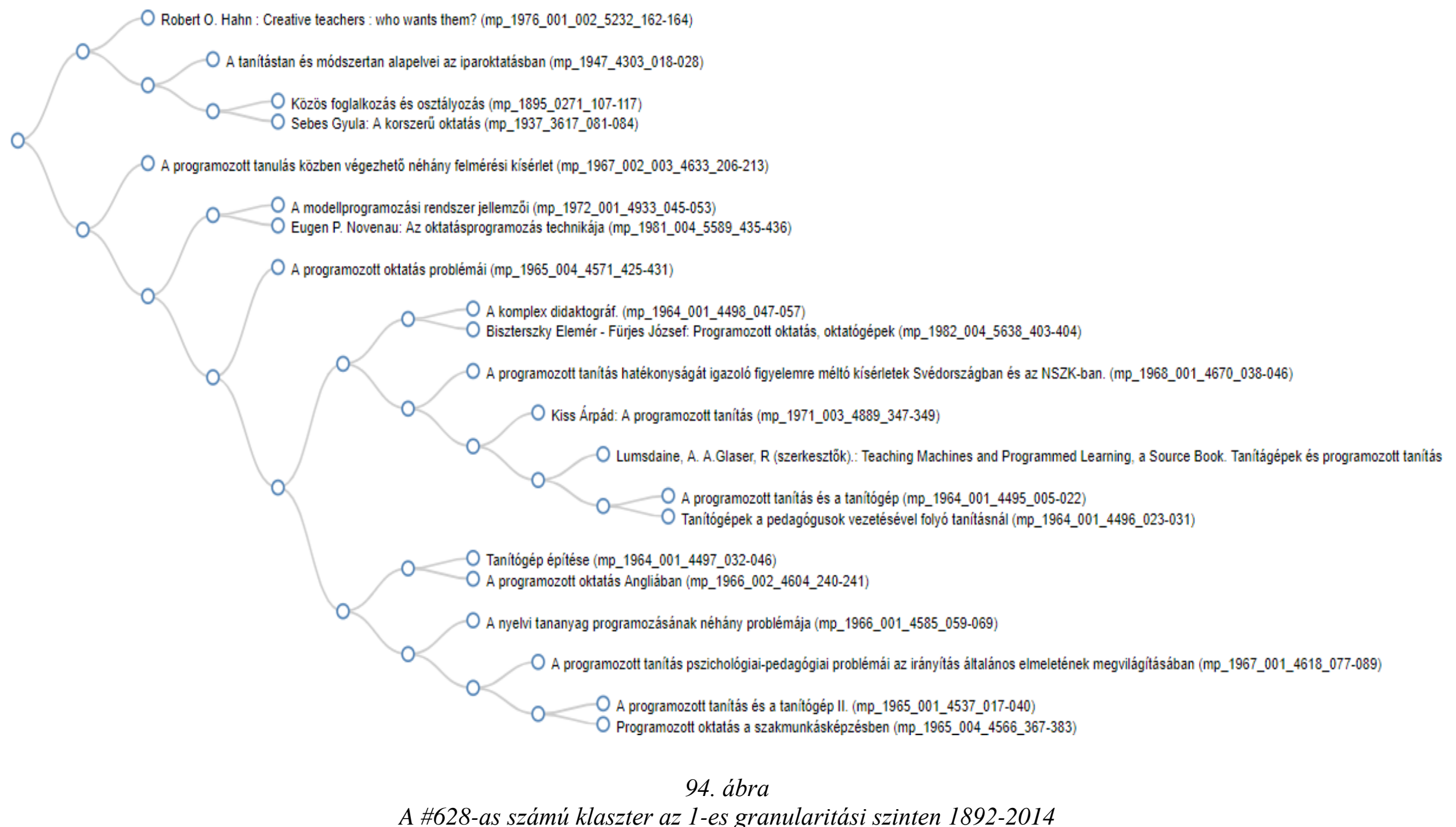




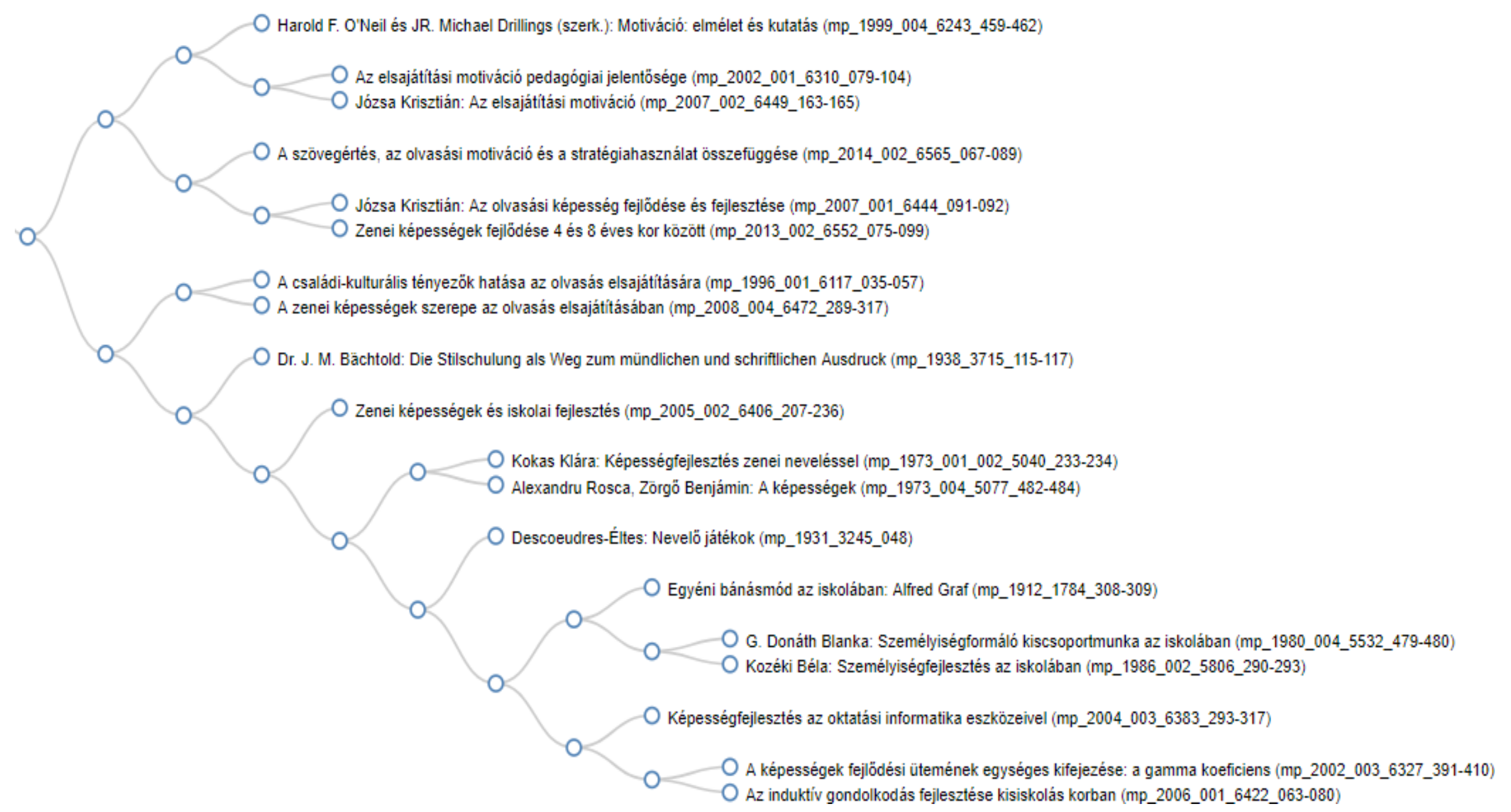

95. ábra

A \#46-os számú klaszter egy részlete a 3-as granularitási szinten 1892-2014 


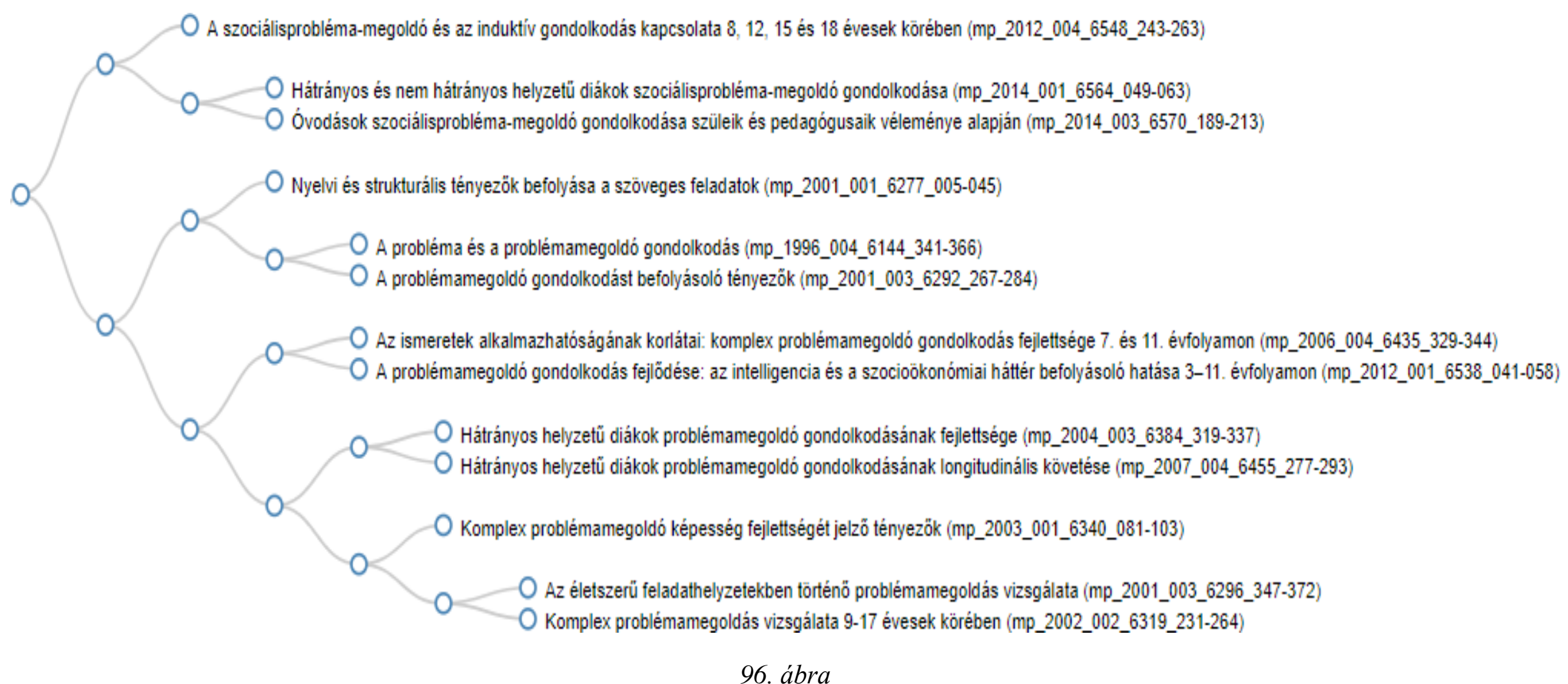

A \#8-as számú klaszter egy részlete a 2-es granularitási szinten 1991-2014 


\subsection{A tartalmi csoportosítás és trendkövetés}

\subsubsection{A tartalmi csoportosítás és trendkövetés háttere}

A kutatási projekt elején, a tartalmi elemzés megtervezése során a különféle gyakoriságvizsgálatok mellett a másik világosan kivehető irányt a tartalmi csoportosítás, azaz a kategóriaalkotás, majd a kategóriák időbeli változásának vizsgálata, azaz a trendkövetés jelentették. Az így előálló eredmények azonban magukban mit sem érnek, ezek értő és befogadható láttatása, azaz az eredmények vizualizálása nélkül. A megfelelő módszer megtalálása nem ment egyik pillanatról a másikra, végül egy „Trendplotter” nevü, Python programnyelven írt önálló fejlesztés biztosította az előzetesen kitüzött célok elérését. Ahogyan a projekt során az összes szövegbányászattal kapcsolatos fejlesztés és eredmény, ennek a programnak az elkészítése is a Szegedi Tudományegyetem Számítógépes Algoritmusok és Mesterséges Intelligencia Tanszékével való együttműködésnek köszönhető. A programot Berend Gábor írta és adaptálta az általunk megfogalmazott igények és elvárások szerint.

A tartalmi csoportosításra vonatkozóan a szoftver müködési elve alapján meg lehet adni egy adott időszakra vonatkozó korpuszt, amelyből kiindulva a program elemzi, hogy az egyes topikokra mennyire jellemzőek az egyes szavak, valamint, hogy az egyes dokumentumokban mekkora mértékben fejeződnek ki az egyes topikok. Az eljárás hátterében müködő LDAmódszert a megfelelő módszertani fejezetben (5.3.) ismertettük. Az ilyenfajta kategóriába sorolásnál természetesen az eredményeket nagymértékben befolyásolja, hogy előzetesen hány besorolási kategóriát határozunk meg. A túl kevés kategória túl általános témacsoportokat eredményezhet, míg túl magas kategóriaszám esetén a részletekben való túlzott elmerülést kockáztatjuk, amely az eredmények befogadhatóságát veszélyezteti, arról nem beszélve, hogy ezáltal a hibás kategóriaalkotás esélye is nagymértékben növekszik. Az optimális kategóriaszám, azaz a megfelelő granularitási szint megtalálása érdekében több kísérletet végeztünk. Végül a végső programváltozatba a 10-15-20 kategória szerinti felbontás lehetősége lett beépítve. Ilyen módon a három granularitási szint biztosít egyfajta rugalmasságot, ugyanakkor az előzetes tesztek alapján az is kiderült, hogy az optimális kategóriaszám nagyjából ebben a nagyságrendben található. A tíz alatti kategóriaszám még nem teszi lehetővé a jól elkülöníthető valódi témacsoportok létrejöttét, míg húsznál több témacsoport esetében már egymást látszólag átfedő témacsoportok is létrejöhetnek.

Ahogyan a többi tartalmi elemzésnél, itt is fontosnak tartottuk, hogy az 1892-2014 és a 1991-2014 közötti időszakok külön-külön is vizsgálhatóak legyenek. Nem volt ez máshogyan 
a trendkövetés esetében sem, így kezdődátumként az 1892 és az 1991 értékek adhatóak meg a program bemeneti paramétereként, míg a végdátum szabadon változtatható, alapértéke a 2014es év. Mindezen opciók mellett a Trendplotter program által előállított grafikonon lehetőség van az eredmények aggregációjára is, mind az X, mind az Y tengely mentén. A vízszintes tengely mentén ez az opció az egyes évek évtizedekre való összevonását és az eredmények interpolálását jelenti, míg a függőleges tengely mentén, a topikok eloszlását tekintve az eredmények normalizálását takarja, eltekintve ezáltal az egyes évfolyamok hullámzó terjedelmétől. Ez az utóbbi nézet így az egyes témák egymáshoz viszonyított aktuális arányaira koncentrál. Az alábbiakban bemutatott eredmények között a bekezdésben tárgyalt mindegyik fajta megközelítésre találhatóak példák.

Az egyes témacsoportok ábrákon szereplő elnevezésének alapjául szolgáló kulcsszavakat táblázatos formában közöljük a mellékletben (5-10. melléklet). Minden témacsoport esetében az első 25 legjellemzőbb szót szerepeltetjük ezekben a táblázatokban. A témacsoportok neveit ezek alapján az adott kategóriára jellemző kulcsszavak alapján határoztuk meg. Minden esetben próbáltuk megtalálni az adott témát minél inkább lefedő, ugyanakkor frappáns és rövid elnevezést. Mivel nem beszélhetünk egzakt kategóriákról, ezért bizonyos esetekben ez a cél fantázianeveken keresztül volt a legegyszerübben megvalósítható. Az egy-két szavas topiknevek szubjektív faktora miatt a rájuk jellemző kulcsszavakat felsoroló, mellékletben szereplő táblázatok gazdagabb információtartalommal szolgálnak, emiatt ezeket a trendkövetés minden vizsgált időszakára és típusára közöljük.

A $\mathrm{K}_{10}$ kutatási kérdés első felére (Korszakonként melyek voltak a leghangsúlyosabb tématerületek a folyóirat életében és hogyan változtak ezek évtizedröl-évtizedre a folyóirat története során?) a 97-102. ábrákon található tématerületek adják meg a választ, míg a második felére (Mennyire követték a szerzők az éppen aktuális nemzetközi kutatási irányokat?) a trendkövetés részben ismertetett, illetve a korábbi gyakorisági és kulcsszavas vizsgálatok nyomán az a válasz adható, hogy a szerzők nagy általánosságban igyekeztek lépést tartani a nemzetközi kutatási irányokkal. Ez különösen tetten érhető a két világháború között, illetve a rendszerváltást követő időszakban. A szocializmus időszakában (főleg annak elején) valamelyest más szelek fújtak ezen a téren, de az 1970-es évektől kezdődően már egészen naprakész módon, észrevehetően a nyugati szakirodalomból átszivárgó témák is megjelentek a publikációk témái között (erről bővebben a szakkifejezések használatának változása részben lesz szó). Az alább közölt ábrák áttekintésén túl ebből a szempontból további érdekes adalékokkal szolgálhat a melléklet részben szereplő témacsoportokat jellemző kulcsszavak listája. 
Az 1892-2014 közötti időszakról összesen három-három, normalizált eredményeket mutató ábrát közlünk, ahol rendre 10, 15 és 20 kategória került megjelenítésre. Minden granularitási szintre vonatkozóan közöljük az évtizedenkénti aggregált és interpolált ábrákat is, ahol az apróbb részletek ugyan elvesznek, azonban éppen ebből következően a főbb trendek sokkal jobban láthatóvá válnak. A K 11 kutatási kérdésre az általunk elvégzett tartalmi elemzések alapján a következő válasz adható: a Magyar Pedagógia életében három nagyobb mértékü korszakváltást sikerült kimutatni. Ezek volumenét tekintve a következő sorrend alakítható ki: az első tematikus váltás a második világháború utáni időszakra, illetve a lap 1961-es újraindulására tehető, a második a rendszerváltás utáni időszakra, míg a harmadik az 1900-as évek elejére, amikor lap nagyjából tíz éves lett. $\mathrm{A} \mathrm{K}_{11}$ kutatási kérdés második felére koncentrálva elmondható, hogy a korszakváltások időszakában kevésbé volt jellemző a témák egymásra épülése, rétegződése és a szerves fejlődés, sokkal inkább éles tematikus váltásoknak lehettünk ekkor szemtanúi. Ez különösen érvényesnek tekinthető a két nagyobb korszakváltásra, ahol a történelmi háttérrel együtt értelmezve az eredményeket könnyedén belátható, hogy az uralkodó politikai ideológia - szemléletében átszivárogva a neveléstudományi diskurzusba - nagymértékben befolyásolta a lap tartalmát. A köztes időszakokban már sokkal inkább jelen volt a kutatási kérdésünkben is megfogalmazott folyamatos egymásra épülés, illetve az egyes témák szerves fejlődése és rétegződése.

Az eredmények alapján elmondható, hogy a második világháború, illetve az azt követő szünet a lap megjelenésében szinte minden esetben átrendezte a fő témák vonalait. Nem egyszer előfordul, hogy az addig népszerünek mondható témák lapbeli reprezentációja szinte elvágólag eltünik ennél a tartalmi diskurzusváltásnál, míg más témák előbukkannak a semmiből és átveszik a korábbiak helyét. Természetesen nem mindig történnek ennyire drasztikus változások, de az egyértelmű változások mindenesetre határozottan tetten érhetőek. Hasonlóan erőteljes korszakhatárnak tekinthető a rendszerváltás időszaka. A harmadik, talán az előző kettőnél valamelyest kisebb horderejű változást az 1900-as évek elején sikerült azonosítani, nagyjából a lap tíz éves kora tájékán. Ez egyébként többé-kevésbé egybeesik a folyóirat terjedelmének jelentős bővülésével (a publikációk számának változását lásd a 8 . ábrán), illetve a századfordulón történt főszerkesztőváltással. Ez azt jelenti, hogy a cikkek megnövekedett száma egyúttal témák közötti átrendeződést okozott, valószínüleg teljesen új témák is szép számmal megjelenhettek ekkortájt. A korszakhatárok az ábrákon ott érhetőek tetten, ahol egyegy sáv jelentősen szélesebbé válik, azaz kitágul (grafikusan: <), vagy éppen ellenkezőleg, egy sáv veszít szélességéből, azaz összeszükül (grafikusan: >). 
A $\mathrm{K}_{12}$ kutatási kérdésünk (Egybeesnek-e folyóiratban tapasztalható korszakhatárok a magyar neveléstudományban elfogadott korszakhatárokkal?) megválaszolásához - mintegy kiindulási alapként - szükséges annak megvizsgálása, hogy vannak-e egyáltalán konszenzusos, elfogadott korszakhatárok a magyar neveléstudományban. Németh $(2013 ; 2015)$ tanulmányai nyomán először az az érzésünk támad, hogy nincsenek igazán ilyenek, inkább tudományfejlődési modellekről és irányzatokról beszélhetünk, melyek sok esetben egymással párhuzamosan, időben átfedve léteztek, különböző, referenciaszemélyekhez vagy helyekhez köthető iskolákat teremtve ezáltal. A fölöttes tudományos teret tekintve azonban Németh (2015) tanulmányában is megtalálhatóak az eredményeink nyomán kibontakozó korszakhatárok, mint például: „Ezek a hatások - egy viszonylag rövid, az 1940-es évek második felétől 1989-ig tartó kitérőt leszámítva - a 20. század utolsó harmadában újra erőteljesen érvényesülnek majd.”, illetve: „Ezek a recepciós folyamatok jól nyomon követhetők a magyar egyetemeken a tudományok 19. századi korai intézményesülése időszakában, illetve a 20. század elején kibontakozó német szellemtudományos orientáció vagy a reformpedagógia, továbbá annak tudományos vonulatát jelentő empirikus pedagógia jelentkezése kapcsán éppen úgy, mint más elöjellel a szocialista pedagógia szovjet orientációjának, majd az 1970-es évektől mind erőteljesebben érvényesülő újbóli nyugat felé fordulás időszakában.” (Németh, 2015, p. 255)

Emellett a $\mathrm{H}_{10}-\mathrm{H}_{12}$ vonatkozásában egyébként is nagyon fontos gondolatnak tartjuk Németh (2015, p. 255) állítását, miszerint a hazai neveléstudomány fejlődése valójában recepciótörténetként értelmezhető: „....a kisebb tudományos potenciállal és infrastruktúrával rendelkező országok, így a magyar tudományos közösség (leginkább a humán és társadalomtudományok terén érvényesülö) alapvető sajátossága az éppen kurrens tudományos irányzatok átvételében, recepciójában ragadható meg. Ebből a nézőpontból vizsgálva, a tudományos teljesítmény leginkább a recepció gyorsaságában, illetve annak eredeti adaptációjában nyilvánul meg.” Az alábbiakban a trendkövetés tartalmi csoportosításon alapuló ábrái következnek, először az ábrákat, majd a rájuk vonatkozó elemzést közölve. 


\subsubsection{A tartalmi csoportositás és trendkövetés eredményei}

A 97. ábra évenkénti bontásban mutatja az 1892-2014 között tapasztalható tartalmi trendeket tíz témacsoport kialakítása mentén, míg a 98. ábra évtizedenkénti bontásban teszi ugyanezt. Az első témaként azonosított „,nemzetköziség” névvel illetett téma idevágó módon illusztrálja az előző bekezdésben tárgyalt recepciós megközelítés helyességét (természetesen nem kizárólagos módon). Főként a nemzetközi szakirodalom folyóiratban való megjelenését kell mögötte érteni, ahogyan az a témát lefedő kulcsszavakból egyértelműen kiderül. A második világháborút megelőzően nagyobb részaránnyal képviseltette magát, mint a későbbiekben. A második témaként azonosított „nyelvtanulás” topik ábrán való grafikus reprezentációja egybevág a gyakoriságvizsgálatoknál és kulcsszavas elemzéseknél megállapítottakkal. A nyelvtanulással kapcsolatos témák a folyóirat kezdeti szakaszában különösen népszerüek voltak. Az olyan klasszikus nyelvek, mint a latin és görög mellett a modern nyelvek is képviseltették magukat a témák között: a francia, német és angol nyelveknek fontos szerep jutott ebben az időszakban a lap hasábjain. A nyelvtanulás természetesen mindig jelen volt témaként a lap életében, azonban a kezdeti időszakban különösen hangsúlyos témának tekinthető, hiszen 30-40\% körüli részarányt képvisel a többi téma között. A harmadik témacsoportot jelentő „humanista témák” bővebb magyarázatra szorul. Egy ernyőtémáról van szó, amelynek legfőbb ismérve az emberközpontúság, többek között olyan kulcsszavak jellemzik, mint az ember, élet, szellemi, világ, lelki, érték, stb. A topik az 1910-es évektől nagyjából az 1940-es évekig élte virágkorát, ebben bizonyára szerepe volt a két világháborúnak és az ekkortájt a lapban népszerü lélektani témáknak. Az 1950-es évek éles váltást hozott ennél a témacsoportnál is, a lap hatvanas évekbeli újraindulása után már jóval kisebb részarányt tudott csak elérni.

A negyedik és ötödik témacsoportot az „oktatási intézmények” és a „népoktatás” jelentik. A négyes topik esetében olyan kulcsszavak jellemzőek, mint az iskola, tanár, középiskola, intézet, tanuló, egyetem, tanterv, felső, polgári, gimnázium, igazgató, állami. Míg az ötös témacsoportnál olyan jellemző kulcsszavak fordulnak elő, mint a népmüvelés, népiskola, néptanító, népoktatás, [népoktatók] lapja, népnevelö, stb. A két téma szorosan összefügg: a kulcsszavakból is látható, hogy az oktatás két szintjét jelenítik meg. A negyedik témacsoport esetében az is kiderül, hogy alapvetően egy oktatásszervezési témáról van szó. A 97. ábrán az „oktatási intézmények” sávot megvizsgálva megállapítható, hogy ez a témacsoport is főként a második világháború elött volt jelen, bár már ekkor is kisebb súlyt képviselt, mint amit a 2-es és 3-as témák esetében tapasztalhattunk. Az ötödik témacsoportra ez a megállapítás még inkább 
érvényes, érthető módon a szocialista időszakban már csak marginálisan, szinte a hibahatáron belül lévő mértékben fordul csak elö. Ezt a rendkívül alacsony előfordulást a hibás találatok mellett esetleg a neveléstörténeti tárgyalásmód magyarázhatja.

A következő, hatodik témacsoportot a „didaktika” névvel illettük, alapvetően egy oktatáselméleti megközelítésű ernyőtémáról van szó, amely a legjelentősebb szerepre a szocializmus időszakában tett szert. A korábbiakban elhanyagolható módon van csak jelen, míg a rendszerváltást követően ismét egyfajta visszaszorulása érzékelhető. A hetedik témacsoport („szociális-társadalmi témák”) szintén a második korszakváltásnak tekinthető, második világháborút követő időszakban kezdett el reprezentálódni a lapban, hogy azután viszonylag egyenletesen növekedjen, ahogyan az az évtizedes bontást alkalmazó 98. ábrán jól kivehető. A rendszerváltást követően még fokozottabb hangsúllyal jelent meg a folyóirat témái között. A kategória néhány jellemző kulcsszava: család, környezet, érzelmi, szociális, szülö, gyermek, közösség. A „mérés-értékelés” nyolcadik témakörként talán az elemzett időszak egyik legfeltörekvőbb témáját, egyben a folyóirat irányultságának megváltozását jelenti. Az 1970-es években kezdett elindulni önálló témaként, majd a rendszerváltás környékén kezdett el igazán berobbanni, hogy azután egyre nagyobb és nagyobb hangsúlyra tegyen szert. Az utolsó öt évben már 30-40\% körüli részaránnyal képviselteti magát a témák között, rávilágítva ezzel a folyóirat jelenlegi fő tartalmi irányultságára.

A tízes kategóriabontás esetében a neveléstörténetet és a vallással kapcsolatos témákat nem tudtuk egymástól elkülöníteni az elemzések során, ami a kilencedik témacsoport nevéből is kiderül: „neveléstörténet, vallás”. Néhány a témát jellemző kulcsszó: történet, comenius, régi, eötvös, korszak, protestáns, egyház, katolikus, kollégium. Összességében elmondható, hogy a témacsoport viszonylag egyenletes súllyal ível át a folyóirat több mint százéves történetén, általában stabilan 10\%-os részarány alatt maradva a többi téma között. Az utolsó, tizedik témacsoport az „,iskolai munka” nevet kapta, az olyan kulcsszavak miatt, mint a tanuló, osztály, munka, feladat, anyag, ismeret, tanulás, tevékenység, tárgy, iskola, figyelem, gyermek. Az egyes évtizedekben elég hullámzóan szerepel, viszonylag alacsony részaránnyal indul, a kezdeti marginalitás után kicsit növekszik, majd stagnál. A folyóirat 1960-as újraindulása után új erőre kap és a legnagyobb figyelmet ebben az időszakban kapja. Igazából rövid, de erös felfutás után újra kezd háttérbe szorulni, bár a rendszerváltásig az erősebb témák között tud maradni, onnantól viszont újra marginálissá válik és a vizsgálati időszak végéig stagnálást mutat. 


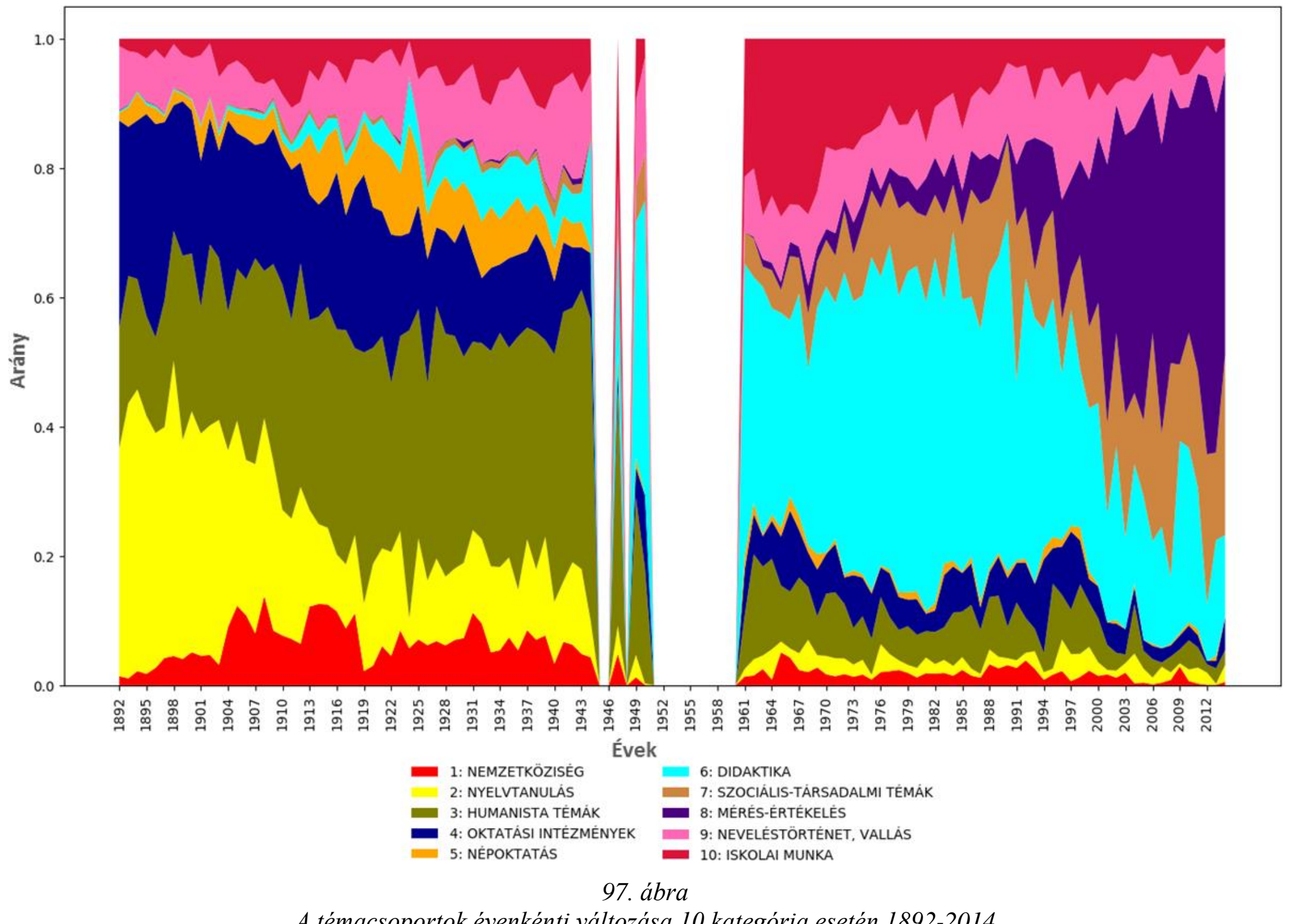

A témacsoportok évenkénti változása 10 kategória esetén 1892-2014

[Témacsoportok kulcsszavai: 5. melléklet] 
További válaszul szolgálva a $\mathrm{K}_{10}$ kutatási kérdésünkre, az évtizedenkénti bontást megjelenítő 98. ábrán az aktuálisan legnépszerübb diskurzusokat áttekintve, rendre a következő időbeli sorrend bontakozik ki a vezető témák tekintetében: nyelvtanulás, humanista témák, didaktika, mérés-értékelés. Úgy is fogalmazhatnánk, hogy az itt felsorolt témák az adott kor leginkább domináns témáit jelölik. A nyelvtanulás 1908 környékén adja át a stafétát a humanista témáknak, amely a második világháború végéig tartja magát, hogy azután átadja a vezető helyet a didaktikai témájú publikációknak. Ez a téma kis fáziskéséssel nagyjából a rendszerváltást követő pár évig tartja a domináns pozíciót, hogy azután átvegye helyét az utóbbi idők abszolút nyertese, a mérés-értékelés. A felsorolt domináns témák váltakozása nem meglepő módon, többé-kevésbé egybeesik a korábban bemutatott korszakhatárokkal is, tovább árnyalva ezzel a $\mathrm{H}_{10}-\mathrm{H}_{12}$ hipotéziseket.

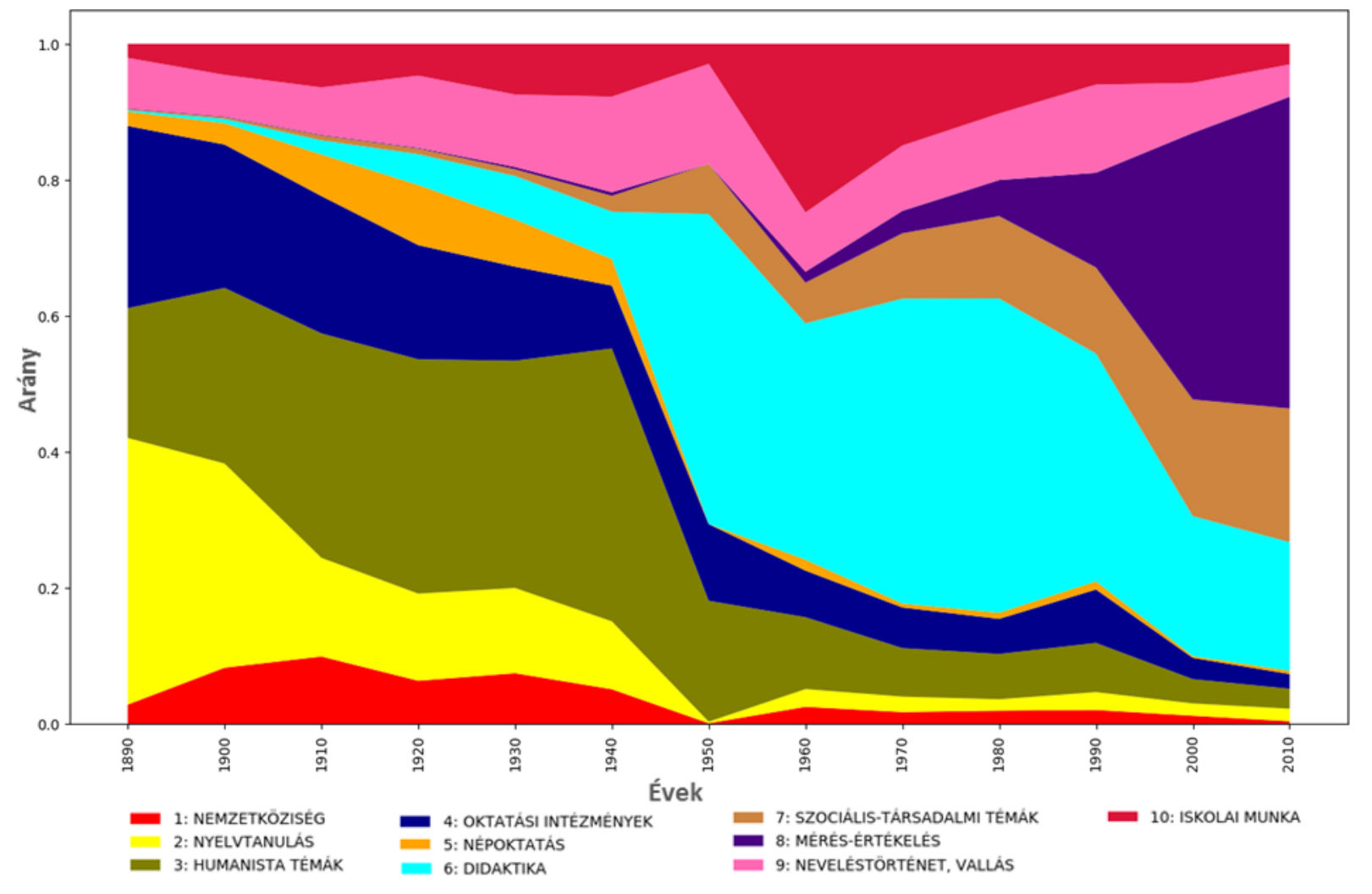

98. ábra

A témacsoportok évtizedenkénti változása 10 kategória esetén 1892-2014

[Témacsoportok kulcsszavai: 5. melléklet] 


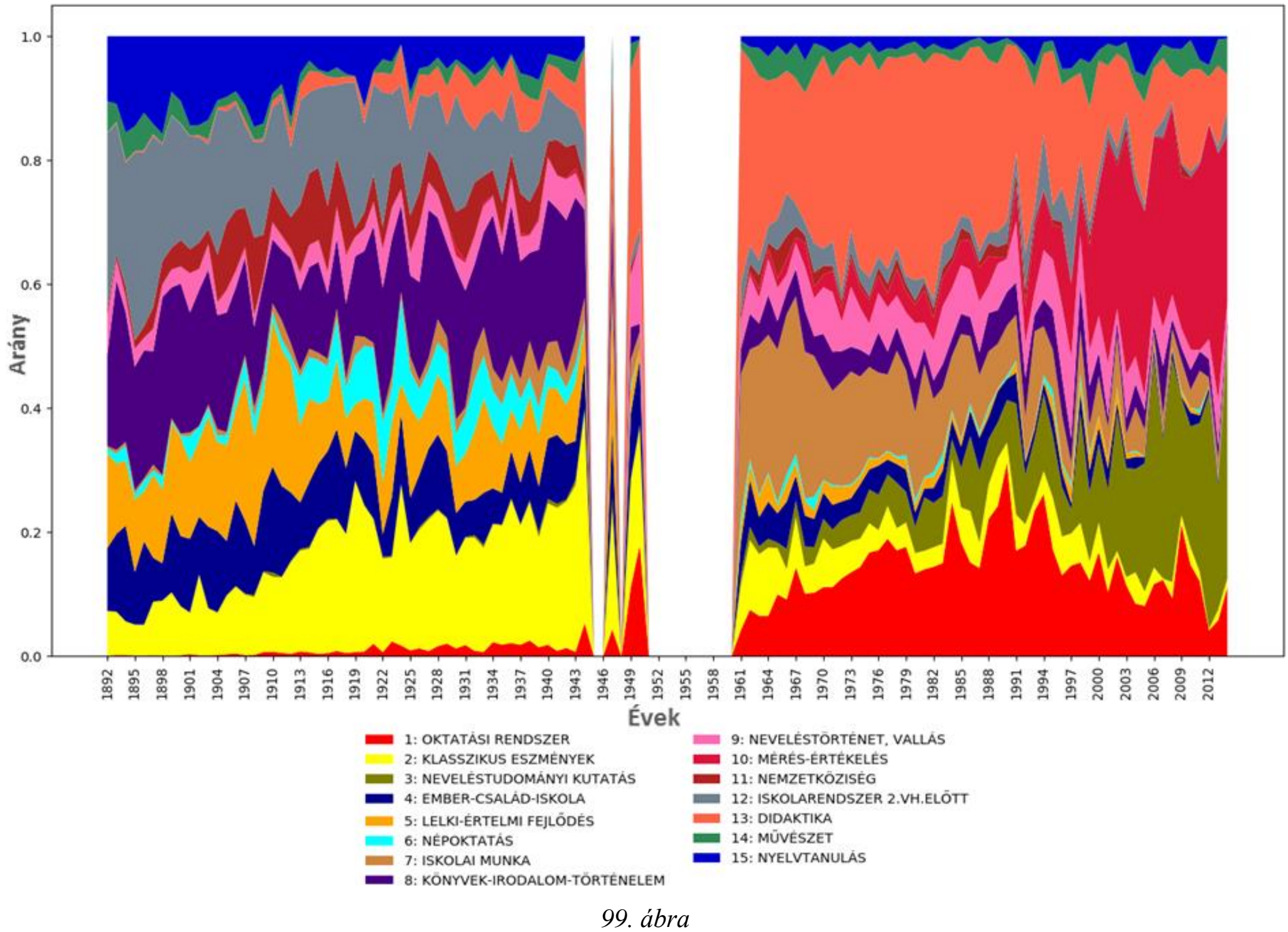

A témacsoportok évenkénti változása 15 kategória esetén 1892-2014

[Témacsoportok kulcsszavai: 6. melléklet] 


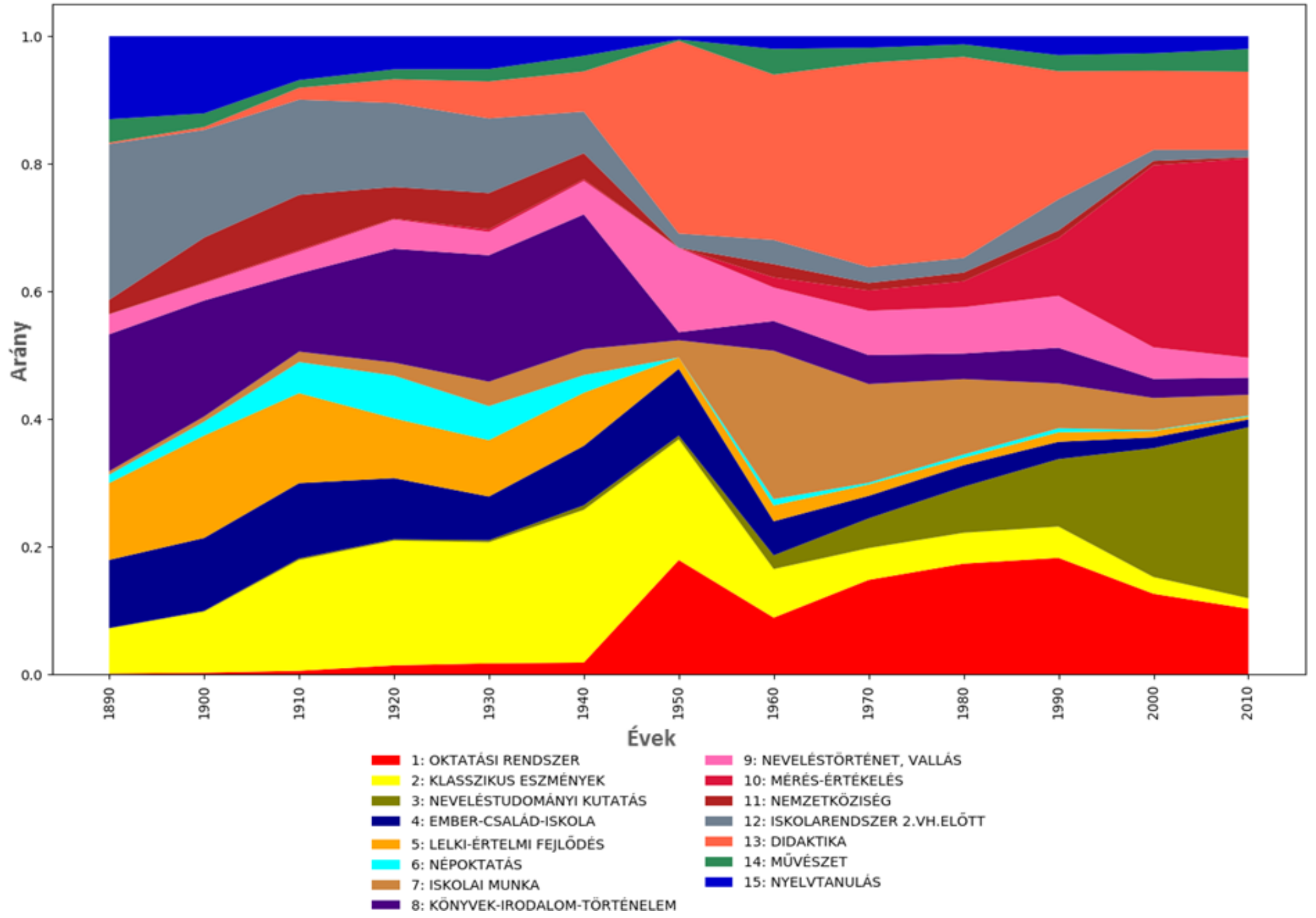

100. ábra

A témacsoportok évtizedenkénti változása 15 kategória esetén 1892-2014

[Témacsoportok kulcsszavai: 6. melléklet] 
A tízes kategóriabontás után, a 99. és 100. ábrákon a tizenötös kategóriabontást láthatjuk. Természetesen egyes témák ismerősek lehetnek a tíz kategóriát megjelenítő 97. és 98. ábrákról, mint például a nyelvtanulás, a népoktatás vagy a didaktika. A plusz öt helyet kihasználva vannak azonban szétbomló, illetve újonnan keletkező témák is, mint például a művészet vagy a klasszikus eszmények. Az ezekkel a témákkal azonosított cikkek természetesen a korábbi elemzésben is jelen voltak, csupán nem bontódtak ki önálló témaként, hanem valamely fölöttes témacsoportban fejeződtek ki. Például az „,iskolarendszer a második világháború előtt” (12-es téma a 99. és a 100. ábrán) téma tíz kategória esetében valószínűleg nagyban átfed az „oktatási intézmények" (4-es téma a 97. és 98. ábrán) témacsoportjával, ahogyan a mindkét granularitási szinten 9-es számmal jelölt vallási témák között is nagy átfedés tételezhető fel.

Az első kategóriaként azonosított „oktatási rendszer” topik láthatóan a második világháborút követően tud kibontakozni igazán, ez valószínüleg az ekkortájt megváltozó terminológiának és szemléletmódnak köszönhető. Az 1-es témacsoport esetében láthatóan a 12es témacsoport (,iskolarendszer a második világháború előtt”) komplementer témájáról, egyfajta időbeli folytatásáról van szó, a megváltozó terminológia miatt azonban az algoritmus elkülönítette egymástól ezt a két témacsoportot. Ezt az elképzelést alátámasztja, hogy alapvetően hasonló kulcsszavak határozzák meg a két témakategóriát (pl. iskola, oktatás, tanterv, egyetem). Az első témánál differenciáló kulcsszavaknak tekinthetőek az általános iskola, gazdasági, társadalmi kifejezések, míg a 12-es esetében olyan, a témacsoportra kifejezetten jellemző, régiesebb kifejezések differenciálnak, mint a népiskola, polgári, felső, kereskedelmi, polgári iskola, elemi. A második témacsoportként azonosított témacsoport a „klasszikus eszmények” nevet kapta, és olyan kulcsszavak határozzák meg, mint a nevelés, élet, ember, erkölcsi, nemzet, szabadság, világ, munka, műveltség, szellem, társadalom, eszmény, gondolat, eszme, stb. A második világháború előtti időszak egyik vezető témacsoportját jelenti, a szocialista időszakban jelentősen visszaesik, de a rendszerváltást követően is egyre inkább marginalizálódó témacsoportról beszélhetünk.

A harmadik témacsoportot jelentő „neveléstudományi kutatás” a lap hatvanas évekbeli újraindulása előtt szinte kimutathatatlan, sőt igazából az 1970-es években indul hódító útjára, hogy majd a rendszerváltást követően (szinte párhuzamosan a 10-es mérés-értékelési kategóriával) komoly részarányt érjen el a témák között. Terminológiáját tekintve is rokon témáknak tekinthetőek, jó néhány hasonló kulcsszóval; differenciáló kulcsszavaknak tekinthetjük az attitűd, szociális, motiváció, motívum, szülő kifejezéseket. Alapvetően a 3-as témacsoport esetében is a Magyar Pedagógia utóbbi évtizedeire jellemző kvantitatív paradigma kifejeződését láthatjuk. A negyedik témacsoport az „ember-család-iskola” nevet kapta, főleg 
különböző (élet)szerepek és személyközi viszonyok kifejeződéséről van szó. A legnépszerübb időszakában, a folyóirat kezdetén sem mondható domináns témának a 10\% alatti részaránnyal, amiből folyamatosan veszít, az elmúlt évtizedekben szinte eltünve a témacsoportok közül. Hasonló utat fut be az ötödik témacsoport („,lelki-értelmi fejlődés”), ezért feltételezhetően itt is rokon témákról van szó. A hatodik témacsoport a „népoktatás”, ugyanazt a pályát mutatva, mint a tízes kategóriabontás esetében. A hetedik témacsoportként azonosított „iskolai munka” szintén megfeleltethető a tízes kategóriabontás azonos elnevezésű témájának, és ugyanúgy érvényesek rá az ott elmondottak.

Új témaként jelentkezik viszont a „könyvek-irodalom-történelem” témacsoport, olyan jellemző kulcsszavakkal, mint a magyar, könyv, szerző, irodalom, értekezés, könyvtár, kötet, fejezet, tanulmány, folyóirat, kiadás, tudományos, irodalmi, tudós, előadás, társaság, olvasó. A kulcsszavak felsorolásából egyértelműen kiderül, hogy alapvetően egy recenziós témakörről van szó, amely igazán a második világháború előtti időszakban tudott kiteljesedni a folyóiratban. Az 1960-as évektől kezdődő időszakban sem tűnt el teljesen, azonban jelentősége visszaszorult, és nagyjából ugyanazon a szinten stagnálta végig az azóta eltelt időszakot. A kilencedik témacsoport („neveléstörténet, vallás”) ismét egybeesést mutat a tízes kategóriabontás kilencedik témacsoportjával, így ugyanúgy érvényesek rá az ott elmondottak. Hasonló a helyzet az itt tizedik témacsoportként megjelölt, míg a tízes bontásban 8-as számmal jelzett „mérés-értékelés” kategória esetében. A 11-es témacsoport a „,nemzetköziség” szintén megjelenik a korábbi ábrákon, ott 1-es témacsoportként, a trendeket tekintve természetesen ugyanúgy érvényesek itt is az ott leírtak. A tizenkettedik témára vonatkozó gondolatokat az 1es témacsoportnál ismertettük, mivel összefüggő területekről van szó. A tizenhármas számmal jelölt „didaktika” téma megint csak nem szolgál újdonságokkal a tízes kategóriabontás ábrájához képest, ahogyan a tizenötödik, „nyelvtanulás” témára vonatkozó ismérveket sem ismételnénk meg. Új kategóriát jelent azonban a 14-es, „művészet” téma, olyan kulcsszavakkal, mint a zene, rajz, müvészi, alkotás, müvészet, ábrázolás, esztétikai, vers, forma, hang, film, stb. Az évtizedes felbontású 100. ábrán talán jobban kivehető, hogy a lap életében - bár viszonylag alacsony részaránnyal - folyamatosan jelen voltak a művészeti témák. 


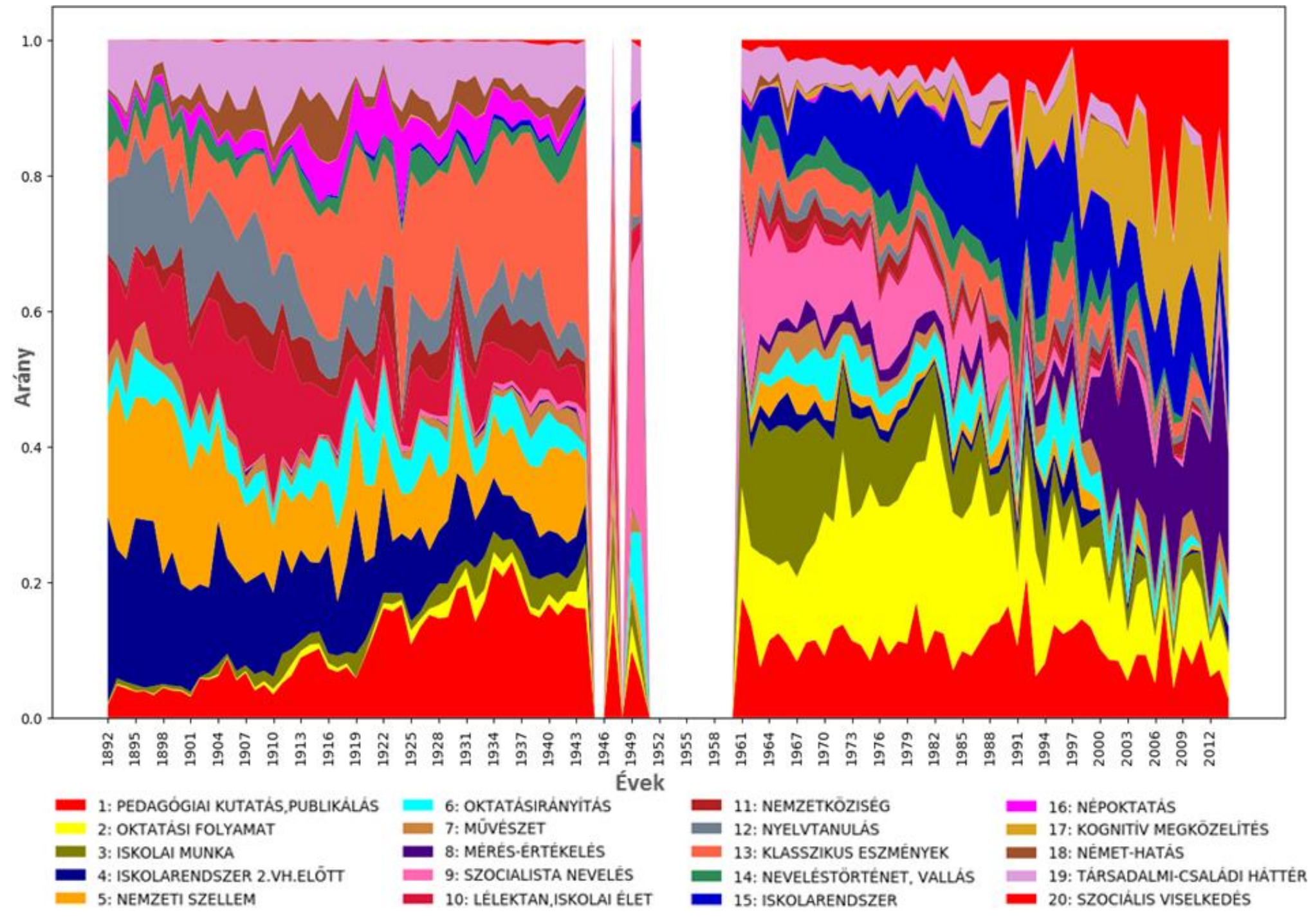

101. ábra

A témacsoportok évenkénti változása 20 kategória esetén 1892-2014

[Témacsoportok kulcsszavai: 7. melléklet] 


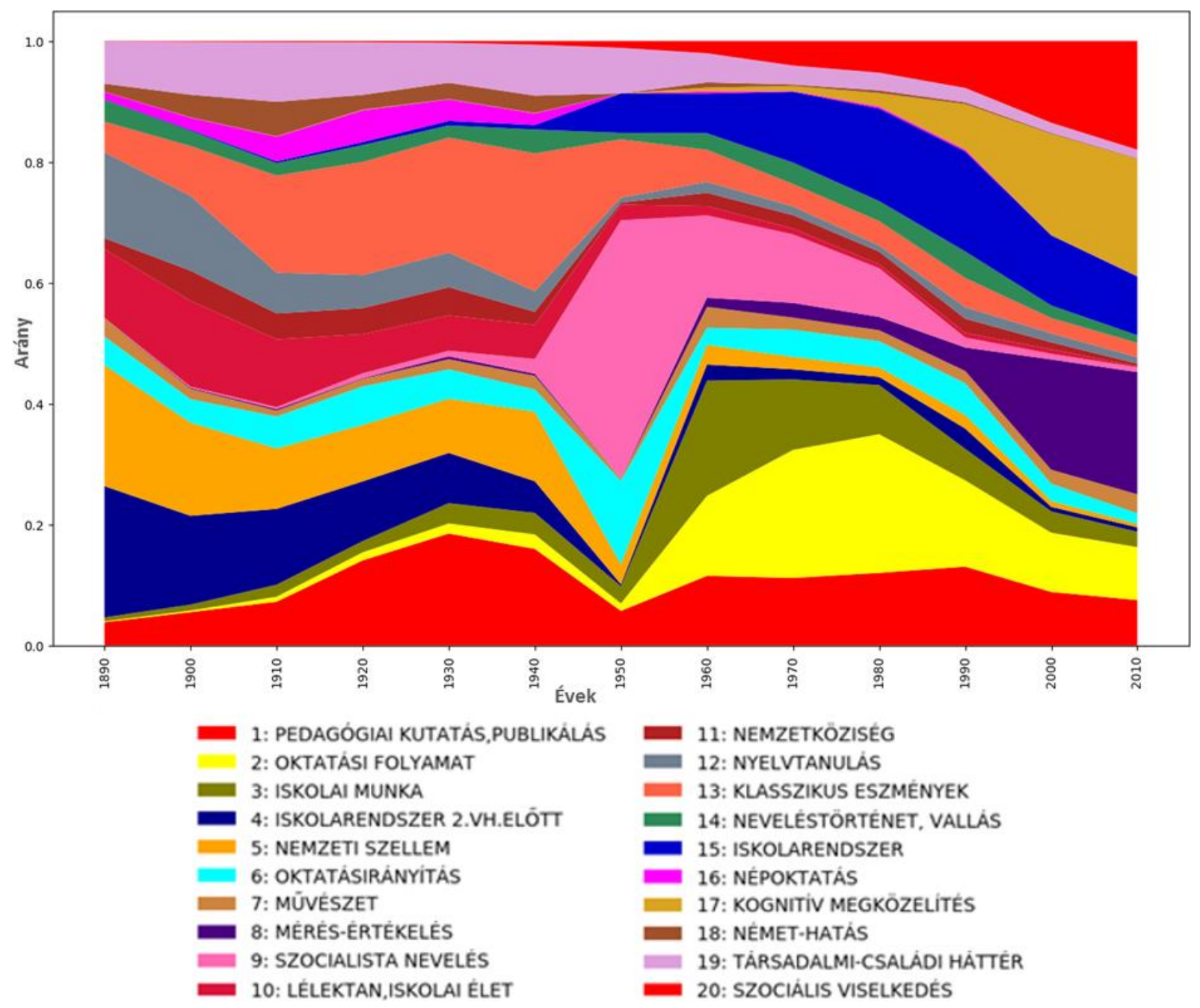

102. ábra

A témacsoportok évtizedenkénti változása 20 kategória esetén 1892-2014

[Témacsoportok kulcsszavai: 7. melléklet]

A teljes elemzett időszakra vonatkozóan az utolsó kategóriabontást a húszas csoportosítás jelenti (101-102. ábra). Ebben az esetben is sok korábban megismert kategória visszaköszön. Az első kategória egyből egy alapkategóriának tekinthető, amely a kezdeti alacsonyabb részarány után végigkíséri a folyóirat történetét. Elsősorban a pedagógiai (neveléstudományi) kutatás és publikációs világ szókincse köszön vissza a témacsoport kulcsszavaiban, például: szerző, könyv, tanulmány, kötet, fejezet, tudományos, írás, címü, folyóirat, hazai, előadás, kutatás. Talán a tizenötös kategóriabontás 8-as témacsoportjával („könyvek-irodalomtörténelem") rokonítható leginkább, de bizonyosan más, korábbi témacsoportokból is kerültek át ide topikok a témák részletesebb specifikálásának köszönhetően. A második témacsoport, melyet itt az „oktatási folyamat” névvel illettünk, az 1960-as években kezd nagyobb jelentőségre szert tenni, a korábbi „didaktika” témacsoporttal mutat rokon vonásokat, abban is hasonlítva arra, hogy a szocialista időszakban tud igazán népszerű lenni, a rendszerváltást 
követően azonban veszít jelentőségéből, bár jelentős téma marad. A harmadik, „,iskolai munka” kategória mintázata szinte egy az egyben megegyezik a tizenötös kategóriabontás azonos elnevezésü, 7-es számmal jelzett témájával, ahogyan az itteni 4-es témacsoport (,,iskolarendszer a második világháború előtt”) is megfeleltethető az ottani 12-es témacsoportnak.

Új témaként jelentkezik a ,nemzeti szellem” (5-ös témacsoport), ez a kezdeti időszakban körülbelül 20\%-os részarányról indul, ami hamarosan 10\%-ra csökken, a második világháborúig ki is futja magát a téma, utána már nem tölt be jelentős szerepet. A topik főként a hazafias nevelést reprezentáló kulcsszavai közül néhány: magyar, élet, nemzet, ifjúság, nemzeti, szellem, haza, világ, ifjú, eszme, hely, szeretet, isten, igazság, régi, szív. Szintén új témaként jelentkezik a hatodik témacsoport, „oktatásirányítás” néven, viszonylag állandó részarányt (5\% körül) képvisel egészen a kezdetektől az elemzés végéig. A következő témacsoport a 7-es számmal jelzett „müvészet” megfeleltethető a tizenötös bontás 14-es témájának. A nyolcadik témacsoport a „mérés-értékelés”, amely annyira domináns téma az utóbbi évtizedekben, hogy mindhárom granularitási szinten kimutatható módon, önálló témaként jelent meg, és kongruensen ugyanazt a mintázatot mutatja mindegyik esetben.

A kilencedik témacsoport a „szocialista nevelés” nevet kapta, mivel olyan kulcsszavak jellemzik, mint a szocializmus, világnézeti, kommunista, szovjet, termelés, Makarenko. A téma időtartama egybeesik a szocialista államberendezkedés évtizedeivel, nagyjából 10-15\%-os részarányt képviselve ebben az időszakban. Ez azt jelenti, hogy a $\mathrm{H}_{11}$ hipotézisünkben megfogalmazott állítás politikai ideológiák hatásaira vonatkozó része beigazolódni látszik ebben a korszakban. A tizedik témacsoport a „lélektan, iskolai élet” a tizenötös témafelosztás „lelki-értelmi fejlődés” témájával rokonítható, hasonló pályát futnak be. A tizenegyedik témacsoport a „,nemzetköziség” szintén megjelenik mindhárom granularitási szinten, itt is érvényesnek tekinthetőek a korábban elmondottak, ahogyan a tizenkettedikként azonosított „nyelvtanulás” témánál is ugyanez a helyzet. A 101. ábra tizenharmadik témacsoportja („klasszikus eszmények”) a 99. ábra azonos címkéjü, 2-es témacsoportjának feleltethető meg, ahogyan a tizennegyedik témacsoport („,neveléstörténet, vallás”) is előkerült eddig minden szinten.

A húszas bontás tizenötödik témacsoportja (,iskolarendszer”) feltételezésünk szerint a korábbi, tízes és tizenötös bontásban hangsúlyos témaként jelen lévő „didaktika” témacsoport egyik komponense a 2-es („oktatási folyamat”) mellett. Erre utal, hogy a didaktikához hasonlóan mindkettő a hatvanas évektől kezdődően a rendszerváltást követő évekig tölt be dominánsabb szerepet a topikok között. A tizenhatodik témacsoportot jelentő „,népoktatás” is egy állandó szereplő, hiszen ott volt minden trendkövetéses ábrán. A következő, 17-es 
témacsoport („kognitív megközelítés”) új témaként érdekesebb ilyen szempontból. Valószínűleg a korábbi ábrákon a „mérés-értékelés” (tíz és tizenöt kategória esetén) és a „neveléstudományi kutatás” (tizenöt kategóriánál) témacsoportokon belül reprezentálódott, húsz kategória esetében már önálló témaként sikerült detektálni, a következő meghatározó kulcsszavak mentén: stratégia, kompetencia, motiváció, tudás, kognitív, modell, környezet, képesség, információ. A szükített 1991-2014 közötti vizsgálati ablakban még inkább ki fog bomlani a téma. A tizennyolcadik téma („német-hatás”) azonosítása szintén érdekes meglepetéssel szolgál. A folyóirat életszakaszának nagyjából első ötven évében a német hatás tapinthatóan olyan erős volt, hogy önálló témacsoportként sikerült azonosítani a következő kulcsszavak mentén: német, leipzig, berlin, erziehung, über, eine, németország, unterricht, deutsch, fröbel, schule, geschichte, porosz, stb. A témacsoport megjelenése kapcsán visszacsatolnánk Németh (2015, p. 255) már hivatkozott, recepciós folyamattal kapcsolatos nézeteire, különösen annak német vonatkozásaira: „A 19. század második felétől kibontakozó magyar neveléstudományos gondolkodást leginkább a külföldi, elsősorban a német szellemi áramlatok átvétele, befogadása és meghonosítása jellemezte.” Ezt a hatást a Magyar Pedagógia esetében a 18-as témacsoport által sikerült azonosítanunk, amely eredmény a $\mathrm{H}_{10}$ és $\mathrm{H}_{12}$ hipotézis vonatkozásában is figyelembe veendő.

A húszas bontás maradék két témája a „társadalmi-családi háttér” és a „szociális viselkedés". A folyóirat története során a két téma együttesen körülbelül azonos részarányt képvisel (kivéve a legutolsó időszakot, amikor a szociális viselkedés kutatása nagyon megerősödött), csak időközben egy teljes átrendeződés figyelhető meg közöttük. A kezdeti időszakban a társadalmi-családi háttér téma a dominánsabb, a szociális viselkedéssel kapcsolatos témák szinte egyáltalán nincsenek jelen, majd a hatvanas években kezdődő felfutó trendnek köszönhetően pozíciójuk megfordul, hogy napjainkra a 19-es témacsoport marginalizálódjon. Az algoritmus minden bizonnyal a megváltozó szakmai terminológia és az új kutatási irányok miatt tett különbséget a két téma között. 


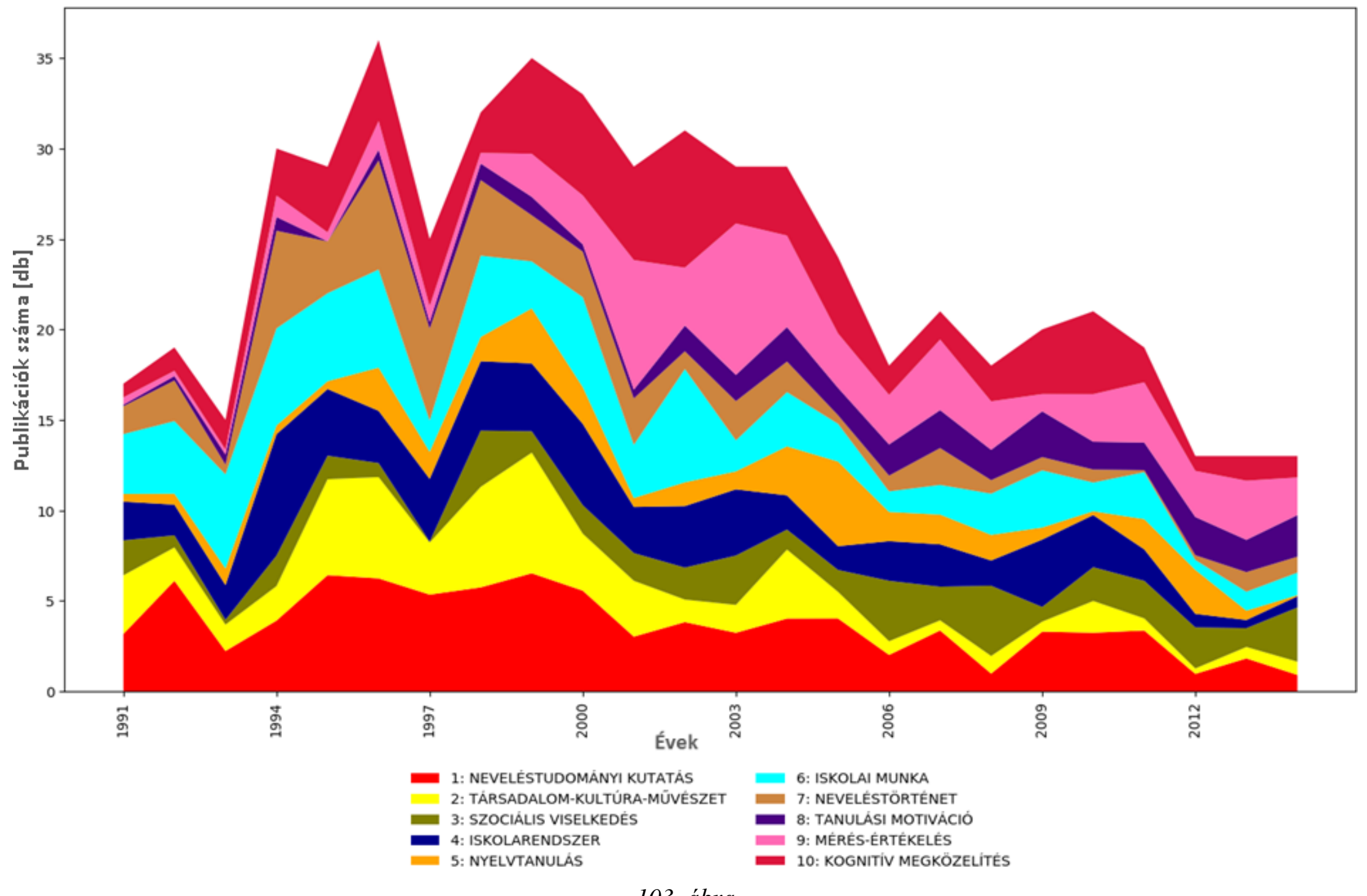

103. ábra

A témacsoportok évenkénti változása 10 kategória esetén 1991-2014

[Témacsoportok kulcsszavai: 8. melléklet] 


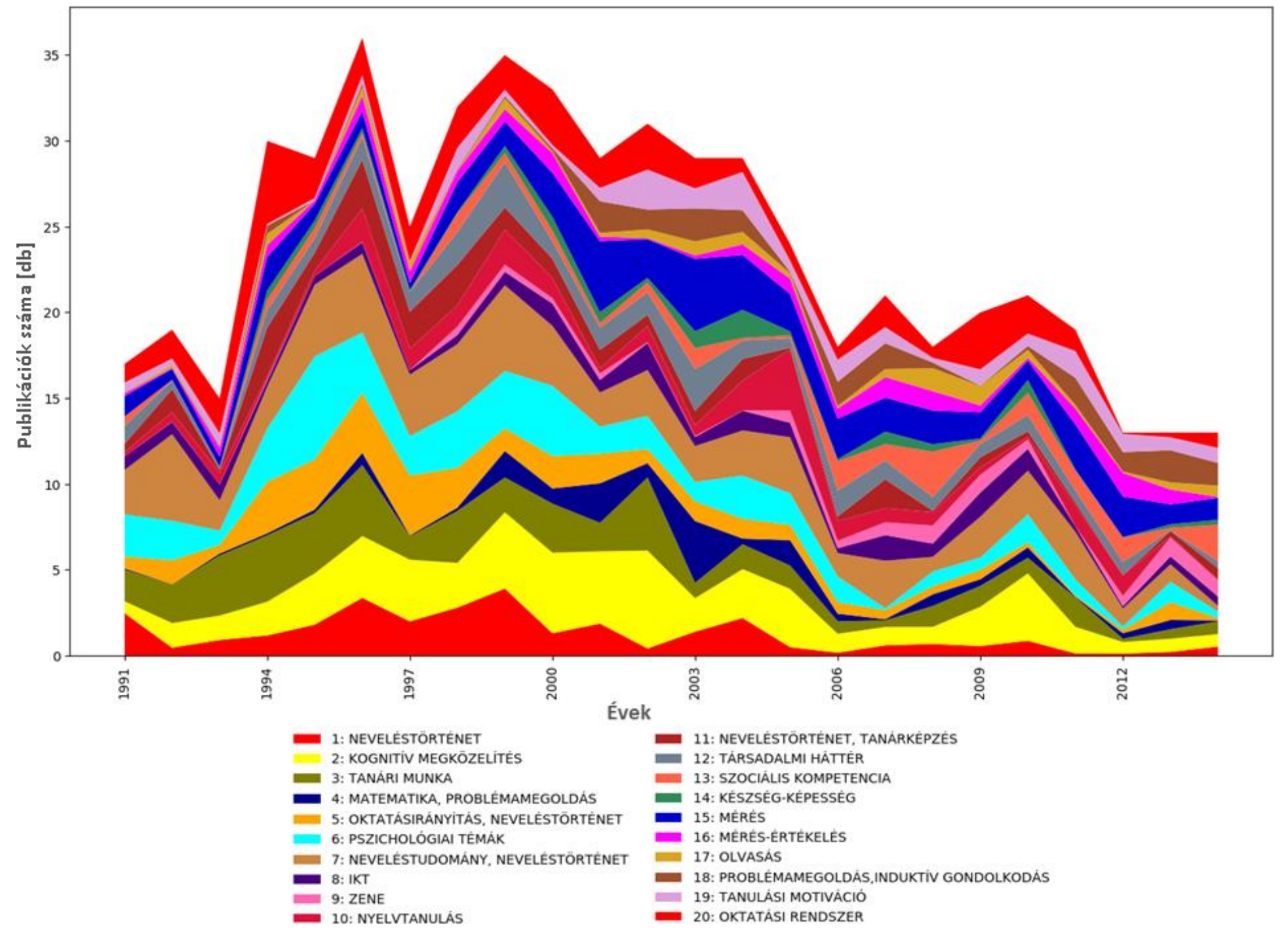

104. ábra

A témacsoportok évenkénti változása 20 kategória esetén 1991-2014

[Témacsoportok kulcsszavai: 9. melléklet] 
A folyóirat teljes megjelenési időszakának vizsgálata mellett a korábbi szemléletnek megfelelően fontosnak gondoltuk az utolsó huszonöt éves időablak önálló elemzését is, melyet a tízes és a húszas kategóriabontás mentén el is végeztünk, ennek eredményei a 103. és 104. ábrán láthatóak. Azonban itt részletes szöveges kommentárok segítségével már nem mennénk végig az egyes témacsoportokon, hiszen az eddigiek alapján az ábrák tulajdonképpen magukért beszélnek, főként amennyiben az értelmezést kiegészítjük a mellékletben megtalálható kulcsszólistákkal. Mindenesetre magyarázatra szorul az eltérő grafikus megjelenítés, hiszen míg az 1892-2014 közötti időszakban 100\%-os területdiagramokat használtunk, amelyek elsősorban az egyes témacsoportok egymáshoz viszonyított részarányaira hivatottak rámutatni, addig a 1991-2014 közötti vizsgálati időszakban az ábrát normalizálatlanul hagytuk, így azon az egyes évfolyamok közötti terjedelmi eltérések is megjelennek. Tettük mindezt abból a megközelítésből, mert negyed évszázad kevésbé alkalmas az igazán trendszerü folyamatok azonosítására, sok esetben a témák közötti ingadozás inkább a véletlennek vagy éppen a terjedelmi korlátok szabta határoknak köszönhető. Az y tengely skálája ezt figyelembe véve a normalizálatlan adatokat közlő grafikonokon a publikációk darabszámát jelöli.

Mindezekkel a megszorításokkal együtt is tanulságosak az időszak ábrái, hiszen a vizualizációk által sikerült azonosítanunk a folyóirat utóbbi huszonöt évének legfontosabb témacsoportjait, megalkotva ezzel a folyóirat legutóbbi időszakának tematikus térképét. A „tartalmi térképek” értelmezéséhez különösen fontosnak gondoljuk a 8-9. mellékletben szereplő kulcsszólisták figyelembevételét, mivel ezekből derül ki, hogy milyen jellemző kulcsszavak találhatóak az általunk megalkotott témacsoport-elnevezések mögött. A rendszerváltást követő időszakot tekintve ugyanezeknek a kulcsszólistáknak az elemzése segít $\mathrm{H}_{10}$ hipotézisünk (A Magyar Pedagógiában megjelenő témák rövid időbeliséggel követik a nemzetközi neveléstudományban felbukkanó trendeket) igazolásában is. A 8-9. mellékletben közölt kulcsszavak különböző kutatási irányokat és területeket reprezentálnak, amelyek trendszerü változásait már a tartalmi elemzés kategóriabontást alkalmazó 103. és 104. ábráiról olvashatjuk le. Összességében elmondható, hogy a Magyar Pedagógiában megjelenő témák nagyrészt a nemzetközi kutatási irányok és módszerek gyorsabb-lassabb átvételén és adaptálásán alapulnak, mely elképzelés egybecseng a tartalmi elemzés többi eredményével és a vonatkozó szakirodalom megállapításaival. 


\subsection{Egyes szakkifejezések használatának változása és első előfordulásuk detektálása}

A trendvizsgálatok makroszintjének tekinthető tartalmi csoportok képzése mellett ugyanúgy a kezdeti célkitüzések között szerepelt a mikroszintü elemzési megoldás megteremtése, amely a kategóriaszintű vizsgálatokon túl az egyes önálló szavak és szakkifejezések vizsgálatát jelenti. Ez a vizsgálati módszer természetesen ugyanazon a korpuszon alapul, viszont a csoportképzés helyett tetszőleges szóalakokat fogad bemeneti paraméterként, amely szólista alapján a korábban már ismertetett Python programozási nyelven készült Trendplotter alkalmazás rajzolja ki a megfelelö ábrát. A program az elemzendő szavak listáját mintegy elengedhetetlen bemeneti paraméterként önálló szövegfájlban várja - észszerü keretek között - számbeli korlátozás nélkül, ezáltal egyszerre akár nagyobb mennyiségü szó lekérdezhetőségét megvalósítva, de a bemeneti fájl alapján akár egyetlen kifejezés kirajzolhatóságát is lehetővé téve.

A programnak szabadon megadhatunk kezdö- és végdátumot, ahogyan a normalizált és normalizálatlan forma között is ugyanúgy választhatunk, mint a korábbiakban. Fontos kapcsolót jelent még annak eldöntése, hogy a program a grafikon rajzolásakor az abszolút gyakoriságokból kiindulva az egyes szavak összes előfordulását vegye figyelembe, vagy relatív gyakoriságokon nyugvó eredményeket szeretnénk kapni, ahol egy szó egy dokumentumban (cikkben) csak egyszer számolódik el, hiába fordul elő abban többször. Az önálló szóalakok lekérdezhetősége mellett itt is megteremtettük a korábbiakban alkalmazott kollokációs lista alapján (lásd 10. melléklet) az összetett szakkifejezések vizsgálatát. Az ebben a szakaszban bemutatott, egyes szavak és szakkifejezések trendvizsgálatait megjelenítő grafikonok kiválasztása önkényes módon történt, rengeteg más kutatási téma vagy jelenség felfutásáról és lecsengéséröl közölhettünk volna eredményeket. Az itt szereplőknél nyilvánvalóan jóval több elemzést végeztünk el, melyek közül itt csak néhány kiragadott, érdekesebb példát tudunk bemutatni. Másik, legalább ennyire hangsúlyos célunk a módszertani sokszínűség lehetőségeinek bemutatása volt, összhangban az értekezés általános céljaival.

Elsőként a kvantitatív és kvalitatív paradigma lapban való reprezentációját vizsgáltuk, egészen egyszerü módon a két szó egymáshoz való arányainak megjelenítésével. Az eredmények a 105. ábráról leolvashatóak, úgy tünik, hogy pusztán a „kvantitatív” szóalakkal (a különféle potenciális utótagok figyelmen kívül hagyásával) jellemzett kvantitatív paradigma az eredmények alapján jobban jellemzi a lapot a két kulcsszó vizsgálata nyomán, bár az utóbbi időben növekedésnek indult a „kvalitatív” jelző nettó előfordulása a lap hasábjain, egyes években már túlsúlyt érve el. A 106. ábrán az egyes tantárgyak és iskolai tevékenységcsoportok 
lapban való relatív előfordulásának változásait néztük meg. A grafikonról leolvasható, hogy a rajz és az olvasás egész évszázadon átívelő népszerüségnek örvend, ezzel szemben például a biológia vagy a kémia szóalakok már jóval nagyobb ingadozást mutatnak az egyes években. A testnevelés a kezdeti években nem mondható jellemző témának, míg a nyelvtanról ez sokkal inkább megállapítható. A grafikon bal oldali részén az is kivehető, hogy a XX. század elején mikor kezdtek az egyes iskolai tantárgyak és tevékenységcsoportok a lekérdezésben megnevezett nevükön előfordulni a folyóiratban. A biológia, fizika és kémia a lap alapításához képest nagyjából tíz éves késéssel kezdtek el megjelenni, míg a zene ezzel szemben már a kezdetektől jelen volt a folyóiratban.

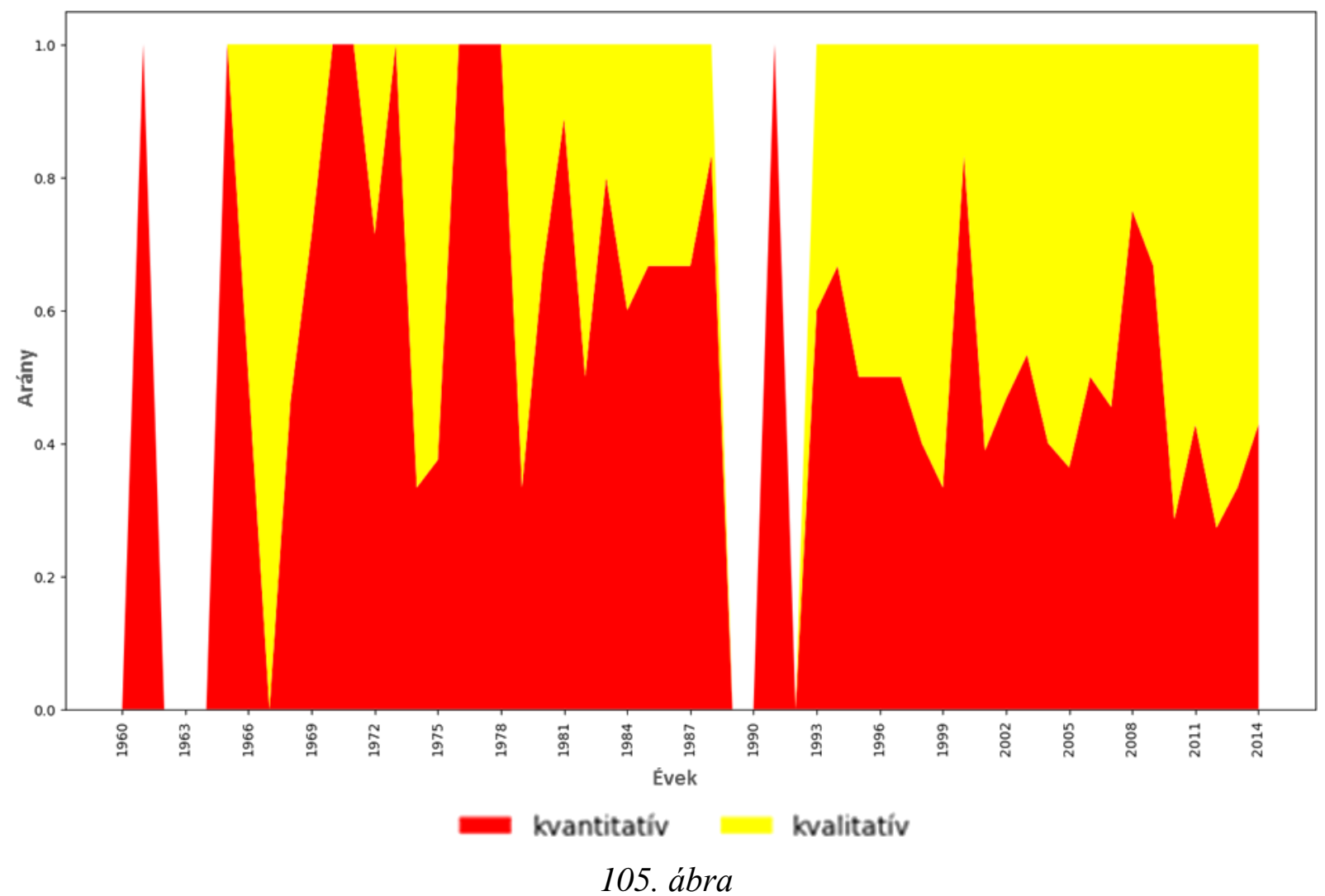

A kvantitatív és kvalitativ szavak egymáshoz való viszonya a folyóiratban 1960-2014 között az. abszolút elöfordulások alapján 


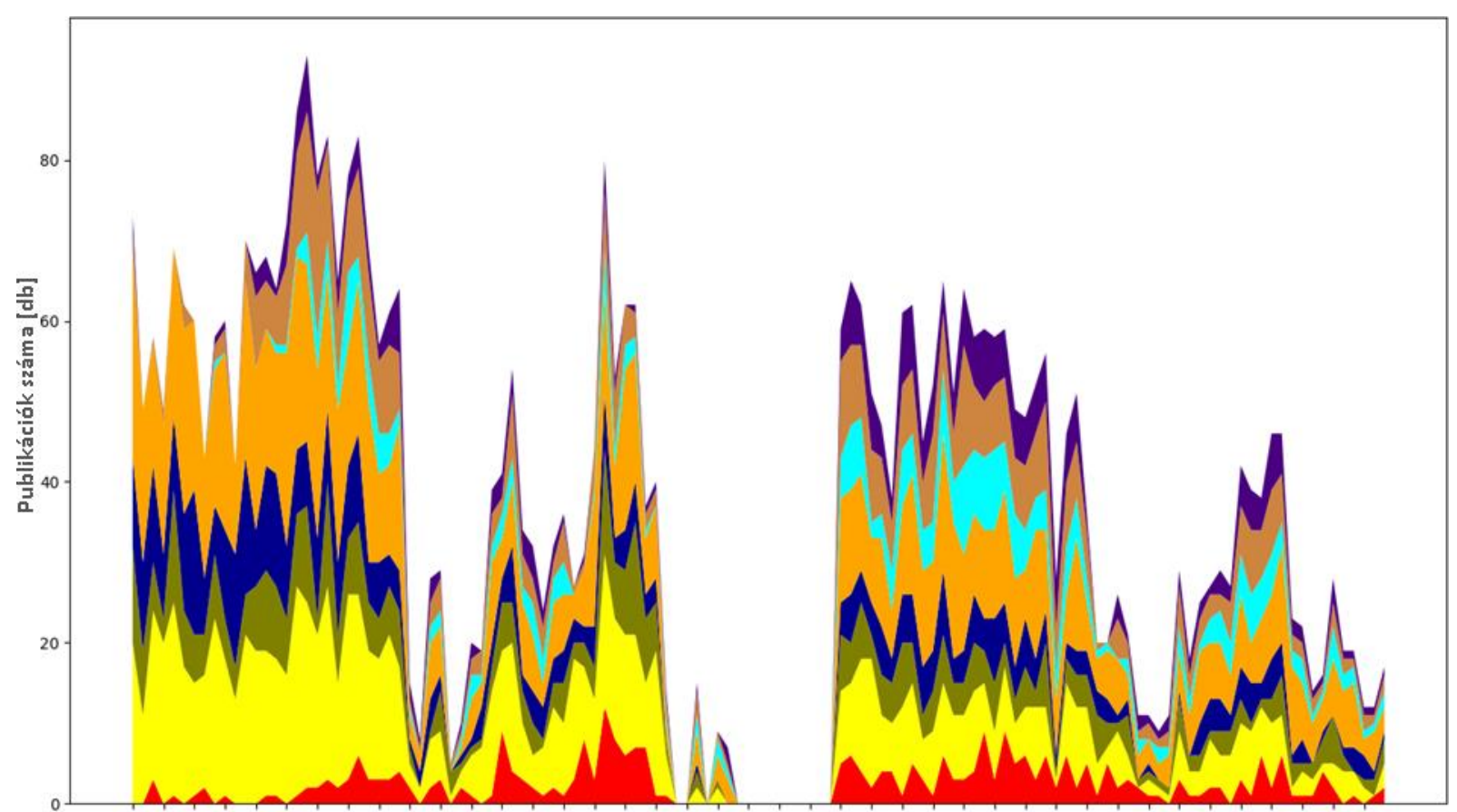

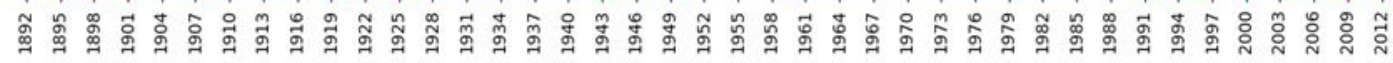

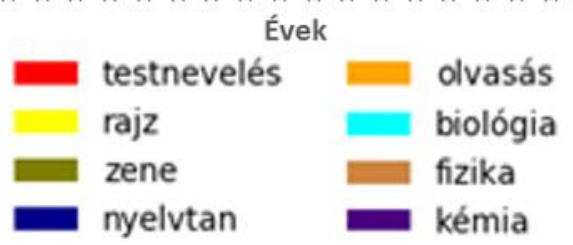

106. ábra

Az egyes tantárgyak elnevezésének relatív elöfordulása a folyóiratban 1892-2014

A következő, 107. ábrán néhány kutatási irány előfordulásait elemeztük a folyóirat 1961es újraindulásától kezdődően. Az attitűdvizsgálatok és a motivációval kapcsolatos kutatások már ekkor is megjelentek, majd folyamatosan jelen voltak a kutatási témák között. Az attitüdvizsgálatok kapcsán még egy emelkedő trend is kirajzolódik, míg a motivációval kapcsolatos publikációk egy adott szinten állandósultak. A másik két vizsgált kulcsszó esetében rendszerváltás utáni felbukkanás tapasztalható. A 107. ábrán látható az is, hogy az „induktív gondolkodás" már az 1990-es évek első felében megjelent, de igazán az ezredfordulótól kezdve kezdtek el foglalkozni vele a szerzők, míg az „önszabályozó tanulás” néhány év késéssel követte csak. Érdekes megfigyelni az azonos mintázatot e két kulcsszó esetében: egy-egy korábbi említés, azután néhány év szünet, majd folyamatos, ám viszonylag alacsony reprezentáció. Még meglepőbb eredményt kapunk, amennyiben az „induktív gondolkodás” szókapcsolatot a lap teljes időtartamára kérdezzük le, mivel a 108. ábrán látható módon találatokat kapunk az 1902-es és 1909-es évekből is, azonban ezután majdnem 90 évig nem fordul elő ez a szókapcsolat. Ha az eredményeket árnyalandó, az „induktív” jelzőt önállóan vizsgáljuk, hasonló eredményeket kapunk, a használati trendek egy irányba mutatnak. 


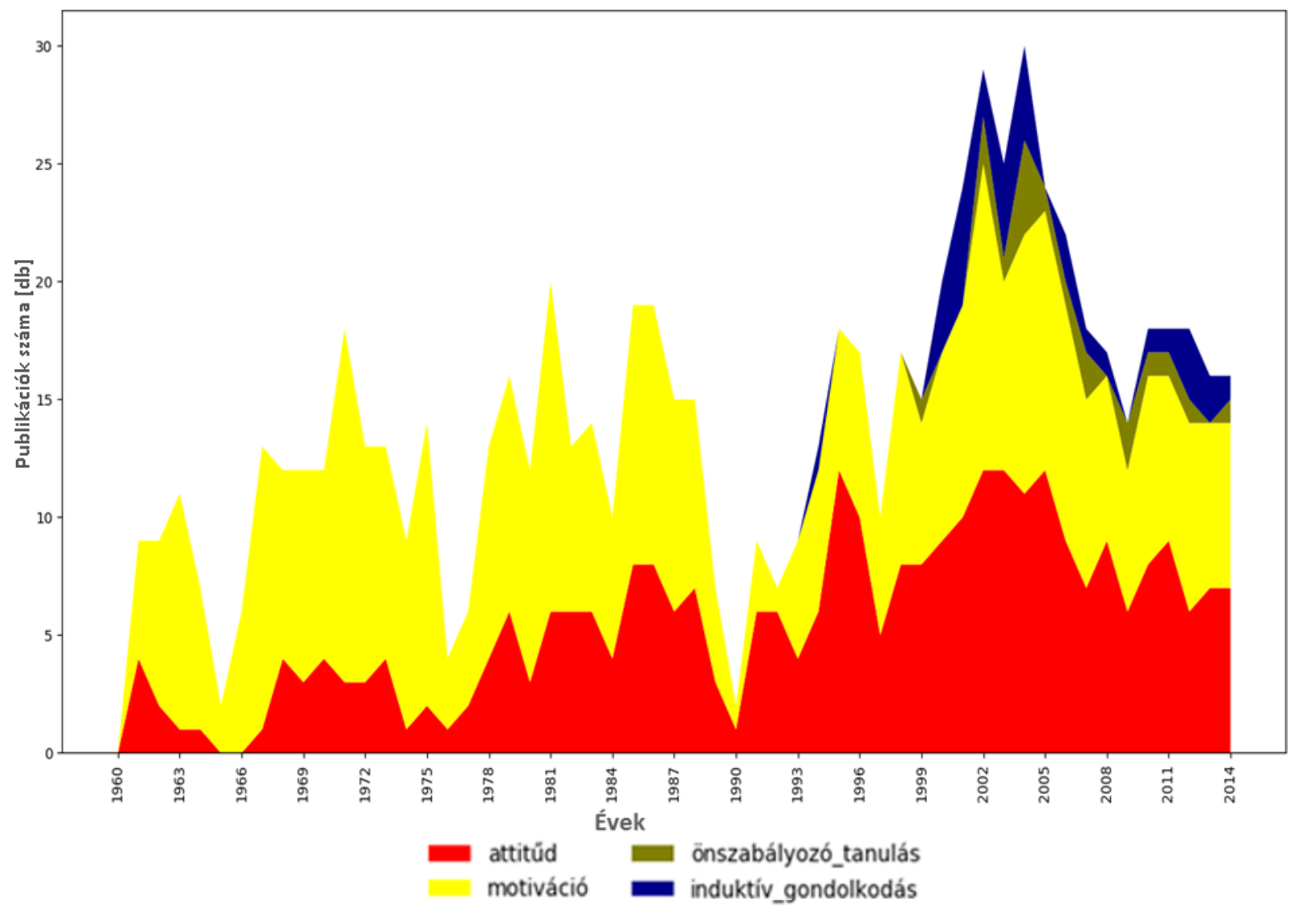

107. ábra

Néhány kiválasztott kutatási irány trendjei a relatív elöfordulások alapján 1961-2014

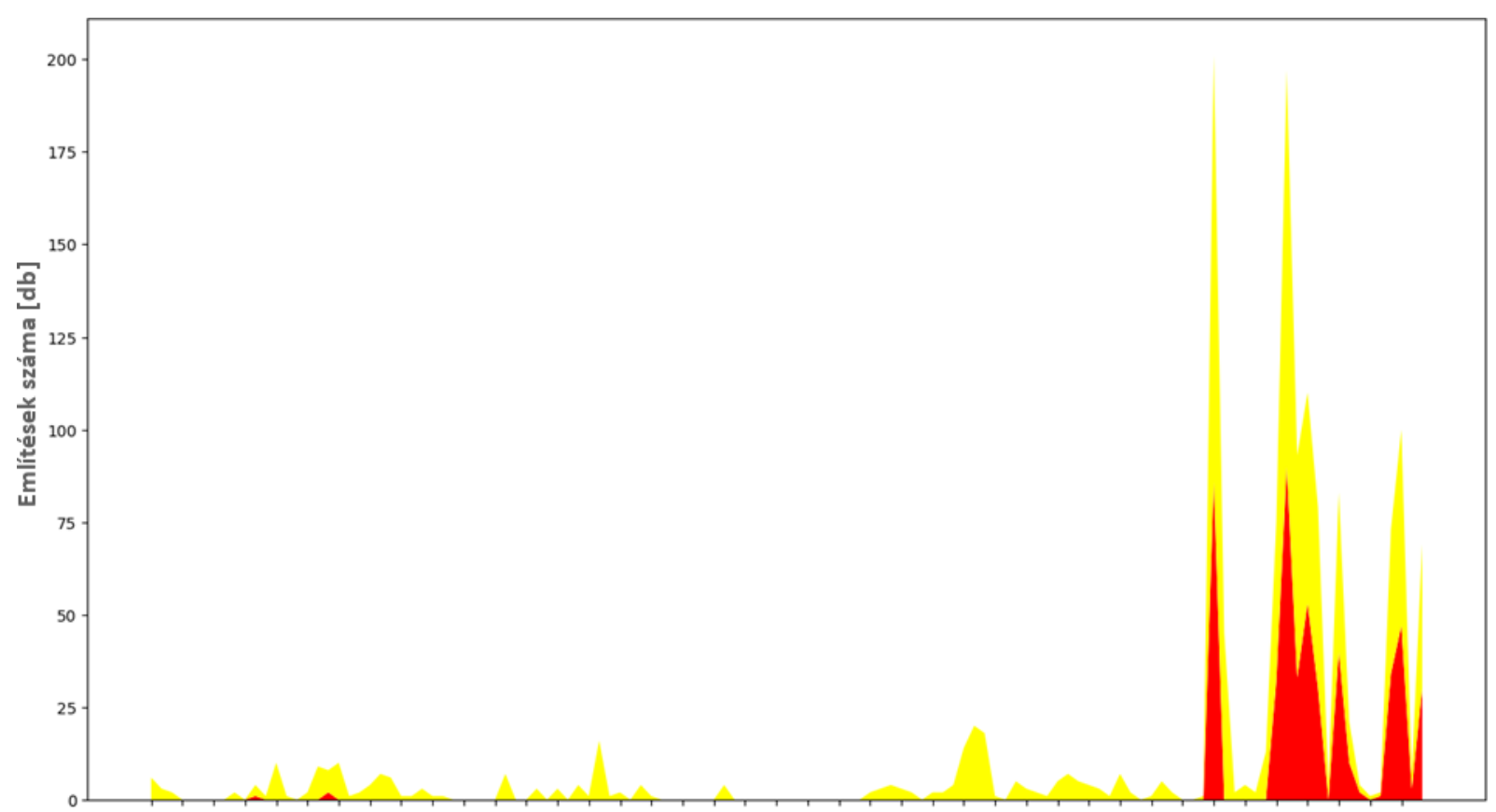

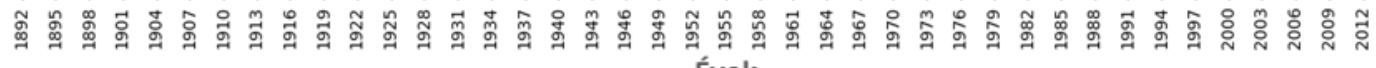
Évek

induktív_gondolkodás induktiv

108. ábra

$A z$, induktív gondolkodás” és az ,induktív” kifejezések abszolút elöfordulásai a lapban 1892-2014 
Az általunk alkalmazott módszer - ahogyan azt az „,induktív gondolkodás” kifejezés példáján láthattuk - alkalmas az egyes szakkifejezések első előfordulásainak detektálására is. A 109. ábrán ezt a fajta alkalmazást mutatjuk be, a „reziliencia” és a ,proszocialitás” kulcsszavak példáján keresztül. A proszocialitás kifejezés 1995-ben szerepelt először a lapban, viszonylag sok említéssel, egy-egy említése történt 1998-ban és 2009-ben, illetve közepesnek tekinthető 10-15 említése 2007-ben és 2014-ben a vizsgált időablakban. A következő kifejezés a reziliencia volt, amelynek 2007-es említése az első és egyben az utolsó is a vizsgált időszakban. Kiegészítve a 107. ábra relatív kulcsszó-előfordulásait, a 110. ábra további elemzéseket mutat be a szükített, 1991 utáni időszakra vonatkozóan az abszolút előfordulásokra alapozva a „tanulási környezet”, az „attitűd”, a „motiváció”, az „önszabályozó tanulás”, az „induktív gondolkodás” és a „tanulási stratégia” kifejezésekkel. Ugyanezen logika alapján a 111. ábra a 109. ábra továbbgondolásának tekinthető, kibővítve a korábbi két kulcsszót az „,inklúzió” és a „kooperatív tanulás” kifejezésekkel. A használati trendek mellett - mind a négy szó vonatkozásában - egyúttal az első előfordulásaik is leolvashatóak az ábráról.

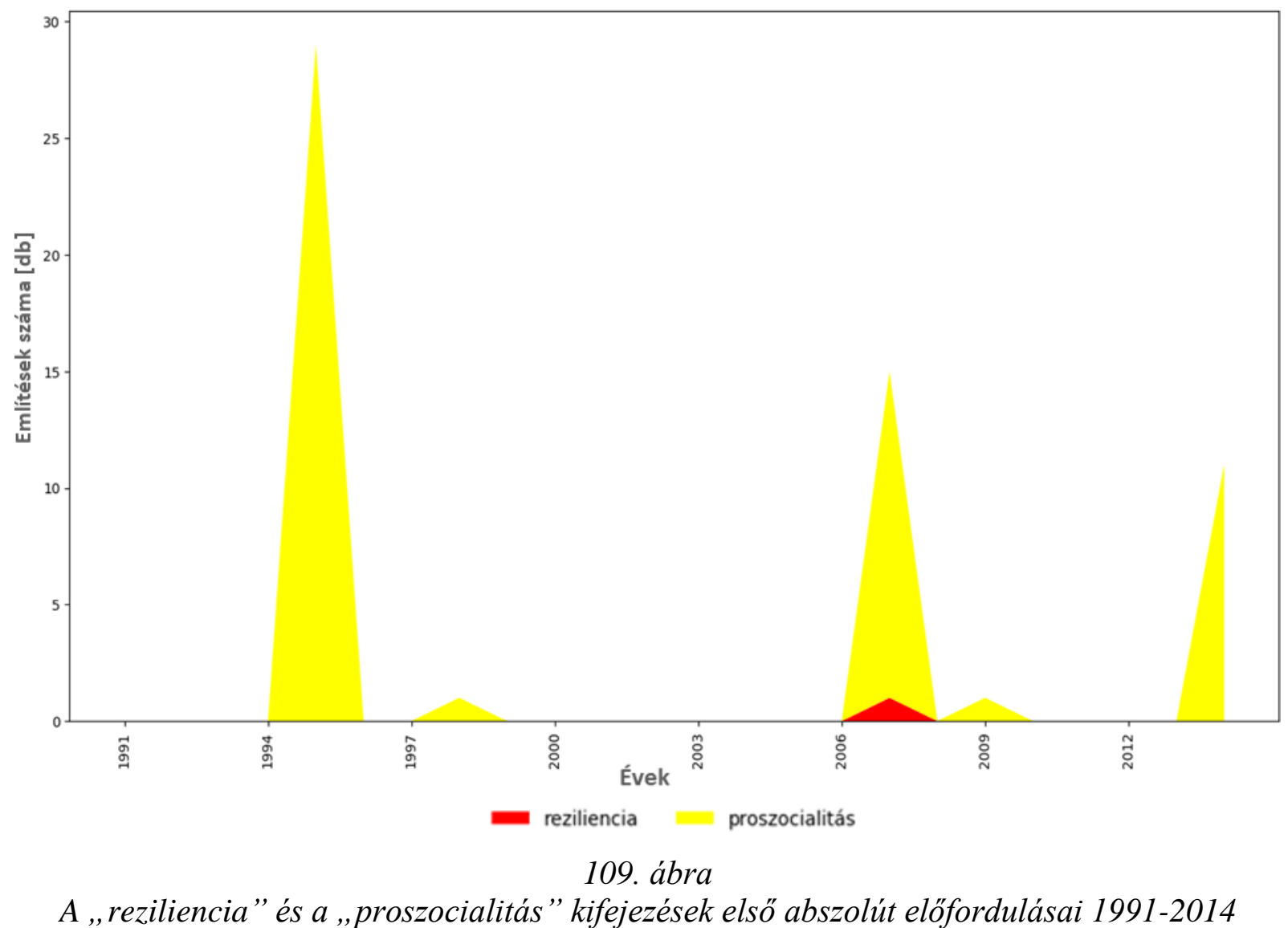




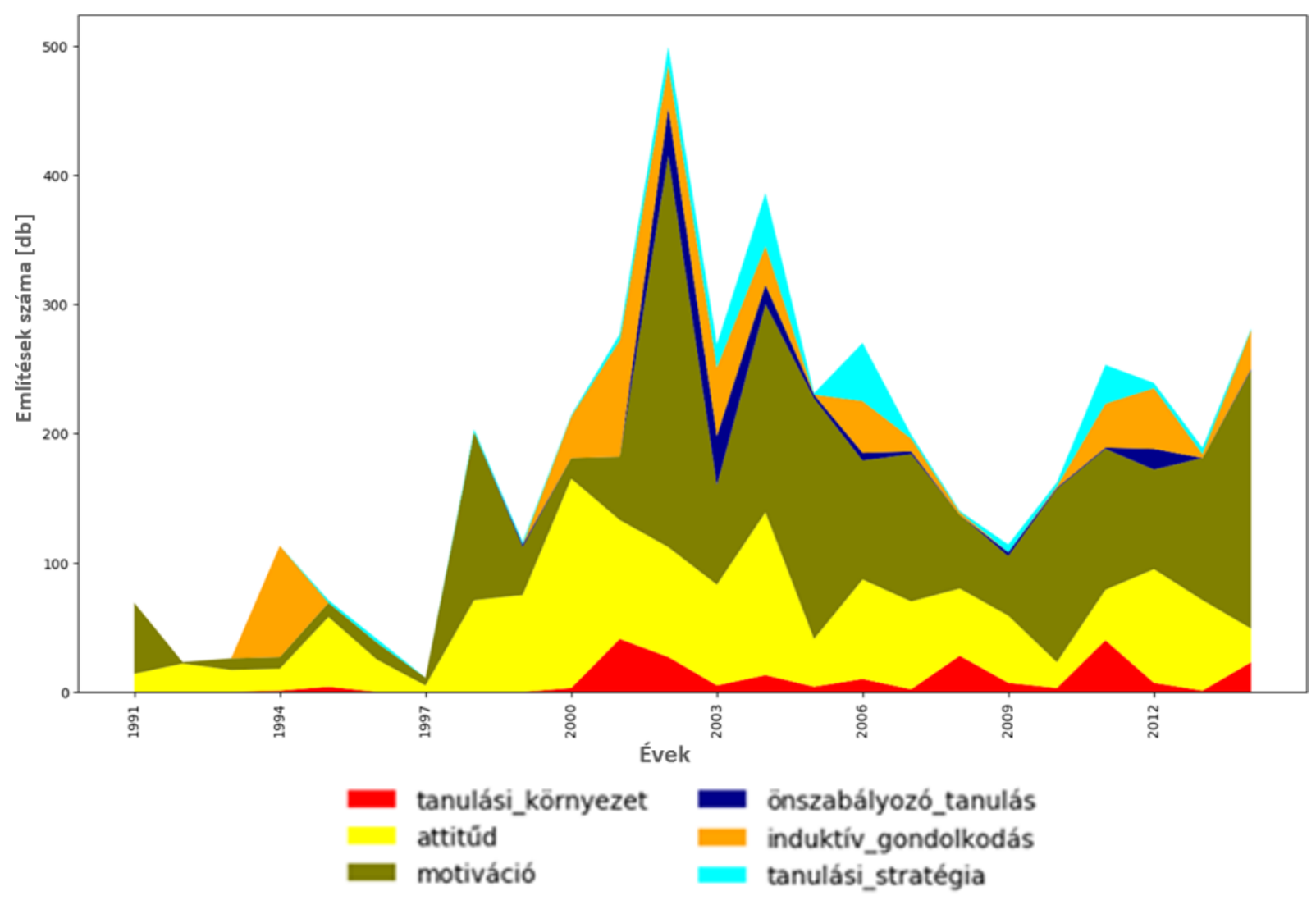

110. ábra

További kutatási irányok trendjei, abszolút elöfordulásaik alapján 1991-2014

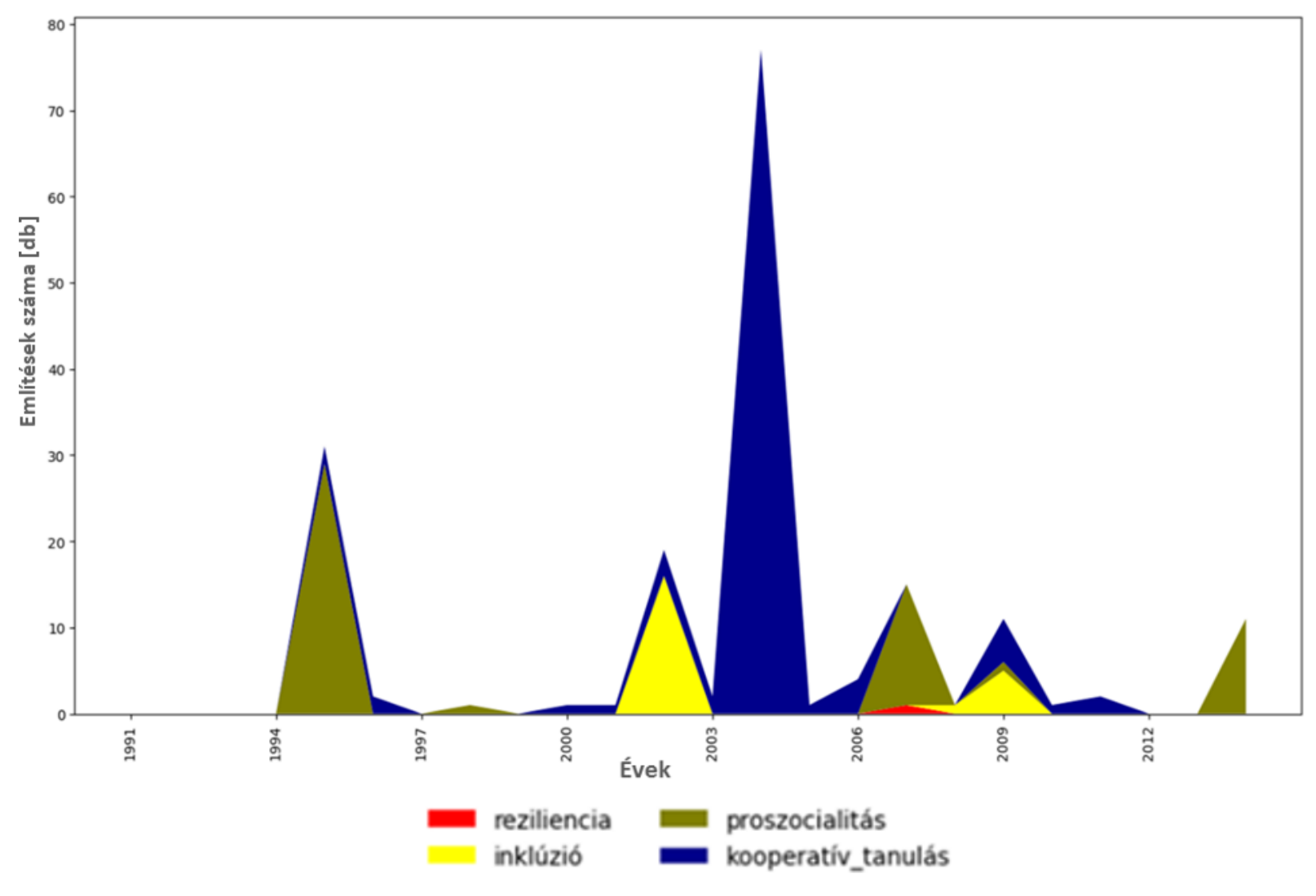

111. ábra

A kiválasztott kifejezések abszolút elöfordulásai és első megjelenésük a folyóiratban 1991-2014 
A fejezet utolsó két elemzésében (112. és 113. ábra) ismertetett eredmények (részletesen 1. Nagy, 2017) elméleti hátterét Nahalka István (2016) tanulmánya jelentette, az esélyegyenlőség témakörében alkotott modellek és szóhasználat vonatkozásában. A 112. ábra elemzésében az „esélyegyenlőség” és az „esélyegyenlőtlenség” szóalakok Magyar Pedagógiában való előfordulását vizsgáltuk abból a megfontolásból, mert Nahalka tanulmányának első bekezdésében felhívja a figyelmet a speciális szóhasználatra. A hivatkozott tanulmányban a két kifejezés rendre három, illetve húsz esetben fordul elő. A cikkben sürübben szereplö, ám idegenebbül hangzó esélyegyenlőtlenség kifejezést lekérdezve a Google keresőrendszerében teljesen más arányokat tapasztalhatunk: 17000 találat érkezik erre, míg 402000 az esélyegyenlőség változatra. Ezek az arányok már sokkal inkább megfelelnek a Magyar Pedagógia-beli szóhasználati szokásoknak is. Az eredményeket részletesen megvizsgálva, a 112. ábráról kiderül, hogy a folyóirat szerzői ugyan mindkét kifejezést használják, azonban sokszoros népszerüségi eltolódás figyelhető meg az „esélyegyenlőség” alak javára. Mindezen túl az is leolvasható az ábráról, hogy az esélyegyenlőség kérdése egyre kurrensebb témát képvisel a folyóirat tanulmányaiban. A 113. ábrán a Nahalka által felállított modellek kulcsszavakkal történő jellemezhetőségét és az egyes modellek Magyar Pedagógiabeli jelenlétét vizsgáltuk meg. Az ábra elsősorban demonstrációs célokat szolgál, szemléltetve azt, hogy a kidolgozott módszer segítségével lehetőség nyílik az összetettebb, rétegzett tartalmi vizsgálódások elvégzésére is, amennyiben jellemző kulcsszavakkal azonosíthatóvá tudjuk tenni az egyes kutatási irányokat vagy tudományos modelleket. A három modell közül a szegregációmodell a legdominánsabb, ezt a deficit-modell követi, míg a legkevésbé a látens-diszkrimináció modellt jellemző kulcsszavak jelennek meg a lap hasábjain.

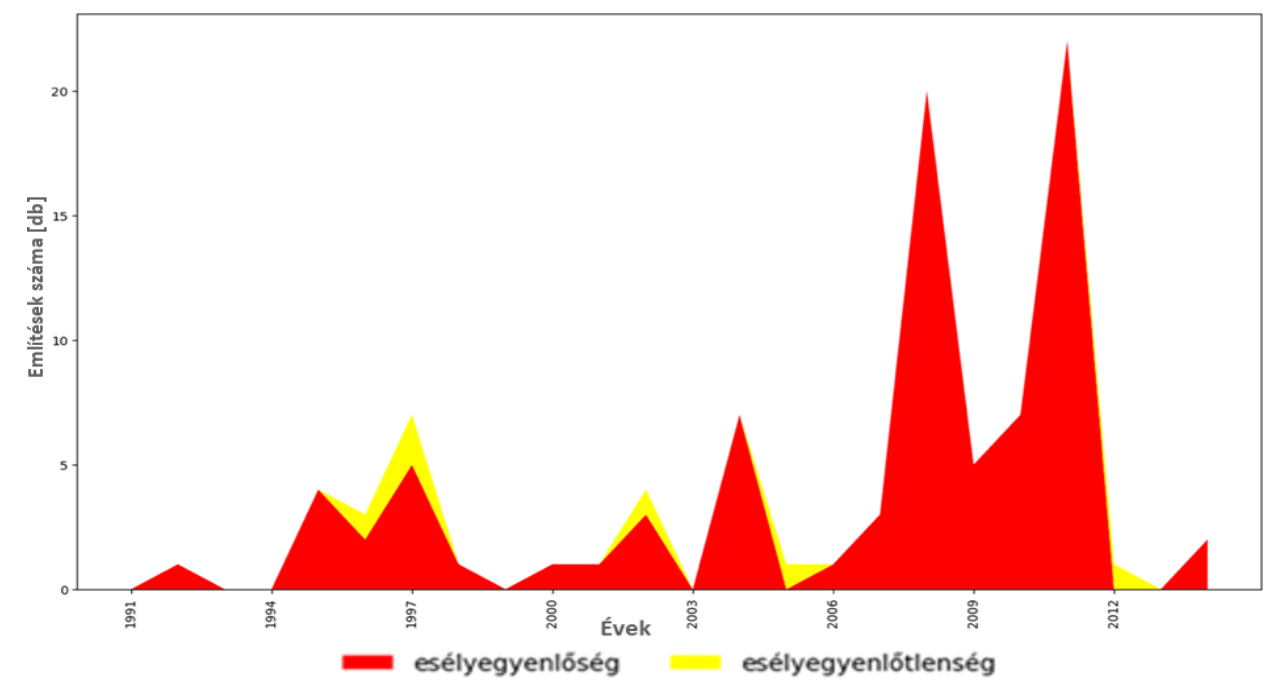

112. ábra

Az "esélyegyenlöség" és "esélyegyenlötlenség" szavak abszolút használata 1991-2014 


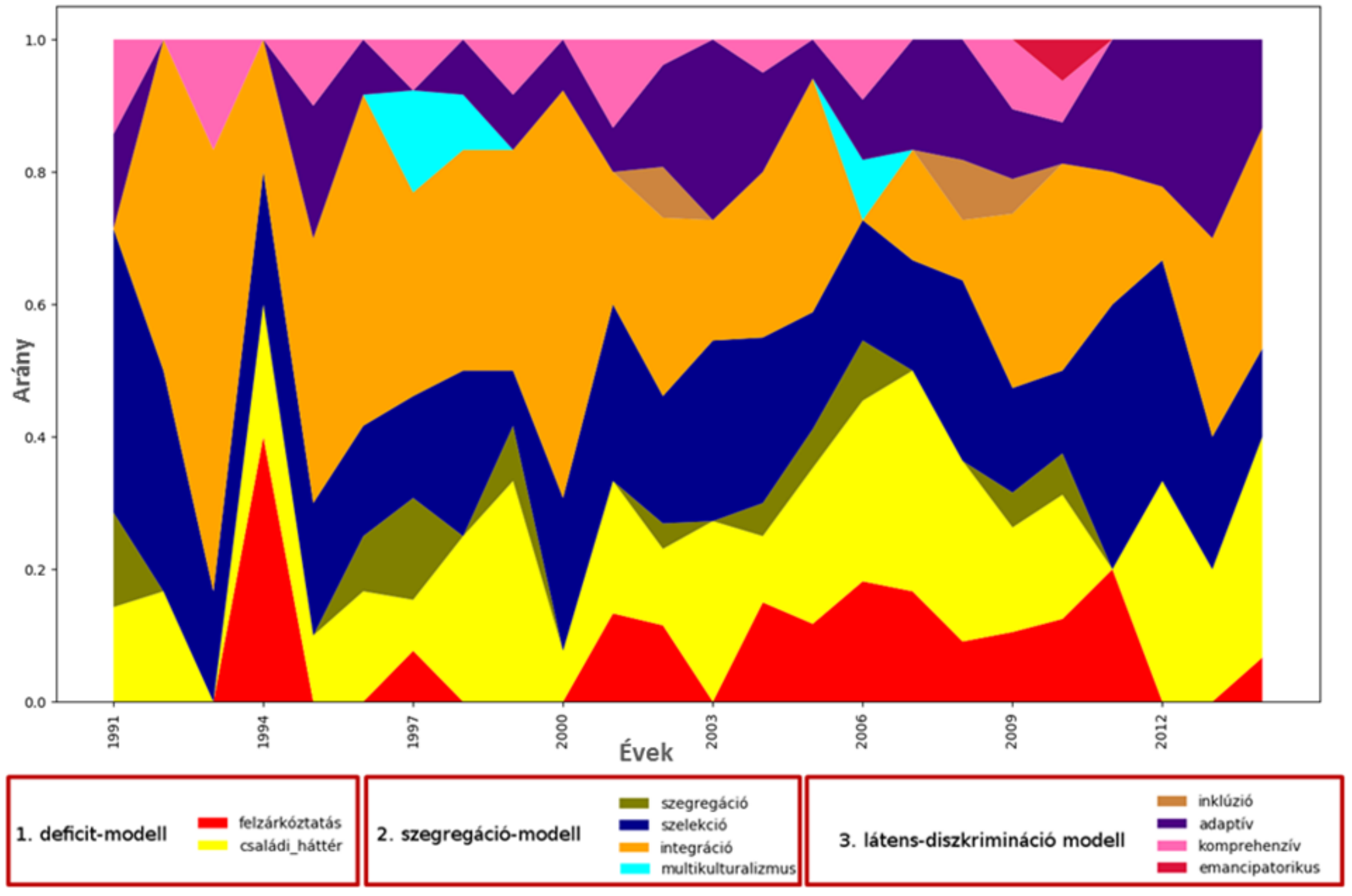

113. ábra

Topikok képzése kulcsszavak segitségével 1991-2014 


\subsection{További lehetőségek a tartalmi elemzések vizualizálására}

A 8.1. pontban kifejtettük, hogy a tartalmi elemzések során megszülető ábrák hosszas kísérletezés eredményei. A megfelelő módszerek megtalálása során számos lehetőséget megvizsgáltunk, amelyekböl végül kialakultak az éles adatokon használt vizualizálási módszerek. Ezen eljárások előképeit a 8.1.2-es pontban mutattuk be, mellettük azonban további lehetőségeket is megvizsgáltunk, amelyek szélesebb körü felhasználását ugyan végül elvetettük, ám ettől függetlenül tanulságosnak tartjuk módszertani bemutatásukat a további hasonló kutatási projektek segítése végett.

Az első megoldás egy a Szegedi Tudományegyetem Számítógépes Algoritmusok és Mesterséges Intelligencia Tanszék kutatói által kifejlesztett és publikált (Berend \& Farkas, 2013) Java alapú, korábbi fejlesztésű program (keyphraseViz) adaptálásán alapult. Kutatásaik során fejlesztői a programot többek között egy-egy internetes hírportál cikkeinek kulcsszavas vizualizálására használták fel. Ebbe a programba lettek betöltve a Magyar Pedagógiára vonatkozó megfelelő adatok, amelyek azután az 114-116. ábrákon bemutatotthoz hasonló grafikus kimenetet produkáltak. Az 114. ábrán az egyes kategóriadobozok láthatóak a legjellemzőbb kulcsszavakkal felcímkézve, míg a 115. ábrán pedig egy ilyen szövegdoboz belső tartalma látható, az egyes cikkek azonosítószámaival ellátva. Az egyes elemekre kattintva leolvashatóak az adott cikk legfontosabb kulcsszavai, míg a következő, 116. ábrán a hasonló tartalmú cikkek egymáshoz való viszonya látható, a klaszterizálás egyfajta gráf-szerü ábrázolásával.

A következő bemutatott eljárás Kessler (2017) Scattertext nevü, Python programozási nyelven írt fejlesztésének adaptálásán alapszik. Ebbe a környezetbe szintén be lettek töltve a Magyar Pedagógia vonatkozó szövegei, amelyek a 117. ábrán látható grafikus kimenetet eredményezték. Az ábrán az első tíz és az utolsó tíz évfolyam cikkeinek valamilyen szempontból karakterisztikusnak tekinthető szavai láthatóak. A módszert végül nem használtuk fel szélesebb körüen, így nem is került legyártásra hasonló ábra további időszakokra vonatkozóan. Azon túl, hogy az egyes szavakhoz a gyakorisági egyenes mentén különböző numerikus pontértékek kerülnek hozzárendelésre, az eljárás az egyes szavak szövegkörnyezeti láttatására is alkalmas volna. 


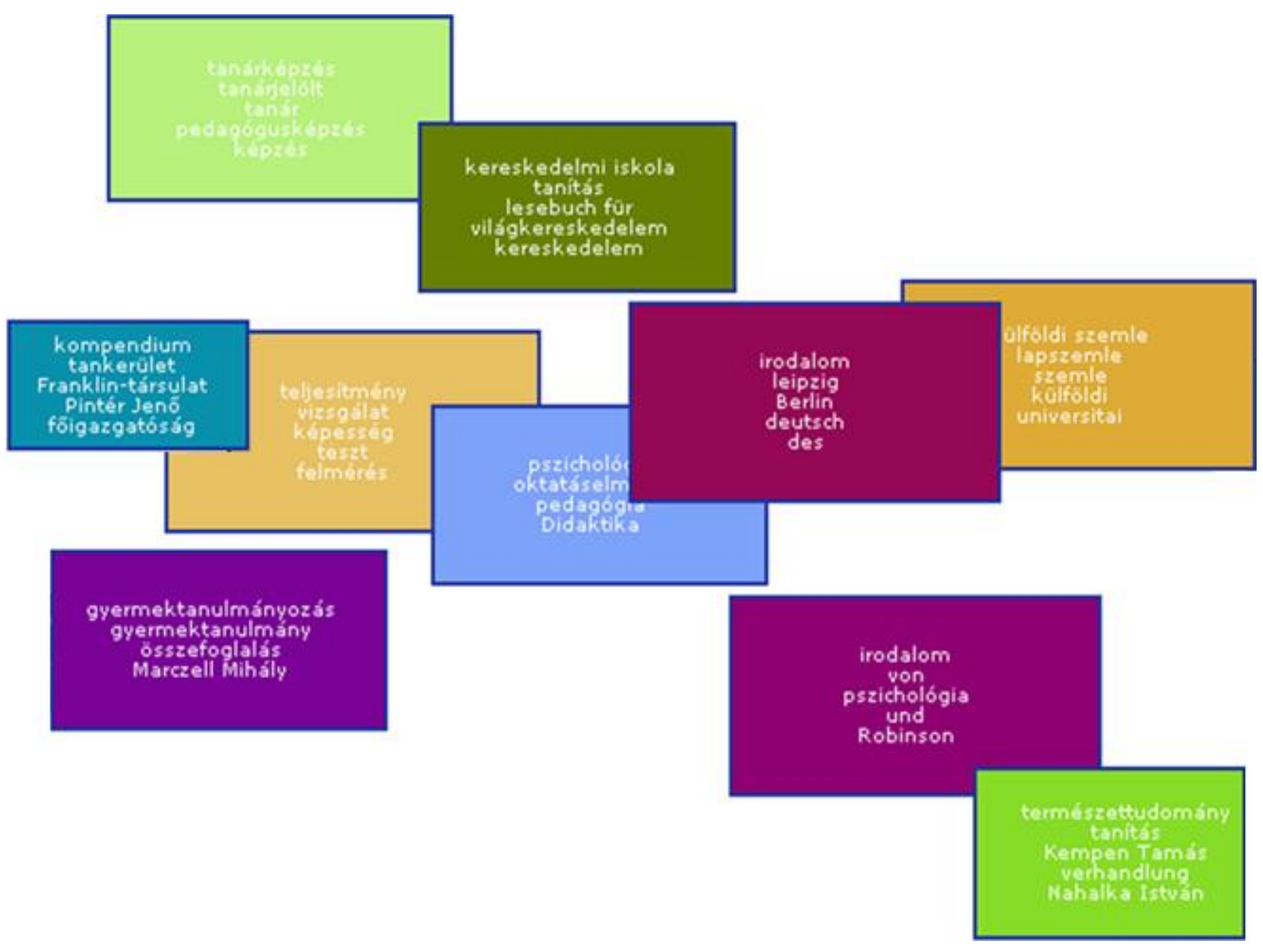

114. ábra

A „keyphraseViz” program grafikus kimenetének részlete

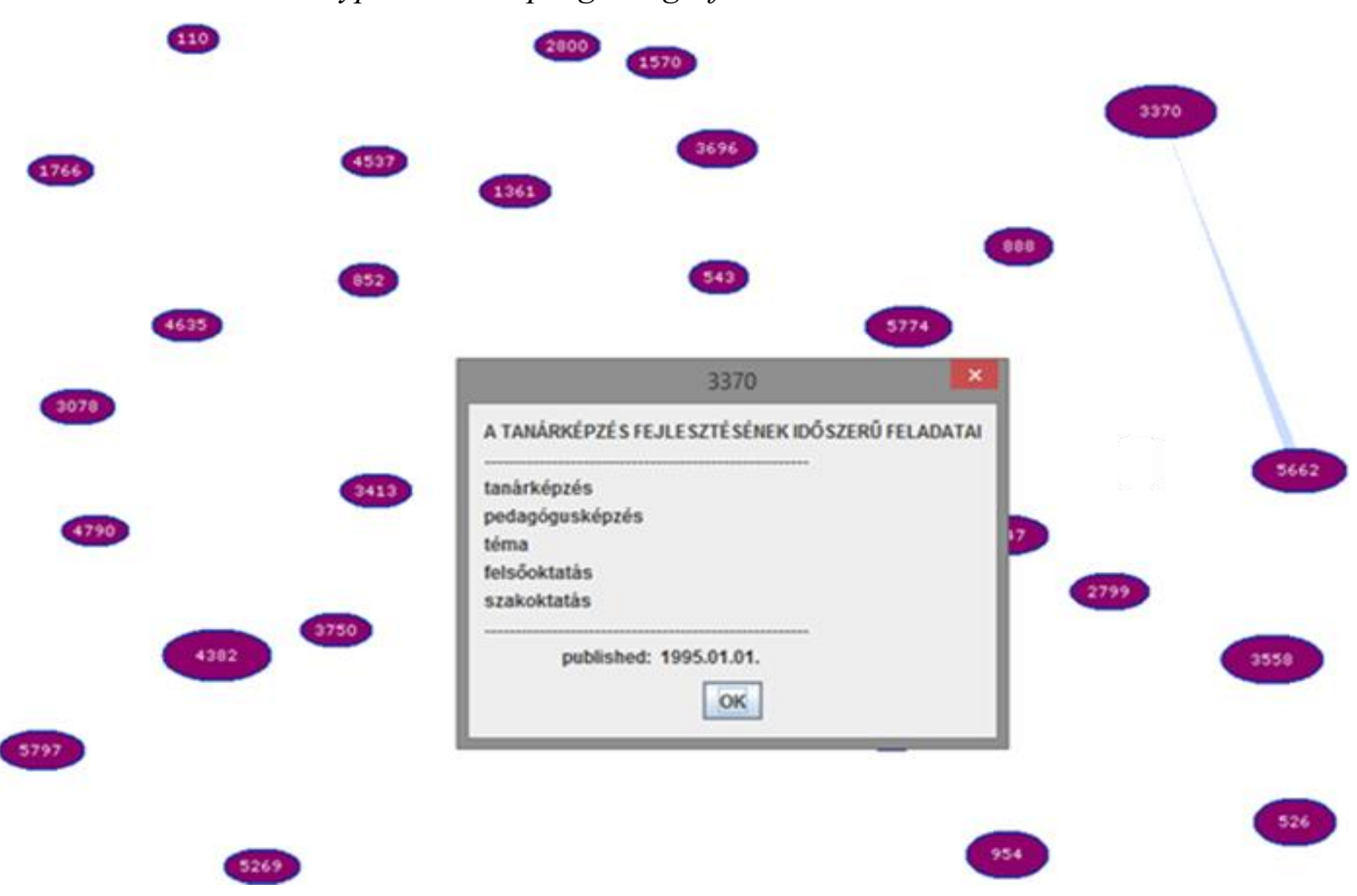

115. ábra

Az elözö ábra egy ,,dobozának” tartalma, az egyes cikkek azonositó számaival 


\section{Tematikusan hasonló cikkek detektálása}

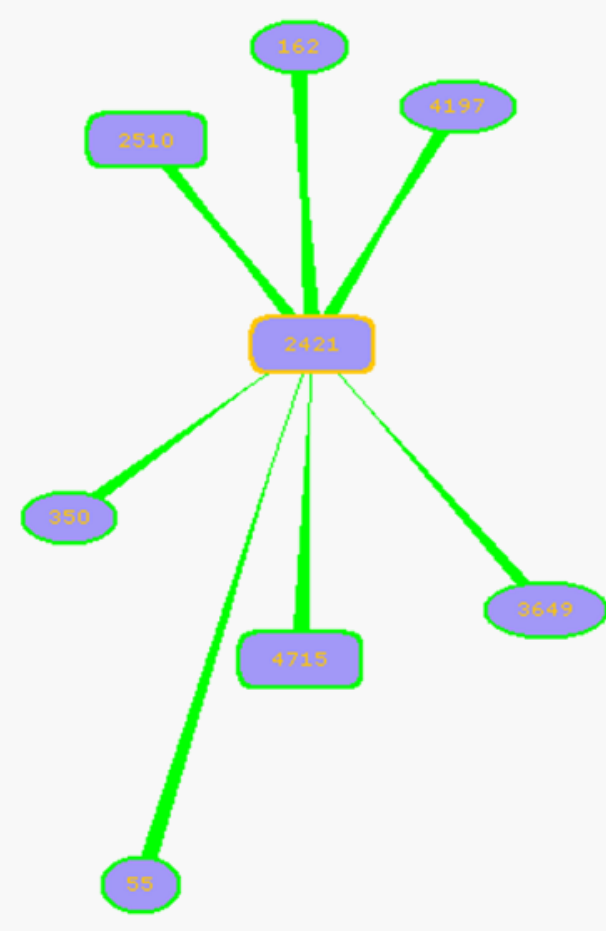

2421: Az általános iskolások idegennyelvtanulási attitűdjei és motivációja 2510: Általános iskolás tanulók attitűdje és motivációja az angol mint idegen nyelv tanulására

162: Az általános iskolások nyelvtanulási attitüdjei és nyelvválasztása Magyarországon 4197: A nyelvi attitüdök és az idegen nyelvi motiváció változásai 1993 és 2004 között Magyarországon 350: Az angol nyelvtanulási motiváció alakulása Budapesten tanuló egyetemisták és föiskolások körében

55: A családi környezet hatása az idegen nyelvi motivációra: egy kvalitatív módszerekkel történő kutatás tanulságai 4715: Első évfolyamos német szakos egyetemi hallgatók nyelvtanulási motivációja 3649: Siketek és nagyothalló felnőttek idegennyelv-tanulási motivációja

116. ábra

A klaszterizálás egyfajta gráf-szerü ábrázolása

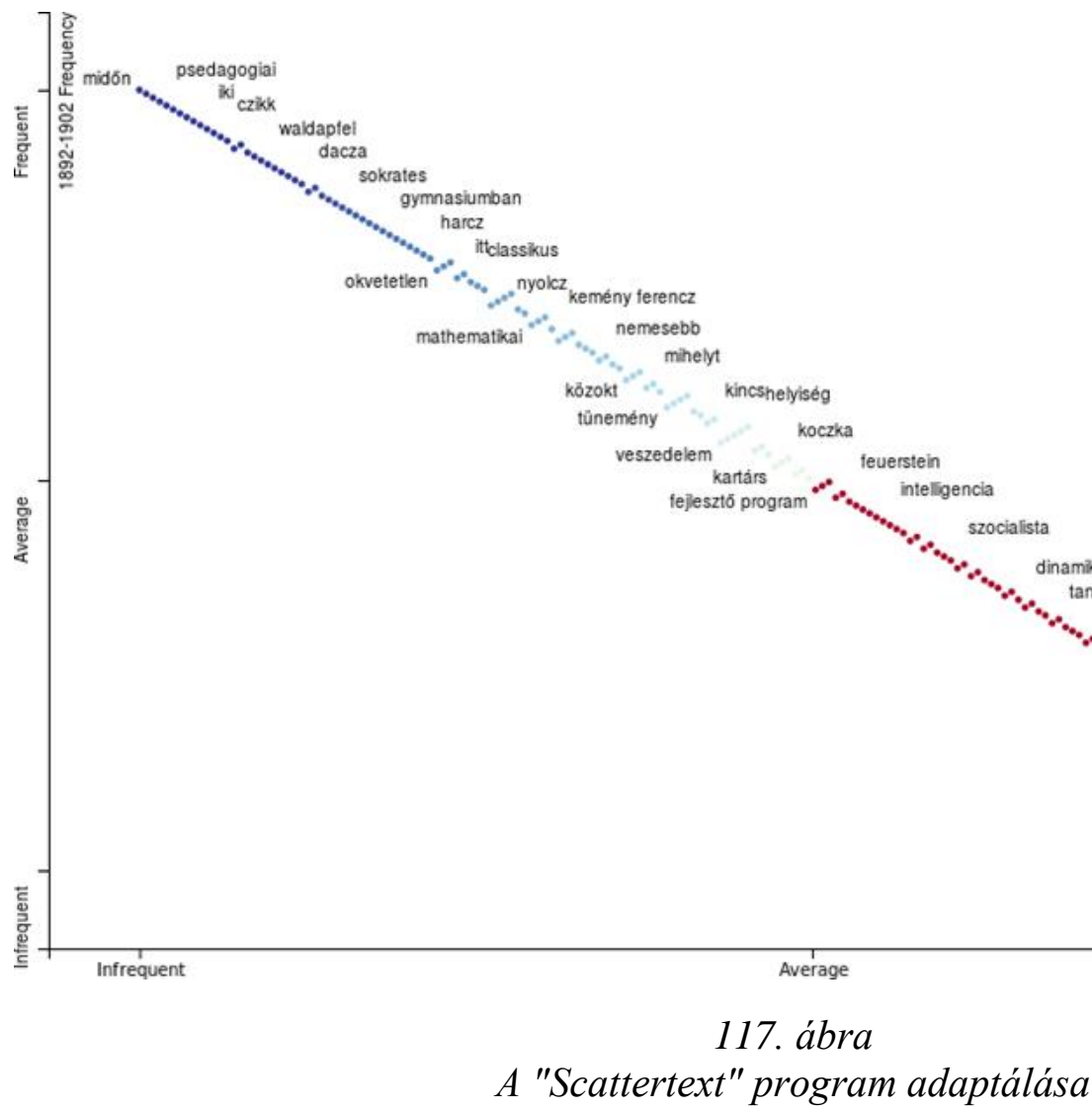




\section{AZ EREDMÉNYEK ÖSSZEGZÉSE, LIMITÁCIÓK ÉS TOVÁBBI KUTATÁSI IRÁNYOK}

\subsection{A kutatás relevanciája és környezete}

Az eredmények körültekintő értelmezéséhez és megvitatásához mindenképpen szükséges a kutatás kiindulási alapjainak, illetve fö motivációinak tisztázása, amelyet esetünkben a társadalomtudományok, azon belül is a neveléstudomány hivatkozási adatbázisokban való szerény jelenléte testesített meg. A tudományos élet haladó szereplői számára az olyan nemzetközi hivatkozási adatbázisok használata, mint a Web of Science vagy a Scopus mára megkerülhetetlenné váltak. Mindemellett elmondható, hogy hazánkban akár teljes tudományterületek kimaradhatnak azokból az előnyökből, amelyet ezeknek az adatbázisoknak a használata nyújthat, mivel számos diszciplína csak marginális mértékben reprezentálódik ezekben, ahogyan az a SciVal adatbázis adatai alapján a 118. ábrán látható. Az OECD Frascati Manual kiadványa szerinti Field of Science and Technology (FOS) tudománytaxonómiai osztályozás szerint a humántudományok 3,7\%-al, míg a teljes társadalomtudományi szféra 8,6\%-al van képviselve Magyarországról a Scopus adatbázisban, ezen belül specifikusan a neveléstudomány 4,2\%-al (348 darab publikáció) van jelen a 2013-2017 közötti ötéves periódusban.

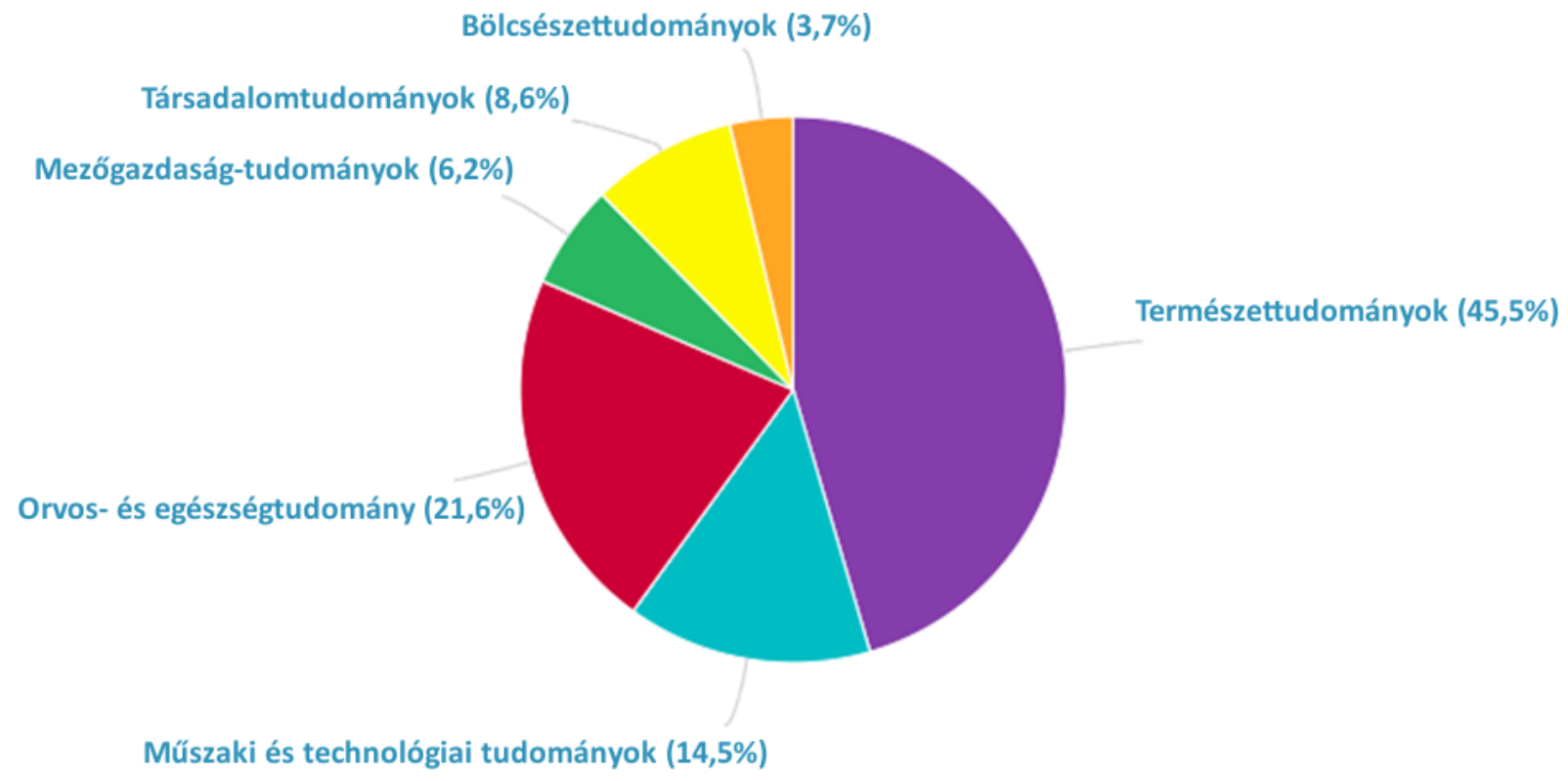

118. ábra

Magyarország tudományos kibocsátása a SciVal adatai alapján 2013-2017 között a FOS osztályozás szerinti tudományágak bontásában 
A jelenség több okra vezethető vissza, egyrészt a „puha tudományágak” publikálási szokásai jelentősen eltérnek a „kemény tudományok” publikálási gyakorlatától (ti. tanulmánykötet, monográfia, konferencia-elöadás, stb.), másrészt ezen területek hazai kutatói előszeretettel publikálnak olyan folyóiratokban, amelyeket a nemzetközi hivatkozási adatbázisok nem indexelnek. Ennek ellenére részükről ugyanolyan elemi igény mutatkozna saját tudományterületük belső szerkezetének felderítésére. Mindezt az elvárást a tudományos együttmüködés hálózatainak felderítése által, egy-egy folyóirat, vagy ezen keresztül továbbépítkezve akár egy egész diszciplína hivatkozási hálózatának megalkotásával lehet teljesíteni. A disszertációban tárgyalt kérdések interdiszciplináris jellege sok esetben megkerülhetetlen, illetve magában a tudományszervezésben lezajlott változásokat tükrözi, azonban a neveléstudomány jó adaptációs képességének megtartása miatt kiemelten fontos velük foglalkoznunk saját tudományágunk területén is. Ezek közé tartoznak a tudománymetria aktuális trendjei, köztük az MTMT körül kialakult polémiák, az Open Access különböző útjai, vagy a DOI és az Open Journal System szerkesztőségi rendszer terjedése, illetve az egyre inkább expanzióban lévő repozitóriumok és más adatbázisok viszonyának tisztázása a neveléstudományhoz.

Annál is inkább szükséges foglalkoznunk ezekkel az aktuális kérdésekkel, mert jó néhány közülük csak az elmúlt néhány évben nyert létjogosultságot a neveléstudomány területén, így sok esetben még újszerünek vagy ismeretlennek hatnak. Például ilyen fejleménynek tekinthető az impakt faktor és más hasonló tudománymetriai indikátorok begyürüzése a társadalomtudományok területére, de szintén az elmúlt évek eredménye, hogy nagyon sok esetben a kutatók kötelezettségévé és egyben saját, jól felfogott érdekévé vált MTMT-profiljuk naprakészen tartása. Elmondható, hogy ez a publikációs adatokat nyilvántartó bibliográfiai adatbázis mára megkerülhetetlen ponttá vált a hazai tudományos életben.

A tudománymetriai nézőpontot folyamatosan érik kritikák, a tapasztalható visszásságok és a sokszor túlzottan elitista megközelítésmód miatt. Ezeket a vitákat ugyan a szükségesnél talán kevésbé volt alkalmunk megjeleníteni a disszertációban, hiszen a tudománymetria útkeresésének feltárása önálló disszertációt érdemelt volna, ugyanakkor a 2.1.1. pont nyolcadik bekezdésében számos szakirodalmi hivatkozást közlünk, amelyek ezt a nézőpontot állítják fókuszba. Mindemellett ismét deklaráltan szeretnénk felhívni a figyelmet, hogy akár az MTMTből, akár a nemzetközi hivatkozási adatbázisokból kinyerhető tudománymetriai mérőszámok önmagukban nem tekinthetőek automatikus értékmérő indikátoroknak, hiszen ezeket rengeteg körülmény, környezetspecifikus változó befolyásolhatja, árnyalhatja. Ez a megállapítás természetesen ugyanígy érvényesnek tekintendő az általunk közölt kutatási eredmények egyes 
tudománymetriai jellegü mutatóira is.

Átalakulóban van a tudományos folyóiratok kiadási modellje, napról-napra új adatbázisok (pl. ADT, EHM), intézményi repozitóriumok (pl. REAL, Contenta, DEA, stb.), keresőmotorok (pl. Wolfram Alpha, EDS) és új mérési eljárások (pl. PlumX) születnek. Ennek fényében nem véletlen, hogy egyre több szó esik a publikálási szokások megváltozásáról: minden tudatos kutató tisztában van azzal, hogy nem mindegy, hogy hol jelenteti meg kutatási eredményeit, hiszen ez a későbbiekben jelentősen befolyásolhatja személyes tudományos karrierjét. Ebböl a nézőpontból is érdemes vizsgálat alá vetnünk az olyan új hatásokat, mint amilyet például az Open Access mozgalom képvisel, vagy éppen ezen mozgalom viszonyát az ún. predátor folyóiratokhoz. További friss fejleményt jelent a neveléstudományi folyóiratok teljes szövegét szabadszavasan kereshetővé tévő adatbázisok megjelenése, vagy a digitálisobjektum-azonosító 2015 év eleji megjelenése a terület két vezető folyóirata esetében. A fenti fejlemények iránymutató trendeknek tekinthetőek, sok hasonló várható még az elkövetkező években, így mindenképpen az új lehetőségek megfelelő ismerete, azután pedig körültekintő adaptálása kívánatos. Ha a neveléstudomány kutatói nem akarnak lemaradni a tudományágak közötti egyre fokozódó versenyben, akkor kénytelenek alkalmazkodni a megváltozott és permanensen változó helyzethez.

A kutatás létjogosultságát bizonyítja a számtalan hozzánk eljutott javaslat és észrevétel arra vonatkozóan, hogy a vizsgálatot célszerü volna kiterjeszteni a vezető hazai szakfolyóiratokban megjelent tanulmányokra, a konferenciakötetek tartalmára, a tanulmánykötetekre és a különféle kézikönyvekre. Bár mindez túlmutat lehetőségeinken, saját munkánkat kezdőlépésnek tekintjük azon az úton, amely végül elvezet odáig, hogy a neveléstudomány egészére vonatkozóan elkészüljön ezeknek a fontos eredményeknek a feltárása.

Az értekezés egy több mint százéves folyóirat tudománymetriai és tartalmi elemzésének eredményeit, nehézségeit és a kutatás további perspektíváit mutatja be. A tudománymetriai elemzésekre minden tudományterületen nagy szükség lenne, hiszen csak ezek a helyzetelemzések tudják feltárni az adott tudományág belső jellemzőit, állapotát, viszonyait, amelyek ismerete mindenképpen szükséges az egészséges fejlödéshez. Nincs ez másként a neveléstudomány esetében sem. A kutatási projekt megtervezése során kutatási tervünkben a következő lépéseket azonosítottuk, amelyeket az elmúlt években - összhangban az előzetes tervekkel - sikerült megvalósítani:

0. Digitalizálás és a kiadói PDF-ek begyüjtése a szerkesztőségtől

1. Adatbázisépítés: metaadatolás és full-text indexelés 
2. A full-text szövegkorpusz feldolgozása szövegbányászati módszerek segítségével

3. A kapott adatok értelmezése, elemzése, következtetések levonása

4. Vizualizálás: gráfok, diagramok, hőtérképek, szófelhők készítése

5. Eredmények prezentálása, publikálása

\subsection{Metaadatokon nyugvó eredmények}

A kutatási projekt első pillérének tekinthető, a folyóiratcikkek metaadatain alapuló vizsgálódások eredményeit a következők szerint tudjuk összefoglalni. Az elvégzett helyzetelemzés egyik tapasztalata a hazai neveléstudományi folyóiratokban megjelenő publikációk darabszámában lecsapódó csökkenő tudományos aktivitás. Az eredményt együtt értelmezve a magyar kutatók nemzetközi publikációs gyakorlatával, a hazai neveléstudomány mennyiségi kibocsátásának csökkenése figyelhető meg. Ez az eredmény ellentétes első hipotézisünknek a publikációk számának és szerzőinek számbeli növekedését feltételező részével. A tendencia mögé tekintve, a Magyar Pedagógiában megjelent tanulmányok további mutatóit vizsgálva, összességében pozitív trendekről tudtunk beszámolni. A vizsgált folyóirat esetében ilyen indikátort jelent a tanulmányok hosszának és kidolgozottságának növekedése, illetve a kutatók közötti fokozódó tudományos együttműködés, amely tudománymetriai szempontból a társszerzővel együtt írt cikkek arányának növekedésében érhető tetten. Ez utóbbi jelenség egybevág a nemzetközi közegben tapasztalhatókkal és negyedik hipotézisünkkel is. Ennél általánosabb, akár a hazai neveléstudomány egészére vonatkoztatható következtetések levonásához részletesebb elemzésekre, további tudományterületi szakfolyóiratok és egyéb tudományos müfajok bevonásására volna szükség. Az általunk ismertetett eredmények egyfajta kiindulópontnak tekinthetőek az egyik meghatározó orgánum önálló vizsgálatán keresztül.

A disszertáció következő fontos kutatási kérdéscsoportját a folyóirat szerzői összetételének minél alaposabb vizsgálata jelentette. A hasonló elemzések egyik alapvető kérdését jelenti annak eldöntése, hogy a konkrét nevek közlésre kerüljenek vagy maradjanak az anonimitás homályában, esetleg monogramokkal hivatkozzanak rájuk. Véleményünk szerint az utóbbi megoldások nagymértékben rontják az eredmények áttekinthetőségét, ezért a minél teljesebb körü érthetőség miatt a teljes névalakok közlését választottuk. A legtöbbet publikáló szerzők listáját intézményi affiliációjukkal és a kapott hivatkozások számával együtt a 4. táblázatban közöltük. Ez a részletes és konkrét adatközlés hiánypótló a magyar neveléstudományi közegben. Azonosítottuk a Magyar Pedagógia legtöbbet publikáló szerzőit, illetve azokat a központi személyeket, akiknek munkáira a legtöbb hivatkozás érkezett a folyiratban többi szerző irányából. 
A szerzők intézményi hátterével kapcsolatban szintén konkrét adatokat közlünk, amelyekböl a Szegedi Tudományegyetem és az Eötvös Loránd Tudományegyetem vezető szerepe bontakozik ki több adatsort összevetve. Ez alátámasztja a második hipotézisünkben foglaltakat: a folyóirat szerzői között valóban meghatározó szerepet tölt be a Szegedi Tudományegyetem Neveléstudományi Intézetében uralkodó, kognitív pszichológiai paradigmát képviselő kutatói csoport, mivel a legtöbbet publikáló és legnagyobb hatású szerzők egy része ebböl a körből kerül ki. Harmadik hipotézisünkben a szerzők intézményi háttérét illetően azt feltételeztük, hogy kimutathatóak lesznek elkülönülő csoportok a társszerzőségi gráfban. A gráfot elemezve megfigyelhetőek intézmények szerint teljesen elkülönülő csoportok (lásd 19. ábra), illetve a nagyobb méretü komponenseken belül is vannak intézményeken belüli szerzői alhálózatok, de ezek általában egy-egy centrális összekötő személyen (hub) keresztül általában valamilyen módon összekapcsolódnak (17-18. ábra).

Kutatásunk alapján további fontos, a folyóirat életét alapvetően befolyásoló tendenciákra is rávilágítottunk: csökkent a külföldi szerzők súlya, a női szerzőké pedig folyamatosan növekedett. Az utóbbi eredmény igazolja az ötödik hipotézisünkben megfogalmazottakat a női szerzők szerepéről. A szerzők szektorbeli helyzetét vizsgálva kijelenthetjük, hogy az akadémiai szféra jelentősen felülreprezentált, ugyanakkor marginálisan előfordulnak az oktatásirányítási szervezetekből és a közoktatásból érkező szerzők is. Az utóbbi csoport arányának növelése szerencsés fejlemény volna a jövőben, mert a kutatópedagógusi mozgalom kiteljesedését és megerősödését jelentené.

Szintén a metaadatokra alapozva, a társszerzőség által felvetett kérdéseket is tárgyaltuk a társszerzős cikkek arányának és az együtt publikáló szerzők felfedésével. A nemzetközi trendeknek megfelelően a tárgyalt folyóirat esetében egyértelmüen megfigyelhető a több szerző által írt cikkek arányának növekedése, ezáltal a tudományos együttmüködés fokozódása, amely alapvetően pozitív folyamat - remélhetőleg - egy újabb, később pontosabban detektálható tendencia kezdete. A több szerző által írt cikkek egyfajta minőségi mutatónak tekinthetőek, hiszen ezek általában nagyobb, kiterjedtebb tudományos kutatásokról számolnak be, ahol a siker érdekében szükségszerü a nagyobb csapatok együttmüködése, esetenként interdiszciplináris szakemberek bevonásával, amely tovább erősítheti a tudományág fejlődését. 


\subsection{Hivatkozásvizsgálatok}

A neveléstudományi kutatásban történtek már különféle kísérletek a tudományág hivatkozási szokásainak és mintázatainak felderítésére, így kutatásunk tulajdonképpen ezen projektek sorába illeszthető a Magyar Pedagógiára vonatkozó részletes eredmények közlésével. Elképzelésünk szerint az itt alkalmazott megközelítés az eddigiekhez képest mélyebb vizsgálódást tett lehetővé, mert bár csak egyetlen kiválasztott folyóiratot vizsgál, azt azonban a lehető legnagyobb részletességgel teszi, mégpedig olyan innovatív, automatizált eszközök bevonásával, amelyekhez hasonlókat a nemzetközi hivatkozáskinyeréssel foglalkozó vállalkozások is használnak.

Az eredmények alapján elmondható, hogy a tudománymetria releváns és újszerü lehetőségeket tartogat a neveléstudományi kutatás számára is. Segítségével áthidalhatóvá válik a nemzetközi hivatkozási adatbázisokban tapasztalható hiátus, amely azáltal jön létre, hogy a magyar nyelvü neveléstudományi sajtó egyáltalán nem reprezentálódik ezekben az adatbázisokban. Emiatt ezekből az adatbázisokból csak arról a viszonylag kisszámú publikációról szerezhetünk értesüléseket, amelyeket a magyar neveléstudósok a tudománymetriai indexelő adatbázisok rendkívül szigorú kritériumait teljesítő, nemzetközi lapokban közölnek. Ahogyan azt Csapó (2016) részletesen ismerteti, a hazai neveléstudomány ilyen irányú kibocsátása összevetve más európai országokkal, rendkívül alacsony szintre állt be. Mindebből következik, hogy a teljes neveléstudományi kutatói palettának és tudományos kibocsátásnak csak igen kis szelete vizsgálható ezeknek a professzionális tudománymetriai eszközöknek a segítségével. Az általunk itt alkalmazott és bemutatott módszer célkitüzése ennek az ürnek az áthidalása.

A hivatkozásvizsgálatokon keresztül kirajzolódó legfontosabb megválaszolandó kérdés a körül bontakozik ki, hogy mely pontok jelentették a legfontosabb változásokat a folyóirat elmúlt huszonöt évének történetében. Megfelelve előzetes várakozásainknak, időben elörehaladva egyre több szakirodalmi hivatkozás felhasználása jellemzi a lapot, ugyanakkor megfigyelhető az éves publikációszám általános csökkenése, majd egy alacsonyabb szinten beálló stagnálása. A hivatkozott forrásokat a minőség dimenziójában vizsgálva - elsősorban a hatodik és kilencedik hipotézisünkben foglaltak szerint - pozitív irányú tendenciák látszanak kibontakozni egyes indikátorok mentén. Elmondható, hogy a szerzők egyre frissebb szakirodalmat használnak munkájuk során, továbbá illeszkedve az általánosabb trendekhez, egyre több folyóiratcikkre, sőt ezen belül egyre több nemzetközi folyóiratcikkre való hivatkozás történik részükröl, összhangban a hatodik hipotézisünkben megfogalmazottakkal. Ezek az 
eredmények már szinte megelőlegezik az impakt faktoros cikkekre történő hivatkozások arányának emelkedését, amit kilencedik hipotézisünkben fogalmaztunk meg, az interdiszciplinaritás fokozódásával együtt, bár ez utóbbiról nem ennyire egyértelműek az eredmények. Ugyan jelen vannak interdiszciplináris forrásokra történő hivatkozások is, azonban kijelenthető, hogy a Magyar Pedagógia esetében inkább egy zártabb szaklapról beszélhetünk, ahol a neveléstudományi folyóiratokra való hivatkozások vannak túlsúlyban.

A hivatkozások különböző szempontú eloszlásának vizsgálata nyomán szintén sok érdekes következtetés vonható le. Ilyen például a hivatkozások interdiszciplináris eloszlása, amelynek nyomán több figyelemreméltó trend bontakozik ki, de legalább ennyire fontos eredménynek tekinthető a leghivatkozottabb szakirodalmi források címének, típusának, nemzetköziségének és a kapott hivatkozások számának kataszterbe foglalása (6. táblázat). A négy leghivatkozottabb forrásra vonatkozó feltételezés egyetlen kivételtől eltekintve beigazolódott. Ugyanennek a vizsgálatnak a keretében az egyes források műfaji azonosítása is megtörtént, így képet kaphatunk arról, hogy melyek a legnépszerübb tudományos müfajok a hivatkozások darabszámának eloszlását illetően. Ezen eredmények alapján vált megválaszolhatóvá hetedik hipotézisünk, miszerint létezik néhány sürün hivatkozott, nagy hatású szerkesztett tanulmánykötet, esetleg monografikus mü, amelyeket előszeretettel használnak a szerzők munkájuk során. A leghivatkozottabb harminc szakirodalmi forrásból nyolc darab könyv, amellyel bizonyítottnak tekintjük feltevésünket. Kevésbé igazolható a hipotézis konferencia-előadásokra és disszertációkra vonatkozó része, mert bár jelen vannak ezek a müfajok is, szerepük a vártnál sokkal marginálisabb.

A különféle eloszlások után a személyek dimenziója következik, hiszen a leghivatkozottabb szerzők listáján (7. táblázat), illetve az elkészült két hivatkozási hálózatban már ők képezik az elemzendő granularitási szintet. A leghivatkozottabb szerzők esetében fontos kiemelni az elvégzett munkák közül a nemzetközi kontextussal való összevetés jelentőségét. Mivel az egész tanulmányon végigvonul a nemzetközi hivatkozási adatbázisok jelentősége, emiatt mindenképpen indokoltnak tekinthető a leghivatkozottabb szerzők esetében kapott eredmények nemzetközi reputációval való összevetése, a Scopus adatbázist tekintve ilyen szempontból referenciának (28. ábra). Referenciaszemélyekre vonatkozó nyolcadik hipotézisünk több részből állt. Sikerült igazolni, hogy a legidézettebb szerzők listája összefüggést mutat a lapban legtöbbet publikálókéval. Felemásabb eredményeket kaptunk a Magyar Pedagógia szerzőinek nemzetközi reputációját illetően, bár az eredményeket alaposabban vizsgálva általában megtalálható a magyarázat az egyes személyek esetében, így igazoltnak tekinthetjük a hipotézis ezen részét is. 
Az elkészült belső és teljes hivatkozási hálózatok grafikus közlését illetően a nagy méretbeli kiterjedés miatt ugyan nehézségek jelentkeztek, amiket a domináns részletek kiemelt közlésével próbáltunk meg áthidalni. Emellett természetesen mindkét hivatkozási háló esetében részletesen ismertettük a gráfokra vonatkozó lényeges tulajdonságokat, amelyek nyomán a legfontosabb tudnivalók a teljes részletességủ ábrák hiányában is befogadhatóvá válnak. Már a konkrét hivatkozási gráfon túlmutató eredményeket képvisel a hálózat csomópontjainak intézményi hátterủ azonosítása, amely által további következtések levonására nyílik lehetőség a hazai neveléstudomány belső viszonyait illetően. Erre vonatkozott egyébként nyolcadik hipotézisünk utolsó része is, amely a hivatkozási hálózat elkülönülő csoportjairól szólt. A teljesen szeparált csoportok nem voltak jellemzőek a hivatkozási hálózatban, ugyanakkor jól kivehető a belső hivatkozási hálózat intézményi hátterét bemutató 31. ábrán, hogy teljesen érthető módon az azonos intézményhez tartozó szerzők előszeretettel hivatkozzák egymás munkáit. Ezeket az eredményeket érdemes összevetni a korábbiakban tárgyalt társszerzőségi elemzésekkel is.

\subsection{Tartalmi elemzés}

A tartalmi elemzések során igyekeztünk többféle módszert használni, a hosszú időtávot felölelő nagymennyiségü információ különböző szeleteinek láttatására. A 114 év és az 50 ezer oldal tartalmi sokszínüségének bemutatása komoly kihívást jelentett, amelyre a különböző perspektívák alkalmazásával próbáltunk meg adekvát válaszokat találni. Elsősorban ez a megközelítés indokolja a tartalmi elemzés részben közölt sokfajta és az egyes fajtákon belül is nagyszámú elemzést. Az itt közölt eredmények egy része célzottan kísérleti jellegü, hiszen egyes elemzési megoldásokat végül teljes egészében nem használtunk ki a maguk potenciáljában, ugyanakkor módszertani okok miatt ezek ismertetését is fontosnak gondoljuk. Ezek közé tartozik a hasonló cikkek detektálása, a klaszteranalízis és még néhány további vizualizálási kísérlet. Hasonló okokból teljeskörüen feltártuk a tartalmi elemzések során potenciálisan felhasználható segédforrásokat, referenciapontokat, amelyek közül végül csak néhányat emeltünk be a konkrét elemzésekbe.

A gyakoriságvizsgálatok, a kulcsszavakkal kapcsolatos vizsgálatok eredményei, a hasonló cikkek detektálása, a tartalmi csoportosítás és trendkövetés, illetve az egyes szakkifejezések használatának változása mind olyan elemzéstípusokat jelentettek, amelyek elképzelésünk szerint kiegészítették egymást, és ugyanannak az információtömegnek egy-egy eltérő szeletét világították meg. A gyakoriságvizsgálat a tartalomelemzés egyik legklasszikusabb módszereként a relatív és abszolút módon leggyakrabban előforduló szavak 
vizsgálatán alapul, ennek a megközelítésnek próbáltunk egyfajta keretet adni a kidolgozott módszereken keresztül, melyet elsősorban a különböző gyakorisági toplisták, illetve a hötérképes ábrázolási megoldás jelentettek. Az eredmények következő nagy szeletét az egyes évtizedekre jellemző szavak és szakkifejezések adják. Ebbe az elemzési megoldásba már a különböző segédforrásokból kinyert, cikkekre vonatkozó kulcsszavak is bevonódtak. Új és saját eredménynek tekinthetőek az automatikus kulcsszavazás segítségével kirajzolt 78-92. ábrák. Ezek relevanciáját alátámasztja, hogy fő vonalaikban megerősítik a különféle külső segédforrások felhasználásával készített elemzéseket. A többféle, párhuzamosan alkalmazott megközelítés eredményei egymást árnyalják és egyúttal a módszer megalapozottságát erősítik.

A tartalmi elemzésekre vonatkozóan megfogalmazott kutatási kérdésekre elsősorban a tartalmi csoportosítás és trendkövetés részben tudtunk válaszokat adni. Azonosítottuk a leghangsúlyosabb tématerületeket a folyóirat életében, illetve kimutattuk, hogy hogyan változott ezek egymáshoz viszonyított aránya az idő előrehaladásával. Egyfajta korszakhatárként azonosítottuk az 1900-es évek elejét, a második világháborút követő időszakot (továbbá a lap 1961-es újraindulását) és a rendszerváltást. Emellett a nemzetközi hatások átszürődése is tetten érhető volt, ahogyan sikerült azonosítani a három korszakhatárnak tekinthető tematikus váltást a lap történetében. Ismerve a történelmi-politikai hátteret, ezek a tematikus változások általában az uralkodó politikai ideológia oldaláról indukálódtak, kivéve talán az 1900-as évek elején tapasztalható kisebb horderejü tematikus változásokat, amelyek inkább szakmai motivációjú változásnak tekinthetőek. A korszakhatárnak ítélt pontoktól eltekintve jellemző a témák folyamatos egymásra épülése, rétegződése és egyfajta szerves fejlődése, ahogyan azt előzetesen is feltételeztük.

A fentieket figyelembe véve igazolható volt a tizedik hipotézisben megfogalmazott kitétel, miszerint az egyes évtizedes időszakokat önállóan vizsgálva kimutatható változások vannak a lap jellemző témáiban. Az is elmondható - összhangban a szakirodalommal és feltételezésünkkel -, hogy a Magyar Pedagógiában megjelenő témák viszonylag rövid időbeliséggel követik a nemzetközi neveléstudományban felbukkanó trendeket és új kutatási irányokat. Emiatt a folyóirat abból a szempontból is vezető szerepet betöltő médiumnak tekinthető a hazai neveléstudományon belül, hogy megjelenési felületet biztosít a friss, nemzetközi szakirodalomra általában késedelem nélkül reagáló, mélyen szakmai indíttatású kutatási irányokat megjelenítő publikációk számára. Ez a megállapításunk elsősorban arra a körülményre vonatkozik, hogy hosszú időn keresztül itt jelentek meg először a hazai szaksajtóban a friss nemzetközi szakirodalomból átszürődő új kutatási témák. Mindezen eredmények természetesen Németh $(2014,2015)$ recepciótörténeti megközelítésének tükrében 
értelmezendőek. Tizenegyedik hipotézisünkben egyfajta párhuzamosságot feltételeztünk a neveléstudomány egészét foglalkoztató korszakos kérdések és az éppen uralkodó politikai ideológiák hatásai között. Úgy gondoltuk, hogy ez a kétfajta szemlélet általában és folyamatosan jelen volt a lap története során. Ez a feltételezés az esetek többségében igaznak tekinthető, kivéve a néhány, durva elhajlásokat produkáló viharos politikai-ideológiai időszakot. A rendszerváltást követően szintén nem jellemző a politikai indíttatású, akár oktatásirányítási kérdéseket tárgyaló tanulmányok jelenléte a lapban, ebben az időszakban már sokkal inkább egy szigorúan szakmai tanulmányokat közlő orgánum képe rajzolódik ki előttünk. Összhangban minden eddigi megállapítással, utolsó hipotézisünk nyomán a kimutatható korszakhatárok főbb vonalaikat tekintve egybeesnek a hazai neveléstudomány fö sodrával.

\subsection{Limitációk és további kutatási irányok}

A kutatási projekt három pillére miatt a további lehetséges kutatási irányok is háromfelé ágaznak. Egyfajta fölöttes és közös bővítési lehetőséget jelentene mindhárom esetben a problématér kiterjesztése: a magyar neveléstudományi szaksajtó meghatározó folyóiratainak széleskörü elemzésekbe való bevonása, amely mindenekelőtt az Iskolakultúra, az Új Pedagógiai Szemle és az Educatio folyóiratokat jelenthetné. Még ideálisabb esetben potenciálisan bevonható elemzési lehetőséget jelenthetne az 1.3.1. részben ismertetett feltörekvő folyóiratok teljes körü vizsgálata, lefedve ezzel tulajdonképpen az egész magyar neveléstudományi szaksajtót. Emellett az általunk alkalmazott módszer alkalmas volna a folyóiratcikkek mellett létező más tudományos műfajok hasonló alapokon nyugvó elemzésére is. Szerencsés volna - a minél teljesebb körü eredmények érdekében - bevonni az elemzésekbe a könyveket (legyenek azok szerkesztett tanulmánykötetek vagy monografikus müvek), a doktori értekezéseket és a szöveges formában is reprezentálódó különféle konferenciaelőadásokat. A felsorolt müfajok esetében ugyanúgy el lehetne végezni a metaadatokon nyugvó elemzéseket, a hivatkozásvizsgálatokat és a tartalmi elemzéseket is, lefedve ezzel a teljes magyar nyelvű neveléstudományi impresszumot. Mindezen feltételek teljesülése esetében volna csak érdemes tovább bővíteni a kutatást a nemzetközi tér irányába, amelyet elsősorban a bibliográfiai-tudománymetriai indexelő adatbázisokon keresztül tartunk megvalósíthatónak. A bekezdésben foglalt nagyívü kutatás megvalósulásán keresztül közel valós képet kaphatnánk a magyar neveléstudományi kutatás jelenlegi helyzetéről, kibocsátásáról és a tudományterületen belüli viszonyokról. 
Sok lehetőséget tartogatna a további kutatási irányokat illetően az MTMT adatbázisban tárolt nagymennyiségü adat elemzésekbe való bevonása (és esetleg a kutatás során kapott eredmények oda való visszajuttatása, például az automatikusan felismert idézések esetében). Össze lehetne például vetni az egyes személyekhez kapcsolódó, a Magyar Pedagógiában azonosított hivatkozási értékeket az MTMT-ben szereplő idézések számával. Mind a metaadatok körében, mind a hivatkozási információk kapcsán komoly bővítési lehetőségként lehetne számolni ezzel a bibliográfiai adatbázissal.

A kisebb léptékü fejlesztési lehetőségeket figyelembe véve, a hivatkozásvizsgálatokra vonatkozóan a nemzetközi szakirodalom tendenciáit tekintetbe véve (például lásd Katy Börner munkásságát) további kutatási irányt jelentene az egyes szerzők közötti hasonlóság vizsgálata az idézéseken keresztül (vagyis annak kimutatása, hogy a hasonló szerzők mennyire idézik egymást), illetve a hasonló cikkek hivatkozások alapján történő detektálása. Érdemes volna megvizsgálni a tanulmányok terjedelmi növekedése mögött meghúzódó mögöttes okokat, hiszen sejthető, hogy az irodalomjegyzékek szintén kimutatott gyarapodása mellett a vizualizációt segítő grafikus megoldások (ábrák, táblázatok, képek) is növelték a cikkek átlagos terjedelmét. Az elmúlt évtizedekben valószínüleg jelentősen nőtt ezek szerepe a tudományos kommunikációban, így a Magyar Pedagógia hasábjain is. A folyamatot egyfajta trendkövetéssel lehetne leginkább tetten érni.

A tartalmi elemzések egy lehetséges bővítési forrását jelentené a mellékletek részben közölt kollokációs lista gyarapítása, elsősorban konferenciakötetek és tanulmánykötetek kulcsszavainak hozzáadásával. A tematikus elemzéseknél szintén kézenfekvő lehetőséget jelentene a több segédforrással, referenciaponttal való összevetés, hiszen munkánkban ezek közül nem használtuk fel az összes rendelkezésre álló alternatívát. Különösen izgalmas volna az OPKM PAD adatbázisának bevonása az elemzésekbe. Ez az adatbázis a tartalmi elemzések mellett a metaadatokra és hivatkozásokra vonatkozóan számos további lehetőséget biztosítana, egy az első bekezdésben felvázolt, kiterjesztett kutatás során. Szintén mindhárom megközelítés esetében érvényes fejlesztési irány tudna lenni a még kifinomultabb vizualizálási megoldások keresése és az esetlegesen a külföldi szakirodalomban már meghonosodott jó példák adaptálása.

A limitációk egy része tulajdonképpen az itt vázolt további kutatási irányokból egyszerűen levezethető. Az általunk közölt eredmények egyetlen folyóirat elemzésén nyugszanak, holott a neveléstudomány egészére érvényes, szélesebb körü és általánosabb következtetések levonásához mindenképpen kiterjedtebb elemzési bázisra lenne szükség. A Magyar Pedagógiában a szerzők által közölt írások valószínűleg a tudományágnak csak egy szűk szeletét tudják megjeleníteni, mindenképpen erről árulkodik az utóbbi évekre különösen 
jellemző alacsony publikációszám. A disszertációban közölt eredmények ezen szempont figyelembevételével értelmezendőek.

Az általunk alkalmazott automatizmusok deklarált hibalehetőségeket tartogatnak több ponton is. Egyik ilyen pont az automatikus szövegfelismerés, amely a technikai korlátok miatt bizonyítottan nem száz százalékos hatásfokú (ugyanakkor nyelvtől és szövegtől függően általában meghaladja a 97\%-ot, lásd például Afli, Barrault, \& Schwenk, 2016 tanulmányát). Szintén az automatizmusokból fakadóan a hivatkozások kinyerése sem lehet tökéletes (a szakirodalom szerint a hibák aránya például a WoS esetében 6-12\%-ra tehető, lásd Olensky, Schmidt, \& Eck, 2016 publikációját), ahogyan a tartalmi elemzések esetén az automatizált kulcsszókinyerésnél is előfordulhatnak hibalehetőségek. Mindezek ellenére úgy gondoljuk, hogy a mintákban található hibák jelentősen nem befolyásolják az eredményeket, mivel hibahatáron belül vannak. A szövegbányászat esetében univerzálisan elfogadott hibahatárok ugyanakkor nem léteznek, hiszen ez doménenként, szövegenként és alkalamzott eljárásonként is jelentős szórást mutathat. Saját kutatásunkat illetően esetlegesen az emberi tévedés esélye sem zárható ki teljes mértékben, például a metaadatok feldolgozása során keletkezhettek ilyenek. Természetesen végig következetesen törekedtünk a különböző hibák elhárítására, illetve több körös minőségellenőrzést alkalmaztunk annak érdekében, hogy a tévedések az elfogadható szinten belül maradjanak.

Maga a kutatás egyfajta pilot projektnek tekinthető, az ilyen projektek mindenféle módszertani és szakmai korlátjával együtt. Nem könnyítette meg a dolgunkat, hogy viszonylag kevés olyan, hasonló jellegü tudománymetriai és tartalmi elemzés zajlott a magyarországi társadalomtudományi kutatás környékén, amelyre módszertani szempontból alapozni tudtunk volna. Talán a tudománymetriai megközelítés esetében volt könnyebb dolgunk, mivel itt volt néhány előképe az általunk elvégzett elemzéseknek, sőt, bizonyos konkrét, általunk is használt vizsgálati módszernek megvoltak a megfelelői az egyes korábbi kutatásokban.

Az automatizált módszereken nyugvó tartalmi elemzések esetében azonban hiátus mutatkozott a hasonló hazai kutatások vonatkozásában. A különféle társadalomtudományok kutatói - beleértve a neveléstudósokat is - főként a klasszikus, emberi erőforrás bevonásán alapuló kódolásos tartalomelemzést alkalmazták eddigi munkáikban. Így egyfajta kényszerüségből, az általunk alkalmazott módszer újdonságnak tekinthető, ezáltal magában hordozva annak a lehetőségét, hogy bizonyos pontokon nem elég kiforrott. Ugyanakkor a felmerülő kritikák és korlátok mellett előnyének tekinthető univerzalitása, tudniillik, hogy a neveléstudomány horizontján kívül, akár más tudományágak esetében is alkalmazható, ahogyan erre a már lezajlott kutatási periódusban is akadtak példák. 


\section{IRODALOM}

Adams, J. (2012). Collaborations: The rise of research networks. Nature, 490(7420), 335. https://doi.org/10.1038/490335a

Afli, H., Barrault, L., \& Schwenk, H. (2016). OCR Error Correction Using Statistical Machine Translation. International Journal of Computational Linguistics and Applications, 7(1), $175-191$.

Akadémiai Kutatóintézetek Tanácsa. (2009). Az Akadémiai Kutatóintézetek Tanácsának 2009. április 20-i, május 25-i és június 15-i ülésének állásfoglalásai. Akadémiai Értesitő, 58(7), $184-187$.

Alperin, J. P. (2014). South America: Citation databases omit local journals. Nature, 511(7508), 155. https://doi.org/10.1038/511155c

American Psychological Association. (2010). Publication manual of the American psychological Association (6th ed.). Washington: American Psychological Association.

Antal, A. (2011). A magyar politikatudomány hiányzó hálózatai. Politikatudományi Szemle, 20(1), 135-142.

Archambault, É., Campbell, D., Gingras, Y., \& Larivière, V. (2009). Comparing bibliometric statistics obtained from the Web of Science and Scopus. Journal of the Association for Information Science and Technology, 60(7), 1320-1326. https://doi.org/10.1002/asi.21062

Asemi, A. (2010). A citation analysis of Iranian journals to open access (OA) articles and journals. Scientometrics, 82(3), 487-494. https://doi.org/10.1007/s11192-010-0184-X

Baker, R. S., \& Yacef, K. (2009). The state of educational data mining in 2009: A review and future visions. Journal of Educational Data Mining, 1(1), 3-17.

Bánkeszi, K. (2010). „Digitalizálni, de...” Érvek és ellenérvek, félelmek és remények. Tudományos és Müszaki Tájékoztatás, 57(7), 275-282.

Barabási, A. L. (2016). A hálózatok tudománya. Budapest: Libri.

Barabási, A. L., Jeong, H., Néda, Z., Ravasz, E., Schubert, A., \& Vicsek, T. (2002). Evolution of the social network of scientific collaborations. Physica A: Statistical mechanics and its applications, 311(3-4), 590-614. https://doi.org/10.1016/s0378-4371(02)00736-7 
Bárd, E. (2009). Referenciaszemélyek a magyar, a német és a francia neveléstudományi diskurzusokban. In Németh A. \& Biró Zs. H. (Eds.), A magyar neveléstudomány a 20. század második felében (pp. 227-244). Budapest: Gondolat.

Bastian, M., Heymann, S., \& Jacomy, M. (2009). Gephi: an open source software for exploring and manipulating networks. Icwsm, 8(2009), 361-362.

Berend, G. (2016). Exploiting extra-textual and linguistic information in keyphrase extraction. Natural Language Engineering, 22(1), 73-95. https://doi.org/10.1017/s1351324914000126

Berend, G., \& Farkas, R. (2013). Keyphrase-driven document visualization tool. The Companion Volume of the Proceedings of IJCNLP 2013: System Demonstrations, 17-20.

Bernius, S., Hanauske, M., König, W., \& Dugall, B. (2009). Open access models and their implications for the players on the scientific publishing market. Economic Analysis and Policy, 39(1), 103-116. https://doi.org/10.1016/s0313-5926(09)50046-X

Bhaskar, R., Danermark, B., Price, L. (2018). Interdisciplinarity and Wellbeing: A Critical Realist General Theory of Interdisciplinarity. London: Routledge. https://doi.org/10.4324/9781315177298

Bíró, I. (2009). Dokumentum osztályozás rejtett Dirichlet-allokációval (Unpublished doctoral dissertation). Eötvös Loránd Tudományegyetem. Retrieved from http://www.tnkcs.inf.elte.hu/vedes/Biro_Istvan_Ertekezes.pdf

Biró, Zs. H. (2009a). A magyar neveléstudományi kommunikáció szereplői. Tudományszociológiai elemzés a központi pedagógiai folyóiratok szerzőiről (1997-2006). In Németh, A. \& Biró, Zs. H. (Eds.), A magyar neveléstudomány a 20. század második felében (pp. 168-209). Budapest: Gondolat.

Biró, Zs. H. (2009b). A magyar neveléstudományi kommunikáció jellemzői (1997-2006), Összehasonlító tudományszociológiai elemzés, avagy kísérlet egy nemzetközi kutatás adaptációjára. Magyar Pedagógia, 109(1), 49-76.

Biró, Zs. H., \& Nagy, P. T. (2018). Az oktatáskutatás inter-és multidiszciplináris jellege. Educatio, 27(1), 84-100. https://doi.org/10.1556/2063.27.2018.1.7 
Bordons, M., Aparicio, J., González-Albo, B., \& Díaz-Faes, A. A. (2015). The relationship between the research performance of scientists and their position in co-authorship networks in three fields. Journal of Informetrics, 9(1), 135-144. https://doi.org/10.1016/j.joi.2014.12.001

Borgatti, S. P., Mehra, A., Brass, D. J., \& Labianca, G. (2009). Network analysis in the social sciences. Science, 323(5916), 892-895. https://doi.org/10.1126/science.1165821

Bornmann, L., \& Mutz, R. (2015). Growth rates of modern science: A bibliometric analysis based on the number of publications and cited references. Journal of the Association for Information Science and Technology, 66(11), 2215-2222. https://doi.org/10.1002/asi.23329

Bornmann, L., Thor, A., Marx, W., \& Schier, H. (2016). The application of bibliometrics to research evaluation in the humanities and social sciences: An exploratory study using normalized Google Scholar data for the publications of a research institute. Journal of the Association for Information Science and Technology, 67(11), 2778-2789. https://doi.org/10.1002/asi.23627

Bower, K., Fisher, J., \& Gerodetti, N. (2017). Open journal systems and undergraduate research: How an open journal system can facilitate digital literacy and a research culture. Sconul Focus, 69, 66-69.

Boyack, K. W., Newman, D., Duhon, R. J., Klavans, R., Patek, M., Biberstine, J. R., et al., \& Börner, K. (2011). Clustering more than two million biomedical publications: Comparing the accuracies of nine text-based similarity approaches. PloS one, 6(3), e18029. https://doi.org/10.1371/journal.pone.0018029

Börner, K. (2010). Atlas of science. Cambridge, MA: MIT Press.

Börner, K. (2015). Atlas of knowledge: Anyone can map. Cambridge, MA: MIT Press.

Börner, K., \& Polley, D. E. (2014). Visual insights: A practical guide to making sense of data. MIT Press.

Brint, S., \& Carr, C. E. (2017). The Scientific Research Output of US Research Universities, 1980-2010: Continuing Dispersion, Increasing Concentration, or Stable Inequality?. Minerva, 55(4), 435-457. https://doi.org/10.1007/s11024-017-9330-4 
Castelli, D., Manghi, P., \& Thanos, C. (2013). A vision towards scientific communication infrastructures. International Journal on Digital Libraries, 13(3-4), 155-169. https://doi.org/10.1007/s00799-013-0106-7

Chan, L. (2004). Supporting and enhancing scholarship in the digital age: The role of Open Access institutional repository. Canadian Journal of Communication, 29(3), 277-300. https://doi.org/10.22230/cjc.2004v29n3a1455

Chen, Y., Börner, K., \& Fang, S. (2013). Evolving collaboration networks in Scientometrics in 1978-2010: a micro-macro analysis. Scientometrics, 95(3), 1051-1070. https://doi.org/10.1007/s11192-012-0895-2

Clarivate Analytics. (2014). 2014 Journal Citation Reports. Retrieved from http://jcr.incites.thomsonreuters.com

Clarivate Analytics. (2017). 2017 Journal Citation Reports. Retrieved from http://jcr.incites.thomsonreuters.com

Csaba, L., Szentes, T., \& Zalai, E. (2014). Tudományos-e a tudománymérés? Megjegyzések a tudománymetria, az impaktfaktor és MTMT használatához. Magyar Tudomány, 175(4), $442-466$.

Csapó, B. (1991). Hagyomány és korszakváltás. A megújult Magyar Pedagógia programja. Magyar Pedagógia, 91(1), 3-6.

Csapó, B. (1992). Száz év - Száz éves a Magyar Pedagógia. Magyar Pedagógia, 92(1), 3-4.

Csapó, B. (1997). A tanulás és oktatás kutatása mint önálló tudományág. Az Iskolakultúra tematikus száma elé. Iskolakultúra, 7(12), 3-13.

Csapó, B. (2000). Utószó a Magyar Pedagógia századik évfolyamához. Magyar Pedagógia, 100(4), 531-533.

Csapó, B. (2005). A Magyar Pedagógia feladata a neveléstudomány fejlesztésében. Iskolakultúra, 15(4), 3-10.

Csapó, B. (2007). Csengeri János öröksége - a Magyar Pedagógia a 21. században. Magyar Pedagógia, 107(1), 79-90.

Csapó, B. (2011). Az oktatás tudományos hátterének fejlődése. Magyar Tudomány, 172(9), 1065-1076. 
Csapó, B. (2016). A tanárképzés és az oktatás fejlesztésének tudományos háttere. Iskolakultúra, 26(2), 3-18. https://doi.org/10.17543/iskkult.2015.11.3

Csapó, B., \& Pukánszky, B. (1993, Eds.). A Magyar Pedagógia első száz évének repertóriuma. Magyar Pedagógia, különszám.

Cselényi, E. (2009). Publikációs és idézettségi aktivitás a Politikatudományi Szemle hasábjain. Politikatudományi Szemle, 18(3), 59-87.

Csengeri, J. (1892). Olvasóinkhoz. Magyar Paedagogia, 1, 1-2.

Csíkos, Cs. (2013). Az impakt faktor a neveléstudományi kutatásokban. Iskolakultúra, 23(9), $3-16$.

Csíkos, Cs., Józsa, K., Korom E., \& Tarkó, K. (1997). Egy formálódó tudományos közösség. Iskolakultúra, 7(12), 108-117.

Cui, W., Wu, Y., Liu, S., Wei, F., Zhou, M. X., \& Qu, H. (2010). Context preserving dynamic word cloud visualization. In 2010 IEEE Pacific Visualization Symposium (PacificVis) (pp. 121-128). IEEE. https://doi.org/10.1109/pacificvis.2010.5429600

David, D., \& Frangopol, P. (2015). The lost paradise, the original sin, and the Dodo bird: a scientometrics Sapere Aude manifesto as a reply to the Leiden manifesto on scientometrics. Scientometrics, 105(3), 2255-2257. https://doi.org/10.1007/s11192-015$1634-2$

Devarakonda, R., Palanisamy, G., Green, J. M., \& Wilson, B. E. (2011). Data sharing and retrieval using OAI-PMH. Earth Science Informatics, 4(1), 1-5. https://doi.org/10.1007/s12145-010-0073-0

Dodds, F. (2017). The future of academic publishing: Revolution or evolution? Learned Publishing, 31(2), 163-168. https://doi.org/10.1002/leap.1109

Elkana, Y. (1978). Toward a metric of science: The advent of science indicators. New York: Wiley.

European Association for Research in Learning and Instruction. (2014). Overview EARLI Publications. $\quad$ Retrieved from http://www.earli.org/resources/Publications/EARLI\%20Publications_Overview\%20201 4.pptx 
Eurostat. (2017). Felsőfokú oktatási statisztikák. Retrieved from https://ec.europa.eu/eurostat/statisticsexplained/index.php?title=Tertiary_education_statistics/hu

Fagan, J., Eddens, K. S., Dolly, J., Vanderford, N. L., Weiss, H., \& Levens, J. S. (2018). Assessing Research Collaboration through Co-Authorship Network Analysis. Journal of Research Administration, 49(1), 76-99.

Fanelli, D., \& Larivière, V. (2016). Researchers' individual publication rate has not increased in a century. PLoS One, 11(3), e0149504. https://doi.org/10.1371/journal.pone.0149504

Fehér, P., \& Aknai, D. O. (2016). Aki "doktor" akar lenni..., avagy doktorjelöltek publikációs teljesítményének összehasonlítása a hazai neveléstudományi doktori iskolákban. In Molnár, Gy. \& Bús, E. (Eds.), PÉK 2016 = [CEA 2016]: XIV. Pedagógiai értékelési Konferencia $=[14$. Conference on Educational Assessment $]$ : Program; Elöadásösszefoglalók = [Program; Abstracts]. (pp. 53). Szeged: SZTE BTK Neveléstudományi Doktori Iskola.

Feldman, R., Fresko, M., Hirsh, H., Aumann, Y., Liphstat, O., Schler, Y., \& Rajman, M. (1998). Knowledge Management: A Text Mining Approach. Proceedings of Second International Conference on Practical Aspects of Knowledge Management (pp. 9.1-9.10).

Feldman, R., Sanger, J. (2007): The Text Mining Handbook: Advanced Approaches in Analyzing Unstructured Data. Cambridge: University Press.

Feuer, M. J., Towne, L., \& Shavelson, R. J. (2002). Scientific culture and educational research. Educational Researcher, 31(8), 4-14. https://doi.org/10.3102/0013189x031008004

Fitzgerald, M. (2012). Introducing regular expressions. Beijing: O'Reilly Media, Inc.

Fortunato, S., Bergstrom, C. T., Börner, K., Evans, J. A., Helbing, D., Milojević, S., et al., \& Barabási, A. L. (2018). Science of science. Science, 359(6379), eaao0185. https://doi.org/10.1126/science.aao0185

Fox, C. W., Paine, C. T., \& Sauterey, B. (2016). Citations increase with manuscript length, author number, and references cited in ecology journals. Ecology and Evolution, 6(21), 7717-7726. https://doi.org/10.1002/ece3.2505

Garfield, E. (1955). Citation indexes for science. Science, 122(3159), 108-111. https://doi.org/10.1126/science.122.3159.108 
Garfield, E. (2006). The history and meaning of the journal impact factor. Jama, 295(1), 9093. https://doi.org/10.1001/jama.295.1.90

Garfield, E. (2009). From the science of science to Scientometrics visualizing the history of science with HistCite software. Journal of Informetrics, 3(3), 173-179. https://doi.org/10.1016/j.joi.2009.03.009

Garfield, E., \& Merton, R. K. (1979). Citation indexing: Its theory and application in science, technology, and humanities. New York: Wiley.

Géczi, J. (2007). A magyar neveléstudományi sajtó a 19-20. század fordulóján. Magyar Pedagógia, 107(1), 57-66.

Géczi, J. (2010). Sajtó, kép, neveléstörténet. Veszprém-Budapest: Iskolakultúra.

Giménez-Toledo, E., Mañana-Rodríguez, J., Engels, T. C., Ingwersen, P., Pölönen, J., Sivertsen, G., ... \& Zuccala, A. A. (2016). Taking scholarly books into account: current developments in five European countries. Scientometrics, 107(2), 685-699. https://doi.org/10.1007/s11192-016-1886-5

Glänzel, W. (2008). Seven myths in bibliometrics about facts and fiction in quantitative science studies. Collnet Journal of Scientometrics and Information Management, 2(1), 9-17. https://doi.org/10.1080/09737766.2008.10700836

Glänzel, W. (2009). A tudománymetria hét mítosza - költészet és valóság. Magyar Tudomány, 170(8), 954-964.

Glänzel, W., Schubert, A., \& Czerwon, H. J. (1999). A bibliometric analysis of international scientific cooperation of the European Union (1985-1995). Scientometrics, 45(2), 185202. https://doi.org/10.1007/bf02458432

Gobert, J. D., Kim, Y. J., Sao Pedro, M. A., Kennedy, M., \& Betts, C. G. (2015). Using educational data mining to assess students' skills at designing and conducting experiments within a complex systems microworld. Thinking Skills and Creativity, 18, 81-90. https://doi.org/10.1016/j.tsc.2015.04.008

González-Pereira, B., Guerrero-Bote, V. P., \& Moya-Anegón, F. (2010). A new approach to the metric of journals' scientific prestige: The SJR indicator. Journal of Informetrics, 4(3), 379-391. https://doi.org/10.1016/j.joi.2010.03.002 
Griggs, R. A., \& Christopher, A. N. (2016). Who's Who in Introductory Psychology Textbooks A Citation Analysis Redux. Teaching of Psychology, 43(2), 108-119. https://doi.org/10.1177/0098628316636276

Guerrero-Bote, V. P., \& Moya-Anegón, F. (2012). A further step forward in measuring journals' scientific prestige: The SJR2 indicator. Journal of Informetrics, 6(4), 674-688. https://doi.org/10.1016/j.joi.2012.07.001

György, A. (1892). A kisdedóvásügy reformja. Magyar Pedagógia, 1, 3-10.

Gyulai, Á. (1934). A Magyar Paedagogia negyven évfolyamának (1892-1931) tartalom- és névmutatója. Magyar Pedagógia, 43, 176-177.

Hajjem, C., Harnad, S., \& Gingras, Y. (2006). Ten-year cross-disciplinary comparison of the growth of open access and how it increases research citation impact. ArXiv preprint, cs/0606079

Harnad, S., Brody, T., Vallieres, F., Carr, L., Hitchcock, S., Gingras, Y., \& Hilf, E. R. (2008). The access/impact problem and the green and gold roads to open access: An update. Serials Review, 34(1), 36-40. https://doi.org/10.1016/j.serrev.2007.12.005

Harzing, A. W., \& Alakangas, S. (2016). Google Scholar, Scopus and the Web of Science: a longitudinal and cross-disciplinary comparison. Scientometrics, 106(2), 787-804. https://doi.org/10.1007/s11192-015-1798-9

Heimerl, F., Lohmann, S., Lange, S., \& Ertl, T. (2014, January). Word cloud explorer: Text analytics based on word clouds. In 2014 47th Hawaii International Conference on System Sciences(pp. 1833-1842). IEEE. https://doi.org/10.1109/hicss.2014.231

Hellebrant, Á. (1906). A magyar paedagogiai irodalom 1905-ben. Magyar Pedagógia, 15, 402456.

Henriksen, D. (2016). The rise in co-authorship in the social sciences (1980-2013). Scientometrics, 107(2), 455-476. https://doi.org/10.1007/s11192-016-1849-x

Hetzner, E. (2008). A simple method for citation metadata extraction using hidden markov models. In Proceedings of the 8th ACM/IEEE-CS joint conference on Digital libraries (pp. 280-284). ACM. https://doi.org/10.1145/1378889.1378937

Hicks, D., Wouters, P., Waltman, L., De Rijcke, S., \& Rafols, I. (2015). The Leiden Manifesto for research metrics. Nature, 520(7548), 429. https://doi.org/10.1038/520429a 
Hódi, Á., \& Tóth, E. (2012). Az amerikai pedagógiai kutatás múltja és jelene. Iskolakultúra, 22(2), 83-94.

Holl, A. (2013a). Adatok, lehetőségek, feladatok. A kutatási adatok hozzáférhetőségéről. Magyar Tudomány, 174(10), 1208-1212.

Holl, A. (2013b). Információáradat és hullámlovaglás. Magyar Tudomány, 174(4), 473-478.

Holl, A. (2016). Tudományos kommunikáció a XXI. században - Open Science. Magyar Tudomány, 177(3), 307-316.

Holl, A. (2017). Elektronikus folyóiratok-helyzetkép. Könyvtári Figyelö, 63(1), 31-35.

Hood, W. W., \& Wilson, C. S. (2001). The Literature of Bibliometrics, Scientometrics, and Informetrics. Scientometrics, 52(2), 291-314. https://doi.org/10.1023/a:1017919924342

Hung, J. L. (2012). Trends of e-learning research from 2000 to 2008: Use of text mining and bibliometrics. British Journal of Educational Technology, 43(1), 5-16. https://doi.org/10.1111/j.1467-8535.2010.01144.x

Inzelt, A., Schubert, A., \& Schubert, M. (2008). Incremental citation impact due to international co-authorship in Hungarian higher education institutions. Scientometrics, 78(1), 37-43. https://doi.org/10.1007/s11192-007-1957-8

Inzelt, A., \& Csonka, L. (2018). A PhD-fokozatot szerzettek karrierje a társadalom-és humán tudományokban. Educatio, 27(1), 30-45. https://doi.org/10.1556/2063.27.2018.1.3

Ivanović, L., \& Ho, Y. S. (2017). Highly cited articles in the Education and Educational Research category in the Social Science Citation Index: a bibliometric analysis. Educational Review, 1-10. https://doi.org/10.1080/00131911.2017.1415297

Jones, R. E., Andrew, T., \& MacColl, J. (2006). The institutional repository. Oxford: Chandos Publishing. https://doi.org/10.1533/9781780630830

Józsa, K., \& Nikolov, M. (2005). Az angol és német nyelvi készségek fejlettségét befolyásoló tényezők. Magyar Pedagógia, 105(3), 307-337.

Kampis G., Soós S., \& Gulyás L. (2011). A magyar tudomány intézményi szerkezete és kompetenciái, 2001-2010: a Reuters-Thomson - ISI Web of Science adatbázis alapján. Magyar Tudomány, 172(8), 963-980.

Kéri, K. (2004). A középkori muszlim nevelési irodalom főbb témái. Magyar Pedagógia 104(4), 409-427. 
King, J. (1987). A review of bibliometric and other science indicators and their role in research evaluation. Journal of Information Science, 13(5), 261-276. https://doi.org/10.1177/016555158701300501

Kinney, Mark B. (2006). A no child left behind közoktatási törvény az USA-ban: Mit tanultunk négy év alatt? Magyar Pedagógia, 106(1), 29-42.

Kinyó, L. (2007). Csengery János szerepe Szeged város tudományos közéletében és a Ferenc József Tudományegyetem fejlődésében. Magyar Pedagógia, 107(1), 67-77.

Klamarik, J., \& Suppán, V. (1892). A Magyar Paedagogiai Társaság Alapszabálya. Magyar Paedagogia, 1, 124-128.

Kóczy, Á. L. (2015). A tudományos folyóiratok értékelése. Könyv és Nevelés, 17(3), 9-28.

Kokas, K. (2014). A periodika-digitalizálás és online szolgáltatás mai gondjai és a szegedi SZTE Klebelsberg Könyvtár gyakorlata. Iskolakultúra, 24(3), 84-94.

Koler-Povh, T., Južnič, P., \& Turk, G. (2014). Impact of open access on citation of scholarly publications in the field of civil engineering. Scientometrics, 98(2), 1033-1045. https://doi.org/10.1007/s11192-013-1101-x

Kollár, I. (2012). Az MTMT-adatbázisról és hatékony feltöltéséről. Hozzászólás Scheuring István cikkéhez. Magyar Tudomány, 173(11), 1583-1588.

Korom, E. (1997). Az EARLI szervezete és müködése. Iskolakultúra, 7(12), 93-96.

Kostoff, R. N. (1998). The use and misuse of citation analysis in research evaluation. Scientometrics, 43(1), 27-43. https://doi.org/10.1007/bf02458392

Kovačević, A., Ivanović, D., Milosavljević, B., Konjović, Z., \& Surla, D. (2011). Automatic extraction of metadata from scientific publications for CRIS systems. Program, 45(4), 376-396. https://doi.org/10.1108/00330331111182094

Krell, F.-T. (2009). The Poverty of Citation Databases: Data Mining Is Crucial for Fair Metrical Evaluation of Research Performance. BioScience, 59(1), 6-7. https://doi.org/10.1525/bio.2009.59.1.2

Krippendorff, K. (1995). A tartalomelemzés módszertanának alapjai. Budapest: Balassi.

Kuteeva, M., \& Airey, J. (2014). Disciplinary differences in the use of English in higher education: Reflections on recent language policy developments. Higher Education, 67(5), 533-549. https://doi.org/10.1007/s10734-013-9660-6 
Laakso, M., Lindman, J., Shen, C., Nyman, L., \& Björk, B. C. (2017). Research output availability on academic social networks: implications for stakeholders in academic publishing. Electronic Markets, 27(2), 125-133. https://doi.org/10.1007/s12525-0160242-1

Laakso, M., Welling, P., Bukvova, H., Nyman, L., Björk, B. C., \& Hedlund, T. (2011). The development of open access journal publishing from 1993 to 2009. PloS one, 6(6), e20961. https://doi.org/10.1371/journal.pone.0020961

Lane, J. (2010). Let's make science metrics more scientific. Nature, 464(7288), 488-489. https://doi.org/10.1038/464488a

Larsen, P. O., \& Von Ins, M. (2010). The rate of growth in scientific publication and the decline in coverage provided by Science Citation Index. Scientometrics, 84(3), 575-603. https://doi.org/10.1007/s11192-010-0202-z

Lee, A., \& Streinu, I. (2008). Pebble game algorithms and sparse graphs. Discrete Mathematics, 308(8), 1425-1437. https://doi.org/10.1016/j.disc.2007.07.104

Leifeld, P., Wankmüller, S., Berger, V. T., Ingold, K., \& Steiner, C. (2017). Collaboration patterns in the German political science co-authorship network. PloS one, 12(4), e0174671. https://doi.org/10.1371/journal.pone.0174671

Leydesdorff, L. (2008). Caveats for the use of citation indicators in research and journal evaluations. Journal of the American Society for Information Science and Technology, 59(2), 278-287. https://doi.org/10.1002/asi.20743

Leydesdorff, L., de Moya-Anegón, F., \& de Nooy, W. (2016). Aggregated journal-journal citation relations in scopus and web of science matched and compared in terms of networks, maps, and interactive overlays. Journal of the Association for Information Science and Technology, 67(9), 2194-2211. https://doi.org/10.1002/asi.23372

Lipson, C. (2018). Cite Right - MLA, APA, Chicago, the Sciences, Professions, and More, Third Edition. University of Chicago Press, https://doi.org/10.7208/chicago/9780226431246.001.0001

Liu, P., \& Xia, H. (2015). Structure and evolution of co-authorship network in an interdisciplinary research field. Scientometrics, 103(1), 101-134. https://doi.org/10.1007/s11192-014-1525-y 
Liu, X., Zhang, J., \& Guo, C. (2013). Full-text citation analysis: A new method to enhance scholarly networks. Journal of the American Society for Information Science and Technology, 64(9), 1852-1863. https://doi.org/10.1002/asi.22883

Luhn, H. P. (1958). A business intelligence system. IBM Journal of research and development, 2(4), 314-319. https://doi.org/10.1147/rd.24.0314

Lynch, C. A. (2003). Institutional repositories: essential infrastructure for scholarship in the digital age. Portal: Libraries and the Academy, 3(2), 327-336. https://doi.org/10.1353/pla.2003.0039

Lynch, C. A., \& Lippincott, J. K. (2005). Institutional repository deployment in the United States as of early 2005. D-lib Magazine, 11(9), 1-11. https://doi.org/10.1045/september2005-1ynch

Magyar Kormány. (2014). 1167/2014. (III. 25.) Korm. határozata a tudományos közlemények közzétételéről szóló nemzeti bibliográfiai adatbázis létrehozatalával kapcsolatos egyes feladatokról. Magyar Közlöny, 44(4501).

Magyar Paedagógiai Társaság. (1906). Magyar Paedagógiai Társaság: nagy-gyülés 1906 január 20-án. Magyar Pedagógia, 15, 113-136.

Magyar Pedagógia. (1993). A Magyar Pedagógia publikációs stílusa. Magyar Pedagógia, 93(1-2), 81-89.

Magyar, A., \& Molnár, G. (2013). Számítógép alapú adaptív és rögzített formátumú tesztelés összehasonlító hatékonyságvizsgálata. Magyar Pedagógia, 113(3), 181-193.

Mahood, Q., Van Eerd, D., \& Irvin, E. (2014). Searching for grey literature for systematic reviews: challenges and benefits. Research Synthesis Methods, 5(3), 221-234. https://doi.org/10.1002/jrsm.1106

Makara, B. G., \& Seres, J. (2013). A Magyar Tudományos Müvek Tára (MTMT) és az MTMT2. Tudományos és Müszaki Tájékoztatás, 60(4), 191-195.

Mauleón, E., Hillán, L., Moreno, L., Gómez, I., \& Bordons, M. (2013). Assessing gender balance among journal authors and editorial board members. Scientometrics, 95(1), 87114. https://doi.org/10.1007/s11192-012-0824-4

McCandless, D. (2010). Az információ gyönyörü : infografika. Budapest: Typotex. 
Meho, L. I. \& Yang, K. (2007). Impact of data sources on citation counts and rankings of LIS faculty: Web of Science versus Scopus and Google Scholar. Journal of the american society for information science and technology, 58(13), 2105-2125. https://doi.org/10.1002/asi.20677

Mershon, S., \& Schlossman, S. (2008). Education, science, and the politics of knowledge: The American Educational Research Association, 1915-1940. American Journal of Education, 114(3), 307-340. https://doi.org/10.1086/529506

Merton, R. K., \& Garfield, E. (1986). Foreword to little science, big science and beyond. In D. J. de S. Price (Eds.), Little Science, Big Science and Beyond (pp. vii-xiii). New York: Columbia University Press.

Mészáros, I. (1992). Magyar Paedagogia - Magyar Pedagógia. 1892-1992. Magyar Pedagógia, 92(1), 5-24.

Micsik, A., Pataki, B., Tóth, Z., Pallinger, P., Prunk-Éger, E., Mátételki, P., ... \& Hermann, Z. (2016). A Magyar Tudományos Müvek Tára 2.0 verziójának fejlesztése. In Mikusné Sárvári Klára (Ed.), Networkshop 2016, Debrecen, 2016.03.29-2016.04.01. NIIFI, Budapest. Retrieved from http://eprints.sztaki.hu/8868/1/NetworkshopMTMT2cikk(3).pdf

Moed, H. F. (2009). New developments in the use of citation analysis in research evaluation. Archivum immunologiae et therapiae experimentalis, 57(1), 13. https://doi.org/10.1007/s00005-009-0001-5

Moed, H. F. (2017). From Eugene Garfield's citation index to Scopus and Google Scholar. In Applied Evaluative Informetrics (pp. 193-208). Springer, Cham. https://doi.org/10.1007/978-3-319-60522-7_14

Moed, H. F., \& Halevi, G. (2016). On full text download and citation distributions in scientificscholarly journals. Journal of the Association for Information Science and Technology, 67(2), 412-431. https://doi.org/10.1002/asi.23405

Molnár, G. (2016). Interaktív problémamegoldó környezetben alkalmazott felfedező stratégiák hatékonysága és azok változása: logfájl-elemzések. Magyar Pedagógia, 116(4), 427-453. https://doi.org/10.17670/mped.2016.4.427 
Molnár, G., \& Pásztor A., (2012). The transition from single testing to complex systems of assessments. In Csapó, B. \& Tóth, E. (Eds.), X. Pedagógiai Értékelési Konferencia-PÉK 2012: Program - Előadás-összefoglalók [10th Conference on Educational Assessment. Program-Abstracts]. (pp. 53.) Szeged: SZTE BTK Neveléstudományi Doktori Iskola.

Molnár, P., (2012). Neveléstudományi társszerzői hálózatok topográfiája és vizualizációja. In: Benedek, A., Tóth, P., \& Vedovatti, A. (Eds.): A munka és nevelés világa a tudományban: XII. Országos neveléstudományi konferencia. (pp. 378.) Miskolc: Közoktatási Vezetők Képzéséért Oktatási és Nevelésfejlesztési Alapítvány. https://doi.org/10.13140/RG.2.2.13160.72961

Molnár, P., (2013). Educational research communities and networks in Hungary. In: Hollstein, B., Drobnič, S., \& Schnegg, M. (Eds.): SUNBELT XXXIII. International Network for Social Network Analysis Annual Conference. (pp. 11-12.) Hamburg: International Network for Social Network Analysis. https://doi.org/10.13140/RG.2.2.22019.40486

Molnár, P. (2018). Társszerzői együttmüködések hálózatai a bírálati rendszerü angol nyelvü neveléstudományi szakfolyóiratokban: európai helyzetkép. In Vidákovich T. \& Fűz N. (Eds.), PÉK 2018 [CEA 2018] XVI. Pedagógiai Értékelési Konferencia [16th Conference on Educational Assessment]: Program és összefoglalók [Programme and abstracts] (pp. 69.). Szeged: SZTE Neveléstudományi Doktori Iskola.

Molnár, P., Pintér, H., \& Tóth, E. (2018a). Co-authorship networks in Hungarian educational journals: 1991-2016: Data Stories 2018 Research Visualization Exhibition at CEU. Retrieved from http://j.mp/hunedunet_91_16_datastories18

Molnár, P., Pintér, H., \& Tóth, E. (2018b): A neveléstudomány társszerzői együttmüködéseinek hálózatai hazai és nemzetközi folyóiratokban. Magyar Pedagógia, 118(4). Manuscript submitted for publication.

Molnár, P., Tóth E., \& Pintér, H. (2018a). A közös alkotás társszerzői mintázatai és dinamikája a neveléstudományi tudás megosztásának és gondozásának hazai formális fórumain, a vezető szakfolyóiratokban 1991 és 2016 között. In Veszelszki Á. \& Cser N. (Eds.), Tudománykommunikáció konferencia: Absztraktkötet (pp. 22.) Budapest: Budapesti Corvinus Egyetem Magatartástudományi és Kommunikációelméleti Intézet. 
Molnár, P., Tóth, E., \& Pintér, H. (2018b). Töredezettség és összekapcsoltság a hazai neveléstudományi folyóiratok társszerzői együttmüködési hálózataiban. In Vidákovich T. \& Füz N. (Eds.), PÉK 2018 [CEA 2018] XVI. Pedagógiai Értékelési Konferencia [16th Conference on Educational Assessment]: Program és összefoglalók [Programme and abstracts] (pp. 70.) Szeged: SZTE Neveléstudományi Doktori Iskola.

Molnár, P., Tóth, E., \& Pintér, H. (2018c): A neveléstudomány társszerzői együttmüködéseinek hálózatai hazai és nemzetközi folyóiratokban. Jel-Kép, (4) 19-33. https://doi.org/10.20520/JEL-KEP.2018.4.19

Mongeon, P., \& Paul-Hus, A. (2016). The journal coverage of Web of Science and Scopus: a comparative analysis. Scientometrics, 106(1), 213-228. https://doi.org/10.1007/s11192015-1765-5

Mooghali, A., Alijani, R., Karami, N., \& Khasseh, A. A. (2012). Scientometric analysis of the scientometric literature. International Journal of Information Science and Management (IJISM), 9(1), 19-31.

Moravscik, M. J. (1987). Comments on Tibor Braun, recipient of the third Derek de Solla Price Award. Scientometrics, 11(5-6), 263-264. https://doi.org/10.1007/bf02279348

Móré, M. (2010). A tartalomelemzés, mint a szakdolgozatírásban alkalmazható kutatási módszer. In Kovácsné Bakosi, É. (Ed.), Társadalomtudományi tanulmányok III. (pp. 4764.). Debrecen: Debreceni Egyetemi Kiadó.

MTA KIK. (2017). Open Access Portál, Kiadóknak - ORCID. Retrieved from http://openaccess.mtak.hu/index.php/kiadoknak/orcid

MTA Pedagógiai Tudományos Bizottság. (2013). Magyar Tudományos Akadémia II. Filozófiai és Történettudományok Osztályának 18/2013. (II. 28.) sz. osztályhatározata. Retrieved from

http://mta.hu/data/dokumentumok/doktori_tanacs/II.\%20Osztaly/PEDTB_MTA\%20II\% 20osztaly_folyoiratok_1006\%20(2).xlsx

Murray-Rust, P., \& Rzepa, H. S. (2002). Scientific publications in XML-towards a global knowledge base. Data Science Journal, 1, 84-98. https://doi.org/10.2481/dsj.1.84

Nagy, A. M. (2016). Nemzetközi publikációs verseny a közgazdaságtudományban. Módszertani javaslatok a tudománymetria területéröl (Unpublished doctoral dissertation). Pannon Egyetem, Veszprém. https://doi.org/10.18136/PE.2016.603 
Nagy, G. (2014). Megy-e a digitalizálás által a világ elébb? Avagy mi végre digitalizálunk? Információs Társadalom, 14(3), 44-52.

Nagy, G. (2016a). Tudománymetria és neveléstudomány. Iskolakultúra, 26(2), 50-62. https://doi.org/10.17543/iskkult.2016.2.50

Nagy, G. (2016b). Tudománymetriai és tartalmi elemzések szövegbányászati módszerekkel. In Mikusné Sárvári, K. (Ed.), Networkshop 2016, Debrecen, 2016.03.29-2016.04.01. Budapest: NIIFI.

Nagy, G. (2017). A neveléstudomány kutatási tendenciái a Magyar Pedagógia negyed évszázadának tükrében. In Kerülő, J., Jenei, T., \& Gyarmati, I. (Eds.), XVII. Országos Neveléstudományi Konferencia: Program és absztrakt kötet (pp. 53). Nyíregyháza: MTA Pedagógiai Tudományos Bizottság, Nyíregyházi Egyetem.

Nagy, G., \& Molnár, G. (2017). A Magyar Pedagógia folyóirat tudománymetriai elemzése: tendenciák, szerzők, társszerzőségi együttmüködés. Magyar Pedagógia, 117(1), 5-27. https://doi.org/10.17670/mped.2017.1.5

Nagy, G., Molnár, S., \& Kokas, K. (2017). A könyvtárak jövőjéröl - Reflexiók egy előzetes kutatási jelentés kapcsán. Tudományos és Müszaki Tájékoztatás, 64(2), 64-82.

Nagy, P. T. (2011). Az oktatásról szóló tudomány kettős nyitottsága. Magyar Tudomány, 172(9), 1077-1089.

Nagy, S. (1981). Húsz év után, új feladatok előtt a Magyar Pedagógia. Magyar Pedagógia, 81(1), 3-12.

Nahalka, I. (2016). Az esélyegyenlőség és komprehenzivitás lehetősége és ellehetetlenülése. Új Pedagógiai Szemle, 66(7-8), 34-39.

Neal, D. R. (Eds.). (2012). Social Media for Academics: A practical guide. Oxford: Chandos Publishing.

Nederhof, A. J. (2006). Bibliometric monitoring of research performance in the social sciences and the humanities: A review. Scientometrics, 66(1), 81-100. https://doi.org/10.1007/s11192-006-0007-2

Németh, A. (2013). A neveléstudomány főbb fejlődésmodelljei és tudományos irányzatai. Neveléstudomány, 1(1), 18-63. 
Németh, A. (2014). A magyar neveléstudomány fejlődése. Nemzetközi tudományfejlödés és recepciós hatások, egyetemi tudománnyá válás, középiskolai tanárképzés. Budapest: Gondolat.

Németh, A. (2015). A neveléstudomány nemzetközi modelljei és tudományos irányzatai. Magyar Pedagógia, 115(3),

255-294. https://doi.org/10.17670/mped.2015.3.255

Németh, A., \& Biró, Zs. H. (Eds.). (2009). A magyar neveléstudomány a 20. század második felében. Budapest: Gondolat.

Németh, A., Biró, Zs. H., \& Garai, I. (Eds.). (2015). Neveléstudomány és tudományos elit a 20. század második felében. Budapest: Gondolat.

Németh, A., Biró, Zs. H., \& Varga, K. (2009). Kísérlet egy nemzetközi kutatás adaptációjára. In Németh, A. \& Biró, Zs. H. (Eds.), A magyar neveléstudomány a 20. század második felében (pp. 147-167). Budapest: Gondolat.

Newman, M. E., \& Girvan, M. (2004). Finding and evaluating community structure in networks. Physical review E, 69(2), 026113. https://doi.org/10.1103/physreve.69.026113

Ojokoh, B., Zhang, M., \& Tang, J. (2011). A trigram hidden Markov model for metadata extraction from heterogeneous references. Information Sciences, 181(9), 1538-1551. https://doi.org/10.1016/j.ins.2011.01.014

Oktatási Hivatal. (2017). Felsőoktatási statisztikák. Retrieved from https://www.oktatas.hu/felsooktatas/kozerdeku_adatok/felsooktatasi_adatok_kozzetetele /felsooktatasi_statisztikak

Olensky, M., Schmidt, M., \& van Eck, N. J. (2016). Evaluation of the citation matching algorithms of CWTS and iFQ in comparison to Web of Science. Journal of the Association for Information Science and Technology,67(10), 2550-2564. https://doi.org/10.1002/asi.23590

Omodei, E., De Domenico, M., \& Arenas, A. (2017). Evaluating the impact of interdisciplinary research: A multilayer network approach. Network Science, 5(2), 235-246. https://doi.org/10.1017/nws.2016.15

Open Access. (2013). A nyílt hozzáférésröl - Stratégiák. Retrieved from http://www.openaccess.hu/strategiak 
Ovadia, S. (2014). ResearchGate and Academia. edu: Academic social networks. Behavioral \& $\begin{array}{llll}\text { Social Sciences } & \text { Librarian, }\end{array}$ https://doi.org/10.1080/01639269.2014.934093

Pap, K. T. (2009). Folyóirat-hivatkozások a neveléstudományi folyóiratokban. In Németh A., \& Biró Zs. H. (Eds.), A magyar neveléstudomány a 20. század második felében (pp. 210226). Budapest: Gondolat.

Paskin, N. (2010). Digital object identifier (DOI®) system. Encyclopedia of library and information sciences, 3, 1586-1592. https://doi.org/10.1081/e-elis3-120044418

Pásztor, A. (2014). Lehetőségek és kihívások a digitális játék alapú tanulásban: egy induktív gondolkodást fejlesztő program hatásvizsgálata. Magyar Pedagógia, 114(4), 281-302.

Pearce, N., Weller, M., Scanlon, E., \& Kinsley, S. (2012). Digital scholarship considered: How new technologies could transform academic work. In Education, 16(1), 33-44.

Peng, F., \& McCallum, A. (2006). Information extraction from research papers using conditional random fields. Information Processing \& Management, 42(4), 963-979. https://doi.org/10.1016/j.ipm.2005.09.002

Piwowar, H. (2013). Altmetrics: Value all research products. Nature, 493(7431), 159. https://doi.org/10.1038/493159a

Polónyi István (2008): Oktatás, oktatáspolitika, oktatásgazdaság. Budapest: Nemzeti Tankönyvkiadó.

Polónyi, I. (2016). A neveléstudomány helyzetéröl. Iskolakultúra, 26(4), 3-20. https://doi.org/10.17543/iskkult.2016.4.3

Popp, J., Balogh, P., Kovács, S., \& Jámbor, A. (2015). Hálózatosodás az agrárgazdaságtanban. Szerzői és hivatkozási kapcsolatok a Kelet-Közép-Európáról szóló szakirodalomban. Közgazdasági Szemle, 62(5), 525-543.

Price, D. de S. (1979). Kis tudomány, nagy tudomány. Budapest: Akadémiai Kiadó.

Priem, J., Piwowar, H. A. és Hemminger, B. M. (2012). Altmetrics in the wild: Using social media to explore scholarly impact. ArXiv preprint, arXiv: 1203.4745

Ramesh, P. \& Ramesha, B. (2013). Global Scenario of Open Access Publishing: A Decadal Analysis of Directory of Open Access Journals (DOAJ) 2003-2012. Journal of Information Science Theory and Practice, 1(3), 47-59. https://doi.org/10.1633/jistap.2013.1.3.4 
Rehrl, M., Palonen, T., Lehtinen, E., \& Gruber, H. (2014). Experts in science: Visibility in research communities. Talent Development and Excellence, 6(1), 31-45.

Romero, C., \& Ventura, S. (2007). Educational data mining: A survey from 1995 to 2005. Expert Systems with Applications, 33(1), 135-146. https://doi.org/10.1016/j.eswa.2006.04.005

Romero, C., Ventura, S., Pechenizkiy, M., \& Baker, R. S. (Eds.). (2010). Handbook of educational data mining. Boca Raton: CRC Press.

Russell, S. J., \& Norvig, P. (2005). Mesterséges intelligencia modern megközelítésben. Budapest: Panem.

San Francisco Declaration (2013). Putting Science into the Assessment of Research. Microbe Magazine, 8(12), 478-479. https://doi.org/10.1128/microbe.8.478.1

Sarawagi, S. (2007). Information extraction. Foundations and Trends ${ }^{\circledR}$ in Databases, 1(3), 261-377. https://doi.org/10.1561/1900000003

Scheuring, I. (2012). Kinek van szüksége az MTMT-adatbázisra? Magyar Tudomány, 173(8), 991-992.

Schriewer, J., \& Keiner, E. (1993). Kommunikationsnetze und Theoriegestalt: Zur Binnenkonstitution der Erziehungswissenschaft in Frankreich und Deutschland. In Schriewer, J., Keiner, E., \& Charle, Ch. (Eds.), Sozialer Raum und akademische Kulturen I A la recherche de l'espace universitaire européen (pp. 277-341). Frankfurt am Main: Peter Lang.

Schubert, A. (2015a). A hálózatok tudománymetriája és a tudománymetria hálózatai. Könyvés Nevelés, 17(2), 22-43.

Schubert, A. (2015b). Az impaktfaktor és akiknek nem kell. Orvosi Hetilap, 156(26), 10651069. https://doi.org/10.1556/650.2015.30212

Schubert, A. (2018). Új utak és útvesztők a tudományos publikálásban és a tudománymetriában. Könyv és Nevelés, 20(1), 7-29.

Schütze, H., Manning, C. D., \& Raghavan, P. (2008). Introduction to information retrieval (Vol. 39). Cambridge University Press.

Sennyey, P., \& Kokas, K. (2011). Könyvtárak a hálózatban: Hogyan változtatta/változtatja meg a könyvtárak jelenét és jövőjét a számítógépes világhálózatba kerülés? Tudományos és Müszaki Tájékoztatás, 58(10), 419-429. 
Sivertsen, G. (2014). Scholarly publication patterns in the social sciences and humanities and their coverage in Scopus and Web of Science. Proceedings of the science and technology indicators conference (pp. 598-604).

Somogyvári, L. (2014). Internationalism and the Third World (Photographs in the Hungarian Educational Press in the 1960's). Hungarian Educational Research Journal, 4(4), 63-71. https://doi.org/10.14413/herj.2014.04.08.

Soós, S., Schubert, A., \& Pléh, Cs. (2009). Tendencies in the Core Journal of Hungarian Psychology (An Exploratory Study). 28th Annual Conference of the European Society of the History of Human Sciences (ESHHS). Budapest, 2009 July 21-25.

Sternitzke, C., \& Bergmann, I. (2009). Similarity measures for document mapping: A comparative study on the level of an individual scientist. Scientometrics, 78(1), 113-130. https://doi.org/10.1007/s11192-007-1961-z

Szabadi, M. (2014). A szociális kompetencia elemeinek, fejlődésének és fejlesztésének feltérképezése zeneterápiás keretben. Magyar Pedagógia, 114(3), 149-188.

Szabó, Zs. G., \& Korom E. (2017). A feladatmegoldási idő változása kombinatív képességre irányuló fejlesztőkísérlet elő- és utótesztje során 3. évfolyamosok körében. In Zsolnai, A. \& Kasik, L. (Eds.), Új kutatások a neveléstudományokban 2016: A tanulás és nevelés interdiszciplináris megközelítése (pp. 209-223). Szeged: SZTE BTK Neveléstudományi Intézet; MTA Pedagógiai Bizottság.

Szabolcs, É. (1999). Tartalomelemzés a gyermekkortörténet kutatásában: gyermekkép Magyarországon, 1868-1890. Budapest: Nemzeti Tankönyvkiadó.

Szabolcs, É. (2004). Tartalomelemzés. In Falus, I. (Ed.), Bevezetés a pedagógiai kutatás módszereibe (pp. 330-339). Budapest: Müszaki Könyvkiadó.

Szécsi, G. (2016). Tudományos kommunikáció az információ korában. Magyar Tudomány, 177(3), 317-325.

Szücs K., \& Kiss A. (2015). Adatbányászati módszerek alkalmazása oktatási környezetben keletkezett adatokon. In Szlávi, P. \& Zsakó, L. (Eds.), INFODIDACT 2015 - Zamárdi, Magyarország, 2015. október 26. Budapest: Webdidaktika.

Taga, M. (2014). Az MTMT szerepe a hazai tudományos életben - hitelesség és visszakereshetőség. Orvosi Könyvtárak, 11(3), 11. 
Tang, K. Y., \& Tsai, C. C. (2016). The intellectual structure of research on educational technology in science education (ETiSE): A co-citation network analysis of publications in selected journals (2008-2013). Journal of Science Education and Technology, 25(2), 327-344. https://doi.org/10.1007/s10956-015-9596-y

Tar, I. (2007). A klasszika filológus Csengery János. Magyar Pedagógia, 107(1), 49-55.

Thomas, W. J., Chen, B., \& Clement, G. (2015). ORCID identifiers: Planned and potential uses by associations, publishers, and librarians. The Serials Librarian, 68(1-4), 332-341. https://doi.org/10.1080/0361526x.2015.1017713

Thomson Reuters. (2013). 2013 Journal Citation Reports. Retrieved from http://wokinfo.com/products_tools/analytical/jcr/

Thuraisingham, B. (2014). Data mining: technologies, techniques, tools, and trends. Boca Raton, FL: CRC Press. https://doi.org/10.1201/b16553

Tichy-Rács, Á. (2012). Kinek van szüksége az MTMT-adatbázisra? Hozzászólás Scheuring István cikkéhez. Magyar Tudomány, 173(11), 1379-1382.

Tight, M. (2014). Working in separate silos? What citation patterns reveal about higher education research internationally. Higher Education, 68(3), 379-395. https://doi.org/10.1007/s10734-014-9718-0

Tijssen, R. J., Visser, M. S., \& Van Leeuwen, T. N. (2002). Benchmarking international scientific excellence: Are highly cited research papers an appropriate frame of reference?. Scientometrics, 54(3), 381-397. https://doi.org/10.1023/a:1016082432660

Tikk, D. (Eds.). (2007). Szövegbányászat. Budapest: Typotex.

Tkaczyk, D., Bolikowski, L., Czeczko, A., \& Rusek, K. (2012). A modular metadata extraction system for born-digital articles. In Document Analysis Systems (DAS), 2012 10th IAPR International Workshop on IEEE (pp. 11-16) https://doi.org/10.1109/das.2012.4

Tkaczyk, D., Szostek, P., Fedoryszak, M., Dendek, P. J., \& Bolikowski, Ł. (2015). CERMINE: automatic extraction of structured metadata from scientific literature. International Journal on Document Analysis and Recognition (IJDAR), 18(4), 317-335. https://doi.org/10.1007/s10032-015-0249-8 
Tóth, I. J., Toman, N., \& Cserpes, T. (2008). A magyar neveléstudomány tudományos aktivitásának felmérése empirikus eszközökkel - Kutatási zárótanulmány. Budapest: Wargo Közgazdasági Elemzö- és Piackutató Intézet.

Tóth, J. (2014). Szimulakratív szignifikáció és szimulakratív színterek-egy deviáns publikációs gyakorlat vizsgálata. Információs Társadalom, 2014(2), 24-44.

Tóth, J. (2016). Az open access publikálás előnyei és hátrányai bölcsészettudományos területen. Médiakutató: médiaelméleti folyóirat, 16(1), 97-112.

Tüskés, G. (2013). A minőség meghatározásának problémájához a bölcsészettudományi alapkutatásokban. Magyar Tudomány, 174(5), 563-574.

Ueno, M. (2004). Data mining and text mining technologies for collaborative learning in an ILMS. In Advanced Learning Technologies, Proceedings. IEEE International Conference (pp. 1052-1053). https://doi.org/10.1109/icalt.2004.1357749

Van Noorden, R. (2015). Interdisciplinary research by the numbers. Nature, 525(7569), 306307. https://doi.org/10.1038/525306a

Van Raan, A. F. (2001). Competition amongst scientists for publication status: Toward a model of scientific publication and citation distributions. Scientometrics, 51(1), 347-357. https://doi.org/10.1023/a:1010501820393

Veroszta, Zs. (2013). Kerekasztal-beszélgetés a digitalizációról, az emlékmentésről és az ezzel együtt járó szelekcióról. Interjúpartnereink: Biszak Sándor, Gárdos Judit, Ládi László, Mikó Zsuzsanna, Nagy Péter Tibor. Educatio, 22(3), 405-412.

Vincze, V. (2013). Domének közti hasonlóságok és különbségek a szófajok és szintaktikai viszonyok eloszlásában. In Tanács, A. \& Vincze, V. (Eds.), IX. Magyar Számítógépes Nyelvészeti Konferencia (pp. 182-192). Szeged: Szegedi Tudományegyetem.

Wang, Y., Bowers, A. J., \& Fikis, D. J. (2017). Automated Text Data Mining Analysis of Five Decades of Educational Leadership Research Literature: Probabilistic Topic Modeling of EAQ Articles From 1965 to 2014. Educational Administration Quarterly, 53(2), 289323. https://doi.org/10.1177/0013161x16660585

Ware, M., \& Mabe, M. (2015). The STM report: An overview of scientific and scholarly journal publishing. 4th edition, International Association of Scientific, Technical and Medical Publishers. $\quad$ Retrieved from https://www.stmassoc.org/2015_02_20_STM_Report_2015.pdf 
Weller, M., Jordan, K., DeVries, I., \& Rolfe, V. (2018). Mapping the open education landscape: citation network analysis of historical open and distance education research. Open Praxis, 10(2), 109-126. https://doi.org/10.5944/openpraxis.10.2.822

West, J. D., Jacquet, J., King, M. M., Correll, S. J., \& Bergstrom, C. T. (2013). The role of gender in scholarly authorship. PloS one, 8(7), e66212. https://doi.org/10.1371/journal.pone.0066212

Willinsky, J. (2009). The access principle: The case for open access to research and scholarship. Cambridge, Mass, London: MIT Press.

Winne, P. H., \& Baker, R. S. (2013). The potentials of educational data mining for researching metacognition, motivation and self-regulated learning. Journal of Educational Data Mining, 5(1), 1-8.

Winters, T. M., Wise, L. L., \& Towne, L. (Eds.). (2005). Advancing scientific research in education. Washington, D.C.: National Academies Press.

Wong, S. L., \& Hodson, D. (2010). More from the horse's mouth: What scientists say about science as a social practice. International Journal of Science Education, 32(11), 14311463. https://doi.org/10.1080/09500690903104465

Wu, L. L., Luesukprasert, L., \& Lee, L. (2009). Research and the long tail: A large-scale citation analysis. In 2009. HICSS'09. 42nd Hawaii International Conference on System Sciences, IEEE. 1-10. https://doi.org/10.1109/hicss.2009.368

Wuchty, S., Jones, B. F., \& Uzzi, B. (2007). The increasing dominance of teams in production of knowledge. Science, 316(5827) 1036-1039. https://doi.org/10.1126/science.1136099

Xia, J., Harmon, J. L., Connolly, K. G., Donnelly, R. M., Anderson, M. R., \& Howard, H. A. (2015). Who publishes in "predatory" journals?. Journal of the Association for Information Science and Technology, 66(7), 1406-1417. https://doi.org/10.1002/asi.23265

Yan, E., \& Ding, Y. (2011). Discovering author impact: A PageRank perspective. Information Processing \& Management, 47(1), 125-134. https://doi.org/10.1016/j.ipm.2010.05.002

Yau, N. (2011). Visualize this: the FlowingData guide to design, visualization, and statistics. John Wiley \& Sons. https://doi.org/10.1002/9781118722213 
Youtie, J., Solomon, G. E., Carley, S., Kwon, S., \& Porter, A. L. (2017). Crossing borders: A citation analysis of connections between Cognitive Science and Educational Research and the fields in between. Research Evaluation, 26(3), 242-255. https://doi.org/10.1093/reseval/rvx020

Zsibrita, J., Vincze, V., \& Farkas, R. (2013). Magyarlanc: A toolkit for morphological and dependency parsing of Hungarian. In International Conference on Recent Advances in Natural Language Processing, RANLP 2013 - Proceedings (pp. 763-771). Red Hook, NY: Curran. 


\section{KöSZÖNETNYILVÁNÍTÁS}

Mindenekelőtt témavezetőmnek, Molnár Gyöngyvérnek szeretném megköszönni a kutatás elvégzéséhez, és a disszertáció megszületéséhez nyújtott szellemi, anyagi* és morális támogatást. Folyamatos iránymutatása és bátorítása nélkül a Magyar Pedagógia folyóirat elemzése ilyen formában semmiképpen sem jöhetett volna létre. Köszönet illeti továbbá Csapó Benő nyitottságát, aki a Neveléstudományi Doktori Iskola vezetőjeként és a vizsgált folyóirat föszerkesztójeként fantáziát látott és befogadott a Doktori Iskolába egy olyan projektet, amely szemléletmódjában merőben eltért a szokványos pedagógiai kutatásoktól. A főszerkesztő mellett köszönetet érdemel a Magyar Pedagógia teljes szerkesztősége, akiktől megkaptam a szükséges kiadói anyagokat és az ezek felhasználásához szükséges engedélyt.

Hatalmas köszönet illeti az informatikai háttér megteremtéséért és a szövegbányászati vizsgálatok elvégzéséért Berend Gábort, aki nélkül a folyóirat tudománymetriai és tartalmi elemzése sehogyan sem készülhetett volna el. Gábor, a Szegedi Tudományegyetem Számítógépes Algoritmusok és Mesterséges Intelligencia Tanszékének munkatársaként végtelen türelmével és odaadásával segítette a több éven át zajló kutatómunkát, akihez bármikor fordulhattam bármilyen kérdéssel.

Doktori tanulmányaim alatt folyamatos támogatást kaptam munkahelyemtől, a Szegedi Tudományegyetem Klebelsberg Kuno Könyvtárától. A könyvtár vezetése, Keveházi Katalin és Kokas Károly személyében végig támogatta ezt a tudománymetriai irányultságú szakmai projektet. Köszönet Sándor Ákosnak, az Automatizálás Fejlesztési Osztály vezetőjének, aki rugalmas hozzáállásával és technikai tanácsaival segített.

A PhD tanulmányok végzéséhez szükséges pozitív hozzáállás mellett nem feledkezhetem meg a könyvtár által nyújtott technikai támogatásról sem. A könyvtár állományában található Magyar Pedagógia példányok alapján, a könyvtár lapbehúzós szkennerén készülhetett el a folyóirat digitalizálása, amely azután természetesen a könyvtár által üzemeltetett repozitóriumban lett feldolgozva. Az előző mondatban kibomló munkafolyamatot természetesen jó néhány könyvtáros kolléga segítette: a digitalizálás körüli munkákban Molnár Sándor volt segítségemre, az adatbázisba szervezést Zawiasa Róbert végezte, míg a metaadatok elkészülésében a könyvtár feldolgozó könyvtárosai nyújtottak pótolhatatlan munkát. Külön köszönöm Laskay Krisztina kolléganőm végtelenül precíz és odaadó lektoráló munkáját.

Végül, de nem utolsósorban hálás vagyok családom és barátaim folyamatos biztatásáért, amely sokat segítettek a nehezebb időszakokban. Édesapám, Nagy Gyula és feleségem, Nagyné Tari Emese végig maximálisan támogattak abban, hogy sikerüljön végigmenni azon a kihívásokkal teli úton, amelyet a doktori képzés jelentett.

\footnotetext{
* A kutatási projektet az OTKA K115497 kutatás támogatta.
} 


\section{RÖVIDÍTÉSEK JEGYZÉKE}

BASE: Bielefeld Academic Search Engine, egy nemzetközi repozitórium-aggregátor szolgáltatás, ami lehetővé teszi a metaadatok közös lekérdezhetőségét.

CRIS: Current research information system, kutatás-nyilvántartási rendszerek összefoglaló elnevezése.

CSV: Comma-separated values, azaz vesszővel tagolt értékek. Egyfajta strukturált szövegfájl, ahol az egyes mezők egyezményes határolókarakterekkel különülnek el.

DOAJ: Directory of Open Access Journals, Open Access folyóiratok nyilvántartó adatbázisa.

DOI: Digital Object Identifier, magyarul digitálisobjektum-azonosító.

EDM: Educational Data Mining, magyarul oktatási adatbányászat.

EDU: Az Educatio folyóirat rövidítése

ERIH Plus: European Reference Index for the Humanities

FOS: Field of Science and Technology az OECD Frascati Manual szerint.

IKT: Angolul ICT, az információs és kommunikációs technológiák gyüjtőfogalom rövidítése.

IQ: $\quad$ Az Iskolakultúra folyóirat rövdítése.

JCR: Journal Citation Reports, a Clarivate folyóiratokat listázó adatbázisa, többek között az impakt faktor forrása.

LDA: Latent Dirichlet allocation, magyarul rejtett Dirichlet allokáció, amely egy generatív valószínűségi modellt valósít meg.

LMS: Learning management system, magyarul tanulásmenedzsment rendszer, például Ilias, Moodle.

LVS: Live video streaming, magyarul élő videóközvetítés.

MARC: MAchine Readable Cataloging, magyarul: géppel olvasható katalogizálás. A bibliográfiai rekordok manuális rögzítésének bevett szabványa a világban.

MP: A Magyar Pedagógia folyóirat rövidítése.

MTMT: Magyar Tudományos Mủvek Tára, Magyarország tudományos kutatói nemzeti bibliográfiai adatbázisa. 
OAI-PMH: Open Archives Initiative Protocol for Metadata Harvesting, a gépileg megvalósított, automatizált adatcserét és lekérdezéseket támogató protokoll.

OCR: Optical character recognition, magyarul optikai karakterfelismerés. Képi tartalmú anyagok átalakítása szöveges formára, a későbbi rugalmasabb használhatóság (kereshetőség, másolhatóság, manipulálhatóság) érdekében.

OECD: Organisation for Economic Co-operation and Development, magyarul Gazdasági Együttmüködési és Fejlesztési Szervezet.

OJS: Open Journal System, elektronikus folyóirat-kiadást és a szerkesztőségi munkafolyamatokat támogató keretrendszer.

SJR: Scientific Journal Rankings, az Elsevier folyóiratokat listázó adatbázisa, többek között a SCImago Journal Rank forrása.

URL: Uniform Resource Locator, magyar fordítása egységes erőforrás-hely; tulajdonképpen internetes oldalak webcímeit értjük alatta.

UPSZ: Az Új Pedagógiai Szemle rövidítése.

WoS: Web of Science, a Clarivate hivatkozás indexelő adatbázisa.

XML: Extensible Markup Language, kiterjeszthető jelölő nyelv. Egyfajta strukturált adatcsereformátum. 


\section{TÁBLÁZATOK JEGYZÉKE}

1. táblázat. A JCR 'Education and Educational Research' kategória impakt faktoros folyóiratai [Forrás: http://jcr.incites.thomsonreuters.com]

2. táblázat. A SCImago Journal Rank Education kategória folyóiratai [Forrás:

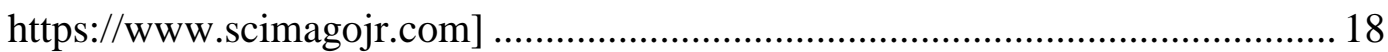

3. táblázat. A vezető neveléstudományi folyóiratok számszaki adatai .................................. 71

4. táblázat. A Magyar Pedagógia 16 legtermékenyebb szerzője 1991-2014.......................... 76

5. táblázat. A Magyar Pedagógia szerzői a társszerzőségi gráf PageRank értékei alapján...... 84

6. táblázat. A Magyar Pedagógia 30 leghivatkozottabb szakirodalmi forrása 1991-2014 között

7. táblázat. A Magyar Pedagógia 44 leghivatkozottabb kutatója név szerint 1991-2014 között 101

8. táblázat. A 25 leggyakoribb szó abszolút gyakorisága a mintában 1892-2014 121

9. táblázat. A 25 leggyakoribb szó relatív gyakorisága a mintában 1892-2014

10. táblázat. A 25 leggyakoribb szó abszolút gyakorisága a szükített mintában 1991-2014. 123

11. táblázat. A 25 leggyakoribb szó relatív gyakorisága a szükített mintában 1991-2014 .... 124

12. táblázat. A vizsgált időszak (1892-2014) elején kevésbé használt, majd felfutó szavak előfordulása az abszolút gyakoriságok alapján

13. táblázat. A vizsgált időszak (1892-2014) elején kevésbé használt, majd felfutó szavak előfordulása a relatív gyakoriságok alapján

14. táblázat. A vizsgált időszak (1892-2014) elején aktívabban használt, majd lecsengő szavak előfordulása az abszolút gyakoriságok alapján

15. táblázat. A vizsgált időszak (1892-2014) elején aktívabban használt, majd lecsengő szavak előfordulása a relatív gyakoriságok alapján 130

16. táblázat. A vizsgált időszakban (1892-2014) tapasztalható speciális esetek előfordulása az abszolút gyakoriságok alapján 


\section{ÁBRÁK JEGYZÉKE}

1. ábra. A folyóiratcikkekre való hivatkozások átlagos arányának alakulása 1995-2007 között (N=449) (Forrás: Tóth, Toman, \& Cserpes, 2008, p. 42) .

2. ábra. A folyóirat-hivatkozások tudományterületenkénti megoszlása a négy magyar pedagógiai folyóiratban (magyar folyóirat-hivatkozások száma összesen: EDU - 905; IQ - 2038; MP - 1020; UPSZ - 688) (Forrás: Pap, 2009, p. 216)

3. ábra. A szövegbányászat általános modellje (Forrás: Tikk, 2007, p. 22)............................ 39

4. ábra. Az e-learning terület kutatásának taxonómiája (Forrás: Hung, 2012, p. 9)

5. ábra. A Magyar Pedagógia emblémái: Pallasz Athéné portréja (1892-1922, 1939-1947, 1991-) és a stilizált bagoly egy könyvespolc elött (1923-1938) .....

6. ábra. Az Iskolakultúra, Educatio és az Új Pedagógiai Szemle folyóiratokban megjelent publikációk számának időbeli változása 1991-2014 [Forrás: Matarka]

7. ábra. A Magyar Pedagógiában megjelent publikációk számának időbeli változása 1991-2014

8. ábra. A Magyar Pedagógiában megjelent publikációk számának időbeli változása 1892-2014

9. ábra. A magyar szerzők nemzetközi publikációs aktivitása a SciVal adatbázis

'Education' kategóriája alapján 2013-2017 között

10. ábra. A Magyar Pedagógia publikációk átlagos hosszának évenkénti változása 1991-2014 .75

11. ábra. A Magyar Pedagógia szerzőinek nemzetiségi megoszlása 1991-2014 .................... 78

12. ábra. A Magyar Pedagógia szerzőinek intézményi háttere 1991-2014 ............................. 79

13. ábra. A Magyar Pedagógia szerzőinek szektorok szerinti megoszlása 1991-2014 ............ 79

14. ábra. A női és férfi szerzők aránya a Magyar Pedagógia szerzői között (1892-2014) ....... 81

15. ábra. A női és férfi szerzők aránya a Magyar Pedagógia szerzői között (1991-2014)....... 81

16. ábra. A Magyar Pedagógia című folyóirat tanulmányaira eső szerzők számának évenkénti változása 1991-2014. 82

17. ábra. A Magyar Pedagógia társszerzőségi gráfjának egyik komponense ......................... 85

18. ábra. A Magyar Pedagógia társszerzőségi gráfjának egyik komponense …....................... 85

19. ábra. A Magyar Pedagógia társszerzőségi gráfjának három kisebb komponense....... .86

20. ábra. A Magyar Pedagógia tanulmányok átlagos hivatkozási számának évenkénti változása (1991-2014) 88

21. ábra. A Magyar Pedagógia tanulmányok hivatkozásainak átlagolt frissessége (1991-2014) 
22. ábra. A folyóiratcikkekre történő hivatkozások arányának változása az összes hivatkozás tükrében

23. ábra. A magyar és nemzetközi folyóiratcikkekre történő hivatkozások időbeli változása

24. ábra. Impakt faktoros folyóiratokra való hivatkozások az évente megjelenő publikációszám tükrében.

25. ábra. Az interdiszciplinaritás a hivatkozások tükrében és a Magyar Pedagógia cikkekre érkező hivatkozások aránya.

26. ábra. A hivatkozások darabszámának ( $\mathrm{N}=14039)$ eloszlása a hivatkozott források szerint és a leghivatkozottabb források szükített mintája

27. ábra. Hivatkozástípusok megoszlása a több mint három hivatkozással rendelkező források esetében

28. ábra. A leghivatkozottabb Magyar Pedagógia szerzők reprezentációja a Scopus adatbázisban

29. ábra. Egy többszerzős cikk idézéseinek elvi megjelenítése a hivatkozási gráfban 104

30. ábra. A belső hivatkozási hálózat egy kiragadott, centrális része 106

31. ábra. A belső hivatkozási hálózat szerzőinek intézményi háttere 108

32. ábra. A teljes hivatkozási hálózat vizuális megjelenítése.

33. ábra. Az eugenika kifejezés évenkénti előfordulása 1892-2014 között sávdiagramon.... 115

34. ábra. Az egyes szavak évenkénti előfordulását mutató tematikus hőtérképes megjelenítés.

35. ábra. Egyes szakkifejezések évtizedenként aggregált előfordulását mutató tematikus hőtérkép.

36. ábra. Egy véletlenszerüen kiválasztott cikk (Pásztor, 2014) korai szófelhős megjelenítése

37. ábra. Az ,iskola” szó abszolút és relatív gyakoriságának színképe a cikkek számának eloszlásához képest (1892-2014) [1 - cikkek száma; 2 - abszolút gyak.; 3 - relatív gyak.]

38. ábra. A „tanuló” szó abszolút és relatív gyakoriságának színképe a cikkek számának eloszlásához képest (1892-2014) [1 - cikkek száma; 2 - abszolút gyak.; 3 - relatív gyak.]*....

39. ábra. A „nevelés” szó abszolút és relatív gyakoriságának színképe a cikkek számának eloszlásához képest (1892-2014) [1 - cikkek száma; 2 - abszolút gyak.; 3 - relatív gyak.]

40. ábra. A „gyermek” és a „gyerek” szó abszolút és relatív gyakoriságának színképe a cikkek számának eloszlásához képest (1892-2014) [1 - cikkek száma; 2 - abszolút gyak.; 3 - relatív gyak.] ${ }^{*}$ 
41. ábra. A minta legelső cikkének (György, 1892) ötven leggyakoribb szava

42. ábra. Egy véletlenszerüen kiválasztott cikk (Magyar \& Molnár, 2013) huszonöt leggyakoribb szava

43. ábra. Az 1892-1899 közötti évek száz leggyakoribb szava a Magyar Pedagógia cikkeiből képzett mintában

44. ábra. Az 1900-1909 közötti évek száz leggyakoribb szava a Magyar Pedagógia cikkeiből képzett mintában

45. ábra. Az 1910-1919 közötti évek száz leggyakoribb szava a Magyar Pedagógia cikkeiből képzett mintában

46. ábra. Az 1920-1929 közötti évek száz leggyakoribb szava a Magyar Pedagógia cikkeiből képzett mintában 136

47. ábra. Az 1930-1939 közötti évek száz leggyakoribb szava a Magyar Pedagógia cikkeiből képzett mintában

48. ábra. Az 1940-1950 közötti évek száz leggyakoribb szava a Magyar Pedagógia cikkeiből képzett mintában

49. ábra. Az 1961-1969 közötti évek száz leggyakoribb szava a Magyar Pedagógia cikkeiből képzett mintában

50. ábra. Az 1970-1979 közötti évek száz leggyakoribb szava a Magyar Pedagógia cikkeiből képzett mintában

51. ábra. Az 1980-1989 közötti évek száz leggyakoribb szava a Magyar Pedagógia cikkeiből képzett mintában

52. ábra. Az 1990-1999 közötti évek száz leggyakoribb szava a Magyar Pedagógia cikkeiből képzett mintában

53. ábra. A 2000-2009 közötti évek száz leggyakoribb szava a Magyar Pedagógia cikkeiből képzett mintában

54. ábra. A 2010-2014 közötti évek száz leggyakoribb szava a Magyar Pedagógia cikkeiből képzett mintában

55. ábra. A Magyar Pedagógia repertórium száz leggyakoribb kulcsszava az 1892-1899 közötti évekböl

56. ábra. A Magyar Pedagógia repertórium száz leghangsúlyosabb kulcsszava az 1892-1899 közötti évekből a kölcsönös információtartalom vizsgálati módszer alapján

57. ábra. A Magyar Pedagógia repertórium száz leghangsúlyosabb kulcsszava az 1892-1899 közötti évekből a khí-négyzet vizsgálati módszer alapján.

58. ábra. A Magyar Pedagógia repertórium száz leghangsúlyosabb kulcsszava az 1900-1909 közötti évekböl a khí-négyzet vizsgálati módszer alapján. 
59. ábra. A Magyar Pedagógia repertórium száz leghangsúlyosabb kulcsszava az 1910-1919 közötti évekből a khí-négyzet vizsgálati módszer alapján

60. ábra. A Magyar Pedagógia repertórium száz leghangsúlyosabb kulcsszava az 1920-1929 közötti évekből a khí-négyzet vizsgálati módszer alapján.

61. ábra. A Magyar Pedagógia repertórium száz leghangsúlyosabb kulcsszava az 1930-1939 közötti évekböl a khí-négyzet vizsgálati módszer alapján

62. ábra. A Magyar Pedagógia repertórium száz leghangsúlyosabb kulcsszava az 1940-1949 közötti évekből a khí-négyzet vizsgálati módszer alapján.

63. ábra. A Magyar Pedagógia repertórium száz leghangsúlyosabb kulcsszava az 1961-1969 közötti évekből a khí-négyzet vizsgálati módszer alapján.

64. ábra. A Magyar Pedagógia repertórium száz leghangsúlyosabb kulcsszava az 1970-1979 közötti évekből a khí-négyzet vizsgálati módszer alapján.

65. ábra. A Magyar Pedagógia repertórium száz leghangsúlyosabb kulcsszava az 1980-1989 közötti évekből a khí-négyzet vizsgálati módszer alapján

66. ábra. A Magyar Pedagógia cikkek száz leghangsúlyosabb tárgyszava a Contenta adatbázisban az 1892-1899 közötti évekböl a kölcsönös információtartalom vizsgálati módszer alapján

67. ábra. A Magyar Pedagógia cikkek száz leghangsúlyosabb tárgyszava a Contenta adatbázisban az 1900-1909 közötti évekből a kölcsönös információtartalom vizsgálati módszer alapján

68. ábra. A Magyar Pedagógia cikkek száz leghangsúlyosabb tárgyszava a Contenta adatbázisban az 1910-1919 közötti évekből a kölcsönös információtartalom vizsgálati módszer alapján

69. ábra. A Magyar Pedagógia cikkek száz leghangsúlyosabb tárgyszava a Contenta adatbázisban az 1920-1929 közötti évekből a kölcsönös információtartalom vizsgálati módszer alapján

70. ábra. A Magyar Pedagógia cikkek száz leghangsúlyosabb tárgyszava a Contenta adatbázisban az 1930-1939 közötti évekből a kölcsönös információtartalom vizsgálati módszer alapján

71. ábra. A Magyar Pedagógia cikkek száz leghangsúlyosabb tárgyszava a Contenta adatbázisban az 1940-1949 közötti évekből a kölcsönös információtartalom vizsgálati módszer alapján

72. ábra. A Magyar Pedagógia cikkek száz leghangsúlyosabb tárgyszava a Contenta adatbázisban az 1961-1969 közötti évekből a kölcsönös információtartalom vizsgálati módszer alapján

73. ábra. A Magyar Pedagógia cikkek száz leghangsúlyosabb tárgyszava a Contenta adatbázisban az 1970-1979 közötti évekből a kölcsönös információtartalom vizsgálati módszer alapján 
74. ábra. A Magyar Pedagógia cikkek száz leghangsúlyosabb tárgyszava a Contenta adatbázisban az 1980-1989 közötti évekből a kölcsönös információtartalom vizsgálati módszer alapján 165

75. ábra. A Magyar Pedagógia cikkek leghangsúlyosabb tárgyszavai a Contenta adatbázisban az 1990-1999 közötti évekböl a kölcsönös információtartalom vizsgálati módszer alapján

76. ábra. A Magyar Pedagógia cikkek leghangsúlyosabb tárgyszavai a Contenta adatbázisban a 2000-2009 közötti évekböl a kölcsönös információtartalom vizsgálati módszer alapján

77. ábra. A Magyar Pedagógia cikkek leghangsúlyosabb tárgyszavai a Contenta adatbázisban a 2010-2014 közötti évekböl a kölcsönös információtartalom vizsgálati módszer alapján

78. ábra. A minta legelső cikkének (György, 1892) khí-négyzet próba szerinti huszonöt legmagasabb értéket kapott automatikus kulcsszava

79. ábra. Egy véletlenszerüen kiválasztott cikk (Magyar \& Molnár, 2013) kölcsönös információtartalom szerinti huszonöt legmagasabb értéket kapott automatikus kulcsszava

80. ábra. Az 1892-1899 közötti évek khí-négyzet vizsgálati módszer alapján generált automatikus kulcsszavai a Magyar Pedagógia cikkeiből képzett mintából

81. ábra. Az 1900-1909 közötti évek khí-négyzet vizsgálati módszer alapján generált automatikus kulcsszavai a Magyar Pedagógia cikkeiből képzett mintából

82. ábra. Az 1910-1919 közötti évek khí-négyzet vizsgálati módszer alapján generált automatikus kulcsszavai a Magyar Pedagógia cikkeiből képzett mintából

83. ábra. Az 1920-1929 közötti évek khí-négyzet vizsgálati módszer alapján generált automatikus kulcsszavai a Magyar Pedagógia cikkeiből képzett mintából

84. ábra. Az 1930-1939 közötti évek khí-négyzet vizsgálati módszer alapján generált automatikus kulcsszavai a Magyar Pedagógia cikkeiből képzett mintából

85. ábra. Az 1940-1949 közötti évek khí-négyzet vizsgálati módszer alapján generált automatikus kulcsszavai a Magyar Pedagógia cikkeiből képzett mintából

86. ábra. Az 1950-es év khí-négyzet vizsgálati módszer alapján generált automatikus kulcsszavai a Magyar Pedagógia cikkeiből képzett mintából

87. ábra. Az 1961-1969 közötti évek khí-négyzet vizsgálati módszer alapján generált automatikus kulcsszavai a Magyar Pedagógia cikkeiből képzett mintából .... 176

88. ábra. Az 1970-1979 közötti évek khí-négyzet vizsgálati módszer alapján generált automatikus kulcsszavai a Magyar Pedagógia cikkeiből képzett mintából .... 177

89. ábra. Az 1980-1989 közötti évek khí-négyzet vizsgálati módszer alapján generált automatikus kulcsszavai a Magyar Pedagógia cikkeiből képzett mintából .... 178 
90. ábra. Az 1990-1999 közötti évek khí-négyzet vizsgálati módszer alapján generált automatikus kulcsszavai a Magyar Pedagógia cikkeiből képzett mintából

91. ábra. A 2000-2009 közötti évek khí-négyzet vizsgálati módszer alapján generált automatikus kulcsszavai a Magyar Pedagógia cikkeiből képzett mintából . 180

92. ábra. A 2010-2014 közötti évek khí-négyzet vizsgálati módszer alapján generált automatikus kulcsszavai a Magyar Pedagógia cikkeiből képzett mintából

93. ábra. A klaszteranalízis kiinduló oldalának részlete

94. ábra. A \#628-as számú klaszter az 1-es granularitási szinten 1892-2014

95. ábra. A \#46-os számú klaszter egy részlete a 3-as granularitási szinten 1892-2014........ 186

96. ábra. A \#8-as számú klaszter egy részlete a 2-es granularitási szinten 1991-2014

97. ábra. A témacsoportok évenkénti változása 10 kategória esetén 1892-2014

[Témacsoportok kulcsszavai: 5. melléklet]

98. ábra. A témacsoportok évtizedenkénti változása 10 kategória esetén 1892-2014

[Témacsoportok kulcsszavai: 5. melléklet]

99. ábra. A témacsoportok évenkénti változása 15 kategória esetén 1892-2014

[Témacsoportok kulcsszavai: 6. melléklet]

100. ábra. A témacsoportok évtizedenkénti változása 15 kategória esetén 1892-2014

[Témacsoportok kulcsszavai: 6. melléklet]

101. ábra. A témacsoportok évenkénti változása 20 kategória esetén 1892-2014

[Témacsoportok kulcsszavai: 7. melléklet]

102. ábra. A témacsoportok évtizedenkénti változása 20 kategória esetén 1892-2014

[Témacsoportok kulcsszavai: 7. melléklet].

103. ábra. A témacsoportok évenkénti változása 10 kategória esetén 1991-2014

[Témacsoportok kulcsszavai: 8. melléklet] 204

104. ábra. A témacsoportok évenkénti változása 20 kategória esetén 1991-2014

[Témacsoportok kulcsszavai: 9. melléklet] 205

105. ábra. A kvantitatív és kvalitatív szavak egymáshoz való viszonya a folyóiratban

1960-2014 között az abszolút előfordulások alapján 208

106. ábra. Az egyes tantárgyak elnevezésének relatív előfordulása a folyóiratban $1892-2014$

107. ábra. Néhány kiválasztott kutatási irány trendjei a relatív előfordulások alapján

1961-2014

108. ábra. Az „induktív gondolkodás” és az „induktív” kifejezések abszolút

előfordulásai a lapban 1892-2014

109. ábra. A „reziliencia” és a „proszocialitás” kifejezések első abszolút előfordulásai

1991-2014 
110. ábra. További kutatási irányok trendjei, abszolút előfordulásaik alapján 1991-2014 ... 212

111. ábra. A kiválasztott kifejezések abszolút előfordulásai és első megjelenésük a folyóiratban 1991-2014

112. ábra. Az "esélyegyenlőség" és "esélyegyenlőtlenség" szavak abszolút használata $1991-2014$

113. ábra. Topikok képzése kulcsszavak segítségével 1991-2014. 214

114. ábra. A „keyphraseViz” program grafikus kimenetének részlete 216

115. ábra. Az előző ábra egy „dobozának” tartalma, az egyes cikkek azonosító számaival . 216

116. ábra. A klaszterizálás egyfajta gráf-szerü ábrázolása. 217

117. ábra. A "Scattertext" program adaptálása 217

118. ábra. Magyarország tudományos kibocsátása a SciVal adatai alapján 2013-2017 között a FOS osztályozás szerinti tudományágak bontásában 218 


\section{A DISSZERTÁCIÓ TÉMAKÖRÉHEZ KAPCSOLÓDÓ PUBLIKÁCIÓK}

Nagy, G. (2014). Megy-e a digitalizálás által a világ elébb? Avagy mi végre digitalizálunk? Információs Társadalom, 14(3), 44-52.

Nagy, G. (2016a). Tudománymetria és neveléstudomány. Iskolakultúra, 26(2), 50-62. https://doi.org/10.17543/iskkult.2016.2.50

Nagy, G. (2016b). Tudománymetriai és tartalmi elemzések szövegbányászati módszerekkel. In Mikusné Sárvári, K. (Ed.), Networkshop 2016, Debrecen, 2016.03.29-2016.04.01. Budapest: NIIFI.

Nagy, G. (2016c). A Magyar Pedagógia folyóirat tudománymetriai és tartalmi elemzése. In Molnár, G., \& Bús, E. (Eds.), PÉK 2016. XIV. Pedagógiai értékelési Konferencia [CEA 2016. 14 TH Conference on Educational Assessment] (pp. 52-52). Szeged: SZTE Neveléstudományi Doktori Iskola.

Nagy, G. (2016d). A Magyar Pedagógia folyóirat tudománymetriai és tartalmi elemzése szövegbányászati módszerrel. In Zsolnai, A., \& Kasik, L. (Eds.), XVI. Országos Neveléstudományi Konferencia Program és absztrakt kötet (p. 273). Szeged: MTA Pedagógiai Bizottság, SZTE BTK Neveléstudományi Intézet.

Nagy, G. (2017). A neveléstudomány kutatási tendenciái a Magyar Pedagógia negyed évszázadának tükrében. In Kerülö, J., Jenei, T., \& Gyarmati, I. (Eds.), XVII. Országos Neveléstudományi Konferencia: Program és absztrakt kötet (pp. 53). Nyíregyháza: MTA Pedagógiai Tudományos Bizottság, Nyíregyházi Egyetem.

Nagy, G., \& Molnár, G. (2017). A Magyar Pedagógia folyóirat tudománymetriai elemzése: tendenciák, szerzők, társszerzőségi együttmüködés. Magyar Pedagógia, 117(1), 5-27. https://doi.org/10.17670/mped.2017.1.5

Nagy, G., Molnár, S., \& Kokas, K. (2017). A könyvtárak jövőjéről - Reflexiók egy előzetes kutatási jelentés kapcsán. Tudományos és Müszaki Tájékoztatás, 64(2), 64-82.

Nagy, G. (2018a). Citation network analysis of an educational research journal. In Vidákovich, T., \& Füz, N. (Eds.), PÉK 2018 [CEA 2018] XVI. Pedagógiai Értékelési Konferencia [16th Conference on Educational Assessment]: Program és összefoglalók [Programme and abstracts] (pp. 72-72). Szeged: SZTE Neveléstudományi Doktori Iskola.

Nagy, G. (2018b). Text Mining-based Scientometric Analysis in Educational Research. In The European Conference on Education 2018 Official Conference Proceedings (pp. 129142). Nagoya, Japán: International Academic Forum.

Nagy, G., \& Molnár, G. (2018). A Magyar Pedagógia folyóirat tudománymetriai elemzése a hivatkozási szokások és a hivatkozási hálózatok tükrében. Magyar Pedagógia, 118(3), 203-235. 


\section{MelLÉKLETEK}




\section{MELLÉKLETEK JEGYZÉKE}

1. melléklet. A folyóirat digitalizálásával kapcsolatos háttéranyagok: felhasználási szerződés; az SZTE Klebelsberg Könyvtár digitalizáló céleszközei, amelyeken a folyóirat digitalizálása történt 268

2. melléklet. A digitalizált folyóirat adatbázisba szervezésével kapcsolatos háttéranyagok: a lapszámok cikkekre bontása; egy PDF oldal szöveges leképezése; hivatkozási lista a PDF oldal szöveges leképeződésében 271

3. melléklet. A folyóirat feldolgozásával kapcsolatos háttéranyagok: három, metaadatokat tároló MARC rekord; a szerzői monogramok feloldását tartalmazó táblázat részlete 275

4. melléklet. A 12. ábra rövidítéseinek feloldása 277

5. melléklet. Az egyes témacsoportok kulcsszavai 10 kategória esetén 1892-2014 között ... 278

6. melléklet. Az egyes témacsoportok kulcsszavai 15 kategória esetén 1892-2014 között ... 279

7. melléklet. Az egyes témacsoportok kulcsszavai 20 kategória esetén 1892-2014 között ... 281

8. melléklet. Az egyes témacsoportok kulcsszavai 10 kategória esetén 1991-2014 között... 284

9. melléklet. Az egyes témacsoportok kulcsszavai 20 kategória esetén 1991-2014 között ... 286

10. melléklet. Az összetett kifejezések vizsgálatát lehetővé tevő kollokációs lista első 100 tétele. 289

11. melléklet. Az elvégzett elemzések a két vizsgálati időablakban (1892-2014 és 1991-2014) 


\title{
1. melléklet. A folyóirat digitalizálásával kapcsolatos háttéranyagok: felhasználási szerzödés; az SZTE Klebelsberg Könyvtár digitalizáló céleszközei, amelyeken a folyóirat digitalizálása történt
}

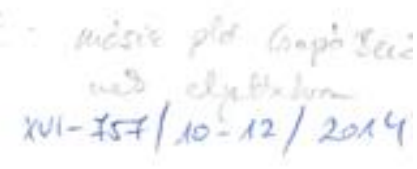

\section{Felhasználási szerzōdés}

amely létrejōtt egyrészrốl a Szegedi Tudományegyetem Klebelsberg Kuno Könyvtảra (6722, Szeged, Ady tér 10. képviseletében eljár: Dr. Keveházi Katalin, föigazgató, telefon: +36 (62) 546-662, e-mail: (katalin.kevehazi@ek.szte.hu), mint felhasználó (továbbiakban: Felhasználó), másrészrōl Dr. Csapó Benő, tanszékvezetổ egyetemi tanár, fószerkesztō (email: csapo@edpsy.u-szeged.hu), mint az alábbiakban pontosan megjelōlt folyóirat, publikáció, kōnyv (a továbbiakban: Mũ) vonatkozásában felhasználási engedély adására jogosult személy (a továbbiakban: logosult):

A Jogosult adatai:

Képviselt szervezet:

\author{
nMagyar Pedagógia" szerkesztôsége \\ SZTE Bölcsészettudományi Kar, Neveléstudományi Intézet \\ Cím: H-6722 Szeged, Petôfi sgt. 30-34. \\ Telefon: Tel./FAX: +3662544354 \\ Kapesolattartó: Molnár Gyöngyvér \\ E-mail: szerk@magyarpedagogia.hu
}

A Mü adatai:

\section{Magyar Pedagógia 1892-1990}

a továbbiakban együttesen: Felek, kőzött alulírott helyen és idóben az alábbi feltételek szerint.

A Felek rögzítik, hogy egyũttmúkődésũk célja a Jogosult által engedélyezett Mưvek minél szélesebb körben tơrténó hozzáférhetōvé tétele a Jogosult tudományos eredményeinek elömozditása, valamint a Felhasználónak a tudományos alkotások terjesztésében való minél aktívabb részvétele érdekében.

1. A Jogosult engedélyt ad arra, hogy a Felhasználó a Mūvet számitógéppel, elektronikus/digitális adathordozóra másolja, rơgzitse, archiválja, indexálja, az indexált metaadatokat a Felhasználó által mindenkor alkalmazott adatbázisokban hozzáférhetôvé tegye, továbbá a Múvet teljes terjedelmében, változatlan tartalommal az interneten keresztül a nyilvánosság számára lehívásra hozzáférhetõvé tegye.

2. A Felek a szerzôdést határozatlan idótartamra, ingyenesen kötik. A Felek kőzött kőtőtt szerzôdés nem biztosit kizárólagos felhasználási jogot Felhasználó részére.

3. Az 1. pontban foglalt felhasználási cselekményekre minden esetben a Felhasználó eszkőzeivel és épūletében kerül sor, a tartalmakhoz való hozzáférés azonban kifejezetten terũleti korlátozások nélkul (akár kulfóldi olvasó számára is) kerul biztositásra.

4. A Felek rögzitik, hogy a Mú felhasználása sorån a Felhasználó jogosult a Mûvet a rendelkezésére álló formátumátalakitási eszkőzokkel tobbszörözni, mely magatartást a Felek kifejezetten nem tekintik átdolgozásnak. A formátumátalakítás során az alkalmazott technológia automatizált múködésének eredményeként a Mú formájában végbemenó váitozásokat a Felek kifejezetten nem tekintik a Mũ szerzójét megilletô személyhez fũzôđoñ jogok sérelmének.

5. A Felhasznạ́ló a Mũ felhasználása során mindvégig a Mũ szerzōjét megilletō személyhez fũzṓdó jogokra tekintettel jár el, igy a névfeltûntetés jogảnak megfelelōen a Felhasználó a Mũ bibliográfiai adatait világosan elérhetōvé teszi a Felhasználó szolgáltatását igénybe vevỏ személyek számára. A Felhasználó is jogosult a szerzôdés tartama alatt a Szerzō névfeltūntetési, és a mủ egységének védelméhez füzödō jogának védelmében fellépni.

$-1-$ 
6. A Jogosult kijelenti, hogy az egyéni, eredeti jellegũ Mữvet kizárólagosan ố szerzi, avagy a Szerzó nevében felhasználási engedély adására jogosult. A Jogosult kőtelezettséget vállal arra, hogy a Mữơn harmadik személynek olyan kizárólagos és nem kizárólagos szerzōi vagyoni/felhasználási jogot, amely a Felhasználó jelen szerzódés szerinti felhasználását korlátozná vagy akadályozná, nem enged. E vonatkozásban a Mưre a Jogosult szavatosságot vállal.

7. Amennyiben a jelen Szerzõdés bármely rendelkezése érvénytelen lenne, vagy azzá válna, a tơbbi rendelkezést ez nem érinti. Bármely érvénytelen rendelkezést közös megállapodással olyan rendelkezéssel kell helyettesiteni, amely a jelen Szerződés céljảnak megfelel, figyelembe véve az érdekeltségek jellegét. Ugyanez vonatkozik arra az esetre, ha szerződési joghézagok merülnének fel.

8. A jelen Szerződés szerint szükséges valamennyi nyilatkozatot a Felek kötelesek írásban megtenni. A Felek a jelen szerződés értelmezésére, és esetleges jogvitájuk rendezésére kikőtik a Szegedi Járásbíróság, illetve a Szegedi Törvényszék kizárólagos illetékességét.

9. A jelen Szerzōdésben nem rendezett kérdésekben a szerzõi jogról szóló 1999. évi LXXVI. törvényt, a jogszavatosságra pedig az eladónak a tulajdonjog átruházásáért való, a Ptk. adásvételi szabályai közőtt meghatározott szavatosságára irányadó rendelkezéseket kell alkalmazni.

10. A Felek jelen Szerződést elolvasták, annak rendelkezéseit megértették, és mint akaratukkal mindenben megegyezōt, helybenhagyólag aláírják.

Kelt: Szeged, 2014. október 13.
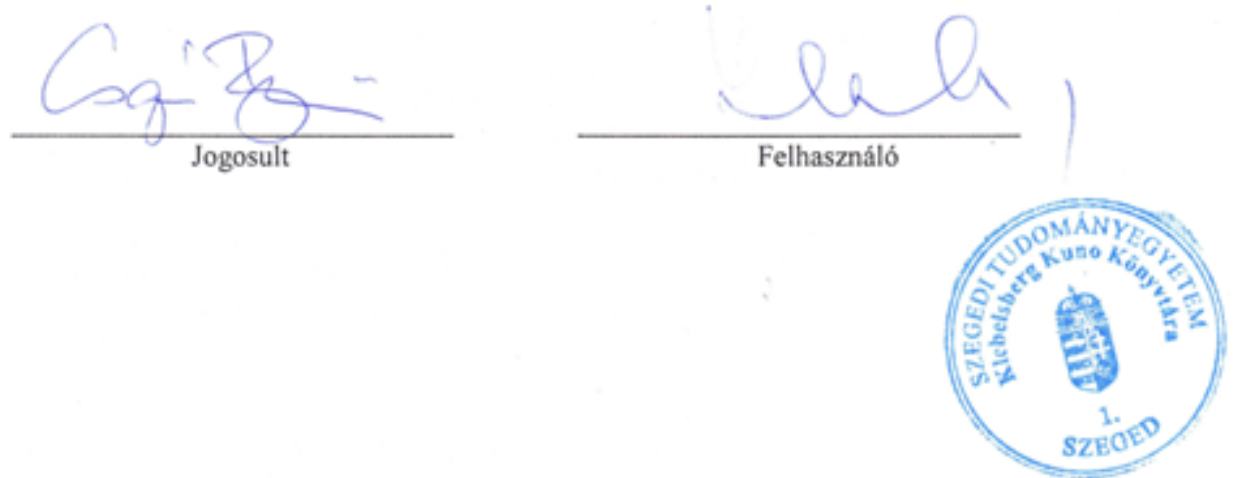

-2 . 

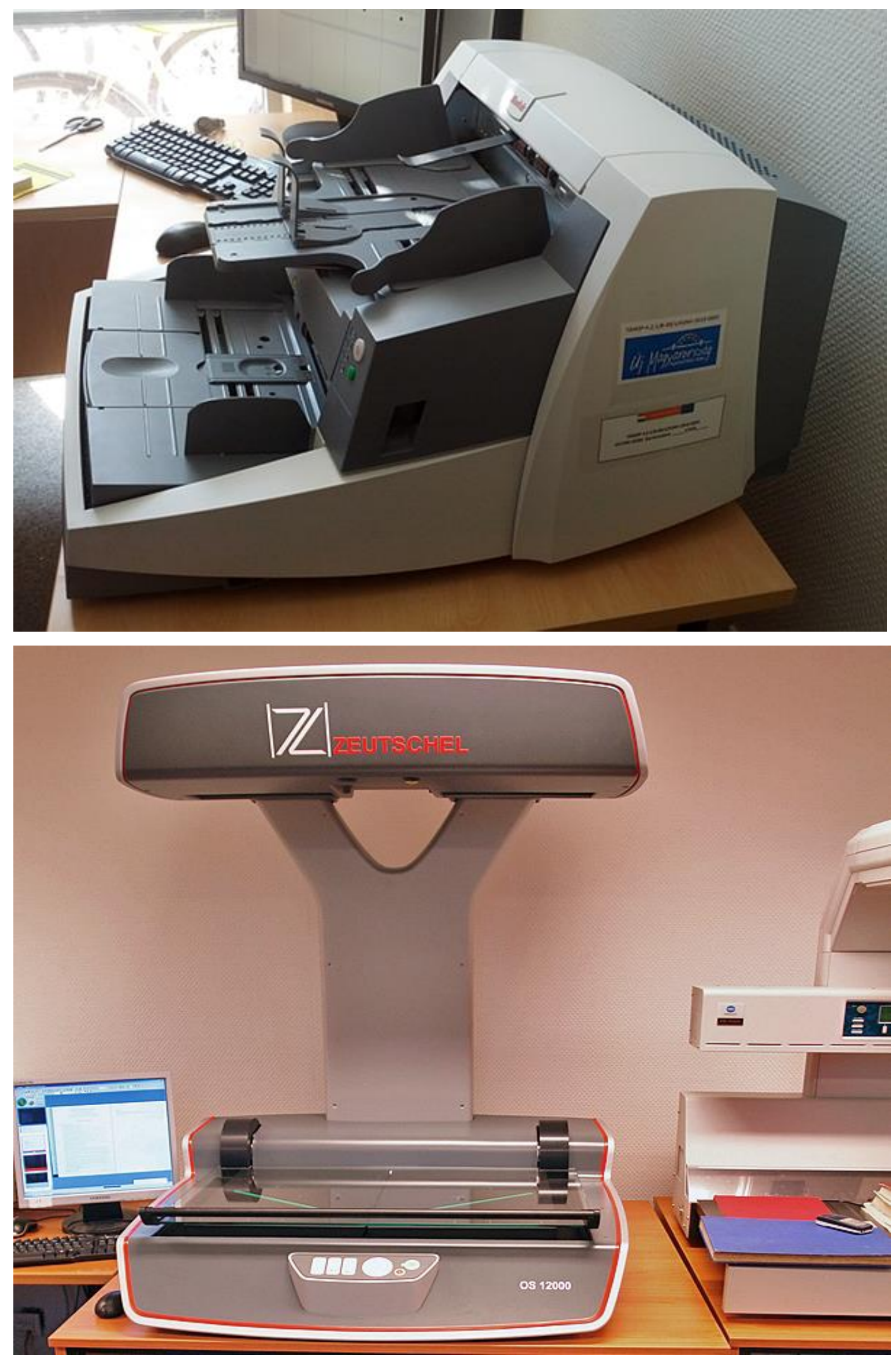
2. melléklet. A digitalizált folyóirat adatbázisba szervezésével kapcsolatos háttéranyagok: a lapszámok cikkekre bontása; egy PDF oldal szöveges leképezése; hivatkozási lista a PDF oldal szöveges leképezödésében

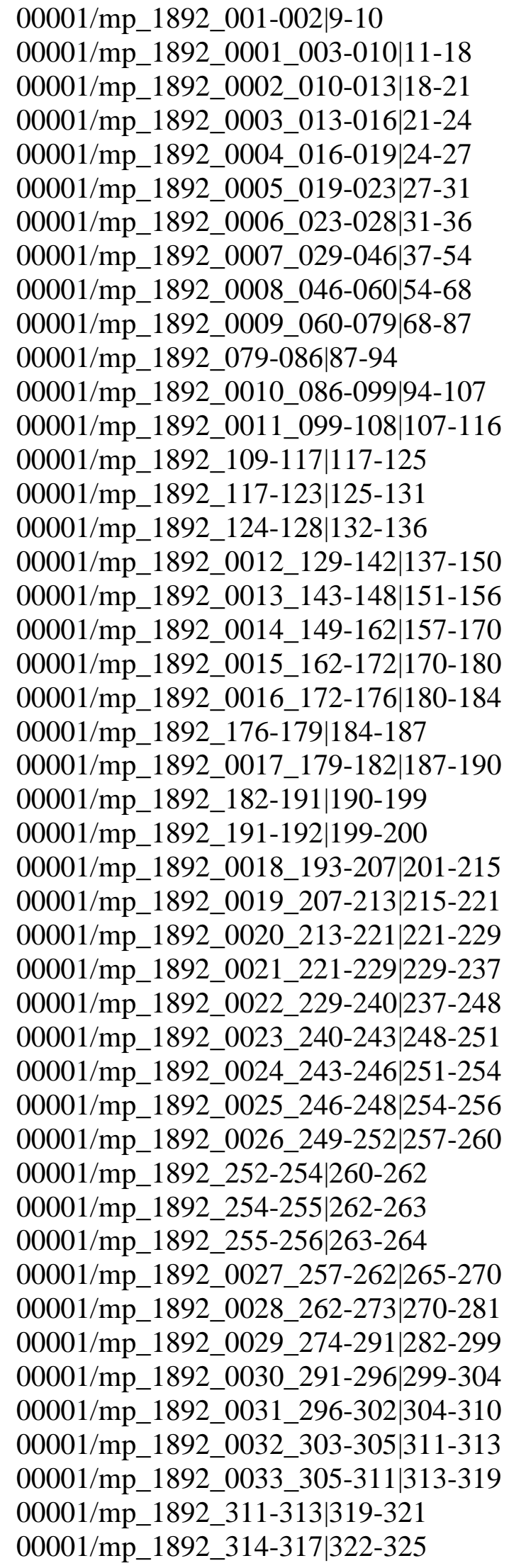


00001/mp_1892_318-320|326-328

00001/mp_1892_0034_321-334|329-342

00001/mp_1892_0035_335-344|343-352

00001/mp_1892_0036_344-351|352-359

$<\mathrm{mpt}$ id="48928">

$<\mathrm{m}$ e="00400/00415" t="Magyar Pedagógia. - 114. évf. (2014) 4. sz." g="114. (2014) 4." h="p.

281." b="842.0 595.22 0.0 0.0" i="48864 4892748927489294895448958 " ref="100415">

<e f="00249/mp_2014_004" p="65"/>

<e f="00249/mp_2014_004_6574_281-302" p="1"/>

$</ \mathrm{m}>$

$<$ f $\mathrm{n}=$ "TimesNewRoman" $\mathrm{s}=$ "9.0" $><\mathrm{t} \mathrm{x}=$ "119.04" $\mathrm{y}=$ "706.4" $>$ MAGYAR PEDAGÓGIA $</ \mathrm{t}>$

$<\mathrm{t} x=" 119.04 " \mathrm{y}=$ "696.441" >114. évf. 4. szám 281-302. (2014)</t>

$<\mathrm{t} \mathrm{x}=" 461.28$ " $\mathrm{y}=" 138.5 ">281</ \mathrm{t}>$

$<\mathrm{t} x=$ "137.94" $\mathrm{y}=$ "638.9" $><\mathrm{b}>$ LEHETÖSÉGEK ÉS KIHÍVÁSOK A DIGITÁLIS JÁTÉK $</ \mathrm{b}></ \mathrm{t}>$

$<\mathrm{t} \quad \mathrm{x}=$ "126.0" $\mathrm{y}=$ "625.1" $><\mathrm{b}>$ ALAPÚ $\quad$ TANULÁSBAN: $\quad$ EGY $\quad$ INDUKTÍV GONDOLKODÁST $</ \mathrm{b}></ \mathrm{t}>$

$<\mathrm{t} x=$ "165.0" $\mathrm{y}=$ "611.3" $><\mathrm{b}>$ FEJLESZTÖ PROGRAM HATÁSVIZSGÁLATA $</ \mathrm{b}></ \mathrm{t}>$

$<\mathrm{t} x=$ "262.14" $\mathrm{y}=$ "579.5" $><\mathrm{b}>$ Pásztor Attila $</ \mathrm{b}></ \mathrm{t}>$

$<\mathrm{t} \quad \mathrm{x}=$ "174.18" $\mathrm{y}=$ "567.26" $><\mathrm{i}>$ Szegedi Tudományegyetem, Neveléstudományi Doktori Iskola $\langle/ \mathrm{i}\rangle\langle/ \mathrm{t}\rangle$

$<\mathrm{t} x=$ "119.04" $\mathrm{y}=$ "519.261" $>$ A játék kiemelkedő szerepet tölt be a pszichológiai fejlődésben ( $<\mathrm{i}>$ Frost $</ \mathrm{i}>,<\mathrm{i}>$ Wortham $</ \mathrm{i}>$ és $<\mathrm{i}></ \mathrm{i}></ \mathrm{t}>$

$<\mathrm{t} x=$ "119.041" $\mathrm{y}=$ "507.261" $><\mathrm{i}>$ Reifel $</ \mathrm{i}>,<\mathrm{i}></ \mathrm{i}>2005$ ), a játékok eszköztárát felhasználó tanítási módszerek hatékonyan $\langle\mathrm{x}>$ integ- $</ \mathrm{x}\rangle\langle/ \mathrm{t}\rangle$

$<\mathrm{t} x=$ "119.041" $\mathrm{y}=$ "495.261" $><\mathrm{y}>$ integ $</ \mathrm{y}>$ rálhatók a formális oktatás mindennapi kereteibe is (1. pl. $<\mathrm{i}>$ Dienes $</ \mathrm{i}>$ és $<\mathrm{i}>\operatorname{Varga}</ \mathrm{i}>, 1989 ;<\mathrm{i}>\operatorname{Varga}</ \mathrm{i}>,</ \mathrm{t}>$

$<\mathrm{t} x=$ 119.041" $\mathrm{y}=$ "483.261">1974). A digitális játékok tanítási célú felhasználásának lehetösége már az erre alkalmas $</ \mathrm{t}>$

$<\mathrm{t} x=$ "119.041" $\mathrm{y}=$ "471.261">technikai eszközök megjelenésekor felmerült $(<\mathrm{i}>$ Lepper $</ \mathrm{i}>$ és $<\mathrm{i}>$ Malone $</ \mathrm{i}>,<\mathrm{i}></ \mathrm{i}>1987)$. A téma iránti $</ \mathrm{t}>$

$<\mathrm{t} x=$ "119.042" $\mathrm{y}=$ "459.261">érdeklődés napjainkban egyre erösödik, hiszen a mai kor „digitális bennszülöttjeinek" $</ \mathrm{t}>$

$<\mathrm{t} \quad \mathrm{x}=$ "119.042" $\mathrm{y}=$ "447.261" $>(<\mathrm{i}>$ Prensky $</ \mathrm{i}>, \quad 2001 \mathrm{a})$ hétköznapjait meghatározza a mobilkommunikációs eszközök és az $</ \mathrm{t}>$

$<\mathrm{t} \mathrm{x}=" 119.042 " \mathrm{y}=" 435.261 ">$ internet használata, valamint a számítógépes és a videojátékok is egyre népszerübbek $</ \mathrm{t}>$

$<\mathrm{t} x=$ "119.042" $\mathrm{y}=$ "423.261" $>$ köreikben. $</ \mathrm{t}>$

$<\mathrm{t} x=$ "133.262" $\mathrm{y}=$ "411.261" $>$ A digitális korban felnövekvő generációk fejlesztéséhez kézenfekvő módszernek $</ \mathrm{t}>$

$<\mathrm{t}$ x="119.042" y="399.261">tünik a játékszoftverek alkalmazása, azonban ezen állítás bizonyítékokkal való alátá-</t>

$<\mathrm{t} \mathrm{x}=$ "1 19.042" y="387.261" $>$ masztása már nem könnyü feladat $(<\mathrm{i}>$ Young $</ \mathrm{i}>,<\mathrm{i}>$ Slota $</ \mathrm{i}>$, $\langle\mathrm{i}\rangle$ Cutter $\langle/ \mathrm{i}\rangle,\langle\mathrm{i}\rangle$ Jalette $\langle/ \mathrm{i}\rangle,\langle\mathrm{i}\rangle$ Mullin $\langle/ \mathrm{i}\rangle,\langle\mathrm{i}\rangle$ Lai $\langle/ \mathrm{i}\rangle,\langle\mathrm{i}\rangle$ Simeoni $\langle/ \mathrm{i}\rangle,\langle\mathrm{i}\rangle\langle\mathrm{i}\rangle\langle/ \mathrm{t}\rangle$

$<\mathrm{t} \quad \mathrm{x}=$ "119.043" $\mathrm{y}=$ "375.261" $><\mathrm{i}>$ Tran $</ \mathrm{i}>$ és $<\mathrm{i}>$ Yukhymenko $</ \mathrm{i}>, \quad<\mathrm{i}></ \mathrm{i}>2012) . \quad$ Az eredményesség mellett gyakran anekdotikus $<\mathrm{x}>$ beszámo- $\langle/ \mathrm{x}\rangle\langle/ \mathrm{t}\rangle$

$<\mathrm{t} x=$ "119.042" $\mathrm{y}=$ "363.261" $><\mathrm{y}>$ beszámo $</ \mathrm{y}>$ lók szólnak, illetve az empirikus kutatásokat gyakran a módszertani szigor alacsony $</ \mathrm{t}>$ 
<t x="119.042" y="351.261">színvonala jellemzi, például a hiányzó kontrollcsoport a kísérleti elrendezésben $\left(<\mathrm{i}>\mathrm{O}{ }^{\prime} \mathrm{Neil}</ \mathrm{i}>,<\mathrm{i}></ \mathrm{i}></ \mathrm{t}>\right.$

$<\mathrm{t} \quad \mathrm{x}=$ "119.042" $\quad \mathrm{y}=$ "339.261" $><\mathrm{i}>$ Wainess $\quad</ \mathrm{i}>$ és $\quad<\mathrm{i}>$ Baker $</ \mathrm{i}>, \quad<\mathrm{i}>2005</ \mathrm{i}>$; $<\mathrm{i}>$ Wouters $</ \mathrm{i}>,<\mathrm{i}>$ van der Spek $</ \mathrm{i}>$ és $<\mathrm{i}>$ van Oostendorp $</ \mathrm{i}>,<\mathrm{i}></ \mathrm{i}>2009$; $<\mathrm{i}>$ Young $</ \mathrm{i}>$ és $<\mathrm{i}></ \mathrm{i}></ \mathrm{t}>$

$<\mathrm{t} x=$ "119.04" $\mathrm{y}=$ "327.261" $>$ mtsai, $<\mathrm{i}></ \mathrm{i}>2012$ ). További probléma, hogy a kutatások gyakran nem épülnek kurrens $<\mathrm{x}>$ oktatás $-</ \mathrm{x}\rangle\langle/ \mathrm{t}\rangle$

$<\mathrm{t} x=$ "119.04" $\mathrm{y}=$ "315.262" $><\mathrm{y}>$ oktatás $</ \mathrm{y}>$ elméleti, pedagógiai pszichológiai ismeretekre $(<\mathrm{i}>\mathrm{Wu}<\mathrm{i}>, \quad<\mathrm{i}>$ Hsiao $</ \mathrm{i}>, \quad<\mathrm{i}>\mathrm{Wu}</ \mathrm{i}>, \quad<\mathrm{i}>$ Lin $</ \mathrm{i}>$ és $\quad<\mathrm{i}>$ Huang $</ \mathrm{i}>, \quad<\mathrm{i}></ \mathrm{i}>$ $2012<\mathrm{i}>) .</ \mathrm{i}\rangle\langle/ \mathrm{t}\rangle$

$<\mathrm{t} x=$ "119.039" y="303.26">Azonban a terület gyors ütemü fejlődésének köszönhetően már összegyült olyan mértékü $</ \mathrm{t}>$

$<\mathrm{t} \quad \mathrm{x}=$ "119.039" $\quad \mathrm{y}=$ "291.26" $>$ kutatás-módszertani $\quad</ \mathrm{t}><\mathrm{t} \quad \mathrm{x}=$ "210.824" $\mathrm{y}=$ "291.26" $>$ szempontból $\quad</ \mathrm{t}><\mathrm{t} \quad \mathrm{x}=$ "273.062" $\mathrm{y}=$ "291.26" $>$ is $\quad</ \mathrm{t}><\mathrm{t} \quad \mathrm{x}=$ "290.879" $\mathrm{y}=$ "291.26" $>$ megfelelően $</ \mathrm{t}><\mathrm{t} \quad \mathrm{x}=$ "351.429" $\mathrm{y}=$ "291.26" $>$ kivitelezett $</ \mathrm{t}><\mathrm{t} \quad \mathrm{x}=$ "407.094" $\mathrm{y}=$ "291.26" >vizsgálat, $</ \mathrm{t}><\mathrm{t} x=$ "456.273" y="291.26" $>$ hogy $</ \mathrm{t}>$

<t x="119.039" y="279.261">megállapíthassuk, a digitális játékok hatékony eszközei lehetnek az ismeretek átadásának $</ \mathrm{t}>$

$<\mathrm{t} \quad \mathrm{x}=$ "119.038" $\mathrm{y}=$ "267.261" $>$ és $</ \mathrm{t}><\mathrm{t} \quad \mathrm{x}=$ "133.801" $\mathrm{y}=$ "267.261" $>\mathrm{a}</ \mathrm{t}><\mathrm{t} \quad \mathrm{x}=$ "144.662" $\mathrm{y}=$ "267.261" $>$ képességek $</ \mathrm{t}><\mathrm{t} \mathrm{x}=$ "196.627" $\mathrm{y}=$ "267.261" $>$ fejlesztésének $</ \mathrm{t}><\mathrm{t} x=" 259.099 "$ $\mathrm{y}=" 267.261 ">(<\mathrm{i}>$ Slitzemann $</ \mathrm{i}\rangle, \quad<\mathrm{i}></ \mathrm{i}></ \mathrm{t}\rangle \quad<\mathrm{t} \quad \mathrm{x}=" 315.178 " \quad \mathrm{y}=" 267.261 ">2011$; $\langle\mathrm{i}\rangle$ Vogel $\langle/ \mathrm{i}\rangle,\langle\mathrm{i}\rangle$ Vogel $\langle/ \mathrm{i}\rangle,\langle\mathrm{i}\rangle$ Cannon-Bowers $\langle/ \mathrm{i}\rangle,\langle/ \mathrm{t}\rangle$

$<\mathrm{t} \quad \mathrm{x}=$ "119.038" $\mathrm{y}=$ "255.261" $><\mathrm{i}>$ Bowers $</ \mathrm{i}>, \quad<\mathrm{i}>$ Muse $</ \mathrm{i}>, \quad<\mathrm{i}></ \mathrm{i}>$ és $<\mathrm{i}>$ Wright $</ \mathrm{i}>$, $\langle\mathrm{i}>2006</ \mathrm{i}\rangle$; $\langle\mathrm{i}>$ Wouters $</ \mathrm{i}\rangle,\langle\mathrm{i}>$ van Nimwegen $</ \mathrm{i}>,<\mathrm{i}>$ van Oostendorp $</ \mathrm{i}>$ és $<\mathrm{i}>$ van $\operatorname{der}</ \mathrm{i}\rangle\langle/ \mathrm{t}\rangle$

$<\mathrm{t} x=$ "119.036" $\mathrm{y}=" 243.261 "><\mathrm{i}>$ Spek $</ \mathrm{i}>,<\mathrm{i}></ \mathrm{i}>2013$ ). Ennek okán a mai kutatások a „Hatékonyak-e” kérdés helyett a „Milyen $</ \mathrm{t}>$

$<\mathrm{t} x=$ "119.036" $\mathrm{y}=$ "231.261">formában, milyen feltételek mellett" kérdések vizsgálatát helyezik elötérbe (1. pl. $<\mathrm{i}>\mathrm{Ke}</ \mathrm{i}>,<\mathrm{i}></ \mathrm{i}></ \mathrm{t}>$

$<\mathrm{t} \quad \mathrm{x}=$ "119.035" $\mathrm{y}=$ "219.261" $>2009 ; \quad<\mathrm{i}>$ McClarty $</ \mathrm{i}>, \quad<\mathrm{i}>$ Orr $</ \mathrm{i}\rangle, \quad<\mathrm{i}>$ Frey $</ \mathrm{i}\rangle$, $<\mathrm{i}>$ Dolan $</ \mathrm{i}>,<\mathrm{i}>$ Vassileva $</ \mathrm{i}>$ és $<\mathrm{i}>$ McVay $</ \mathrm{i}>,<\mathrm{i}></ \mathrm{i}>2012 ;<\mathrm{i}>$ Pásztor $</ \mathrm{i}>, 2013) .</ \mathrm{t}>$ $<\mathrm{t} x=" 133.258 " \mathrm{y}=" 207.26 ">\mathrm{Az}$ elmúlt évtizedek felgyorsult fejlődése egy további lényeges következménnyel is $</ \mathrm{t}>$

$<\mathrm{t} x=$ "119.039" $\mathrm{y}=" 195.26 ">$ járt: egyre nagyobb a jelentősége a képesség jellegű tudásnak, azoknak a gondolkodási $</ \mathrm{t}>$

$<\mathrm{t} x=$ "119.039" y="183.26">müveleteknek, amelyek lehetővé teszik az ismeretek hatékony rendszerezését és $<\mathrm{x}>$ elsajátí- $\langle/ \mathrm{x}\rangle\langle/ \mathrm{t}\rangle$

$<\mathrm{t} x=$ "119.039" $\mathrm{y}=$ "171.26"><y>elsajátí </y>tását, az ismeretek alkalmazását és a különböző kontextusban megjelenő problémák $</ \mathrm{t}>$

$<\mathrm{t} \quad \mathrm{x}=$ "119.039" $\mathrm{y}=$ "159.261">megoldását $\quad(<\mathrm{i}>$ Csapó $</ \mathrm{i}>, \quad 2004 ; \quad<\mathrm{i}>$ Kozma $</ \mathrm{i}>, \quad 2009$; $<\mathrm{i}>$ Resnick $</ \mathrm{i}\rangle, 1987)$. Ugyanakkor a tantervekben $\langle/ \mathrm{t}\rangle\langle/ \mathrm{f}\rangle$

$</ \mathrm{mpt}>$

$<\mathrm{t} x=$ "119.04" $\mathrm{y}=$ "678.08">Csapó, B. (1999): Improving thinking through the content of teaching. In: Hamers, J. H. M., van Luit, J. E. H.</t>

$<\mathrm{t} x=" 133.26 " \mathrm{y}=" 668.061 ">$ és Csapó, B. (szerk.): $<\mathrm{i}>$ Teaching and learning thinking

skills $</ i>$. Swets \&amp; Zeitlinger, Lisse 37-62. $</ \mathrm{t}\rangle$

$<\mathrm{t} x=$ "119.04" $\mathrm{y}=$ "655.1" $>$ Csapó, B. és Nikolov, M. (2009): The cognitive contribution to the development of proficiency in a foreign $\langle/ t>$ 
$<\mathrm{t} x=$ "133.26" $\mathrm{y}=$ "645.081">language. $<\mathrm{i}>$ Learning and Individual Differences $</ \mathrm{i}>$, $\langle\mathrm{b}\rangle 19</ \mathrm{b}\rangle$. 2. sz. 209-218. $</ \mathrm{t}\rangle$

$<\mathrm{t} x=$ "119.039" y="632.06">Csapó, B., Lörincz, A. és Molnár, G. (2012): Innovative

Assessment Technologies in Educational Games $</ t>$

$<t x=" 133.26 " y=" 622.101 ">$ Designed for Young Students. In: Ifenthaler, D., Eseryel, D., Ge, $\mathrm{X}$. (szerk.): $\langle\mathrm{i}\rangle$ Assessment in game-based $\langle/ \mathrm{i}\rangle\langle/ \mathrm{t}\rangle$

$\langle\mathrm{t} x=$ "133.26" $\mathrm{y}=$ "612.081" $><\mathrm{i}>$ learning: foundations, innovations, and perspectives $</ \mathrm{i}>$.

Springer, New York. 235-254.</t >

$<\mathrm{t} x=$ "119.04" y="599.061">Csíkos Csaba (2007): <i>Metakogníció - A tudásra vonatkozó tudás pedagógiája $</ \mathrm{i}>$. Müszaki Kiadó, Budapest. $</ \mathrm{t}>$

$<t \mathrm{x}=" 119.04 " \mathrm{y}=" 586.1 ">$ De Koning, E., Sijtsma, K. és Hamers, J. (2003): Construction and validation of a test for inductive reasoning. $</ \mathrm{t}\rangle$

$<\mathrm{t} x=$ "133.26" $\mathrm{y}=$ "576.081" $><\mathrm{i}>$ European Journal of Psychological Assessment $</ \mathrm{i}>$,

$\langle$ b $>19</$ b $>$. 1. sz. $24-39 .</ t>$

$<\mathrm{t} x=$ "119.039" y="563.061">Debreczeni Dániel Géza (2014): A digitális játék-alapú tanulási

eszközök tervezésének pedagógiai alapjai. $</ \mathrm{t}>$

$\langle\mathrm{t} x=" 133.259 " \mathrm{y}=$ "553.101" $><\mathrm{i}>$ Iskolakultúra $</ \mathrm{i}>$, 10. sz. 15-27. $</ \mathrm{t}\rangle$

$<\mathrm{t} x=$ "119.039" y="540.081">Dienes Zoltán és Varga Tamás (1989): $<\mathrm{i}>$ Dienes Professzor

játékai $</ \mathbf{i}>$. Müszaki Könyvkiadó, Budapest. $</ \mathrm{t}>$

$<\mathrm{t} \mathrm{x}=$ "119.039" y="527.06" $>$ Dobi János (1994): $<\mathrm{i}>$ A matematikatanítás a

gondolkodásfejlesztés szolgálatában: tantárgypedagógiai $\langle\mathrm{x}\rangle$ szöveg- $\langle/ \mathrm{x}\rangle\langle/ \mathrm{i}\rangle\langle/ \mathrm{t}\rangle$

$<\mathrm{t} x=$ "133.259" $\mathrm{y}=$ "517.101" $><\mathrm{i}><\mathrm{y}>$ szöveg $</ \mathrm{y}>$ gyüjtemény $</ \mathrm{i}>$. Pedagógus Szakma

Megújítása Projekt, Budapest. $</ \mathrm{t}>$

$<\mathrm{t}=$ ="119.039" $\mathrm{y}=$ "504.08">Ennis, R. H. (1987): A taxonomy of critical thinking dispositions and abilities. In: Baron, J. B. és Sternberg, $</ \mathrm{t}>$

$<\mathrm{t} x=$ "133.26" $\mathrm{y}=$ "494.061" >R. J. (szerk.): $<\mathrm{i}>$ Teaching thinking skills $</ \mathrm{i}>$. W. H. Freeman and Company, New York. 9-26.</t>

$<\mathrm{t} x=$ "119.039" y="481.1">Frost, J., Wortham, S. és Reifel, S. (2005): <i>Play and child development $</ \mathrm{i}>$. Upper Saddle River, Pearson, New $</ \mathrm{t}>$

$\langle\mathrm{t} x=" 133.26 " \mathrm{y}=" 471.081 ">$ Jersey. $</ \mathrm{t}\rangle$

$<\mathrm{t} x=$ "119.039" $\mathrm{y}=$ "458.061" $>$ Gardner, H. (1991): $<\mathrm{i}>$ The unschooled mind: How children

think and how schools should teach $\langle/ \mathrm{i}\rangle$. Basic Books, $</ \mathrm{t}\rangle$

$\langle\mathrm{t} x=" 133.26 " \mathrm{y}=" 448.101 ">$ New York. $</ \mathrm{t}\rangle$ 
3. melléklet. A folyóirat feldolgozásával kapcsolatos háttéranyagok: három, metaadatokat tároló MARC rekord; a szerzői monogramok feloldását tartalmazó táblázat részlete

$00000026 \mathrm{cab} 2200025$ ir4500

$001 \mathrm{szteda} / \mathrm{miscm} / 1016720$

00520150723113024.8

008150503 s 2001 hu 0 o hun 1

040 aSZ1bhuncSZ1

0410 ahun

044 ahu

10010 aCsíkosjCsaba

24510 aBizonyítási stratégiák megítélése 10-17 éves korbancCsíkos Csaba

4400 aTanulmányok

504 aBibliogr.: p. 343-345.

583 xkfk

6507 aProblémamegoldásxmatematikai

6507 aGondolkodás módszertanaxkutatási jelentésy2001

7730 wszteda/miscm/100415g101. (2001) 3.hp. 319-345.

85641 uhttp://digit.bibl.u-szeged.hu/00400/00415/00196/mp_2001_003_6187_319-345.pdf

$00000026 \mathrm{cab} 2200025$ ir4500

$001 \mathrm{szteda} / \mathrm{miscm} / 1016721$

00520150723125813.7

008150503 s 2001 hu $\quad 0 \quad 0$ hun 1

040 aSZ1bhuncSZ1

0410 ahunbger

044 ahu

10010 aMolnárjGyöngyvér

24513 aAz életszerü feladathelyzetekben történő problémamegoldás vizsgálatacMolnár

Gyöngyvér

4400 aTanulmányok

504 aBibliogr.: p. 370-371.

583 xkfk

6507 aProblémamegoldásxkutatási beszámolóy2001

7730 wszteda/miscm/100415g101. (2001) 3.hp. 347-372.

85641 uhttp://digit.bibl.u-szeged.hu/00400/00415/00196/mp_2001_003_6188_347-372.pdf

$00000026 \mathrm{cab} 2200025$ ir 4500

$001 \mathrm{szteda} / \mathrm{miscm} / 1016722$

00520150723130710.9

008150503 s 2001 hu $\quad 0 \quad 0$ hun 1

040 aSZ1bhuncSZ1

0410 ahunbeng

044 ahu

10010 aCsapójBenő

$24513 \mathrm{aAz}$ induktív gondolkodás fejlődésének elemzése országos reprezentatív felmérés alapjáncCsapó Benő

4400 aTanulmányok

504 aBibliogr.: 390. p.

583 xkfk

6507 aIndukcióxmatematikai gondolkodás 
6507 aInduktív logika mérésexkutatási beszámolóy2001

7730 wszteda/miscm/100415g101. (2001) 3.hp. 373-391.

85641 uhttp://digit.bibl.u-szeged.hu/00400/00415/00196/mp_2001_003_6189_373-391.pdf

\begin{tabular}{|c|c|}
\hline$\overline{[[\text { K. F. }]]}$ & Kemény Ferenc \\
\hline$[[\mathrm{K}-\mathrm{n}]]$. & Kelemen Ignác \\
\hline$[[\mathrm{K}-\mathrm{n}]]$ & Kelemen Ignác \\
\hline [A. Gy.] & Avar Gyula \\
\hline [Á. L.] & Ágner Lajos \\
\hline \multicolumn{2}{|l|}{$[a+\beta]$} \\
\hline \multicolumn{2}{|l|}{ [Agathon] } \\
\hline [B. C.] & Bognár Cecil \\
\hline [B. E.] & Bozóky Endre \\
\hline [B. F.] & Badics Ferenc \\
\hline [B. G.] & Burány Gergely \\
\hline \multicolumn{2}{|l|}{ [b.j.] } \\
\hline \multicolumn{2}{|l|}{ [B-M] } \\
\hline \multicolumn{2}{|l|}{ [bn.] } \\
\hline [Cz. A..] & Czakó Ambró \\
\hline [Cs. E.] & Császár Elemér \\
\hline [Cs. Gy.] & Csizik Gyula \\
\hline [Cs. J.] & Csengeri János \\
\hline [cs. ö.] & Szücs Ernő \\
\hline [E. B.] & Erődi Béla \\
\hline [E. G.] & Endrei Gerzson \\
\hline [eg.] & Endrei Gerzson \\
\hline \multicolumn{2}{|l|}{ [eö.] } \\
\hline [F. E.] & Fináczy Ernő \\
\hline [F. F.] & Fináczy Ernő \\
\hline [f.] & Fináczy Ernő \\
\hline [G. S.] & Geőcze Sarolta \\
\hline [G-s.] & Geőcze Sarolta \\
\hline [Gy. A.] & Gyulai Ágost \\
\hline [Gy. Á.] & Gyulai Ágost \\
\hline
\end{tabular}




\begin{tabular}{|c|c|}
\hline $\mathrm{BCE}$ & Budapesti Corvinus Egyetem \\
\hline BME & Budapesti Műszaki Egyetem \\
\hline CEU & Közép-európai Egyetem \\
\hline $\mathrm{DE}$ & Debreceni Egyetem \\
\hline EDUCATIO & EDUCATIO Társadalmi Szolgáltató Nonprofit Kft. \\
\hline EJF & Eötvös József Főiskola \\
\hline EKF & Eszterházy Károly Főiskola \\
\hline ELTE & Eötvös Loránd Tudományegyetem \\
\hline EVHE & Evangélikus Hittudományi Egyetem \\
\hline FOR & külföldi szerzők \\
\hline KE & Kaposvári Egyetem \\
\hline $\mathrm{KF}$ & Kecskeméti Főiskola \\
\hline KOD & Kodolányi János Főiskola \\
\hline KÖZ & közoktatási intézmények \\
\hline KRE & Károli Gáspár Református Egyetem \\
\hline ME & Miskolci Egyetem \\
\hline MTA & Magyar Tudományos Akadémia \\
\hline MTF & Magyar Táncmüvészeti Főiskola \\
\hline N/A & nincs adat \\
\hline NKE & Nemzeti Közszolgálati Egyetem \\
\hline NYF & Nyíregyházi Főiskola \\
\hline NYME & Nyugat-magyarországi Egyetem \\
\hline $\mathrm{OKI} / \mathrm{OFI}$ & Oktatáskutató és Fejlesztő Intézet \\
\hline $\mathrm{OM}$ & Oktatási Minisztérium \\
\hline OPI & Országos Pedagógiai Intézet \\
\hline $\mathrm{OTH}$ & egyéb intézmény \\
\hline $\mathrm{PE}$ & Pannon Egyetem \\
\hline PETÖ & Pető Intézet \\
\hline PTE & Pécsi Tudományegyetem \\
\hline SOTE & Semmelweis Egyetem \\
\hline SZE & Széchenyi István Egyetem \\
\hline SZIE & Szent István Egyetem \\
\hline SZTE & Szegedi Tudományegyetem \\
\hline WES & Wesley János Lelkészképző Főiskola \\
\hline ZSE & Országos Rabbiképző - Zsidó Egyetem \\
\hline
\end{tabular}


5. melléklet. Az egyes témacsoportok kulcsszavai 10 kategória esetén 1892-2014 között

\begin{tabular}{|c|c|c|c|c|}
\hline 1: nemzetköziség & 2: nyelvtanulás & 3: humanista témák & 4: oktatási intézmények & 5: népoktatás \\
\hline német & nyelv & nevelés & iskola & iskola \\
\hline francia & tanítás & élet & tanár & nevelés \\
\hline angol & tanuló & ember & osztály & lapja \\
\hline nemzetközi & magyar & gyermek & középiskola & népművelés \\
\hline amerikai & könyv & erkölcsi & tanuló & magyar \\
\hline leipzig & irodalom & munka & egyetem & budapest \\
\hline berlin & latin & kérdés & intézet & tanító \\
\hline egyetem & osztály & lélek & iskolai & tanítás \\
\hline paris & tárgy & szellemi & tanító & gyermek \\
\hline education & fordítás & hatás & oktatás & pedagógiai \\
\hline németország & szerző & fejlődés & felső & népiskola \\
\hline külföldi & német & emberi & polgári & néptanító \\
\hline ország & tanár & tudomány & gimnázium & tanügy \\
\hline folyóirat & olvasmány & világ & középiskolai & tanítóképző \\
\hline japán & módszer & iskola & tanítás & értés \\
\hline london & idegen & alap & állami & iskolai \\
\hline nyelv & tanterv & nevelö & tanterv & középiskola \\
\hline irodalom & görög & gondolat & tárgy & gyermekek \\
\hline előadás & anyag & lelki & elemi & népoktatás \\
\hline mozgalom & oktatás & nemzet & törvény & népiskolai \\
\hline háború & nyelvi & érték & intézmény & elemi \\
\hline füzet & irodalmi & szellem & általános & tanügyi \\
\hline franciaország & ismeret & szempont & gyakorlati & oktatás \\
\hline erziehung & munka & természet & képzés & népnevelö \\
\hline kongresszus & kérdés & nemzeti & igazgató & család \\
\hline 6: didaktika & 7: szociális-társadalmi témák & 8: mérés-értékelés & 9: neveléstörténet, vallás & 10: iskolai munka \\
\hline nevelés & iskola & tanuló & magyar & tanuló \\
\hline oktatás & tanuló & feladat & iskola & osztály \\
\hline pedagógia & közösség & eredmény & tanító & munka \\
\hline munka & csoport & képesség & század & feladat \\
\hline társadalmi & gyerek & szint & nemzeti & módszer \\
\hline rendszer & szülő & teszt & magyarország & kérdés \\
\hline iskola & gyermek & vizsgálat & történet & anyag \\
\hline kérdés & vizsgálat & eset & nyelv & eredmény \\
\hline folyamat & szociális & tanulás & comenius & ismeret \\
\hline általános & eredmény & adat & régi & tanulás \\
\hline probléma & eset & teljesítmény & könyv & kísérlet \\
\hline fejlődés & pedagógus & kutatás & német & tanár \\
\hline kutatás & érzelmi & diák & eötvös & eset \\
\hline tevékenység & hatás & minta & korszak & tevékenység \\
\hline elemzés & szerep & táblázat & protestáns & vizsgálat \\
\hline szerző & társadalmi & folyamat & politikai & tárgy \\
\hline tudományos & környezet & nyelv & egyház & tanítás \\
\hline feladat & helyzet & tudás & élet & alkalmazás \\
\hline tanulmány & kapcsolat & különbség & kötet & iskola \\
\hline oktatási & éves & évfolyam & város & kísérleti \\
\hline elméleti & táblázat & modell & haza & megoldás \\
\hline nevelési & család & ábra & katolikus & helyes \\
\hline szocialista & érték & fejlődés & ország & probléma \\
\hline képzés & osztály & mérés & kollégium & figyelem \\
\hline nevelés & lány & értékelés & egyházi & gyermek \\
\hline
\end{tabular}


6. melléklet. Az egyes témacsoportok kulcsszavai 15 kategória esetén 1892-2014 között

\begin{tabular}{|c|c|c|c|c|}
\hline $\begin{array}{l}\text { 1: oktatási } \\
\text { rendszer }\end{array}$ & $\begin{array}{l}\text { 2: klasszikus } \\
\text { eszmények }\end{array}$ & $\begin{array}{c}\text { 3: neveléstudományi } \\
\text { kutatás }\end{array}$ & $\begin{array}{l}\text { 4: ember-család- } \\
\text { iskola }\end{array}$ & $\begin{array}{l}\text { 5: lelki és értelmi } \\
\text { fejlődés }\end{array}$ \\
\hline iskola & nevelés & csoport & gyermek & tanítás \\
\hline oktatás & élet & vizsgálat & iskola & módszer \\
\hline képzés & ember & gyerek & szülö & tárgy \\
\hline általános & erkölcsi & tanuló & tanuló & tudomány \\
\hline rendszer & emberi & iskolai & anya & eredmény \\
\hline intézmény & nemzeti & eredmény & gyermekek & felfogás \\
\hline oktatási & nemzet & attitüd & nevelés & megfigyelés \\
\hline ország & szabadság & szociális & tanító & oktatás \\
\hline társadalmi & világ & átlag & testi & anyag \\
\hline szakmai & munka & eset & élet & szempont \\
\hline középfokú & emberiség & tanulási & osztály & figyelem \\
\hline iskolai & müveltség & motiváció & család & ismeret \\
\hline gazdasági & szellem & táblázat & iskolai & kérdés \\
\hline terület & társadalom & kapcsolat & leány & gyermek \\
\hline felsőoktatás & szellemi & szerep & játék & lélektan \\
\hline nemzetközi & nevelö & hatás & növendék & lelki \\
\hline tanterv & értelem & érték & éves & fejlődés \\
\hline probléma & eszmény & jellemző & ember & elmélet \\
\hline egyetem & érték & különbség & büntetés & érdeklődés \\
\hline tanulmány & lélek & kutatás & ifjúság & gondolkodás \\
\hline iskolarendszer & gondolat & összefüggés & szabad & fogalom \\
\hline munka & hatás & képesség & felnőtt & szellemi \\
\hline fejlesztés & eszme & tényező & nevelö & herbart \\
\hline helyzet & fejlődés & motívum & dolog & kísérlet \\
\hline általános iskola & kultúra & szülö & orvos & tudományos \\
\hline 6: népoktatás & 7: iskolai munka & $\begin{array}{c}\text { 8: könyvek, irodalom, } \\
\text { történelem }\end{array}$ & $\begin{array}{c}\text { 9: neveléstörténet, } \\
\text { vallás }\end{array}$ & 10: mérés-értékelés \\
\hline iskola & tanuló & magyar & magyar & feladat \\
\hline nevelés & munka & könyv & iskola & tanuló \\
\hline lapja & osztály & szerző & tanító & eredmény \\
\hline néptanító & feladat & irodalom & magyarország & teszt \\
\hline budapest & tanár & értekezés & egyház & szint \\
\hline magyar & kérdés & élet & református & képesség \\
\hline tanító & tanulás & könyvtár & katolikus & vizsgálat \\
\hline tanítás & ismeret & kötet & egyházi & eset \\
\hline nőnevelés & módszer & történet & felekezeti & teljesítmény \\
\hline népiskola & anyag & fejezet & gimnázium & mérés \\
\hline pedagógiai & iskola & tanulmány & kollégium & táblázat \\
\hline tanügy & pedagógus & folyóirat & város & évfolyam \\
\hline értés & eredmény & szép & törvény & diák \\
\hline középiskola & tantárgy & kiadás & eötvös & minta \\
\hline iskolai & gyakorlat & tudományos & század & gondolkodás \\
\hline gyermek & iskolai & irodalmi & német & probléma \\
\hline tanítóképző & hallgató & tudós & politikai & folyamat \\
\hline népművelés & pedagógiai & érdekes & tankönyv & ábra \\
\hline
\end{tabular}




\begin{tabular}{|c|c|c|c|c|}
\hline népoktatás & tevékenység & lélek & ratio & különbség \\
\hline tanügyi & probléma & ember & korszak & kutatás \\
\hline népnevelő & eset & előadás & protestáns & adat \\
\hline oktatás & oktatás & hely & nemzeti & fejlődés \\
\hline tanáregylet & általános & társaság & intézet & modell \\
\hline reform & válasz & tudomány & egyetem & megoldás \\
\hline elemi & figyelem & olvasó & történet & szöveg \\
\hline $\begin{array}{c}\text { 11: } \\
\text { nemzetköziség }\end{array}$ & $\begin{array}{l}\text { 12: iskolarendszer } \\
\text { a } 2 \text {. vh. elött }\end{array}$ & 13: didaktika & 14: múvészet & 15: nyelvtanulás \\
\hline német & iskola & pedagógiai & zenei & nyelv \\
\hline francia & tanár & nevelés & gyermek & tanuló \\
\hline angol & középiskola & pedagógia & rajz & osztály \\
\hline leipzig & egyetem & munka & betü & tanítás \\
\hline nemzetközi & intézet & szerző & zene & latin \\
\hline berlin & osztály & folyamat & müvészi & német \\
\hline amerikai & polgári & társadalmi & alkotás & idegen \\
\hline paris & középiskolai & fejlődés & művészet & magyar \\
\hline németország & felső & tudományos & ábrázolás & tanterv \\
\hline egyetem & kérdés & kérdés & esztétikai & nyelvi \\
\hline education & egyetemi & nevelési & vers & tárgy \\
\hline külföldi & tanterv & kutatás & forma & tanár \\
\hline london & gyakorlati & tevékenység & hang & idegen nyelv \\
\hline mozgalom & tárgy & szocialista & film & olvasmány \\
\hline osztrák & oktatás & probléma & müvészeti & görög \\
\hline folyóirat & iskolai & tanulmány & gyerek & középiskola \\
\hline erziehung & tanítás & rendszer & szöveg & nyelvtanítás \\
\hline deutsch & népiskola & gyakorlat & elem & angol \\
\hline előadás & tanító & módszer & vizuális & ismeret \\
\hline háború & törvény & elmélet & világ & francia \\
\hline über & előadás & feladat & ember & oktatás \\
\hline eine & kereskedelmi & neveléstudomány & vonal & módszer \\
\hline franciaország & polgári iskola & kapcsolat & szép & tantárgy \\
\hline irodalom & tanfolyam & személyiség & ének & klasszikus \\
\hline kongresszus & elemi & tudomány & szín & fordítás \\
\hline
\end{tabular}


7. melléklet. Az egyes témacsoportok kulcsszavai 20 kategória esetén 1892-2014 között

\begin{tabular}{|c|c|c|c|c|}
\hline $\begin{array}{c}\text { 1: pedagógiai kutatás, } \\
\text { publikálás }\end{array}$ & $\begin{array}{l}\text { 2: oktatási } \\
\text { folyamat }\end{array}$ & $\begin{array}{l}\text { 3: iskolai } \\
\text { munka }\end{array}$ & $\begin{array}{c}\text { 4: iskolarendszer a } 2 \text {. vh } \\
\text { elött }\end{array}$ & 5: nemzeti szellem \\
\hline szerző & pedagógiai & tanuló & iskola & magyar \\
\hline magyar & folyamat & osztály & tanár & élet \\
\hline pedagógiai & tevékenység & munka & középiskola & ember \\
\hline könyv & pedagógia & tanár & osztály & lélek \\
\hline munka & hatás & feladat & egyetem & dolog \\
\hline tanulmány & rendszer & kérdés & intézet & szép \\
\hline kötet & módszer & anyag & felső & könyv \\
\hline pedagógia & gyakorlat & tanulás & középiskolai & munka \\
\hline fejezet & probléma & iskola & tárgy & irodalom \\
\hline tudományos & nevelés & pedagógus & polgári & tanár \\
\hline irodalom & nevelési & eredmény & tanterv & nemzet \\
\hline kérdés & funkció & módszer & gyakorlati & ifjúság \\
\hline írás & kérdés & ismeret & tanítás & nemzeti \\
\hline címü & fejlődés & hallgató & oktatás & haza \\
\hline folyóirat & ismeret & iskolai & vizsgálat & világ \\
\hline hazai & személyiség & válasz & tanuló & ifjú \\
\hline történet & feladat & tanítási & iskolai & eszme \\
\hline egyetemi & elemzés & eset & növendék & hely \\
\hline neveléstudomány & oktatás & megoldás & kérdés & szeretet \\
\hline pedagógus & feltétel & gyakorlat & kereskedelmi & tanítvány \\
\hline megjelent & vizsgálat & probléma & polgári iskola & szellem \\
\hline nevelés & kapcsolat & tankönyv & tanári & isten \\
\hline előadás & eredmény & önálló & tanfolyam & igazság \\
\hline történeti & szempont & kísérlet & reform & régi \\
\hline kutatás & összefüggés & tanítás & képzés & szív \\
\hline 6: oktatásirányítás & 7: múvészet & $\begin{array}{l}\text { 8: mérés- } \\
\text { értékelés }\end{array}$ & 9: szocialista nevelés & $\begin{array}{l}\text { 10: lélektan, } \\
\text { iskolai élet }\end{array}$ \\
\hline iskola & zenei & feladat & nevelés & tanítás \\
\hline magyar & rajz & tanuló & munka & módszer \\
\hline tanító & gyermek & teszt & szocialista & tárgy \\
\hline törvény & betü & eredmény & dolgozó & emlékezet \\
\hline állami & zene & szint & marxista & munka \\
\hline állam & müvészi & vizsgálat & társadalom & tudomány \\
\hline nemzeti & mủvészet & képesség & fejlődés & eredmény \\
\hline népiskola & írás & teljesítmény & közösség & anyag \\
\hline politikai & esztétikai & eset & szocializmus & oktatás \\
\hline község & olvasás & táblázat & világnézeti & lélektan \\
\hline miniszter & film & évfolyam & nevelési & ismeret \\
\hline hatóság & hang & alap & ember & gondolkodás \\
\hline bizottság & vers & gondolkodás & kérdés & kérdés \\
\hline polgári & forma & adat & tevékenység & szempont \\
\hline egyesület & mủvészeti & probléma & pedagógiai & kísérlet \\
\hline érdek & gyerek & különbség & élet & lelki \\
\hline tanács & vizuális & ábra & közösségi & érdeklődés \\
\hline elemi & elem & matematikai & politikai & megfigyelés \\
\hline
\end{tabular}




\begin{tabular}{|c|c|c|c|c|}
\hline országos & szöveg & mérés & pedagógus & elmélet \\
\hline közoktatásügyi & vonal & átlag & viszony & herbart \\
\hline magyarország & élmény & megoldás & kommunista & jelenség \\
\hline rendelet & ábra & fejlődés & termelés & figyelem \\
\hline felekezeti & tárgy & minta & szovjet & természet \\
\hline eötvös & csoport & szórás & tanuló & képzet \\
\hline kormány & mozgás & érték & makarenko & fogalom \\
\hline 11: nemzetköziség & $\begin{array}{l}\text { 12: } \\
\text { nyelvtanulás }\end{array}$ & $\begin{array}{l}\text { 13: klasszikus } \\
\text { eszmények }\end{array}$ & $\begin{array}{l}\text { 14: neveléstörténet, } \\
\text { vallás }\end{array}$ & 15: iskolarendszer \\
\hline francia & nyelv & nevelés & iskola & iskola \\
\hline angol & tanuló & élet & tanító & oktatás \\
\hline nemzetközi & osztály & ember & magyar & képzés \\
\hline amerikai & tanítás & erkölcsi & század & rendszer \\
\hline német & magyar & emberi & comenius & oktatási \\
\hline ország & latin & eszme & kollégium & általános \\
\hline education & német & nemzeti & latin & intézmény \\
\hline egyetem & idegen & szellemi & erdélyi & szakmai \\
\hline kongresszus & tanterv & érték & protestáns & ország \\
\hline paris & olvasmány & nemzet & katolikus & társadalmi \\
\hline tanár & görög & világ & vallás & iskolai \\
\hline nyelv & tárgy & nevelö & város & szint \\
\hline japán & nyelvi & emberiség & történet & terület \\
\hline állam & irodalom & társadalmi & egyházi & iskolarendszer \\
\hline franciaország & idegen nyelv & szellem & levél & tanterv \\
\hline london & tanár & eszmény & egyház & gazdasági \\
\hline háború & módszer & fejlődés & egyetem & fejlesztés \\
\hline külföldi & dolgozat & müveltség & sárospataki & igény \\
\hline anglia & francia & hatás & intézet & felsőoktatás \\
\hline international & ismeret & gondolat & magyarország & középfokú \\
\hline előadás & nyelvtan & munka & református & program \\
\hline school & nyelvtanítás & kultúra & ratio & helyzet \\
\hline európai & anyag & egyéniség & német & probléma \\
\hline mozgalom & fordítás & társadalom & jezsuita & változás \\
\hline németország & középiskola & értelem & rend & egyetem \\
\hline 16: népoktatás & $\begin{array}{l}\text { 17: kognitív } \\
\text { megközelítés }\end{array}$ & $\begin{array}{l}\text { 18: német- } \\
\text { hatás }\end{array}$ & $\begin{array}{c}\text { 19: társadalmi-családi } \\
\text { háttér }\end{array}$ & $\begin{array}{l}\text { 20: szociális } \\
\text { viselkedés }\end{array}$ \\
\hline iskola & tanulás & német & gyermek & gyerek \\
\hline népművelés & kommunikáció & leipzig & iskola & iskolai \\
\hline lapja & tanuló & berlin & szülő & csoport \\
\hline nevelés & folyamat & pestalozzi & gyermekek & vizsgálat \\
\hline budapest & diák & erziehung & nevelés & tanuló \\
\hline tanító & kutatás & über & munka & eredmény \\
\hline magyar & stratégia & eine & tanuló & szociális \\
\hline tanítás & kompetencia & németország & testi & viselkedés \\
\hline népiskolai & nyelvi & unterricht & tanító & táblázat \\
\hline népiskola & motiváció & deutsch & család & attitüd \\
\hline tanügy & tudás & deutsche & élet & érték \\
\hline néptanító & angol & fröbel & játék & kapcsolat \\
\hline középiskola & szöveg & pädagogik & iskolai & szülő \\
\hline
\end{tabular}




\begin{tabular}{|c|c|c|c|c|}
\hline pedagógiai & olvasási & mathematik & leány & érzelmi \\
\hline iskolai & eredmény & irodalom & osztály & hatás \\
\hline katholikus & olvasás & diesterweg & éves & különbség \\
\hline tanítóképző & kognitív & wien & nevelő & szerep \\
\hline népoktatás & modell & münchen & eset & lány \\
\hline népnevelő & tanár & teubner & szellemi & jellemző \\
\hline tanügyi & eset & berlini & egészség & átlag \\
\hline tanáregylet & környezet & goethe & növendék & pedagógus \\
\hline gyermek & készség & schule & viszony & magas \\
\hline néptan & képesség & geschichte & hatás & pozitív \\
\hline oktatás & információ & porosz & társadalom & motívum \\
\hline reform & értékelés & verlag & foglalkozás & éves \\
\hline
\end{tabular}


8. melléklet. Az egyes témacsoportok kulcsszavai 10 kategória esetén 1991-2014 között

\begin{tabular}{|c|c|c|c|c|}
\hline $\begin{array}{c}\text { 1: neveléstudományi } \\
\text { kutatás }\end{array}$ & $\begin{array}{c}\text { 2: társadalom-kultúra- } \\
\text { múvészet }\end{array}$ & $\begin{array}{l}\text { 3: szociális } \\
\text { viselkedés }\end{array}$ & $\begin{array}{c}\text { 4: } \\
\text { iskolarendszer }\end{array}$ & $\begin{array}{c}\text { 5: } \\
\text { nyelvtanulás }\end{array}$ \\
\hline pedagógiai & nevelés & szociális & iskola & nyelv \\
\hline pedagógia & gyermek & iskolai & oktatás & angol \\
\hline magyar & ember & eredmény & társadalmi & nyelvi \\
\hline tudományos & élet & anya & oktatási & idegen \\
\hline szerző & iskola & kapcsolat & iskolai & német \\
\hline munka & gyerek & csoport & ország & diák \\
\hline nevelés & emberi & vizsgálat & intézmény & tanuló \\
\hline neveléstudomány & kultúra & viselkedés & gimnázium & magyar \\
\hline könyv & család & eset & rendszer & idegen nyelv \\
\hline kutatás & munka & lány & politikai & eredmény \\
\hline fejezet & világ & éves & helyzet & csoport \\
\hline tanulmány & oktatás & érzelmi & gyerek & eset \\
\hline tudomány & művészet & pozitív & európai & szint \\
\hline hazai & szellemi & hatás & felsőoktatási & nyelvtanulás \\
\hline német & gyermekek & gyerek & gazdasági & kutatás \\
\hline kötet & tanító & érzelem & változás & szöveg \\
\hline eredmény & nevelési & átlag & magas & feladat \\
\hline kérdés & pedagógiai & különbség & tanuló & nyelvü \\
\hline neveléstudományi & század & attitüd & kulturális & kérdés \\
\hline fejlődés & szülö & szerep & szám & nyelvtudás \\
\hline folyóirat & társadalom & szülö & társadalom & kommunikációs \\
\hline elemzés & társadalmi & pedagógus & állam & tényező \\
\hline rendszer & természet & tanuló & kérdés & nikolov \\
\hline szakmai & gondolat & érték & cigány & skála \\
\hline egyetem & erkölcsi & negatív & általános & motiváció \\
\hline 6: iskolai munka & 7: neveléstörténet & $\begin{array}{l}\text { 8: tanulási } \\
\text { motiváció }\end{array}$ & $\begin{array}{l}\text { 9: mérés- } \\
\text { értékelés }\end{array}$ & $\begin{array}{l}\text { 10: kognitív } \\
\text { megközelítés }\end{array}$ \\
\hline tanár & magyar & tanuló & feladat & folyamat \\
\hline iskola & iskola & motiváció & tanuló & tanulás \\
\hline tanuló & tanár & tanulási & teszt & tudás \\
\hline gyakorlat & egyetem & zenei & eredmény & probléma \\
\hline pedagógus & tanterv & olvasási & szint & feladat \\
\hline munka & iskolai & olvasás & évfolyam & tanuló \\
\hline pedagógiai & polgári & képesség & teljesítmény & fogalom \\
\hline hallgató & katolikus & tanulás & vizsgálat & kognitív \\
\hline módszer & tanító & vizsgálat & táblázat & elmélet \\
\hline értékelés & hallgató & eredmény & eset & képesség \\
\hline tanári & egyetemi & motívum & képesség & gyerek \\
\hline program & országos & stratégia & ábra & ismeret \\
\hline képzés & tanács & kutatás & minta & kutatás \\
\hline kérdés & munka & teljesítmény & felmérés & összefüggés \\
\hline tanítási & bizottság & tanulási motiváció & különbség & értelmezés \\
\hline oktatás & tanítóképző & iskolai & diák & fejlődés \\
\hline tanítás & népiskola & kérdőíiv & gondolkodás & modell \\
\hline tanterv & intézet & tevékenység & matematikai & gondolkodás \\
\hline
\end{tabular}




\begin{tabular}{|c|c|c|c|c|}
\hline feladat & kollégium & osztály & adat & rendszer \\
\hline iskolai & állami & elsajátítási & probléma & megértés \\
\hline oktatási & református & érték & átlag & stratégia \\
\hline tantárgy & osztály & terület & fejlődés & megoldás \\
\hline eredmény & középiskola & fejlödés & mérés & szöveg \\
\hline szakmai & képzés & eset & megoldás & struktúra \\
\hline csoport & tanárképző & különbség & változó & szempont \\
\hline
\end{tabular}


9. melléklet. Az egyes témacsoportok kulcsszavai 20 kategória esetén 1991-2014 között

\begin{tabular}{|c|c|c|c|c|}
\hline 1: neveléstörténet & $\begin{array}{c}\text { 2: kognitív } \\
\text { megközelítés }\end{array}$ & 3: tanári munka & $\begin{array}{l}\text { 4: matematika, } \\
\text { problémamegoldás }\end{array}$ & $\begin{array}{c}\text { 5: oktatásirányítás, } \\
\text { neveléstörténet }\end{array}$ \\
\hline iskola & folyamat & tanár & feladat & iskola \\
\hline gyerek & tudás & iskola & matematikai & magyar \\
\hline magyar & tanulás & pedagógus & megoldás & tanterv \\
\hline kert & fogalom & gyakorlat & probléma & tanács \\
\hline nevelés & elmélet & munka & teszt & bizottság \\
\hline élet & tanuló & hallgató & tanuló & állami \\
\hline tanító & kutatás & tanári & matematika & politikai \\
\hline oktatás & ismeret & pedagógiai & bizonyítás & egyház \\
\hline század & kognitív & képzés & gondolkodás & törvény \\
\hline korabeli & tanítás & szakos & képesség & országos \\
\hline munka & módszer & figyelem & intelligencia & középiskola \\
\hline ember & fogalmi & tanuló & teljesítmény & ülés \\
\hline történet & probléma & szakmai & problémamegoldás & polgári \\
\hline görög & gondolkodás & feladat & eredmény & tanító \\
\hline tanítás & megértés & tanítás & szöveges & tanuló \\
\hline hely & kérdés & kérdés & vizsgálat & általános \\
\hline kollégium & gyerek & követelmény & szöveges_feladat & rendelet \\
\hline isten & modell & program & következtetés & minisztérium \\
\hline protestáns & kapcsolat & vélemény & szám & miniszter \\
\hline német & vizsgálat & értékelés & feladat megoldás & elemi \\
\hline írás & eredmény & intézmény & szint & gimnázium \\
\hline latin & fejlődés & tantárgy & állítás & közoktatási \\
\hline felvilágosodás & struktúra & tapasztalat & táblázat & népiskola \\
\hline világ & természettudományos & tanterv & problémamegoldó & szocialista \\
\hline $\begin{array}{l}\text { 6: pszichológiai } \\
\text { témák }\end{array}$ & $\begin{array}{l}\text { 7: neveléstudomány, } \\
\text { neveléstörténet }\end{array}$ & 8: IKT & 9: zene & 10: nyelvtanulás \\
\hline nevelés & pedagógiai & csoport & zenei & nyelv \\
\hline gyermek & magyar & kísérleti & képesség & angol \\
\hline ember & szerző & program & zene & nyelvi \\
\hline társadalmi & történeti & kísérlet & szorongás & idegen \\
\hline lelki & könyv & tanuló & tevékenység & német \\
\hline iskola & neveléstudomány & számítógép & flow & diák \\
\hline nevelési & tudományos & módszer & vizsgálat & idegen nyelv \\
\hline élet & fejezet & feladat & fejlődés & magyar \\
\hline pedagógia & kötet & fejlesztés & eredmény & csoport \\
\hline társadalom & neveléstörténet & fejlesztő & élmény & nyelvtanulás \\
\hline emberi & tanulmány & vizuális & zenetanulás & nyelvü \\
\hline kultúra & kutatás & környezet & dallam & kommunikációs \\
\hline személyiség & folyóirat & eszköz & ének & nyelvtudás \\
\hline gyermekek & német & oktatási & hallás & német nyelv \\
\hline érték & neveléstudományi & alkalmazás & kodály & kutatás \\
\hline szellemi & hazai & hatás & ritmus & kétnyelvü \\
\hline egészség & elemzés & készség & apátia & orosz \\
\hline munka & kérdés & kommunikáció & zenei nevelés & nyelvtanulási \\
\hline család & tudomány & kompetencia & zenei müveltség & motiváció \\
\hline
\end{tabular}




\begin{tabular}{|c|c|c|c|c|}
\hline szerep & neveléstörténeti & számítógépes & szerep & anyanyelv \\
\hline tevékenység & évtized & játék & zenei képesség & nyelvtanuló \\
\hline egyén & esemény & kísérleti csoport & tehetséges & nikolov \\
\hline kapcsolat & történet & eszközök & tehetség & angol nyelv \\
\hline világ & téma & projekt & hang & beszélő \\
\hline $\begin{array}{l}\text { 11: neveléstörténet, } \\
\text { tanárképzés }\end{array}$ & 12: társadalmi háttér & $\begin{array}{l}\text { 13: szociális } \\
\text { kompetencia }\end{array}$ & $\begin{array}{l}\text { 14: készség- } \\
\text { képesség }\end{array}$ & 15: mérés \\
\hline egyetemi & iskola & szociális & képesség & tanuló \\
\hline magyar & arány & családi & készség & táblázat \\
\hline tanár & gyerek & viselkedés & szint & eredmény \\
\hline pedagógia & szülö & kapcsolat & fejlődés & vizsgálat \\
\hline hallgató & kulturális & érzelmi & feladat & iskola \\
\hline munka & háttér & éves & összefüggés & iskolai \\
\hline intézet & család & lány & évfolyam & átlag \\
\hline tanárképző & cigány & gyerek & fejlesztés & minta \\
\hline előadás & hátrányos & csoport & fejlettség & érték \\
\hline föiskola & csoport & eredmény & feltétel & különbség \\
\hline polgári & térség & versengés & $\begin{array}{l}\text { kombinatív } \\
\text { képesség }\end{array}$ & szórás \\
\hline tanárképzés & település & érzelem & optimális & adat \\
\hline század & társadalmi & pozitív & teszt & teljesítmény \\
\hline németh & táblázat & pedagógus & eredmény & változó \\
\hline neveléstan & helyzetü & együttmüködés & kombinatív & kérdőív \\
\hline kollégium & népesség & készség & kompetencia & összefüggés \\
\hline képzés & helyzet & segítő & rendszerező & magas \\
\hline tanulmány & diák & negatív & ismeret & szignifikáns \\
\hline tanítóképző & végzettség & hatás & elsajátítás & attitüd \\
\hline szakos & oktatás & szülöi & képesség fejlődés & csoport \\
\hline tanszék & iskolai végzettség & kompetencia & kritériumorientált & hatás \\
\hline kolozsvári & gyermek & szerep & felismerés & osztály \\
\hline tanárjelölt & anyagi & helyzet & komponensrendszer & évfolyam \\
\hline tanítóképző-intézeti & különbség & $\begin{array}{c}\text { szociális } \\
\text { kompetencia }\end{array}$ & $\begin{array}{l}\text { rendszerezö } \\
\text { képesség }\end{array}$ & kapcsolat \\
\hline 16: mérés-értékelés & 17: olvasás & $\begin{array}{c}18: \\
\text { problémamegoldás, } \\
\text { induktív } \\
\text { gondolkodás }\end{array}$ & $\begin{array}{l}\text { 19: tanulási } \\
\text { motiváció }\end{array}$ & 20: oktatási rendszer \\
\hline értékelés & olvasási & teszt & tanulás & oktatás \\
\hline teszt & olvasás & diák & tanulási & oktatási \\
\hline szint & szöveg & gondolkodás & motiváció & ország \\
\hline feladat & stratégia & évfolyam & tanuló & rendszer \\
\hline vizsga & szövegértés & feladat & motívum & európai \\
\hline értékelési & olvasó & induktív & kutatás & intézmény \\
\hline eredmény & kérdés & szint & elsajátítási & politikai \\
\hline teljesítmény & tanuló & teljesítmény & képesség & társadalmi \\
\hline mérés & gyerek & probléma & stratégia & nemzetközi \\
\hline szöveg & osztály & induktív gondolkodás & környezet & felsőoktatás \\
\hline érettségi & megértés & képességszint & folyamat & állam \\
\hline nyelvi & olvasási motiváció & fejlődés & kognitív & változás \\
\hline értékelö & metakognitív & eredmény & célok & amerikai \\
\hline skála & olvasási stratégia & item & motivációs & gazdasági \\
\hline
\end{tabular}




\begin{tabular}{|c|c|c|c|c|}
\hline fogalmazás & képesség & minta & egyén & kérdés \\
\hline magyar & eredmény & $\begin{array}{c}\text { természettudományo } \\
\text { s }\end{array}$ & szociális & kultúra \\
\hline modell & olvasási képesség & képesség & hatás & nemzeti \\
\hline szempont & jelentés & problémamegoldó & vizsgálat & oktatási rendszer \\
\hline kritérium & évfolyam & feladatlap & eredmény & képzés \\
\hline pontszám & használat & vizsgálat & tanulási motiváció & terület \\
\hline szövegalkotás & olvasástanítás & molnár & teljesítmény & felsőoktatási \\
\hline megfelelö & teljesítmény & csapó & viselkedés & autonómia \\
\hline bíráló & gyakoriság & komplex & énkép & magyarország \\
\hline írásbeli & feladat & mérés & tevékenység & .
\end{tabular}


10. melléklet. Az összetett kifejezések vizsgálatát lehetővé tevö kollokációs lista első 100 tétele

\begin{tabular}{|c|c|c|c|c|c|}
\hline$\#$ & kollokáció & $\begin{array}{l}\text { előfordulási } \\
\text { gyakoriság }\end{array}$ & $\#$ & kollokáció & $\begin{array}{c}\text { előfordulási } \\
\text { gyakoriság }\end{array}$ \\
\hline 1. & idegen_nyelv & 2602 & 51. & kutatás_eredmény & 537 \\
\hline 2. & általános_iskola & 2562 & 52. & gyakorló_iskola & 532 \\
\hline 3. & polgári_iskola & 2383 & 53. & görög_nyelv & 529 \\
\hline 4. & magyar_nyelv & 2122 & 54. & angol_nyelv & 523 \\
\hline 5. & elemi_iskola & 1986 & 55. & feladat_megoldás & 523 \\
\hline 6. & magyar_pedagógia & 1909 & 56. & modern_nyelv & 504 \\
\hline 7. & nyelv_tanítás & 1414 & 57. & nevelési_rendszer & 502 \\
\hline 8. & erkölcsi_nevelés & 1373 & 58. & tanuló_teljesítmény & 501 \\
\hline 9. & német_nyelv & 1271 & 59. & iskolai_gyakorlat & 500 \\
\hline 10. & felső_osztály & 1248 & 60. & társadalmi_élet & 497 \\
\hline 11. & általános_müveltség & 1232 & 61. & induktív_gondolkodás & 494 \\
\hline 12. & latin_nyelv & 1216 & 62. & osztályos_tanuló & 494 \\
\hline 13. & testi_nevelés & 1141 & 63. & középiskolai_oktatás & 491 \\
\hline 14. & oktatási_folyamat & 1052 & 64. & közoktatási_tanács & 488 \\
\hline 15. & oktatási_rendszer & 1040 & 65. & nevelö_hatás & 484 \\
\hline 16. & kereskedelmi_iskola & 968 & 66. & programozott_oktatás & 473 \\
\hline 17. & általános_iskolai & 924 & 67. & írásbeli_dolgozat & 459 \\
\hline 18. & polgári_iskolai & 857 & 68. & felső_kereskedelmi & 446 \\
\hline 19. & probléma_megoldás & 816 & 69. & hátrányos_helyzetü & 445 \\
\hline 20. & egyetemi_tanár & 805 & 70. & tudományos_kutatás & 445 \\
\hline 21. & érettségi_vizsgálat & 749 & 71. & magyar_irodalom & 444 \\
\hline 22. & iskolai_végzettség & 717 & 72. & idegen_nyelvi & 443 \\
\hline 23. & közoktatásügyi_miniszter & 700 & 73. & szakmai_képzés & 440 \\
\hline 24. & iskolai_munka & 687 & 74. & felsőoktatási_intézmény & 435 \\
\hline 25. & lelki_élet & 685 & 75. & magyar_nyelvü & 431 \\
\hline 26. & felső_leányiskola & 656 & 76. & családi_élet & 431 \\
\hline 27. & szellemi_élet & 653 & 77. & elemi_népiskola & 426 \\
\hline 28. & középiskolai_tanár & 644 & 78. & pedagógiai_irodalom & 426 \\
\hline 29. & felső_tagozat & 636 & 79. & gyakorló_pedagógus & 425 \\
\hline 30. & iskolai_oktatás & 635 & 80. & heti_óraszám & 418 \\
\hline 31. & pedagógiai_kutatás & 634 & 81. & magyar_nemzet & 414 \\
\hline 32. & pedagógiai_repertórium & 623 & 82. & munka_nevelés & 413 \\
\hline 33. & elemi_iskolai & 621 & 83. & szocialista_ország & 412 \\
\hline 34. & kutatási_eredmény & 616 & 84. & nevelés_történet & 412 \\
\hline 35. & pedagógiai_gyakorlat & 611 & 85. & esztétikai_nevelés & 408 \\
\hline 36. & gyakorlati_élet & 605 & 86. & középfokú_iskola & 407 \\
\hline 37. & alsó_tagozat & 595 & 87. & tudományos_akadémia & 406 \\
\hline 38. & tanulmányi_eredmény & 585 & 88. & egyetemi_hallgató & 406 \\
\hline 39. & mindennapi_élet & 578 & 89. & gyakorlati_alkalmazás & 404 \\
\hline 40. & alsó_osztály & 576 & 90. & társadalmi_fejlődés & 398 \\
\hline 41. & középfokú_oktatás & 573 & 91. & tanítási_gyakorlat & 393 \\
\hline 42. & szellemi_munka & 569 & 92. & tanári_pálya & 389 \\
\hline 43. & vizsgálat_eredmény & 566 & 93. & állampolgári_nevelés & 388 \\
\hline 44. & nevelési_folyamat & 560 & 94. & történeti_fejlődés & 387 \\
\hline 45. & iskolai_élet & 559 & 95. & közös_munka & 387 \\
\hline
\end{tabular}




\begin{tabular}{|l|c|c|c|c|c|}
\hline 46. & iskolai_nevelés & 542 & 96. & szignifikáns_különbség & 385 \\
\hline 47. & pedagógiai_szemle & 540 & 97. & egységes_középiskola & 377 \\
\hline 48. & nyelv_tanulás & 539 & 98. & oktatási_intézmény & 374 \\
\hline 49. & egyesült_államok & 537 & 99. & tanítási_módszer & 370 \\
\hline 50. & tanulási_folyamat & 537 & 100. & családi_nevelés & 370 \\
\hline
\end{tabular}




\begin{tabular}{|c|c|}
\hline \multicolumn{2}{|c|}{ Metaadatokra vonatkozó elemzések } \\
\hline $1892-2014$ & $1991-2014$ \\
\hline \multirow[t]{6}{*}{ Publikációk számának változása } & Publikációk számának változása \\
\hline & Publikációk hosszának változása \\
\hline & Legtermékenyebb szerzők listája \\
\hline & Szerzők nemzetiségi megoszlása \\
\hline & Szerzők intézményi háttere \\
\hline & Szerzők szektorok szerinti megoszlása \\
\hline \multirow[t]{2}{*}{ Női és férfi szerzők aránya } & Női és férfi szerzők aránya \\
\hline & Társszerzős cikkek aránya \\
\hline \multicolumn{2}{|l|}{ Társszerzőségi gráf } \\
\hline \multicolumn{2}{|c|}{ Hivatkozásvizsgálatok } \\
\hline \multirow[t]{15}{*}{$1892-2014$} & $1991-2014$ \\
\hline & $\begin{array}{l}\text { Tanulmányok átlagos hivatkozási számának } \\
\text { változása }\end{array}$ \\
\hline & $\begin{array}{l}\text { Tanulmányok hivatkozásainak átlagos } \\
\text { frissessége }\end{array}$ \\
\hline & Folyóiratcikkekre történő hivatkozások aránya \\
\hline & $\begin{array}{l}\text { Nemzetközi és magyar folyóiratcikkekre történő } \\
\text { hivatkozások aránya }\end{array}$ \\
\hline & $\begin{array}{l}\text { Impakt faktoros folyóiratokra való hivatkozások } \\
\text { aránya }\end{array}$ \\
\hline & $\begin{array}{l}\text { Interdiszciplináris cikkekre való hivatkozások } \\
\text { aránya }\end{array}$ \\
\hline & Leghivatkozottabb szakirodalmi források listája \\
\hline & Hivatkozások eloszlása \\
\hline & Hivatkozástípusok megoszlása \\
\hline & Leghivatkozottabb kutatók listája \\
\hline & Leghivatkozottabb szerzők a Scopusban \\
\hline & Belső hivatkozási hálózat \\
\hline & Belső hivatkozási hálózat intézményi háttere \\
\hline & Teljes hivatkozási hálózat \\
\hline \multicolumn{2}{|c|}{ Tartalmi elemzés } \\
\hline $1892-2014$ & $1991-2014$ \\
\hline Abszolút és relatív gyakorisági toplisták & Abszolút és relatív gyakorisági toplisták \\
\hline \multicolumn{2}{|l|}{ Az egyes évtizedek leggyakoribb szavai } \\
\hline \multicolumn{2}{|l|}{ Repertórium tárgyszavai (1892-1989) } \\
\hline \multicolumn{2}{|l|}{ Contenta repozitórium tárgyszavai } \\
\hline \multicolumn{2}{|l|}{ Automatikus kulcsszavazás } \\
\hline Klaszteranalízis & Klaszteranalízis \\
\hline Tartalmi csoportosítás & Tartalmi csoportosítás \\
\hline Szakkifejezések használatának változása & Szakkifejezések használatának változása \\
\hline
\end{tabular}

